\title{
A ReSponsabilidade por CUStodia no Direito Romano Análise do problema na compra e venda (emptio venditio)
}

\author{
(Tese de Doutorado)
}

Versão corrigida em 05.07.2012. A versão original, em formato eletrônico (PDF), encontra-se disponível na CPG da Unidade

Orientador:

Prof. Eduardo C. Silveira Vita Marchi (Professor Titular da Cadeira de Direito Romano da FADUSP)

Universidade de São Paulo

Faculdade de Direito

São Paulo - 2012 
Aos meus pais, pelo apoio incondicional

Este trabalho contou com o auxílio da FAPESP (Fundação de Amparo à Pesquisa do Estado de São Paulo) 
Ao Prof. Eduardo César Silveira Vita Marchi, dentre tantos outros motivos, pela oportunidade de desenvolver este trabalho sob sua orientação, e pelo seu exemplo de dedicação à carreira universitária;

Aos Professores da Cadeira de Direito Romano pelo aprendizado haurido nesses anos de convívio e pelo incessante e sério labor que, admirável e inspirador, sustenta a confiança no futuro da disciplina no Brasil;

Aos meus queridos amigos, pelo apoio e pela convivência agradabilíssima desses anos transcorridos «Euro citius». Em especial, àqueles encontrados nas Arcadas, Austréia Magalhães Candido e Rodrigo de Lima Vaz Sampaio, e alhures, Georges Abboud (UNESP-PUC) e Sandrine Vallar (Université de Paris II);

À equipe do Leopold-Wenger-Institut für Rechtsgeschichte, pela gentil acolhida em Munique (LMU) que me permitiu desenvolver parte dos trabalhos dessa pesquisa;

À FAPESP (Fundação de Amparo à Pesquisa do Estado de São Paulo) e ao DAAD (Deustscher Akademischer Austausch Dienst), pelo apoio financeiro para essa estadia (março-agosto de 2011) de estudos em Munique; e

Aos bibliotecários da Faculdade de Direito do Largo de São Francisco, pelo atendimento sempre solícito, mesmo em tempos difíceis para a instituição e seu precioso acervo,

Minha sincera gratidão. 


\section{SUMÁRIO}

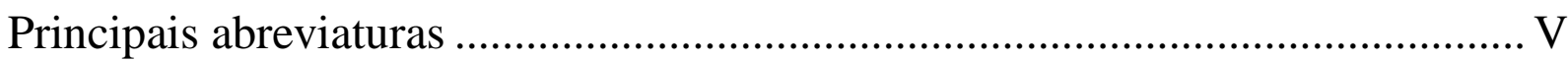

Observações metodológicas gerais ................................................................ VIII

INTRODUÇÃO

PARTe I

«CUSTODIAM PRAESTARE» NO DireIto ROMANO: FONTES, DOUTRINA E Problemas Gerais

Capítulo I - «Custodiam Praestare» nas Fontes Jurídicas Romanas ... 8

1. «Custodela» como forma primitiva de «custodia» ....................................... 8

2. «Custodia» nas fontes jurídicas romanas ....................................................... 10

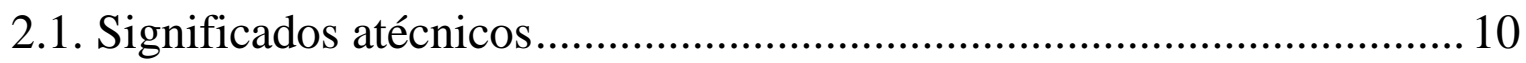

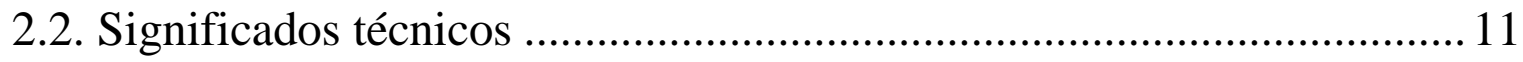

2.3. «Custodia» no direito das obrigações: «custodiam praestare»............... 16

3. «Praestare» e «responsabilidade» ............................................................... 18

3.1. Significados de «praestare» nas fontes jurídicas romanas..................... 18

3.2. O significado «exclusivo» de «praestare» como objeto da obrigação... 21

Capítulo II - «Custodiam Praestare» na Doutrina Romanística........... 32

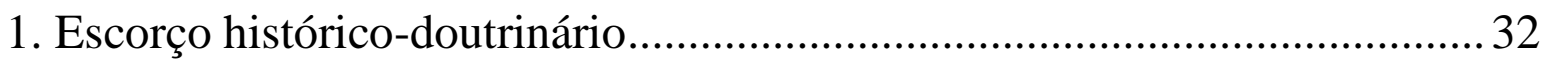

1.1. A «culpa levissima» nas doutrinas do «direito comum» anteriores à

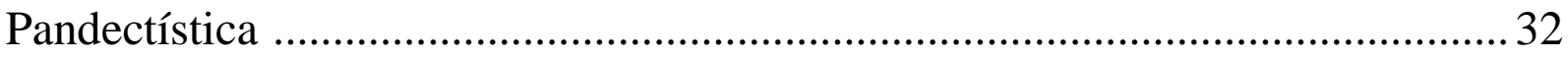

1.2. Pandectística: «custodiam praestare» na «Schuldhaftungskonzeption» 39

1.3. Crítica Interpolacionística: «custodiam praestare» como a «responsabilidade objetiva» do direito clássico................................................... 43

1.4. Reações à communis opinio interpolacionística .................................. 46 
1.4.1. «Custodiam praestare» nas reconstruções unitárias do sistema clássico de responsabilidade contratual 47

1.4.2. Releituras de «custodiam praestare» alternativas à «responsabilidade objetiva». 47

1.4.3. «Custodiam praestare» sob a perspectiva historicamente articulada dos «critérios de responsabilidade» 49

1.5. As contribuições mais recentes sobre a matéria 51

1.5.1. «Custodiam praestare» como «prestação».... 51

1.5.2. Correntes «neo-subjetivistas» .53

2. Os «problemas gerais» da responsabilidade por custodia .55

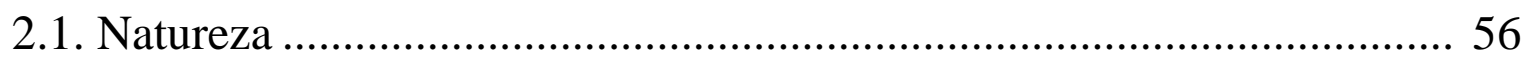

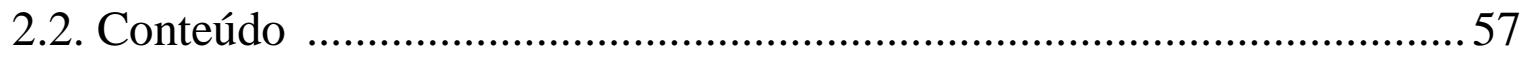

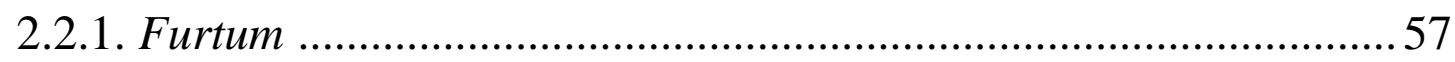

2.2.2. «Fuga servorum qui custodiri solent» ........................................ 59

2.2.3. «Damnum iniuria ab alio datum» ................................................62 62

2.3. Âmbito de aplicação nas espécies contratuais ...................................... 64

2.4. Alterações teóricas e práticas de «custodiam praestare» no curso da iurisprudentia romana 67

\section{Capítulo III - Aspectos Conceituais da Compra e Venda (Emptio}

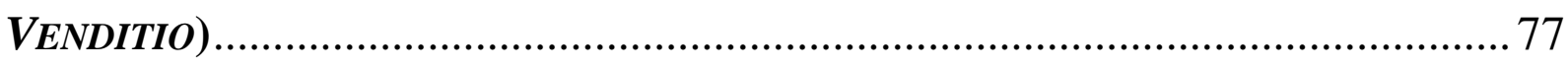

1. Emptio venditio: a compra e venda consensual e obrigatória romana........ 77

2. Obrigações do vendedor na emptio venditio ................................................. 79

3. Âmbito do praestare do vendedor por inadimplemento............................... 81

4. O problema do «periculum rei venditae» no direito romano .......................82

5. O problema da responsabilidade por custodia do vendedor ...................... 90

5.1. Dificuldades teóricas de uma custodia venditoris .......................... 90 
5.2. Estabelecimento da base textual 93

5.2.1. Critérios gerais para a identificação de custodiam praestare nas fontes romanas. 93

5.2.2. Critérios para a seleção dos textos úteis à reconstrução do problema no âmbito da «emptio venditio» 94

\section{PARTe II}

AnÁlise dos TeXtos em Matéria de CoMpra e Venda

Capítulo I - «Vestígios» do «Custodiam Praestare» do Vendedor NA IURISPRUDENTIA REPUBLICANA: ALFENO_....................................................... 97

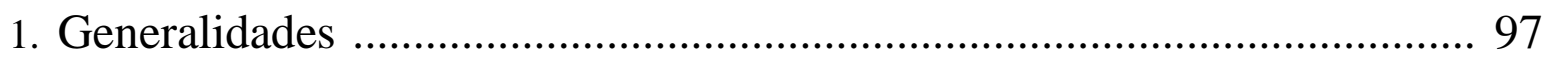

2. $\mathrm{O}$ furto antes da traditio da madeira comprada ......................................... 97

3. A destruição pelo edil das camas vendidas................................................ 106

4. $\mathrm{O}$ incêndio da «insula custodienda» ....................................................... 112

5. A ausência de fontes para a reconstrução do problema do século I d. C. 117

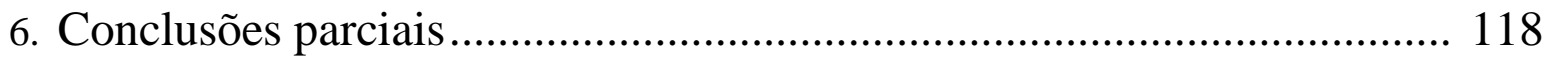

Capítulo II - «Custodiam Praestare» do Vendedor na IURISprudentia adrianéta: Nerácio, Gaio, Celso e Juliano .............................................. 119

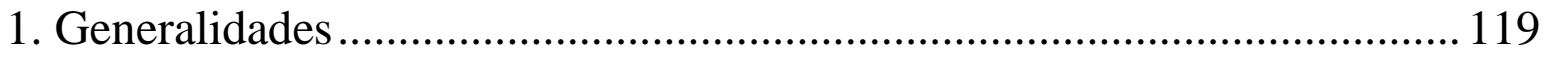

2. Roubo (vi ademptio) da coisa vendida....................................................... 120

3. O furto da «res vendita»........................................................................... 136

4. $\mathrm{O}$ furto da «res vendita» e a legitimação ativa à actio furti......................... 158

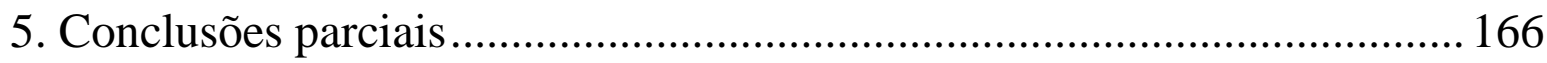


Capítulo III - «CUStodiam PRaEstare» Do Vendedor Na IURISPRUdentia Severiana: Papiniano, Ulpiano e Paulo ................................................. 168

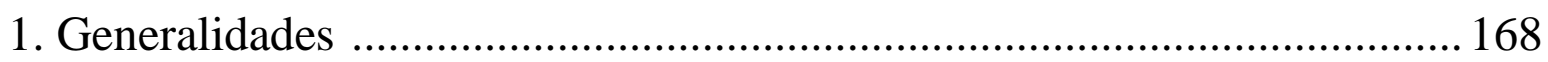

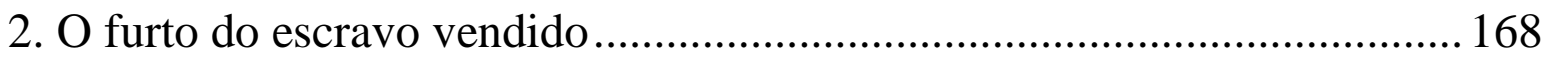

3. Custodiam praestare na compra e venda de vinhos ................................ 172

3.1. Compra e venda de vinho ad mensuram .......................................... 172

3.1.1. Custodiam praestare na compra e venda de vinho ad mensuram 172

3.1.2. «Custodia plena» do vendedor antes da medição ...................... 175

3.2. Limites do «custodiam praestare» do vendedor ................................. 178

3.3. Custodiam praestare na compra e venda de vinho per aversionem... 181

4. Custodiam praestare na compra e venda de imóveis .............................. 184

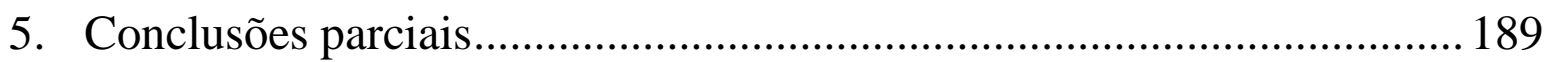

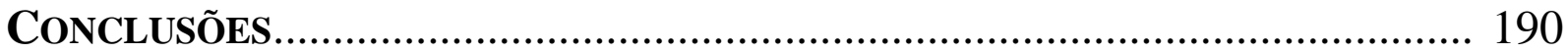

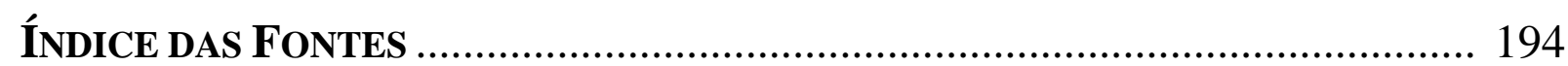

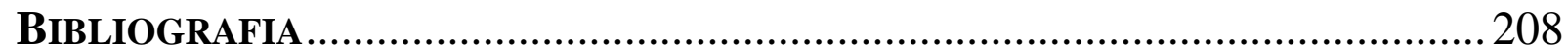

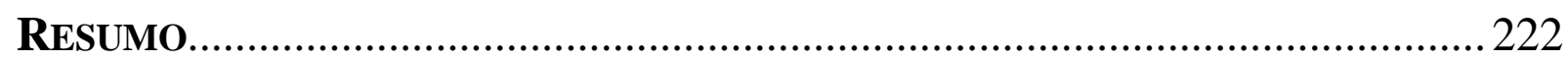

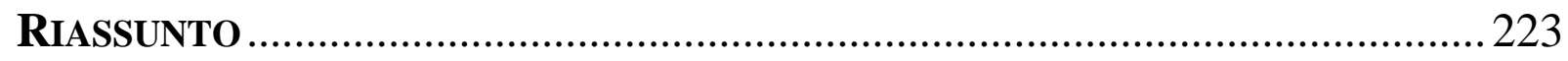

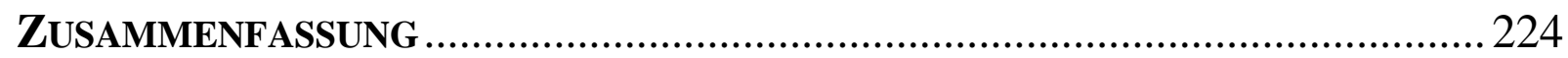




\section{Principais Abreviaturas*}

\section{A) FonTeS}

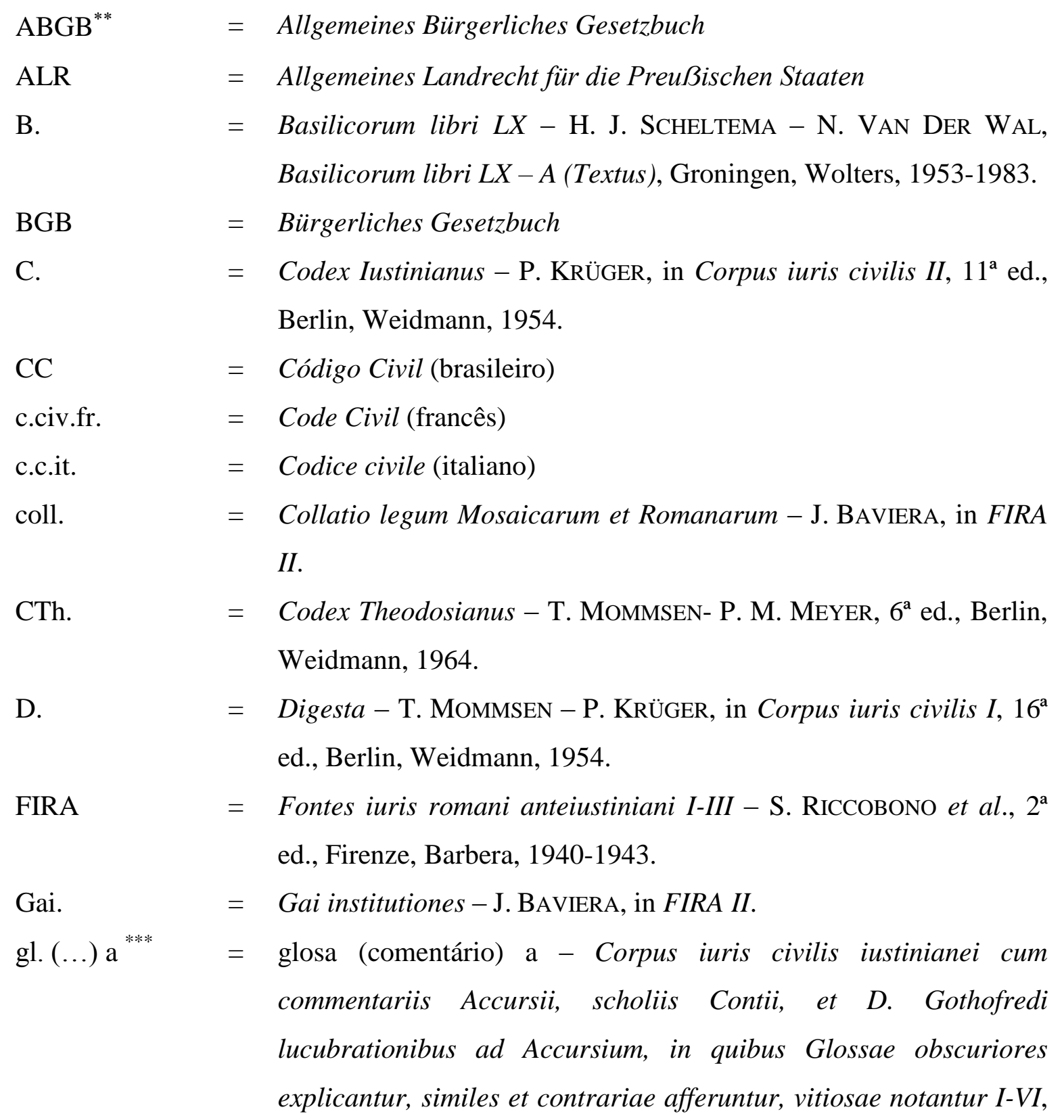

* Utilizaram-se, em geral, as abreviaturas - tanto das fontes quanto dos periódicos, enciclopédias e materiais de apoio - apresentadas em um dos mais conhecidos manuais de referência concernente ao direito privado romano, a saber, M. KASER, Das römische Privatrecht I - Das altrömische, das vorklassische und klassische Recht, $2^{\mathrm{a}}$ ed., München, Beck, 1971, pp. XIX-XXX.

${ }^{* *}$ Reproduz-se, no que concerne às legislações, a forma de citação mais corrente entre os estudiosos de cada país, indicando-se em parênteses, para evitar confusões em certos casos, a data de promulgação da legislação referida, v.g.: CC (1916) ou CC (2002).

*** Com relação à Glosa, faz-se seguir à abreviatura «gl.» as palavras do texto ao qual se prende a glosa, seguidas da indicação numérica daquele, com omissão da inscriptio, v.g.: gl. omnes liberati a D. 4, 2, $14,15$. Cf. H. LANGE, Römisches Recht im Mittelalter I - Die Glossatoren, München, Beck, 1997, p. 122. 
Lion, s.e., 1627.

H.

Inst.

Ord. Filip.

Ord. Manuel.

P.

Pal.

PS

sch.

Sch. A ou B

Theoph.
$=$ Heimbach - G. E. HeIMBACH - K. W. E. HeIMBACH, Basilicorum libri LX, Lipsiae, Barth, 1833-1850.

$=$ Institutiones Iustiniani $-\mathrm{P}$. KRÜGER, in Corpus iuris civilis I, 16 ed., Berlin, Weidmann, 1954.

$=$ Ordenações Afonsinas - Ordenações do Senhor Rey D. Affonso Vlivro IIII, Coimbra, Real Imprensa da Universidade, 1792.

$=$ Ordenações Filipinas - CÂNDIDo Mendes de AlmeIdA, Codigo Philippino, 14 ${ }^{\mathrm{a}}$ ed., Rio de Janeiro, Instituto Philomathico, 1870.

$=$ Ordenações Manuelinas - Ordenaçõens do Senhor Rey D. Manuel - livro IIII, Coimbra, Real Imprensa da Universidade, 1797.

$=$ Las Siete Partidas del Rey Don Alfonso El Sabio, cotejadas com varios codices antiguos por la Real Academia de la Historia I-III, Madrid, Imprenta Real, 1807.

$=$ O. LENEL, Palingenesia iuris civilis - Iuris consultorum reliquae quae Iustiniani Digestis continentur ceteraque iurisprudentiae civilis fragmenta minora secundum autores et libros disposuit I-II (1889), reimpr., Aalen, Scientia, 2000.

$=$ Pauli sententiae receptae $-\mathrm{J}$. BAVIERA, in FIRA II.

$=$ scolvion (escólio) a B. (supra) - H. J. SCHELTEMA - N. VAN DeR WAL - D. HOLWERDA, Basilicorum libri LX - B (scholia), Groningen, Wolters, 1953, 1953-1988*.

$=$ Scheltema $A-$ H. J. Scheltema - N. VAN DeR WAL - D. HOLWERDA, Basilicorum libri LX - A (textus), Groningen, Wolters, 1953, 1953-1983; Scheltema B - H. J. SchelteMA - N. VAN DeR WAL - D. HolwerdA, Basilicorum libri LX - A (scholia), Groningen, Wolters, 1953, 1953-1988.

$=$ Theophili antecessoris institutiones $-\mathrm{C}$. FERRINI, Institutionum

\footnotetext{
* Ainda que a reprodução dos textos se dê conforme essa edição (mais recente), pareceu conveniente indicar, também a edição de G. E. HEIMBACH - K. W. E. HEIMBACH (supra), utilizada por muito tempo pelos estudiosos. Por compacidade, indica-se, entre parênteses, após a referência a um dado escólio das Basílicas v.g. Steph. Eijhøamen a D. 16, 3, 1, 35 - B. 13, 2, 1 -, H II 35; Sch B II 645, sch. 52 = localização do texto na edição HEIMBACH $(\mathrm{H})$, volume II, página 35; e, correspondentemente, na edição Scheltema (Sch), parte B (escólios), volume II, página 645, escólio de número 52. Segue-se, assim, grosso modo, o modelo empregado por D. NÖRR, Die Fahrlässigkeit im byzantinischen Vertragsrecht, München, Beck, 1960.
} 
graeca paraphrasis Theophilo antecessori vulgo tributa I - Libros I et II et prolegomena continens (1884); II - Libros III et IV, stemmam cognationum, apêndices continens (1887), reimpr., Aalen, Scientia, 1967.

UE. $\quad=$ Tituli ex corpore Ulpiani - J. BAVIERA, in FIRA II.

vat. $\quad=$ Fragmenta Vaticana - J. BAVIERA, in FIRA II.

\section{B) Revistas, EnCIClopédias e Materiais de APOIO}

\begin{tabular}{|c|c|c|}
\hline $\mathrm{AcP}$ & $=$ & Archiv für die civilistische Praxis (Tübingen) \\
\hline BIDR & $=$ & Bulletino dell'Istituto di diritto romano (Milano) \\
\hline Digesto IV & $=$ & IV Digesto delle discipline privatistiche - sezione civile (Torino) \\
\hline ED & $=$ & Enciclopedia del diritto (Milano) \\
\hline IURA & $=$ & IURA - Rivista Internazionale di diritto romano e antico (Napoli) \\
\hline KlP & $=$ & Der kleine Pauly - Lexicon der Antike (München) \\
\hline Krit. Vjschr. & $=$ & $\begin{array}{l}\text { Kritische Vierteljahresschrift für Gesetzgebung } \\
\text { Rechtswissenschaft (München). }\end{array}$ \\
\hline LABEO & $=$ & LABEO - Rassegna di diritto romano (Napoli) \\
\hline NDI & $=$ & Nuovo Digesto Italiano (Torino) \\
\hline NNDI & $=$ & Novissimo Digesto Italiano (Torino) \\
\hline Riv. dir. civ. & $=$ & Rivista di diritto civile (Padova) \\
\hline $\mathrm{RE}$ & $=$ & $\begin{array}{l}\text { Paulys Realencyclopädie der classischen Altertumswissenschaft } \\
\text { (Stuttgart) }\end{array}$ \\
\hline RHD & $=$ & Revue historique de droit français et étranger (Paris) \\
\hline RIDA & $=$ & Revue internationale des droits de l'antiquité (Bruxelles) \\
\hline SDHI & $=$ & Studia et documenta historiae et iuris (Roma) \\
\hline $\mathrm{SZ}$ & $=$ & $\begin{array}{l}\text { Zeitschrift der Savigny-Stiftung für Rechtsgeschichte } \\
\text { Romanistische Abteilung (Weimar) }\end{array}$ \\
\hline ThLL & $=$ & Thesaurus Linguae Latinae (Leipzig - München) \\
\hline $\mathrm{TR}$ & $=$ & $\begin{array}{l}\text { Tijdschrift voor rechtsgeschiedenis - Revue d'histoire du droit } \\
\text { (Haarlem - Groningen) }\end{array}$ \\
\hline VIR & $=$ & Vocabularium Iurisprudentiae Romanae (Berlin) \\
\hline ZfCivPr & $=$ & Zeitschrift für Civilrecht und Prozeß (Gießen) \\
\hline
\end{tabular}


ZGRW = Zeitschrift für geschichtliche Rechtswissenschaft (Berlin)

\section{C) Outras}

cf.

col. (cols.)

ID.; ibid.

nt. (nts.)

p. (pp.)

s.d. ou s.e.

v.g.

$[\ldots]$

$<\ldots>$

... ou $(\ldots)$

$=$ confira, confronte, compare.

$=\operatorname{coluna}(\mathrm{s})$.

$=$ (resp.) «idem» o mesmo (autor); «ibidem», na mesma obra citada.

$=$ nota $(\mathrm{s})$ de rodapé.

$=$ página $(\mathrm{s})$.

= sem indicação de data (de publicação) ou de editora.

$=$ «verbi gratia»: por exemplo.

= parênteses quadrados ou colchetes: indicam, no texto latino das fontes, hipóteses de interpolação* .

$=$ parênteses agudos: no texto latino das fontes, indicam propostas de restituição do teor genuíno, em lugar do trecho considerado interpolado; nas traduções em português, assinalam inserções elucidativas ou termos elípticos no texto original ${ }^{* *}$.

$=$ omissão de palavras, trechos ou mesmo parágrafos não relevantes para o assunto estudado.

\section{OBSERVAÇÕeS MetodológICAS GERAIS}

\section{A) Citação e Tradução das Fontes Não-Jurídicas}

Consultaram-se, em regra, para a reprodução e tradução dos trechos extraídos de fontes literárias, as edições Les Belles Lettres (Paris). Cita-se segundo o modelo do Index do Thesaurus Linguae Latinae (ThLL), no que concerne às abreviaturas e grafias do nome do autor e da respectiva obra***.

\section{B) TraduÇão das Fontes Jurídicas}

\section{B.1) FONTES JURÍDICAS EM LATIM}

* Cf. U. WeSEL, Die Hausarbeit in der Digestenexegese - Eine Einführung für Studenten und Doktoranden, München, Kleist, 1966, p. 60.

** Segue-se, assim, a orientação de alguns tradutores, v.g.,: A. D’ORS et al., El Digesto de Justiniano I Constitutiones Preliminares y libros 1-19, Pamplona, Aranzadi, 1968; S. SCHIPANI (cur.), Iustiniani Augusti Digesta seu Pandectae - Digesti o Pandette dell'Imperatore Giustiniano - Texto e Traduzione I - 1-4, Milano, Giuffrè, 2005, p. XXXI; já O. BEREHNDS - R. KNÜTEL - B. KUPISCH - H. HeRMANN SEILER, Corpus Iuris Civilis - Text und Übersetzung I - Institutionen, 2a ed., Heidelberg, Müller, 1997, p. XI, preferem os colchetes «[...]» para tais inserções elucidativas.

*** Cf. Index librorum scriptorum inscriptionum ex quibus exempla afferuntur, Leipzig, Teubner, 2009, pp. IX-228. 
Realizaram-se as traduções das fontes jurídicas romanas em português conforme os seguintes critérios: (a) buscou-se uma versão quanto mais possível literal*; (b) mantiveramse alguns termos em latim - v.g., a designação, em geral, de ações (vindicatio, condictio, actio furti) - já que a versão dessas, além de oferecer dificuldades estilísticas (v.g., «ação de furto»), não contribuiria em maior medida para a compreensão dos textos; (c) verificação das traduções em outras línguas, sejam gerais, sejam, em relação a um texto específico, propostas em manuais ou estudos monográficos ${ }^{* *}$.

Das demais fontes latinas utilizadas, oferecem-se, em regra, versões livres em vernáculo, realizadas com base nos dicionários e materiais de apoio, indicando-se, quando for o caso, eventuais traduções verificadas.

\section{B.2) FonTES JURÍDICAS EM GREgo}

No que concerne às fontes jurídicas em língua grega (bizantinas), serviu de embasamento a tradução latina das Basílicas (texto e escólios) presente na edição de G. E. HEIMBACH - K. W. E. HEIMBACH $(\text { supra })^{* * *}$.

\section{B.3) FONTES JURÍDiCAS EM OUTRAS LÍNGUAS}

Por coerência, oferecem-se também traduções livres dos artigos de legislação civil estrangeira citados ao longo do estudo. No que respeita às fontes jurídicas escritas em língua portuguesa (v.g., Ordenações), optou-se por transcrevê-las tal como figuram nas

\footnotetext{
* Segue-se, assim, a recomendação de U. WeSEL, Die Hausarbeit cit. (nt. " supra) p. 37.

${ }^{* * *}$ No que concerne às principais fontes jurídicas utilizadas com tradução nessa investigação:

(a) Digesto: H. Hulot, Les cinquantes livres du digeste ou les pandectes de l'Empereur Justinien II, Paris, Rondonneau, 1804; ID., ibid. III, 1804; ID., ibid. VI, 1804; ID., ibid. VII, 1805; G. VIGNALLI, Corpo del diritto - Digesto II, Napoli, Pezzuti, 1856; ID., ibid. III, Napoli, Morelli, 1857; ID., ibid. VI, 1858; I. L. GARCIA Del CoRral, Cuerpo del derecho civil romano I - Primera Parte - Instituta - Digesto, Barcelona, Molinas, 1889; ID. ibid. III - Primera Parte - Digesto, Barcelona, Redondo y Xumetra, 1897; A. D'ORS et al., El Digesto de Justinano I - Constitutiones Preliminares y Libros 1-19, Pamplona, Aranzadi, 1968; ID., ibid. III - Libros 37 a 50, Pamplona, Aranzadi, 1968; O. BEHRENDS - R. KNÜTEL - B. KUPISCH - H. H. SEILER, Corpus Iuris Civilis - Text und Übersetzung III - Digesten 11-20, Heidelberg, Müller, 1999; S. SCHIPANI (cur.), Iustiniani Augusti Digesta seu Pandectae - Digesti o Pandette dell'Imperatore Giustiniano - Testo e traduzione III, Milano, Giuffrè, 2007; (b) Institutas (de Justiniano): além das obras já referidas em «(a)», A. CORREIA - G. SCIASCIA, Manual de Direito Romano II - Institutas de Gaio e de Justiniano vertidas para o português em confronto com o texto latino, $2^{a}$ ed., São Paulo, Saraiva, 1955; E. NARDI, Istituzioni di diritto romano - B - Testi 1 e 2, Milano, Giufrè, 1986; (c) Institutas de Gaio: além dessas duas últimas, F. DE ZULUETA, The Institutes of Gaius I - Text with critical notes and translation, Oxford, Clarendon, 1953.

Dão-se, nessa sede, as obras de apoio empregadas para uma versão do texto latino em língua portuguesa, mencionando-se uma ou outra, ao longo do estudo, apenas quando houver alguma particularidade que justifique assinalar a divergência entre os tradutores, a fim de circunstanciar também a opção realizada.

${ }_{* * * *}^{*}$ Cf. Basilicorum libri LX, Lipsiae, Barth, 1833-1850.
} 
edições utilizadas em cada caso, o que explica a atualização ortográfica em algumas reproduções e não em outras.

\section{C) Citação Bibliográfica}

Seguem-se as soluções gráficas do sistema franco-italiano* Indicam-se os elementos essenciais da obra apenas na primeira vez em que se fizer referência a ela em nota de rodapé. Nas citações subseqüentes, designa-se somente parte do título (e também do volume, em alguns casos) com a indicação, entre parênteses, da nota na qual consta a sua descrição completa $^{* *}$. V.g.: M. KASER, Das römische Privatrecht I cit. (nt. 04 supra) = obra citada anteriormente, na nota 04 , com todos os dados necessários para sua correta identificação.

\section{D) OUtras Particularidades}

Utilizaram-se algumas reimpressões de obras clássicas, o que se assinala, a fim de evitar equívocos quanto à exata data de edição do volume, no final da citação, e entre colchetes, pela abreviatura «reimpr.», seguida do ano da edição que foi reimpressa. V.g.: H. HEUMANN - E. SECKEL, Handlexikon zu en Quellen des römischen Rechts, $11^{\mathrm{a}} \mathrm{ed}$. , Graz, Akademische, 1957, p. 400 [reimpr. 1907] = a 11 a ed. é de 1907, reimpressa em 1957 (volume efetivamente consultado).

Também no caso de obras clássicas, das quais existam muitas edições, indicam-se, além das páginas, também as secções originais (v.g., §§) em que se divide o livro, para permitir, se for o caso, a identificação da passagem referida em edição diversa da citada***. V.g.: B. WINDSCHEID, Lehrbuch des Pandektenrechts II, $5^{\mathrm{a}}$ ed., Frankfurt am Main, Rütten \& Loening, 1882, p. 365 [= $\$ 358]$.

\footnotetext{
* Cf., pormenorizadamente, E. C. SILVEIRA MARChI, Guia de Metodologia Jurídica-Teses, Monografias e Artigos, $2^{\text {a }}$ ed., São Paulo, Saraiva, 2009, pp. 167-204.

${ }^{* * *}$ Uma particularidade assume a citação de um artigo de C. A. CANNATA, intitulado Sul problema della responsabilità nel diritto privato romano, e publicado em dois volumes sucessivos da revista IURA: 43, de 1992 e 44, de 1993. Tais ensaios foram posteriormente (1996) reunidos pelo autor em um volume autônomo, também denominado Sul problema della responsabilità nel diritto privato romano - Materiali per um corso di diritto romano. Nesse caso, citam-se, entre parênteses, após a abreviatura do título, também as datas, do seguinte modo: C. A. CANNATA, Sul problema (1992) ou (1993) ou (1996) cit. (nt. 04 supra). Ainda que bastasse a citação do livro mais recente (1996), pareceu oportuna, dada a maior facilidade de se encontrarem os volumes da revista IURA, a indicação dos artigos nessa publicados. A citação, em alguns casos, não da última edição de uma obra, mas de uma anterior justifica-se em vista, principalmente, de traçar o escorço histórico-doutrinário, ou assinalar mudanças de orientação de um autor na mesma obra.

**** Cf. E. C. SilveIRA MARChI, Guia cit. (nt. ${ }^{*}$ supra), p. 203.
} 


\section{INTRODUÇÃO}

Sob a perspectiva das categorias dogmáticas de referência atuais, o tema estudado inserir-se-ia no âmbito do «problema da responsabilidade contratual», isso é, o dever de reparação do dano decorrente do inadimplemento imputável de uma obrigação oriunda, em regra, de um contrato ${ }^{1}$.

Tratar-se-ia de um «problema» que - disciplinado nas várias codificações civis modernas $^{2}$ - não teria sido estranho também à consideração dos juristas romanos, a seguir

\footnotetext{
1 «Responsabilidade», em geral, designaria a situação de um sujeito, Caio, contra o qual o ordenamento reconhece uma pretensão de outro sujeito, Tício, protegida por ação, por um dano sofrido por esse último. Essa pretensão de Tício correlacionar-se-ia com uma obrigação de Caio e, conforme o modo como se verifica tal correlação, costuma-se distinguir entre «responsabilidade contratual» e «responsabilidade extracontratual». A pretensão de Tício e, correspondentemente, a obrigação de Caio, surgiriam sempre de um fato danoso para o primeiro, assim qualificado seja por subtrair-lhe uma vantagem que lhe adviria do adimplemento de uma obrigação já existente a cargo de Caio, seja por violar um direito de Tício não decorrente, nesse caso, de uma relação jurídica pré-existente entre os sujeitos (como, v.g., a propriedade). Nessa última hipótese, a obrigação de Caio para com Tício nasceria do próprio fato danoso, contemporaneamente à sua responsabilidade, ou melhor, a obrigação surgiria já como «relação de responsabilidade» («rapporto di responsabilità») (obrigação de ressarcimento), verificando-se, nesse caso, o que se chama de «responsabilidade extracontratual», ou «aquiliana» ou ainda «responsabilidade civil».

No que concerne à primeira hipótese, o contrato (ou outra fonte obrigacional lícita) originaria, para o devedor, uma obrigação de proporcionar à contraparte certa vantagem, ou seja, incumbir-lhe-ia um dever de prestação; tornando-se essa impossível (hipótese-parâmetro), apresentar-se-ia, então, a situação de responsabilidade. Dado que a obrigação inadimplida tem por fonte, na maior parte das vezes, o contrato, denomina-se a responsabilidade que dela surge de «responsabilidade contratual». Cf. C. A. CANNATA, Sul problema della responsabilità nel diritto privato romano, in IURA 43 (1992), pp. 06-08; 21-22; ID., Sul problema della responsabilità nel diritto privato romano - Materiali per un corso di diritto romano, Catania, Torre, 1996, pp. 06-07; 10; ID., Responsabilità contrattuale nel diritto romano medievale e moderno, in Digesto IV - Discipline privatistiche - sezione civile 17 (1998), pp 67-68 e nt. 01; também, A. DI MAJO, Responsabilità contrattuale, in Digesto IV - Discipline privatistiche - sezione civile 17 (1998), pp. 25-27.
}

Como noção, portanto, a «responsabilidade» - e, logo, também aquela dita «contratual» - diria respeito à inobservância de um dever, fonte de um dano para o sujeito destinatário desse; por essa, seria o sujeito «responsável», isto é, deveria ele suportar todas as conseqüências das sanções ou, mais genericamente, dos remédios previstos pelo ordenamento. Cf. A. Di MAJO, Responsabilità cit. (nt. 01 supra), p. 25.

Ademais, tanto no caso da «responsabilidade extracontratual» quanto no da «responsabilidade contratual», para que Caio respondesse a Tício pelas consequências do fato danoso, seria necessária a possibilidade de esse fato ser imputado a Caio: por outros termos, não bastaria apenas a violação, em termos materiais, do dever. Limitadamente à «responsabilidade contratual», a operação resumir-se-ia ao problema da imputabilidade ao devedor do inadimplemento (qualificação que o fato danoso receberia nesse âmbito específico) - valeria dizer, da impossibilidade superveniente da prestação -, questão essa que seria resolvida com o emprego de critérios de imputação variáveis, nesse âmbito, segundo fatores como, v.g., o tipo de relação obrigacional, o regime do negócio delineado pelas partes. Cf. C. A. CANNATA, Sul problema (1992) cit (nt. 01 supra), p. 23; ID., Sul problema (1996) cit. (nt. 01 supra), pp.18-20; A. Di MAJO, Responsabilità cit. (nt. 01 supra), p. 25

2 À parte os dispositivos concernentes a cada espécie contratual em particular, cf., v.g., e principalmente, $\S \S 275-276$, BGB; arts. 1146-1147, C. civ. fr.; arts. 1176 e 1218, c.c. it., e uma síntese desses principais modelos de organização de um sistema de responsabilidade contratual em A. Di MAJO, Responsabilità cit. (nt. 01 supra), pp. 30-36. No que concerne ao sistema jurídico brasileiro nessa matéria - arts. 389, 392-393 CC (correspondentemente, arts. 1056-1058 CC de 1916) - cf., v.g., A. AlviM, Da Inexecução das 
a sugestão do material presente nas fontes jurídicas concernentes ao tratamento das conseqüências do não cumprimento da obrigação pelo devedor ${ }^{3}$.

Seria possível deduzir, das fontes romanas, uma visualização da responsabilidade contratual pela iurisprudentia de modo não unitário, nelas se delineando um sistema que seria a expressão de várias linhas de solução, conforme a variedade de gênese das relações obrigacionais, as várias épocas e os tipos de obrigação ${ }^{4}$.

O problema teria encontrado regulamentação ${ }^{5}$, primeiramente, na regra dos veteres sobre a perpetuatio obligationis, relativa ao oportere - oriundo, principalmente, de stipulatio ou de legado per damnationem ${ }^{6}$ - cujo objeto consistisse na dação de coisa específica (certam rem dare). Não se verificando essa em razão do perecimento da coisa por um factum promissoris, considerava-se «perpétua» (não extinta) a obrigação («...perpetuari obligationem»), superando-se, por esse esquema conceitual, a dificuldade oferecida pela efetiva inexistência da coisa, necessária para a condemnatio ${ }^{7}$.

No curso do século II a. C., ter-se-ia introduzido - ao lado da perpetuatio obligatonis, ainda válida em relação àquelas obrigações de dare certam $\mathrm{rem}^{8}$ - outra

Obrigações e suas Conseqüências, 4ª ed., São Paulo, Saraiva, 1972, pp. 01-02; 05-07; 261-262; 323-337, principalmente; F. C. PONTES DE MIRANDA, Tratado de direito privado XXII - Parte Especial - Direito das Obrigações - Obrigações e suas espécies - Fontes e espécies de obrigações, $3^{\mathrm{a}}$ ed., Rio de Janeiro, Borsoi, 1971, pp. 68-72.

3 Sobre a responsabilidade, em geral, como objeto de reflexão pela iurisprudentia romana, C. A. CANANTA, Sul problema (1992) cit. (nt. 01 supra), p. 02; ID., Responsabilità cit. (nt. 01 supra), p. 68. Acerca do modo como os juristas romanos compreendiam os fenômenos relativos às consequências jurídicas do inadimplemento, cf., v.g., M. SARGENTI, Problemi della responsabilità contrattuale, in SDHI 20 (1954), pp. $162-165$.

${ }^{4}$ Cf., v.g., V. ARANGIO-RUIZ, Responsabilità contrattuale in diritto romano, $2^{\mathrm{a}}$ ed., Napoli, Jovene, 1958 [reimpr., 1933], p. 09; 30; R. CARDILLI, L'obbligazione di «praestare» e la responsabilità contrattuale in diritto romano (II sec. a. C. - II sec. d. C.), Milano, Giuffrè, 1995, p. 507.

${ }^{5}$ Cf., v.g., M. KASER, Das römische Privatrecht I - Das altrömische, das vorklassische und klassische Recht, München, Beck, 1971, pp. 513-514 e nt. 02; M. TALAMANCA, Istituzioni di diritto romano, Milano, Giuffrè, 1990, pp. 660-661.

${ }^{6}$ Cf. M. TAlAMANCA, Istituzioni cit. (nt. 05 supra), p. 660; mais pormenorizadamente, C. A. CANNATA, Sul problema della responsabilità nel diritto privato romano, in IURA 44 (1993), pp. 10-18; ID., Sul problema (1996) cit. (nt. 01 supra), pp. 114-121.

${ }^{7}$ Cf. Paul. 17 ad Plaut., D. 45, 1, 91, 3; cf. R. CARDILli, L'obbligazione cit. (nt. 04 supra), p. 507.

${ }^{8} \mathrm{O}$ dogma da perpetuatio obligationis (deverbativo cunhado pelos romanistas) não se mostrava adequado em relação às obrigações de facere e, em geral, àquelas conexas com o diverso sistema das actiones incertae. Essa construção dogmática dos veteres representaria, de fato, a primeira fase da história dogmática dos problemas de responsabilidade e teria permanecido válido - para as stipulationes de dare certam rem e legado per damnationem - ao lado das novas formulações do pensamento jurídico, prova da consciência científica dos juristas romanos que, ao criar novos mecanismos de valoração, aptos para outras e novas relações obrigacionais, não teriam abandonado aquele mais adequado à estrutura de outras.

Assim, como observa C. A. CANNATA, se na física moderna, a teoria da relatividade representou um avanço em relação à física galileu-newtoniana, seria ainda às leis desta que se recorre quando se trata apenas de projetar a edificação de um casa, e não de lançar um satélite em órbita. Cf. Sul problema (1993) cit. (nt. 06 supra), p. 20; ID., Sul problema (1996) cit. (nt. 01 supra), p. 123.

A coexistência dessas várias perspectivas nos textos jurídicos romanos teria condicionado, ademais, a disciplina de algumas codificações modernas, na qual conviviriam sejam tendências sistemáticas - como os 
forma de valoração do inadimplemento das relações obrigacionais tuteladas, no plano do ius civile, em termos de oportere ex fide bona, e, no do ius honorarium, pela previsão direta da prestação devida nas fórmulas in factum, inovação essa assinalada pelo recurso ao verbo praestare ${ }^{9}$.

No que concerne, especificamente, a algumas dessas relações, das quais se originariam obrigações de conteúdo mais complexo (facere $)^{10}$, encontram-se, nas fontes romanas, textos ${ }^{11}$ que contêm um discurso mais geral, por assim dizer, acerca do regime de responsabilidade pelo inadimplemento ${ }^{12}$.

Nos vários contratos, responde-se por dolo e culpa (dolum et culpam praestare), encontrando a responsabilidade o seu limite no caso fortuito (casus a nullo praestantur). Tratar-se-ia, em suma, dos termos conformantes da regula iuris que a compilação justinianéia parece oferecer na matéria ${ }^{13}$, fazendo-se ainda presente, seja sob o plano normativo, seja sob o interpretativo ou sob ambos, no direito civil de países (europeus e latino-americanos) ligados à tradição romanística ${ }^{14}$.

Contudo, a atividade interpretativa das fontes romanas, principalmente a partir da Pandectística alemã, permitiu a individualização de soluções não enquadráveis no aludido «sistema subjetivo». Custodiam praestare, custodiae nomine teneri, empregadas em relação a alguns devedores, assumiram particular relevância por sugerir a existência de hipóteses nas quais se respondia pelo inadimplemento independentemente da $\mathrm{culpa}^{15}$.

arts. 1176 e 1218 do c.c. it., que consagram, respectivamente, o princípio culpam et diligentiam praestare, surgido nas relações do novum ius civile e do ius honorarium, e o princípio da impossibilitas, próprio do rem dare oportere, decorrente de stipulatio - sejam aspectos ligados à tipicidade. Cf. R. CARDILLI, L'obbligazione cit. (nt. 04 supra), p. 507. Sobre a interpretação das regras formuladas pelo Código Civil italiano, cf., v.g., A. Di MAJO, Responsabilità cit. (nt. 01 supra), p. 26; C. A. CANNATA, Le obbligazioni in generale, in P. RECIGNO (cur.), Trattato di diritto privato IX-1 - Obbligazioni e contratti, Torino, UTET, 1984, pp. 55-58; G. VISINTINI - L. CABELLA PISU, L'inadempimento delle obbligazioni, in P. RECIGNO (cur.), Tratatto di diritto privato IX-1 - Obbligazioni e contratti, Torino, UTET, 1984, pp. 155-236; entre nós, F. C. PONTES DE MIRANDA, Tratado de Direito Privado XXII cit. (nt. 02 supra), pp. 69-70.

${ }^{9}$ Cf. R. CARDILLI, L'obbligazione cit. (nt. 04 supra), p. 109; 507-509, principalmente.

${ }^{10}$ Cf. C. A. CANNATA, Sul problema (1993) cit. (nt. 06 supra), pp. 18-19; ID., Sul problema (1996) cit. (nt. 01 supra), pp. 121-123.

${ }^{11}$ Cf. coll. 10, 2, 1; Ulp. 28 ad Sab., D. 13, 6, 5, 2-4; e, sobretudo, Ulp. 29 ad Sab., D. 50, 17, 23.

${ }^{12}$ Cf. P. VocI, 'Diligentia', 'custodia', 'culpa' - I dati fondamentali, in SDHI 56 (1990), pp. 135-137.

${ }^{13}$ Cf. C. A. CANNATA, Sul problema (1992) cit. (nt. 01 supra), p. 01; ID., Sul problema (1996) cit. (nt. 01 supra), p. 01.

${ }^{14}$ Cf. R. CARDILli, Un diritto comune in materia di responsabilità contrattuale nel sistema giuridico romanistico, in Riv. dir. civ. a. 44, n. 3 (1998), p. 316; 328; 353-354 e infra (Parte I, Cap. II, 1.1), sobre a projeção in omne aevum dessa regula e de seus conceitos pela compilação e as suas vicissitudes na tradição jurídica romanística até o advento das codificações.

${ }^{15}$ Tal afirmação não implica reconhecer que, anteriormente, a existência de regulamentações dissonantes da regula (culpam praestare) não fosse sensível aos intérpretes, mas que - coerentemente ao método e às finalidades do estudo - teriam recorrido tais juristas a expedientes interpretativos com vistas a conferir homogeneidade ao sistema do Corpus Iuris Civilis examinado. Cf., v.g., R. CARDILLI, Un diritto comune cit. (nt. 14 supra), p. 328-329. 
Individualizou-se, assim, a «responsabilidade por custodia», expressão com a qual se traduziu a locução «custodiam praestare» dos textos jurídicos, e que designaria segundo a doutrina corrente nos principais manuais e enciclopédias - um critério objetivo de determinação da responsabilidade pelo inadimplemento devido a determinados eventos causadores do perecimento do objeto da prestação (precipuamente, o furto, mas também a fuga de escravos em alguns casos, e o dano ilicitamente causado por terceiros) ${ }^{16}$.

Esse regime teria aplicação em algumas hipóteses ${ }^{17}$ - mais ou o menos seguras como, v.g., a do comodatário, de certos conductores operis, como o tintureiro e o alfaiate (respectivamente, fullo e sarcinator), do transportador marítimo, estalajadeiro e locador de estábulos para animais ${ }^{18}$ (respectivamente, nauta, caupo e stabularius), do avaliador de bens (inspector), do guardião de armazéns (horrearius), do credor pignoratício e do vendedor $^{19}$.

Tais devedores, portanto, responderiam pela impossibilidade de restituição - à parte o caso do vendedor, obrigado à entrega - da coisa devida ocasionada por certos eventos, sem a possibilidade de eximir-se da responsabilidade mediante a prova da observância de todo cuidado e diligência ${ }^{20}$.

Dentre aquelas possíveis aplicações, uma das mais controversas seria a hipótese de reconhecimento de tal regime (custodiam praestare) no âmbito da compra e venda, mais precisamente, como um dos critérios de determinação da responsabilidade do vendedor ${ }^{21}$.

Por outros termos, parece ter sido apenas no âmbito de um setor da Pandectística alemã, no século XIX, que os esforços de sistematização do material justinianeu puseram em evidência um regime de responsabilidade por inadimplemento que não se subsumia por completo na regula iuris - culpam praestarecasus a nullo praestantur - que a compilação oferecia nessa matéria. Cf, mais detalhadamente, infra (Parte I, Capítulo II, 1.2).

${ }^{16}$ Cf., v.g., M. KASER, Das römische Privatrecht I cit. (nt. 05 supra), pp. 506-507; M. TALAMANCA, Istituzioni cit. (nt. 05 supra), p. 664; ID. Custodia, in ED 11 (1962), p. 562; G. I. LuZZATTO, Custodia, in NNDI 5 (1957), pp. 93-94.

${ }^{17}$ Tais relações obrigacionais nas quais haveria aplicação da custodia seriam, como nota M. TALAMANCA, sempre tutelados ou por iudicia bonae fidei ou por fomulae in factum conceptae. Cf. Custodia cit. (nt. 16 supra), p. 562.

${ }^{18}$ Cf. H. HeUmAnN - E. SeCKel, Stabularius, in Handlexikon zu den Quellen des römischen Recht, $11^{\mathrm{a}}$ ed., Graz, Akademische, 1957, p. 529 [reimpr. 1907]. Para a versão do termo em vernáculo parece essa perífrase preferível, pois que mais precisa juridicamente, a «dono de estábulo», como propõe, v.g., V. CÉSAR DA SILVEIRA, Stabularius, in Dicionário de Direito Romano II, São Paulo, Bushatsky, 1957, p. 634.

${ }^{19}$ Cf., v.g., M. KASER, Das römische Privatrecht I cit. (nt. 05 supra), p. 508.

${ }^{20}$ Por outros termos, considerar-se-ia responsável o devedor apenas pela verificação do modo como se deu a impossibilidade da prestação. Cf. M. TALAMANCA, Istituzioni cit. (nt. 05 supra), p. 664.

${ }^{21}$ Cf. E. RABEL, Custodia, in NDI 41 (1938), p. 511; E. VOLTERRRA, Istituzioni di diritto privato romano, Roma, La Sapienza, 1993, p. 504; 625; G. I. LuZzATTo, Custodia cit. (nt. 16 supra), p. 94; C. A. CANNATA, Ricerche sulla responsabilità contrattuale nel diritto romano, Milano, Giuffrè, 1966, p. 134, nt. 49; M. TAlamanCA, Custodia cit. (nt. 16 supra), p. 563; ID., Vendita (diritto romano), in ED 46 (1993), p. 448; M. KASER, Das römische Privatrecht I cit. (nt. 05 supra), p. 508 e nt. 39. 
O problema de responsabilidade pelo inadimplemento em geral, em relação ao vendedor, apresentar-se-ia no caso em que, diferido o cumprimento da obrigação de entregar a coisa, o objeto da prestação viesse a perecer ou deteriorar-se antes da sua tradição ao comprador ${ }^{22}$.

Se por um lado - no estado atual da doutrina romanística - não pareceria haver dúvidas de que estaria o vendedor obrigado a responder pela perda da coisa devido a um evento para a ocorrência do qual tenha havido dolo ou culpa de sua parte ${ }^{23}$, por outro, daria lugar a maiores problemas determinar se ele seria responsável tout court - com base na custodia - pelo inadimplemento devido a eventos como, v.g., o furto da coisa - valeria dizer, responsável independentemente de culpa ${ }^{24}$.

As dificuldades, à parte as diferenças estruturais entre o contrato de compra e venda e os demais em que se reconheceria a operatividade de custodiam praestare na determinação da responsabilidade do devedor ${ }^{25}$, adviriam, em grande medida, do quadro complexo oferecido pelas fontes jurídicas nessa matéria ${ }^{26}$.

Propõe-se a investigação do problema da responsabilidade por custodia no âmbito da compra e venda, a partir da individualização e estudo dos textos jurídicos da compilação justinianéia $^{27}$ no contexto dos quais for provável, ainda que ausente o dado textual («custodiam praestare» ou locuções similares), o envolvimento do instituto a influenciar, de algum modo, as soluções dos juristas.

Trata-se de uma análise que se justificaria, mais amplamente, pela importância do problema da responsabilidade por custodia na romanística em geral $^{28}$, e, sob a perspectiva

${ }^{22}$ Cf., v.g., M. MARrone, Istituzioni di diritto romano, Padova, Palumbo, 2006, p. 640; A. METRO, L'obbligazione di custodire nel diritto romano, Milano, Giuffrè, 1966, p. 187; M. KASER, Das römische Privatrecht I cit. (nt. 05 supra), p. 508.

${ }^{23}$ Cf. infra (Parte I, Capítulo III, 3).

${ }^{24}$ Cf. M. TAlamancA, Vendita cit. (nt. 21 supra), pp. 446-447, nt. 1499.

${ }^{25}$ Cf. V. ARANGIO-RUIZ, La compravendita in diritto romano II, Napoli, Jovene, 1956, p. 247 [reimpr. 1954]; M. TAlamanCA, Custodia cit. (nt. 16 supra), p. 563.

${ }^{26}$ Cf. M. TAlamancA, Vendita cit. (nt. 21 supra), p. 446; mais recentemente, M. SERRANO-VICENTE, Custodiam praestare - La prestación de custodia en el derecho romano, Madrid, Tébar, 2006, p. 263.

${ }^{27}$ Afirmação resultante do espólio das fontes úteis, em princípio, para a reconstrução da matéria, e não de uma delimitação prévia da base textual (Quellenlage) para o estudo. Cf. infra (Parte I, Cap. III, 5.2).

${ }^{28}$ Não obstante o fato de consistir em um dos temas clássicos na romanística européia, não recebeu, entretanto um tratamento monográfico nem no âmbito dos estudos jurídicos brasileiros, nem, aparentemente, nas investigações romanísticas em língua portuguesa em geral, limitando-se as informações concernentes a 
da delimitação ao contrato de compra e venda, por ser esse uma das sedes nas quais se verificam ainda maiores dúvidas quanto à aplicabilidade de custodiam praestare.

Nas monografias dedicadas ao tema da responsabilidade por custodia, os textos em matéria de compra e venda - por não se tratarem daqueles principais para a reconstrução geral da matéria como um todo - não constituem o centro da análise ${ }^{29}$. Por sua vez, o assunto também recebe algum tratamento nas investigações concernente a um tema confrontante, a saber, o periculum rei venditae, sendo apresentado, entretanto, já em sua aplicação particular, fora de uma contextualização conceitual de custodiam praestare $^{30}$.

Como proposta analítica, tem-se estudar o problema da responsabilidade por custodia do vendedor no direito romano como objeto principal, mediante o exame exegético dos textos relacionados, levando-se em consideração tanto os resultados mais recentes obtidos em matéria de reconstrução histórico-dogmática de custodiam praestare em geral quanto - dentro de certos limites - de periculum rei venditae ${ }^{31}$.

Objetiva-se, por esse modo, verificar os elementos que se poderiam individualizar para o delineamento de um quadro reconstrutivo - ainda que bastante fragmentário - da responsabilidade por custodia do vendedor no direito romano.

Divide-se a exposição em duas partes: grosso modo, na primeira, oferecem-se os subsídios indispensáveis para o enquadramento histórico-dogmático de custodiam praestare no direito romano; por sua vez, dedica-se a segunda parte ao tratamento do problema especificamente no âmbito da compra e venda (emptio venditio).

notas - nem por isso de menor importância - em sede manualística. Entre nós, v.g., E. CHAMOUN, Instituições de Direito Romano, $3^{\mathrm{a}}$ ed., Rio de Janeiro, Forense, p. 329; J. C. MoREIRA Alves, Direito Romano, $14^{\mathrm{a}}$ ed., Rio de Janeiro, Forense, 2007, pp. 409-411, principalmente [= § 207].

${ }^{29}$ Aparentemente, essa perspectiva parece fazer-se presente também no último estudo monográfico dedicado ao tema M. SERRANO-VICENTE, Custodiam praestare cit. (nt. 26 supra), pp.263-314.

${ }^{30}$ Cf., v.g., M. BAUER, Eine dogmengeschichtliche Untersuchung zur Gefahrtragung beim Kauf, Berlin, Duncker \& Humblot, 1998, pp. 59-63; 81-92; M. PENNITZ, Das periculum rei venditae - Ein Beitrag zum «actionerechtlichen Denken im römischen Privatrecht, Wien-Köln-Weimar, Böhlau, 2000, pp. 380-408. Tal verificação não assume, naturalmente, teor de crítica, uma vez que a responsabilidade por custodia não constitui o objeto de estudo, mas um aspecto secundário na consideração total do problema do periculum rei venditae, vale dizer, dos riscos de perecimento fortuito da coisa vendida antes da traditio.

${ }^{31}$ Por outros termos, tem-se por propósito conduzir uma investigação de custodiam praestare em um âmbito mais limitado - contrato de compra e venda (emptio venditio) -, sem prescindir dos elementos conceituais «gerais» do instituto. Pareceu-nos mais adequado proceder desse modo a fim de poder valorar, ao lume dessas noções mais gerais, os textos concernentes à responsabilidade do vendedor pelo inadimplemento, para a interpretação dos quais concorrem também as análises exegéticas - mais aprofundadas, muitas vezes - realizadas nos estudos dedicados ao tema confrontante já aludido. 
Principia-se pelo exame da terminologia das fontes jurídicas ${ }^{32}$, com base no qual se identifica o contexto técnico-jurídico de emprego da locução «custodiam praestare» pela iurisprudentia romana, passando-se, em seguida, à tentativa de precisar o seu significado pela análise mais detida dos termos que integram, em regra, a locução ${ }^{33}$.

Prossegue-se com a exposição das principais interpretações dessa pela doutrina romanística, estabelecendo-se no final, em torno dos textos fundamentais, as proposições da interpretação que se tem firmado atualmente na matéria ${ }^{34}$. Encerra-se essa secção com a apresentação dos aspectos fundamentais do contrato de compra e venda (emptio venditio), das principais dificuldades para o reconhecimento de um custodiam praestare a cargo do vendedor e das fontes em princípio úteis para a reconstrução da matéria ${ }^{35}$.

Além da seleção - e explicação dos critérios para tanto - desses textos, procedeuse, ainda na primeira parte , ao seu agrupamento para análise ${ }^{36}$, operação da qual resultou a estruturação dos capítulos e demais secções da segunda parte.

Seja pela presença da locução, seja pela correlação do Sachverhalt com problemas afeitos à responsabilidade por custodia, seja ainda pela inserção pelos estudiosos na respectiva discussão, o espólio das fontes compõe-se de textos referíveis ao período que medeia entre o final do século I a. C. e o século III d. C., à parte a difícil valoração de um texto das Institutas de Justiniano (3, 23, 3a).

Empregou-se - tendencialmente, ao menos - o critério cronológico na ordem de exame desses testemunhos das fontes romanas: parte-se, assim, dos textos referíveis à iurisprudentia tardo-republicana (Alfeno), seguindo-se aqueles atribuídos aos juristas do período adrianeu (Nerácio, Gaio, Celso e Juliano) e, sucessivamente, serveriano $\left(\right.$ Papiniano, Ulpiano e Paulo) ${ }^{37}$.

Por fim, fazem-se convergir os resultados parciais, obtidos a partir da análise dos textos em cada uma dessas secções, para a formulação das conclusões finais, com vistas a consentir, dentro de certos limites, uma valoração de conjunto dos elementos para a reconstrução histórico-dogmática do custodiam praestare do vendedor no direito romano.

\footnotetext{
${ }^{32}$ Segue-se, nesse ponto, a orientação metodológica de, dentre outros, A. METRO, ao adotar como ponto de partida o espólio das fontes relativas à custodia. Cf. L'obbligazione cit. (nt. 22 supra), p. 03.

${ }^{33}$ Cf. infra (Parte I, Cap. I).

${ }^{34}$ Cf. infra (Parte I, Cap. II).

${ }^{35}$ Cf. infra (Parte I, Cap. III).

${ }^{36}$ Cf. infra (Parte I, Cap. III, 5.2).

${ }^{37}$ Cf. infra (Parte II, Caps. I-III).
} 
(PARTE I)

«CUSTODIAM PRAESTARE» NO DIREITO ROMANO

FONTES, DOUTRINA E PROBLEMAS GERAIS

\section{CApítulo I \\ «CUSTODiam PRAESTARE» NAS FONTES JURÍdiCAS RoMANAS}

\section{1. «Custodela» como forma primitiva de «custodia»}

A seguir Festo, em obra situável na segunda metade do século II d. C. ${ }^{38}$, «custodela»seria uma forma arcaica de «custodia»: «custodelam dicebant antiqui, quam nunc dicimus custodiam» ${ }^{39}$. Esse vocábulo, com efeito, é empregado na literatura latina por Plauto, no século III a. C. ${ }^{40}$ e, no século II d. C. - como um arcaísmo -, por Apuleio ${ }^{41}$, assumindo, nesses autores, o significado de «guarda», «vigilância», «proteção» ${ }^{42}$.

No que concerne, por sua vez, às fontes jurídicas, a aparentemente única ${ }^{43}$ ocorrência de «custodela» dá-se nas Institutas de Gaio $(2,104)$, ao recordar o jurista, no

${ }^{38}$ Cf., v.g., R. HERZOG - P. L. SCHMIDT, Handbuch der lateinischen Literatur der Antike IV, München, Beck, 1997, p. 241; R. NicKEL, Lexicon der antiken Literatur, Düsseldorf-Zürich, Artemis \& Winkler, 1999, p. 261 .

${ }^{39}$ (= Os antigos chamavam de «custodela» aquela que agora nós chamamos de «custódia»). Cita-se de: W. M. LindSAY, Sextus Pompeius Festus - De verborum significatu quae supersunt cum Pauli epitome, Leipzig, Teubner, 1913, p. 44.

${ }^{40}$ Em Plauto ( 240 a. C. - 184 a. C.), os dois termos já coexistem: Capt. 457 («...ne quoquam pedem ecferat sine custodela»); Rud. 379-380 («si amabat, rogas, quid faceret? adservaret dies noctesque, in custodia esset semper»); 625 («...more antiquo in custodelam suom commiserunt caput...»); 696 («...in custodelam nos tuam ut recipias et tutere»); Merc. 233 («...visus sum in custodelam simiae concredere»); Most. 406 («in tuam custodelam meque et meas spes trado, Tranio»). Cf. F. CorRADINI (cur.), Custodela, in Totius latinitatis lexicon I, Padova, s. e., 1864, p. 956; J. MERTEL, Custodela, in ThLL IV, $5^{\text {a }}$ ed., München, Saur, 2007, p. 1554.

${ }^{41}$ Cf. met. 2, 22 («...'et quae, tu' inquam 'dic sodes, custodela ista feralis?'»); 7, 13 («et illas quidem divitas publicae custodelae comisere...»); 9, 1 («...et mediis lanii manibus ereptus, custodela salutaris mihi gaudebam carceris»); 9, 17 («hic uxorem generosam et eximia formositate praeditam mira custodela munitam domi suae quam cautissime cohibebat»); 10, 14 («...iamque curam diligentiorem et acriorem custodelam et dinumerationem adhibebant partium»). Cf. F. CORRADINI (cur.), Custodela, in Totius I cit. (nt. 40 supra), p. 956; J. MERTEL, Custodela, in ThLL IV cit. (nt. 40 supra), p. 1554.

A utilização de termos antiquados parece ser, ademais, recorrente em Apuleio ( 125 d. C. $-\sim 170$ d. C.). Cf., v.g., M. ALBRECHT, Geschichte der römischen Literatur - Von Andronicus bis Boethius II, München, Saur, 1992, p. 1156 e nt. 02, com indicação de literatura específica.

${ }^{42}$ Cf. J. PARIS, La responsabilité de la custodia en droit romain, Paris, Sirey, 1926, p. 04; G. C. J. J. VAN DEN BERGH, Custodiam praestare: custodia-liability or liability for failing custodia?, in TR 43 (1975), p. 63; R. ROBAYE, L'obligation de garde - Essai sur la responsabilité contractuelle en droit romain, Bruxelles, Saint Louis, 1987, pp. 14-15 e nts. 03-07.

${ }^{43}$ Trata-se do único texto indicado por H. HEUMANN - E. SECKEL, Custodela, in Handlexikon cit. (nt. 18 supra), p. 116, B. KÜBLER, Custodela, in VIR I, Berlin, Reimer, 1903, col. 1150; J. MERTEL, Custodela, in 
século II d. C., a fórmula do testamento per aes et libram: «...FAMILIAM PECUNIAMQUE TUAM ENDO MANDATELA TUA CUSTODELAQUE MEA 〈ESSE AIO EAQUE〉 ... » ${ }^{44}$.

Também nesse caso, «custodela» assumiria o sentido de «vigilância», «guarda», «cuidado» ${ }^{45}$, analogamente, portanto, à acepção primitiva de «tutela» ou «curatela» ${ }^{46}$, a saber, mero ato (ou série de atos) destinado à gestão ou proteção, não consistente em um dever jurídico propriamente dito ${ }^{47}$.

Por sua vez, «custodia», nas fontes jurídicas romanas, surge em variados contextos, e a seguir as divisões e classificações - mais ou menos convergentes - dos principais dicionários de vocábulos das fontes jurídicas latinas, seria possível individualizar tanto usos correspondentes a uma acepção geral (dita «atécnica») quanto empregos mais propriamente técnicos ${ }^{48}$

ThLL IV cit. (nt. 40 supra), p. 1554; explicitamente quanto a ser esse o único texto jurídico em que figura a palavra, A. METRO, L'obbligazione cit. (nt. 22 supra), p. 09, nt. 18; 84, nt. 195.

${ }^{44}$ Trata-se de um trecho cuja restituição textual é controversa: cf., v.g., P. KRÜGER - G. STUDEMUND, Gai Institutiones, $7^{\mathrm{a}}$ ed., Berlin, Weidmann, 1823, p. 65; J. ReINACH, Gaius institutes, Paris, Les Belles Lettres, 1950, p. 55, nt. 01; M. DAVID - H. L. W. NeLSON, Gai Institutionum Commentarii IV - Kommentar, Leiden, Brill, 1954, pp. 315-318. Transcreveu-se aquela prevalente nas várias edições (dentre as quais, também V. ARANGIO-RUIZ - A. GUARINO, Breviarium iuris romani, $6^{a}$ ed., Milano, Giuffrè, 1983, p. 74, nt. 01). Tratarse-ia da fórmula a ser pronunciada pelo emptor familiae dentre os ritos testamentários, realizados por imitação do velho direito («...propter veteris iuris imitationem...»), o que confirmaria, segundo R. ROBAYE, o arcaísmo de «custodela». Cf. L'obligation cit. (nt. 42 supra), p. 15.

${ }^{45}$ Cf. A. ERnout - A. MeILlet, Custos, in Dictionnaire étymologique de la langue latine - Histoire des mots, Paris, Klincksieck, 1939, p. 249; G. C. J. J. VAN DEN BERGH, Custodiam cit. (nt. 42 supra), p. 63; R. ROBAYE, L'obligation cit. (nt. 42 supra), p. 16.

Sobre a interpretação do trecho, mais detalhadamente, E. WEISS, Mandatela und custodela, in SZ 42 (1921), pp. 111-112, principalmente, do qual resulta a leitura de «custodela» como «Hüteverpflichtung»; aparentemente de acordo, também a tradução de J. REINACH: «te conservant ta famille et ta fortune en vertu d'un mandat et sous ma garde...»-Gaius institutes cit. (nt. 44 supra), p. 55; M. DAVID - H. L. W. NELSON, Gai Institutionum cit. (nt. 44 supra), p. 317: «...in einer mir zwecks Erfüllung eines Auftrags überlassenen Obhut»; M. KASER, Das römische I cit. (nt. 05 supra), p. 108 e nt. 26.

${ }^{46}$ Correlação estabelecida, em forma dubitativa («...d'après tutela?»), também por A. ERNOUT - A. MeILlet, Custos, in Dictionnaire cit. (nt. 45 supra), p. 249.

${ }^{47}$ Cf. J. PARIS, La responsabilité cit. (nt. 42 supra), p. 04; maiores reservas quanto à possibilidade de identificar o significado do termo com base nos demais vocábulos portadores do mesmo sufixo («-ela»), não obstante a sua intuição inicial por aquele de «poder sobre coisas», A. METRO, L'obbligazione cit. (nt. 22 supra), pp. 09-10.

${ }_{48}$ Consultaram-se, fundamentalmente, E. VOLKMAR, Custodia, in VIR I, Berlin, Reimer, 1903, cols. 1150-1153 (cujo plano é aquele fundamentalmente seguido no panorama das fontes a ser apresentado a seguir, dada a sua maior completude e articulação; também as siglas utilizadas, entre colchetes - v.g., «I.A»nas notas de rodapé correspondem às suas secções e subsecções), H. HEUMANN - E. SECKEL, Custodia, in Handlexikon cit. (nt. 18 supra), pp. 116-118, e também os estudos sobre a responsabilidade por custodia nos quais se dedica uma secção à análise terminológica, indicados oportunamente.

Dado que - como nota R. ROBAYE, L'obligation cit. (nt. 42 supra), p. 14 - o significado particular que um termo pode assumir na linguagem dos juristas não implica o total afastamento da terminologia jurídica daquela comum (atécnica), consultaram-se também as fontes latinas não jurídicas, a fim de estabelecer, quando possível, paralelos - ainda que em caráter exemplificativo - com os empregos do vocábulo nos textos jurídicos. Para tanto, empregou-se, principalmente, J. Mertel, Custodia, in ThLL IV, $5^{\text {a }}$ ed., München, Saur, 2007, pp. 1554-1560; de semelhante modo, ao se tratar das fontes não jurídicas, as siglas usadas (v.g., «I A» ou, mais precisamente, «I.A.1» etc.), nas notas de rodapé, entre colchetes, no final da citação, correspondem às repartições estabelecidas por esse autor no verbete aludido. 


\section{2. «Custodia» nas fontes jurídicas romanas}

Persegue-se, nessa sede, o escopo de individualizar os âmbitos de problemas jurídicos nos quais se verifica a utilização - verossimilmente técnica - do termo «custodia» para se fixar, dentre esses - como uma primeira aproximação - aquele setor que constituiria o objeto deste estudo.

\subsection{Significados atécnicos}

A seguir o elenco de E. VOLKMAR, «custodia», em sentido próprio e geral, designa a atividade de guarda, vigilância, exercida sobre determinadas coisas, tais como, v.g, argentum, nummus, carcer, domus, tabulae, templum, villa ${ }^{49}$.

Trata-se de uma acepção também recorrente nas fontes literárias ${ }^{50}$, mediante formulações variadas (seja utilizado o termo absolutamente, seja unido ao genitivo do

Nas notas de rodapé, buscou-se utilizar um critério diferenciado de citação: (a) fontes jurídicas: transcrição do trecho e, entre parênteses redondos, a indicação da fonte (segundo a numeração do índice filológico); (b) fontes não jurídicas: indicação da fonte e, entre parênteses redondos, a transcrição do trecho concernente ao problema estudado.

${ }^{49}$ Cf. «...custodiam argenti forte vel nummorum...»(Afr. 8 quaest., D. 47, 2, 62 [61], 7); «...carceris custodiam...» (Pomp. l. sing. enchir., D. 1, 2, 2, 30); «...operas custodiae domus ei indixerit...custodit domum...» (Gai. l. sing. de casib., D. 38, 1, 49) (também, coll. 10, 7, 4: «...idoneam custodiam domus...»); «...si custodiam tabularum aedituus...suscepit...»(Ulp. 68 ad ed., D. 43, 5, 3, 3); «servos ad custodiam templi reliquerat...» (Scaev. 19 dig., D. 34, 1, 17) (também Papin. 9 resp., D. 40, 12, 35: «servos ad templi custodiam...»); «...non solum ad cultum custodiamve villae...»(Ulp. 20 ad Sab., D. 33, 7, 12, 35); ademais, «...custodia alicuius rei...» (Gai. 5 ad ed. prov., D. 19, 2, 40) (também Ulp. 30 ad ed., D. 16, 3, 1 pr.: «...quod custodiendum alicui datum est...»). Além dessas construções com genitivo, identificam-se outras: «...ad custodienda ea, quae sine custodia salva esse non possunt...» (Ulp. 41 ad ed., D. 37, 9, 1, 25); «...et si custodia marito committitur...»(Ulp. 31 ad Sab., D. 23, 3, 9, 3); «...sola custodia et rerum...venditio committitur» (Hermog. 1 iur. epit., D. 26, 7, 48); «...nam desiderant tam villae quam agri custodiam...» (Pomp. 6 ad Sab., D. 33, 7, 15, 2); «plane si talem custodiam ea habitatio non habuit...» (Ulp. 1 ad ed. aed. cur., D. 21, 1, 17, 15); «... quam <custodiam>dominis...praestare...»(Ulp. 50 ad ed., D. 29, 5, 1 pr.); «... aedificare custodiae causa...» (Pomp. 5 ad Sab., D. 7, 1, 73); «...si quid custodiae causa fecit...» (Ulp. 61 ad ed., D. 29, 2, 20 pr.); «...qui custodiae gratia navibus praeponuntur...»(Ulp. 14 ad ed., D. 4, 9, 1, 3); «...tradere claves et anulum custodiae causa...» (Papin. 8 resp., D. 31, 77, 21); «...mandatum habens et custodiae legem» (Ulp. 30 ad ed., D. 16, 3, 1, 12); «...merces intervenit custodiae...» (Ulp. 30 ad ed., D. 16, 3, 1, 9); «...periculum custodiae praestare...» (Gai. 5 ad ed. prov., D. 19, 2, 40); «'tugurii' appellatione omne aedificium, quod rusticae magis custodiae convenit quam urbanis aedibus, significatur...» (Pomp. 30 ad Sab., D. 50, 16, 180 pr.); «...quod si operae eius servi cum custodia pensabantur...» (Ulp. 30 ad ed., D. 16, 3, 1, 9); «...nauta...mercedem accipiunt non pro custodia...» (Gai. 5 ad ed. prov., D. 4, 9, 5 pr.) (também Gai. 5 ad ed. prov., D. 19, 2, 40: «qui mercedem accipit pro custodia alicuius rei...»). Cf. VIR I cit. (nt. 48 supra), p. 1150 [= I.A].

$\mathrm{Na}$ legislação imperial, o termo também é usado nessa acepção: v.g., «...ac portuum perniciosa custodia...» (Hon. et Theod., C.Th. 7, 16, 1, de 408); «...parentum saepe custodiae nutricum...deluduntur...» (Const., C. Th. 9, 24, 1, 1, de 320); «...sub custodia protectorum...» (Grat., Val. et Theod., C. Th. 9, 27, 3, de 382); «...milites pro custodia locorum...» (Iust., C. 1, 27, 2, 3, de 534); «...et permaneat fida custodia» (Const., C. 9, 4, 1, 2, de 320); «...ac salutis publicae custodiam gerit...» (Val. et Valent., C. 9, 36, 2, 2, de 365); «...horreorum gerere custodiam...» (Valent. et Val., C. 12, 52, 2, de 373); Cf. A. METRO, L'obbligazione cit. (nt. 22 supra), pp. 11-12. 
objeto da atividade de custódia), e surge tanto em contextos mais gerais ${ }^{51}$ quanto naqueles atinentes a operações militares ${ }^{52}$.

\subsection{Significados técnicos}

«Custodia», em sentido próprio, apresenta-se também em contextos jurídicos mais específicos e assume significados como: (a) cuidado de certa coisa («cura rei») que o

${ }^{50}$ Cf. R. RoBAYE, L'obligation cit. (nt. 42 supra), pp .15-16; 18.

${ }^{51}$ Cf. v.g., PLAVT. Rud. 380 («...asservaret dies noctesque, in custodia esset semper»); 858 («post huc redito atque agitato hic custodiam»); CIC. epist. 15, 2, 6 («...regis...vitam...omni cura custodiaque defenderent...»); nat. deor. 2, 158 («canum vero tam fida custodia...»); SALL. epist. Mithr. 8 («Eumenem...habitum custodiae agri captivi...»); LIV. 23, 7, 3 («...plebs repente omnes comprehensos velut custodiae causa balneis include iussit...»); 28, 11, 6 («...caesa flagro est Vestalis cuius custodia eius noctis fuerat...»); 39, 51, 5 («... ex iis quosdam ocultos ne custodia saepirentur»); VERG. Aen. 7, 486 («...cui regia parente armenta et late custodia credita campi»); georg. 4, 165 («sunt quibus ad portas cecidit custodia sorti...»); 4, 327 («...frugum et pecudum custodia sollers»); HYG. fab. 202 («...at corvum qui custodiam praebuerat...»); OV. fast. 1, 119 («me penes est unum vasti custodia mundi...»); PETRON. 112 («itaque unius cruciarii parentes ut viderunt laxatam custodiam...»); PLIN. nat. 33, 5, 15 («...aedituum custodiae eius...»); TAC. ann. 13, 44 («...et Pontia consciae ancillae custodiam cubiculi mandat»); APVL. met. 2, 23 («...'ad custodiam mariti tui fidenter accessit’»). Cf. J. MeRTEL, Custodia, in ThLL IV cit. (nt. 48 supra), pp. 15541555 [= I.A e B.1]

${ }^{52}$ Cf. v.g., Cic. de orat. 2, 272 («...cum ille se custodiae causa diceret in castris remansisse...»); Phil. 7, 19 («idcirco in hac custodia et tamquam specula collocati sumus...»); 12, 24 («haec mea sedes est, haec vigilia, haec custodia, hoc praesidium stativum»); Tusc. 5, 58 («...et quibus convenis et feris barbaris corporis custodiam committebat»); CAES. civ. 1, 17, 3 («interim...certasque cuique partes ad custodiam urbis attribuit»); 1, 75, 2 («...quos suae custodiae causa habere consueverat...»); 2, 36, 3 («...et de custodia ac defensione urbis hortarentur»); 3, 25, 2 («...tanto erant alacriores ad custodias...»); 3, 39, 1 («...isdemque custodiam navium longarum tradidit...»); 3, 40, 1 («...navem, quae erat ad custodiam...posita»); BELL. Afr. 46, 4 («...cum longis navibus...custodiae causa in salo esse iusserat..»); BELL. Alex. 17, 6 («...custodia portus relicta naves...adplicarunt...»); SALL. Iug. 65, 2 («...item postea custodiae causa turmam equitum Romanorum...»); LIV. 1, 15, 8 («...trecentosque armatos ad custodiam corporis...»); 1, 43, 2 («seniores ad urbis custodiam...»); 2, 11, 2 («...castra posuit navibus undique accitis et ad custodiam...»); 5, 13, 1 («Anxur...receptum est... die festo custodiis urbis»); 5, 46, 9 («...per praeruptum eoque neglectum hostium custodia saxum...»); 7, 37, 13 («...custodiae et praesidii causa...»); 21, 11, 3 («...ad custodiam vinearum...dispositis»); 21, 49, 7 («...ad curam custodiae...»); 24, 37, 8 («...clavesque portarum et custodiam arcis...»); 25, 37, 6 («...subeuntes...in custodiam valli...»); 27, 15, 11 («...ad proditionem custodiae loci...»); 27, 15, 13 («...quique custodiam portubus habebant...»); 28, 1, 8 («ea stationibus, vigiliis, omni iusta militari custodia tuta et firma esse»); 28, 42, 22 («...ad custodiam urbis atque Italiae...»); 32, 26, 17 («...intentiorem custodiam habere...»); 33, 4, 2 («...neglegenter custodias servassent...»); 43, 10, 1 («...et modicum custodiae causae Cretensium praesidium»); 43, 22, 6 («claves portarum custodiamque murorum...»); 44, 31, 14 («...in custodiam...tribuno militum traditus...»); CVRT. hist. Alex. Magn. 5, 2, 16 («...praesidere arcis custodiae...»); 5, 4, 14 («...ad custodia castrorum...»); 8, 13, 18 («...ut a custodia huius opportunitatis oculos hostium averteret...»); VELL. hist. rom. 2, 72, 4 («...qui classi et custodiae maris praefuerat...»); FRONT. strat. 2, 2, 14 («...dum tota nocte in statione custodiae est»); 3, 10, 8 («qua visa cum omnia navigia quae pro custodia portus...»); 3, 11, 1 («...remissa urbis custodia...»); 3, 13, 2 («...diligenter Romanis...custodias agentibus»); TAC. hist. 3, 69, 4 («Vitellianus miles socordi custodia clausos circumdedit»); SVET. Iul. 68 («...custodiam portae commissi castelli retinuit»); Aug. 49 («...ceterum numerum partim in urbis partim in sui custodiam adlegit...»); Nero 21 («...militem positum ad custodiam aditus...»); Galba 12 («item Germanorum cohortem a Caesaribus olim ad custodiam corporis...»); APVL. mund. 26 («ante fores viri fortes...regalium laterum tutela pervigili custodiam...sustinebant»). Cf. J. MERTEL, Custodia, in ThLL IV cit. (nt. 48 supra), pp. 1555-1556 [= I.B.2]. 
devedor está obrigado a «praestare» ao $\operatorname{credor}^{53}$; (b) conservação («conservatio») ${ }^{54}$; (c) poder sobre coisas («potestas rei») ${ }^{55}$; (d) poder sobre pessoas (tais como réus, fugitivos, condenados $)^{56}$.

${ }^{53}$ Trata-se dos textos que deram suporte à identificação, nas fontes romanas, da «responsabilidade por custodia», objeto - delimitadamente ao contrato de compra e venda (emptio venditio) - da presente análise. Cf. infra (Parte I, Cap. I, item 2.3). Cf. E. VOLKMAR, Custodia, in VIR I cit. (nt. 48 supra), col. 1151-1152 [= I.B.1].

${ }^{54} \mathrm{Cf}$. «...qui in metu ruinae incendii...apud alium custodiae causa deponit» (coll. 10, 7, 3); «...ea autem, quae custodiae magis causa quod ad usus patris familias eo delata sunt...»(PS 3, 6, 39); «...quae ibi custodiae causa deposita sunt» (PS 3, 6, 44); «...et actorem custodiae causa in possessione rerum hereditariarum esse» (Iul. 1 dig., D. 5, 1, 27); «est enim iusta causa possidendi custodiae gratia» (Ulp. 20 ad ed., D. 10, 3, 7, 8); «...custodiae causa reponere in horreis...reposita sunt...» (Iavol. 2 ex Cass., D. 32, 84); «...sed si qua eo congesserat non usus ipsius causa, de custodiae gratia...» (Ulp. 20 ad Sab., D. 33, 7, 12, 29); «...si praesentis custodiae...thensauro depositum esset...» (Scaev. 3 resp., D. 34, 2, 39, 1); «...custodiae gratia possessio datur...» (Papin. 28 quaest., D. 36, 3, 5, 1); «...nec tam possessio rerum ei quam custodia datur... ut saltem taedio perpetuae custodiae extorqueat heredi cautionem» (Ulp. 52 ad ed., D. 36, 4, 5 pr.); «...si quis aliquid vel lucri causa...vel custodiae condiderit sub terra» (Paul. 31 ad ed., D. 41, 1, 31, 1); «...non possessionem, sed custodiam rerum et observationem concedit» (Paul. 54 ad ed., D. 41, 2, 3, 23); «...sed sunt in possessione custoidae causa» (Ulp. 69 ad ed., D. 41, 2, 10, 1); «...at si custodiae causa deponatur...»(Scaev. 2 ex Min., D. 41, 2, 39); «...pecuniam in terra custodiae causa condiderat» (Papin. 23 quaest., D. 41, 2, 44 pr.); «custodiae enim causa rem tenet» (Iul. 44 dig., D. 41, 5, 2 pr.); «...et placet interim eos in possessionem mittendos custodiae causa...» (Paul. 57 ad ed., D. 42, 4, 9, 1); «...sed magis custodiam et observationem nobis concedit...» (Pomp. 23 ad Q. Muc., D. 42, 4, 12); «...qui custodiae causa missi sunt in possessionem...» (Ulp. 69 ad ed., D. 43, 17, 3, 8). Cf. E. VOLKMAR, Custodia, in VIR I cit. (nt. 48 supra), p. 1152 [= I.B.2].

Também nas fontes literárias se encontrariam exemplos do termo nessa acepção: v.g., CiC. fin. 2, 113 («...inest ad humanam societatem iustitae fida custodia...»); 4, 27 («...appeteret etiam conservationem sui earumque rerum custodiam...»); off. 2, 78 («...ut sit libera et non sollicita suae rei cuiusque custodia»); leg. 2, 29 («...ut advigiletur facilius ad custodiam ignis...»); nat. deor. 2, 124 («tantam ingenuit animantibus conservandi sui natura custodiam»); 2, 145 («...ad incolumiatis custodiam»); Tuc. 2, 55 («...contentio; ea est sola officii tamquam custodia»); LIV. 5, 40, 8 («...quisve ea locus fideli asservaturus custodia esset...»); 6, 1, 2 («...una custodia fidelis memoriae rerum gestarum...»); 38, 1, 7 («...ubi custodia regiae pecuniae esse solita erat...»); VELL. hist. rom. 1, 4, 2 («sed illis diligentior ritus patrii mansit custodia...»); PLIN. nat. 7, 108 («... 'librorum Homeri custodiae detur'...»); SEN. benef. 6, 22, 1 («...et in custodiam universi disposita...»); 6, 43, 3 («quid custodiam recusamos?»); ColVM. 1, 6, 9 («...ut ex iis, quae sunt in plano, custodiam recipiant humidarom rerum...»); 7, 8, 1 («...longiorem patitur custodiam»); PETRON. 102 («...qui scaphae custodiam tenet»); QVINT. inst. 6, 1, 20 («nam et cautiores ad custodiam suae religionis iudices facit...»). Cf. J. MERTEL, Custodia, in ThLL IV cit. (nt. 48 supra), pp. 1556-1557 [= II.B].

${ }^{55}$ Cf. «...custodiam nostram evaserit...» (Gai. 2, 67); «...in custodia bonorum esse ...» (Ulp. 41 ad ed., D. 37, 9, 1, 17); «...custodiamque ei afuturus tradidit» (Paul. 10 ad Sab., D. 39, 2, 38 pr.); «cum vero evaserit custodiam nostram...» (Gai. 2 rer. cott., D. 41, 1, 3, 2); «...quia non sit sub custodia notra...» (Paul. 54 ad ed., D. 41, 2, 3, 3); «...res mobiles... quatenus sub custodia nostra sint...» (Paul. 54 ad ed., D. 41, 2, 3, 13); «...custodiae nostrae aves subiectae...» (Gai. 2 rer. cott., D. 41, 2, 3, 15); «...quod rerum mobilium neglecta atque omissa custodia...» (Papin. 26 quaest., D. 41, 2, 47); «...quia nihil interest, utrum mihi an et cuilibet iusserim custodia tradatur» (Iavol. 5 post., D. 41, 2, 51); «...vel usum fructum vel custodiam habuit...» (Ulp. 69 ad ed., D. 43, 16, 1, 33). Cf. E. VOLKMAR, Custodia, in VIR I cit. (nt. 48 supra), col. 1152 [= I.B.3].

Nesses empregos, dar-se-ia a inserção de «custodia» na teoria da posse, no âmbito da qual exerceria um papel relevante no problema de sua aquisição e - principalmente - de sua conservação. Mais precisamente, seria ela um modo particular de manifestação do elemento material da posse, podendo consistir seja na detenção física (forma típica), ou em uma situação mais ampla, capaz de assegurar a um sujeito a potencialidade da detenção material de certa coisa. Cf. A. METRO, L'obbligazione cit. (nt. 22 supra), p. 29; 36; 43; 48-49 (principalmente); 74-76.

${ }^{56}$ Cf. «...in vinculis custodiaque publica erit...» (coll. 9, 2, 2); «...ludum custodiamve coniecti fuerint...» (Gai. 1, 13); «plane si vinculis vel custodia militari impeditus...»(Ulp. 74 ad ed., D. 2, 11, 4, 1); «quod non solum ad eum pertinent, qui publica custodia coercetur...» (Call. 2 ed. mon., D. 4, 6, 9); «...nec in custodia nec in vinculis sit...» (Ulp. 12 ad ed., D. 4, 6, 28, 1); «diligens custodia etiam vincere permittit» (Ulp. 1 ad ed., D. 11, 4, 1, 7); «...stationarii fugitivos deprehensos recte in custodiam retinent» (Paul. 1 sent., D. 11, 4, 
Reconhece-se, ainda, um uso técnico-jurídico nas ocorrências em que o vocábulo é referido à (e) custodia ventris e custodia partus ${ }^{57}$.

Verificam-se também nas fontes jurídicas algumas utilizações metafóricas de «custodia» - com paralelos nas fontes literárias - nos casos em que ela designa (metonimicamente) seja o prisioneiro (isso é, o sujeito posto «sob custódia») ${ }^{58}$, seja o

4); «...quive in vinculis custodiave publica erit...»(Call. 4 de cognit., D. 22, 5, 3, 5); «...post accusationem in custodia fuerit defunctus indemnatus...» (Ulp. 45 ad ed., D. 28, 1, 9); «...licet in carcere soleant diligentioris custodiae causa recipi» (Ulp. 10 ad Sab., D. 28, 3, 6, 7); «...de carcere vel custodia dimitteret...» (Ulp. 27 ad ed., D. 47, 2, 52, 12); «...qui in eadem custodia errant...» (Ulp. 8 de off. proc., D. 47, 18, 1 pr.); «de custodia reorum proconsul aestimare solet...» (Ulp. 2 de off. proc., D. 48, 3, 1); «...custodiam vel ferrum...in carcerem inferri passus est...» (Paul. l. sing. de poen. mil., D. 48, 3, 8); «...homo, qui ex custodia producitur...»(Cels. 37 dig., D. 48, 3, 11 pr.); «...dies, quos in custodiam fecisset»; «...quis in custodia fuit...» (Papin. l. sing. de adult., D. 48, 5, 12 [11], 5); «...sine accusatoribus in custodiam recepti sunt...» (Paul. 1 sent., D. 48, 18, 22); «...nisi si quis ex vinculis vel cutodia detentus...» (Call. 6 de cognit., D. 48, 19, 28, 7); «...in custodiam receptus secum attulit» (Ulp. 10 de off. proc., D. 48, 20, $6)$; «...qui in custodia vel in vinculis vel compedibus decesserunt...» (Paul. 5 sent., D. 49, 14, 45, 1); «...cum sub custodia vel in carcere esset...» (Mac. 2 de re milit., D. 49, 16, 13, 5); "vinculorum' appellatione vel privata vel publica vincula significant, 'custodiae' vero tantum publicam custodiam» (Ven. 7 stipul., D. 50, 16, 224). Cf. E. VolKMAR, Custodia, in VIR I cit. (nt. 48 supra), col. 1152-1153 [= I.B.4].

${ }^{57}$ Cf. G. C. J. J. VAN DEN BERGH, Custodiam cit. (nt. 42 supra), p. 64; R. ROBAYE, L'obligation cit. (nt. 42 supra), p. 16 e nt. 19. «Custodia ventris» e «custodia partus» não são expressões utilizadas nas fontes; nessas, empregam-se formulações como, v.g., ventrem custodire, partum custodire. Com efeito, no VIR I, estes textos são apresentados no verbete «custodio»(I.2): «qui in utero est, perinde ac si...custoditur...» (Paul. l. s. de port., q. lib. Dam., D. 1, 5, 7); «...quod ventrem custodierit» (Ulp. 34 ad ed., D. 25, 3, 1, 11); «...ad ventrem custodiendum...»(Ulp. 34 ad ed., D. 25, 3, 1, 12); «...de inspiciendo custodiendoque partu...qui ventrem custodiant» (Ulp. 24 ad ed., D. 25, 4, 1, 10); «...ne venter inspiceretur aut partus custodiretur» (Iul. 24 dig., D. 25, 4, 2, 1); «...et partum custodire permittendum sit» (Scaev. 20 dig., D. 25, 4, 4). Cf. E. Volkmar, Custodio, Berlin, Reimer, 1903, cols. 1153 [= I.2]. Em suma, essas locuções, aparentemente, resultam de um deverbativum, analogamente a «perpetuatio obligationis». Cf. supra (Introdução).

Tratar-se-ia de institutos aos quais se dedicam dois títulos do Digesto (D. 25, 3 e D. 25, 4): a partir de Ulp. 24 ad ed., D. 25, 4, 1, 10, tem-se notícia de um edito pretório, da época adrianéia, no qual se continham regras tedentes a evitar a simulação de gravidez e a substituição de recém-nascido por parte da viúva - com vistas aos direitos sucessórios - logo após a morte do marido. Conformavam-se três principais figuras jurídicas: a inspectio ventris, a custodia ventris e a custodia partus. A segunda consistia em uma atividade destinada à vigilância do quarto da mulher durante o último mês de gravidez; a última, na assistência ao parto, incumbente a algumas mulheres livres. Cf. A. BERGER, Inspicere ventrem, in Encyclopedic Dictionary of Roman Law, Philadelphia, The American Philosophical Society, 1953, p. 504; A. METRO, L'obbligazione cit. (nt. 22 supra), pp. 13-18; sobre a terminologia das fontes («venter», «partus»), cf. os respectivos verbetes de H. HeumanN - E. SeCKel, Handlexikon I (cit. 18 supra), pp. 407-408; 618; H. M. FranÇA MAdEIRA, $O$ Nascituro no Direito Romano - Conceito, Terminologia e Princípios, São Paulo, Companhia Edotra Nacional, 2005, pp. 13-49.

${ }^{58}$ Cf. v.g., «...miles custodiam dimiserit...»; «qui custodiam militi prosequenti magna manu excusserunt capite puniuntur...»(PS 5, 31, 1-2); «...ut preauditas custodias...»(Ulp. 1 de off. proc., D. 1, 16, 6 pr.); «inter quae custodiarum quoque cognitionem esse» (Ulp. 7 de off. proc., D. 2, 12, 9); «cum praeses...aut custodiis...fuerit ocupatus» (Ulp. 49 ad ed., D. 38, 15, 2, 2); «...custodias audiri posse rescriptum est...» (Mod. 3 de poen., D. 48, 1, 12, 1); «ne quis receptam custodiam...dimmitat...»(Ven. 2 de off. proc., D. 48, 3, 10); «milites si amiserint custodias...»; «...custodia militibus evaserit...»; «...quibus custodiae evaserint...»; «...qui custodiam dimmisit...»(Call. 5 de cognit., D. 48, 3, 12 pr.-1); «...levis persona custodiae fuit... custodiam quis dimiserit...cum custodia cum altero custode simul fugisset...» (Mod. 4 de poen., D. 48, 3, 14, 2); «...sed si se custodia interfecit vel praecipitaverit...»(Mod. 4 de poen., D. 48, 3, 14, 3.); «...si casu custodia defuncta dicatur...» (Mod. 4 de poen., D. 48, 3, 14, 5); «...custodia, si tamen intersit eam adprehendi...» (Mod. 4 de poen., D. 48, 3, 14, 6.); «...facere custodias se auditurum...»; «...et proferantur custodiae...» (Paul. 5 sent., D. 48, 18, 18, 9); «...in custodiis gradum servandum esse...» (Call. 6 de cognit., D. 48, 19, 28, 14). Cf. E. VolKMAR, Custodia, in VIR I cit. (nt. 48 supra), col.1153 [= II.A]. 
guardião (o custódio $)^{59}$, ou ainda o local ${ }^{60}$ em que se exerce a atividade de vigilância ou guarda (o cárcere) ${ }^{61}$.

Também nas fontes literárias: SEN. epist. 5, 7 («...eadem catena et custodiam et militem copulat...»); dial. 9, 11, 12 («Ptolemaeum...inter Gaianas custodias vidimus»); PLIN. epist. 10, 19, 1 («...quod usque adhuc factum, na per milites adservare custodias debeam»); SVET. Tib. 61 («et in recognoscendis custodiis precanti cuidam...respondit...»); APVL. Socr. 16 («...et trahere veluti custodiam suam ad iudicium...»). Cf. J. MERTEL, Custodia, in ThLL IV cit. (nt. 48 supra), pp. 1558-1559 [= III.A.2]

${ }^{59} \mathrm{Cf}$. «reos sane accipiat vinciatque custodia et excubiis sollertibus vigilanter observet» (Grat., Val. et Theod., C. Th. 9, 40, 13, de 382 [390?]); «...si acervum lignorum emero et eum venditor tollere me iusserit, simul atque custodiam posuissem, traditus mihi videtur» (Iavol. 5 ex post Lab., D. 41, 2, 51). Cf., Cf. E. VOLKMAR, Custodia, in VIR I cit. (nt. 48 supra), col.1153 [= II.B]; também, J. MERTEL, Custodia, in ThLL IV cit. (nt. 48 supra), p. 1558 [= III.A.1.b].

Quanto às fontes não jurídicas: Plavt. Capt. 254 («...vinclis cutodiisque circummoeniti sumus»); CATVLL. carm. 62, 33; («namque tuo advento vigilat custodia semper»); CAES. Gall. 2, 29; 4 («...impedimentis...custodiam ex suis ac praesidio...reliquerunt»); 7, 27, 1 («...custodias in muro dispositas...»); 7, 55, 9 («...praesidia custodiasque...disponere...»); civ. 1, 59, 2 («....custodias stationesque equitum vitabant...»); 2, 19, 3 («...custodias vigiliasque...disposuit...»); 3, 25, 4 («...a custodiis classium loca...vacabant...); 3, 101, 2 («...nullis custodiis neque ordinibus certis...»); BeLL. Afr. 7, 2 («....centurionibus ad portas oppidi et custodiis impositis...»); BELL. Alex. 13, 1 («....custodiae exigendi portorii causa dipositae»); LIV. 5, 46, 8 («...per hostium custodias...»); 26, 46, 2 («...ulla armatorum statio aut custodia opposita...»); Тів. 1, 2, 5 («nam posita est nostrae custodia saeva puellae»); 2, 4, 33 («sed pretium si grande feras, custodia victa est»); PROP. 2, 18, 35 («ipse tuus semper tibi sit custodia lectus»); CIc. Catil. 1, 8 («...coloniam...praesidiis, custodiis, vigiliis..munitam?»); 2, 26 («...vestra tecta vigiliis custodiisque defedite»); 4, 8 («horribiles custodias circumdat...»); Marcell. 32 («...non modo excubias et custodias sed etiam...pollicemur»); Att. 14, 5, 2 («...orbis terrae custodiis non modo saepti...»); Verg. Aen. 6, 574 («cernis, custodia qualis vestibulo sedeat...»); Ov. met. 6, 572 («fugam custodia claudit...»); 8, 684 («unicus anser erat, minimae custodia villae»); 12, 148 («dumque vigil Phrygios servat custodia muros»); trist. 3, 14, 41 («custodia muri summovet infestos clausaque prota Getas»); VelL. 2, 88, 2 («...urbis custodiis praepositus...»); PLIN. nat. 5, 2 («...dracones custodiae instar fuisse...»); 21, 9 [12] («...inductam custodiam bibere iussit...»); SEN. contr. 2, 5, 4 («ubi custodiae cessant?»); 2, 7, 3 («in has servandae integritatis custodias nulla libido inrumpet»); SEN. epist. 70, 23 («cum adveheretur nuper inter custodias quidam ad matutinum spectaculum...»); TAC. hist. 3, 59 («...locorum custodias Vitellii elapsum»); ann. 1, 28 («hi vigiliis, stationibus, custodiis portarum se inserunt...»); 12, 68 («...cunctos aditus custodiis clauserat...»); 14, 25 («...ne Euphraten transgressi hostium custodiis circumvenirentur...»); SVET. Iul. 86 («...custodias Hispanorum...se removisse»); Aug. 65 («....saepsitque insuper custodia militum»). Cf. J. MERTEL, Custodia, in ThLL IV cit. (nt. 48 supra), p. 1558 [= III.A.1].

${ }^{60}$ Recordado por H. HeumanN - E. SeCKel, Custodia, in Handlexikon cit. (nt. 18 supra), p. 118; Cf. J. MERTEL, Custodia, in ThLL IV cit. (nt. 48 supra), pp. 1559-1560 [= III.B]; contrário a uma categoria autônoma, nesse caso, uma vez que inseríveis naquela de «detenção carcerária» em geral (assinalada, supra, como «poder sobre pessoas»), A. METRO, L'obbligazione cit. (nt. 22 supra), pp. 28-29, nt. 54.

${ }^{61}$ Cf. v.g., «...quive in vinculis custodiaque publica erit...» (coll. 9, 2, 2); «...inve ludum custodiamque coniecti fuerint...» (Gai. 1, 13); «...vel in ludum vel custodiam coniecti fuerunt...» (Ulp. reg. 1, 11); «...nec in custodia nec in vinculis sit...» (Ulp. 12 ad ed., D. 4, 6, 28, 1); «...recte in custodiam retinent» (Paul. 1 sent., D. 11, 4, 4); «...quive in vinculis custodiave publica erit...» (Call. 4 de cogn., D. 22, 5, 3, 5); «...post accusationem in custodia fuerit defunctus indemnatus...» (Ulp. 45 ad ed., D. 28, 1, 9); «...de carcere vel custodia dimitteret...») (Ulp. 37 ad ed., D. 47, 2, 52, 12); «...custodiam vel ferrum....inferri passus est...» (Paul. l. sing. de poen. milit., D. 48, 3, 8); «...homo, qui ex custodia producitur...» (Cels. 37 dig. D. 48, 3, 11 pr.); «...in custodiam fecisset»; «...in custodia fuit...» (Papin. l. sing. de adult., D. 48, 5, 12, 5); «...in custodiam recepti sunt...» (Paul. 1 sent., D. 48, 18, 22); «nisi si quis ex vinculis vel custodia detentus...» (Call. 6 de cogn., D. 48, 19, 28, 7); «...quae in custodiam receptus secum attulit» (Ulp. 10 de off. proc., D. $48,20,6)$; «bona eorum qui in custodia vel...decesserunt...» (Paul. 5 sent., D. 49, 14, 45, 1); «...quia custodiae refuga...» (Macer 2 de re milit., D. 49, 16, 13, 5); «'tugurii' appellatione omne aedificium, quod rusticae magis custodiae convenit quam urbanis aedibus, significatur» (Pomp. 30 ad Sab., D. 50, 16, 180); "'vinculorum' appellatione vel privata vel publica vincula significant, 'custodiae' vero tantum publicam custodiam» (Venul. 7 stipul., D. 50, 16, 224). Cf. supra, nt. 60.

De semelhante modo, nas fontes não jurídicas: v.g., PLAVT. Poen. 1365 («ut sis apud me lignea in custodia»); CIC. ad Q. fr. 1, 2, 14 («...hominem comprehendit et in custodiam Ephesi tradidit...»); div. 1, 52 («...Socrates, cum esset in custodia publica...»); fin. 5, 53 («...multi in custodia, multi in exsilio dolorem 
Por fim, outro emprego figurado de custodia - mais freqüentemente, contudo, de «custodire» ${ }^{62}-$ seria aquele correspondente à idéia de «observância»e «respeito» às leis, constituições imperiais ou costumes ${ }^{63}$.

suum doctrinae studiis levarunt»); Lael. 14 («animus...evolet tamquam e custodia vinclisque corporis...»); Tusc. 1, 71 («...cum facile posset educi e custodia...»); 1, 118 («...emittique nos e custodia et levare vinclis...»); CAES. civ. 3, 104, 3 («...Lentulus comprehenditur ab rege et in custodia necatur»); BELL. Hisp. 26, 2 («servi indicio omnes in custodiam esse coniectos»); SALL. Catil. 50, 3 («...qui in custodiam traditi erant»); 50, 4 («...qui in custodiis tenebantur...»); CVRT. 6, 5, 10 («...quos tradi in custodiam iussit»); 8, 3, 17 («...ad se in custodiam mitteret»); VELL. 2, 42, 3 («...mandatisque custodiae quos ceperat...»); SEN. epist. 26, 10 («quid ad illum carcer et custodia et claustra?»); 65, 16 («subducit...se custodiae, in qua tenetur...»); dial. 9, 10, 3 («eadem custodia universos circumdedit...»); 9, 16, 3 («existi ex custodia»); ColvM. 1, 8, 16 («...an ipsae sedes custodiae satis tutae munitaeque sint...»); QVINT. inst. 2, 17, 20 («...e custodia ut mulier evasit...»); LIV. 26, 16, 6 («...allii per...urbes in custodias dati...»); 30, 43, 5 («...qui capti in publica custodia essent»); TAC. ann. 3, 36 («...donec accitam...attineri publica custodia iussit»); APVL. met. 7, 2 («...in publicam custodiam receptum...»); SVET. Cal. 29 («...ex custodia subscribens rationem se purgare dicebat»; Vit. 2 («...in custodiam fratri datus...»). Cf. J. MERTEL, Custodia, in ThLL IV cit. (nt. 48 supra), pp. 1559-1560 [= III. B e C].

${ }^{62}$ Cf. E. VOlKMAR, Custodio, in VIR I cit. (nt. 57 supra), col. 1154 [= II.3].

${ }^{63}$ Cf. A. Metro, L'obbligazione cit. (nt. 22 supra), pp. 05-06; G. C. J. J. VAN DEN BerGH, Custodiam cit. (nt. 42 supra), p. 64; R. ROBAYE, L'obligation cit. (nt. 42 supra), p. 16 e nt. 18.

Cf., v.g., «sed in ceteris quoque partibus iuris ista regula custoditur...» (coll. 10, 2, 2); «idem iuris in intinere et actu custodiendum esse ait Labeo...» (Iavol. 3 ex post., D. 7, 4, 24, 1); «...sciet se formam ac statum antiquorum aedificiorum cutodire debere» (Ulp. 1 de off. cons., D. 8, 2, 11, 1); «idem et de itinere custoditur» (Paul. 13 ad Plaut., D. 8, 6, 7); «omni enim modo custodiri debet iusiurandum...» (Paul. 18 ad ed., D. 12, 2, 26 pr.); «diligenter igitur fines mandati custodiendi sunt...» (Paul. 32 ad ed., D. 17, 1, 5, 1); « «propter domini enim, inquit, securitatem custoditur lex, ne periculum subeat»(Ulp. 32 ad ed., D. 18, 7, 1); «...custodiri id pactum debet»(Iul. 18 dig., D. 23, 4, 18); «idemque custoditur in his, qui praefecturam annonae vel vigilum gerunt» (Hermog. 2 iur. epit., D. 27, 1, 41, 1); «...si ius legitimarum hereditatium integrum inter eos custodiri velit» (Flor. 10 inst., D. 28, 6, 37); «...emancipando filios obsecutus voluntati supremum iudicium uxoris suae custodiri voluit» (Papin. 16 quaest., D. 35, 1, 70); «quod enim re integra custoditur, hoc non inique etiam post ruinam aedium praestabitur» (Ulp. 53 ad ed., D. 39, 2, 9 pr.); «idque custoditur et si delegante eo...»(Hermog. 6 iur. epit., D. 39, 5, 33, 3); «...quae circa emptores custodiri solent» (Pomp. 7 epist., D. 40, 5, 20); «sed et generi posterisque datae custodiaeque ad eos, qui ex feminis nati sunt...»(Ulp. 3 opin., D. 50, 6, 1, 2). Cf. E. VOLKMAR, Custodio, in VIR I cit. (nt. 57 supra), col. 1154 [= II.3].

Tal emprego é, ademais, recorrente na legislação imperial: «quam legem in annotationibus quoque nobis de iterando post sententiam iudicio custodire debebis» (Const., C.Th. 1, 5, 3, de 331); «sane hanc distinctionem volumus custodiri...» (Theod. et Val., C.Th. 4, 10, 3, de 426); «quam legem et de praesterito custodiri oportet» (Const., C.Th. 4, 12, 1, de 314); «in honoribus hunc ordinem volumus custodiri...» (Grat.Val. et Theod., C.Th. 6, 22, 7, de 383); «quem ordinem...conveniet custodiri» (Val., Valent. et Grat., C.Th. 7, 13, 7, de 375); «legem nostrum...volumus custodiri» (Val., Theod. et Arc., C.Th. 8, 11, 5, de 389); «...et nostra debent custodire mandata» (Const., C.Th. 10, 4, 1, de 313); «...norma legis antea promulgatae in ceteris omnibus custodita» (Theod. et Val., C.Th. 10, 10, 34, de 430); «...haec tempora custodienda sunt...» (Hon. et Theod., C.Th. 11, 31, 9, de 423); «antiquam...consuetudinem laudabilitas tua praecipiat custodiri...» (Arc. et Hon., C.Th. 12, 1, 166, de 400); «...qui divina praecepta custodiant» (Hon. et Theod., C.Th. 16, 5, 54, de 414); «pactum...praeses provinciae secundum ius custodiri efficiet» (Diocl. et Max., C. 2, 3, 17, de 286 ); «...ut Leoniana constitutio....et non solum ea immutilata custodiatur...» (Iust., C. 5, 3, 20, 7, de 531533); «...omnia iura, quae ex Theodosiana vel mostra lege descendunt, immutilata custodiantur» (Iust., C. 5, 13, 1, 16 a, de 530); «...praeses provinciae...in dirimenda disceptatione legum placita custodiet» (Diocl. et Max., C. 8, 10, 5, de 290); «nam et consuetudo praecedens et ratio quae consuetudinem suasit custodienda est...» (Alex., C. 8, 52, 1, de 224); «quae regula...custodienda erit» (Grat., Val. et Theod., C. 9, 49, 8, 2, de 380); «...nisi statuta fuerint custodita»(Grat., Val. et Theod., C. 12, 59, 3, 2, de 386). Cf. A. METRO, L'obbligazione cit. (nt. 22 supra), p. 06, nt. 07.

Não faltariam exemplos dele também nas fontes literárias: QVINT. inst. 11, 1, 57 («nescio...decoris custodia ...examinanda sit»); decl. 306, p. 201, 18 («...minorque fuerit verborum custodia cum intellecturi non timebantur»); TERT. adv. Val. 4, 3 («...Axionicus memoriam Valentini integra custodia regularum eius consolatur»). Cf. J. MeRTEL, Custodia, in ThLL IV cit. (nt. 48 supra), p. 1557 [= II.C]. 
Abstraindo-se, por ora, dos usos do termo no contexto de problemas relacionados ao direito das obrigações, a todas essas ocorrências de «custodia» nas fontes jurídicas estaria subjacente o significado - próprio e basilar - de «guarda», «viligância» ${ }^{64}$.

\section{3. «Custodia» no direito das obrigações: «custodiam praestare»}

Dentre os empregos técnicos do termo, individualizou E. VOLKMAR uma categoria - assinalada, supra, como «(a)»- de usos no sentido de guarda da coisa («cura rei») que o devedor está obrigado a «praestare» ao credor. Nos textos integrantes desse grupo, «custodia» equivaleria, em alguns, a «diligentia in custodiendo» ${ }^{65} \mathrm{e}$, em outros, manterse-ia autônoma em relação à «diligentia» ${ }^{66}$.

Em ambos os casos, tratar-se-ia de ocorrências do termo no âmbito do direito das obrigações $^{67}$, relacionadas a algumas figuras contratuais ${ }^{68}$, como, v.g., (a.1) compra e venda $^{69}$; (a.2) locação ${ }^{70}$; (a.3) sociedade $^{71}$; (a.4) $\operatorname{mandato}^{72}$; (a.5) $\operatorname{comodato}^{73}$; (a.6) depósito $^{74} ;$ (a.7) penhor $^{75}$ e (a.8) «outras relações» ${ }^{76}$.

${ }^{64}$ Cf. G. C. J. J. VAN DEN BERGH, Custodiam cit. (nt. 42 supra), p. 64; R. RoBAYE, L'obligation cit. (nt. 42 supra), p. 16; também nesse sentido, aparentemente, M. SERRANO-VICENTE, Custodiam cit. (nt. 26 supra), p. 49 e, principalmente, p. 54; contra, por sua vez, a possibilidade de se individualizar uma «acepção fundamental» - «Grundbedeutung» - mesmo limitadamente aos três principais significados de «custodia» por ele identificados (em vista do objeto de sua investigação, a saber, a «obrigação de custodiar») - (a) «vigilância», «cuidado», correspondente àquele vulgar, (b) «poder sobre coisas» e, finalmente, (c) «responsabilidade contratual»-, A. METRO, L'obbligazione cit. (nt. 22 supra), pp. 83-84 e nt. 195.

${ }^{65}$ Cf. v.g., «custodiam plane commodatae rei etiam diligentem debet praestare» (Ulp. 28 ad ed., D. 13, 6, 5, 5); «...dolum mihi tantum praestabit: si sui, et custodiam» (Ulp. 29 ad Sab., D. 13, 6, 10, 1); Ulp. 8 ad ed., D. 13, 7, 13, 1; «...ut non solum dolum, sed etiam culpam et custodiam praestet» (Ulp. 30 ad ed., D. 16, 3, 1, 35); «...talis custodia desideranda est a venditore, qualem bonus pater familias suis rebus adhibet» (Gai. 10 ad ed. prov., D. 18, 1, 35, 4); «...custodiam...qualem praestare venditorem oporteat, utrum plenam, ut et diligentiam praestet... et puto eam diligentiam venditorem exhibere debere, ut fatale damnum vel vis magna sit excusatum» (Gai. 2 rer. cott., D. 18, 6, 2, 1); «..qua enim custodia consequi potuit...» (Ulp. 5 ad ed., D. 19, 2, 41). Cf. E. VolKMAR, Custodia, in VIR I cit. (nt. 48 supra), col. 1151 [= I.B.1 (a)].

${ }^{66}$ Cf. v.g., «...custodia enim et diligentia rei commodatae praestanda est» (PS 2, 4, 3); «...et dolum et culpam et diligentiam et custodiam in totum me praestare debere» (Ulp. 28 ad ed., D. 13, 6, 5, 15); «...custodiam et diligentiam praestare debet» (Paul. 7 ad Plaut., D. 19, 1, 36). Cf. E. VolKMAR, Custodia, in VIR I cit. (nt. 48 supra), col. 1151 [= I.B.1 (b)].

${ }^{67}$ Cf. J. PARIS, La responsabilité cit. (nt. 42 supra), p. 09; M. SERRANO-VICENTE, Custodiam cit. (nt. 26 supra), p. 49.

${ }^{68}$ Cf. E. VolKmar, Custodia, in VIR I cit. (nt. 48 supra), cols. 1151-1152 [= I.B.1]; H. HeUMANN - E. SECKEL, Custodia, in Handlexikon cit. (nt. 18 supra), p. 116.

${ }^{69} \mathrm{Cf}$. «si res vendita per furtum perierit...quid inter eos de custodia rei convenerat:...talis custodia desideranda est a venditore, qualem bonus paterfamilias suis rebus adhibet» (Gai. 10 ad ed. prov., D. 18, 1, $35,4) ;$ «...sed et custodiam ad diem mensurae venditor praestare debet...» (Ulp. 28 ad Sab., D. 18, 6, 1, 1); «...custodiam autem ante admetiendi diem qualem praestare venditorem oporteat...» (Gai. 2 rer. cott., D. 18, $6,2,1) ;$ «...si aversione vinum venit, custodia tantum praestanda est...»(Ulp. 28 ad Sab., D. 18, 6, 4, 1); «...vino...vendito finis custodiae est avehendi tempus...»(Ulp. 28 ad Sab., D. 18, 6, 4, 2); «...quamvis eam custodire debuerim, quia custodia adversus vim parum proficit» (Ner. 3 membr., D. 19, 1, 31 pr.); «...antequam...tradat, custodiam et diligentiam praestare debet»; «...pars est custodiae diligentiaeque...» (Paul. 7 ad Plaut., D. 19, 1, 36); «...dum venditoris custodia est, is stipulari debet omnemque diligentiam emptori praestare...» (Paul. 48 ad ed., D. 39, 2, 18, 9); «...si emptor rem, cuius custodiam venditorem 
Mais precisamente, «custodia» parece relacionar-se, nessas ocorrências, ao problema do inadimplemento da obrigação oriunda dos vários contratos (ex contractu), ou seja, ao fenômeno da «responsabilidade contratual» ${ }^{77}$. De fato, em não poucos textos, apresenta-se ela ao lado de conceitos - dolus, culpa, diligentia (e, negativamente, casus fortuitus, vis maior) - interpretados, em geral, como «critérios de responsabilidade» ${ }^{78}$.

Em tais casos, ainda, é possível notar que - semelhantemente a esses demais conceitos referidos (dolus, culpa) - o termo, na maior parte das vezes, aparece relacionado ao verbo «praestare», mais freqüentemente como seu complemento ${ }^{79}$ : «custodiam praestare» ${ }^{80}$.

praestare oportebat...» (Ulp. 29 ad Sab., D. 47, 2, 14, 1). Cf. E. VolKMAR, Custodia, in VIR I cit. (nt. 48 supra), cols. 1151-1152 [= I.B.1].

${ }^{70}$ Cf. «...fullo et sarcinator mercedem capiendo custodiam praestant» (Gai. 3, 206); «...et res custodiae eorum commitere» (Ulp. 14 ad ed., D. 4, 9, 1, 1); «...puto...eum recipere custodiam...» (Ulp. 14 ad ed., D. 4, $9,1,8)$; «...mercedem accipiunt non pro custodia...et tamen custodiae nomine tenentur» (Gai. 5 ad ed. prov., D. 4, 9, 5 pr.); «...nisi custodiam eorum recepit» (Paul. 2 sent., D. 19, 2, 55 pr.); «...qua enim custodia consequi potuit...» (Ulp. 5 ad ed. D. 19, 2, 41); «rerum custodiam, quam horrearius conductoribus praestare deberet...» (Lab. 5 post. ex Iavol. epit., D. 19, 2, 60, 9); «praestare enim custodiam debet» (Ulp. 29 ad Sab., D. 47, 2, 12 pr.); «et si custodia eius ad eum pertineat...» (Ulp. 29 ad Sab., D. 47, 2, 14, 17); «...quia custodia rei ad te pertinet...» (Ulp. 42 ad Sab., D. 47, 2, 48, 4); «...quia recipiendo periculum custodiae subit» (Ulp. 38 ad ed., D. 47, 5, 1, 4). Cf. E. VolKMAR, Custodia, in VIR I cit. (nt. 48 supra), cols. 1151-1152 [= I.B.1].

${ }^{71}$ Cf. «...quia custodiam praestare debuit, qui aestimatum accepit» (Ulp. 31 ad ed., D. 17, 2, 52, 3). Cf. E. VolKMAR, Custodia, in VIR I cit. (nt. 48 supra), cols. 1151-1152 [= I.B.1].

${ }^{72}$ Cf. «...ut et custodiam mihi praestes...» (Paul. 5 quaest., D. 19, 5, 5, 4). Cf. E. VolKMAR, Custodia, in VIR I cit. (nt. 48 supra), cols. 1151-1152 [= I.B.1].

${ }^{73}$ Cf. «custodia enim et diligentia rei commodatae praestanda est» (PS. 2, 4, 3); «custodiam plane commodatae rei etiam diligentem...debet praestare» (Ulp. 28 ad ed., D. 13, 6, 5, 5); «etiam pulli te custodiam praestare debere...» (Ulp. 28 ad ed., D. 13, 6, 5, 9); «...verum custodiam eum praestare debere...» (Ulp. 28 ad ed., D. 13, 6, 5, 14); «...et diligentiam et custodiam...me praestare debere» (Ulp. 28 ad ed., D. 13, 6, 5, 15); «...mea causa dedi, dum volo pretium exquirere, dolum mihi tantum praestabit: si sui, et custodiam» (Ulp. 29 ad Sab., D. 13, 6, 10, 1); «custodiam...praestare debet, quam praestant hi quibus res commodata est...» (Paul. 5 ad Sab., D. 18, 6, 3); «...quia custodiam praestare non debeat» (Ulp. 29 ad Sab., D. 47, 2, 14, 10); «...quia et huius custodia ad eum pertinet» (Ulp. 29 ad Sab., D. 47, 2, 14, 15). Cf. E. VolKMAR, Custodia, in VIR I cit. (nt. 48 supra), cols. 1151-1152 [= I.B.1].

${ }^{74} \mathrm{Cf}$. «...custodiam non praestat...» (Gai. 3, 207); «...ad custodiam rei pertinet...» (Ulp. 30 ad ed., D. 16, 3, 1 pr.); «...si se quis deposito obtulit,...non solum dolum, sed...et custodiam praestet...» (Ulp. 30 ad ed., D. 16, 3, 1, 35). Cf. E. VolKMAR, Custodia, in VIR I cit. (nt. 48 supra), cols. 1151-1152 [= I.B.1].

${ }^{75}$ Cf. «venit et custodia: vis maior non venit» (Ulp. 8 ad ed., D. 13, 7, 13, 1). Cf. E. VolKMAR, Custodia, in VIR I cit. (nt. 48 supra), cols. 1151-1152 [= I.B.1].

${ }^{76}$ «...fructuarius custodiam praestare debet» (Paul. 75 ad ed., D. 7, 9, 2); «...heres furti habebit actionem: eius interest: nihil enim refert, cur praestari custodia debeat» (Papin. 12 quaest., D. 47, 2, 81 [80], 2). Cf. E. VOLKMAR, Custodia, in VIR I cit. (nt. 48 supra), cols. 1151-1152 [= I.B.1].

${ }_{77}$ Cf. H. Heumann - E. SeCKel, Custodia, in Handlexikon cit. (nt. 18 supra), p. 116; A. Metro, L'obbligazione cit. (nt. 22 supra), p. 03. É, com efeito, nessa vinculação dogmática - abstraindo-se, por ora, da questão de se determinar a «natureza» da custodia (ou seja, se consistente em um «critério de responsabilidade» ou em uma «prestação») - que figura nos vários estudos já desde a Pandectística: «Haftung für Custodia», «responsabilità per custodia», «responsabilité de la custodia», «responsabilidade por custódia». Cf. infra (Parte I, Cap. II).

${ }^{78}$ Com efeito, cf., v.g., Gai. 2 rer. cott., D. 18, 6, 2, 1; Ulp. 29 ad Sab., D. 13, 6, 10, 1; Ulp. 8 ad ed., D. 13, 7, 13, 1; Ulp. 30 ad ed., D. 16, 3, 1, 35; Ulp. 28 ad ed., D. 13, 6, 5, 15; Ulp. 29 ad Sab., D. 13, 6, 10, 1; Ulp. 8 ad ed., D. 13, 7, 13, 1.

${ }^{79}$ Cf. A. Metro, L'obbligazione cit. (nt. 12 supra), pp. 03-04; M. SerRANo-Vicente, Custodiam cit. (nt. 26 supra), p. 49. Mas também, como notam H. HEUMANN - E. SECKEL, «custodiae nomine teneri», «custodia 
A considerar, portanto, essa sugestão, embasada na terminologia das fontes jurídicas citadas, a atração de «custodia» para o âmbito do problema do inadimplemento obrigacional parece dever-se ao outro termo integrante - tendencialmente, ao menos - das locuções, a saber, «praestare» ${ }^{81}$.

\section{3. «Praestare» e «responsabilidade»}

Dentre as acepções que «praestare» pode assumir nas fontes jurídicas, busca-se verificar a possibilidade de individualização de um significado técnico-jurídico específico do vocábulo em matéria de obrigações, que consinta uma maior aproximação à perspectiva romana de uma parte, ao menos, do problema da «responsabilidade contratual ${ }^{82}$.

\subsection{Significados de «praestare» nas fontes jurídicas romanas}

Ainda que em menor medida comparativamente às fontes não jurídicas, «praestare» apresenta-se empregado, nas fontes jurídicas, em acepções e contextos bastante variados ${ }^{83}$.

ad aliquem pertinet», «venit custodia in hac actione», «periculum custodiae praestat»). Cf. Custodia, in Handlexikon cit. (nt. 18 supra), p. 116.

${ }^{80}$ Do catálogo oferecido por E. VolKMAR, Custodia, in VIR I cit. (nt. 48 supra) cols. 1151-1152 [= I.B.1], contaram-se 23 empregos de «custodia» como objeto direto de «praestare» e outros dois em que o termo estaria também relacionado ao verbo (v.g., «custodia praestanda»), de um total de 39 textos citados.

${ }^{81}$ Como nota R. CARDILLI, «praestare» parece ocupar, ao lado de «actione teneri», tendo-se em vista os contextos em que é comumente empregado, uma posição central na reconstrução do problema da responsabilidade contratual no direito romano. Cf. L'obbligazione cit. (nt. 04 supra), pp. 01-02; ID., L'obligation de praestare et la responsabilité contractuelle en droit romain, in RIDA 43 (1996), p. 83.

${ }^{82}$ Por consequiência, enfrentar-se-ia também o problema prático consistente na «tradução» - em língua e conceitos modernos - da noção romana expressa por «custodiam praestare».

${ }^{83}$ Cf. C. A. CANnATA, Sul problema (1993) cit. (nt. 06 supra), p. 20, nt. 245; ID., Sul problema (1996) cit. (nt. 01 supra), p. 124, nt. 60; também R. CARDILLI, L'obbligazione cit. (nt. 04 supra), p. 111, no que concerne à ampla variedade semântica do termo nas fontes latinas em geral.

Os principais significados, nos autores latinos, seriam: (a) estar adiante («ante stare»), de que deriva, em sentido figurado: (a.1) prevalecer, ser superior, ser melhor (praecellere) - v.g., PLAVT. Bacch. 387 («homini amico, qui est amicus ita uti nomen possidet, nisi deos ei nil praestare...»); (a.2) ser melhor, em uso impessoal (melius est) - v.g., CIC. Phil. 14, 34 («...coniugibus, quod eis viris carebunt, quos laudare quam lugere praestabit...»); (a.3) preceder, com relação a lugar, posição («id quod praepositum esse», «praecedere») - v.g., LVCAN. bell. civ. 4, 30 («...dum primae perstant acies, hostemque fefellit et prope consertis obduxit castra maniplis»); (a.4) prevalecer, quando referido a poder, força (praeesse, praevalere) v.g., MACR. Sat. 1, 23, 6 («nam quia, in quocumque signo fuerit, praestat omnia signa et sidera signorumque praestites deos...»); (a.5) preceder, em referência à ordem lógica - v.g., PS. AVG. categ. 20, 168 («...cum naturaliter simul sunt, nullum...eorum praestat alteri...); (a.6) usos em locuções indicativas de medidas v.g., APVL. flor. 18, 29 («cui scilicet multo tanta praestat illa altera merces, quam Thalen memorant suasisse») (1. praesto - I. A e B; II.A, B e C; III); (b) apresentar, fornecer, mostrar (praebere, dare): (b.1) favorecer, aproveitar (praebere, dare) - v.g., Cic. Phil. 9, 12 («et quidem etiam ad famam Ser. Sulpici fili arbitror pertinere ut videatur honorem debitum patri praestitisse»); (b.2) com alguma sutileza ou conotação particular diz-se ser prestado - v.g., HoR. epist. 1, 11, 14 («...furnos et balnea laudat ut fortunatam plene 
Nessas últimas, «praestare» ${ }^{84}$, à parte usos muito freqüentes - de se considerarem atécnicos - no significado de (a) «pôr à disposição», «proporcionar», «fornecer», «conceder» ${ }^{85}$, encontrar-se-ia empregado - técnica e prevalentemente em termo quantitativos $^{86}$ - no sentido geral de (b) «executar uma prestação» («eseguire una

praestantia vitam...») (2. praesto - I.A e B); (c) assumir, prometer, observar (in se recipere, promittere vel implere, servare): (c.1) especialmente em matéria jurídica - CIC. top. 66 («...quid eum qui mandasset eumve cui mandatum esset alterum alteri praestare oporteret...»); (c.2) em sentido mais lato, na linguagem comum - v.g., PLIN. epist. 10, 52 («...generi humano, cuius tutela et securitas saluti tuae innisa est, incolumem florentemque praestarent») (2. praesto - II.A e B). Cf. J. RAMMINGER, Praesto, in ThLL X, 2, 5 $5^{\mathrm{a}}$ ed., München, Saur, 2007, cols. 906-909 [= 1. praesto]; 913-927 [= 2. praesto], cuja classificação, em seus delineamentos mais gerais, reproduziu-se supra, com a indicação das subdivisões estabelecidas pelo autor nos verbetes referidos; também, E. FORCELLINI - G. FURLANETTO - V. DE-VIT, Praesto, in Totius latinitatis lexicon IV, Prati, Aldiani, 1868, pp. 826-827.

${ }^{84}$ Cf. C. A. Cannata, Sul problema (1993) cit. (nt. 06 supra), pp. 21-25; ID., Sul problema (1996) cit. (nt. 01 supra), pp. 124-126; também H. HEumANn - E. SECKEL, Praestare, in Handlexikon cit. (nt. 18 supra), pp. 452-453, que oferece um quadro diverso, mas não - aparentemente - discrepante em termos substanciais; uma classificação dos usos jurídicos de «praestare» nas fontes jurídicas propôs também R. MAYR, reconduzindo-os a três significados jurídicos fundamentais: «gewähren», «leisten» e «haften». Cf. Praestare, in SZ 42 (1921), pp. 211-225.O correspondente verbete do VIR IV - J. MENNER - B. SCHMEISSER - J. Zerobin - M. MeInhart (org.), Praesto, Berlin - New York, Gruyter, 1985, cols. 1054-1083 - não organiza, nesse caso, os empregos do vocábulo segundo o critério dos significados por ele assumidos, mas conforme as várias construções sintáticas, razão pela qual se preferiu - contrariamente ao que se verificou em relação à «custodia»-partir dos estudos de C. A. CANNATA (supra), por oferecer, mais recentemente, um quadro articulado - resultante, ao que parece, de uma seleção feita a partir do catálogo do VIR - Sul problema (1993) cit. (nt. 06 supra), p. 20, nt. 245; ID., Sul problema (1996) cit. (nt. 01 supra), p. 124, nt. 60 - segundo as várias acepções do termo nas fontes jurídicas.

${ }^{85}$ Cf., v.g., Gai. 1 ad leg. duod. tab., D. 1, 2, 1; Pomp. l. s. enchir., D. 1, 2, 2, 35; Ulp. 70 ad ed., D. 43, 20, 1, 13; const. Tanta pr.; Iust., C. 1, 17, 2 pr. (de 533). Além disso, seriam identificáveis certos grupos de textos: (a) assim, subjaz a um deles a idéia de que o ordenamento jurídico, a lei, o magistrado, o juiz, os juristas, o imperador «praestant» um direito, uma ação, um remédio, uma dilação e outros: Gai. 2, 155; Gai. 3, 50-51; UE. 29, 1; Inst. 1, 12, 6; Inst. 2, 19, 1; Inst. 2, 20, 35; Inst. 4, 1, 8; Pomp. 1. s. enchir., D. 1, 2, 2, 49; Paul. 11 ad ed., D. 4, 2, 21, 6; Gai. 4 ad ed prov., D. 4, 4, 25, 1; Paul. 18 ad ed., D. 9, 4, 26, 6; Papin. 12 resp., D. 21, 1, 55; Papin. 20 quaest., D. 22, 1, 3 pr.; Ulp. 36 ad Sab., D. 24, 3, 12; Pomp. 21 ad Sab., D. 39, 2, 41; Ulp. 58 ad ed., D. 42, 1, 4, 5; Ulp. 64 ad ed., D. 42, 6, 1, 6; Grat., Valent. Et Theod., C. 1, 19, 4 (de 382); Iust., C. 4, 5, 10, 1 (de 530); Iust., C. 6, 43, 1, 1 (de 529); Iust., C. 7, 54, 3, 3 (de 531); Diocl. et Maxim., C. 8, 50, 7 (de 291); Iust., C. 8, 58, 2 (de 528); (b) um meio processual «praestat» uma vantagem a quem dele se vale: vat. 226; vat. 249, 7; Iul. 21 dig., D. 27, 10, 7, 1; Ulp. 52 ad ed., D. 39, 1, 1, 20; (c) «advocationem praestare», como, v.g., Ulp. 45 ad ed., D. 38, 2, 14, 9; (d) «sacrosanctis evangeliis tactis iuramentum praestant», em Iust., C. 3, 1, 14,4 (de 530); outros empregos, ainda, em matéria de (e) repúdio: Ulp. 74 ad ed., D. 2, 11, 2, 9; Iul. 62 dig., D. 24, 2, 6; Papin. l. s. de adult., D. 48, 5, 12, 13; (f) tutela: Diocl. et Maxim., C. 5, 37, 16 (de 293); Diocl. et Maxim., C. 7, 32, 7 (de 293); Diocl. et Maxim., C. 7, 33, 5 (de 293); Paul.4 ad Plaut., D. 39, 6, 33; (g) cumplicidade em furto: PS. 4, 3, 4; Ulp. 1 opin., D. 2, 14, 52, 1; Ulp. 6 opin., D. 5, 2, 27 pr.; Paul. 32 ad ed., D. 17, 1, 22, 5; Scaev. 22 dig., D. 33, 1, 21, 4; Iav. 9 ex post. Lab., D. 47, 2, 91, 1; Call. 3 de iur. fisc., D. 49, 14, 3 pr.; Alex., C. 2, 3, 9 (de 222); Alex., C. 2, 4, 6, 1 (de 230); (h) em tema de «actio ad exhibendum»: Ulp. 24 ad ed., D. 10, 4, 9, 5; analogamente, v.g., Paul. 1 ad ed., D. 2, 4, 19; Paul. 8 ad ed., D. 3, 3, 42, 2; Paul. 20 ad ed., D. 5, 3, 36, 1, Pomp. 33 ad Sab., D. 8, 1, 15, 1. Cf. C. A. CANNATA, Sul problema (1993) cit. (nt. 06 supra), pp. 21-23, nts. 248-258; ID., Sul problema (1996) cit. (nt. 01 supra), pp. 124-125, nts. 63-72; mais limitadamente, H. HEUMANN - E. SECKEL, Praestare, in Handlexikon cit. (nt. 18 supra), p. 452; essas ocorrências corresponderiam, aparente e aproximativamente, àqueles inseridos por R. MAYR seja na categoria de usos «não-jurídicos» ou «atécnicos», seja naquela dos usos reconduzíveis a «gewähren». Cf. Praestare cit. (nt. 84 supra), pp. 211-212 e nts. 01 e 03; 214 e nts. 0714; 215, nts. 01-42; 216, nts. 01-02; 223 e nt. 03.

${ }^{86}$ Cf. C. A. CANNATA, Sul problema (1993) cit. (nt. 06 supra), p. 21; ID., Sul problema (1996) cit. (nt. 01 supra), p. 125; limitadamente às fontes jurisprudenciais, R. MAYR, Praestare cit. (nt. 84 supra), p. 214 e nt. 07. 
${\text { prestazione») em } \text { geral }^{87} \text {, mais frequentemente uma prestação devida }}^{88}$, como assinalariam certas construções: «praestare debet», «praestare cogitur», «praestare oportet» ${ }^{89}$.

Com efeito, fontes do século I a. C. ao século III d. C., e de proveniências independentes ${ }^{90}$, ofereceriam uma noção convergente de «praestare»: o termo figura como um dos objetos do «oportere ${ }^{91}$, ao lado de «dare» e «facere» ${ }^{92}$. Se, por um lado, o sentido

${ }^{87}$ Nessa acepção, «praestare» apresenta-se nas mais variadas formulações: (a) sem menção do objeto (v.g., Scaev.1 resp., D. 15, 3, 20); (b) com menções genéricas, como, v.g., quodcumque, tot, quid, aliquid, quiddam (v.g., Papin. 9 resp., D. 36, 2, 26, 2), ou pronomes como haec, ista, id, id quod (v.g., Ulp. 1 ad ed. aed. cur., D. 21, 1, 29 pr.); (c) com referências quantitativas, v.g., certam quantitatem, plus, nihil, duplum, quadruplum, omnia, totum, partem, (v.g., Ulp. 1 opin., D. 2, 14, 52, 3) (d) com orações subordinadas introduzidas por «ut» ou «si» (v.g., Paul. 10 ad Plaut., D. 39, 2, 22 pr.; Gai. 18 ad ed. prov., D. 30, 70, 3) e, por fim, (e) ligado aos mais variados vocábulos - v.g., rem, corpus, hominem, servum, mancipium, Stichum, nummos, pecuniam, quantitatem, summam, materiam, aurum, panem, vinum, acetum, fenum, frumentum, lanam, tunicas, fundum, scapham, partus, nundinas, fructus, sortem, usuram, commodum, causam, pignora, honoraria, alimenta, cibaria, diaria et vestiaria, compendium, impensam, accessiones, sumptum, emolumentum, indemnitatem, pensionem, mercedem, solarium, tributa, vectigal, publicum, ministerium, officium, operas, opus, sarta tecta, donum, munus, dotem, hereditatem, legata e fideicomissa, kalendarium e nomen, peculium, poenam, praemium, salarium, conductionem, dominium, proprietatem, possessionem, ius, servitutem, viam iter actum aquae ductum, aditum, usum fructum, frui, lavationem, habitationem, facultatem, actionem, obligationem, cautionem e similares, fideiussorem, aestimationem, quanti ea res est, pretium, arras, expensas, damnum, libertatem, patientiam, praesentiam, habere licere, promissa, quod non debitum, modum, condicionem, rationem, instrumenta, reditus, obsequium, cetera. Cf., com ampla citação de fontes, C. A. CAnNATA, Sul problema (1993) cit. (nt. 06 supra), pp. 25-30, nts. 269-381; ID., Sul problema (1996) cit. (nt. 01 supra), pp. 125-126, nts. 84-196; H. HEUMANN - E. SECKEL, Praestare, in Handlexikon cit. (nt. 18 supra), p. 452; a seu turno, tais empregos corresponderiam àqueles inseridos por R. MAYR seja na categoria dos usos reconduzíveis a «leisten». Cf. Praestare cit. (nt. 84 supra), p. 211; 212 e nt. 04; 217 e nts. 02-05; 218, nts. 01-04; 219 e nts. 01-04; 220 e nts. 01-10; 221 e nts. 01-05; 224 e nt. 07; 225 e nts. 01-04; 226 e nts. 01-05.

${ }^{88}$ Não faltam, porém, empregos nos quais o verbo alude a uma «prestação de fato», ou seja, não juridicamente devida e exigível, v.g.: Marcian. 5 reg., D. 15, 1, 40, 1; Papin. 8 resp., D. 33, 1, 10, 1 e 3; Scaev. 17 dig., D. 33, 1, 19, 1-2; Scaev. 17 dig., D. 33, 2, 33 pr.-1; Papin. 8 resp., D. 34, 1, 9, 1; Scaev. 17 dig., D. 34, 1, 15, 1-2. Cf. C. A. CANNATA, Sul problema (1993) cit. (nt. 06 supra), p. 23 e nt. 261; ID., Sul problema (1996) cit. (nt. 01 supra), p. 125 e nt. 76; também assim, aparentemente, A. BERGER, Praestare, in Encyclopedic cit. (nt. 57 supra), p. 646.

${ }^{89}$ Cf., respectivamente, v.g., Iul. 15 dig., D. 19, 1, 24, 2; Ulp. 16 ad ed., D. 6, 1, 17, 1; Pomp. 35 ad Sab., D. 13, 7, 6, 1. Cf. A. CANNATA, Sul problema (1993) cit. (nt. 06 supra), p. 23 e nt. 262; ID., Sul problema (1996) cit. (nt. 01 supra), p. 125 e nt. 77.

${ }^{90}$ Cf. lex de Gallia Cisalpina $(22,31)$ (de 49-42 a. C.) («...si is eam rem, quae ita ab eo petetur deve ea re cum eo agetur, ei quei eam [rem] petet deve ea re aget, aut iei quoius nomine ab eo petetur quomve eo agetur in iure apud eum, quei ibei i(ure) d(eicundo) p(raerit), d(are) f(acere) p(raestare) restituereve oportere aut...») (FIRA I, p. 174), lex Irnitana (79, 50; 83, 48) (sob Domiciano - 81-96 d. C.) («...deve remissione facienda ei quem municipibus eius municipi quid dare facere praestare oportebi[t]...»); («...ii om]nes eas operas dare facere praestareque debento») (A. D’ORS - J. D’ORS, Lex Irnitana - Texto bilingüe, s.1., Universidade de Santiago de Compostela, 1989, p. 61; 67), Gai. 4, 2 («in personam actio est, qua agimus cum aliquo, qui nobis vel ex contractu vel ex delicto obligatus est, id est cum intendimus DARE FACERE PRAESTARE OPORTERE») (= é 'in personam' a actio pela qual demandamos alguém que se obrigou conosco, ou por contrato, ou por delito, isso é, quando pretendemos <que ele> esteja obrigado a dar, fazer ou prestar) e Paul. 2 inst., D. 44, 7, 3 («obligationum substantia non in eo consistit, ut aliquod corpus nostrum aut servitutem nostram faciat, sed ut alium nobis obstringat ad dandum aliquid vel faciendum vel praestandum») (= A essência das obrigações não consiste em fazer nossa alguma coisa ou servidão, mas em obrigar alguém a nos dar algo, ou fazer ou prestar). Conferiu-se também J. C. MOREIRA AlvES, Direito Romano cit. (nt. 28 supra), p. 375 [= $\$ 192]$.

91 Uma vez que «oportere» indicaria a obrigação («obligatio»), a tríade «dare facere praestare» consistiria no conteúdo dessa, ou seja, na prestação devida. Cf. C. A. CANnATA, Per lo studio della responsabilità per colpa nel diritto romano classico, Milano, La Goliardica, 1967-1968, p. 04. 
assumido por esses dois últimos não apresenta maiores dificuldades de determinação ${ }^{93}$, o significado do primeiro, na tríade, oferece maiores problemas ${ }^{94}$.

Por outros termos: ao contrário de uma obrigação consistente em (ou, vale dizer, que tenha por conteúdo) um «dare» ou um «facere», a individualização dos contornos de uma obrigação de «praestare» não se daria com a mesma segurança.

\subsection{O significado «exclusivo» de «praestare» como objeto da obrigação}

Nas ocorrências categorizáveis em «(b)» (supra), utiliza-se o verbo em relação a prestações, seja sem aludir ao modo de execução dessas (ou não precisamente individualizadas como de «dare» ou «facere») $)^{95}$, seja referido a uma ou outra delas ${ }^{96}$ ou mesmo às duas cumulativamente ${ }^{97}$, do que seria possível deduzir a ausência de um significado específico de «praestare» como conteúdo da obrigação ${ }^{98}$.

Em outras palavras, «praestare» exprimiria - como categoria mais ampla ${ }^{99}-$, indiferentemente, as obrigações consistentes ou em «dare» ou em «facere», articulando-se

\footnotetext{
92 Cf. R. CARDILLI, L'obbligazione cit. (nt. 04 supra), p. 02; ID., L'obligation cit. (nt. 82 supra), p. 82.

${ }^{93}$ Para os juristas romanos, «dare» designava a prestação consistente na transferência da propriedade de certa coisa, assim como a atribuição de outro direito real; «facere», por sua vez, expressava qualquer outra prestação (compreensiva também do «dare»-Papin. 27 quaest., D. 50, 16, 218), fosse uma atividade material ou a realização de um negócio jurídico, compreendendo também a abstenção de determinados comportamentos (ou seja, o «non facere» - Paul. 12 ad Sab., D. 45, 1, 2, 5). Cf. F. PASTORI, «Dare facere praestare», in NNDI 5 (1957), pp. 157-158; M. KASER, Das römische Privatrecht I cit. (nt. 05 supra), p. 489; C. A. CANnATA, Sul problema (1993) cit. (nt. 06 supra), p. 20; ID., Sul problema (1996) cit. (nt. 01 supra), p. 124; M. TALAMANCA, Obbligazioni (diritto romano), in ED 29 (1979), p. 30 e nt. 198; ID., Istituzioni cit. (nt. 05 supra), pp. 515-516; M. MARRONE, Istituzioni cit. (nt. 22 supra), pp. 411-412.

94 Cf., v.g., F. PASTORI, «Dare facere praestare» cit. (nt. 93 supra), pp. 158-159; G. Grosso, Obbligazioni - contenuto e requisiti della prestazioni - obbligazioni alternative e generiche, $3^{\mathrm{a}}$ ed., Torino, Giappichelli, 1966, p. 29; R. CARDILLI, L'obbligazione cit. (nt. 04 supra), p. 02.

${ }^{95}$ Cf., v.g., PS 3, 8, 4; Inst. 2, 25 pr.; Iul. 35 dig., D. 4, 6, 41; Ulp. 7 ad l. Iul. et Pap., D. 24, 3, 64, 5; Mod. 9 resp., D. 31, 33, 1; Maec. 9 fideicom., D. 35, 2, 32, 4. Cf. C. A. CANNATA, Sul problema (1993) cit. (nt. 06 supra), p. 24, nts. 263-264; ID., Sul problema (1996) cit. (nt. 01 supra), p. 125, nts. 78-79.

${ }^{96}$ Assim, em relação a essas duas útimas: (a) «dare»: v.g., Paul. 2 ad Ner., D. 3, 5, 18, 4; Papin. 11 quaest., D. 5, 1, 41; Ulp. 15 ad ed., D. 5, 3, 33, 1; Afr. 5 quaest., D. 7, 1, 36, 2; Paul. 9 ad Plaut., D. 7, 1, 46 pr.; Pomp. 33 ad Sab., D. 8, 3, 20 pr.; Ulp. 28 ad Sab., D. 8, 4, 6, 3; Ulp. 32 ad ed., D. 19, 5, 20, 1; Iavol. 13 epist., D. 24, 1, 50 pr.; Scaev. 3 resp., D. 34, 1, 20, 1; Paul. 14 resp., D. 34, 2, 35 pr.-1; Ulp. 17 ad Sab., D. 45, 1, 114; (b) «facere»: v.g., Pomp. 33 ad Sab., D. 8, 3, 20 pr.; Ner. 3 membr., D. 19, 1, 31 pr.; Ulp. 32 ad ed., D. 19, 2, 15, 2. Cf. C. A. CANNATA, Sul problema (1993) cit. (nt. 06 supra), p. 24 e nts. 266-267; ID., Sul problema (1996) cit. (nt. 01 supra), p. 125, nts. 81-82.

${ }^{97}$ Cf. Ulp. 16 ad ed., D. 6, 1, 17, 1; Pomp. 10 epist., D. 19, 1, 55; Ner. 4 membr., D. 46, 6, 11. Cf. C. A. CANNATA, Sul problema (1993) cit. (nt. 06 supra), p. 24 e nt. 265; ID., Sul problema (1996) cit. (nt. 01 supra), p. 125 , nt. 80.

${ }^{98}$ Cf. C. A. Cannata, Per lo studio cit. (nt. 91 supra), p. 08; ID., Sul problema (1993) cit. (nt. 06 supra), p. 30; ID., Sul problema (1996) cit. (nt. 01 supra), p. 126.

${ }^{99}$ A partir desse significado geral de «praestare» - compreensivo do «dare» e do «facere» - indicativo do adimplemento da obrigação (independentemente do objeto), é que se compreenderia o uso, na dogmática moderna, do vocábulo «prestação» (e também, em forma verbal, «prestar») como o termo técnico para indicar, genericamente, o «objeto da obrigação». Cf., v.g., T. G. L. MAREZOLL, Über Dare, Facere und
} 
esses, na tríade descritiva do conteúdo do oportere, em «círculos concêntricos» ${ }^{100}$ (ou ainda, como termos de um «crescendo»), do mais específico (dare) para o mais geral $(\text { praestare })^{101}$.

Contudo, além desse significado geral ${ }^{102}$, pretendeu-se individualizar também um âmbito semântico exclusivo de «praestare» ${ }^{103}$, ou seja, que não consentiria uma substituição por um dos demais termos da tríade, conferindo-se ao vocábulo individualidade como objeto da obrigação, ou seja, como prestação específica ${ }^{104}$.

À parte alguns esforços nos antigos comentários à compilação, de perscrutação do sentido de «praestare» dos textos romanos em algumas locuções ${ }^{105}$, o enfrentamento direto

Präestare als Gegenstand der Obligationen, in ZfCivPr 10 (1837), p. 274; P. BonfANTE, Corso di diritto romano IV - Le obbligazioni, Milano, Giuffrè, 1979, p. 47; GRosso, Obbligazioni cit. (nt. 94 supra), p. 30; M. MARRONE, Istituzioni cit. (nt. 22 supra), p. 412.

${ }^{100}$ Cf. C. A. Cannata, Per lo studio cit. (nt. 91 supra), p. 31.

${ }^{101}$ Cf. R. MAYR, Praestare cit. (nt. 84 supra), p. 226.

$102 \mathrm{O}$ reconhecimento desse significado geral de «praestare» poderia ser considerado um ponto de convergência dos vários estudiosos acerca do problema: v.g., T. G. L. MAREZOLL, Über Dare, Facere, Praestare cit. (nt. 99 supra), p. 274; F. A. SchILLING, Lehrbuch für Institutionen und Geschichte des römischen Privatrechts III, Leipzig, Barth, 1846, p. 05; M. A. BETHMANN-HollweG, Der römische Civilprozeß II - Formulae, Bonn, Marcus, 1865, p. 261, nt. 05 [= § 93]; A. BRINZ, Lehrbuch der Pandekten II, $2^{\text {a }}$ ed., Erlangen, Deichert, 1879, p. 92 [= § 238]; R. MAYR, Praestare cit. (nt. 84 supra), p. 199; $201 ;$ G. Grosso, Obbligazioni cit. (nt. 94 supra), p. 12; 30; 32; F. PASTORI, Profilo dogmatico e storico dell'obbligazione romana, Milano - Varese, Cisalpino, 1951, p. 115; 117; 145; indiretamente, também, C. A. CANNATA, Sul problema (1993) cit. (nt. 06 supra), p. 30; 34; ID., Sul problema (1996) cit. (nt. 01 supra), p. $126 ; 130$.

De certo modo, precedeu-os J. CUJAS (Cuiacius 1520-1590), ao comentar o texto de Paulo (2 inst., D. 44, 7, 3 pr.): «praestare autem generale verbum est, quod et dare in se continet, et facere: quod et in idiotismo, «prester argent»: latine usurpatur pro mutuum dare...» (= «praestare», pois, é um termo geral, que compreende em si tanto o «dare» quanto o «facere»: o que também 〈se verificaria〉 no estilo popular de dizer «prester argent» (em francês atual, «prêter argent»-emprestar dinheiro): em latim, usa-se, em vez disso, «dar em mútuo»). Cf. Commentarius ad titulos digestorum, in Opera Omnia VI, Prati, Giachetti, 1838, col. 1341.

${ }^{103}$ Poucos são - como observa R. MAYR, Praestare cit. (nt. 84 supra), p. 199 e nts. 04 e 05 - aqueles que se contentam com o significado geral de «praestare», como, v.g., M. A. BETHMANN-HOLLWEG, Der römische Civilprozeß II cit. (nt. 102 supra), p. 261, nt. 05; 274 [= 93$].$

Limitam-se, por sua vez, outros autores a referir o caráter controverso de um - provável - significado estrito do termo: v.g., B. WINDSCHEID - T. KIPP, Lehrbuch des Pandektenrechts II, 9a ed., Frankfurt am Main, Rütten \& Loenig, 1906, p. 14, nt. 04 [= § 252], que, sintenticamente, refere-se às várias interpretações: «sehr bestritten ist der Sinn des Ausdrucks praestare (die obligatorische Leistung überhaupt? Leistung aus dare und facere gemischt? Deliktsleistung? Sicherheitsleistung? Einstehen für etwas?» (= é muito discutido o sentido da expressão «praestare»: a prestação obrigacional em geral? Uma prestação mista de dare e facere? Uma prestação delitual? Uma prestação de garantia? Responder por algo?); também H. HEUMANN - E. SECKEL, Praestare, in Handlexikon cit. (nt. 18 supra), p. 452.

${ }^{104}$ Cf. C. A. CANNATA, Sul problema (1993) cit. (nt. 06 supra), p. 34; ID., Sul problema (1996) cit. (nt. 01 supra), p. 130.

${ }^{105} \mathrm{Na}$ literatura anterior a H. DONEAU (Donellus 1527-1591), não se encontraria um tratamento específico do significado atribuído ao termo pelos juristas romanos. Com efeito, nos comentários dos antecessores bizantinos à compilação justinianéia, o termo é vertido, em língua grega, de modo não unívoco: assim, v.g., o «praestare», em um mesmo texto - Ulp. 28 ad ed., D. 13, 6, 5, 2- B. 13, 1, 5 («...dolum...et culpam praestamus...dolus praestatur solus...et culpam et periculum praestet....et dolus et culpa praestatur») - foi «traduzido» por Estéfano como «Cat eøet ai» (isso é, «estar obrigado»), mas também, em outras passagens, por «ajait eitai» - sch. Shmei wsai (H II 07; Sch. B II 608, sch. 11), e por Cirilo como «ajait eitai» (ou seja, «responder por algo») - sch. Ent a (H II 06; Sch B II 607, sch. 06). 
Os Glosadores e Comentadores também não parecem ter-se preocupado em esclarecer o «praestare» romano: com efeito, não se verificam indícios em sentido contrário nas glosas apostas a textos que poderiam dar lugar a digressões por parte desses, v.g., Ulp. 28 ad ed., D. 13, 6, 5, 2; Ulp. 29 ad ed., D. 50, 17, 23 e Paul. 2 inst., D. 44, 7, 3. Segundo R. CARDILli, esses juristas ter-se-iam limitado à releitura dos efeitos do reconhecimento do praestare em termos de teneri, ou seja, sujeição do devedor às conseqüências do inadimplemento: ilustrativos, a propósito, gl. contractus a D. 50, 17, 23; gl. praestare a D. 50, 16, 71, 1, e alguns comentários de BARTOLO (Bartolus de Saxoferratis, 1314-1357) - In secundam Digesti veteris partem commentaria, Venetiis, Apud Iuntas, 1570, fol. 81, col. 03 (a D. 13, 6, 5, 2): «...quando aestimatio facit quem teneri de casu fortuito» (=...quando a aestimatio faz alguém responder pelo caso fortuito); ID., ibid., fol. 82, col. 02 (a D. 13, 6, 5, 2): «...aut illa culpa caditur in moram et tenet de casu..» (=...ou por aquela culpa incorre-se em mora e responde pelo caso <fortuito>); Cf. L'obbligazione cit. (nt. 04 supra), p. 03-04; ID., L'obligation cit. (nt. 82 supra), p. 84.

Em contrapartida, poder-se-ia visualizar em H. DONEAU a tentativa de elucidar o significado que «praestare» assumia para os juristas romanos.

Um primeiro testemunho desses esforços seria visualizável já na proposta do jurista de - após examinar, em geral, os gêneros da «culpa» - verificar quais deles devem ser «prestados» em cada contrato («...quid earum videlicet in unoquoque contractu sit praestandum») (= qual dos 〈gêneros da culpa〉, com efeito, há de ser prestado em cada contrato), ou seja, «...cuius culpae nomine debitor teneatur, aut non teneatur: ut si tenetur, non liberetur, quamvis res debita sine dolo malo eius perierit, aut deterior facta sit: si non tenetur, liberetur...» (= isto é, a título de qual culpa o devedor seja ou não responsável: assim, se é responsável, não será liberado, embora a coisa devida tenha perecido sem dolo dele, ou tenha-se deteriorado; se não é responsável, será liberado). Cf. Commentarii de iure civili cum notis Osualdi Hilligeri, in Opera Omnia IV, Lucae, Riccomini, 1764, col. 683 [= 1. XVI, t. VII, § 19].

Mais precisamente, detém-se o autor na explicação de algumas locuções das fontes jurídicas romanas (a partir do sumário: «casum fortuitum praestare, culpam et dolum praestare, diligentiam praestare: quid per haec verba significetur, et in quo differant») nas quais se apresenta o termo «praestare», em sede de comentário a Alex. Sev., C. 4, 24, 6 (de 225): «Casum fortuitum non praestari locutio est nostris usitata, sed ad aliquid novum, proinde et observanda est. Dicere solemus in commodato, in pignore, et in omnibus contractibus, in quibus utriusque et creditoris et debitoris, aut solius debitoris utilitas versatur, dolum et culpam praestandam esse, casum fortuitum praestandum non esse, l. si ut certo, $\S$ nunc videndum, D. commod. Haec omnia uno sensu. Sed dicimus praeterea in his omnibus diligentiam esse praestandam, d. l. si ut certo, $\S$ nunc videndum, $\S$ custodiam. $l$. in rebus, D. commod., et aliis in rebus innumeris. Hoc vero, ne erremus, eodem sensu non dicitur. Diligentiam praestandam esse cum dicimus, significatur diligentiam esse adhibendam: hoc sic explicatur in $\S$ item is, vers. at si et $\S$ ult. Instit. quibus modis re contr. obligat. Cum autem dicimus dolum, culpam, casum praestari, contrarium significatur. Nos non dicimus adhibendum esse dolum, adhibendam esse culpam, aut adhibendum casum, sed contra significatur, haec omnia removenda esse, et propter haec debitorem teneri. Quid ergo his verbis intellegimus? Respondeo: dolum culpam, casum fortuitum praestare locutio est non propria, sed figurata ubi causa ponitur pro effectu, met wnumicwß dolus pro damno dolo dato, culpa pro damno culpa dato, casus pro damno quod casu fortuito contigit. Itaque hic sensus est: culpa et dolus praestanda sunt, id est damna et culpa dolo contingentia praestanda sunt. Item casus fortuitus praestandus non est, id est, damnum casu fortuito contingens praestandum non est. Quamobrem pro casibus fortuitis hic dictum est: quae casibus fortuitis accidunt, nempe damna, haec vero non praestantur. Quare his verbis, casus fortuitos non praestari, haec sententia exprimitur, si res casu foruito vel perempta, aut amissa, vel deterior facta sit, debitorem non teneri, sed eatenus liberari». ( = A locução «não ser prestado o caso fortuito» é usada pelos nossos, mas há de ser observada sob um novo aspecto. Costumamos dizer que no comodato, no penhor, e em todos os contratos nos quais há vantagem para ambos, credor e devedor, ou apenas para o devedor, «há de ser prestado» o dolo e a culpa, e «não há de ser prestado» o caso fortuito $\langle$ D. 13, 6, 5, 2>. E tudo isso <dizemos $>$ em um só sentido. Mas, além disso, dizemos que, em

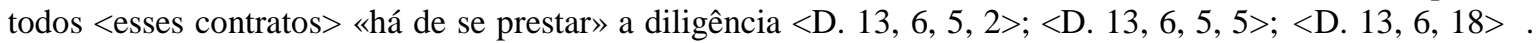
Isso, em verdade, a fim de que não erremos, não é dito no mesmo sentido. Quando dizemos que a diligência «há de ser prestada», significa que se há de observar a diligência. Isso é assim explicado em <Inst. 3, 14, 2〉. Por outro lado, quando dizemos que «há de ser prestado» o dolo, a culpa e o caso, significa o contrário. Nós não dizemos que se há de observar o dolo, ou a culpa, ou o caso, mas o contrário, <ou seja>, que hão de ser afastados todos esses, e, que o devedor por eles responde. O que, pois, entendemos por essas palavras? Respondo: a locução «prestar» o dolo, a culpa, o caso fortuito não é própria, mas figurada, na qual a causa é tomada pelo efeito: metonímico. Assim, dolo <é tomado> por dano causado por dolo, culpa, por dano causado por culpa, caso, por dano que se deve à ocorrência de um caso fortuito. Desse modo, este é o sentido: «hão de se prestar a culpa e o dolo», isto é, «hão de se prestar» os danos cujas ocorrências se devam à culpa e dolo. Assim , <a sentença〉 «não se há de prestar o caso fortuito», <significa〉 «não há de ser prestado»o 
do problema - a saber, a razão de ser de «praestare» como objeto da obrigação, ao lado dos demais termos da tríade - ter-se-ia verificado somente na primeira metade do século XIX, no âmbito das investigações pandectísticas ${ }^{106}$.

Dentre elas, assume particular relevo a tese de P. E. HusChKE, por consistir no «ponto de partida» para o posicionamento que se afirmaria em seguida, a saber, a vinculação semântica entre «praestare» e «responsabilidade» ${ }^{107}$.

$\mathrm{O}$ terceiro elemento da tríade exprimiria, para o autor, apenas um mediato ou eventual objeto da obrigação: tratar-se-ia, por outros termos, do dever de não tornar impossível, por um comportamento (comissivo ou omissivo) imputável, o «dare» ou o «facere», consistentes, esses últimos, nos objetos imediatos da obligatio (e pelos quais o obrigado deveria «einstehen») ${ }^{108}$.

dano que ocorra por um caso forutito. Pois em relação aos casos fortuitos foi dito: aqueles eventos que acontecem por casos fortuitos, isto é, os danos, «não são prestados». Porque com esses termos «não serem prestados os casos fortuitos» exprime-se esta sentença: que o devedor não é responsável, mas liberado, se a coisa, por caso fortuito, perecer, perder-se ou deteriorar-se). Cf. Commentarii in Codicem Iustiniani II, in Opera Omnia VIII, Lucae, Riccomini, 1765, cols. 27; 31-32.

No discurso de H. DONEAU, seriam individualizáveis dois aspectos de particular interesse: (a) a diferenciação entre formulações como, de um lado, dolum, culpam e casum fortuitum praestare («locutiones figuratae», nas quais o objeto do verbo é, propriamente, o dano que se deva a dolo, culpa ou caso fortuito), e, de outro, diligentiam praestare; e (b) a relação direta e imedita entre «praestare» e «teneri», uma vez que ao reconhecimento de um «quid praestare» corresponderia um «teneri», e, em contrapartida, ao de um «quid non praestare», um «liberari». Cf. R. CARDILLI, L'obbligazione cit. (nt. 04 supra), pp. 05-06.

Com efeito, o segundo aspecto posto em relevo pelo autor encontraria apoio, ainda, na sequência do comentário: «...et ideo cum dicimus, commodatarium casum fortuitum non praestare, sic intelligimus, commodatarium non teneri, si res commodata, quam restituere debuit, casu perierit...Creditorem casum fortuitum non praestare pignoraticia actione, hoc sic intelligimus: creditorem non teneri, si res pignorata, ad quam restituendam tenebatur, ipsa perierit...» (= e assim, quando dizemos que o comodatário «não presta»o caso fortuito, entendemos assim: que o comodatário não é responsável se a coisa comodada, que deveu restituir, tiver perecido por caso... <de semelhante modo, quando dizemos> que o credor 〈pignoratício> «não presta» o caso fortuito, pela ação pignoratícia, entendemo-lo assim: que o credor não é responsável, se a coisa dada em penhor, a cuja restituição estava obrigado, tiver perecido...). Cf. Commentarii in Codicem Iustiniani II cit. (nt. 105 supra), col. 32.

106 Abrem-se as discussões com a contribuição de T. G. L. MAREZOLL: «praestare» estaria relacionado, segundo o autor, às bonae fidei actiones (ou iudicia), no âmbito das quais se daria uma indistinção dos três termos («dare», «facere» e «praestare»); em contrapartida, nas stricti iuris actiones seria necessária uma individualização precisa do objeto como «dare» ou «facere», de modo que «praestare» seria apenas referível àqueles iudicia. Cf. Über Dare, Facere, Praestare cit. (nt. 99 supra), pp. 285-286, fundamentalmente; também p. 308; mais recentemente, essa posição foi acolhida por É. CUQ, Manuel des institutions juridiques des romains, Paris, Plon, 1917, p. 371, nt. 03.

Em contrapartida, G. F. PUCHTA sustentou - uma vez admitido que Gai 4, 2 se referisse às intentiones de todas as actiones in personam, isso é, tanto às ex contractu quanto às ex delicto - que «praestare» estivesse relacionado, precisamente, a essas últimas como expressão do damnum decidere. Cf. Lehrbuch der Pandekten, Leipzig, Barth, 1838, p. 213, nt. b [= § 201]; também, ID., Cursus der Institutionen I, 10 $0^{\mathrm{a}}$ ed., Leipzig, Breitkopf und Härtel, 1892, p. 489 e n. (aa) (na qual se contrasta a tese de T. G. L. MAREZOLL) [= $\S$ 165]; ID. ibid. II, p. 305 [= § 259]; alinha-se substancialmente a essa tese, F. C. Von SAVIGNY, System des heutigen römischen Rechts V, Berlin, Veit u. Comp., 1841, pp. 599-601 [= nn. XXVIII] e nt. (a).

${ }^{107}$ Cf. R. CARDILLI, L'obbligazione cit. (nt. 04 supra), p. 10.

${ }^{108}$ Cf. P. E. HusCHKE, Kritische Bemerkungen zum vierten Buch der Institutionen des Gaius, in ZGRW 13 (1846), p. 251 e nt. 04. 
Assim, inadimplido o «dare» ou o «facere», surgiria para o credor a ação para a indenização do dano. «Praestare oportere» seria, portanto, a «Obligation als Klage», ou seja, a obrigação de deixar-se condenar - o «condemnari oportere», locução essa que representaria a primeira («praestare oportere») em uma relação processual já introduzida $^{109}$.

Esse liame vislubrado pelo autor entre o «praestare» romano e a sujeição à condenação (condemnari oportere) ${ }^{110}$ teria constituído, como já adiantado, um dos pressupostos para sua interpretação, em seguida, em chave de Haftung ${ }^{111}$.

De fato, teria cabido a R. VON JHERING, estabelecer o equacionamento entre «praestare» e «Haftung» ${ }^{112}$, conceitos esses que, segundo o autor, contrapor-se-iam à «Verpflichtung» em sentido estrito: se, por um lado, essa última teria um conteúdo positivo (a prestação - «Leistung»), e seria incondicionada, por outro, a obrigação «Verbindlichkeit»- do devedor, sob a perspectiva da «Haftung», seria condicionada e de conteúdo negativo (ressarcimento $-\ll$ Schadloshaltung») ${ }^{113}$.

«Haften» (isso é, «praestare», para os juristas romanos) seria a expressão desse aspecto negativo da obrigação: referir-se-ia, pois, a algo que deveria ter sido evitado segundo o contrato, e por cuja ocorrência deveria o obrigado «responder» («aufkommen», «einstehen»). Encontraria explicação, nesses termos, o pareamento de «praestare», ao lado de «dare» e «facere», como objeto da obligatio, tal como se verificaria nas fontes jurídicas romanas $^{114}$.

\footnotetext{
${ }^{109}$ Cf. P. E. HuSCHKE, Kritische cit. (nt. 108 supra), pp. 252-253 e nt. 06.

110 Verifica-se, no entanto, uma mudança de orientação por parte de P. E. HuSCHKE, que se alinha, posteriormente, à opinião de G. F. PUCHTA e F. C. VON SAVIGNY (cf. nt. 106, supra). Cf. Iurisprudentiae anteiustinianae quae supersunt in usum maxime accademicum, $5^{\mathrm{a}}$ ed., Leipzig, Teubner, 1886, p. 344, nt. 04: «Etiam praestare ('et aliis quibusdam modis', Inst.) recte habet, qua incerta, sed ad personam et culpam spectante appelllatione Gaius actionum ex delicto venientium intentiones videtur complecti voluisse». (= Tem-se, certamente, também praestare - nas Institutas «et aliis quibusdam modis» <4, 6, 1>) -, termo incerto mas referente à pessoa e à culpa, com o qual Gaio parece ter querido completar as intentiones das actiones provenientes do delito).

${ }^{111}$ Cf. R. CARDILLI, L'obbligazione cit. (nt. 04 supra), p. 10.

${ }^{112} \mathrm{O}$ autor visualiza uma ligação substancial - mas não linguística - do vocábulo com «praes», de modo que «praestare» teria assumido valor prático e consistência jurídica no direito romano nos moldes da obrigação do «praes» (antiga figura de heterogarante, utilizada no âmbito processual, e naquele das relações com o populus Romanus, as civitates, ou privadas). Cf. Geist des römischen Rechts auf den verschiedenen Stufen seiner Entwicklung III, $5^{\text {a }}$ ed., Leipzig, Breitkopf und Härtel, 1906, pp. XXIV-XXV e nt. (*) [prefácio à $4^{\mathrm{a}}$ ed., 1888]; sobre os praedes, cf. M. TALAMANCA, Istituzioni cit. (nt. 05 supra), pp. 504- 506; 571-572.

${ }^{113}$ Essa contraposição entre os conceitos é exemplificada pelo autor nos seguintes termos: o vendedor «está obrigado» («verpflichtet») a entregar a coisa, mas «responde» («haftet») pela prestação da evicção, vícios ocultos, dolus e culpa. O condicionamento da «Haftung» (valeria dizer, do «praestare»), como esclarece R. VON JHERING, resultaria propriamente do fato de a obrigação depender da ocorrência de algo que deveria ter sido evitado ou do aparecimento de algo - v.g., o vício da coisa - que não deveria. Cf. Geist III cit. (nt. 112 supra), p. XXV.

${ }^{114}$ Cf. R. VON JHERING, Geist III cit. (nt. 112 supra), pp. XXV-XXVI e nt. (*).
} 
Também no âmbito da romanística italiana do início do século XX são verificáveis alinhamentos a essa interpretação, pela qual se teria dado a assimilação entre o «praestare» romano e a noção de «responder» («haften», «rispondere») ${ }^{115}$.

Com efeito, P. BONFAnTE, apoiado na hipótese etimológica de derivação de «praes» (ou seja, «praes-stare» - «estar garante») ${ }^{116}$, sustenta que «praestare» designaria os mesmos objetos de «dare» e «facere», mas sob uma perspectiva diversa, a saber aquela correspondente ao aspecto da obligatio (garantia) e não do debitum ${ }^{117}$.

Tal assertiva encontraria confirmação, além da etimologia, no fato de que, nos casos em que o termo se apresenta em seu significado exclusivo (isso é, não subsumível ao «dare» ou ao «facere»), os complementos-objetos - v.g., dolum, culpam, diligentiam, custodiam, casum, id quod interest - consistiriam não em uma coisa ou em um fato, mas sim em uma «responsabilidade» ${ }^{118}$.

Fixava-se, desse modo, a equação entre «praestare» e «responsabilidade» que figura, nos estudos sucessivos, como um «risultato acquisito» ${ }^{119}$ : por outros termos, seria de se entender que o sentido técnico-jurídico exclusivo de «praestare», como conclusão desse processo interpretativo, consistisse em «responder».

${ }^{115}$ Cf., v.g., G. PACCHIONI, que traduz o «praestandum» da definição de obligatio encontrada no já referido texto de Paulo (3 inst., D. 44, 7, 3) como «responder», ainda que se reporte, em nota, àquela de Florentino que, segundo opinião corrente - v.g., J. C. MOREIRA AlVES, Direito Romano cit. (nt. 28 supra) p. 375, nt. 05 [= § 207] - seria aquela recolhida nas Institutas imperiais (3,13 pr.). Cf. Apendice I a F. C. SAVIGNY, Le obbligazioni, trad. it. de G. PACChIONI, Torino, UTET, 1912, p. 655 e nt. 03. Também S. PEROZZI, para quem «praestare» não significaria o objeto de um «obbligo»: seu emprego dava-se, segundo o autor, nas hipóteses em que o pretor convidava o juiz para julgar se o réu devia ser responsável por dolo, culpa, caso, etc., significando, portanto, essas «responsabilità» e não prestações, em sentido próprio. Cf. Istituzioni di diritto romano II - Obbligazioni ed azioni - diritto ereditario - donazioni, Roma Athaeneum, 1928, pp. 113-114 e nt. 03.

116 Diversamente, nesse ponto, da ligação vislumbrada por R. VON JHERING (substancial mas não lingüística) (supra). Como hipóteses etimológicas, tem-se a derivação de praestare de duas formas: (a) «prae-stare» ou de (b) «praes-stare», que se refletiriam nas duas acepções assumidas pelo termo, respectivamente, (a) «estar diante» (voranstehen) e (b) «garantir, assegurar» (bürgen, haften, einstehen). Cf. A. WAlde - J. B. HofmAnN, Praesto, in Lateinisches etymologisches Wörterbuch II, $3^{\mathrm{a}}$ ed., Heidelberg, Winter, 1954, p. 355. De outro lado, A. ERNOUT-A. MEILLET parecem reconhecer uma única forma orginária, qual seja, «prae-sto». Cf. Praesto, in Dictionnaire cit. (nt. 45 supra), p. 532.

${ }^{117}$ Cf. Corso IV cit. (nt. 99 supra), pp. 47-48 [edição de 1979, embasada nos cursos de 1918-1919 e 19191920 - G. CRIFÒ, ibidem, p. VI - nota introdutiva]; ID., Istituzioni di diritto romano, $8^{\mathrm{a}}$ ed., Milano, Vallardi, 1925 , p. $364[=\S 118]$.

${ }^{118}$ Cf. P. BonfanTe, Corso IV cit. (nt. 99 supra), pp. 47-48; e, mais claramente, ID., Istituzioni cit. (nt. 117 supra), p. 364 [= § 118]: «...ma in modo specifico e con uso exclusivo denota quegli elementi, più spesso accessori o accidentali, in cui ha rilievo il momento della garentia e della responsabilità per l'adempimento».

119 Cf. R. CARDILli, L'obbligazione cit. (nt. 04 supra), p. 12. Com efeito, isso se poderia verificar também nas investigações acerca da «responsabilidade por custodia» desse período: limitadamente às mais importantes contribuições, J. PARIS, La responsabilité cit. (nt. 42 supra); V. ARANGIO-RUIZ, Responsabilità cit. (nt. 04 supra); G. I. LuZZATTO, Caso fortuito e forza maggiore come limite alla responsabilità contrattuale I - La responsabilità per custodia, Milano, Giuffrè, 1938, nas quais não se verifica um enfrentamento do problema do significado de «praestare» na locução analisada (custodiam praestare). 
A contribuição de R. MAYR teria assinalado outra importante etapa no estudo do problema ${ }^{120}$ : individualiza o autor três acepções jurídicas fundamentais nas quais «praestare»se apresentaria nas fontes jurídicas romanas (documentais, pré-justinianéias e justinianéias): «gewähren», «leisten»e «haften» ${ }^{121}$.

Entretanto, no que concerne à individualização de um significado específico do verbo como objeto do oportere, isso é, como prestação diversa do «dare» e do «facere» na tríade descritiva do objeto da obrigação, atém-se o autor a um «negatives Resultat», reconhecendo ao vocábulo, nesse caso, apenas o significado genérico, passível de compreender, como categoria conceitual mais ampla, os dois outros ${ }^{122}$.

À parte aqueles autores que se alinham à tese de R. MAYR ${ }^{123}$, aqueles que reconhecem um sentido exclusivo de praestare como objeto do oportere (seja «garantir e responder», seja ressarcir») ${ }^{124}$ não teriam considerado o problema fundamental dessa admissão, a saber: como «garantir» e «responder» poderiam figurar como objeto da obrigação, isso é, um quid precedente ao responder processual (actione teneri) ${ }^{125}$.

Com G. GRosso, ter-se-ia verificado a reconsideração de um significado exclusivo de «praestare» como objeto do oportere ${ }^{126}$, que consistiria, precisamente, na incorporação da idéia de garantia. Obrigações de «praestare» seriam, portanto, obrigações de «garantia», aspecto que as individualizaria em relação àquelas de daquelas de «dare» e de «acere» ${ }^{127}$.

${ }^{120}$ Cf. C. A. CANNATA, Per lo studio cit. (nt. 91 supra), p. 09, nt. 01.

${ }^{121}$ Limitadamente ao último significado, «praestare» assumiria o sentido de «haften», indubitavelmente, segundo o autor, quando ligado a certos objetos, v.g., culpam, dolum, custodiam, diligentiam, negligentiam, casum, factum, periculum, vitium, bonam fidem, curam, vim, damnum, moram, evictionem. Cf. R. MAYR, Praestare cit. (nt. 84 supra), pp. 213, nts. 12-19; 221, nts. 07-09; 222, nts. 01-12.226, nt. 05. É difícil, assim, reconhecer (diante do «zweifellos») certa hesitação por parte do autor no que concerne à «tradução» do significado do verbo nesses empregos (entre «Leistung» e «Haftung für eine Leistung, für einen Erfolg»), como pretende R. CARDILLI, L'obbligazione cit. (nt. 04 supra), p. 13.

${ }^{122}$ Assim: «..daß diese Dreiheit vom Besonderen zum Allgemeinen aufsteigt, insofern das facere auch das dare und praestare beides in sich begreift, nicht bloß gewisse Leistungen bezeichnet» (= que essa tríade cresce do mais particular para o geral, de modo que o facere compreende o dare e o praestare ambos, e não apenas indica prestações determinadas). Cf. R. MAYR, Praestare cit. (nt. 84 supra), p. 226.

${ }^{123}$ Cf. v.g., P. VoCI, Le obbligazioni romane - Corso di pandette - Il contenuto dell'obligatio, Milano, Giuffrè, 1969, p. 42; F. STURM, Stipulatio Aquiliana - Textgestalt und Tragweite der Aquilianischen Ausgleichsquittung im klassischen römischen Recht, München, Beck, 1972, p. 123; M. TALAMANCA, Obbligazioni cit. (nt. 93 supra), p. 30 e nt. 200.

${ }^{124}$ Cf. v.g., E. Albertario, Corso di diritto romano - Le obbligazioni - Parte I, Milano, Giuffrè, 1936, pp. 192-198; F. PASTORI, Profilo cit. (nt. 102 supra), p. 158; E. BETTI, Istituzioni di diritto romano II - 1, Padova, Cedam, 1960, p. 04. Diverge-se, além disso, quanto à configuração desse «praestare», «traduzido» com recurso a uma dessas noções supra, como obrigação primária ou secundária, decorrente do inadimplemento da primária - nesse útlimo sentido, v.g., A. HÄGERSTRÖM, Der römische Obligationsbegriff II - Über die Verbalobligation, Uppsala-Leipzig, 1941, pp. 267-268.

${ }^{125}$ Cf. CARDILLI, L'obbligazione cit. (nt. 04 supra), pp. 13-14.

${ }^{126}$ Cf. CARDILLI, L'obbligazione cit. (nt. 04 supra), p. 16.

${ }^{127}$ Cf. Obbligazioni cit. (nt. 94 supra), p. 33. 
«Praestare», assim, configurar-se-ia como «garantir» e «responder», acepções verificáveis em locuções como praestare dolum, culpam, casum, evictionem e outras, v.g., «debitorem locupletem esse», ou apenas «debitorem esse», indicativas de obrigações nas quais prevaleceria o aspecto da garantia ${ }^{128}$.

Restituía-se, por esse modo, uma função ao «praestare» como vocábulo expressivo de uma prestação específica (isso é, como um particular objeto da obrigação, não subsumível a prestações consistentes em «dare» ou «facere»), o que a ele havia sido negado por seu deslocamento para a área semântica da «responsabilidade» ${ }^{129}$.

Os esforços de individualização de um significado exclusivo de «praestare», que se faria presente em locuções como «servum sanum esse», «furem non esse», «vispellionem non esse», «debitorem esse», e também «dolum, culpam», «casum», «evictionem» praestare $^{130}$, teriam confluído, finalmente, para a tese de C. A. CANNATA ${ }^{131}$.

Rigorosamente, o verbo não poderia ser traduzido - como propunha a doutrina anterior $^{132}$ - com recurso a termos como «garantir»e $\left\langle\right.$ responder» ${ }^{133}$.

Essas várias situações configuráveis como «obrigações de praestare» - que, por seu valor paradigmático, poderiam ser resumidas em «sanum esse praestare», «dolum praestare», «custodiam praestare», «casum praestare ${ }^{134}-$ teriam como elemento comum a idéia de «assicurazione» ${ }^{135}$. A obrigação de praestare implicaria, pois, um dever de

${ }^{128}$ Cf. G. Grosso, Obbligazioni cit. (nt. 94 supra), pp. 33-34; também F. PASTORI, Profilo cit. (nt. 102 supra), p. 147.

${ }^{129}$ Cf. R. CARDILli, L'obbligazione cit. (nt. 04 supra), p. 16. Parece-nos que esse deslocamento assinalado pelo autor possa encontrar expressão na posição de M. TALAMANCA, ao notar que o verbo «praestare» é empregado, freqüentemente, não para exprimir um tipo de prestação - figurando como um conteúdo da obligatio - mas a determinação do critério de responsabilidade por inadimplemento, com base no qual, nos vários casos, responde-se, tal como nas expressões praestare dolum, culpam, custodiam. Cf. Obbligazioni cit. (nt. 93 supra), p. 30, nt. 200.

${ }^{130}$ Cf. P. E. HuSCHKE, Kritische cit. (nt. 108 supra), p. 248; F. A. ScHILlING, Lehrbuch III cit. (nt. 102 supra), p. 05; G. GROSso, Obbligazioni cit. (nt. 94 supra), p. 32; também F. PASTORI, Profilo cit. (nt. 102 supra), p. 143; a propósito, também F. STURM, Stipulatio cit. (nt. 123 supra), p. 118 e nts. 249-251.

${ }^{131}$ Nesse autor se vislumbra o ponto de convergência da progressiva mudança da perspectiva moderna a favor da romana na visualização do problema. Cf. R. CARDILLI, L'obbligazione cit. (nt. 04 supra), p. 16.

${ }^{132}$ Especialmente aquela de G. GROSso, Obbligazioni cit. (nt. 94 supra), pp. 31-34; 36-37. Se, por um lado, a utilização dessas noções teria a vantagem de permitir, sob o ponto de vista prático, uma adequada tradução em língua e conceitos modernos das locuções utilizadas pelos juristas, por outro, contrastaria ela com a perspectiva romana. E assim, seja pelo caráter unitário do uso de «praestare» (ao qual se faria corresponder uma tradução dupla - ora «garantir», ora «responder»), seja pelo fato, ainda, de «responder» (por inadimplemento) não coadunar com o uso do verbo indicativo de uma prestação particular (isso é, o conteúdo da obrigação - oportere). Cf. C. A. CANnATA, Per lo studio cit. (nt. 91 supra), p. 09.

${ }^{133}$ Cf. C. A. Cannata, Per lo studio cit. (nt. 91 supra), p. 09.

${ }^{134}$ Cf. Per lo studio cit. (nt. 91 supra), p. 14.

135 Cf. C. A. CANnAta, Per lo studio cit. (nt. 91 supra), p. 13. Assim, pois, o sujeito que «praestat», «assegura o destinatário acerca de alguma coisa», assumindo o dever de efetuar, diretamente, a atividade ou proporcionar certo resultado, devendo, em caso contrário (isso é, de inadimplemento), responder. Cf., mais recentemente, ID., Sul problema (1993) cit. (nt. 06 supra), p. 34; ID., Sul problema (1996) cit. (nt. 01), p. 130. 
proteger a contraparte em relação a dadas circunstâncias, fatos ou eventos, com a assunção variável de $\operatorname{riscos}^{136}$.

Por sua vez, os diversos complementos regidos pelo verbo determinariam não apenas a diversidade do objeto concreto da obrigação, como também aquela dos critérios para a valoração do inadimplemento, ou seja, do regime de responsabilidade ${ }^{137}$.

Ainda que de natureza bastante diversa - relativos a eventos, situações, comportamentos ou mesmo outros que, na moderna dogmática, seriam caracterizáveis como «critérios de responsabilidade» - os objetos de «praestare» encontrariam unidade sob a perspectiva romana, na qual o problema da «responsabilidade contratual» seria identificável com aquele do inadimplemento da obrigação ex contractu ${ }^{138}$.

Por outros termos, os «critérios de responsabilidade» seriam, sob o prisma dos juristas romanos, vistos como problemas de inadimplemento de obrigações de «praestare» («dolum», «culpam», «custodiam»praestare) que acederiam às prestações de «dare»e «facere» de uma dada relação obrigacional e teriam por efeito agravar ou atenuar a entidade dessa prestação principal ${ }^{139}$.

${ }^{136}$ Por outros termos, ter-se-ia uma prestação consistente em «fornire un'assicurazione rafforzata e concretata da un'assunzione di rischio» ou «fornire piena assicurazione in ordine a». Esse significado de «praestare» nas várias locuções seria, sob a perspectiva substancial, ativo («assicurazione»), com uma implicação passiva («assunzione del rischio»). Entretanto, reconhece o autor que, no caso da obrigação de «dolum praestare», não se poderia reconhecer esse aspecto da assunção de risco, uma vez que o dolo concretiza-se por fatos voluntários, dos quais resta excluía a aleatoriedade característica do risco em sentido próprio. Cf. C. A. CANNATA, Per lo studio cit. (nt. 91 supra), pp. 13-14; 16; 22; 28, nt. 04; 29. Com algumas variações, ID., Sul problema (1993) cit. (nt. 06 supra), p. 34; 40; ID., Sul problema (1996) cit. (nt. 01), p. 130; 136.

${ }^{137}$ Cf. C. A. CAnNATA, Per lo studio cit. (nt. 91 supra), p. 14; 21-22; 26-27; ID., Sul problema (1993) cit. (nt. 06 supra), p. 33; ID., Sul problema (1996) cit. (nt. 01 supra), p. 129.

${ }^{138}$ Cf. C. A. CANNATA, Per lo studio cit. (nt. 91 supra), p. 22; 24-25.

139 Trata-se de um idéia que recebe maior esclarecimento em mais recente contribuição: os «critérios de responsabilidade», sob a perspectiva romana, seriam, fundamentalmente, «obrigações subsidiárias» «Nebenpflichten» -, cuja violação apenas poderia ser considerada na ação na qual se lamentasse o inadimplemento da principal. Pretendeu-se, assim, explicar o significado das construções, presentes nas fontes, nas quais os vocábulos (sob a perspectiva moderna) alusivos a «critérios de responsabilidade» - v.g., dolus, culpa, custodia - figuram como objetos do verbo «praestare».

A não-acionabilidade autônoma das obrigações de «praestare» explicaria, ademais, a ausência do verbo no âmbito das fórmulas processuais, uma vez que, normalmente, o demandante apenas poderia deduzir em juízo a inexecução de obrigações consistentes em «dare» ou «facere». Com relação, ainda, a essas locuções indicativas de «critérios de responsabilidade», observa o autor que o verbo não assume, por si mesmo, valor positivo ou negativo: assim, «dolum praestare» (v.g., Ulp. 29 ad Sab., D. 50, 17, 23) equivaleria a «dolum abesse praestare» (v.g., Afr. 8 quaest., D. 19, 1, 30, 1; Flor. 8 inst., D. 18, 1, 43, 2); «culpam praestare»a «culpam abesse praestare» (v.g., Paul. 19 ad ed., D. 9, 3, 6, 2; Ulp. 1 ad aed. cur.,D. 21, 1, 31, 14). Cf. C. A. CANnATA, Per lo studio cit. (nt. 91 supra), p. 21; 24-27; ID., Sul problema (1993) cit. (nt. 06 supra), p. 37-40 e nt. 421; ID., Sul problema (1996) cit. (nt. 01), p.133-136 e nt. 236.

A subsidiariedade das obrigações de praestare (a uma obrigação consistente em dare ou facere) poderia, ainda, ser elucidada do seguinte modo: o vendedor deve entregar a coisa (facere), e garantir (praestare) a existência de determinadas qualidades; o transportador obriga-se a transportar (facere) certa coisa, e agir, na consecução dessa tarefa, com diligência (diligentiam praestare); o depositário obriga-se à restituição da coisa e assegura o deponente de abster-se de um comportamento doloso que possa causar a sua destruição (dolum 
Dessas proposições teria resultado, como nota R. CARDILLI ${ }^{140}$, o reconhecimento de uma função de «praestare» dentro do oportere primário, bem como a recuperação de um significado unitário do verbo («assicurare») em relação aos diferentes complementos aos quais se encontra ligado nas fontes jurídicas romanas ${ }^{141}$.

Entretanto, C. A. CANNATA não teria procedido a uma reconsideração completa da relação entre «praestare» e «actione teneri», assim como daquela entre «praestare» e a «responsabilidade» moderna ${ }^{142}$.

Segundo R. CARDILl, «praestare» assumiria, em contextos jurídicos, o sentido de «stare praes», isso é, «estar garante de algo», significado que se amplia gradativamente de modo a poder designar tanto a situação de garantia expressamente prometida quanto o reconhecimento dessa situação, pela iurisprudentia, em determinadas relações obrigacionais, fossem civis ou pretorianas ${ }^{143}$.

Esse praestare, valeria dizer, essa condição de garante («stare praes»), figuraria, sob a perspectiva romana, como um objeto específico da obrigação, ao lado do «dare» e do «facere», ainda que não exprima, como esses, um comportamento do devedor, mas uma condição debitória ${ }^{144}$.

Inadimplida a obrigação (quidquid dare facere ou reddere), considerar-se-ia o devedor obrigado a assumir a «condição de garante», valeria dizer, a responder pela ocorrência, sobrepondo-se à prestação inadimplida dentro do oportere primário ${ }^{145}$. O reconhecimento dessa condição de garantia («praestare») não seria, entretanto, automático,

praestare). Cf. B. SCHMIDLIN - C. A. CANNATA, Droit privé romain II - Obligations - Successions Procédure, Lausanne, Payot, 1987, pp. 18-10.

${ }^{140}$ Cf. L'obbligazione cit. (nt. 04 supra), pp. 16-17.

${ }^{141}$ Com efeito, pretendeu C. A. CANNATA visualizar nesses empregos técnicos de «praestare» uma perspectiva dogmática na qual os problemas de responsabilidade seriam reportados aos da prestação, como em: Ulp. 32 ad ed., D. 19, 1, 13, 16: In his autem, quae cum re empta praestari solent, non solum dolum, sed et culpam prastandam arbitror: nam et Celsus libro octavo digestorum scripsit, cum convenit, ut venditor praeteritam mercedem exigat et emptori praestet, non solum dolum, sed et culpam eum praestare debere $(=$ Em relação àquelas coisas que costumam ser prestadas com a coisa vendida, considero que <por elas> se responda não apenas por dolo, mas também por culpa. Pois também Celso escreveu, no oitavo livro dos digestos, que se foi convencionado que o vendedor exija o aluguel atrasado e preste ao comprador, deve ele <o vendedor> responder não apenas por dolo, mas também por culpa). «Praestare» assumiria, seja no enunciado de Ulpiano, seja na citação de Celso, dois sentidos diversos, a saber, o de «eseguire uma prestazione» e o de «responder», respectivamente, sem que se possa identificar, na mentalidade do autor do fragmento, um hiato entre o uso inicial e o sucessivo. Cf. Sul problema (1993) cit. (nt. 06 supra), p. 39; ID., Sul problema (1993) cit. (nt. 01 supra), p. 135.

${ }^{142}$ Cf. L'obbligazione cit. (nt. 04 supra), p. 17.

${ }^{143}$ Cf. L'obligation cit. (nt. 82 supra), pp. 187-188; ID., L'obligation cit. (nt. 82 supra), p. 86-90.

144 Mais claramente, R. CARDILLI, L'obligation cit. (nt. 82 supra), p. 86-87; todavia, já ID., L'obbligazione cit. (nt. 04 supra), p. 55; 177.

${ }^{145}$ Seria o praestare (situação de garantia), portanto, um quid intermediário entre a obrigação de dare facere ou reddere e o responder processual (actione teneri); seu reconhecimento figuraria, portanto, como o pressuposto desse último, aspecto esse particular do fenômeno do «responder contratual» romano. Cf. R. CARDILLI, L'obbligazione cit. (nt. 04 supra), p. 185; também p. 19. 
mas dependeria de ulteriores elementos de valoração, ligados ou à verificação da conduta do devedor (dolus, culpa) ou a hipóteses típicas de perecimento (custodia) ${ }^{146}$.

Assim configurado o «praestare» romano - «stare praes» -, seria ainda possível continuar a referi-lo com recurso à noção de «responsabilidade» em seu sentido mais amplo, qual seja, «sujeição a determinadas consequências», contanto que se tenha ainda presente a particularidade de ser o «praestare» um elemento interno ao oportere primário $^{147}$.

Esses, em estreita síntese, os resultados das investigações acerca do significado técnico-jurídico exclusivo de «praestare»: «haften», «rispondere», «garantire», «assicurare», «stare praes» (como condição debitória). As linhas gerais desse debate prestar-se-iam, limitadamente ao tema de que se ocupa («custodiam praestare»), a compreender alguns aspectos das discussões, principalmente, acerca de sua natureza.

${ }^{146}$ Cf. R. CARDILLI, L'obbligazione cit. (nt. 04 supra), pp. 185-186; ID., L'obligation cit. (nt. 82 supra), pp. 89-90.

147 Desse modo, para R. CARDILLI, compreendida a inserção e a função de um praestare interno ao oportere primário (situação de garantia precedente e pressuposto mesmo do actione teneri), apresentar-se-ia o problema de sua compreensão ao jurista moderno. E, dentro desses limites assinalados pelo autor, não haveria maiores problemas em se utilizar, para «traduzi-lo», o conceito de «responsabilidade». Cf. L'obbligazione cit. (nt. 04 supra), p. 07; 18; 55. 


\section{CAPítulo II \\ «CUSTODIAM PRAESTARE» NA DOUTRINA RomaníSTICA}

\section{Escorço histórico-doutrinário}

\subsection{A «culpa levissima» nas doutrinas do «direito comum» ${ }^{148}$ anteriores à Pandectística}

Antes de se proceder ao exame das contribuições pandectísticas, no âmbito das quais teria tido lugar a individualização da «custodia clássica» ${ }^{149}$, convém - dada a identidade dos textos que constituíram objeto de reflexão também por juristas anteriores verificar prováveis precedentes ${ }^{150}$ já nos «antigos comentários» ${ }^{151}$ à compilação justinianéia.

Essa última oferece como «regula iuris antiqui»: ressalvado o princípio dispositivo («sed haec...contractibus»), em alguns negócios, dos quais auferem vantagens ambas as partes contratantes, o devedor responderia, diante do perecimento do objeto da prestação,

\footnotetext{
148 Toma-se «direito comum» - ou «ius commune» - na acepção de experiência jurídica verificada na Europa entre os séculos XII, quando se assitiu ao florescimento das universidades medievais, e o surgimento das primeiras codificações, no início do século XIX, principalmente. A base desse «direito comum»-que, conceitualmente, pressuporia um «ius proprium»- consistia, fundamentalmente, no direito romano da compilação justinianéia, balizado pela interpretação das escolas medievais, bem como no direito canônico («conúbio» esse que se designou «utrumque ius»). Cf. G. ERMINI, Diritto comune, in NNDI 5 (1957), pp. 827-828; F. CALASSO, Medio evo del diritto I - Le fonti, Milano, Giuffrè, 1954, pp. 388-389; 407; U. WESEL, Geschichte des Rechts - Von den Frühformen bis zur Gegenwart, 3ª ed., München, Beck, 2006, pp. 319-320, principalmente.

Com efeito, nesse largo período - à parte o direito da Igreja, estudado já desde o século XII pelos Decretistas e, mais tarde, pelos Decretalistas -, no direito romano do Corpus Iuris Civilis se concentram os trabalhos doutrinários (seguindo-se diferentes métodos de estudo e ensino) de Glosadores, Comentadores e Humanistas e Jusnaturalistas. Cf. J. GILISSEN, Introduction historique au droit - Esquisse d'une histoire universelle du droit - Les sources du droit-Les sources du droit depuis le XIII e siècle - Élements d'histoire du droit privé, Bruxelles, Bruylant, 1979, pp. 177-178; 314; 333.

${ }^{149}$ Atribui-se, em geral, a J. BARON, a identificação da «responsabilidade por custodia clássica» nos textos justinianeus (infra), razão pela qual se costuma partir, nos escorços histórico-doutrinários do tema, de sua contribuição, metodologicamente inserível nos quadros da Pandectística alemã novecentista.

${ }^{150}$ Um exame exaustivo e pormenorizado da literatura jurídica medieval ultrapassaria os limites propostos desse estudo, constituindo já matéria de uma investigação própria. Por essa razão, permitimo-nos guiar, para essa limitada exposição, pelos - poucos, aliás - estudos precedentes que compreendem também a literatura anterior àquela pandectística. Fundamentalmente, T. ENGELMANN, Die custodia praestatio nach römischen Recht, Nördlingen, Beck, 1887, pp. 06-12, principalmente; H. DILCHER, Die Theorie der Leistungsstörungen bei Glosssatoren, Kommentatoren und Kanonisten, Frankfurt am Main, Klostermann, 1960.

151 Seriam incluíveis, nesses «antigos comentários», também aqueles realizados pelos antecessores bizantinos - professores nas escolas jurídicas do Império, e alguns deles membros das comissões de preparação da obra compilatória de Justiniano - recolhidos nos chamados «escólios antigos» das Basílicas. Cf. U. WESEL, Die Hausarbeit in der Digestenexegese - Eine Einführung für Studenten und Doktoranden, München, Kleist, 1966, pp. 28-29. Reservamos, contudo, a análise de alguns desses extratos para uma outra secção do estudo. Cf. infra (Parte I, Cap. II, 2.4).
} 
por dolo e culpa (v.g., na compra-e-venda, locação); por outro lado, naqueles em há proveito apenas para um deles (v.g., no depósito), a responsabilidade do devedor limitarse-ia ao dolo; em todo caso, não se responderia pelo perecimento devido a eventos fortuitos («a nullo praestantur») ${ }^{152}$.

Tal «regula», cristalizada já no direito clássico ${ }^{153}$ - e sintetizável em «culpam praestare» e «casus a nullo praestantur» -, ter-se-ia projetado - substancialmente intocada - tanto na reflexão dos intérpretes do direito comum quanto, mais tarde, nas codificações civis de tradição romanista ${ }^{154}$.

${ }^{152}$ Cf. Ulp. 29 ad Sab., D. 50, 17, 23: Contractus quidam dolum malum dumtaxat recipiunt, quidam et dolum et culpam. Dolum tantum: depositum et precarium. Dolum et culpam mandatum, commodatum, venditum, pignori acceptum, locatum, item dotis datio, tutelae, negotia gesta: in his quidem et diligentiam. Societas et rerum communio et dolum et culpam recipit. Sed haec ita, nisi si quid nominatim convenit (vel plus vel minus) in singulis contractibus: nam hoc servabitur, quod initio convenit (legem enim contractus dedit), excepto eo, quod Celsus putat non valere, si convenerit, ne dolus praestetur: hoc enim bonae fidei iudicio contrarium est: et ita utimur. Animalium vero casus mortesque, quae sine culpa accidunt, fugae servorum qui custodiri non solent, rapinae, tumultus, incendia, aquarum magnitudines, impetus praedonum a nullo praestantur (= Alguns contratos admitem somente <a responsabilidade> por dolo; outros, <a responsabilidade> tanto por dolo quanto por culpa. Apenas por dolo: o depósito e o precário. Por dolo e culpa: o mandato, o comodato, a compra e venda, o penhor, a locação, a dação de dote, de tutela, a gestão de negócios. Nesses, certamente, <admite-se> também <a responsabilidade> por diligência. A sociedade e o condomínio admitem <a responsabilidade> por dolo e por culpa. Contudo, tal se dá, a não ser que outra coisa se tenha expressamente convencionado (seja para mais ou menos) em cada contrato. Porque se observará o que se convencionou inicialmente (pois o contrato criou a obrigação), com exceção daquilo que Celso considera não ser válido, <a saber>, se se tiver convencionado que não se responderá por dolo. Pois isso é contrário ao juízo de boa-fé, e assim usamos <observar>. Ninguém responde, certamente, pelos acidentes e mortes de animais que ocorrem sem culpa, fuga dos escravos que não costumam ser custodiados, roubos, motins, incêndios, forças das águas e incursões de salteadores).

Substancialmente coerente, Ulp. 28 ad ed., D. 13, 6, 5, 2-4; Alex., C. 4, 24, 6 (de 225) e coll. 10, 2, 1. Cf. R. CARDILLI, L'obligation cit. (nt. 82 supra), p. 123; 128; ID., Un diritto comune cit. (nt. 14 supra), p. 328. Para a exegese do texto, mais recentemente, também C. A. CANNATA, Sul problema (1996) cit. (nt. 01 supra), pp. 47-49, e, principalmente, S. TAFARO, Regula e ius antiquum in D. 50, 17, 23 - Ricerche sulla responsabilità contrattuale, Bari, Cacucci, 1994.

${ }^{153}$ Cf., com pormenores, a análise do processo de sedimentação dos termos dessa «regula iuris» (conformada, como tal, já no século II d. C.) - e dos seus «protagonistas»: Quinto Múcio, Sabino, Nerácio, Celso, Juliano e Gaio -, reflexo de um modelo (o sabiniano, precisamente) de valoração das consequências do inadimplemento que teria prevalecido no plano do sistema da compilação) - em R. CARDILLI, L'obbligazione cit. (nt. 04 supra), pp. 415-503, principalmente; ID., L'obbligation cit. (nt. 82 supra), pp. 100125.

154 A permanência da regula no «sistema romanístico» representaria, de fato, mais um dos setores nos quais se teria verificado uma significativa continuidade dos conceitos e regras da tradição romana. No que concerne ao panorama europeu, tal se verificaria, a rigor, até o século XIX, a partir do qual algumas codificações acolheram conceitos distintos para a disciplina do problema da responsabilidade contratual.

Atribui-se, com efeito, ao Code civil francês (1804) o pioneirismo nesse desvio, ao introduzir o conceito de «cause étrangère qui ne peut lui être imputée» (art. 1147), ao qual se alinhou também, dentre outros, o Codice civile italiano (1865) (art. 1225: «causa esterna non imputabile»). Sob o plano normativo, teria rompido também com a tradição romana o Bürgerliches Gesetzbuch (1865-1900), ao codificar (§ 275), por influência de B. WINDSCHEID - Lehrbuch des Pandektenrechts II cit. (nt. 103 supra), pp. 82-98 [= § 264] -, a nova dogmática - centrada no conceito de «Unmöglichkeit» - elaborada por F. MOMMSEN (Die Unmöglichkeit der Leistung in ihrem Enfluß auf obligatorische Verhältnisse, in Beiträge zum Obligationenrecht I, Brauschweig, Schwetschke und Sohn, 1853, p. 247, principalmente). Cf. R. CARDILLI, Un diritto comune cit. (nt. 14 supra), p. 319; ID., L'obligation cit. (nt. 82 supra), p. 131.

Em contrapartida, as codificações latino-americanas despontantes contemporaneamente teriam seguido uma orientação própria, no sentido de manter-se arraigada à tradição dos textos justinianeus, podendo-se 
falar, com relação a essas, em «continuidade (também) normativa» da regula romana. Tratar-se-ia, portanto, de mais um âmbito de problemas no qual se verificaria a especificidade do «sistema jurídico latinoamericano» dentro do sistema romanístico. Cf. R. CARDILLI, Un diritto comune cit. (nt. 14 supra), pp. 328330; 339-341; 345; ID., L'obligation cit. (nt. 82 supra), p. 122; 130. Sobre a singularidade do direito latinoamericano no sistema romano-germânico, P. CATALANO, Sistema jurídico latino-americano, in Enciclopédia Saraiva do Direito 69 (1997), pp. 253-261.

Com efeito, nota-se essa via própria nas primeiras codificações latino-americanas oitocentistas: o Código Civil de Chile (1855), de A. BELlo (art. 1547), a Consolidação das Leis Civis (1858) e o Esboço (18601865), de A. TEIXEIRA DE FREITAS (infra), e ainda o Código Civil argentino (1871), da autoria de D. VÉLEZ SARSFIELD (arts. 511-514). Essas teriam acolhido, segundo R. CARDILLI, um modelo de regulamentação do problema das consequências do inadimplemento contratual com raízes no amadurecimento histórico do próprio sistema, resultante da interpretação e aplicação, na América Latina, do direito romano transfundido tanto nas Siete Partidas quanto nas Ordenações do Reino de Portugal, «pedras fundantes» do modelo que desenvolve a regula romana de modo independente das orientações seguidas por parte das codificações européias. Cf. Un diritto comune cit. (nt. 14 supra), p. 340.

De fato, lê-se em P. V, tit. II, Ley III: «Por ocasión perdiendo algunt home la cosa que hobiese rescebido emprestada que fuese de aquellas que non se pueden contar, nin pesar nin medir, asi como caballo, ó armas, ó paños ó outra cosa semejante, non es tenudo de la pechar el que la rescibe si se pierde sins u culpa. Et por ocasion se pierde et non por su culpa si gela quemase fuego com otras sus cosas, ó si se cayese la casa desuso et la matase, ó si gela llevasen avenidas de águas, ó gela robasen los enemigos, ó gela furtasen ladrones, ó si la perdiese sobre mar por alguna tempestad ó por quebrantamiento de algunt navio en que la llevase, ó em outra manera semejante destas». E no livro IV, tit. 53, §§ 2 e 3 das Ordenações Filipinas (1603): § 2. «E porque este contracto se faz regularmente em proveito do que recebe a cousa emprestada, $e$ não do que a empresta, fica obrigado aquelle, a que se empresta, guarda-la com toda a diligencia, como se fôra sua. E não somente se lhe imputará o dolo e culpa grande, mas ainda qualquer culpa leve e levissima, assi pela cousa principal, como pelo acessório (...); §3. Porém, se a cousa perecesse por caso fortuito, não será obrigado o commodatario a pagar o dano, salvo quando no dito caso fortuito interviesse culpa sua (...)».

Limitadamente ao direito brasileiro, o «jurisconsulto do Império» indica, explicitamente, como raízes do modelo que faz confluir para suas obras: as Ordenações Filipinas (IV, tit. 53, § 1 in fine), em relação aos arts. 501-502 da Consolidação; e, no que concerne aos arts. 881 e 884 do Esboço, a doutrina sobre a culpa, própria do direito romano, e a regra casus a nullo praestantur de Ulp. 29 ad Sab., D. 50, 17, 23 e Alex., C. 4, 24, 6 (de 225). Cf. A. TeIXEIRA DE FreITAS, Consolidação das Leis Civis, $3^{\mathrm{a}}$ ed., Rio de Janeiro, Garnier, 1876, p. 340, nt. 29; ID., Esboço do Código Civil I, Brasília, Ministério da Justiça-Universidade de Brasília, 1983, p. 208; R. CARDILLI, Un diritto comune cit. (nt. 14 supra), p. 342.

Nas obras de A. TEIXEIRA DE FREITAS referidas pode-se notar, ademais, a passagem da situação da «regula» da sedes materiae do comodato - Art. 501. É obrigação do commodatario guardar a cousa emprestada com o maior cuidado, tanto a principal, como o seu acessório; e responde, não só pelo dólo, e culpa larga; como pela culpa leve, e levissima; art. 502. Não responde o commodatario pelo damno originado de caso fortuito, excepto: $\S 1^{\circ}$ se houve estipulação em contrário; $\S 2^{\circ}$ se houve mora na restituição da cousa; $\S 3^{\circ}$ se empregou a cousa em uso differente daquelle, para que lhe-fôra emprestada; $\S$ 4 e em geral, sempre que no caso fortuito houve culpa - na Consolidação das Leis Civis, àquela pertinente às obrigações em geral - Art. 881. As faltas do devedor, não havendo na lei (art. 847) ou nos atos jurídicos disposição em contrário, serão graduadas do seguinte modo: $1^{\circ}$. Se a obrigação for de proveito recíproco para o devedor e credor, ou só de proveito para o devedor; responderá este por toda a culpa (arts. 845 e 846). $2^{\circ}$. Se a obrigação for de proveito só para o credor, responderá unicamente o devedor pela culpa grave (art. 845); art. 884. Não será o devedor responsável para com o credor, quando as perdas e interesses resultarem de caso fortuito ou força maior (art. 883); exceto nos seguintes casos: $1^{\circ}$ Se por contrato o devedor houver tomado a seu cargo as conseqüências do caso fortuito; $2^{\circ}$ Se o caso fortuito houver ocorrido por culpa do próprio devedor (art. 832, n. 1); $3^{\circ}$. Se houver ocorrido, estando já o devedor em mora; não tendo sido esta motivada também por caso fortuito - no Esboço do Código Civil.

A continuidade da regula romana (regras e conceitos) não teria sofrido ruptura também no Código Civil brasileiro de 1916 (Código Beviláqua), constituindo o fundamento dos artigos em matéria de responsabilidade contratual (arts. 1057-1058, retomados, com algumas alterações redacionais, nos arts. 392393 do Código Civil de 2002), alinhando-se, juntamente com várias outras codificações latino-americanas, ao que se poderia denominar «modelo latino-americano». Cf. R. CARDILLI, Un diritto comune cit. (nt. 14 supra), p. 344, com ampla citação dessas legislações.

Esse «ius commune» em matéria de responsabilidade contratual, vigente em uma ampla área geográfica, caracterizar-se-ia pela maior radicação nos textos romanos (ou seja, uma opção consciente pelo modelo mais 
Os juristas desse longo período - tomando por regra em matéria de responsabilidade contratual um modelo construído sobre, de um lado, o binômio doloculpa («dolum et culpam praestare»), e, de outro, limitado pelos casos fortuitos («casus a nullo praestantur») ${ }^{155}$ - tiveram de concentrar seus esforços em tornar coerentes, com esse modelo, as soluções que, no âmbito da compilação, pareciam desviar-se dele ${ }^{156}$.

Parece, de fato, ter sido essa a via trilhada por Glosadores, Comentadores ${ }^{157}$ e Humanistas também em relação ao «custodiam praestare» dos textos jurídicos romanos, uma vez que não haveria - nos limites da «regula» - lugar para um «critério objetivo» (a seguir a reconstrução prevalente) - independente da culpa - de determinação da responsabilidade.

Dos intépretes medievais, mais especificamente, dos Glosadores, teria provindo - e granjeado aceitação até o século XVI, de modo a poder considerar-se, na matéria, a orientação «dominante» - a tripartição da culpa em «culpa lata», «culpa levis» e «culpa levissima» ${ }^{158}$.

Essa última corresponderia a uma forma de responsabilidade autônoma ${ }^{159}$, que, remontante aos primeiros Glosadores ${ }^{160}$, seria definida por ACCURSIO (Accursius, 1182 1263) como o agravamento da simples culpa (culpa levis), e para ilustrá-la, recorre o jurista aos textos da compilação nos quais se verificaria a aplicação de «custodiam

coerente àquele oferecido como «regra» pela compilação justinianéia), evidenciada, por sua vez, principalmente: (a) pela centralidade da utilitas contrahentium como fundamento da responsabilidade nos diversos contratos; (b) pela manutenção da culpa como critério de imputação do inadimplemento; e (c) pelo caso fortuito como limite da responsabilidade. Cf. R. CARDILLI, Un diritto comune cit. (nt. 14 supra), pp. 341-342.

${ }^{155}$ Cf. R. CARDILLI, L'obligation cit. (nt. 82 supra), p. 100; 123.

${ }^{156} \mathrm{Se}$, por um lado, a ciência jurídica desses séculos não teria discutido os pressupostos e limites da regra que, em matéria de responsabilidade contratual, encontravam nos textos justinianeus, foi-lhe possível enquadrar os testemunhos divergentes, existentes no mesmo Corpus Iuris Civilis, por meio de torneios interpretativos dos termos informantes da regula, como, v.g., culpa, caso fortuito. Exemplificativo, a propósito, a releitura do «etiam si sine culpa» em termos de «culpa levissima»: «S.(cilicet) levi. Levissima tamen intervenit. Nam si nec levissima intervenit, ergo fuit casus fortuitus, et sic non tenetur: (...)» (= isso é, <mesmo sem culpa> leve. Contudo, dá-se a culpa levíssima. Pois se não se dá nem mesmo a <culpa> levíssima, logo, ocorreu caso fortuito, e, assim, não se responde). Cf. gl. etiam si sine culpa a D. 4, 9, 3, 1. Cf. R. CARDILli, L'obligation cit. (nt. 48 supra), p. 130; ID., Un diritto comune cit. (nt. 14 supra), pp. 328329 e nt. 51, cuja integração textual («scilicet») se reproduz.

${ }^{157}$ Sobre os Glosadores e Comentadores, cf., v.g., A. GUARINO, L'esegesi delle fonti del diritto romano I, Napoli, Jovene, 1968, pp. 10-12; F. CALASSO, Medio evo cit. (nt. 148 supra), p. 368-369.

${ }^{158}$ Cf. T. Engelmann, Die custodiae praestatio cit. (nt. 150 supra), p. 07; M. TAlamanCA, Colpa civile (diritto romano e intermedio), in ED 7 (1960), p. 523.

${ }^{159}$ Cf. H. DILCHER, Die Theorie cit. (nt. 150 supra), p. 75.

${ }^{160}$ Aparentemente, a Bulgaro (Bulgarus, antes de 1100 - 1166) e MARTINO Gosia (Martinus, 1100 1166), que já acenariam à tripartição da culpa aludida supra. Cf. M. TALAMANCA, Colpa cit (nt. 158 supra), p. 523 . 
praestare». Nota-se, com efeito, que as fattispecie integrantes dessa responsabilidade por «culpa levissima» seriam aquelas do furto da coisa devida ${ }^{161}$.

Além da conformação da figura (ou seja, do seu Tatbestand), ter-se-iam esforçado os Glosadores para determinar o campo de aplicação da culpa levissima, que teria sido deduzido tanto daquelas hipóteses de responsabilidade por custodia (seja ex lege ou convencional) quanto do princípio da utilitas contrahentium ${ }^{162}$.

Assim, consideram-se responsáveis por culpa levissima, em decorrência do precedente «custodiam praestare», v.g., o comodatário (contanto que - como normalmente se dá - o negócio somente lhe aproveite - «tibi gratia tantum») ${ }^{163}$, o depositário (caso assuma expressamente ou tenha-se oferecido para o depósito), e também o vendedor que tenha, por pacto, assumido a obrigação de prestar uma particular custodia ${ }^{164}$.

Posteriormente, entre os Pós-Glosadores ou Comentadores, ter-se-ia verificado a retomada da tentativa de descrever a figura da «culpa levissima», disso resultando o resumo de BARTOLO: consistiria essa na «media neglegentia ex fatuitate procedens quae consistit in eo quod quis minorem diligentiam habet, quam ille qui est diligentissimus» ${ }^{165}$.

${ }^{161}$ Cf. v.g., gl. debet a Inst. 3, 14, 3: Hic nota aliud esse dolum, ut quando est machinatio studiosa: ut (...). 2. Aliud latam culpam, ut, non intelligere quod omnes intelligunt: ut (...). 3. Aliud levem, ut desidiae, et negligentiae: (..). 4. Aliud levissimam, ut si quocumque modo potuit praevidere, et non praevidit. Unde furtum fieri non potest sine levissima culpa: ut (...). Aliud casum fortuitum, qui scilicet praevideri non potest. ut (...) (= Nesse ponto, nota <que> uma coisa é o dolo, tal como se verifica quando o ardil é propositado, [...]; 2. Outra coisa é a culpa lata, como se dá na hipótese de não se compreender o que todos compreendem, [...]; 3. Outra coisa é a <culpa> leve, como as indolências e negligências: [...]; 4. Outra coisa <ainda> é a <culpa> levíssima, que se dá quando se pôde, por qualquer modo, prever e não se previu. Do que resulta que o furto não pode ocorrer sem uma culpa levíssima [...]. Outra coisa é o caso fortuito que não pode ser previsto, [...]).Também gl. vel alio fortuito a C. 4, 34, 1: Innuit latrocinium esse fortuitum casum, quod verum est: ut (...). Et est latrocinium palam, maxime in silvis: furtum est clam: ut (...). Sed an furtum sit fortuitus casus? Videtur quod non: eum non videatur fieri sine culpa, ut (...). Sed certe imo quandoque est. ut (..). E, de semelhante modo, gl. etiam si sine culpa a D. 4, 9, 3, 1 (transcrito supra) (= Acenou-se que o latrocínio é um caso fortuito, o que é acertado. [...]. E o ataque de salteradores é <realizado> por uso de força aberta, mormente quando se verifica em meio ao bosque. O furto é clandestino, [...]. Mas <indaga-se> se o furto seja um caso fortuito. Parece que não, <pois> que ele não parece ser feito sem culpa <da vítima (entende-se) $>$. Mas, certamente, algumas vezes, o <furto> é <um caso fortuito>. Cf. H. DiLCHER, Die Theorie cit. (nt. 150 supra), p. 76.

${ }^{162}$ Cf. H. DILCHER, Die Theorie cit. (nt. 150 supra), p. 76.

${ }^{163}$ Cf. H. DILCHER, Die Theorie cit. (nt. 150 supra), p. 77.

${ }^{164}$ Cf. H. DILCHER, Die Theorie cit. (nt. 150 supra), p. 79.

165 (= média negligência, decorrente de tolice, que consiste no fato de que alguém tem menor diligência do que um outro que é diligentíssimo). Entretanto, BARTOLO confere à culpa levissima uma nova definição, que divergiria daquela de seus predecessores por tomar como «modelo» para a valoração da conduta não um abstrato pater familias, mas um homo diligentissimus da mesma condição e profissão do devedor concretamente considerado: «...levissima culpa, est deviatio incircunspecta ab ea diligentia, quam habent homines diligentes, et diligentissimi eiusdem conditionis et professionis...» (= culpa levíssima é o desvio não proposital daquela diligência que usam empregar os homens diligentes e diligentíssimos da mesma condição e profissão). Cf. In secundam Digesti veteris partem comentaria cit. (nt. 105 supra), fol. 109, col. 01 (a D. 16, 3, 32). Cf. H. DILCHER, Die Theorie cit. (nt. 150 supra), p. 81e nt. 268; 83. 
De semelhante modo, os Comentadores parecem ter reconhecido a aplicação dessa responsabilidade para algumas figuras de devedores, como, v.g., o comodatário (no caso de ser o único beneficiário do contrato) ${ }^{166}$ e o locatário (conductor) no caso de receber o pagamento especificamente pela custódia da coisa ou a tiver assumido expressamente ${ }^{167}$.

A «culpa levissima» apresentar-se-ia como uma Haftungsform autônoma, situada entre a culpa levis e o casus também em alguns textos dos Canonistas ${ }^{168}$. Ter-se-iam, em partes, repetido, entre esses juristas, as controvérsias já provenientes dos civilistas quanto ao campo de aplicação da figura, restando, do mesmo modo como nos Glosadores e Comentadores, como único ponto incontroverso, a responsabilidade do comodatário por esse critério $^{169}$.

Deve-se a H. DONEAU ${ }^{170}$ o rompimento com essa lição, ao sustentar a identidade juridicamente - da «culpa levis» e da «culpa levissima», reconhecendo, tão-só, duas culpas: a «culpa lata» e a «culpa levis» ${ }^{171}$. A seu turno, insistiu o jurista da Escola Humanista na distinção - dentro de cada uma dessas duas espécies - entre «culpa in faciendo» e «culpa in non faciendo» ${ }^{172}$. E, nesse sistema, fez-se inserir a custodia dos textos jurídicos na noção de «culpa levis in non faciendo» ${ }^{173}$.

Em suma, mesmo na doutrina da culpa desse jurista, - que não teria logrado eliminar, definitivamente, a «culpa levissima» dos conceitos utilizados pelos juristas - não parece ter havido um desprendimento da custodia em relação à culpa, permanecendo, na

${ }^{166}$ Cf. H. DILCHER, Die Theorie cit. (nt. 150 supra), pp. 81-82; 84 e nt. 279.

${ }^{167}$ Cf. H. DilCHER, Die Theorie cit. (nt. 150 supra), p. 82; 86.

${ }^{168}$ Cf. H. DILCHER, Die Theorie cit. (nt. 150 supra), p. 87.

${ }^{169}$ Cf. H. DILCHER, Die Theorie cit. (nt. 150 supra), pp. 87-88; 90.

170 Contrariamente a J. CUJAS, maior expoente do «mos gallicus», caracteriza-se H. DONEAU pelo emprego do método dogmático (e não analítico, como o primeiro), investigando nos textos romanos o que seriam os «princípios gerais» de direito, a fim de deduzir, logicamente, as consequências, a fim de construir um direito romano teórico. Cf. J. GILISSEN, Introduction cit. (nt. 148 supra), pp. 325-326.

${ }^{171}$ Em uma hipótese, entretanto, H. DONEAU parece reconhecer - como exceção à regra - a existência de uma obrigação, a cargo do comodatário, de observância de um grau de diligência incomum, valorando-se sua responsabilidade com base na «culpa levissima». Trata-se, especificamente, do caso de ter o comodatário, em situação de perigo («damnum fatale»), salvado, em primeiro lugar, as suas próprias coisas ao invés da coisa alheia que detinha em empréstimo (Ulp. 28 ad ed., D. 13, 6, 5, 4). Cf. Commentarii de iure civili, in Opera Omnia IV cit. (nt. 105 supra), cols. 682-683 [= 1. XVI, cap. 07, § 18]; T. EngELmANN, Die custodiae praestatio cit. (nt. 150 supra), p. 08; M. TALAMANCA, Colpa cit. (nt. 158 supra), p. 532. Sobre a interpretação desse fragmento e sua tradição no plano do direito codificado, cf., entre nós, R. LIMA VAZ SAMPAIO, Da Responsabilidade do Comodatário pelo Caso Fortuito ou de Força Maior - Acerca do Princípio do Sacrifício da Coisa Própria, in Revista da Faculdade de Direito da USP 113 (2008), pp. 10271071.

${ }^{172}$ Cf. Commentarii de iure civili, in Opera Omnia IV cit. (nt. 105 supra), cols. 678-680 [= 1. XVI, cap. 07, $\S \S 15$ e 16]. Cf. T. EngELmanN, Die custodiae praestatio cit. (nt. 150 supra), pp. 03-04; 07.

${ }^{173}$ Dar-se-ia a sua implicação todas as vezes em que, nos textos, fosse dito que o devedor estava obrigado a «praestare» não apenas a culpa, mas também a diligentia ou custodia, como nos casos - em regra (v.g., comodatário, credor pignoratício) - nos quais apenas um dos contratantes auferisse vantagens do negócio. Cf. Commentarii de iure civili IV cit. (nt. 105 supra), col. 702 [= 1. XVI, cap. 07, § 33]; T. ENGELMANN, Die custodiae praestatio cit. (nt. 150 supra), p. 08. 
leitura de H. DONEAU, interpretada como uma modalidade de diligentia - a saber, diligentia in custodiendo ${ }^{174}$ - cuja inobservância configuraria culpa (precisamente, «culpa levis in non faciendo»), orientação da qual não teriam divergido, substancialmente ao menos, outros Humanistas ${ }^{175}$.

Os resultados de H. DoneaU, se por um lado são repropostos - em suas linhas fundamentais - na literatura sucessiva (pandectística, principalmente), por outro, não granjearam acolhida no tratado especificamente dedicado à culpa de S. PUFENDORF (1632$1694)^{176}$.

Retorna, no sistema concebido pelo jurista da Escola do Direito Natural ${ }^{177}$, a tripartição da culpa em «culpa lata», «culpa levis» e «culpa levissima» ${ }^{178}$, correspondente aos três graus do conceito a ela oposto ${ }^{179}$, isto é, a «diligentia» ${ }^{180}$. Uma «parte» desta última seria a «vigilantia» ou - como os jurisconsultos (romanos, entende-se) preferiam denominá-la - «custodia» ${ }^{181}$ : como «pars diligentiae», essa teria também os três graus da

${ }^{174}$ Cf. Commentarii de iure civili IV cit. (nt. 105 supra), col. 704 [= 1. XVI, cap. 07, § 36: «..id est diligentia diligentis patrisfamilias ad rem custodiendam necessaria» (= isso é, a diligência de um diligente paterfamilias necessária para a guarda da coisa)]. Cf. T. ENGELMANN, Die custodiae praestatio cit. (nt. 150 supra), pp. 08-09.

${ }^{175}$ A afirmação do não-suplantamento da «culpa levissima» na ciência jurídica posterior poderia encontrar elementos de apoio em uma passagem de A. VINNEN (Vinnius, 1588-1657), na qual o nauta, caupo e stabularius são considerados dentre aqueles que deveriam responder por culpa levissima.

Em comentário a Inst. 3, 24, 5, ao discutir os limites da responsabilidade do locatário (conductor), detémse o jurista no já referido Ulp. 14 ad ed., D. 4, 9, 3, 1: «...edicto vero omnimodo qui recipit, teneatur, etiamsi sine culpa ejus res periit aut damnum datum est, ita tamen, ut nec ille praestet casus fortuitos, seu quod damno fatali aut vi majore contigit. Igitur ex sententia Jurisconsulti is, qui recepit, praestat medium aliquid inter culpam et casum fortuitum, quod non praestat conductor: atqui hoc medium nihil aliud esse fateri omnes debent quam culpam levissimam» (=...pelo edito <de receptis>, na verdade, quem recebeu, de qualquer modo, <a coisa no navio, na hospedaria ou no estábulo>, responderá, ainda que a coisa tenha perecido ou tenha-se danificado sem culpa sua, todavia ele não responderá pelos casos fortuitos, nem por aquilo que ocorreu por dano fatal ou por força maior. Logo, segundo a opinião do jurista <Ulpiano〉, aquele que recebeu <a coisa no navio, na hospedaria ou no estábulo〉, responde por um meio-termo entre a culpa e o caso fortuito, pelo qual não responde o locatário. Ora, devem todos reconhecer que esse termo-médio nada mais é do que a culpa levíssima). Cf. In quattuor libros Institutionum Imperialium Commentarius II, Venetiis, Graziosi, 1768, p. 187. Sobre a resistência do sistema da tripartição da culpa próprio da Glosa, cf. T. Engelmann, Die custodiae praestatio cit. (nt. 150 supra), p. 03; M. TAlAmANCA, Colpa cit. (nt. 157 supra), p. 533, principalmente.

Além disso, o trecho comprovaria a permanência da interpretação da custodia como uma modalidade de culpa (precisamente, a «culpa levissima») no âmbito na Escola Humanista, doutrina essa que deveria sua existência, segundo J. BARON, à incompreensão, por esses juristas, da «Haftung für custodia». Cf. «Diligentia exactissima, diligentissimus paterfamilias» oder die Haftung fur Custodia, in AcP 52 (1869), p. 55.

${ }^{176}$ Cf. De culpa commentatio juris naturalis et civilis, Lemgow, Meyer, 1741.

177 Cf., v.g., J. GILISSEN, Introduction cit. (nt. 148 supra), p. 345; U. WESEL, Geschichte cit. (nt. 148 supra), pp. 379-381; no que concerne ao tema de estudo, T. ENGELMANN, Die custodiae praestatio cit. (nt. 150 supra), pp. 09-12.

${ }^{178}$ Cf. De culpa commentatio cit. (nt. 176 supra), p. 73 (= P. II, Cap. IV, § 2).

${ }^{179}$ Cf. De culpa commentatio cit. (nt. 176 supra), p. 102 (= P. II, Cap. V, § 35).

${ }^{180}$ Cf. De culpa commentatio cit. (nt. 176 supra), pp. 40-41; 43-44 (= P. I, Cap. IV, § 16; §§ 26-28).

${ }^{181}$ Cf. De culpa commentatio cit. (nt. 176 supra), pp. 39-40 (= P. I, Cap. IV, §§ 12- 13). 
diligentia e da culpa (neglegentia) ${ }^{182}$, não se restringindo - como se propunha até então apenas a designar o maior grau da diligentia («summus diligentiae gradus» - ou seja, o contraposto da «culpa levissima») ${ }^{183}$.

De qualquer modo, a «custodia» também não parece ter ganhado, no sistema traçado por S. PUFENDORF, individualidade em relação à culpa, o que seria consequência de seu atrelamento conceitual - como parte dele - com a «diligentia». Logo, o inadimplemento da obrigação de custodia (ínfima, minus plena ou plena) - em última análise, daquela de diligentia - continuaria valorado como culpa (respectivamente, lata, levis ou levissima) ${ }^{184}$.

\subsection{Pandectística: «custodiam praestare» na «Schuldhaftungskonzeption»}

Sob a perspectiva da Pandectística alemã ${ }^{185}$, a culpa ocuparia, nas fontes romanas, uma posição central na consideração do problema da imputação do inadimplemento, figurando aquela como o princípio a ser aplicado em matéria de responsabilidade contratual $^{186}$ : por outros termos, daquelas fontes jurídicas seria deduzível uma «Schuldhaftungskonzeption» ${ }^{187}$.

${ }^{182}$ Cf. De culpa commentatio cit. (nt. 176 supra), p. 86 (= P. II, Cap. IV, § 40); p. 102 (= P. II, Cap. V, § 36): «Pars diligentiae custodia est. (P. I. C. IV. $\S$ XII). Unde qualis gradus cum culpa exigitur, talis etiam custodiae gradus» (= A custódia é parte da diligência. Assim, aquele grau <de diligência> que se exigir, e de culpa, tal será também o grau de custódia <exigido>).

${ }_{183}$ Cf. De culpa commentatio cit. (nt. 178 supra), p. 87 (= P. II, Cap. IV, § 41).

${ }^{184}$ Com efeito, sugeriria tal conclusão a passagem: «Vix quisquam recentiorum JCtorum est, qui quid custodiae nomine veteres acceperint, recte intelligat. (...), sed sufficit notare, custodiam casibus fortuitis opponi, eum vero gradum accipi, qui pro modo gradus culpae negotio conveniat» (= Dificilmente há algum dos mais recentes juristas que compreenda o que os juristas romanos entendessem com o termo «custodia». [...] Mas é suficiente notar que a custódia é oposta aos casos fortuitos, que <ela, custódia> recebe, na verdade, aquele grau que, conforme a medida do grau de culpa, convier ao negócio). Cf. De culpa commentatio cit. (nt. 178 supra), pp. 109-110 (= P. II, Capt. VI, § 12).

No que concerne, particularmente, ao vendedor, dele se exigiria a diligentia (e a custodia) média (ou seja, a diligência do diligens - e não do diligentissimus - paterfamilias) em relação à coisa antes da entrega ao comprador, limitando-se, em regra, a sua responsabilidade à culpa levis. Cf. De culpa commentatio cit. (nt. 178 supra), pp. 274-276 (P. IV, Cap. VIII, §§ 13-15).

${ }^{185}$ Serviu-nos, fundamentalmente, de base para a periodização que se segue, o panorama traçado por R. CARDILli, L'obbligazioni cit. (nt. 04 supra), pp. 19-58. Entende-se por Pandectística aquela orientação desenvolvida no âmbito da Escola Histórica alemã já no século XVIII, mas que teria atingido seu auge no século seguinte, tendente a criar uma teoria geral da parte do direito privado fundado principalmente no direito justinianeu (que constituía, precisamente, o direito comum vigente). As obras de cunho geral bem como as monografias tendem a criar uma teoria geral do direito privado com base, principalmente, na compilação de Justiniano. Neles seria notável o esforço de abstração e construção sistemática destinado a identificar princípios informadores, com base nos quais buscam esclarecer todo o sistema jurídico, em suas normas específicas. Sob o ponto de vista da ciência romanística, a Pandectística representaria o ponto de chegada do estudo do direito justinianeu iniciado em Bolonha, e compreendido como «direito comum» vigente. Cf. G. IMPALLOMENI, Pandettistica, in NNDI 12 (1957), pp. 350-353.

${ }^{186}$ Cf., v.g., R. Von JHERING, Das Schuldmoment im römischen Privatrecht, Gießen, Roth, 1867, p. 08; A. PERNICE, Labeo - Römisches Privatrecht im ersten Jahrhundert der Kaiserzeit - B - II, Aalen, Scientia, 
Contudo, foi também na ciência jurídica desse período que essa concepção (mais precisamente, seus pressupostos dogmáticos) entra em crise, uma vez concentrada a atenção sobre elementos - precipuamente a custodia $^{188}$ - que ofereciam dificuldades para se admitir a responsabilidade por culpa como exauriente de todas as hipóteses presentes nos textos da compilação justinianéia ${ }^{189}$.

Às duas principais teses antagônicas sobre a custodia que caracterizam o panorama doutrinário do século XIX antecedem resultados como os de E. LÖHR e F. SchÖMANN, metodologicamente também ligados à Pandectística.

Quanto ao primeiro, seu sistema ressentiria a influência de H. DONEAU, ao admitir a bipartição da culpa em lata e levis e uma ulterior distinção em culpa in faciendo e culpa in non faciendo ${ }^{190}$.

Mais precisamente, a custodia seria uma parte da diligentia (termo mais amplo), a saber, aquela dirigida à guarda de certa coisa e, em termos concretos, corresponderia à obrigação de responder - tout court (tratar-se-ia de uma «Verbindlichkeit» reconhecida «unbedingt») - pelos danos decorrentes do furto da coisa, já que o simples furto sempre poderia ser evitado pelo emprego da diligência ${ }^{191}$.

1963 [reimpr. 1878], p. 339 (sobre a custodia). Esse autor, se por um lado considerou o problema da imputação como consistente no tratamento do pressuposto subjetivo da responsabilidade («subjektive Voraussetzung der Haftung») - coerentemente aos princípios do sistema pandectístico -, por outro, teria evidenciado a insuficiência dessa perspectiva (imputação por culpa do inadimplemento) para explicar todos os testemunhos presentes nas fontes jurídicas romanas. Cf. R. CARDILLI, L'obbligazione cit. (nt. 04 supra), p. 27.

${ }^{187}$ Tratar-se-ia, como quer R. CARDILLI, de uma escolha dogmática da Pandectística na reconstrução do problema do inadimplemento, possivelmente condicionada seja pelo emprego do método sistemático (o que implicaria uma «ética do inadimplemento» coerente com a Willenstheorie, elemento fundante do edifício pandectístico), seja por fatores socioeconômicos, a saber, a necessidade de adequação às exigências da nascente burguesia produtiva alemã. Cf. L'obbligazione cit. (nt. 04 supra), pp. 21-25 e nt. 57.

${ }^{188}$ Com efeito, B. WINDSCHEID, ao acentuar o caráter não absoluto da proposição segundo a qual o devedor não responde quando não seja culpado pela impossibilidade do objeto da prestação, aduz como confirmação disto o caso em que o devedor é responsável por todo acontecimento que poderia ter sido evitado pelo emprego de uma guarda reforçada ou vigilância por parte deste - em suma, a custodia em sentido técnico («custodia in tecnischem Sinn») - de modo que apenas restariam excluídos da sua esfera de responsabilidade o damnum fatale, a vis maior e o casus cui resisti non potest. Cf. Lehrbuch des Pandektenrechts II cit. (nt. 103 supra), p. 62, nt. 09 [= $\$ 264]$.

${ }^{189}$ Cf. R. CARDILl, L'obbligazione cit. (nt. 04 supra), pp. 27-28; 29, nt. 70. Com efeito, observou C. A. CANNATA que, se a perspectiva acerca do direito da compilação - sintetizável na máxima «kein Übel ohne Schuld», de R. Von JHERING, Das Schuldmoment cit. (nt. 186 supra), p. 08 - manteve-se no que respeita à responsabilidade extracontratual (diante das dificuldades que ofereciam textos como Gai. 3, 211 para dela se afastar radicalmente), teria tido ela sorte diversa no que concerne à responsabilidade contratual, uma vez que passou a ser atacada já na segunda metade do século XIX, antes mesmo que a Crítica Interpolacionística se difundisse como método generalizado da pesquisa romanística. Cf. C. A. CANNATA, Sul problema (1992) cit. (nt. 01 supra), p. 03; C. A. CANNATA, Sul problema (1996) cit. (nt. 01 supra), p. 02.

${ }^{190}$ Cf. T. Engelmann, Die custodiae praestatio cit. (nt. 150 supra), pp. 15-16.

${ }^{191}$ Cf. Die Theorie der Culpa, Gießen, Heyer, 1806, p. 72; 77; ID., Beyträge zur der Theorie der Culpa, Gießen-Darmstadt, Heyer, 1808, pp. 163-164. Aparentemente - e assim entende T. ENGELMANN, Die custodiae praestatio cit. (nt. 150 supra), p. 16 - estaria subjacente à teoria do autor uma presunção de culpa 
A seu turno, propôs F. SCHÖMANN - apoiado no discutido Ulp. 29 ad Sab., D. 50, 17, 23 - uma quadripartição da culpa: culpa lata, culpa levis, (omissão de) custodia e diligentia $^{192}$.

A custodia corresponderia à mais alta vigilância possível exigível de alguns devedores (v.g., vendedor, locador e locatário) a fim de evitar seja o perecimento total, seja o extravio da coisa, ou por um terceiro (em caso de furto), ou por ela mesma (na hipótese de fuga do escravo devido ${ }^{193}$. Em contrapartida, a diligentia - o quarto grau - diria respeito às deteriorações da coisa, sendo exigida apenas de algumas figuras de contratantes (v.g., comodatário $)^{194}$.

Deve-se, entretanto, a J. C. HASSE a elaboração de uma das teses de maior influência no cenário jurídico oitocentista ${ }^{195}$ : «custodia» seria, para o autor, nada mais do que uma aplicação da diligência, ou seja, uma parte ou uma espécie dessa última («diligentia in custodiendo»), e a inobservância dessa obrigação, existente em alguns casos, seria de se considerar culpa $^{196}$.

$\mathrm{O}$ afastamento substancial daquela que se poderia considerar a «doutrina dominante» até a segunda metade do século XIX, deu-se, porém, por obra de J. BARON, ao qual se deveria a «emulsão», a partir das fontes romanas, de uma «eminente Haftung», a «custodia im höchsten Sinn» ou «custodia im eminenten Sinn», posteriormente também «subjective Custodia» ou «technische Custodia» ${ }^{197 .}$

nessas hipóteses (a evitabilidade in abstracto do simples furto). Contra essa interpretação da custodia por E. VON LÖHR, F. SCHÖMANN, Prüfung der Theorie der Culpa des Herrn Egid von Lohr als Bestätigung seiner Abhandlung über Culpa, Giesen-Wetzler, Tasché und Müller, 1806, p. 37, principalmente.

${ }^{192}$ Cf. Lehre vom Schadensersatze I - Culpa, Gießen-Wetzler, Tasché und Müller, 1806, pp. 80-99, principalmente.

${ }^{193}$ Cf. F. SCHÖMANN, Lehre I cit. (nt. 192 supra), pp. 89-90.

${ }^{194}$ Cf. F. SCHÖMANN, Lehre I cit. (nt. 192 supra), p. 90; 110.

195 A polarização das principais teses sustentadas sobre o assunto no século XIX segue, nessa secção, aquela traçada por C. A. CANNATA, Ricerche cit. (nt. 21 supra), pp. 26-33.

${ }^{196}$ Cf. J. C. HASSE, Die Culpa des römischen Rechts - Eine civilistische Abhandlung, $2^{\mathrm{a}}$ ed., Bonn, Marcus, 1838, pp. 283-286 [= § 76]; 291 [= § 78], principalmente; sobre a interpretação dessa passagem do autor, J. PARIS, La responsabilité cit. (nt. 42 supra), p. IV, nt. 01.

Nessa proposição se refletiria, mais uma vez, a influência da teoria de H. DONEAU, como quer T. Engelmann, Die custodiae praestatio cit. (nt. 150 supra), p. 09. Seguem a tese do autor, em suas linhas fundamentais, v.g. G. F. PUCHTA, Vorlesungen über das heutige römische Recht II, $6^{\mathrm{a}}$ ed., Leipzig, Tauchnitz, 1874, pp. 99-100 [= §§ 264-267]; C. G. WÄCHTER, Pandekten I -Allgemeiner Teil, Leipzig, Breitkopf und Härtel, 1880, p. 443 [= $\$ 86]$; P. A. H. WETTER, Pandectes contenant l'histoire du droit romain et la legislation de Justinien III - Les obligations, Paris, Librarie Génerale de Droit et de Jurisprudence, 1910, pp. 38-39 [= § 294]; K. L. ARNDTS, Lehrbuch der Pandekten I, 14 a ed., Stuttgart, Cottaschen, 1889, p. 143 [= 86]; R. SoHM, Institutionen - Geschichte und System des römischen Privatrechts, 16 ${ }^{\mathrm{a}}$ ed., München-Leipzig, Puncker \& Humblot, p. 494, nt. 03 [= § 76].

${ }^{197}$ Cf. «Diligentia» cit. (nt. 175 supra), p. 46; ID., Die Haftung bis zur höheren Gewalt, in AcP 78 (1892), pp. 203-310; ID., Pandekten, $8^{\text {a }}$ ed., Leipzig, Duncker \& Humblot, 1893, p. 226; pp. $421-427$ [= $\S 237$ e 238]. Essa «Custodia im höchsten Sinn» contrapor-se-ia a outra «custodia», também recorrente nas fontes, a saber, a «custodia boni patris familias», ou seja, a custódia normal («gewöhnliche Custodia») ou «objective 
Tratar-se-ia de uma figura de responsabilidade («Haftpflicht») - designada ora por «custodia», ora por «diligentia», «diligentia exacta», «diligentia exactissima», «diligentiam qualem diligentissimus pater familias suis rebus adhibet» - pela qual estariam obrigados alguns devedores a responder - mesmo sem culpa - pelo dano causado a coisa por culpa de terceiros ou pelo furto ou pela danificação da coisa (móvel, necessariamente) devida ${ }^{198}$.

Essas expressões assinalariam, segundo J. BARON, não um agravamento da lógica da culpa, mas propriamente uma responsabilidade legal de garantia («Garantiehaftung») até os limites do caso fortuito e da força maior. Sua introdução teria visado a colmatar uma lacuna jurídica nos casos de subtração por furto ou danificação da coisa: mesmo que sem culpa - o que seria, ademais, difícil de provar pelo devedor -, o inadimplemento não se deveria a caso fortuito (com consequente liberação do obrigado); logo, mais justo seria fazer o devedor, a quem cabia o proveito do negócio, suportar o dano, respondendo por ele, sem possibilidade de provar sua não-culpa ${ }^{199}$.

Em síntese, «custodiam praestare» - ou seja, a «technische Custodia» dos juristas romanos - teria como elementos caracterizadores: (a) ser não apenas a responsabilidade por culpa alheia («Haftung für fremde Schuld»), mas também a por casus minor («niederer Zufall» ${ }^{200}$ ), pois que ocorrências evitáveis mediante uma atividade de guarda pessoal agravada; e (b) limitação pela força maior («höhere Gewalt»), compreensiva dos eventos irresistíveis, insuperáveis mesmo pela mais elevada diligência ${ }^{201}$.

Custodia». O devedor obrigado a essa última, em caso de inadimplemento, responderia apenas por sua culpa pelo evento causador do perecimento do objeto da prestação.

Em contrapartida, a primeira - em regra, sem complementos nos textos (daí «Custodia schlechthin») designaria, propriamente, a particular Haftung individualizada por J. BARON: responsabilidade, independentemente de culpa, por furto ou dano causado à coisa devida. Essa seria, portanto, a acepção técnica do termo «custodia» nas fontes romanas - «Custodia im technischen Sinn» -, expressão cunhada por B. WINDSCHEID em crítica à tese de J. BARON, e posteriormente acolhidas por esse último para contrapor a «objective Custodia» e a sua «subjective Custodia» (ou «technische Custodia»). Cf. Die Haftung cit. (nt. 198 supra), p. 205; 208; 308; ID., Pandekten cit. (nt. 198 supra), pp. 421-422 [= § 237]; C. A. CANNATA, Ricerche cit. (nt. 21 supra), p. 28; ID., Sul problema (1996) cit. (nt. 01 supra), p. 02, nt. 02.

${ }^{198}$ Cf. J. BARON, «Diligentia» cit. (nt. 175 supra), p. 46; ID., Die Haftung cit. (nt. 198 supra), p. 207; 228; ID., Pandekten cit. (nt. 198 supra), pp. 421-422 [= §237].

${ }^{199}$ Cf. «Diligentia» cit. (nt. 175 supra), p. 61; 93-94, principalmente. A custodiae praestatio era, segundo o autor, apenas uma categoria jurídica («juristische Denkform») que permitia aos romanos introduzir em seu direito a responsabilidade até a força maior, tendo para eles o significado de um expediente formal (tal como a ficção). Uma vez que tinham como ponto de partida uma responsabilidade exclusiva por culpa (própria), era-lhes necessário recorrer a um expediente - um «Mittelglied»-para a introdução da responsabilidade por culpa alheia (e também por casus minor) em seu sistema jurídico. Cf. ID., Die Haftung cit. (nt. 198 supra), pp. 224-225; 297. Contra, T. EngElmann, Die custodiae praestatio cit. (nt. 150 supra), pp. 56-57.

${ }^{200}$ Sobre esse conceito, especialmente, J. BARON, Pandekten cit. (nt. 198 supra), pp. 424-425 [= § 238].

${ }^{201}$ Cf. J. BARON, Die Haftung cit. (nt. 198 supra), p. 206; 226; 230; 303-307; ID., Pandekten cit. (nt. 198 supra), pp. 421-422 [= $§ 237]$. 
Ainda no âmbito da Pandectística seriam identificáveis posicionamentos intermediários, tanto sob a perspectiva estritamente dogmática ${ }^{202}$, quanto também sob aquela histórica como, neste último caso, os esforços de A. PERNICE para a solução do problema da custodia ${ }^{203}$.

Nesse particular âmbito do direito das obrigações, o conceito de custodia ter-se-ia alterado, correspondendo à equação sustentada por J. C. HASSE (isso é, como diligentia in custodiendo) apenas no final desse processo evolutivo (ou seja, no direito justinianeu). Para os juristas clássicos, a custodia apresentava-se com autonomia - seja no que concerne ao conteúdo, seja ao regime prático - em relação à diligentia, até o período adrianeu, a patir do qual teria tido início a assimilação conceitual das duas figuras ${ }^{204}$.

Na proposta de A. PERnICE ter-se-ia a primeira tentativa de solucionar, em chave histórica, o problema oferecido pelas contradições das fontes na matéria, ao deduzir uma provável modificação - operada já no direito clássico - no sistema de responsabilidade contratual romano $^{205}$.

\subsection{Crítica Interpolacionística: «custodiam praestare» como a «responsabilidade objetiva» do direito clássico}

Coerentemente à tendência dessa fase dos estudos romanísticos de contrapor os dois períodos do direito romano (bipolarismo) - o clássico e o justinianeu -, vislumbramse dois sistemas de responsabilidade contratual: um, informado por critérios objetivos, cujo exemplo fundamental seria a custodia, e o outro, centrado no conceito de culpa $^{206}$.

Sob esse novo método, as investigações sobre o problema da «responsabilidade por custodia» orientam-se, a partir do início do início do século XX, em torno de duas principais reconstruções histórico-dogmáticas.

De um lado, opõe-se L. LUSIGNANI à tese de J. BARON sobre a custodia como uma figura particular de Haftung exorbitante dos limites da culpa - responsabilidade absoluta

\footnotetext{
${ }^{202}$ Cf., v.g., B. WINDSCHEID, a partir da $4^{\mathrm{a}}$ edição de seu Lehrbuch des Pandektenrechts, parece dividir uma opinião «intermediária», por admitir que, nas fontes, o termo custodia - além de um particular sentido técnico - consistiria em uma modalidade de diligentia (por sua vez, consistente no oposto da culpa em seu significado técnico), qual seja, aquela destinada à proteção de uma coisa («custodia ist die auf Schutz einer Sache gerichtete diligentia»). Cf. II cit (nt. 103 supra), p. 62, nt. 09 [= § 384]; 64, nt. 02 [= § 264].

${ }^{203}$ Cf. Labeo II cit (nt. 186 supra), pp. 345-360.

${ }^{204}$ Cf. A. PERnICE, Labeo II cit (nt. 186 supra), pp. 359-360, fundamentalmente.

${ }^{205}$ Cf. M. Serrano-Vicente, Custodiam cit. (nt. 26 supra), p. 62.

${ }^{206}$ Cf. R. CARDILLI, L'obbligazione cit. (nt. 04 supra), p. 30 e nt. 72.
} 
por furto e por damnum iniuria datum -, configuração essa que teria ela assumido, segundo o primeiro, apenas no direito justinianeu ${ }^{207}$.

Enucleadas e afastadas as interpolações compilatórias, essa custodia nada mais seria, no direito clássico, do que uma responsabilidade por culpa, ou seja, pela inobservância do dever de diligência exigível em cada relação obrigacional ${ }^{208}$.

Entretanto, a partir de E. SECKEL, esses termos da reconstrução invertem-se, dandose à custodia, interpretada como critério objetivo de responsabilidade («einstehen für niederen Zufall»), uma posição autônoma no direito clássico, reinterpretada, no direito pósclássico, à luz da teoria da culpa, como «diligentia bonis patris familias hinsichtlich der Bewachung» ${ }^{209}$. Na doutrina clássica, custodiam praestare figuraria como o penúltimo termo da «Funfteilung der praestanda»: dolus, culpa, diligentia, custodia e vis maior ${ }^{210}$.

A essa perspectiva se teriam alinhado, com efeito, a maior parte dos estudiosos da primeira metade do século XX, dentre os quais, v.g., F. HAYMANN ${ }^{211}$, na Alemanha, e também J. PARIS, na França ${ }^{212}$.

Em certos limites ${ }^{213}$ também aderente a essa perpectiva, V. ARANGIO-RUIZ ${ }^{214}$ é considerado o máximo expoente desse filão interpretativo que se firmou como communis opinio sobre a matéria em parte considerável do século $\mathrm{XX}^{215}$.

207 Cf. La responsabilità per custodia secondo il diritto romano I - Il receptum natuarum cauponum stabulariorum - Gli altri casi di locatio conductio, Modena, Soliani, 1900, p. 41; 53-55; 57; 63, principalmente; 65-66; 70; 72.

${ }^{208}$ Cf. L. LUSIGNANI, La responsabilità I cit. (nt. 207 supra), p. 23; 38, principalmente. Em suma, no que concerne ao direito clássico, esse autor teria acolhido a tese de J. C. HASSE, como observa J. PARIS, La responsabilité cit (nt. 42 supra), p. VI. Suas proposições fundamentais parecem ter granjeado a adesão de autores como A. DE MEDIO, Caso fortuito e forza maggiore in diritto romano, in BIDR 20 (1908), p. 175 e nt. 02 (v.g.); também, em certos limites, C. FERrini - G. Grosso, Manuale di Pandette, $4^{\mathrm{a}}$ ed., Milano, Società Editrice Libraria, s. d., pp. 455-456; C. FERRINI, Storia e teoria del contratto di comodato nel diritto romano, in E. AlBERTARIO (cur.), Opere di Contardo Ferrini III - Studi vari di diritto romano e moderno Sulle obbligazioni, sul negozio giuridico, sulle presunzioni, Milano, Hoepli, 1929, p. 152; 158; 160; 178.

${ }^{209}$ Cf. H. HEUMANN - E. SECKEL, Custodia, in Handlexicon cit. (nt. 18 supra), p. 116.

${ }^{210}$ Cf. H. HeUMANN - E. SECKEL, Custodia, in Handlexicon cit. (nt. 18 supra), p. 117.

${ }^{211}$ Cf. Textkritische Studien zum römischen Obligationenrecht I - Die Haftung für Custodia, in SZ 40 (1919), pp. 171-175.

${ }^{212}$ Cf. La responsabilité cit. (nt. 42 supra), pp. XVI-XVII.

213 De fato, declara o autor ter reafirmado a tese de E. SECKEL, mas por uma via diversa, a saber, o confronto entre o Gaio genuíno (das Institutas) e o pseudo-Gaio (das res cotidianae), contraposição que lhe teria dado um critério mais seguro para contrapor o pensamento clássico ao bizantino. Cf. Responsabilità cit. (nt. 04 supra), p. 75.

${ }^{214}$ Cf. As idéias fundamentais já se encontravam lançadas na primeira edição, de 1927, mas teriam sofrido - como nota M. SERRANO-VICENTE - um significativo temperamento na segunda. Cf. Custodiam cit. (nt. 26 supra), pp. 67-68 e nt. 114. Com efeito, cf. V. ARANGIO RuIZ, Responsabilità cit. (nt. 04 supra), p. $173 ; 195 ; 270$.

${ }^{215}$ Seguem-no, nas linhas fundamentais de sua reconstrução histórica do sistema de responsabilidade contratual romano, não obstante diferenças quanto às premissas, v.g., G. I. LuZZATTO, Caso cit. (nt. 119 supra), pp. 39-40, principalmente; A. METRO, L' obbligazione cit. (nt. 22 supra), p. 95, nt. 07; 96-97; 98, nt. 20; 106, nt. 46. 
Em larga síntese, resulta da investigação do autor que o sistema de responsabilidade contratual romano apoiava-se, no direito clássico, nos conceitos de dolus e custodia, fundamentalmente $^{216}$. Essa última teria aplicação nas hipóteses em que certo devedor detém coisa alheia (a ser restituída), e tem por efeito torná-lo responsável, em caso de inadimplemento (por perda da coisa), independentemente de um comportamento reprovável de sua parte relacionado ao evento causador da impossibilidade da prestação ${ }^{217}$.

Por outros termos, «custodiam praestare», no período clássico, designaria uma responsabilidade objetiva, isso é, independente da culpa $^{218}$ : nas relações contratuais em que tivesse aplicação, o devedor estaria obrigado a responder pelas consequências do inadimplemento devido a certos eventos (furto, damnum iniuria causado por terceiros) ${ }^{219}$.

Só mais tarde se teria verificado a penetração do conceito de culpa no direito romano, razão pela qual seria de se considerar de origem espúria (interpolação) as referências a essa - ou, em geral, a fundamentação da responsabilidade em termos subjetivos - nas fontes clássicas ${ }^{220}$.

Mais precisamente, nos textos jurídicos romanos seria identificável uma dupla extratificação no que concerne às manipulações: uma, pós-clássica, responsável pela introdução do critério da culpa; a outra, compilatória (justinianéia), à qual se deveria atribuir a inserção das referências à diligentia ${ }^{221}$.

Também a «responsabilidade por custodia» não sobreviveu aos esforços de harmonização compilatórios, sofrendo uma transformação em diligentia in custodiendo, ou seja, inserida na lógica da imputação do inadimplemento por culpa: enfim, uma responsabilidade subjetiva ${ }^{222}$.

216 A aparente justificativa dessa orientação, como nota M. TALAMANCA, consistia na limitação da responsabilidade do devedor, nas relações contratuais tuteladas por iudicia bonae fidei, ao dolus por ser esse o contraposto da bona fides. Além disso, a noção de dolus dessa vertente interpretativa abrangeria também hipóteses de responsabilidade que poderiam ser consideradas culposas - v.g., V. ARANGIO-RUIZ, Responsabilità cit. (nt. 04 supra), p. 29. Cf. Vendita cit. (nt. 21 supra), p. 446, nt. 1487; 447, nt. 1489.

${ }^{217}$ A reconstrução do panorama do direito clássico nessa matéria embasa-se nas informações - reputadas, sem mais, clássicas - de Gai. 3, 205-207 (infra): o discurso de Gaio, conexo aos pressupostos de legitimação ativa à actio furti seriam, para o autor, tudo quanto se poderia afirmar, com segurança, acerca da responsabilidade além do dolo no direito clássico. Cf. V. ARANGIO-RuIZ, Responsabilità cit. (nt. 04 supra), p. 65 .

${ }^{218}$ Cf. V. ARANGIO-RuIZ, Responsabilità cit. (nt. 04 supra), p. 66. Retomava-se, assim, limitamente à configuração dogmática de «custodiam praestare», a interpretação iniciada por J. BARON (supra), revelandose equivocado o prognóstico de T. ENGELMANN: «...daß es ihr <die Baron'sche Theorie> gelingen wird, Anhänger zu gewinnen, halten wir für sehr unwahrscheinlich» (= ... consideramos muito improvável que ela <a teoria de Baron> conseguirá granjear seguidores,). Cf. Die custodiae praestatio cit. (nt. 150 supra), p. 67.

${ }^{219}$ Cf. V. ARANGIO-RUIZ, Responsabilità cit. (nt. 04 supra), p. 266.

${ }^{220}$ Cf. V. ARANGIO-RuIZ, Responsabilità cit. (nt. 04 supra), p. 43; 71; 248-250.

${ }^{221}$ Cf. V. ARANGIO-RUIZ, Responsabilità cit. (nt. 04 supra), pp. 94-99.

${ }^{222}$ Cf. V. ARANGIO-RUIZ, Responsabilità cit. (nt. 04 supra), pp. 270-271, principalmente. 
Grosso modo, poder-se-ia afirmar que, na literatura da Crítica Interpolacionística, verificou-se, progressivamente ${ }^{223}$, um processo de eliminação da culpa como critério de responsabilidade contratual empregado pela iurisprudentia clássica $^{224}$.

\subsection{Reações à communis opinio interpolacionística}

Em meados do século XX, as conclusões da Crítica Interpolacionística nessa matéria já não mais recebem total acolhida por parte dos estudiosos 225 .

Da eliminação da culpa do sistema de responsabilidade contratual romano do período clássico - subsistindo, nesse, apenas «critérios objetivos» (dentre os quais, e principalmente, a «responsabilidade por custodia») - não resultava uma reconstrução convincente, tendo-se em vista alguns textos das fontes ${ }^{226}$.

Agrupam-se, nos itens seguintes, as três principais direções do processo revisionista da (até então) communis opinio sobre o assunto. A principal contribuição desses autores teria sido a reabilitação do lugar da culpa («culpam praestare») no direito clássico ${ }^{227}$, e a admissão de sua coexistência com a custodia («custodiam praestare») 228

${ }^{223}$ Com efeito, «custodiam praestare» desponta, em um primeiro momento, como uma responsabilidade objetiva em um sistema ainda caracterizado como subjetivo, centrado na culpa. Por outros termos, como notou A. FliniauX, essa custodia figura como um «îllot qui émerge sur l'océan de la subjectivité». Cf. Compte reundu de J. PARIS, La responsabilité de la custodia en droit romain, p. 111.

${ }^{224}$ Dava-se seguimento, assim, ao processo de erosão - iniciado já no âmbito da própria Pandectística da perspectiva «kein Übel ohne Schuld» em relação ao direito romano. Cf. C. A. CANNATA, Sul problema (1992) cit. (nt. 01 supra), p. 03. Uma crítica de conjunto da reconstrução majoritária do problema na literatura interpolacionística até os anos 30 oferece R. CARDILLI, L'obbligazione cit. (nt. 04 supra), p. 43; sobre a definitiva superação dessa doutrina, M. KASER, Das römische Privatrecht I cit. (nt. 05 supra), p. 509; M. TALAMANCA, Vendita cit. (nt. 21 supra), pp. 446-447; ID., Istituzioni cit. (nt. 05 supra), p. 659.

${ }^{225}$ Além dos autores infra, é também elucidativa a ponderação de E. RABEL quanto aos resultados da opinião majoritária sobre o assunto nesse período. Suas reservas centram-se, precisamente, no desfavor com que vinha considerada a culpa no sistema romano clássico de responsabilidade contratual por, v.g., V. ARANGIO-RUIZ. Parece ao autor mais verossímil que a custodia não tivesse - tal como pretendido - uma posição dominante no direito clássico, correspondendo a um resíduo arcaico nas fontes (nos termos expressos por Gaio, nas Institutas). Mais consentânea à concepção dos juristas clássicos teria sido a introdução de doutrinas mais refinadas, dirigidas à consideração do comportamento individual do devedor (em suma, a culpa). Cf. Custodia cit. (nt. 21 supra), pp. 511-512.

${ }^{226}$ Em Ulp. 32 ad ed., D. 19, 2, 9, 5, reporta-se uma opinião atribuída a Celso, segundo a qual conductores como o fullo e o sarcinator seriam responsáveis por culpa («culpam praestare»). Dado que esses devedores são considerados por Gaio (3, 205) como responsáveis por custodia, concluíram alguns autores que o primeiro texto não continha uma expressão genuína de um jurista clássico como Celso, e o teor original seria reobtido pela substituição de «culpa» por «custodia». Cf., v.g., G. I. LuZZATTO, Caso cit. (nt. 119 supra), p. 180.

Essa hipótese de interpolação e proposta de integração textual - que já encontravam reservas de expoentes da própria Crítica Interpolacionística, como V. ARANGIO-RUIZ - seriam, como nota C. A. CANNATA, emblemáticas da incompreensão e dos excessos da doutrina interpolacionística na matéria. Cf. Ricerche cit. (nt. 21 supra), p. 29.

227 Cf. C. A. CANNATA, Sul problema (1992) cit. (nt. 01 supra), p. 05.

${ }_{228}$ Superava-se, assim, um limite conceitual característico do período interpolacionístico, ao admitir e explicar - seja sob o plano histórico, seja sob o dogmático - a concorrência de uma responsabilidade por 


\subsection{1. «Custodiam praestare» nas reconstruções unitárias do sistema clássico de responsabilidade contratual}

A obra de G. MARTON assinalaria a primeira sólida reação à tese interpolacionística majoritária, sintetizável como «entre dolus e custodia, tertium non datur» ${ }^{229}$. Na reconstrução do sistema de responsabilidade contratual clássico, teria lugar não apenas a responsabilidade por custodia, mas também a responsabilidade por culpa.

Dada a valoração dessa (culpa) com base em um modelo comportamental, ou seja, um padrão objetivo de conduta, tanto «culpam praestare» quanto «custodiam praestare» teriam operatividade na conformação de um sistema de responsabilidade fundamentalmente objetivo ${ }^{230}$.

Tratar-se-ia de tentativas de reconstrução do sistema clássico de responsabilidade contratual de modo unitário e não articulado ${ }^{231}$. A readmissão da culpa dentre os critérios de imputação do inadiplemento elaborados e utilizados pela iurisprudentia clássica teria requerido, por parte de G. MARTON e K. VISKY (para esse, limitamente ao período republicano), uma reconsideração conceitual da culpa para inseri-la em um sistema objetivo, no qual seria possível - entende-se - a sua interrelação com custodia $^{232}$.

\subsubsection{Releituras de «custodiam praestare» alternativas à «responsabilidade objetiva»}

A seu turno, concentrou-se outra vertente doutrinária - em crítica à reconstrução majoritária sobre o problema da responsabilidade contratual no direito romano - na

culpa e de uma responsabilidade por custodia. Cf. R. CARDILLI, L'obbligazione cit. (nt. 04 supra), p. 442, nt. $28 ; 462$, nt. 64.

${ }^{229}$ Cf. V. ARANGIO-RUIZ, Istituzioni di diritto romano, $4^{\mathrm{a}}$ ed., Napoli, Jovene, 1937, p. 384.

$230 \mathrm{Cf}$. Un essai de reconstruction du dévélopement probable du système classique romain de responsabilité civile, in RIDA 3 (1949), pp. 189-191; também, ID., Rinascita della dottrina della responsabilità per custodia, in IURA 7 (1956), pp. 121-131; de semelhante modo, K. VISKY, La responsabilité dans le droit romain à la fin de la République, in RIDA 3 (1949), pp. 482-483.

231 Não se teria logrado, assim, superar os limites da doutrina dominante, justamente em função da visualização do problema da responsabilidade contratual como expressão de um sistema unitário. Além disso, não se superou, na valoração dos critérios de imputação elaborados pela iurisprudentia clássica, a superficial descrição desses mediante as categorias «responsabilidade por culpa»e «responsabilidade sem culpa». Cf. R. CARDILLI, L'obbligazione cit. (nt. 04 supra), p. 37.

${ }^{232}$ Para K. VISKY, com efeito, a custodia não mais seria senão uma articulação interna da culpa, uma aplicação dessa aos casos em que certo devedor recebe coisa alheia e deve aplicar-se à sua guarda, disso decorrendo uma valoração mais estrita da responsabilidade. Tal seria admissível uma vez que a culpa não seria apenas negligência em sentido estrito, mas assumiria uma coloração objetiva («teinte objective»). Cf. La responsabilité cit. (nt. 230 supra), p. 482. 
categoria utilizada por essa última para exprimir uma série de critérios empregados pelos juristas clássicos.

$\mathrm{Na}$ doutrina interpolacionística, com efeito, a culpa apresentava-se negativamente, isso é, sob a perspectiva de sua ausência - como conceito geral para a descrição de uma série de critérios que dela prescindiam (dentre os quais custodiam praestare $)^{233}$. Por esse elemento comum - a indiferença da conduta culposa do devedor na valoração da imputação do inadimplemento -, reuniram-se variados critérios de imputação em uma «categoria de acomodação» - a «responsabilidade objetiva» - sem esclarecer, contudo, o fundamento essencial desses critérios ${ }^{234}$.

Dirigem-se, assim, os esforços de autores como P. KRÜCKMANN e E. BETTI, à busca de outros conceitos, que se revelassem mais adequados do que categorias meramente descritivas («responsabilidade sem culpa»), para expressar a concepção clássica da responsabilidade contratual ${ }^{235}$.

No que concerne ao primeiro, sua tentativa consistiu em introduzir, a fim de explicar o quadro das soluções clássicas nessa matéria, o conceito moderno de «Versicherungshaftung», que, segundo P. KRÜCKMANN, seria a chave conceitual para se compreender, dentre outros, também «custodiam praestare» ${ }^{236}$.

«Custodia», assim como «diligentia», consistiriam - fato não observado, segundo o autor, pela doutrina dominante - em comportamentos humanos e não em qualquer outro fato ou situação, e como tal poderia ser causa de uma Haftung, mas não - como consideraria aquela - a própria Haftung ${ }^{237}$.

Assim configurado - «Kustodiaplicht» -, a valoração do inadimplemento dessa obrigação constituiria uma figura mista («Mischgebilde») que conteria, ao mesmo tempo, Zufallshaftung e Verschuldshaftung: com efeito, o que para o responsável é Zufall, para o autor do dano seria culpa ou Dritthaftung ${ }^{238}$. Sob essa perspectiva, «custodiam praestare» importaria em uma responsabilidade pelo não impedimento do dano à coisa, objeto da prestação, e teria sido - sob a perspectiva evolutiva, em termos históricos, do direito romano - a primeira manifestação da Haftung por omissão culposa ${ }^{239}$.

${ }^{233}$ Cf. R. CARDILLI, L'obbligazione cit. (nt. 04 supra), p. 30 e nt. 72.

${ }^{234}$ Cf. R. CARDILLI, L'obbligazione cit. (nt. 04 supra), pp. 30-31.

${ }^{235}$ Cf. R. CARDILLI, L'obbligazione cit. (nt. 04 supra), p. 38.

${ }^{236}$ Cf. Versicherungshaftung im römischen Recht, in SZ 63 (1943), pp. 42-51.

${ }^{237}$ Cf. P. KRÜCKMANN, Custodia, in SZ 64 (1944), p. 05.

${ }^{238}$ Cf. P. KRÜCKMANN, Custodia cit. (nt. 237 supra), p. 02; 24.

${ }^{239}$ Cf. P. KRÜCKMANN, Custodia cit. (nt. 237 supra), pp. 03-04; 24. Uma valoração geral dos resultados desse autor - seja sob a perspectiva estritamente dogmática, seja sob aquela da reconstrução histórica dos 
Limitadamente à custodia, teria resultado da tentativa do autor, ainda que sob a leitura de uma nova chave conceitual («Versicherungshaftung»), uma custodia cujo inadimplemento seria valorado como culposo, repropondo-se, portanto, um modelo substancialmente subjetivo ${ }^{240}$.

Por sua vez, individualiza E. BETTI no conceito de «autoresponsabilità» a idéia subjacente às soluções da iurisprudentia clássica em matéria de responsabilidade contratual, e que permitiria compreender a concepção romana do problema. Tratar-se-ia da necessidade, na qual se encontra o devedor inadimplente, de sofrer as consequiências de seu comportamento voluntário, positivo, com o qual determinou, causando dano ao credor, a impossibilidade da prestação devida ${ }^{241}$.

A responsabilidade por custodia seria, segundo o autor, uma aplicação dessa noção, uma vez que se nela se verificaria uma valoração típica da situação criada com a entrega da coisa ao devedor. Com efeito, o vigilante exercício da custodia, na normalidade dos casos (quod plerumque accidit), seria idôneo, abstratamente, a defender a coisa de certos eventos (v.g., furto e dano causado por terceiros), de modo que, a imputabilidade - em caso contrário - derivaria de uma valoração típica, realizada com base em critérios objetivos ${ }^{242}$.

\subsection{3. «Custodiam praestare» sob a perspectiva historicamente articulada dos «critérios de responsabilidade»}

Por fim, ainda que em processo revisionista, retoma-se o tratamento do problema da responsabilidade contratual mais atreladamente à perspectiva tradicional, contrariamente à relativa ruptura das orientações precedentes.

critérios de responsabilidade no direito clássico - oferece R. CARDILLI, L'obbligazione cit. (nt. 04 supra), pp. $39-40$.

${ }^{240}$ Cf. R. CARDILli, L'obbligazione cit. (nt. 04 supra), p. 40.

${ }^{241}$ Cf. Istituzioni II-1 cit. (nt. 124 supra), pp. 332-335; 352-354.

242 Não se trataria, porém, de uma «responsabilidade objetiva» no sentido de «responsabilidade sem culpa», já que a culpa não seria, no caso, um elemento irrelevante. Essa é, com efeito, levada em consideração, mas sob uma valoração típica, fundamentada na situação objetiva surgida com a entrega da coisa. Em razão do poder de controle - e, logo, de prevenção do furto e do dano - reconhecem os juristas romanos uma custodia a cargo do devedor como «garanzia di conservazione in vista di una restituzione», não se eximindo o devedor dessa responsabilidade mediante a demonstração de ter sido, concretamente, diligente no exercício da atividade. Como nota R. CARDILLI, a «autoresponsabilità», idéia na qual se lastreariam, segundo E. BETTI, os vários critérios de valoração típica utilizados pelos juristas romanos, nada mais seria senão a responsabilidade por culpa, com a particularidade de que esta seria reconhecida com base em critérios que prescindem da valoração da conduta concreta do devedor. Não teria resultado, portanto, da contribuição desse autor uma explicação e reconstrução adequadas dos critérios de imputação operantes ao lado da culpa tanto no direito pré-clássico quanto no clássico. Cf. L'obbligazione cit. (nt. 04 supra), p. 42; 44; também C. A. CAnNATA, Ricerche cit. (nt. 21 supra), p. 141. 
A responsabilidade por custodia teria sofrido uma limitação em relação à projeção por ela ocupada no âmbito da reconstrução dominante, a saber, como critério geral de imputação operante em um sistema de responsabilidade objetiva, vigente - como pretendido por aquela communis opinio - no direito romano clássico ${ }^{243}$.

No mesmo sentido pode-se considerar a apresentação, por M. KASER, do sistema de responsabilidade contratual pré-clássico e clássico como informado por três conceitos fundamentais: dolus, culpa e custodia $^{244}$. Os juristas teriam reconhecido essa última em alguns casos nos quais o devedor tinha a detenção de coisa alheia e daria ela fundamento, na hipótese de impossibilidade da prestação devida a certos eventos (v.g., furto), a uma Haftung particular, independente de culpa para a imputação do inadimplemento ${ }^{245}$.

Essa operatividade contemporânea dos critérios de responsabilidade é também admitida por M. TALAMANCA, do que resulta um sistema clássico informado tanto por critérios subjetivos (dolus e culpa), quanto objetivos (custodia) $)^{246}$.

No que concerne a «custodiam praestare», observa esse autor que não se trataria nem de um critério geral, nem único: com efeito, seria ele um critério aplicável apenas a algumas relações obrigacionais, e não exauriria, ademais, todo o expectro do «responder» contratual do devedor. Assim, responder-se-ia por custodia em relação a certas modalidades de inadimplemento (critério típico), deixando-se lugar para a valoração de outras hipóteses com base em outros critérios (dolus, culpa $)^{247}$.

Com o enquadramento dos âmbitos específicos de cada critério e os esforços de compreensão dos significados e da relação entre eles, ter-se-ia superado o esquema dominante na literatura interpolacionística de fazer corresponder uma responsabilidade objetiva e uma subjetiva a dois momentos diversos da historia do direito romano ${ }^{248}$.

${ }^{243}$ A propósito, notou M. SARGENTI que a alternativa entre culpa e custodia, e a compreensão, nessa última, de todas as formas de responsabilidade objetiva concebidas, com método casuístico, pela iurisprudentia romana - propostas da doutrina romanística em matéria de responsabilidade contratual -, resultaria em um esquematismo tão arriscado quanto aquele que visualiza todo o problema da responsabilidade sob a perspectiva do dolo, da culpa e das gradações dessa última. Cf. Problemi cit. (nt. 03 supra), p. 161.

${ }^{244}$ Cf. Das römische Privatrecht I cit. (nt. 05 supra), p. 506.

${ }^{245}$ Cf. Das römische Privatrecht I cit. (nt. 05 supra), pp. 506-507.

${ }^{246}$ Cf., v.g., Custodia cit. (nt. 16 supra), pp. 562-563.

${ }^{247}$ Cf. M. TAlamanCA, Custodia cit. (nt. 16 supra), p. 562.

${ }^{248} \mathrm{O}$ panorama do sistema de responsabilidade contratual, como observa R. CARDILLI, que resulta dessas proposições coincidiria com aquele já delineado nas contribuições do período interpolacionistico. Cf. $L$ ' obbligazione cit. (nt. 04 supra), p. 48, nt. 93. De fato, nas reconstruções de autores como, v.g., E. SECKEL, F. HAYMANN e J. PARIS (supra), a identificação de uma custodia objetiva não parecia excluir a genuinidade da culpa como critério aplicado pelos juristas clássicos, seja em geral, seja no âmbito de uma relação contratual especifica. Em relação a esse último cf. La responsabilité cit. (nt. 42 supra), p. XVII. 
O recurso a tais categorias conceituais dar-se-ia, então, para descrever os critérios de imputação contemporaneamente operantes no sistema ${ }^{249}$.

\subsection{As contribuições mais recentes sobre a matéria}

A partir da década de 60, os estudos especificamente dedicados à responsabilidade por custodia parecem seguir, de modo a poder agrupá-los, por comodidade de exposição, duas orientações ${ }^{250}$.

De um lado, C. A. CANNATA - ao que parece mais alinhado aos resultados até então $\operatorname{propostos}^{251}$ - teria aprofundado não apenas os termos dogmáticos do problema, mas também a dimensão histórica de «custodiam praestare» no direito romano. Por outro lado, uma vertente de autores que retoma a concepção - difusa na Pandectística - da custodia como aplicação da diligência, cuja inobservância implicaria a responsabilidade por culpa.

\subsection{1. «Custodiam praestare» como «prestação»}

Limitado o âmbito de aplicação de «custodiam praestare» como critério objetivo de responsabilidade no direito clássico, de modo a consentir uma cooperatividade com a culpa na determinação da responsabilidade por inadimplemento de um mesmo devedor, a atenção de C. A. CANNATA concentrou-se na determinação da natureza dessa «responsabilidade» nos vários momentos de sua história e na tentativa de estabelecer a sua importância no problema da responsabilidade contratual ${ }^{252}$.

A consideração de «custodia» como termo alusivo a um particular critério de responsabilidade resultaria, para o autor, de um equívoco entre custodia e responsabilidade por custodia. «Custodiam praestare» consistiria na terminologia técnica expressiva de um particular regime de responsabilidade contratual mas que, por referir-se a uma prestação específica - a custodia -, aludiria ao regime de responsabilidade por essa prestação, não podendo, assim, ser configurada como regime geral de responsabilidade ${ }^{253}$.

Por «custodia» os juristas clássicos aludiam a um comportamento, conhecido e tecnicamente definido: uma conduta que se deveria observar para assegurar um resultado.

\footnotetext{
${ }^{249}$ Cf. R. CARDILli, L'obbligazione cit. (nt. 04 supra), p. 46, nt. 91; 47.

250 Cronologicamente, as investigações de C. A. CANNATA precedem à outra corrente de autores, representantes da tese oposta, razão pela qual se principia pela exposição sumária de suas proposições.

${ }^{251}$ Cf. Ricerche cit. (nt. 21 supra), p. 111.

${ }^{252}$ Cf. Ricerche cit. (nt. 21 supra), p. 38.

${ }^{253}$ Cf. Ricerche cit. (nt. 21 supra), p. 36; $45 ; 57$.
} 
Essa prestação (custodia) estaria funcionalmente relacionada a um regime próprio de responsabilidade: por outros termos, seria a responsabilidade pelo inadimplemento de um certo tipo de prestação ${ }^{254}$.

Dessa interrelação entre custodia-prestação e custodia-responsabilidade, deduz C. A. CANNATA - divergindo da doutrina «objetiva», sob essa perspectiva - que «custodiam praestare» não corresponderia, essencialmente, a um «critério de responsabilidade», mas a uma obrigação contratual ${ }^{255}$. Os juristas romanos, com essa locução, exprimiam o fato de se estar obrigado a proporcionar o resultado - nesse caso, a proteção da coisa de certos riscos - que poderia ser obtido com a custodia. A não verificação desse, importaria, por sua vez, em inadimplemento imputável ${ }^{256}$.

O particular modo de valoração da prestação, portanto, é que determinaria o seu regime de responsabilidade, sem necessidade de se recorrer a um critério de responsabilidade, o que consentiria, segundo o autor, na aproximação de «custodiam praestare» com a categoria moderna da «obligation de résultat» ${ }^{257}$.

Por esses resultados, a tese de C. A. CANNATA assumiria particular importância pois não se teria limitado a uma explicação descritiva de «custodiam praestare», isso é, como exemplo de «responsabilidade sem culpa», buscando, antes, compreender seu significado e fundamento ${ }^{258}$.

Ainda que não inteiramente conforme a C. A. CANNATA, R. CARDILLI considera que na locução «custodiam praestare», «custodia» teria um significado específico, que se referiria tanto à idéia de custodire quanto à dos eventos que esta atividade deve evitar; «praestare», a seu turno, exprime o particular status de garante, reconhecido pela

${ }^{254}$ Cf. C. A. CANNATA, Ricerche cit. (nt. 21 supra), p. 57; 127.

255 Cf. C. A. CANNATA, Ricerche cit. (nt. 21 supra), p. 128. Essa tese apóia-se nas conclusões do autor quanto ao significado específico de praestare nas fontes romanas, indicativo de uma prestação específica («assicurare»), que, como elementos diferenciadores, teriam os variados complementos objetos: custodiam praestare, portanto, seria, sob essa perspectiva, mais uma das obrigações de praestare individualizadas pelo autor. Cf., nesse sentido, C. A. CANNATA, Per lo studio cit. (nt. 91 supra), pp. 13-14, principalmente e supra.

${ }^{256}$ Cf. C. A. CANNATA, Ricerche cit. (nt. 21 supra), p. 129.

${ }^{257}$ Cf. C. A. CANnAta, Ricerche cit. (nt. 21 supra), p. 130; ID., Per lo studio cit. (nt. 91 supra), p. 17. Mais precisamente, a noção delineada por esse autor corresponderia à «obligation de résultat» na teoria de $\mathrm{H}$. MAZEAUD - L. MAZEUAD - A. TUNC, Traité théorique et pratique de la responsabilité civile délictuelle et contractuelle I, 5 ed., Paris, Montchrestien, 1957, pp. 115-117 [= n. 103-3]; e não àquela de R. DEMOGUE, Traité des obligations en general I - Sources des obligations V, Paris, Rousseau, 1925, pp. 583-594, principalmente [= n. 1237]. Em relação ao primeiro, caracterizaria a «obligation de résultat» o fato de que, não atingido o resultado visado pelas partes, presume-se responsável o devedor, salvo a possibilidade de ele alegar um caso de força maior. Tratar-se-ia do tipo corrente de obrigação, uma vez que esse regime de prova seria, segundo o autor, o únivo previsto pelo C. civ. art. 1315.

${ }^{258}$ Cf. R. CARDILLI, L'obbligazione cit. (nt. 04 supra), p. 54. Adere aos seus resultados, v.g., M. KASER, Die actio furti des Verkäufers, in SZ 96 (1979), pp. 99-100. 
iurisprudentia como conseqüência das modalidades que causaram a não-restituição da $\operatorname{coisa}^{259}$.

Sob esta perspectiva, procederia o equívoco identificado por autores como C. A. CANNATA na qualificação de custodia - tal como a culpa e o dolo - como «critério de responsabilidade», já que o termo refere-se à atividade à qual se consideram vinculados alguns contraentes ${ }^{260}$.

A formulação custodiam praestare encerraria uma elipse, uma síntese de um procedimento lógico: nesta, o primeiro termo refere-se à atividade do guardião - o custodiar - interpretado de modo típico, ou seja, como vigilância apta a evitar certos eventos (a fuga, para os veteres, e o furto, para os juristas sucessivos), sem que isto implique um juízo sobre a existência da culpa; por sua vez, «praestare» indicaria o «responder» do devedor coligado a esta atividade ${ }^{261}$.

Mais recentemente, M. SERRANO-VICENTE parece alinhar-se, em certo sentido, à interpretação de custodiam praestare como uma prestação e não um critério de responsabilidade. Essa prestação dar-se-ia, inicialmente e durante uma boa parte do período clássico, apenas no âmbito dos bonae fidei iudicia. Trata-se-ia de uma prestação de conteúdo técnico, compreensiva, em princípio, da atitude necessária para evitar o furto, mais tarde também do damnum iniuria causado por terceiro, e, finalmente, convertendo-se em um dever geral de vigilância ${ }^{262}$.

Além disso, o cumprimento desta prestação submeter-se-ia a uma valoração objetiva, pois se considera que o seu correto cumprimento sempre produz o resultado visado $^{263}$.

\subsubsection{Correntes «neo-subjetivistas»}

G. MACCORMACK, em contraposição aos estudos anteriores, nos quais custodia e culpa são expressões de critérios específicos pelos quais se determina a responsabilidade de um sujeito («standards of liability»), visualiza outra relação entre tais conceitos ${ }^{264}$.

«Custodiam praestare» designaria, segundo o autor, não um critério de responsabilidade («to be liable for custodia»), mas o conteúdo de uma obrigação («to

\footnotetext{
${ }^{259}$ Cf. L'obbligazione cit. (nt. 04 supra), p. 183.

${ }^{260}$ Cf. R. CARDILLI, L'obbligazione cit. (nt. 04 supra), p. 183.

${ }^{261}$ Cf. R. CARDILli, L'obbligazione cit. (nt. 04 supra), p. 186.

${ }^{262}$ Cf. Custodiam praestare cit. (nt. 26 supra), p. 316.

${ }^{263}$ Cf. M. SERRANO-VICENTE, Custodiam praestare cit. (nt. 26 supra), p. 316; 330.

${ }^{264}$ Cf. Custodia and culpa, in SZ 89 (1972), p. 154.
} 
show, furnish custodia»), consistente na conservação, salvaguarda da coisa («to keep an object safe»). Em regra, o devedor de quem se exigisse a custodia responderia pelo inadimplemento caso houvesse $c u l p a^{265}$, não se verificando a pretendida responsabilidade automática pelo perecimento da coisa devido a certos eventos ( $«$ strict liability») ${ }^{266}$.

Desse modo, segundo G. MACCORMACK, compreender-se-ia a utilização, nos textos, ora de custodia, ora de culpa, em relação à posição jurídica de certo devedor (v.g., vendedor, comodatário, locatário). Com efeito, o emprego de um ou de outro estaria condicionado pela perspectiva do jurista: ao tratar de uma prestação à qual está obrigado o sujeito pelo contrato, usa-se custodia («obligation»); por outro lado, usa-se mais apropriadamente culpa, ao se discutir uma questão de responsabilidade («liability») ${ }^{267}$.

Seguindo-se tais orientações, também P. Vocı individualiza a responsabilidade subjetiva (dolus e culpa) como o princípio seguido pelo direito romano na matéria. As fontes dariam notícia de duas espécies de obrigações exigíveis do devedor: a de diligência comum e a de diligência exata, correspondente, essa última, à «diligentia» ${ }^{268}$.

A diligentia, como dever particular incumbente ao devedor, poderia dirigir-se ou à defesa e conservação da coisa (diligentia in custodienda re ou, tout court, custodia), ou a uma atividade de administração (diligentia in administrando) ${ }^{269}$.

Em qualquer uma das duas espécies, ao requerer-se do contratante diligentia, impor-se-lhe-iam deveres maiores em relação a outros devedores dos quais se exige um grau menor de diligência (comum). De todo modo, essa circunstância não interferiria na qualificação da responsabilidade que, decorrente da inobservância da diligência exigida, seria, portanto, culposa (omissão da diligência comum ou da exata, isso é, diligentia) ${ }^{270}$.

A custodia figura, ainda uma vez, como uma prestação (diligentia in custodienda re), dando-se, se verificado o inadimplemento, uma responsabilidade por omissão de

\footnotetext{
${ }^{265}$ Uma responsabilidade pelo dano ocorrido sem culpa do devedor («strict liability») dar-se-ia no caso de circunstâncias como a existência de um acordo, seja implícito na natureza da transação (v.g., em relação ao nauta, caupo e stabularius, sócio), seja resultante de uma convenção expressa entre as partes ( $v . g$., tal como em relação ao horrearius, nuntius). Cf. G. MACCORMACK, Custodia cit. (nt. 264 supra), pp. 178-179.

${ }^{266}$ Cf. G. MACCORMACK, Custodia cit. (nt. 264 supra), pp. 155; 159; 171; 178.

267 «Ulpa», ademais, seria o termo ao qual recorreriam os juristas para a apresentação e discussão de problemas relacionados ao inadimplemento da prestação em geral, e não apenas da prestação de custodia. Cf. Custodia cit. (nt. 264 supra), p. 179; pp. 179-213 (demonstração da proposição pelo exame das ocorrências de custodia e culpa nos textos em matéria de emptio venditio, locatio conductio, comodato, sociedade, penhor e hipóteses enquadráveis na categoria de contratos inominados - v.g., o inspector); p. 216. Também parece ser essa, essencialmente, a posição de P. VoCI, 'Diligentia' cit. (nt. 12 supra), pp. 75-77; 122-123.

${ }^{268}$ Cf. 'Diligentia' cit. (nt. 12 supra), p. 31.

${ }^{269}$ Cf. P. VocI, 'Diligentia' cit. (nt. 12 supra), pp. 31-32; 36.

${ }^{270}$ Cf. P. VocI, 'Diligentia' cit. (nt.12 supra), p. 37; 97; 122.
} 
custodia, mais precisamente, por ter o devedor ensejado o ilícito causado por outrem (em suma, responde-se por culpa) ${ }^{271}$.

Também R. ROBAYE contrapõe-se à «doutrina dominante», qual seja, a tese interpolacionística da custodia clássica como um critério de responsabilidade objetiva. A custodia, desde a época clássica, nada mais seria senão uma modalidade de culpa, isso é, uma «culpa in custodiendo», conclusão que se imporia, segundo o autor, por exigências de praticabilidade do sistema ${ }^{272}$.

\section{Os «problemas gerais» da responsabilidade por custodia}

$\mathrm{Na}$ exposição anterior, percorreram-se as principais vertentes interpretativas sobre a «responsabilidade por custodia» principalmente sob a perpectiva da inserção dessa nas reconstruções do sistema (principalmente clássico) de responsabilidade contratual romano.

271 Logo, a expressão, comumente empregada, «responsabilidade por custodia», consistiria em um «solecismo gramatical e jurídico», uma vez que haveria responsabilidade por omissão de custodia. Cf. P. VocI, 'Diligentia' cit. (nt. 12 supra), p. 47; 63-64; 75.

A tentativa do autor de enquadramento de «custodiam praestare» como uma modalidade da obrigação de diligentia exigida de alguns devedores, cuja inobservância não poderia configurar senão culpa (culpam praestare), não parece esclarecer, entretanto, o modo como se dava a valoração concreta do inadimplemento. Aparentemente, não parece resultar da releitura do autor uma mudança prática no modo de valoração concreta do inadimplemento da prestação de custodia: o devedor seria responsável se verificadas certas hipóteses - típicas, por assim dizer - de perda do objeto da prestação (v.g., furto, dano causado por terceiros). Em suma, requerer-se-ia do devedor, obrigado a custodiam praestare, a prevenção dos danos causados por fontes externas, nos limites do «evitável» com o emprego da diligentia. Cf. P. VocI, 'Diligentia' cit. (nt. 12 supra), pp. 76-77; 86, principalmente.

${ }^{272} \mathrm{Cf}$. Responsabilité objective ou subjective en droit romain - Question de terminologie et de méthode, in TR 58 (1990), pp. 349-352. A tentativa de R. ROBAYE de retomar teses correntes na Pandectística (supra) apóia-se, fundamentalmente, no (pretenso) «problema insolúvel» identificado pelo autor, e não superado pelos prosélitos da «custodia objetiva», a saber: a coexistência, em alguns textos, dos critérios da culpa e da custodia em relação a um mesmo devedor («culpam et custodiam praestare»).

Assim, não se poderia explicar a razão da interpolação da culpa nesses casos, uma vez que se custodia já havia assumido o significado de culpa in custodiendo, seria desnecessária ou mesmo inútil uma inserção compilatória da primeira. Por sua vez, se considerada clássica a cópula «culpam et custodiam praestare», os defensores da «custodia objetiva» deparar-se-iam com outro obstáculo, qual seja, se o devedor estivesse obrigado de todo modo, com base em uma responsabilidade sem culpa (custodia), resultaria inútil o acostamento da culpa, uma vez que, sob a perspectiva dos recursos do credor-demandante, a custodia exerceria um papel consuntivo da culpa, de modo a neutralizar sua operatividade. Cf. Responsabilité objective cit. (nt. 272 supra), pp. 351-352.

Nota-se que o autor dispensa atenção a teses em grande parte já superadas no período, fundamentalmente as proposições de V. ARANGIO-RUIZ - Cf. R. ROBAYE, Responsabilité objetctive cit. (nt. 272 supra), p. 352, nts. 17-18. Com efeito, o autor insiste em criticar «pontos sensíveis» apenas no âmbito de teses do período interpolacionístico sobre a responsabilidade contratual e, particularmente, sobre a responsabilidade por custodia. Em contrapartida, não são examinados os resultados mais recentes obtidos pela doutrina romanística nessa matéria, na qual se propõem novas soluções a problemas como, v.g., (a) a inserção compilatória da culpa; (b) a concepção generalizante da alteração dogmática da custodia como equivalente da culpa; (c) a redução dos critérios de responsabilidade clássicos ao dolus e à custodia; (d) a pretendida propriedade consuntiva da custodia (como responsabilidade objetiva geral) em relação à culpa, desconsiderando-se os limites e âmbitos de aplicação específicos desses critérios, de natureza precisamente distintas. 
Na sequiência, discorre-se, com maiores detalhes - e segundo a orientação que, não obstante detalhes, tem-se firmado, na atualidade, como majoritária ${ }^{273}$ - sobre os principais aspectos do instituto estudado, a saber: natureza, conteúdo, hipóteses de aplicação e as suas transformações no curso do direito romano ${ }^{274}$.

Objetiva-se, com isso, oferecer um panorama da compreensão geral de custodiam praestare pelos estudiosos nos limites aptos a consentir, posteriormente, a correlação com os problemas que se apresentam quanto à sua discutida aplicação à compra e venda ${ }^{275}$.

\subsection{Natureza}

À parte alguns posicionamentos remontantes à Pandectística, segundo os quais a custodia era interpretada como uma prestação (Leistung) deduzida in obligationem ${ }^{276}$, dever-se-ia a C. A. CANNATA a retomada dessa orientação na romanística moderna.

Desse modo, «custodiam praestare» não designaria um critério de responsabilidade, mas sim uma prestação contratualmente devida por certas figuras de devedores, cujo inadimplemento implicava uma valoração particular com vistas a imputação, resultando em um regime de responsabilidade independente da culpa $^{277}$.

Por outro lado, V. ARANGIO-RuIZ considera a palavra custodia anfibológica, de modo que seria necessário estabelecer, vez por vez, se a palavra indica o fato de ter algo sob a própria guarda, ou a responsabilidade objetiva de Gaio, ou ainda a diligentia custodiendae rei dos pós-clássicos e justinianeus ${ }^{278}$.

\footnotetext{
${ }^{273}$ Entende-se, nessa sede, por «doutrina majoritária» aquela - por assim dizer - «objetiva», atendo-se ao elemento comum aos posicionamentos particulares assumidos pelos autores que aderem a essa interpretação. Com efeito, parece ser ela a única a sustentar-se, com os temperamentos que recebeu ao longo do século XX, diante dos textos recolhidos na compilação e de uma interpretação - sem os excessos da Crítica Interpolacionística - atenta à historicidade (e não à busca de uma sistematicidade homogênea e orgânica nessa matéria) do material recolhido na compilação justinianéia. Por essa razão, pareceu-nos forçoso segui-la em suas proposições fundamentais, o que não exclui, na sede particular de interpretação dos textos, a utilização dos argumentos de um ou outro autor aderente a outra corrente (como, v.g., a «neo-subjetiva»).

${ }^{274}$ Segue-se, para tanto, a ordem como comumente são tratados esses aspectos nas sínteses manualísticas e enciclopédicas. Cf., v.g., V. ARANGIO-RuIZ, Responsabilità cit. (nt. 04 supra), p. 100; 163; G. I. LUZZATO, Custodia cit (nt. 16 supra), pp. 93-94; M. TALAMANCA, Custodia cit. (nt. 16 supra), pp. 562-563.

${ }^{275}$ Com efeito, parece oportuno compor um panorama dos problemas gerais do instituto por permitir esse - na investigação de custodiam praestare em um âmbito mais restrito - não só a melhor compreensão do que teria sido mais uma aplicação da figura (ou seja, pela identificação dos elementos comuns), como também a possibilidade de evidenciar as particularidades dessa no regime jurídico da compra e venda.

${ }^{276}$ Cf. A. BRINZ, Pandekten II cit. (nt. 102 supra), p. 274; J. BARON, Die Haftung cit. (nt. 175 supra), p. 211.

${ }^{277}$ Cf. supra.

${ }^{278}$ Cf. Responsabilità cit. (nt. 04 supra), p. 269-270; também A. METRO, Custodiam praestare, in Labeo 13 (1967), p. 67, principalmente.
} 


\subsection{Conteúdo}

Entende-se, em regra, por «conteúdo» de custodiam praestare, o conjunto de eventos, causadores da perda ou deterioração do objeto da prestação, pelas quais estaria o devedor obrigado a responder. Dada a particularidade do regime, a determinação desses eventos importa em estabelecer os limites da responsabilidade por custodia $^{279}$.

\subsubsection{Furtum}

Consiste o furto na hipótese mais segura de evento causador da perda do objeto da prestação pela qual o devedor obrigado a custodiam praestare deveria responder. Com efeito, já na literatura interpolacionística, assumiram centralidade para a reconstrução do problema, os parágrafos do manual de Gaio sobre os pressupostos para a legitimação ativa

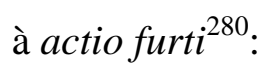

Gai. 3, 205: Item si fullo polienda curandave aut sarcinator sarcienda vestimenta mercede certa acceperit eaque furto amiserit, ipse furti habet actionem, non dominus, quia domini nihil interest ea non periisse, cum iudicio locati a fullone aut sarcinatore suum consequi possit, si modo is fullo aut sarcinator rei praestandae sufficiat; nam si solvendo non est, tunc quia ab eo dominus suum consequi non potest, ipsi furti actio competit, quia hoc casu ipsius interest rem salvam esse.

206: Quae de fullone aut sarcinatore diximus, eadem transferemus et ad eum cui rem commodavimus; nam ut illi mercedem capiendo custodiam praestant, ita hi quoque utendi commodum percipiendo similiter necesse habet custodiam praestare.
Assim, se um tintureiro recebeu uma roupa para limpar ou tratar ou um alfaiate para consertar, por retribuição certa, e a tivesse perdido por furto, tem ele a actio furti e não o proprietário, porque nada interessa a este que ela não pereça, pois que pode obter o seu, em demanda de locação, do tintureiro ou do alfaiate, supondo-se que estejam em condições de pagar. Em caso contrário, não sendo solvente, pois que então o proprietário não pode dele obter o seu, compete a ele mesmo <proprietário> a actio furti, porque neste caso lhe interessa a conservação da coisa.

O que dissemos acerca do tintureiro ou do alfaiate, transferimo-lo também àquele a quem comodamos uma coisa. Pois como aqueles, recebendo a retribuição, respondem pela custódia, assim, também este, recebendo a comodidade de usar, deve, semelhantemente, responder pela custódia.

${ }^{279}$ Cf. M. TAlamanCA, Custodia cit. (nt. 16 supra), p. 562.

${ }^{280}$ Cf. F. HAYMANN, Textkritische I cit. (nt. 211 supra), p. 167; V. ARANGIO-RUIZ, Responsabilità cit. (nt. 04 supra), pp. 64-66; E. RABEL, Custodia cit. (nt. 21 supra), p. 511. 
Inserem-se eles no contexto de um discurso iniciado no $§ 203$, e elucidariam a afirmação geral de que o legitimado à propositura da actio em questão seria aquele que tivesse o interesse prevalente na conservação da coisa ( «rem salvam esse»), ainda que não fosse o proprietário dela ${ }^{281}$.

Assim, o tintureiro e o alfaiate seriam os legitimados ativos, em caso de furto da coisa dada a lavar ou remendar, à actio furti contra o ladrão, pois seria deles o maior interesse na conservação da coisa, uma vez que seria possível ao proprietário, pela actio locati, receber deles a indenização («suum») pela não restituição da coisa. Em contrapartida, prevê-se a possibilidade de ser o dominus o legitimado ativo à propositura da actio contra o ladrão, caso não tivessem o fullo ou o sarcinator em condições financeiras de pagar-lhe o id quod interest ${ }^{282}$.

Estende-se a mesma disciplina ao comodatário ( $§ 206$ ), em caso de furto da coisa emprestada, uma vez que também esse último estaria obrigado a «custodiam praestare», não se verificando o mesmo em relação ao depositário $(\S 207)^{283}$. O interesse, nos primeiros casos, base da legitimação à actio furti, assentar-se-ia nesse custodiam praestare

${ }^{281}$ Sobre o problema da responsabilidade contratual nas Institutas de Gaio e a suspeita de lacunas, nessa matéria, no manuscrito veronês, cf. F. M. DE ROBERTIS, I problemi della responsabilità contrattuale nelle Istituzioni di Gaio e le lacune nel manoscrito Veronese, in Studi in onore di Biondo Biondi I, Milano, Giuffrè, 1965, pp. 375-394.

A ausência de um problema do praestare nas Institutas de Gaio, um dos problemas fundamentais que se apresentam em relação ao jurista, deu fundamento à crítica interpolacionística para a reconstrução do sistema clássico de responsabilidade, do qual fariam parte apenas os conceitos de dolus e custodia em sentido objetivo. Trata-se, entretanto, de uma resposta simplista e unilateral ao "problema" apresentado pelas Institutiones, que não leva em consideração toda uma série de textos gaianos nos quais se pode evidenciar uma grande atenção ao problema do praestare: 9 ad ed. prov., D. 13, 6, 18 pr.; 2 aur., D. 44, 7, 1, 4; Inst. 3, 14, 2 (praestare do comodatário); 10 ad ed. prov., D. 18, 1, 35, 4; 2 cot. rer., D. 18, 6, 2, 1; Inst. 3, 23, 3a (praestare do vendedor); Inst. 3, 25, 9 (praestare do sócio); 10 ad ed. prov., D. 19, 2, 25, 3-8; Inst. 3, 24, 5 (praestare do conductor).

Para R. CARDILLI, não seria, diante destes testemunhos, necessário recorrer à hipótese de uma lacuna no manuscrito veronês decorrente da supressão de um transcritor pós-clássico, podendo-se explicar esta "ausência" tanto pela fragmentariedade dos contratos examinados, como também pela diferença entre a finalidade das diversas obras de Gaio. Neste sentido, o silêncio das Institutas sobre a matéria dever-se-ia a uma opção consciente por parte do jurista de não enfrentar o problema em um curso institucional.

Além disso, é provável que o estado da reflexão sobre as regras, acumuladas pela iurisprudentia para cada contrato, não permitia ainda uma formulação de síntese, idônea para ser acolhida em uma obra de instituições. Cf. L'obbligazione cit. (nt. 04 supra), pp. 483-484 e nt. 03; 485.

${ }^{282}$ Cf. F. HAYMAnN, Textkritische I cit. (nt. 211 supra), pp. 168-169; V. ARANGIO-RuIZ, Responsabilità cit. (nt. 04 supra), pp. 64-65; G. I. LuZZATTO, Caso fortuito cit. (nt. 119 supra), p. 55, nt. 03; 74; 76, nt. 01; E. RABEL, Custodia cit. (nt. 21 supra), p. 511; M. SERrano-VICEnTE, Custodiam praestare cit. (nt. 26 supra), p. 160.

Contra essa interpretação corrente, fundamento da custodia técnica, v.g., J. C. HASSE, Die Culpa cit. (nt. 196 supra), p. 281; P. KRÜCKMANN, Custodia cit. (nt. 237 supra), pp. 30-31, que desloca a interpretação do Sachverhalt em termos não de Zuffalshaftung, mas de Dritthaftung, ou seja, de responsabilidade dos artífices por fato de prepostos à guarda das coisas entregues; G. MACCORMACK, Custodia cit. (nt. 264 supra), p. 161.

${ }^{283}$ Cf. V. ARANGIO-RUIZ, Responsabilità cit. (nt. 04 supra), p. 65. 
do fullo, sarcinator e comodatário $^{284}$, cujo reconhecimento dependeria tão-só da verificação do evento (furto da coisa), e não da culpa desses devedores: vale dizer, tratarse-ia de uma responsabilidade objetiva ${ }^{285}$.

Por outros termos, o jurista, ao afirmar que tais contratantes tinham o interesse prevalente na conservação da coisa, pressuposto do interesse para a legitimação à actio furti, teria individualizado como fundamento, por sua vez, daquele interesse, o fato de que tinham de «custodiam praestare», ou seja, responder tout court pelo furto da coisa locada ou emprestada, perante o locador e o comodante, respectivamente ${ }^{286}$.

Além desses parágrafos, o furto é também o evento considerado em outros textos, nos quais há relação com um custodiam praestare do devedor que remontam mesmo a juristas anteriores a Gaio, como, v.g., Labeão.

Em geral, poder-se-ia dizer que o reconhecimento de custodiam praestare, em relação a esses devedores, implicava em considerá-los responsáveis pelo inadimplemento devido ao furto da coisa, ou seja, por uma hipótese típica de perda do objeto da prestação, sem se perquirir acerca de uma culpa concreta do devedor pela ocorrência do evento ${ }^{287}$.

\subsection{2. «Fuga servorum qui custodiri solent»}

Desde os estudos do período interpolacionístico, já se reconheceu que o furto cometido por um terceiro contra o devedor obrigado a custodiam praestare, isso é,

\footnotetext{
${ }^{284}$ Cf. R. CARDILLI, L'obbligazione cit. (nt. 04 supra), p. 488.

${ }^{285}$ Cf. V. ARANGIO-RUIZ, Responsabilità cit. (nt. 04 supra), p. 66; 267.

${ }^{286}$ Mais sinteticamente: of fullo, sarcinator e comodatário tinham a actio furti porque o contrato tornavaos responsáveis perante a contraparte pelo furto das coisas que detinham. Cf. V. ARANGIO-RUIZ, Responsabilità cit. (nt. 04 supra), p. 141, nt. 01; 144.

${ }^{287}$ Enfim, o furto poderia ocorrer, concretamente, por culpa ou não do devedor, circunstância essa que seria indiferente para os obrigados a custodiam praestare. De fato, nem sempre o furto deve-se à culpa do devedor, como parece sustentar J. CUJAS, segundo a qual um diligente patefamilias não seria vítima de furto (= «...denique diligenti patrifamilias nunquam furtum fit»). Cf. Tractatus ad Africanum VIII, in Opera Omnia I, Lutetiae Parisiorum, s. e., 1658, col. 1484 (a D. 13, 6, 21).

Essa opinião não parece manter-se em outra passagem: «Quibus verbis satis demonstratur, posse furtum fieri sine culpa eius, cui fit. Sunt furta quaedam, quae nulla diligentia vitari possunt, ut quae admittunt saccularii, qui praestigiis quibusdam et arte inevitabili sinu pecunias nobis eripiunt. Horum furtum adscribam non culpae, sed casui: quod etiam ocutllatissimo et prudentissimo contingit» (= Por essas palavras demonstra-se suficientemente que um furto pode ser cometido sem culpa daquele que o sofre. Há alguns furtos que não podem ser evitados por nenhuma diligência, como aqueles que praticam os concussionários, que, por certos prestígios e por uma arte inevitável, retiram-nos dinheiro da bolsa. $\mathrm{O}$ furto <praticado por> esses não atribuirei à culpa, mas ao caso: o que também acomete o <homem> previdentíssimo e prudentíssimo). Cf. Commentarii in lib. IX Quaestionum Papiniani, in Opera Omnia IV, Lutetiae Parisiorum, s. e., 1658, col. 237 (a D. 47, 2, 79).

Admitem, de fato, um furto sem culpa do devedor, J. BARON, «Diligentia» cit. (nt. 175 supra), p. 46, nt. 02; F. HAYMANN, Textkriitische I cit.(nt. 211 supra), p 168.
} 
responsável por custodia (com a consequência de não liberá-lo da restituição da coisa ou de seu valor) - hipótese prevista nos parágrafos das Institutas de Gaio - não exauriria o conteúdo dessa responsabilidade ${ }^{288}$.

Com efeito, Ulpiano refere-se a uma dúvida, remontante aos veteres, consistente em determinar se o comodatário estaria obrigado a custodiam praestare de um escravo dado em empréstimo:

Ulp. 28 ad ed., D. 13, 6, 5, 6: Sed an etiam hominis commodati custodia praestetur, apud veteres dubitatum est. Nam interdum et hominis custodia praestanda est, si vinctus commodatus est, vel eius aetatis, ut custodia indigeret: certe si hoc actum est, ut custodiam is qui rogavit praestet, dicendum erit praestare.
Discutiu-se, entre os antigos juristas, se também se responde pela custódia de um escravo comodado. De fato, algumas vezes se há também de responder pela custódia de um escravo, se foi comodado agrilhoado, ou <se> por razão de sua idade, necessitasse de custódia. Certamente, se foi estabelecido que a pessoa que tivesse pedido em empréstimo <o escravo> tivesse de prestar a custódia, há de se dizer que responde.

Se por um lado, deu-se mais crédito ao furto ${ }^{289}$, seja por ser a hipótese prevista nos parágrafos das Institutas de Gaio (o «Gaio autêntico» da literatura interpolacionística), seja por ser o evento considerado no texto - por testemunho direto - mais antigo (de Labeão) que reporta um custodiam praestare, tem-se, por outro, valorado com maior atenção a remissão aos juristas republicanos («apud veteres») do fragmento ulpianeu ${ }^{290}$.

Os «veteres» são mencionados, também em matéria de comodato, como solucionadores de outra dúvida, a saber, se o custodiam praestare de uma coisa estendia-se também àquela que a acompanhava (concretamente, se o comodatário de uma égua deveria responder também pela custódia do potro) ${ }^{291}$. Dado que o evento mais comum passível de

\footnotetext{
${ }^{288}$ Cf., v.g, V. ARANGIO-RuIZ, Responsabilità cit. (nt. 04 supra), p. 66.

${ }^{289}$ Dada essa tipicidade de que se reveste o evento como conteúdo de custodiam praestare, a ele foi dada primazia também na ordem dessa exposição.

${ }^{290}$ Cf. R. CARDILLI, L'obbligazione cit. (nt. 04 supra), pp. 178-182; ID., L'obligation cit. (nt. 82 supra), pp. 94-95.

${ }^{291}$ Cf. Ulp. 28 ad ed., D. 13, 6, 5, 9: Usque adeo autem diligentia in re commodata praestanda est, ut etiam in ea, quae sequitur rem commodatam, praestari debeat: ut puta equam tibi commodavi, quam pullus commitabatur: etiam pulli te custodiam praestare debere veteres responderunt (= Em relação à coisa comodada, há de se prestar a diligência até ao ponto em que deva ser prestada também em relação àquela que segue a coisa comodada. Por exemplo: comodei-te uma égua, que estava acompanhada de um potro: os antigos juristas responderam que tu deves responder também pela custódia do potro).
} 
ocorrer, tratando-se de animais, fosse a fuga e não o furto, ter-se-ia transposto a mesma consideração no que concernia aos escravos ${ }^{292}$.

A perspectiva desses juristas seria, prevalentemente, a de uma custódia destinada a evitar não eventos externos, mas internos, próprios da coisa custodiada. Justificar-se-ia, desse modo, a razão da dúvida em relação ao escravo comodado, uma vez que geralmente - esse não requer uma vigilância especial destinada a evitar a sua fuga ${ }^{293}$.

Excepcionam-se, no texto, dois casos: o de um escravo entregue sob grilhões (vinctus), circunstância indicativa de sua inclinação à fuga, e o de um escravo infans ${ }^{294}$, hipóteses nas quais, ocorrendo o evento, o comodatário responderia pela custódia, isso é, mesmo sem culpa.

Dada, portanto, a referência da locução, para os veteres, aos casos de fuga de cavalos e de escravos, teria sido esse evento - e não o furto ou o dano causado por terceiros (infra), casos discutidos pelos juristas posteriores ${ }^{295}$ - a assumir primeira relevância, em termos históricos, como conteúdo do custodiam praestare incumbente a certos devedores ${ }^{296}$.

A essa complexa casuística dos veteres (escravo agrilhoado e o infans), ter-se-ia sobreposto uma distinção, da qual dariam notícia as fontes ${ }^{297}$, entre os «servi qui custodiri

292 Cf. R. CARDILli, L'obbligazione cit. (nt. 04 supra), p. 179; 371-373; ID., L'obligation cit. (nt. 82 supra), p. 95. Ainda que não se detenha no argumento, também se refere à fuga (e não ao furto), nesse caso, V. ARANGIO-RUIZ, Responsabilità cit. (nt. 04 supra), p. 170.

${ }^{293}$ Cf. R. CARDILLI, L'obbligazione cit. (nt. 04 supra), pp. 178-179.

294 A pouca idade do escravo teria sido individualizada pela iurisprudentia como uma ulterior exceção pois que tais características do escravo requeriam também um controle e uma vigilância particulares. Entretanto, nesse caso, não assumiria relevância apenas uma custódia destinada a evitar a fuga - pois que não seria facilmente imaginável, em um escravo de pouca idade, o desidério de fugir - mas também a contrastar eventos provenientes de fatores externos, como, v.g., o furto. Seria, portanto, conjecturável que a hipótese de comodato de escravo infans poderia ser a expressão de um significado típico de custodire, historicamente posterior, que se traduziria em uma custódia idônea não apenas a evitar a fuga, mas também o furto. Cf. R. CARDILLI, L'obbligazione cit. (nt. 04 supra), pp. 179-180.

${ }^{295}$ No que concerne ao furto, esse teria assumido preponderância nas discussões jurisprudenciais posteriores, em matéria de custodiam praestare, em razão da maior relevância da recorrência desse, em termos quantitativos, a partir do momento em que se reconhece custodiam praestare no âmbito do comodato de coisas inanimadas. Cf. R. CARDILLI, L'obbligazione cit. (nt. 04 supra), pp. 178-181.

296 Por outros termos, a perspectiva originária dos juristas republicanos, em relação ao custodiam praestare, não estaria ligada ao furto, mas sim à fuga - do animal, e, em alguns casos, do escravo - , como evento pelo qual se responderia por custodia. O perecimento por furto da coisa devida, segundo R. CARDILLI, não teria sido solucionado, originalmente, em termos de custodiam praestare (como comprovaria, ademais, Paul. 3 Alf. epit., D. 18, 6, 15, 1), o que se teria verificado apenas a partir da época de Labeão. Cf. L'obbligazione cit. (nt. 04 supra), pp. 179-180; 371. Contra, mais recentemente, M. SERRANO-VICENTE, para o qual, os critérios empregados no texto de Ulpiano corresponderiam a sobreposições, desse último ou de um jurista intermediário, sob o ponto de vista terminológico, a fim de adaptar à idéia da custódia um problema apresentado por juristas (os veteres) que tinham em mente outra ação (actio commodati in factum) e critérios valorativos distintos. Para o autor, a inserção da hipótese de fuga do escravo no rol de eventos que a custodia visa a evitar, dever-se-ia ao fato de que o escravo que foge seria um fur sui. Cf. Custodiam praestare cit. (nt. 26 supra), p. 252; 354.

${ }^{297}$ Cf. Ulp. 29 ad Sab., D. 50, 17, 23; Gai. 9 ad ed. prov., D. 13, 6, 18 pr. 
solent» e os «servi qui custodiri non solent», baseada em um critério diverso (a saber, o da objetivação dos hábitos do escravo e de suas condutas precedentes) do empregado por aqueles juristas, mas com vistas a atingir a mesma finalidade ${ }^{298}$.

Desse modo, nos casos normais (isso é, de «servi qui custodiri non solent»), o comodatário apenas responderia se tivesse havido um nexo causal entre a fuga (ou o furto) do escravo e uma conduta culposa de sua parte ${ }^{299}$; em contrapartida, tratando-se de «servi qui custodiri solent», que implicava o reconhecimento de um custodiam praestare, responderia o devedor pela ocorrência do evento que ocasionou a perda da prestação ${ }^{300}$.

\subsection{3. «Damnum iniuria ab alio datum»}

Aludem as fontes, ainda, a uma pretensa controvérsia entre dois juristas do século II d. C. ${ }^{301}$ acerca da extensão de custodiam praestare também ao dano - damnum iniuria datum - causado por terceiros à coisa (concretamente) detida em locação e em comodato $^{302}$ :

Iul. 1 dig., D. 13, 6, 19: Ad eos, qui servandum aliquid conducunt aut utendum accipiunt, damnum iniuria ab alio datum non pertinere procul dubio est: qua enim cura aut diligentia consequi possumus, ne aliquis damnum nobis iniuria det?
Não há duvida de que não cabe o dano ilicitamente causado por outro sujeito àqueles que tomam a seu cargo o cuidado de alguma coisa <por locação> ou a recebem para usar <por comodato>. Pois com que cuidado ou diligência podemos conseguir que alguém não nos cause ilicitamente um dano?

${ }^{298}$ Cf. R. CARDILLI, L'obbligazione cit. (nt. 04 supra), p. 181.

${ }^{299}$ Cf. Ulp. 28 ad ed., D. 13, 6, 5, 13.

300 Trata-se da conclusão que parece sugerir R. CARDILLI, L'obbligazione cit. (nt. 04 supra), p. 181 e nt. 194; 182; já também V. ARANGIO-RUIZ, Responsabilità cit. (nt. 04 supra), pp. 96-97; P. VocI, 'Diligentia' cit. (nt. 12 supra), p. 70; 98, nt. 48.

301 Esses fragmentos ensejaram o surgimento de copiosa literatura exegética, à qual, a título exemplificativo, reenvia-se: v.g., B. AlbANESE, D. 13, 6, 19 e D. 19, 2, 41 no quadro dos problemas da «custodia», in Studi in onore di Giuseppe Grosso I, Torino, Giappichelli, 1968, pp. 79-96; C. A. CANNATA, Ricerche cit. (nt. 21 supra), pp. 62-117; ID., Sul problema (1992) cit. (nt. 01 supra), pp. 33-61;ID., Sul problema (1996) cit. (nt. 01 supra), pp. 28-30; R. CARDILLI, L'obbligazione cit. (nt. 04 supra), pp. 175-178; 318-319; 482-492; D. R. MARTINS RODRIGUES, Aspectos da responsabilidade civil por fato de terceiro no direito romano, in Revista da Faculdade de Direito da USP 96 (2001), pp. 85-91; M. SERRANO-VICENTE, Custodiam praestare cit. (nt. 301 supra), pp. 224-360.

${ }^{302} \mathrm{Um}$ breve confronto dos dois textos já seria suficiente para demonstrar o liame entre eles, ou seja, o fato de Ulpiano referir-se exatamente à controvérsia reportada por Juliano. No primeiro texto, faz-se menção seja ao conductor rei servandae, seja ao comodatário, cancelado esse último no texto de Ulpiano, o que se justificaria pela sua ligação com o fragmento anterior, na compilação, atribuído a Gaio. Cf. V. ARANGIORUIZ, Responsabilità cit. (nt. 04 supra), p. 165. 
Ulp. 5 ad ed., D. 19, 2, 41: Sed de damno ab alio dato agi cum eo non posse Iulianus ait: qua enim custodia consequi potuit, ne damnum iniuria ab alio dari possit? Sed Marcellus interdum esse posse ait, sive custodiri potuit, ne damnum daretur, sive ipse custos damnum dedit: quae sententia Marcelli probanda est.
Mas Juliano diz que não é possível demandá-lo pelo dano ilicitamente causado por um outro, pois com qual cuidado se poderia conseguir que não se verificasse um dano ilicitamente causado por outrem? Porém, Marcelo diz que, às vezes, pode-se <demandar>, ou se se pôde custodiar para que não ocorresse o dano, ou se o próprio guardião o causou. Essa opinião de Marcelo deve ser aprovada ${ }^{303}$.

Juliano teria afirmado, categoricamente, que a custódia não seria uma atividade hábil a impedir que alguém causasse um dano ilícito (damnum iniuria) à coisa que se tem sob guarda (seja para essa tarefa específica, seja por estar em empréstimo), recusando-se, por conseqüência, reconhecer a responsabilidade desses contratantes por tal dano aportado por terceiro. Em contrapartida, Marcelo teria sustentado uma opinião mais flexível, ao admitir que, em certas hipóteses, tal responsabilidade possa ser estabelecida ${ }^{304}$.

A exclusão de que o damnum iniuria datum pudesse ser evitado com o emprego da devida custódia por parte de Juliano talvez tivesse por fundamento o fato de que o damnum iniuria comporta uma violência (vis) à coisa por parte do terceiro - contrariamente ao furto (subtração clandestina) - contra a qual a vigilância nada poderia. Disso resultaria a sua não inclusão no âmbito de eventos contrastáveis com a custodia ${ }^{305}$.

Já Marcelo não teria propriamente contrariado Juliano, mas contemperado a sua assertiva, ao ponderar que, em certos casos, esse dano poderia ser evitado com o emprego da custodia: não teria havido, entretanto, um deslocamento da questão de aferição da culpabilidade do devedor. Antes, seria mais acertado supor que o jurista ainda se mativesse na linha de raciocínio de Juliano: a evitabilidade do dano seria de verificar em elementos concretos, como as características do objeto sob guarda e as circunstâncias da ocorrência do dano (isso é, se clandestino ou violento) ${ }^{306}$.

A observação de Marcelo, seguida por Ulpiano, teria ensejado a inserção do damnum iniuria ab alio datum, isso é, o dano causado por terceiro à coisa sob a detenção do devedor, desde que evitável (em termos abstratos - «sive custodiri potuit»), dentre os

\footnotetext{
${ }^{303}$ Verificou-se também a tradução em português de D. R. MARTINS RoDRIGUES, Aspectos cit. (nt. 301 supra), pp. 85-86.

${ }^{304}$ Cf. D. R. MARTINS RODRIGUES, Aspectos cit. (nt. 301 supra), p. 86.

${ }^{305}$ Cf. A. Metro, L'obbligazione cit. (nt. 22 supra), p. 120; D. R. MARTINS RodRIGUES, Aspectos cit. (nt. 301 supra), p. 86.

${ }^{306}$ Cf. D. R. MARTIns Rodrigues, Aspectos cit. (nt. 301 supra), pp. 88-90.
} 
eventos abrangidos pela esfera de custodiam praestare, ou seja, veio - dentro daqueles limites - a integrar o seu conteúdo, juntamente com o furto ${ }^{307}$.

\section{3. Âmbito de aplicação nas espécies contratuais}

Dentre os vários aspectos controversos do tema estudado (v.g., as causas típicas de perecimento), tem-se também o da ausência de uma referência completa das categorias de devedores responsáveis por custodia $^{308}$. A listagem que deles fornecem os estudiosos é, já desde a Pandectística, bastante variável, notando-se tanto posições ampliativas quanto bastante restritivas no que concerne às hipóteses nas quais a custodia-Haftung teria tido aplicação $^{309}$.

Mais seguramente, sabe-se, a partir do elenco gaiano das Institutas (3, 205-206), que a responsabilidade por custodia era aplicada ao tintureiro (fullo), ao alfaiate-remendão ${\text { (sarcinator })^{310} \text { e ao comodatário }}^{311}$, porém não também ao depositário $(3,207)^{312}$. Se, por um lado, o contraste entre esses últimos sob a perspectiva do regime de responsabilidade poderia encontrar explicação no critério da utilitas contrahentium ${ }^{313}$, maiores dificuldades

${ }^{307}$ Cf. J. BARON, «Diligentia» cit. (nt. 175 supra), p. 49.

${ }^{308}$ Cf. M. SARgenti, Problemi cit. (nt. 03 supra), p. 148; E. C. SILVEIRA MARCHI, Dos riscos pela perda fortuita da coisa vendida no direito romano, in Revista da Faculdade de Direito da USP 96 (2001), pp. 5859.

${ }^{309}$ Cf., v.g., J. BARON, «Diligentia» cit. (nt. 175 supra), p. 88; 94; ID., Die Haftung cit. (nt. 198 supra), pp. 204-205; ID., Pandekten cit. (nt. 198 supra), pp. 422-423.

${ }^{310}$ Cf., além do texto citado, Lab. 5 ex post., D. 19, 2, 60, 2; PS 2, 31; 29; Ulp. 29 ad Sab., D. 47, 2,12 pr. - G. I. LuZZATTO, Caso cit. (nt. 16 supra), pp. 147-148; M. KASER, Das römische Privatrecht I cit. (nt. 05 supra), p. 508 e nt. 35; M. SERRANO-VICENTE, Custodiam praestare cit. (nt. 26 supra), p. 245.

${ }^{311}$ Cf., além do parágrafo do manual de Gaio, PS 2, 4, 3; Inst. 3, 14, 2; 4, 1, 16; Ulp. 28 ad Sab., D. 13, 6, 5, 5; 6; 9; 14 e 15; Ulp. 29 ad Sab., D. 13, 6, 10, 1; Gai. 9 ad ed. prov., D. 13, 6, 18 pr.; Iul. 1 dig., D. 13, 6, 19; Gai. 2 aur., D. 44, 7, 1, 4; Ulp. 29 ad Sab., D. 47, 2, 14, 10; 15; Afr. 8 quaest., D. 47, 2, 62, 6 - G. I. LuZZATTO, Caso cit. (nt. 16 supra), p. 105; M. KASER, Das römische Privatrecht I cit. (nt. 05 supra), p. 508 e nt. 34; 533 e nt. 04; P. VocI, 'Diligentia' cit. (nt. 12 supra), p. 66; M. SERRANo-VICENTE, Custodiam praestare cit. (nt. 26 supra), p. 245.

${ }^{312}$ A referência ao diverso regime do depósito assinalaria a preocupação de Gaio, legítima em uma obra jurídica elementar (manual), em esclarecer que custodiam praestare não é característico da obrigação de custodiar a coisa por si mesma (de fato, a causa do depósito seria um «quid custodiendum»), mas derivaria do típico «assetto d'interessi» ao qual dá vida o negócio. Em suma, ter-se-ia preocupado o jurista em elucidar a relação semântica entre «custodia» como tal, e o particular significado assumido pelo termo na locução técnica «custodiam praestare». Cf. R. CARDILLI, L'obbligazione cit. (nt. 04 supra), pp. 488-499.

Contudo, uma exceção constituiria o caso do depositário que se tivesse oferecido para a guarda da coisa, por pressupor, nesse caso, um interesse próprio no negócio, justificando-se o reconhecimento, nesse caso, de um custodiam praestare a seu cargo. (Ulp. 30 ad ed., D. 16, 3, 1, 35). Cf., nesse sentido, V. ARANGIO-RUIZ, Responsabilità cit. (nt. 04 supra), p. 117; outra explicação dessa atribuição oferece C. A. CANNATA, Ricerche cit. (nt. 21 supra), p. 133.

${ }^{313}$ Cf. C. A. CANNATA, Ricerche cit. (nt. 21supra), p. 133. 
oferece o arrolamento do fullo e sarcinator - conductores operis - dentre os Custodiapflichtige $e^{314}$.

Independentemente do problema da extensibilidade ou não do regime a todos os conductores operum ou mesmo à locatio conductio em geral ${ }^{315}$, atesta-se também o

${ }^{314}$ Tais dificuldades concerniriam, primeiramente, à razão pela qual se atribuiria a esses artesãos citadinos da antiga Roma um regime de responsabilidade que se poderia considerar agravado. Com efeito, nesses casos, a obrigação de guarda (custodia) da coisa dada para lavar ou remendar ao fullo e ao sarcinator não seria principal, como aquela devida, v.g., por pessoas contratadas para a execução de uma atividade específica de vigilância (conductor rei servandae), mas acessória (Gai. 5 ad ed. prov., D. 4, 9, 5). Precisamente por essa diferença, não seria clara a razão pela qual corresponderia a tais conductores o periculum custodiae.

M. SERRANO-VICENTE considera que o emprego dessas figuras (fullo ou fullo e sarcinator) pelos juristas explicar-se-ia pelas características sociais desses ofícios, que os constituiriam protótipos de devedores em relação aos quais a obrigação de custodia assumia relevância. O tintureiro e o alfaiate constituiriam, portanto, «modelos» de artesãos inseridos em um âmbito de atividades cuja natureza, consideração social e prática comercial justificariam a existência da obrigação de custodia - custodiam praestare - destinada a evitar o furto. Cf. Custodiam praestare cit. (nt. 26 supra), pp. 160-166.

No que concerne, especificamente, aos fullones e sarcinatores, é possível que o reconhecimento de um custodiam praestare a seu cargo esteja relacionado ao fato de esses artesãos exercerem os seus ofícios em locais abertos como a rua, disso resultando a recorrência do furto das vestes a eles confiadas. Cf. F. KNIEP, Gai institutionum commentarius tertius $\$ \S 88-225$ - Obligationenrecht - Text mit Erklärung und Anhängen, Jena, Fischer, 1917, p. 481; V. ARANGIO-RUIZ, Responsabilità cit. (nt. 04 supra), p. 127; P. KRÜCKMANN, Custodia cit. (nt. 237 supra), p. 05.

Com efeito, um texto extraído de uma monografia atribuída a Papiniano ( Ast unomico" monobiblo"), na qual teria o jurista tratado dos direitos e deveres de certos funcionários municipais (os «aśst unomoi», provavelmente os quattuorviri viis in urbi purgandis), encarregados do saneamento urbano e do policiamento das vias - cf. A. GUARINO, L'esegesi delle fonti del diritto romano I, Napoli, Jovene, 1968, pp. 230-231, assinalaria a prática, por parte desses, de secar roupas na via pública: D. 43, 10, fr. único, 4: Epimel eisqusan de; cai; of $w^{\prime \prime}$ pro; $t$ wa ejgasthriwn mhden proceimenon hł pl hn ejan cnaf eu," idhatia yugh/ h] tejt wn procou," exw tiqh. tiqesqusan de; cai; out oi, wste mh; cw uein afraxan badizein.) (= Zelem <os curatores urbium> para que nada seja colocado diante das oficinas; excepcionalmente, se o tintureiro secar as roupas ou o artífice puser as rodas fora <da oficina>, coloquemnas esses também de modo que o veículo possa passar) (a partir da tradução latina de M. MOMMSEN-P. KRÜGER). É possível que se fundamente nessa circunstância de fato a justificativa da responsabilidade do fullo e do sarcinator que propõe C. A. CANNATA, a saber, a necessidade de se evitarem inconcludentes questões de prova. Cf. Ricerche cit. (nt. 21 supra), pp. 133-134.

Outro problema, em parte já acenado, consiste na valoração da menção ao fullo e ao sarcinator nos textos suprarreferidos como hipóteses exaustivas ou apenas exemplificativas (isso é, exemplos escolásticos), sendo extensível a outras figuras de empreiteiros (conductores operum). Encontram-se, nas fontes, outras referências à locução relacionada a certos conductores, como, v.g., o portador de uma carta para a entrega (Ulp. 29 ad Sab., D. 47, 2, 14, 17), ocorrências que teriam sugerido a certos autores uma concepção ampliativa no sentido visualizar o custodiam praestare como critério fundamental de valoração da responsabilidade dos conductores operum em geral (v.g., pastor, ourives, vidraceiro, transportador de colunas). Cf., v.g., G. I. LuZZATTO, Caso cit. (nt. 119 supra), pp. 180-182; 190-201 que admite, entretanto, no que concerne à locatio conductio operis, o recurso por parte dos juristas a critérios diversos da custodia imperitia, vitium operis -, mas situáveis no mesmo plano dessa por seu caráter «objetivo».

A orientação que se parece seguir é a de considerar os conductores referidos por Gaio apenas como exemplos, sendo possível a extensão a outras figuras de empreiteiros contanto que assuma relevância, na fattispecie, um praestare específico pela guarda (custodia) da coisa. Cf. V. ARANGIO-RUIZ, Responsabilità cit. (nt. 04 supra), pp. 124-131; especialmente, p. 127, nt. 01; 131; M. SARGENTI, Problemi cit. (nt. 03 supra), pp. 154-157; M. KASER, Das römische Privatrecht I cit. (nt. 05 supra), p. 508 e nt. 41; M. SERRANOVICENTE, Custodiam praestare cit. (nt. 26 supra), pp. 160-166.

315 Além da questão a que se referiu na nota anterior, discute-se também acerca da possível aplicação de custodiam praestare ao locador de coisas (locator rei), com base em alguns textos como, v.g., Inst. 3, 24, 5; Diocl. et Maxim., C. 4, 65, 28, de 294. Cf. V. ARANGIO-RuIZ, Responsabilità cit. (nt. 04 supra), p. 130-138; 
reconhecimento de um custodiam praestare a cargo do administrador de armazéns (horrearius) pelas mercadorias depositadas nos espaços por ele postos à disposição $(\text { horrea })^{316}$.

Embora ainda prevaleçam os elementos de dúvida ${ }^{317}$, provavelmente se submetiam a essa responsabilidade o transportador marítimo, o estalajadeiro e o mantenedor de estábulos (nauta, caupo e stabularius) pela perda dos objetos dos clientes introduzidos em seus estabelecimentos ${ }^{318}$.

Custodiam praestare apresenta-se ainda em relação a outras figuras de devedores, como, v.g. ${ }^{319}$, a do sócio que recebe a coisa do outro para a execução de determinada tarefa $^{320}$, do credor pignoratício ${ }^{321}$, do usufrutuário ${ }^{322}$ e do avaliador (inspector) de bens ao qual foi dado o objeto, em seu próprio interesse, para avaliação ${ }^{323}$.

G. I. LuZZatto, Caso cit. (nt. 119 supra), pp. 204-208; 211; M. SARGENTI, Problemi cit. (nt. 03 supra), pp. 156-157; P. VocI, 'Diligentia' cit. (nt. 12 supra), p. 66.

${ }^{316}$ Cf. Lab. 5 ex post., D. 19, 2, 60, 6 e 9; Paul. l. s. de of. praef. vig., D. 1, 15, 3, 2; D. 19, 2, 55 pr.; coll. 10, 9; Alex. C. 4, 65, 4 pr. e , de 222 - V. ARANGIO-RuIz, Responsabilità cit. (nt. 04 supra), pp. 118-121, para quem o horrearius nada mais seria senão uma aplicação particular de conductor rei servandae, parte de uma relação contratual que se poderia configurar como um «depósito retribuído»; G. I. LUZZATTO, Caso cit. (nt. 119 supra), pp. 226-230; M. KASER, Das römische Privatrecht I cit. (nt. 05 supra), p. 508 e nt. 37; C. A. CANNATA, Ricerche cit. (nt. 21 supra), p. 133; 138-139.

O significado de horreum não é unívoco: em geral, designa «armazém», podendo-se destinar, entretanto, a várias finalidades: (a) celeiro para o armazenamento de grãos (ou seja, um granarium) adquiridos pelo «Estado» para a venda ou distribuição pública de cereais; (b) depósito de víveres em geral, para fins privados, públicos ou militares; (c) armazém para mercadorias de diversas espécies, como materiais de construção importados (v.g., granito, mármore); (d) local seguro para a guarda, análogo às modernas casas de depósitos para bens móveis e cofres em bancos (horrea publica), representando, para os particulares, principalmente na época do Império, um lugar seguro contra o furto e o incêndio para o armazenamento de objetos preciosos; e (e) «dispensas», nas casas ou propriedades particulares (horrea privata), destinadas à acomodação de variados utensílios e produtos agrícolas (v.g., grãos, legumes ou mesmo vinho). Cf. H. DESSAU, Cella, in RE III.2 (1899), pp. 1871-1879; E. FIECHTER, Horreum, in RE VIII.2 (1913), pp. 24582463.

${ }^{317}$ Cf. M. SARGENTI, Problemi cit. (nt. 03 supra), p. 148.

${ }^{318}$ Cf. Ulp. 14 ad ed., D. 4, 9, 3, 1-2; Gai. 5 ad ed. prov., D. 4, 9, 5; Gai. 5 ad ed. prov., D. 19, 2, 40. Cf. V. ARANGio-Ruiz, Responsabilità cit. (nt. 04 supra), pp. 103-110; G. I. LuZZATTO, Caso cit. (nt. 119 supra), pp. 159-161; M. KASER, Das römische Privatrecht I cit. (nt. 05 supra), p. 508 e nt. 36. O enquadramento da responsabilidade do nauta, caupo e stabularius no regime da responsabilidade por custodia já no direito clássico é matéria controversa entre os estudiosos. Conjectura-se que, originariamente, estivessem os transportadores marítimos, estalajadeiros e mantenedores de estábulos sujeitos a uma responsabilidade absoluta pela não restituição da coisa («omnimodo teneri»), sendo essa, posteriormente, limitada (por obra, provavelmente, da exceptio) de modo a sugerir a assimilação do regime disso resultante com aquele de custodiam praestare reconhecido no âmbito de algumas relações contratuais como a locatio conductio estabelecida com o fullo ou o sarcinator. Cf. v.g., M. SARGENTI, Problemi cit. (nt. 03 supra), pp. 153-156, que atribui a Gaio a autoria dessa assimilação e, consequentemente, das referências à custodia em textos como 5 ad ed. prov., D. 4, 9, 5; M. KASER, Das römische Privatrecht I cit. (nt. 05 supra), p. 508, nt. 36.

${ }^{319}$ Cf., v.g., C. A. CANNATA, Ricerche cit. (nt. 21 supra), p. 134, nt. 48.

${ }^{320}$ Cf. Ulp. 31 ad ed., D. 17, 2, 52, 2 - V. ARANGIO-RUIZ, Responsabilità cit. (nt. 04 supra), pp. 121-124; M. KASER, Das römische Privatrecht I cit. (nt. 05 supra), p. 508 e nt. 43.

${ }^{321}$ Cf. Inst. 3, 14, 4; Ulp. 38 ad ed., D. 13, 7, 13, 1; 30; Diocl. et Maxim., C. 8, 13, 19, de 293. Cf. V. ARANGIO-RuIZ, Responsabilità cit. (nt. 04 supra), pp. 138-146; G. I. LuZZATTO, Caso cit. (nt. 119 supra), p. 238; 247, mais concludentemente; M. KASER, Das römische Privatrecht I cit. (nt. 05 supra), p. 509 e nt. 44; P. VocI, 'Diligentia' cit. (nt. 12 supra), p. 66. 
Todas essas - mais ou menos discutidas - hipóteses de aplicação teriam como traço comum o reconhecimento de um custodiam praestare de um devedor que, em decorrência do contrato, detivesse coisa alheia, seja para uso, seja para execução de um serviço sobre ela (limpeza, conserto, transporte, mera vigilância ou avaliação), seja ainda como garantia de uma obrigação.

\subsection{Alterações teóricas e práticas de «custodiam praestare» no curso da iurisprudentia romana}

À parte alguns acenos na literatura pandectística ${ }^{324}$, ter-se-ia difundido propriamente no âmbito dos estudos influenciados pelo método interpolacionístico a visualização, nos textos jurídicos romanos analisados, de duas concepções diversas da responsabilidade por custodia: uma, correspondente à noção clássica de responsabilidade «objetiva»; outra, a uma reelaboração dessa com a finalidade de subsumi-la à responsabilidade por culpa.

Apresentar-se-ia essa última nas formulações de custodiam praestare como exacta, exactissima diligentia custodiendae rei, ou seja, tão-só uma aplicação da diligentia (in custodiendo), atribuíveis aos compiladores justinianeus que, dando consecução a um processo já iniciado no direito pós-clássico ${ }^{325}$, teriam introduzido a sua nova dogmática do inadimplemento pela reinterpretação da custodia clássica em sentido subjetivo ${ }^{326}$.

${ }^{322}$ Cf. Paul. 75 ad ed., D. 7, 9, 2. Cf. M. KASER, Das römische Privatrecht I cit. (nt. 05 supra), p. 451 e nt. 37; P. VoCI, 'Diligentia' cit. (nt. 12 supra), p. 66; 99.

${ }^{323}$ Cf. Ulp. 9 ad ed. prov., D. 13, 6, 10, 1; Ulp. 28 ad ed., D. 19, 5, 17, 4. Cf. V. ArangIO-RUIZ, Responsabilità cit. (nt. 04 supra), pp. 110-115; G. I. LuZZATTO, Caso cit. (nt. 119 supra), pp. 231-233; M. KASER, Das römische Privatrecht I cit. (nt. 05 supra), p. 508 e nt. 38; P. VocI, 'Diligentia' cit. (nt. 12 supra), p. 66.

${ }^{324}$ Cf. A. PERnICE, Labeo II cit. (nt. 186 supra), pp. 359-360; contra, J. BARON, embasado em um argumento que ressentiria certa influência evolucionista: a reconstrução de A. PERNICE não faria sentido já que não resultaria verossímil uma passagem - em época adrianéia, como propõe esse autor - de uma responsabilidade sem culpa para uma responsabilidade por culpa própria apenas. Ao contrário, a evolução - a considerar a experiência jurídica do tempo do autor no âmbito do direito privado - seria admissível em sentido inverso, de uma responsabilidade por culpa a uma responsabilidade que dela prescindiria. Cf. Die Haftung cit. (nt. 198 supra), pp. 214-216.

325 Testemunhariam a incompreensão, por parte dos juristas pós-clássicos, dos fragmentos jurisprudenciais clássicos relativos ao custodiam praestare, textos como PS 2, 4, 2-3. Cf. G. I. LUZZATTO, Caso cit. (nt. 119 supra), p. 34, nt. 01; M. SERRANO-VICENTE, Custodiam praestare cit. (nt. 26 supra), p. 369, nt. 1185.

${ }^{326}$ Cf. V. ArANGIO-RUIZ, Responsabilità cit. (nt. 04 supra), pp. 72-73, principalmente; G. I. LUZZATTO, Caso cit. (nt. 119 supra), pp. 33-34; 45, nt. 02; E. RABEL, Custodia cit. (nt. 21 supra), p. 511; M. TAlamancA, Custodia cit. (nt. 16 supra), pp. 562-563; ID., Vendita cit. (nt. 21 supra), p. 448; M. SARGENTI, Problemi cit. (nt. 03 supra), p. 223; C. A. CANNATA, Ricerche cit. (nt. 21 supra), p. 143; M. SERRANOVICENTE, Custodiam praestare cit. (nt. 26 supra), p. 354; 369-370. 
Assim, em relação ao comodatário - típica hipótese de devedor responsável por custodia $^{327}$ - atestaria, v.g., a sobreposição da perspectiva pós-clássica ou justinianéia ${ }^{328}$ :

Gai. 9 ad ed. prov., D. 13, 6, 18 pr.: In rebus commodatis talis diligentia praestanda est, qualem quisque diligentissimus pater familias suis rebus adhibet, ita ut tantum eos casus non praestet, quibus resisti non possit, veluti mortes servorum quae sine dolo et culpa eius accidunt, latronum hostiuumve incursus, piratarum insidias, naufragium, incendium, fugas servorum qui custodiri non solent. (...)
Em relação às coisas comodadas, há de ser observada a diligência que um pater familias diligentíssimo observa em relação às suas próprias coisas, de modo que não se responda apenas por aqueles eventos contra os quais não se possa resistir, tais como a morte dos escravos que ocorrem não por dolo ou culpa sua, o ataque de salteadores ou inimigos, emboscadas de piratas, naufrágio, incêndio, fuga de escravos que não costumam ser custodiados. (...)

Mais recentemente, tem-se assinalado que esse processo de desmantelamento da conformação originária de custodiam praestare em uma modalidade de diligentia poderia já ter resultado da intersecção de tendências já verificáveis na iurisprudentia clássica no sentido de individualização de um critério-guia para a articulação geral da responsabilidade do devedor nas várias relações obrigacionais ${ }^{329}$.

Assim, de um lado, Gaio, que teria propugnado por um critério geral de comportamento: a diligentia; de outro, juristas como Paulo, Ulpiano e Modestino (mas já, aparentemente, Pompônio), por um critério geral de responsabilidade, qual seja, a culpa. Essas tendências - conceitualmente complementares - ter-se-iam, assim, integrado progressivamente no direito pós-clássico e completado, finalmente, no direito justinianeu ${ }^{330}$.

De qualquer modo, - seja pós-clássica ou compilatória, seja um desenvolvimento já de orientações clássicas - essa «subjetivização» da responsabilidade por custodia em diligentia exactissima, diligentia diligentissimi patris familias não teria repercutido em sensíveis transformações sob o ponto de vista do regime prático ${ }^{331}$.

Assim, ao se exigir de determinado devedor a observância de uma exactissima diligentia in custodiendo (ou a diligentia de um diligentissimus paterfamilias), não

\footnotetext{
${ }^{327}$ Cf. supra (Parte I, Cap. II, 2.3).

${ }^{328}$ De semelhante modo, em Gai. 2 aur., D. 44, 7, 1, 4, o conceito clássico de custodia teria sido transformado em critério subjetivo de responsabilidade pela perífrase «exactissima diligentia custodiendae rei». Cf. V. ARANGIO-RUIZ, Responsabilità cit. (nt. 04 supra), pp. 72-73 e nt. 01.

${ }^{329}$ Cf. M. SERRANO-VICENTE, Custodiam praestare cit. (nt. 26 supra), p. 370.

${ }^{330}$ Cf. M. SERRANO-VICENTE, Custodiam praestare cit. (nt. 26 supra), p. 370.

${ }^{331}$ Cf. G. I. LuZZATTO, Caso cit. (nt. 119 supra), p. 40; 42; 48-49; 130, nt. 01; C. A. CANNATA, Ricerche cit. (nt. 21 supra), p. 145.
} 
resultariam excusadas as perdas devidas aos eventos (furto, dano causado por terceiros) contrastáveis com a custodia. Por outros termos, se um «regular» paterfamilias pode não evitar ocorrências como o furto da coisa, um diligentissimus paterfamilias seguramente in abstracto - poderia $^{332}$.

Desse modo, pois, os compiladores puderam manter, mesmo que sob outra formulação teórica, as vantagens que se obtinham com o reconhecimento, a cargo de certos devedores, da responsabilidade por custodia $^{333}$, pois que, se sob a perpectiva dogmática, custodiam praestare e a exactissima diligentia in custodiendo e outras locuções similares difeririam, confluiriam elas, em contrapartida, sob a prática, para o mesmo resultado.

A propósito, parece de interesse notar o tratamento dado à custodia nos comentários gregos dos juristas do século VI d. C., a fim de valorar a dimensão das alterações aportadas e da concepção que as embasava.

Aprontada a compilação em 533 d. C., com a promulgação do Digesto e das Institutas $^{334}$, floresceu sobre esses livros - não obstante a «proibição» do Imperador ${ }^{335}$ copiosa literatura de comentários (redigidos em língua grega) por parte dos juristas do século VI d. C. ${ }^{336}$, alguns deles integrantes das comissões de preparação daqueles e professores de direito («antecessores») ${ }^{337}$ nas escolas jurídicas do Império (Constantinopla e Beirute $)^{338}$.

${ }^{332}$ Cf. R. CARDILLI, L'obbligazione cit. (nt. 04 supra), p. 514.

Tratar-se-ia, de fato, de uma pseudo-responsabilidade subjetiva, apoiada em um expediente lógicointerpretativo, a saber, a presunção de culpa. Logo, ao invés de ser configurado como uma responsabilidade absoluta por determinados eventos, como no direito clássico, custodiam praestare passa a ser interpretado no esquema de uma particular figura de diligentia, ou seja, de um comportamento subjetivo mais acurado, pelo qual se presume que o devedor teria conseguido evitar o evento que tornou impossível o cumprimento da prestação principal. Haveria, entretanto, uma diferença: a possibilidade de liberação do devedor, contanto que pudesse demonstrar a observância da particular diligentia requerida nessas relações contratuais, o que, em termos fáticos, seria difícil de se verificar, dada a dificuldade da realização de tal prova diante de eventos como o furto da coisa. Cf. G. I. LuZZATTO, Caso cit. (nt. 116 supra), p. 42; 47-48 e nt. 02; $49-50$ e nt. 01; 51$52 ; 99$.

${ }^{333}$ Cf. G. I. LuZZATto, Caso cit. (nt. 119 supra), pp. 47-48.

${ }_{335}^{334} \mathrm{Cf}$. Tanta/Dedwcen, § 23, principalmente.

${ }^{335}$ Cf. Deo acutore, $\S 12$; Tanta/Dedwcen, $\S 21$. O aparecimento de numerosos comentários no período que medeia entre 533 a 560 d. C. (dito «período dos antecessores») ensejaria a reinterpretação do sentido da medida imperial: com efeito, não parece ter visado o imperador a impedir a realização de obras explicativas, mas a de impedir que se fizessem nos próprios códigos manuscritos, o que poderia levar, em futuras reproduções, o copista a confundir o texto legal e os comentários. Por outros termos, objetivou-se, tal como a outra proibição de Justiniano, a saber, a de utilização de siglas (Deo auctore, § 13; Tanta/Dedwcen, § 22; Cordi, § 5), a preservação textual dos códigos compilados. Cf. N. VAN DER WAL - J. H. A. LOKIN, Historiae iuris graeco-romani delineatio - Les sources du droit byzantin de 300 à 1453, Groningen, Forsten, 1985, pp. 36-37.

${ }^{336}$ Cf. v.g., H. J. SCHELTEMA, L'enseignement de droit des antécesseurs, Leiden, Brill, 1970, p. 01.

${ }^{337}$ Analogamente ao que se verificava, antes da modificação introduzida por Justiniano, com a designação dada aos principiantes dos estudos jurídicos («dupondii») (Omnem, § 2), os professores de direito eram referidos como «antecessores», vocábulo também proveniente do jargão militar. Tratava-se, com efeito, dos militares encarregados, na armada bizantina, de ir avante das tropas em marcha para fazer o reconhecimento 
A legislação justinianéia, predominantemente, compunha-se de textos escritos em latim, ao passo que os estudantes, em sua maioria, provinham das regiões de língua grega do Império, sem domínio suficiente do primeiro $^{339}$. Tendo-se em consideração tais dificuldades é que se poderia compreender o caráter (e também a estrutura) da produção jurídica dos antecessores $^{340}$, destinada tanto ao ensino quanto à prática administrativa e dos foros $^{341}$.

No que concerne às obras escolares, os seus resíduos refletiriam o funcionamento dos «cursos-duplos» ${ }^{342}$, nos quais se estudava cada texto ( $r$ bt om) duas vezes ${ }^{343}$ : na primeira, o professor ditava um index (tradução grega livre, mais ou menos extensa, do

do território, inspecionar as vias, encontrar os caminhos mais praticáveis, as fontes e pastos, assim como os melhores lugares para o exército fixar acampamento.

O ensino das ciências jurídicas comparava-se, portanto, a uma campanha militar: a tropa de estudantes fazia-se preceder pelo professor, a quem cabia a abertura das vias e o reconhecimento do terreno. Com efeito, Justiniano exorta-os a abrir o caminho, por ele encontrado, aos estudantes de direito: «Incipite igitur legum doctrinam eis dei gubernatione tradere et viam aperire, quam nos invenimus, quatenus fiant optimi iustitiae et rei publicae ministri et vos maximum decus in omne saeculum sequatur...» (= Começai, portanto, a ensinar-lhes a doutrina jurídica, sob a condução de Deus, e abrir-lhes o caminho, o qual nós encontramos, para que se tornem ótimos ministros da justiça e da res publica e siga-vos a máxima glória em todo o tempo...). (Omnem, § 11). Cf. H. J. SCHELTEMA, L'enseignement cit. (nt. 337 supra), p. 03; N. VAN DER WAL - J. H. A. LOKIN, Historiae cit. (nt. 335 supra), p. 38.

338 Assim, v.g., a Teófilo, professor em Constantinopla e integrante da comissão de preparação das Institutas imperiais e do Digesto (Imperatoriam, § 3; Omnem, § 2; Tanta/Deatucen, § 9; 11), atribuem-se, além da aráfrase das Institutas, fragmentos de comentários ao Digesto; também Isidoro, um dos professores aos quais se dirige a const. Omnem, teria apostilado cursos sobre o Digesto e o Codex; desse último, entretanto, o mais detalhado comentador teria sido Taleleu, professor em Beirute, e outro destinatário da constituição imperial; Doroteu, por sua vez, também referido na const. Omnem, e membro da comissão de preparação das Institutas e do Digesto (Imperatoriam, § 3; Omnem, § 2; Tanta/Deducen, § 9; 11), teria sido autor de uma tradução desse último não destinada, entretanto, ao uso escolar, mas à prática. Cf. N. VAN DER WAL - J. H. A. LOKIN, Historiae cit. (nt. 335 supra), pp. 41-47.

339 Cf. H. J. SCHELTEMA, L'enseignement cit. (nt. 337 supra), pp. 11-12, principalmente; N. VAN DER WAL - J. H. A. LOKIN, Historiae cit. (nt. 335 supra), p. 40.

${ }^{340}$ Cf. H. J. SCHELTEMA, L'enseignement cit. (nt. 337 supra), p. 11.

${ }^{341}$ Cf. N. VAN DER WAL - J. H. A. LOKIN, Historiae cit. (nt. 335 supra), pp. 46-47.

${ }^{342}$ Não há segurança quanto ao fato de ter sido introduzida essa nova metodologia no ensino da legitima scientia precisamente a partir da reforma justinianéia do ensino jurídico, embora seja bastante provável em função da ausência de testemunhos de sua aplicação em época anterior. Cf. N. VAN DER WAL - J. H. A. LOKIN, Historiae cit. (nt. 335 supra), p. 40.

${ }^{343}$ É o que parece sugerir H. J. SCHELTEMA, L'enseignement cit. (nt. 337 supra), p. 14; 18. Nesse sentido também o interpreta R. BONINI, L'età giustinianea e bizantina, in M. TALAMANCA (dir.), Lineamenti di storia del diritto romano, $2^{\mathrm{a}}$ ed., Milano, Giuffrè, 1989, p. 696. 
texto latino) $)^{344}$; na outra, dedicava-se aos aspectos propriamente jurídicos (mas, às vezes, também linguísticos), mediante comentários (chamados, genericamente, par agr af ai $)^{345}$.

Os mesmos obstáculos linguísticos apresentavam-se também aos que deveriam servir-se da legislação imperial com finalidades aplicativas, para a superação dos quais era necessário recorrer às traduções e comentários lato sensu em grego preparados pelos juristas da época ${ }^{346}$.

Com exceção da Paráfrase de Teófilo, essa literatura resultante dessa atividade dos antecessores foi conservada apenas fragmentariamente, integrando - em sua maior parte os chamados «escólios antigos» das Basílicas ${ }^{347}$, coleção bizantina bem posterior (datável entre o final do século IX d.C. e início do seguinte) ${ }^{348}$.

${ }^{344}$ Precediam essas traduções (indices), em alguns casos, os recursos - já remontantes ao uso escolar dos
séculos anteriores - denominados prot ewor iqa : essas consistiam em reportar, no início do tratamento de um
texto, uma regra já tratada anteriormente, quando encerrasse esse uma aplicação particular daquela regra jurídica ou representasse uma exceção a ela.

A função dessas traduções ou adaptações do texto em grego era a de permitir ao estudante, por leitura comparativa, entender o texto latino sem precisar, mais tarde, consultar o index. Cf. H. J. SCHELTEMA, L'enseignement cit. (nt. 337 supra), pp. 13-14; N. VAN DER WAL - J. H. A. LOKIN, Historiae cit. (nt. 335 supra), p. 22; 40.

${ }^{345}$ Tais anotações (chamadas, genericamente, paragraf aì poderiam assumir formas variadas, correspondentes a modalidades também já utilizadas no período anterior à reforma justinianéia do ensino jurídico: v.g., as ejwt apocrisei", questões propostas pelos estudantes e as respostas do professor, e as upomhnmat a, explicações gerais sobre o fragmento tratado. Cf. N. VAN DER WAL - J. H. A. LOKIN, Historiae cit. (nt. 335 supra), p. 40; 22.

${ }^{346}$ Poderia exemplificar essa outra destinação da produção literária desses juristas a tradução (integral) do Digesto aprontada por Doroteu e os resumos escritos nas margens dos próprios manuscritos (ditos summae), que vão sob o nome de Cirilo e de outro incógnito, chamado pelos pósteros de Anônimo. Cf. N. VAN DER WAL - J. H. A. LOKIN, Historiae cit. (nt. 335 supra), pp. 46-47.

${ }^{347}$ A elaboração das Basílicas pode ser compreendida em função das dificuldades de aplicação do direito da compilação justinianéia com o passar do tempo, o que teria levado alguns imperadores, a partir do século VIII, a organizar novas compilações do direito em língua grega.

Sob Leão, o Sábio (886-911 d. C.), teriam tido origem as «Basílicas» (t a; Basil ica), que revelariam o propósito de reunir o material do Corpus iuris em uma única compilação, com texto mais conciso, eliminação das regras já abrogadas, e em grego: um trabalho, em suma, de depuração das antigas leis («ajacaøar si" t w९ pal ai wn nomon»). Disso resultou uma obra dividada em 60 livros, e esses subdivididos em títulos, nos quais se articulam material proveniente do Digesto, do Codex e das Novelas, de duas ou apenas de um deles. Cf. A. GuARINo, L'esegesi I cit. (nt. 314 supra), pp. 529-531; N. VAN DER WAL - J. H. A. LOKIN, Historiae cit. (nt. 335 supra), pp. 81-82; 84-85.

O texto das Basílicas compõe-se de extratos provenientes dos resumos do Anônimo, de Cirilo (em relação ao Digesto), do index de Taleleu (em relação ao Codex), e das Novelas, que, por serem em sua maior parte em grego, citam-se os textos originais. Em meados do século X d. C., esse texto teria recebido um aparato de escólios, isto é, de comentários, extraídos das obras dos juristas bizantinos do tempo de Justiniano, os quais se denominaram «escólios antigos», em oposição aos «escólios novos», que constituem uma série redigida especificamente como comentários sobre o texto das Basílicas - já entre os séculos XI e XII d. C. Cf. C. G. E. HEIMBACH, Basilicorum libri LX - VI - Prolegomena et manuale Basilicorum continens, Leipzig, Barth, 1870, pp. 124-127; 144-145, 194, 196; A. GUARINO, L'esegesi I cit. (nt. 314 supra), p. 532; V. GIUFFRÈ, Scollii, in NNDI 16 (1957), pp. 771-772; N. VAN DER WAL - J. H. A. LOKIN, Historiae cit. (nt. 335 supra), p. 82; 91.

Completava-se, assim, cada texto com uma série de outros, oriundos de outras fontes que não aquela que constituía o texto propriamente, permitindo ao leitor - ignorante do latim - comparar várias traduções e adaptações do original, e fazer-se uma melhor idéia do teor genuíno do texto. É, pois, nesses escólios ditos «antigos» que se situam os fragmentos dos comentários realizados pelos antecessores sobre as várias partes 
Dado que esses juristas tinham diante de si os textos da compilação justinianéia para elucidar a consulta desses «comentários gregos» parece oportuna para verificar, como já se adiantou, a orientação da ciência jurídica bizantina do século VI d. C. acerca do «custodiam praestare» que encontrava nos textos latinos ${ }^{349}$.

$\mathrm{Na}$ maior parte dos textos, a terminologia «clássica» foi reportada sem modificações: ao «custodiam praestare» do rbt on faz-se corresponder, no jargão grego, expressões como coust wdi an crewst ei ${ }^{350}$, na acepção de «dever a custódia», «praestare a custódia» ${ }^{351}$.

Por sua vez, as alterações terminológicas ${ }^{352}$ verificadas em outros - a graduação da custodia, pelo uso de formulações como açribest ath $\mathrm{f} u \mathrm{u}$ ach ${ }^{353}$ e a subjetivização do

da compilação: v.g., trechos da obra de Estéfano de comentário ao Digesto «completam» os textos correspondentes dos livros do Digesto tratados nas aulas; para os demais, utilizaram-se passagens de Doroteu; por sua vez, os capítulos das Basílicas tomados do Codex são escoliados por fragmentos do comentário, dentre outros, de Taleleu. Cf. N. VAN DER WAL - J. H. A. LOKIN, Historiae cit. (nt. 335 supra), pp. 90-91.

${ }^{348}$ Cf. N. VAN Der WAL - J. H. A. LOKIN, Historiae cit. (nt. 335 supra), p. 40.

${ }^{349}$ Apesar de ser o «Konservatismus» a característica marcante dessa época, esse não impediu os juristas bizantinos de introduzir algumas modificações. Com efeito - e tal seria válido particularmente para as idéias de subjetivação dominantes no Verschuldenrecht - notam-se esforços desses juristas para retomar algumas idéias já presentes na compilação, interpretando os textos nesta deixados intocados em um sentido novo que se faria exprimir já nas traduções que deles realizavam. Cf. D. NöRR, Die Fahrlässigkeit im byzantinischen Vertragsrecht, München, Beck, 1960, p. 111.

Esses escólios, portanto, consentiriam individualizar a concepção das escolas jurídicas orientais em relação ao direito clássico e pós-clássico, uma vez que poderiam oferecer, em seu conjunto, um quadro mais completo do direito oriental do que a própria compilação justinianéia. Assumiriam, desse modo, valor juntamente com outras fontes, v.g., a Paráfrase de Teófilo - como fonte de cognição para a teoria jurídica da época de Justiniano. Cf. D. NÖRR, Die Fahrlässigkeit cit. (nt. 349 supra), pp. 12-14; 64.

${ }^{350}$ Assim, v.g., Dor. Ean a D. 47, 2, 14 pr. - B. 60, 12, 14 (H V 457; Sch B VIII 3351; sch. 72): «...custodiam...praestet»/«...coust wdi an crewst h...»; Dor. Ezht høh a D. 47, 2, 14, 10 - B. 60, 12, 14 (H V 461; Sch B VIII 3348; sc. 35): «...custodiam praestare...»/«...crewst ei coust wdi æn...». Cf. D. NöRR, Die Fahrlässigkeit cit. (nt. 349 supra), p. 64, nt. 02.

Além desses, poderiam ser citados: Kyr. Eij pragma a D. 13, 6, 10, 1 - B. 13, 1, 10 (H II 15; Sch B II 616, sch. 02): «...praestabit... et custodiam...»/《...apait w‥ cai ;coust wdian...»; Steph. Eij høamen a D. 16, 3, 1, 35 - B. 13, 2, 1 (H II 35; Sch B II 645, sc. 52): «...sed etiam culpam et custodiam praestet...»/《... apo; coulvpa" h] coust wdiq" cat eh/..»; Steph. Shmei wsai a D. 17, 2, 52, 3 - B. 12, 1, 50 (H I 752; Sch B II 481): «...custodiam praestare debuit...»/«...coust wdiæ/ dey t out est in f ul ach/caqupobal I etrw...».

$351 \mathrm{Cf}$. as respectivas traduções dos escólios na edição HEIMBACH (nota anterior): «custodiam...praestet...», «...custodiam non debet...», etc.

${ }^{352}$ No que respeita à análise terminológica das fontes bizantinas, observa D. NÖRR que tais juristas teriam preferido - mais frequentemente - à clara utilização dos conceitos, as traduções ou paráfrases com sinônimos, de modo que não é fácil distinguir, nos vários casos, se tal tradução consiste em um recurso estilístico ou exprime a incompreensão, pelo intérprete, da tecnicidade do vocábulo. Die Fahrlässigkeit cit. (nt. 349 supra), p. 09.

${ }^{353}$ Cf., v.g., D. 13, 6, 5, 9 - B. 13, 1, 5 (H II 10; Sch A II 713); D. 13, 6, 10, 1 - B. 13, 1, 10 (H II 15; Sch A II 715); D. 13, 6, 5, 14 - B. 13, 1, 5 (H II 11; Sch A II 714); D. 18, 6, 4, 1 e 2 - B. 53, 7, 10 (H V 119; Sch A VII 2461); D. 18, 6, 3 - B. 53, 7, 7 ( Sch A VII 2461); D. 47, 2, 14, 17 - B. 60, 12, 14 (H V 464; Sch A VIII 2822). Cf. D. NÖRR, Die Fahrlässigkeit cit. (nt. 349 supra), p. 64, nt. 03.

Essas citações provêm do texto das Basílicas e não dos escólios ditos «antigos». No entanto, como se esclareceu supra, também para a composição daquele foram utilizados os resumos, epítomes, traduções e adaptações gregas dos «textos justinianeus» realizadas por juristas do século VI d. C., dentre eles, predominantemente, a Paráfrase de Teófilo (para as Institutas), o index de Anônimo (para o Digesto) e o 
conceito, por locuções como f ul ach; ejimel hV, coust wdi đejpi mel est ath $\mathrm{h}^{354}$, ajrel ei peri; thn $\mathrm{f} u \mathrm{achm}^{355}$, esclarecimentos (v.g., «...hft oi diligent $\mathrm{iq}{ }^{356}$ ), ou mesmo a reprodução do termo como ą̧ra ejimekeia ${ }^{357}$ (ou, simplesmente, diligentia ${ }^{358}$ ) demonstrariam a tendência de subjetivização e de dissolução do conceito de custodia $^{359}$.

Tais reformulações, entretanto, não teriam afetado o regime prático da «aćribest ath cai;uperbal I ousa par af ul ach», definição dada à «custodía» pelo autor da Paráfrase $\mathrm{P}^{360}$. Ainda entre os juristas bizantinos, consistiria ela na atividade capaz de evitar o furto da coisa devida ${ }^{361}$. Também em relação à fuga do escravo, a solução - ao

comentário de Taleleu (para o Codex). Cf. N. VAN DER WAL - J. H. A. LoKIN, Historiae cit. (nt. 335 supra), p. 82.

É, aparentemente, essa a razão - embora não deixe explícito D. NÖRR - pela qual esse autor serve-se também do texto das Basílicas citados supra para uma investigação do quadro terminológico do período dos antecessores e não apenas dos escólios.

${ }^{354}$ Cf. Steph. Shmei wsai a D. 13, 6, 5, 2 - B. 13, 1, 5 (H II 07; Sch B II 608, sch. 11); Kyr. Ful achn a D. 13, 6, 5, 2 - B. 13, 1, 5 (H II 08; Sch B II 610, sch. 18); e também outras formulações semelhantes: Anon. Toi oi a D. 13, 6, 18 pr. - B. 13, 1, 18 (H II 19; Sch B II 621, sch. 06) («... asf al wi f ul att esqai ...»); Steph. Edwca a D. 19, 2, 13, 6 - B. 20, 1, 13 (H II 341; Sch B III 1177, sch. 06) («...f ul att ein epimel w ...»). Cf. D. NöRR, Die Fahrlässigkeit cit. (nt. 349 supra), p. 65, nt. 02.

${ }^{355}$ Cf. v.g., Steph. Ht oi soi ;a D. 19, 2, 40 - B. 20, 1, 39 (H II 359; Sch B III 1199, sch. 01). Cf. D. NöRR, Die Fahrlässigkeit cit. (nt. 349 supra), p. 65.

${ }^{356}$ Cf. v.g., Steph. Shmei wsai a D. 13, 6, 5, 5 - D. 13, 1, 5 (H II 08; Sch B II 609, sch. 17); Steph. Epeidh;a D. 13, 6, 5, 13 - B. 13, 1, 5 (H II 11; Sch B II 612, sch. 39). Cf. D. NÖRR, Die Fahrlässigkeit cit. (nt. 349 supra), p. 65, nt. 03.

${ }^{357}$ Cf. v.g., Dor. Dia;a D. 47, 2, 12 pr. - B. 60, 12, 12 (HeImBaCh V 455; Scheltema B VIII 3342, sc. 01); Thal. Epeidh; a C. 6, 2, 22 - B. 60, 6, 39 (H V 404; Sch B VIII 3269, sch. 05). Cf. D. NöRR, Die Fahrlässigkeit cit. (nt. 349 supra), p. 64, nt. 05.

${ }^{358} \mathrm{Cf}$. Theoph. 4, 1, 16-17 (correspondente a Inst. 4, 1, 16-17, parágrafos nos quais se faz presente tão-só «custodiam praestare»). Cf. D. NÖRR, Die Fahrlässigkeit cit. (nt. 349 supra), p. 65 e nt. 04. Ter-se-ia, nessas referências, ademais, exemplo de um uso da literatura jurídica do período dos antecessores (mas já, provavelmente antes desse), a saber, o registro de palavras em letras do alfabeto latino em meio ao comentário grego, mas declinadas segundo as regras da gramática grega: «...caxin diligentían écr ewst ei

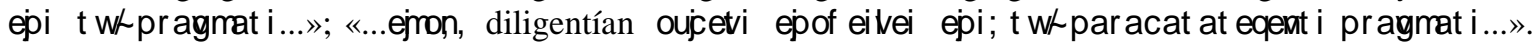
Cf., mas sem indicação de exemplos, N. VAN DER WAL - J. H. A. LOKIN, Historiae cit. (nt. 335 supra), pp. 21-22.

${ }^{359}$ Cf. D. NÖRR, Die Fahrlässigkeit cit. (nt. 349 supra), pp. 64-66.

${ }^{360}$ Cf. Theoph. 3, 23, 3 a, no qual também se registra «custodía», em letras latinas, em meio ao texto grego.

${ }^{361}$ Cf. Steph. Shmei wsai a D. 17, 2, 52, 3 - B. 12, 1, 50 (HeImBACH I 752; SCheltema B II 481) (a); Thal. Epeidh a C. 6, 2, 22 - B. 60, 6, 39 (H V 404; Sch B VIII 3269, sch. 05) (b).

A elucidação de Estéfano (a) insere-se no contexto da discussão dos limites da responsabilidade do sócio que recebeu um rebanho aestimatum para apascentar: Shmei wsai, of i hJmen t wh I hst wh ef odo" t uchra; eihai docei perigt asi", hJde; cl oph; ouc esti tuchra; perigt asi", coust wdia/ dey tout est in

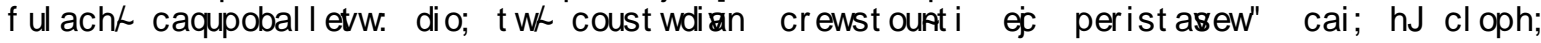
cinduneuet ai, ej w//mh; coust wdian perivt o; cl apen ejedei xat o. Koust wdi an de; nohson ejt auga, hh aei; I egei pl emam coust wdian, tout est i thn epi mel h coust wdian, w't e cai; cl oph" per igi mesqai: cai; m; t hn genichn l egomeahn coust wdian, t out est $\mathrm{i}$ thn $\mathrm{t} w /$ dolw/ pro" eoicui an: cai ; apl w"

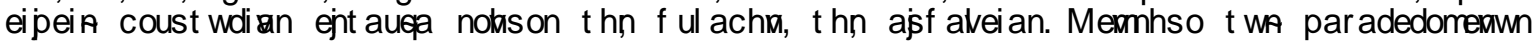
soi par' ejrou ej tw/e vdig. th" commodati tou par ont o" sunt agmat o", cai; shmei wsai, of $\mathrm{i}$ hJ cloph; ouc uperbaimei thn ejact an diligentian, eij mb; cata; dolvon h] raqumian hJ tuchra; gegonen auf h perigt asi". (=Nota <tu> que o ataque de salteadores parece ser um evento casual <isso é, fortuito>, mas o furto não é uma ocorrência fortuita, pois devia <o contratante> a custódia e a vigilância: em razão disso, aquele que deve a custódia, responde também pelo furto, se realmente não tivesse aplicado a custódia à coisa <que fora> furtada. Entenda, pois, <por> custódia, aquela chamada sempre de custódia 
menos no que tange ao resultado prático - desses comentadores não difere da encontrada nos textos do Digesto ${ }^{362}$.

Já no que concerne à compreensão do damnum iniuria causado por um terceiro no «custodiam praestare» incumbente a alguns devedores - questão controversa na iurisprudentia do século II d. C. - os antecessores teriam optado pela solução negativa ${ }^{363}$, ao considerá-lo um evento fortuito, pelo qual não se responde ${ }^{364}$.

plena, ou, às vezes, custódia diligente, pela qual se consegue evitar o furto. E não <entenda> <por> aquela custódia dita geral, isto é, aquela similar ao dolo. E, para dizer de modo simples, entenda a custódia aqui $\langle$ referida $>\langle$ como $>$ a guarda, a caução. Lembra-te daquelas coisas que te foram transmitidas por mim $<$ no fragmento $\rangle$ cinco $\langle$ do título atinente ao $\rangle$ comodato $\langle$ D. 13, 6, 5>, dessa parte $\langle$ isso é, da parte de rebus $\rangle$, e nota $\langle$ tu $\rangle$ que o furto não supera a diligência exata, se esse evento fortuito não ocorrer por dolo ou negligência).

No texto do Digesto (rhton), as hipóteses pela quais o sócio não responderia seriam, v.g., a de latrocinium (isso é, assalto, cf. H. HEUMANN - E. SECKEL, Latrocinium, in Handlexicon cit. (nt. 18 supra), p. 307) e incêndio, considerados «damna fatalia». Em contrapartida, tratando-se de subtração da coisa por ladrões, estaria o sócio obrigado pela actio pro socio, pois «custodiam praestare debuit». Também esse contraste, limitadamente ao caso de assalto, é estabelecido por Estéfano, de cujo escólio resultaria a evitabilidade do furto pelo sócio obrigado à custodia, porém não do t w̧ I hst w̧ ef odo", considerado evento fortuito (t uchra;perigt asi").

Entretanto, reconhece D. NÖRR que a parte final desse escólio sugeriria uma mudança também no que concerne ao resultado prático do problema tratado: além da subjetivização, Estéfano pareceria admitir a liberação do devedor (diante da perda da coisa devida ao furto) que tivesse observado um comportamento diligente na guarda da coisa. Cf. Die Fahrlässigkeit cit. (nt. 349 supra), p. 63; 66-67.

Também o trecho do comentário de Taleleu ao Codex (b) parece eluciar a orientação do antecessor quanto à resistibilidade do furto pela diligência (a saber, a açra eji melveia) que se exigia do comodatatário: Epeidh; gar oJcat a; cierhsin efwn ti acran ejimeleian ej' aut w/ crewst ei $\sim$ hJde; akra ejimeveia thn

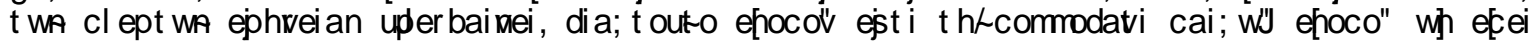
cai ; t hn $f$ ourt $i, \ldots$ (=Pois que o comodatário deve a suma diligência em relação à coisa comodada, $\mathrm{e}$ a suma diligência supera o abuso dos ladrões, <e> assim, ele <o comodatário> estará sujeito à <actio> commodati e, porque sujeito <a essa ação>, tem ele, pois, também a actio furti,...).

Esse texto, que na edição K. W. E. HeIMBACH - C. G. E. HEIMBACH limita-se ao trecho reportado, e na SCHELTEMA recebe um aditamento (a partir do codex Parisinus graecus 1350), parece, com efeito, corroborar a doutrina majoritária sobre as consequiências práticas do reconhecimento do «custodiam praestare»: responsabilidade pelo furto da coisa devida independentemente de culpa, mas dependente tão-só do fato «típico», qual seja, o furto. Cf. supra.

${ }^{362}$ Cf. v.g., Steph. Shmei wsai a D. 13, 6, 5, 6 - D. 13, 1, 5 (H II 8; Sch B II 628, sch. 04); Steph. Epeidh a D. 13, 6, 5, 13 - B. 13, 1, 5 (H II 11; Sch B II 612, sch. 39); Kyr. Ful achn a D. 13, 6, 5, 6 - D. 13, 1, 5 (HE II 8; Sch B II 610, sch. 18); Kyr. D crhsameno" a D. 13, 6, 18 pr. - B. 13, 1, 18 (H II 19; Sch B II 620, sch. 02), mas também os demais escólios desse texto; D. 6, 1, 21 - B. 15, 1, 21 (H II 158; Sch A II 769); D. 50, 17, 23 - B. 2, 3, 23 (H I 66; Sch A I 51 ).

Com efeito, afirma Cirilo, em comentário a D. 13, 6, 5, 6: Ful achn ejimel h apait eitai oJ crhsameno": oi cethn ouj apait eitai f ul att ein, eij mh; dedememo" ejdoqh, h] micra" hh hلicia", h] t outo sunef unhøh. (=O comodatário deve a custódia diligente: não deve custodiar o escravo, a não ser que te tenha sido entregue agrilhoado, ou seja $<$ o escravo $>$ de pouca idade, ou isso tenha sido convencionado).

Em conformidade com os textos reportados no Digesto (particularmente, D. 13, 6, 5, 6 e 13) (supra), os juristas bizantinos excluem, em regra, a existência de uma custodia a cargo do comodatário que possa evitar a fuga, existindo essa apenas em casos excepcionais (a entrega do servus em grilhões, a sua pouca idade que pudesse requerer uma vigilância para impedir a fuga, ou, finalmente, a explícita cláusula contratual). Cf. D. NÖRR, Die Fahrlässigkeit cit. (nt. 349 supra), p. 67.

${ }_{363}$ Cf. Steph. Anagnwai a D. 13, 6, 19 - B. 13, 1, 19 (H II 21; Sch B II 622 sch. 02); Kyr. H a[ ogo" a D. 13, 6, 19 - B. 13, 1, 19 (H II 21; Sch B II 622, sc. 01); ej etlevou a D. 13, 6, 19 - B. 13, 1, 19 (H II 21; Sch B II 634, sch. 02); Steph. Ht oi a D. 19, 1, 40 - B. 20, 1, 39 (H II 359; Sch B III 1199, sch. 01).

A idéia de que o dano iniuria causado por um terceiro - contrariamente ao furto - superava a diligência humana na concepção dos bizantinos - cf. G. I. LuZZATO, Caso cit. (nt. 119, supra), pp. 152-153, nt. 01 expressar-se-ia, com maior clareza, neste texto de Estéfano: Anagnwai dig.... tel eut. Uperball ei thn 
A custodia (ainda que em suas reformulações), ademais, teria conservado uma posição autônoma no «sistema dominante», por assim dizer, de responsabilidade concebido pelos bizantinos, sistema esse quadripartido, fundamentalmente expresso na série: dolus culpa-diligentia (exacta) - casus $^{365}$.

Já com precedentes no Digesto - em Ulp. 28 ad Sab., D. 13, 6, 5, 2-3 e 29 ad Sab., D. 50. 17, 23 - esse esquema teria máxima expressão em um comentário de Estéfano ${ }^{366}$, do

ajor wpiahn te front ida cai; ejimekeian to; pant h ejcclinai tou,' al ogw" te cai; paranomw' hua" ajlicourt a". To; aut ov f hsin oJ Oul piano," ej $\mathrm{t} w /$ ma y dig. th" l ocati toude tou sunt agmat o". Anagnwqi pant W' ta," ejceise paragraf al. (=Lê <tu> <do>Digesto..... ult. <ulteriormente citado?>. Supera o cuidado e a diligência humana o poder evitar tudo aquilo que nos lesa inesperada e injustamente. Isso mesmo disse Ulpiano na <fragmento> 41 do Digesto, <no título dedicado à actio > locati <D. 19, 2>, dessa parte <isso é, da parte de rebus〉. Lê inteiramente as anotações ali feitas).

${ }^{364}$ Cf. G. I. LuZZATO, Caso cit. (nt. 119, supra), p. 152, nt. 01.

${ }^{365}$ Segundo D. NÖRR, pode-se reconhecer aos juristas do século VI d. C. um sistema de responsabilidade relativamente constante, tendo-se esforçado aqueles para desenvolver modelos já presentes no Digesto. Não obstante o interesse pela perspectiva sistemática, a ciência jurídica bizantina não no teria levado às últimas consequências, como atestariam as não poucas variações. Cf. Die Fahrlässigkeit cit. (nt. 349 supra), p. 84; 87.

${ }^{366}$ Cf. Shmei wsai a D. 13, 6, 5, 2-3 - B. 13, 1, 5 (H II 07; Sch B II 608, sch. 11): Shmei wsai of i ef 'wia ej t ou aut ou sunal I agmat o" edater o" wf el eitai t wh sunal l axant wn, w' eji; th" prasew' cai; misqusew', cai; w'J eji; diat imht h" dhl onoti, w'l eji; proico', cai; w'l ejpi; ejecurrou cai; coinuniq", t ote ouj momon apo; dolvou, al I a; cai; apo; coulpa" hf oi coust wdia" oJ rdø" cat ecet ai. (1) crhsameno" ouh, of e men ev tou crhsqent o" pragmat o" edatero" wf el eitai o\{ te crhsa" cai; oJcrhsameno", t ove ajo; dolvou cai; ajo; coulvpa" hf oi coust wdi" monh" cat evet ai . Enga de; mono" oJ crhsameno" wf el eitai, t otve ouj momon dovon, al I a cai; coulvpan hf oi coust wdian cai; diligent ian apait eitai. Diligent ian de; ouj h\} auto," peri; ta; oicei a tiqet ai

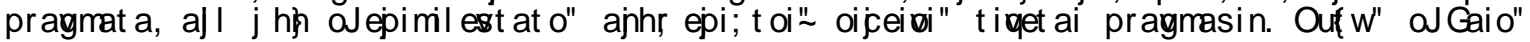
ej $\mathrm{t} w /$ md'. $t$ wn Dig. bib. Fhsim. Thn de; $t$ oiauthn diligent ian cal $w^{2}$ ah $\mathrm{t} i$ " cai; coust wdian, ouc apl hn, oujle; thn caoolou, af I' epimel est athn apocal esh/ Kai ; coust wdian gar oJ crhsameno" epimel est athn, ej w/ pro," wf evei an aut ou monou oda $\sim$ t o; crhsqen, ejpi; t w $\sim$ pragmat i crewst ei; w'J oJnomico," ej tw/paront i dig., di ' wh ejif evei l egwn aut on coust wdian, ouj thn t ucousan, oujle; $t$ hn cagolvou, all', ejil el est athn of eivein eji; t w/ pragmat i parascein. Sunel ont a $t$ oimun eipein oJcrhsameno", eij men cai; aut o," cai; oJcrhsa" ej t ou pragmat o" wf el eitai, dovon cai; coukpan hf oi coust wdian eji; tw/ pragmat i monon crewst ei. eij de; mono" wf el eitai, tote crewst ei dolvon cai; coulvpan cai; dil igent ian hf̣ oi coust wdian ejimel est athn. Eij de; mono" oJ crhsa" wf el eitai [|t ote crewst ei dól on cai; coulpan cai; diligent ian hf̣ oi coust wdian epimel est athn: eij de; mono" oJ crhsa" wf el eitai|] tove dolvon apait eitai cai; momon oJ crhsameno", w'l eji; t wn schnicwn, oil" oJa[cwn ejit el wr gean efrhsevt ina, f aidrot eran deixai t oi" suniousi thn gean boul omeno". (= Nota <tu> que, nos contratos que aproveitam a ambas as partes contratantes, tais como a compra e venda, a locação, a estimação do dote, o penhor e a sociedade, o devedor <responde> não apenas por dolo, mas também por culpa ou custódia. Assim, quando o comodato beneficiar ambos, tanto o comodante quanto o comodatário, então o comodatário <responde> apenas por dolo e culpa ou custódia. Porém, quando o benefício cabe apenas ao comodatário, esse <responderá> não apenas por dolo, mas também por culpa ou custódia e diligência. Não deve, porém, aquela diligência que ele dispensa à sua própria coisa, mas sim aquela que um homem diligentíssimo observa em relação às suas próprias coisas. Assim diz Gaio no livro 44 do Digesto $<2$ aur., D. 44, 7, 1,4>. Chamou-se, corretamente, tal diligência a ser observada e custódia, não simples, e nem geral, mas diligentíssima. Desse modo, pois, o comodatário aplica uma custódia diligentíssima à coisa comodada, se o comodato apenas o beneficia, como diz o jurisconsulto nesse Digesto, e se dessume das palavras que ele <o comodatário> deve, em relação às coisas comodadas, uma custódia não simples e geral, mas diligentíssima. Para dizer em breves palavras: o comodatário, se o comodato tanto o beneficia quanto o comodante, <responde> somente por dolo e culpa ou custódia em relação às coisas; se, no entanto, benficia apenas o <comodatário>, responde por dolo e culpa e diligência ou custódia diligentíssima. Se, por outro lado, aproveita apenas ao comodante [<responde $\rangle$ esse por dolo e culpa e diligência e custódia diligentíssima; se beneficia apenas o comodante], o comodatário <responde> tão-só por dolo, como no caso dos atores, aos quais o magistrado emprestou, ao oferecer um espetáculo público, algumas coisas a fim de que tornassem a apresentação mais deleitante aos expectadores). 
qual se poderia inferir a série: dolvo" - coulvpa hṭ oi coust wdi (ou seja apl h, cagolvou,

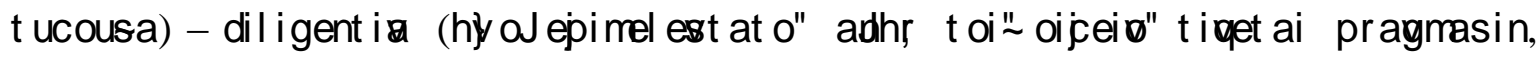
coust wdir ejimel est ath) - t a; t uchraß̧57.

Em suma, a seguir os resultados de D. NÖRR, a reprodução da «configuração clássica» da custodia em alguns textos dos escólios dever-se-ia à fidelidade dos bizantinos aos textos comentados; entretanto, a ciência jurídica desse período interpretou-a, fundamentalmente, como diligentia in custodiendo ${ }^{368}$.

Não obstante, os «escólios antigos», fragmentos da literatura jurídica dos antecessores, confirmariam a permanência das soluções clássicas, uma vez que às «subjetivizações» (já provenientes do direito pós-clássico) não teria correspondido uma alteração do regime prático de «custodiam praestare» ${ }^{369}$.

Considerou-se, para a versão do texto, também a tradução parcial ("Enga de; momo" - coust wdi an eji mel est athn») dele feita por C. FERRINI, Storia e teoria del contratto di commodato nel diritto romano, in E. AlBERTARIO (cur.), Opere di Contardo Ferrini III cit. (nt. 208 supra), p. 151.

${ }^{367}$ Com algumas variações, esse esquema também se encontra em outros escólios, v.g.: Kyr. Enqa a D. 13, 6, 5, 2 - B. 13, 1, 5 (H II 06; Sch B II 607, sc. 06): dolus-culpa-diligentia-casus fortuitus (se recebida a coisa aestimata); Kyr. Ocrhsameno" a D. 13, 6, 8 pr. - B. 13, 1, 18 (H II 19; Sch B II 620, sch. 02): dolusculpa-exacta diligentia-exclusão do casus fortuitus; Steph. Ouc apait ei a D. 17, 2, 52, 3 - B. 12, 1, 50 (H I 751; Sch B II 481, sch. 10): dolus-culpa-custodia; Steph. Tosauthn (Sch B III 1010, sch. 02) e Jrqw2 a D. 7, 9, 1 - B. 16, 9, 1 (Sch B III 1011, sch. 06): dolus-culpa-diligentia exacta. Cf. D. NöRR, Die Fahrlässigkeit cit. (nt. 349 supra), pp. 85-86.

${ }^{368}$ Cf. Die Fahrlässigkeit cit. (nt. 349 supra), p. 68; 111-112. A terminologia utilizada nessas versões e adaptações gregas para a «transformação» da custodia clássica em diligentia não é, como já observava G. I. LUZZATTO, totalmente precisa, uma vez que os comentadores bizantinos referem-se indistintamente a, v.g., diligentia, akra ou acribest ath ejimeveia, ejact a diligentia, ejimel estath coust wdia, epi melveia... hḩ t iqet ai ejimel est at o" ajhrv. Cf. Caso cit. (nt. 119 supra), p. 91, nt. 03.

${ }^{369}$ Cf. D. NÖRR, Die Fahrlässigkeit cit. (nt. 349 supra), p. 62. 


\section{Capítulo III}

\section{ASPECTOS CONCEITUAIS dA COMPRA E VENDA (EMPTIO VENDITIO $)^{370}$}

\section{Emptio venditio: a compra e venda consensual e obrigatória romana}

Os textos juriprudenciais acerca do tema estudado, em sua delimitação (isso é, relacionados à emptio venditio), em sua maior parte, são atribuídos a juristas do final do século I d. C. ao III d. C., período em que já se encontrava afirmada a compra e venda obrigatória e consensual no direito romano ${ }^{371}$.

Todavia, essas características - obrigatoriedade e consensualidade ${ }^{372}$ - que singularizam a compra e venda romana (na figura da emptio venditio) em relação à mesma «função sócio-econômica» (a troca entre a disponibilidade definitiva da coisa e o seu valor expresso em dinheiro ${ }^{373}$ ) presente em outros direitos da Antigüidade ${ }^{374}$, corresponderiam à compra e venda do período clássico ${ }^{375}$.

Antes de se conceder tutela à compra e venda obrigacional e consensual - o que teria dependido do surgimento dos iudicia bonae fidei, verificado na segunda metade do

\footnotetext{
${ }^{370}$ Apresentam-se as informações necessárias sobre o contrato (emptio venditio) subjacente às discussões dos textos a serem examinados infra (Parte II) - cf. U. WESEl, Die Hausarbeit cit. (nt. 151 supra), p. 51. Cf., em geral, R. ZIMMERMAnN, The Law of Obligations - Roman Foundations of the Civilian Tradition, London, Oxford University, 1996, pp. 230-302.

${ }^{371}$ Esses dois aspectos, porém, não se afirmaram contemporaneamente no pensamento jurídico romano: se, por um lado, o contrato obrigacional consistiu em novidade rapidamente empregada nessa experiência (ou seja, já a partir do século III a. C.), por outro, a - mera - consensualidade (isto é, a relevância do acordo, firmado por qualquer modo) teria observado um processo mais lento de consolidação, verificada, plenamente, em meados do século I a. C. De fato, em alguns textos que poderiam documentar o período precedente $-v \cdot g$., formulários catonianos e varronianos - far-se-ia presente a exigência de determinadas formalidades das quais deveriam revestir-se os acordos (v.g., auctiones e formas para-estipulatórias). Cf. M. TALAMANCA, Vendita cit. (nt. 21 supra), p. 311; ID., Istituzioni cit. (nt. 05 supra), p. 582.

372 Sob o primeiro aspecto, caracterizar a compra e venda como contrato «consensual» significaria reconhecer que o mero acordo entre as partes (acerca da troca entre a coisa e o seu preço em dinheiro) atribuiria ao negócio eficácia jurídica (cf. Gai. 3, 136; Inst. 3, 22, 1). Por sua vez, a sua qualificação como «obrigatório» poria em relevo a carência de efeitos reais do negócio, pelo qual as partes apenas se vinculam, uma, a transferir o gozo pacífico da coisa à contraparte, obrigada, por sua vez, ao pagamento do preço desta. Cf. A. BuRdESE, Vendita (diritto romano), in NNDI 20 (1975), pp. 594-595.

${ }^{373}$ Cf. M. TALAMANCA, Istituzioni cit. (nt. 05 supra), p. 581.

${ }^{374}$ Cf. M. TAlamanCA, Vendita cit. (nt. 21 supra), p. 303; 310 e nt. 60; 320; ID., Istituzioni cit. (nt. 05 supra), p. 582; A. BURDESE, Vendita cit. (nt. 372 supra), p. 595; E. VOLTERRA, Istituzioni cit. (nt. 21 supra), p. 496.

${ }^{375}$ Cf. M. TAlamanCA, Istituzioni cit. (nt. 05 supra), p. 582.
} 
século III a. C. ${ }^{376}$-, a «função sócio-econômica» da compra e venda assume relevância no âmbito da experiência jurídica romana sob diversa formalização jurídica ${ }^{377}$.

Com efeito, a troca da coisa contra o preço teria, originariamente ${ }^{378}$, sido regulamentada - analogamente aos demais ordenamentos antigos - como troca imediata das prestações e dotada, prevalentemente ao menos, de efeitos reais ${ }^{379}$, tal como se dá com a mancipatio $^{380}$.

Se, por um lado, o ponto de partida da experiência jurídica romana - ou seja, uma compra e venda como negócio translativo de propriedade ${ }^{381}$ - não gera maiores controvérsias na doutrina romanística, por outro, a reconstrução do processo evolutivo da compra e venda contextual àquela obrigacional e consensual constituiria objeto de ampla discussão ${ }^{382}$.

${ }^{376}$ Cf. M. TAlamancA, Vendita cit. (nt. 21 supra), p. 305; p. 309 e nt. 56; ID., Istituzioni cit. (nt. 05 supra), pp. 580-581.

${ }_{377}$ Cf. M. TAlamanca, Vendita cit. (nt. 21 supra), p. 303; ID., Istituzioni cit. (nt. 05 supra), pp. 581-582.

${ }^{378}$ A história da compra e venda, segundo Paulo (33 ad ed., D. 18, 1, 1 pr.), ter-se-ia iniciado, em época anterior ao conhecimento da moeda, com o estágio de simples escambo («baratto»; «Baratt»), isto é, a troca de coisa por coisa (permutatio): «Origo emendi vendendique a permutationibus coepit. Olim enim non ita erat nuтmus neque aliud merx, aliud pretium vocabatur...»: ( = A origem da compra e venda começou com as permutas. Pois, outrora, não havia a moeda, e nem uma <prestação> era chamada de mercadoria, nem a outra de preço...). Cf., v.g., E. VOlTERRA, Istituzioni cit. (nt. 21 supra), p. 496 e nt. 01.

379 Trata-se do negócio - designado, na doutrina moderna, «compravendita reale», «compravendita imediata», «compravendita a contanti», «Barkauf», «Handkauf», «Baraustausch», «compra e venda à vista», «compra a contado», «venda manual» - no qual se verifica a contemporaneidade entre a conclusão do acordo e a o adimplemento das prestações. Cf. M. KASER - R. KNÜTEL, Römisches Privatrecht, $19^{\text {a }}$ ed., München, Beck, 2008, p. 223; M. TALAMANCA, Istituzioni cit. (nt. 05 supra), pp. 582; M. KASER, Das römische Privatrecht I cit. (nt. 05 supra), pp. 545-546; E. VOLTERRA, Istituzioni cit. (nt. 21 supra), p. 496, nt. 01.

Nessa compra e venda real, o problema reduzia-se a determinar o momento no qual se dava a transferência da propriedade ao adquirente. Se, por um lado, o acordo existente entre as partes careceria de valor obrigacional, por outro, a eventual entrega da coisa pelo alienante (sem a aquisição de um direito de crédito sobre o preço não pago pela contraparte) não constituiria um problema, já que seria considerado (ao menos para as res mancipi) o pagamento do preço (em eventual concurso com outros elementos, v.g., a mancipatio) como o momento determinante para a transferência da propriedade. Cf. M. TALAMANCA, Vendita cit. (nt. 21 supra), pp. 303-304.

${ }^{380}$ Além da mancipatio (em sua estrutura primitiva, isto é, como formalização do pagamento do aes rude, correspectivo da coisa adquirida pelo comprador), M. KASER vislumbra a ocorrência desse fenômeno - o «Barkauf» - também na compra e venda informal, entre cidadãos romanos, na originária troca de res nec mancipi, e também nas relações desses com peregrinos, no comércio de coisas de toda espécie (até mesmo de res mancipi). Cf. Das römische Privatrecht I cit. (nt. 05 supra), p. 545; M. KASER - R. KNÜTEL, Römisches cit. (nt. 379 supra), p. 223; A. BURDESE, Vendita cit. (nt. 372 supra), p. 595. 595.

${ }^{381}$ Cf. M. TAlamancA, Vendita cit. (nt. 21 supra), p. 304; A. BURDESE, Vendita cit. (nt. 372 supra), p.

${ }^{382}$ Neste debate, seria necessário, como acentua M. TALAMANCA, distinguir o problema da afirmação da compra e venda consensual e obrigacional na experiência jurídica romana, questão ligada ao surgimento e desenvolvimento dos iudica bonae fidei, e aquele - conexo, mas diverso - dos meios pelos quais se supriam, diante da ausência do esquema da obligatio consensu contracta, as necessidades de accreditamento de uma das prestações.

Observa ainda esse autor que, se por um lado, a visão unitária, para a qual as etapas de desenvolvimento da obligatio consensu contracta devem ser vistas nas formas de venda obrigacional anteriores à introdução do contrato consensual nas relações entre cidadãos não seja afastável abstratamente, por outro, não faltaria legitimidade à outra corrente, conforme a qual estas formas que supriam a ausência do contrato consensual 
Independentemente da hipótese adotada para explicar a origem da emptio venditio $^{383}$, essas características com as quais se apresenta na experiência jurídica romana consensualidade e a obrigatoriedade - ter-se-iam mantido substancialmente inalteradas na iurisprudentia clássica e na chancelaria imperial até Diocleciano ${ }^{384}$, regime que, após algumas modificações no período pós-clássico orientadas à concepção de venda real, teria retornado, parcialmente, com Justiniano ${ }^{385}$.

A emptio venditio figuraria, portanto, no sistema contratual romano, como o contrato originado a partir do acordo das partes que obriga ${ }^{386}$ uma, à entrega da coisa ${ }^{387}, \mathrm{e}$ a outra, à contraprestação de determinada soma de dinheiro ${ }^{388}$.

\section{Obrigações do vendedor na emptio venditio}

Pelo contrato, o comprador obriga-se à transferência da propriedade do preço ao vendedor $^{389}$, cuja posição jurídica, no que concerne às obrigações originadas do negócio,

não teriam influenciado, decididamente, no surgimento do esquema da obligatio consensu contracta. Cf. Vendita cit. (nt. 21 supra), p. 304; 306.

${ }^{383}$ Assim, v.g., (a) como resultado do desenvolvimento gradativo da originária venda à vista, que teria atravessado, até atingir a obligatio consensu contracta, uma fase na qual se teria configurado como contrato real; (b) como desenvolvimento de uma prática precedente, pela qual se dava o accreditamento de uma ou de ambas as prestações pelo emprego da stipulatio; (c) por sua vez, pretendeu-se demonstrar a derivação da emptio venditio a partir da extensão da mancipatio - originalmente, ato baseado no acordo das partes cuja eficácia consistia na aquisição da disponibilidade material da coisa (res mancipi móvel) - às coisas imóveis, assumindo, então, mero caráter obrigacional; (d) ou como figura originada a partir das auctiones privadas, modeladas, por sua vez, nas auctiones públicas do erário; (e) no intervento do pretor, mediante a concessão de meios de tutela - não embasados no sistema civilístico (ius civile) - de expectativas creditórias fundamentadas em transações de compra e venda não formalizadas pela mancipatio e nem asseguradas por stipulatio. Cf. uma síntese dessas proposições em M. TALAMANCA, Vendita cit. (nt. 21 supra), pp. 305-311.

${ }_{384}$ Cf. M. TAlamanCA, Vendita cit. (nt. 21 supra), pp. 319-320.

${ }^{385}$ Cf. A. BURDESE, Vendita cit. (nt. 21 supra), p. 595.

${ }^{386}$ Decorrência do caráter meramente obrigatório da compra e venda romana, na qual o acordo das partes gera apenas recíprocas obrigações entre as partes, sendo necessário, para a obtenção da disponibilidade material da coisa - que, tendencialmente, deve levar à aquisição também da propriedade -, a consecução de um ato sucessivo. Cf. M. TAlamanCA, Vendita cit. (nt. 21 supra), pp. 370-371.

387 Objeto da prestação devida pelo vendedor pode consistir em várias coisas (res mancipi, res nec mancipi, corpórea ou incorpórea, direito real limitado de gozo, crédito, herança, e também de coisas futuras), designado, nas fontes, como merx. A rigor, trata-se, porém, de um termo que compreenderia, com exceção dos escravos, apenas as coisas móveis (Ulp. 74 ad ed., D. 50, 16, 66; Afr. 3 quaest., D. 50, 16, 207). Cf. A. BURDESE, Vendita cit. (nt. 372 supra), p. 596 e nt. 02.

${ }^{388}$ Tem-se, na determinação da substância do preço, uma controvérsia que dividiu as escolas de direito em Roma (noticiada por Gai. 3, 141; Inst. 3, 23, 2; Paul. 33 ad ed., D. 18, 1, 1 pr.-1), até o início do século II d. C., diante da admissão, por parte de Sabino, de que o preço pudesse consistir em coisa diversa da pecunia numerata, provavelmente motivada pela necessidade de tutela da permutatio. Por outro lado, a tese proculeiana - contrária à identificação entre emptio venditio e permutatio - acabou por afirmar-se na iurisprudentia e, finalmente, por ser acolhida pelo direito justinianeu. Cf. M. TALAMANCA, Vendita cit. (nt. 21 supra), p. 312 e nts. 82 e 88; 313; A. BuRdESE, Vendita cit. (nt. 372 supra), p. 596. 
apresentaria maior complexidade ${ }^{390}: \ll o b$ evictionem se obligare possessionem tradere et purgari dolo malo» ${ }^{391}$.

$\mathrm{O}$ vendedor deveria transmitir à contraparte a posse («possessionem tradere») - e não a propriedade (como nas obligationes in dando, decorrentes, v.g., de stipulatio e legado per damnationem) - pacífica da coisa («habere licere») ${ }^{392}$, cujo prolongamento no tempo seria garantido pela responsabilidade por evicção («evictionem se obligare») ${ }^{393}$.

A transferência do domínio dar-se-ia ${ }^{394}$, em conformidade com a estrutura obrigacional do contrato, e desde que o vendedor fosse proprietário da coisa alienada, pela realização de um dos atos abstratamente idôneos para tal fim: mancipatio, in iure cessio, traditio $^{395}$. Em contrapartida, se não fosse o vendedor proprietário da res vendita, o comprador poderia adquirir a propriedade, presentes os requisitos, por usucapio $^{396}$.

${ }^{389}$ Cf. Ulp. 32 ad ed., D. 19, 1, 11, 2; Paul. 32 ad ed., D. 19, 4, 1 pr. Além disso, o comprador poderia ser obrigado - diante da intentio da actio venditi destinada ao quidquid dare facere oportet ex fide bona - ao pagamento de juros, caso tivesse obtido a disponibilidade da coisa antes do pagamento do preço (cf. Paul. 3 resp., D. 22, 1, 18, 1; Ulp. 32 ad ed., D. 19, 1, 13, 20), ao ressarcimento do dano sofrido pelo vendedor em razão do atraso na recepção ou retirada da coisa, ao reembolso das despesas com a conservação desta (cf. Cels. 8 dig., D. 19, 1, 38, 1), assim como ao cumprimento de prestações acessórias, decorrentes de eventuais circunstâncias que exijam a cooperação com o vendedor para o adimplemento da obrigação deste (cf. Pomp. 20 ad Sab., D. 19, 1, 9), e também de obrigações assumidas por pactos anexos ao contrato a favor da contraparte (in diem addictio e lex commissoria). Por fim, ao comprador também caberia a obrigação, que gravava sobre o vendedor, de abstenção de comportamento doloso (purgari dolo malo), obrigação residual que teria como fonte o oportere ex fide bona. Cf. M. KASER - R. KNÜTEL, Römisches cit. (nt. 379 supra), p. 228; M. TAlamancA, Istituzioni cit. (nt. 05 supra), p. 586; ID., Vendita cit. (nt. 21 supra), pp. 378-379 e nt. 778; 384, nt. 843; A. BURDESE, Vendita cit. (nt. 372 supra), p. 597; p. 600; E. VOLTERRA, Istituzioni cit. (nt. 21 supra), p. 506. 586.

${ }^{390}$ Cf. M. TAlamanCA, Vendita cit. (nt. 21 supra), p. 384, nt. 843; ID., Istituzioni cit. (nt. 05 supra), p.

${ }^{391}$ Cf. Paul. 32 ad ed., D. 19, 4, 1 pr.: «...venditori sufficit ob evictionem se obligare possessionem tradere et purgari dolo malo ...»: ( = incumbe ao vendedor assumir a garantia pela evicção, transferir a posse $<$ da coisa> e abster-se de qualquer comportamento doloso). A tripartição paulina teria visado determinar, de modo mais completo possível, o conteúdo da obrigação do vendedor, e apresentaria - como, aliás, todas as classificações dos juristas romanos - um caráter tópico, dado o contexto do discurso em que se insere, a saber, o da diferença entre as obrigações do comprador e do vendedor. Cf. M. TALAMANCA, Vendita cit. (nt. 21 supra), pp. 384-385.

${ }^{392}$ Cf. Paul. 32 ad ed., D. 19, 4, 1 pr.; Ulp. 34 ad Sab., D. 18, 1, 25, 1; Ulp. 31 ad ed., D. 19, 1, 11, 2; Afr. 8 quaest., D. 19, 1, 30, 1; Sev. et Carac., C. 8, 44, 3 (de 210 d. C.); Ulp. 32 ad ed., D. 19, 1, 11, 8; Afr. 8 quaest., D. 19, 2, 33. Cf. M. TALAMANCA, Vendita cit. (nt. 21 supra), pp. 379-380 e nts. 786, 787 e 790; ID., Istituzioni cit. (nt. 05 supra), p. 586; A. BuRDESE, Vendita cit. (nt. 372 supra), p. 597.

393 A actio empti, assim, não seria cabível para reclamar a falta de aquisição da propriedade pelo comprador, que apenas poderia demandar legitimamente o vendedor após evicto, isto é, vencido em um processo judicial por alguém que ostentasse um melhor direito sobre a coisa (propriedade ou direito real parcial). Cf. M. KASER - R. KNÜTEL, Römisches cit. (nt. 379 supra), p. 227; M. TALAMANCA, Vendita cit. (nt. 21 supra), p. 381; pp. 385-386; ID., Istituzioni cit. (nt. 05 supra), p. 587; M. KASER, Das römische Privatrecht I cit. (nt. 05 supra), p. 553-554.

${ }^{394}$ Cf. Cels. 3 dig., D. 12, 4, 16, sobre o qual, v.g., M. KASER - R. KNÜTEL, Römisches cit. (nt. 379 supra), pp. 227-228; M. TALAMANCA, Vendita cit. (nt. 21 supra), pp. 380-382.

395 Cf. M. KASER - R. KNÜTEL, Römisches cit. (nt. 379 supra), p. 227.

${ }^{396}$ Cf. Lab. 5 post. a Iav. epit., D. 18, 1, 80, 3, cuja importância, no que concerne à delimitação do âmbito da obrigação do vendedor de «possessionem tradere» é ressaltada por M. TALAMANCA, Vendita cit. (nt. 21 supra), p. 382; ID., Istituzioni cit. (nt. 05 supra), p. 587. 
O cumprimento da obrigação de «possessionem tradere» por parte do devedor implicava, ainda, a transferência da posse livre de toda ingerência - legítima, fática ou juridicamente - do vendedor ou de terceiros (vacua possessio $)^{397}$, bem como tutelável por interditos (possessio ad interdicta) ${ }^{398}$.

Correlata à obrigação de «possessionem tradere», a garantia por evicção («evictionem se obligare») presta-se a assegurar ao comprador a continuidade do habere licere, obtido a partir da entrega da posse (traditio possessionis) ${ }^{399}$. Esta garantia, entretanto, não teria consistido em um efeito direto na concepção originária da compra e venda consensual e obrigatória, dependendo de assunção por verborum obligatio ${ }^{400}$.

Por sua vez, o último elemento da tripartição paulina acerca do conteúdo da obrigação do vendedor - «purgari dolo malo» ${ }^{401}$ - figura como categoria instrumental e marginal (e também gravante sobre o comprador), que não assumiria uma clara posição na diferenciação entre conteúdo da obrigação e critérios de imputação da responsabilidade ${ }^{402}$.

\section{3. Âmbito do praestare do vendedor por inadimplemento}

O problema dos critérios de determinação da responsabilidade contratual apresentar-se-ia em relação ao vendedor, já que a consistência pecuniária da obrigação do comprador - isso é, o «pretium solvere» - não daria lugar a tais questões ${ }^{403}$.

A seguir os indícios fornecidos pelas fontes, a valoração da responsabilidade do vendedor por inadimplemento no direito romano seria dada segundo os critérios correntes na iurisprudentia clássica - do dolus, da culpa e também da custodia ${ }^{404}$.

Se, por um lado, o dolus ${ }^{405}$ e a culpa ${ }^{406}$ não ofereceriam maiores dificuldades, no estado atual da doutrina romanística, essas se concentrariam, por outro, na caracterização

\footnotetext{
${ }^{397}$ Especificamente em relação aos imóveis, Paul. 5 ad Sab., D. 19, 1, 2, 1; Papin. 27 quaest., D. 22, 1, 4 pr.; Pomp. 9 ad Sab., D. 19, 1, 3, 1. Cf. M. KASER - R. KNÜTEL, Römisches cit. (nt. 379 supra), p. 227 ; M. TALAMANCA, Vendita cit. (nt. 21 supra), p. 382.

${ }^{398}$ Cf. Ulp. 31 ad ed., D. 19, 1, 11, 13; Pomp. 9 ad Sab., D. 19, 1, 3 pr. Cf. M. TalamanCA, Vendita cit. (nt. 21 supra), p. 382; ID., Istituzioni cit. (nt. 05 supra), p. 587.

${ }^{399}$ Cf. M. TALAMANCA, Vendita cit. (nt. 05 supra), p. 385.

${ }^{400}$ Cf. M. TALAMANCA, Vendita cit. (nt. 05 supra), p. 386.

${ }^{401}$ Essa estrutura conceitual apresentar-se-ia também em alguns outros textos da compilação, v.g., Proc. 6 epist., D. 18, 1, 68, 2; Afr. 8 quaest., D. 19, 1, 30, 1; Flor. 8 inst., D. 18, 1, 43, 2. Cf. M. TALAMANCA, Vendita cit. (nt. 21 supra), p. 384.

${ }^{402}$ Cf. M. TAlamanCA, Vendita cit. (nt. 21 supra), pp. 384-385 e nt. 845; ID., Istituzioni cit. (nt. 05 supra), p. 586.

${ }^{403}$ Cf. V. ARAngio-RuIZ, La compravendita in diritto romano II, Napoli, Jovene, 1956, p. 245 ; M. TALAMANCA, Vendita cit. (nt. 21 supra), p. 446.

${ }^{404}$ Cf. V. ARANGIO-RUIZ, La compravendita II cit. (nt. 403 supra), pp. 245-246; M. TALAMANCA, Vendita cit. (nt. 21 supra), pp. 446-447.
} 
de custodiam praestare no âmbito da compra e venda ${ }^{407}$, razão pela qual constitui esse o objeto de estudo dessa investigação.

Antes de se proceder à tentativa de equacionar os principais obstáculos para o delineamento dos contornos do instituto no regime jurídico da compra e venda (ou mesmo para sua admissão, segundo posicionamentos menos recentes), parece oportuno dedicar alguma consideração a um problema confinante - de modo a explicar o exame conjunto que muitas vezes deles faz a doutrina romanística ${ }^{408}$-, a saber, o dos riscos de perda fortuita da coisa vendida, denominado, comumente, «periculum rei venditae».

\section{O problema do «periculum rei venditae» no direito romano}

Designa-se com esse termo o problema da suportação do risco de perecimento ou deterioração fortuitos da coisa vendida no direito romano. Em termos mais concretos, a questão consistiria em determinar se, perecida ou deteriorada fortuitamente a res vendita antes de ser transferida ao comprador, continuaria esse obrigado ou não ao pagamento do preço ao vendedor ${ }^{409}$.

405 A existência de textos no quais a responsabilidade do vendedor seria imputada com base apenas no dolo - v.g., Iavol. 2 ex Plaut., D. 18, 2, 19 pr.; Pomp. 9 ad Sab., D. 19, 1, 6, 8; Paul. 5 ad Sab., D. 18, 6, 5 pr.; Ulp. 49 ad Sab., D. 18, 4, 2, 5 e 7; Ulp. 32 ad ed., D. 19, 1, 13, 17 - explicar-se-ia, em sua maior parte, pela particularidade das fattipecie tratadas, em relação às quais o dolus figuraria como o único critério de imputação apropriado, em vista do caso que se toma em consideração. Cf. M. TALAMANCA, Vendita cit. (nt. 21 supra), p. 447 e nt. 1496.

${ }^{406}$ Com efeito, a informação contida em Ulp. 29 ad Sab., D. 50, 17, 23 - a saber, a inserção da emptio venditio entre os contratos nos quais se responde por dolus e culpa («dolum et culpam recipiunt») - seria corroborada por outros textos nos quais se considera o vendedor responsável por dolus ou culpa (ou por culpa apenas) ou ainda se referem à sua obrigação de diligentia (cujo descumprimento apenas poderia ser imputado a título de culpa): v.g., Lab. 2 pith., D. 19, 1, 54 pr.; Proc. 6 epist., D. 18, 1, 68 pr.; Pomp. 27 ad Sab., D. 18, 4, 3; Paul. 5 ad Sab., D. 18, 2, 14, 1; Ulp. 32 ad ed., D. 19, 1, 13, 16; Inst. 3, 23 , 3 e 3a; Paul. 16 quaest., D. 18, 4, 21; Paul. 44 ad ed., D. 39, 2, 18, 8 e 9; Paul. 10 ad Sab., D. 39, 2, 38 pr.; Alf. 2 dig., D. 18, 6, 12. Cf. M. TAlamanCA, Vendita cit. (nt. 21 supra), p. 446; p. 447, nts. 1492-1493.

Contrariamente ao que se verificava em parte da literatura interpolacionística, que considerava exclusivamente o dolus e a custodia como critérios operantes no direito clássico e que se poderia considerar defitivamente superada - cf., v.g., M. TALAMANCA, Vendita cit. (nt. 21 supra), pp. 446-447 - observa-se, mais recentemente, esforços no sentido de demonstrar a relevância do culpam praestare no contrato de compra e venda já desde Quinto Múcio (no já citado Proc. 6 epist., D. 18, 1, 68 pr.). Cf., nessse sentido, R. CARDILli, L'obbligazione cit. (nt. 04 supra), pp. 222-223 e nt. 91.

${ }^{407}$ Cf., v.g., M. TALAMANCA, Vendita cit. (nt. 21 supra), p. 446 e a literatura já referida na Introdução.

${ }^{408}$ Cf. M. TAlamanCA, Vendita cit. (nt. 21 supra), p. 447, nt. 1499.

409 Por outros termos, mais amplamente, tratar-se-ia de uma questão concernente ao «Preisgefahr» (ou também «Vergütungs-» ou «Gegenleistungsgefahr»), que se apresentaria no âmbito dos contratos sinalagmáticos (Austauschverträgen), e diria respeito à obrigação de adimplir a contraprestação. Cf. M. KASER - R. KNÜTEL, Römisches Privatrecht cit. (nt. 379 supra), p. 229. Quanto à circunscrição do problema à compra e venda (Gefahrtragung beim Kauf), cf., v.g., E. C. SILVEIRA MARCHI, Periculum rei venditae e periculum dotis aestimatae, in Revista da Faculdade de Direito da USP 93 (1998), pp. 26-27; ID., Acerca da traditio no âmbito do problema dos riscos na compra e venda-Os casos das «camas vendidas» (Paul. 3 Alf. 
Por esses termos se conforma um dos mais célebres problemas do direito das obrigações, tendo longa história na reflexão dos juristas ${ }^{410}$, e recebido diversas regulamentações no plano do direito codificado ${ }^{411}$.

epit., D. 18, 6, 3 e 15 pr.) e da «madeira comprada» (Paul., 3 Alf. epit., D. 18, 6, 15, 1, in Revista da Faculdade de Direito da USP 99 (2004), p. 38; M. PENNITZ, Das periculum cit. (nt. 30 supra), p. 03; M. SERRANO-VICENTE, Custodiam cit. (nt. 26 supra), p. 272.

${ }^{410}$ Cf. R. KNÜTEL, Augusto Teixeira de Freitas e il periculum nella compravendita, in S. SCHIPANI (cur.), Augusto Teixeira de Freitas e il diritto latino-americano, Padova, CEDAM, 1988, p. 490.

Em princípio, como se discorrerá na seqüência, o direito da compilação justinianéia parece acolher a solução de atribuição dos riscos ao comprador (periculum emptoris). De interesse notar, porém, que já mesmo na Escola Culta, houve quem individualizasse, como princípio romano em tema de periculum rei venditae, a solução de que os riscos caberiam ao vendedor. Com efeito, J. CuJAS, em comentário a Afr. 8 quaest., D. 19, 2, 33, sumaria a «distinctio»: «ante traditionem perempta re vendita pretii remissio vel repetitio est. Post traditionem pretii remissio vel restitutio non est» (= antes da tradição, tendo perecido a coisa vendida, tem lugar a remissão ou a repetição do preço. Após a tradição, não há lugar para a remissão ou a restituição do preço). Em termos práticos, diante do perecimento fortuito da res vendita antes da entrega, o comprador teria contra o vendedor a actio empti não para cobrar-lhe o id quod interest, mas para obter a liberação da actio venditi (com a qual poderia ser compelido ao pagamento do preço), ou conseguir - se já tiver pago esse último - a sua restituição. Cf. Ad Africanum Tractatus VIII, in Opera Omnia I cit. (nt. 287 supra), col. 1525 (a D. 19, 2,33); e também a observação de J. BARBEYRAC, na tradução de S. PUFENDORF (De iure naturae et gentium libri VIII), Le droit de la nature et des gens ou système general des principes les plus importants de la morale, de la jurisprudence et de la politique II, $6^{\mathrm{a}}$ ed., Basle, Thourneisen, 1750, p. 66, nt. 06; M. KonstantinOVITCH, «Le periculum rei venditae» em droit romain, Lyon, Bosc \& Riou, 1923, pp. 08-09; 68.

Reconhece J. CUJAS o óbice representado pela regra que se encontra nas Institutas imperiais, segundo a qual, uma vez perfeita a compra e venda, o risco passa ao comprador, ainda que não tenha havido a sua tradição, com a consequência prática de que o comprador continuaria obrigado ao pagamento do preço. $\mathrm{E}$ pretende o jurista vencê-lo - ou conciliá-lo - a partir de uma distinção entre regras de diverso caráter - «ex summo iure» e «ad aequitatem» - presentes nos dois livros da compilação justinianéia: «sed iuris regulae in Institutionibus proponuntur, quae omnes sunt ex summo iure, \& rudimenta: in Digestis incrementa iuris \& diligentius exactae res ad aequitatem. Et vero aequius est ut qui rem non est nactus emptor pretium non solvat» (= mas nas Institutas são estabelecidas regras jurídicas que são todas oriundas do rigor do direito, bem como os seus elementos primeiros; no Digesto, <são apresentados> os desenvolvimentos e as matérias exatas mais diligentemente <orientadas> à equidade. E, na verdade, é mais eqüitativo que o comprador, que não obteve a coisa, não pague o preço). Cf. Ad Africanum Tractatus VIII in Opera Omnia I cit. (nt. 287 supra), col. 1525 (a D. 19, 2, 33).

Contra a proposta de J. CUJAS - que não teria, ademais, sido rigorosamente coerente, como pretende M. KONSTANTINOVITCH, «Le periculum» cit. (nt. 410 supra), pp. 68-70 -, G. NoODT (1647-1725), para o qual o caso tratado por Africano seria singular, isso é, excepcional, de modo a não dever ser «ad consequentiam trahendum», já que, em outros textos (especificamente, 8 quaest., D. 46, 3, 39), o mesmo jurista teria seguido a regra jurídica comumente aplicada, a saber: a coisa vendida, uma vez perfeita a compra e venda, estaria ao risco do comprador, devendo esse último pagar de todo modo o preço à contraparte. A regra romana teria explicação, segundo o autor, no fato de que, perfecta emptione, o comprador é considerado credor, e o vendedor devedor, e esse, quando de uma coisa específica, libera-se da obrigação na hipótese de se verificar o seu perecimento natural («interitu naturali»). Cf. Opera Omnia II - Comentarium in Digesta Justiniani, Sacratissimi Principis - Libros XXVII Digestorum sive Pandectarum, Köln, Huisch, 1732, p. 323; 326.

$\mathrm{Na}$ Escola do Direito Natural, o princípio romano, até então dominante nas mais importantes áreas jurídicas (direito ibérico, antigo direito francês e direito alemão), começa a sofrer maiores críticas. Vê-se, com efeito, em H. GROOT (Grotius 1583-1645), uma opinião contrária à regra, ao considerar que, no caso de venda cujo cumprimento for diferido, os riscos deveriam correr por conta do vendedor até o traspasso do domínio sobre a coisa («quod si actum sit ne statim dominium transeat, obligabitur venditor ad dandum dominium, atque interim res erit commodo et periculo venditoris...») (= mas se for acordado que a propriedade não passe imediatamente, o vendedor será obrigado a transferi-la, e durante esse tempo, o proveito e o risco da coisa correrão por conta do vendedor...). Cf. R. KNÜTEL, Augusto Teixeira de Freitas cit. (nt. 410 supra), p. 493 e nt. 19.

Dentre outras regras, a atribuição do risco ao comprador («res periculo est emptoris») seria de arrolar dentre as «invenções do direito civil» («commenta sunt iuris civilis») e, segundo o jurista, agradou à maior 
parte dos legisladores a solução contrária, ou seja, «ut ad traditionem usque res commodo et periculo venditoris sit» (= que até a tradição, o proveito e o risco da coisa corra por conta do vendedor). Cf. De iure belli ac pacis libri III, Paris, Nicolau Buon, 1625, p. 284 [= II, 12, 15]. Consultou-se a tradução de P. PRADIER-FODÉRÉ, Le droit de la guerre et de la paix, Paris, Presses universitaires de France, 2005, p. 340.

Também S. PUFENDORF discute o princípio romano de atribuição dos riscos, qual seja «heic notum est, jus Romanum statim ac emptio perfecta est, periculum rei venditae attribuere emtori, licet res nondum sit tradita, ac venditor adhuc dominus sit» (= É sabido, nesse ponto, que o direito romano, tão logo perfeita a compra e venda, atribui o risco da coisa vendida ao comprador, ainda que a coisa não lhe tenha sido entregue, e o vendedor seja, até o momento, proprietário <dela>). Põe-se em relevo a dificuldade dessa solução diante da máxima res perit domino: «ubi difficultas oritur, quomodo heic ad emtorem possit pertinere periculum rei, cujus ipse nondum est dominus; cum tamen alias res domino suo pereat, seu damna illa, quae rem, ab alio detentam, incurrunt citra culpam detentoris, in dominum redundent» (= disso surge a dificuldade: por que, nesse caso, o risco da coisa possa caber ao comprador, que até então não é proprietário dela, se em outros casos a coisa perece para o seu dono, ou aqueles danos que acometem a coisa detida por outro sem a culpa do detentor, recaem sobre o proprietário $<?>$ ).

As várias tentativas de conciliação não pareciam claras nem convincentes ao jurista para explicar, afinal, por que razão ao comprador e não ao vendedor cabiam os riscos da coisa (com a consequiência de perder a coisa e dever, além disso, pagar o preço à contraparte) ocorrentes antes do cumprimento de sua obrigação («vacuam possessionem transferre»). Por outro lado, haveria consonância com a aequitas naturalis distinguir, a fim de atribuir o periculum, a parte a quem se devesse o retardo na entrega da coisa. Cf. De iure naturae et gentium libri VIII, $2^{\mathrm{a}}$ ed., Frankfurt am Main, Andrea, 1684, pp. 724-725 [= V, 5, § 3]. Verificouse também a tradução francesa de J. BARBEYRAC, Le droit de la nature II cit. (nt. 410 supra), pp. 64-67. Para R. KNÜTEL, S. PUFENDORF teria, substancialmente, aprovado o «princípio germânico». Cf. Augusto Teixeira de Freitas cit. (nt. 410 supra), p. 494.

${ }^{411}$ Em primeiro lugar, cabe destaque - por ter consistido, aparentemente, na primeira ruptura com a tradição romana nessa matéria - ao ALR (Allgemeines Landrecht für die Preußischen Staaten) (1794), codificação não restrita apenas ao direito privado, estruturada segundo o sistema de S. PUFFENDORF e consistente em uma das denominadas «Naturrechtskodifikationen». O direito civil, ainda que de base essencialmente romana, teria apresentado alguns melhoramentos técnicos, dentre os quais o principal segundo U. WESEL - teria sido a disciplina do risco na compra e venda (Gefahrtragung). Cf. Geschichte des Rechts cit. (nt. 148 supra), p. 224; 414-416; R. KNÜTEL, Augusto Teixeira de Freitas cit. (nt. 410 supra), p. 494.

Com efeito, ao vendedor caberiam os riscos da coisa antes da tradição: § 95: «so lange der Verkäufer dem Käufer die Sache noch nicht übergeben hat, bleibt bey allen freywilligen Verkäufen, wenn sie nicht in Pausch und Bogen geschlossen, oder sonst ein Anderes ausdrücklich verabredet worden, Gefahr und Schade dem Verkäufer zur Last» (= enquanto o vendedor ainda não tiver transferido a coisa ao comprador, fica, em todas as vendas voluntárias, se elas não foram celebradas globalmente ou então outra coisa foi expressamente acordada, o risco e o dano a cargo do vendedor).

Tal solução, à parte diferenças no que tange a aspectos particulares, teria sido seguida v.g., pelo ABGB (Allgemeines Bürgerliches Gesetzbuch) (1811): $\$ 1064$ com remissão à disciplina válida para a permuta, em especial §§ 1048-1049: «Ist eine Zeit bedungen, zu welcher die Übergabe geschehen soll, und wird in der Zwischenzeit entweder die vertauschte bestimmte Sache durch Verbot außer Verkehr gesetzt, oder zufälliger Weise ganz, oder doch über die Hälfte am Werte zu Grunde gerichtet, so ist der Tausch für nicht geschlossen anzusehen» (= se foi condicionado um tempo, no qual a tradição deve acontecer, e a coisa determinada, objeto da troca, nesse lapso de tempo, ou for colocada fora do comércio por proibição, ou arruinar-se de modo fortuito, inteira ou acima da metade de seu valor, a permuta deve ser considerada como não celebrada); $\S$ 1049: «Andere in dieser Zwischenzeit durch Zufall erfolgte Verschlimmerungen der Sache und Lasten gehen auf die Rechnung des Besitzers...» (= Outras deteriorações e encargos da coisa resultantes de caso fortuito, nesse lapso de tempo, cabem ao proprietário...), e também pelo BGB, § 446 I 1: «mit der Übergabe der verkauften Sache geht die Gefahr des zufälligen Untergangs und der zufälligen Verschlechterung auf den Käufer über» (= com a tradição da coisa vendida, passa o risco da perda fortuita e da deterioração fortuita ao comprador). Cf. U. WeSEL, Geschichte cit. (nt. 148 supra), pp. 223-224; R. KNÜTEL, Augusto Teixeira de Freitas cit. (nt. 410 supra), p. 495; 498; E. C. SILVEIRA MARCHI, Dos riscos cit. (nt. 409 supra), p. 46.

Em contrapartida, o Code Civil (1804), art. 1624, com remissão da disciplina do problema, a saber «la question de savoir sur lequel, du vendeur ou de l'acquéreur, doit tomber la perte ou la détérioration de la chose vendue avant la livraison» - às normas atinentes aos contratos ou obrigações convencionais em geral, teria seguido outra solução: art. 1138 al. 2: «elle <l'obligation de livrer la chose> rend le créancier propriétaire et met la chose à ses risques dès l'instant où elle a dû être livrée, encore que la tradition n'en ait point été faite, à moins que le débiteur ne soit en demeure de la livrer; auquel cas la chose reste aux risques 
de ce dernier» (ela - a obrigação de entregar a coisa - torna o credor proprietário e coloca a coisa a seu risco desde o instante no qual ela deveu ser entregue, ainda que a tradição não tenha sido feita, a menos que o devedor esteja em mora de entregá-la; nesse caso, a coisa fica ao risco desse último) (cf., também, C. civ. art. 711; 1583). De semelhante modo, v.g., o Codice civile italiano (1865), art. 1125: «nei contratti che hanno per oggetto la traslazione della proprietà o di altro diritto, la proprietà o il diritto si trasmette e si acquista per efetto del consenso legitimamente manifestato, e la cosa rimane a rischio e pericolo dell'acquirente, quantunque non ne sia seguita la tradizione» (= nos contratos que têm por objeto a transmissão da propriedade ou de outro direito, a propriedade ou o direito transmitem-se e adquirem-se por efeito do consentimento legitimamente manifestado, e a coisa fica sob o risco e perigo do adquirente, ainda que não se tenha seguido a sua entrega); e também o c.c. it. (1942), art. 1465. Cf. R. KNÜTEL, Augusto Teixeira de Freitas cit. (nt. 410 supra), p. 498 e nt. 47.

No OR (Obligationenrecht, quinta parte do ZGB - Schweizerisches Zivilgesetzbuch, o código civil suíço, de 1907 - com numeração própria dos dispositivos), art. 185 I: «sofern nicht besondere Verhältnisse oder Verabredungen eine Ausnahme begründen, gehen Nutzen und Gefahr der Sache mit dem Abschlusse des Vertrages auf den Erwerber über» (= contanto que particulares relações ou acordos não embasem uma exceção, as vantagens e o risco da coisa passam, com a conclusão do contrato, ao adquirente), entrevê R. KNÜTEL uma solução de compromisso entre a solução francesa e o princípio germânico, observado no que se refere à passagem da propriedade. Cf. Augusto Teixeira de Freitas cit. (nt. 410 supra), p. 497, nt. 44.

Em relação ao direito brasileiro, cabe lembrar, precipuamente, a doutrina das Ordenações Filipinas, vigentes no Brasil até a entrada em vigor do Código Civil (1917), segundo a qual o risco seria suportado pelo comprador desde a conclusão (ou perfeição) do contrato: «tanto que a venda de qualquer cousa he de todo perfeita, toda a perda e perigo que dahi em diante acerca della aconteça, sempre acontece ao comprador, ainda que a perda e dano aconteça, antes que a cousa seja entregue...» (1. IV, tit. 8 pr.), sem divergências de fundo quanto à disciplina das compilações anteriores em matéria: Ord. Afons. 1. IV, tit. 46; Ord. Manuel. 1. IV, tit. 31, como observa F. C. PONTES DE MIRANDA, Tratado de Direito Privado - Parte Especial XXXIX Direito das Obrigações - Compra-e-Venda - Troca - Contrato Estimatório, $3^{\mathrm{a}}$ ed., Rio de Janeiro, Borsoi, 1972, pp. 271-272 [= $§ 4321,2$ e 3]. Anterior a essas compilações reinóis, as Siete Partidas não teriam acolhido solução divergente (isso é, permanecia ainda o «princípio do direito romano»): «cumple se la vendida en dos maneras...e la una se faze en escrito, la otra fin el e quando la compra se faze sin escrito, aveniendo se el comprador con el vendedor, el uno de la cosa, e el otro del precio: dende adelante, el daño que viniesse en la cosa, es del comprador... maguer la cosa non sea passada al su poder» (V, t. 5, Ley 23). Cf. R. KNÜTEL, Augusto Teixeira de Freitas cit. (nt. 410 supra), p. 493 e nt. 16.

Com efeito, é essa a orientação do direito pátrio em matéria de distribuição dos riscos na compra e venda que noticia A. TEIXEIRA DE FREITAS na Consolidação: art. 538: «As questões sobre a perda da cousa vendida antes da sua entrega serão decididas pelas seguintes regras: $\$ 1^{\circ}$. nas vendas condicionais a perda total, pendendo a condição, será por conta do vendedor; $\S 2^{\circ}$. Mas a perda parcial ou a deterioração, pendendo a condição, será por conta do comprador, salvo se da parte do vendedor houver mora na entrega...; $\$ 5^{\circ}$. nas cousas, que se vendem por peso, ou medida, ou por prova, toda a perda antes de tais operações é por conta do vendedor, e depois delas por conta do comprador; $\S 6^{\circ}$. nas que se não vendem por medida, mas por junto a a esmo, a perda pertencerá desde logo ao comprador, não a tendo o vendedor tomado a si»...; art. 539: «Aplicar-se-ão estas regras, quando as partes não tiverem convencionado de outro modo». Cf. $3^{\mathrm{a}}$ ed., Rio de Janeiro, Garnier, 1876, pp. 352-355, e nts. 36 e 38, nas quais o jurista, mais explicitamente, individualiza a «regra geral» das Ordenações, qual seja, «dêsde a perfeição do contracto o perigo é logo por conta do comprador» (nt. 38, in fine); também, nt. ao art. 903, § $1^{\circ}$ do Esboço.

As Ordenações, e, por conseguinte, a Consolidação, em cuja base estava o direito então vigente (recolhido nas primeiras), alinhar-se-iam ao «princípio do direito romano». Cf. R. KNÜTEL, Augusto Teixeira de Freitas cit. (nt. 410 supra), p. 490 e nt. 03. Com efeito, é de interesse notar que já juristas oitocentistas admitiam o direito romano («direito imperial») como base de toda a ordenação IV, 8. Cf. J. P. MELLO FREIRE, Institutiones juris civilis lusitani cum publici tum privati, Lisboa, Academia de Lisboa, 189 (?), p. 34 [= liv. 4, 3, §16]; M. AlMEIDA E SoUSA DE LOBÃO, Fascículo de dissertações jurídico-práticas I, Lisboa, Imprensa Nacional, 1866, p. 326. Quanto à vinculação, em geral, das Ordenações, no setor do direito privado, ao direito comum, cf. L. C. AzEvedo, Introdução à História do Direito, $2^{\mathrm{a}}$ ed., São Paulo, Revista dos Tribunais, 2007, p. 194, afirmação limitada às Manuelinas, extensível, não obstante, às Filipinas, uma vez que teriam consistido, no conjunto, em uma atualização das primeiras, reunindo, sem propósito inovador, a Coleção de Duarte Nunes de Leão e as leis extravagantes posteriores em um só livro. Cf. I. M. POVEDA Velasco, Ordenações do Reino de Portugal, in Revista da Faculdade de Direito da USP 89 (1994), p. 24.

Tal «princípio» das Ordenações teria, a seguir L. CUNHA GONÇALVES, confluído para o direito português codificado, nos arts. 717 e 719, conjugado com a distinção entre contratos que envolvem a transferência da propriedade (correndo o risco por conta do adquirente, na qualidade de proprietário) e contratos que não na 
Se o comprador resultasse totalmente liberado do pagamento do preço (na hipótese de perecimento da coisa) ou houvesse redução deste (no caso de deterioração), isso significaria que o periculum era suportado pelo vendedor (periculum venditoris). Em

produzem (cabendo os riscos, então, ao proprietário-devedor). Cf. Tratado de Direito Civil - Em comentário ao Código Civil português IV-2, $2^{\mathrm{a}}$ ed., São Paulo, Max Limonad, s.d., pp. 810-811 [= § 574].

Entretanto, o Código Comercial brasileiro (de 1850) já não se mostrava fiel à disciplina da legislação civil - art. 206: «logo que a venda é de todo perfeita, e o vendedor põe a coisa à disposição do comprador, são por conta deste todos os riscos dos efeitos vendidos, e as despesas que se fizerem com a sua conservação, salvo se ocorrerem por fraude ou negligência culpável do vendedor, ou por vício intrínseco da coisa vendida, e tanto em um como em outro caso, o vendedor responde ao comprador pela restituição do preço com os juros legais, $e$ indenização dos danos» - ao estabelecer regra semelhante àquela destinada a prevalecer no direito codificado brasileiro. Cf. C. Bevilaqua, Codigo Civil dos Estados Unidos do Brasil IV, Rio de Janeiro, Alves, 1943, p. 294. A consonância com o art. 1127 do Código Civil de 1916, já notada pelo codificador, foi reafirmada por F. C. PONTES DE MIRANDA, ao interpretar o «pôr à disposição» do texto legal como tradição. Cf. Tratado de Direito Privado XXXIX cit. (nt. 411 supra), p. 275 [= 4322,2 e 3].

A. TEIXEIRA DE FREITAS, no Esboço, pretendeu inovar na disciplina desse problema, a propósito de cuja disciplina nas Ordenações já exprimia reservas na Consolidação (cf. nt. 30 ao art. 537 e nt. 27 ao art. 534). Cf. R. KNÜTEL, Augusto Teixeira de Freitas cit. (nt. 410 supra), p. 493. Em nota ao art. 903, § $1^{\circ}$, o «jurisconsulto do Império» dava as razões de sua contrariedade à regra do «direito atual»: a atribuição do risco de perecimento, mesmo antes da tradição, ao comprador, seria injusta, contradiria o princípio de que a coisa perece por conta do dono («res perit domino»), e seria impassível, ainda, de justificação em uma legislação como a brasileira, na qual se distingue o direito pessoal e o direito real, não se confundindo a obrigação com o domínio. Cf. Código Civil - Esboço I cit. (nt. 411), pp. 210-211; sobre a interpretação da referida nota, R. KNÜTEL, Augusto Teixeira de Freitas cit. (nt. 410 supra), pp. 499-503.

Dessa doutrina teria resultado, também no Esboço, na sedes materiae da compra e venda, o art. 2024: «enquanto o vendedor não fizer tradição (...) da coisa vendida (...), correm por sua conta todos os riscos dela, e pertencem-lhe todos os frutos e acessões; a menos que não tenha havido convenção expressa (...) em contrário, ou que o comprador não fique constituído em mora de recebê-la». Abandonava-se, pois, a solução que, segundo a «doutrina dominante» em matéria de periculum rei venditae, teria sido a orientação de princípio nas fontes jurídicas romanas em favor da solução germânica (ou «da traditio»), opção essa pioneira de A. TEIXEIRA DE FREITAS no panorama do direito latino-americano. Cf. R. KNÜTEL, Augusto Teixeira de Freitas cit. (nt. 410 supra), p. 490; 493; 498.

Tal orientação permanece no Código de 1916 (art. 1127, caput; cf., também, mais amplamente, arts. 865868 e 957), reproduzido sem alterações no de 2002 (art. 492, caput): «até o momento da tradição, os riscos da coisa correm por conta do vendedor, e os do preço por conta do comprador». Cf. E. C. SILVEIRA MARCHI, Periculum cit. (nt. 409 supra), p. 27; ID., Dos riscos cit. (nt. 409 supra), p. 46; C. M. SILVA PEREIRA - R. FICHTNER, Instituições de Direito Civil III - Contratos, Declaração Unilateral de Vontade, Responsabilidade Civil, $11^{\mathrm{a}}$ ed., Rio de Janeiro, Forense, 2003, p. 194.

Logo, no direito pátrio vigente, o vendedor suporta os riscos desde a conclusão do contrato até à entrega do bem vendido, salvo cláusula em contrário (ou seja, assunção de riscos pelo comprador, total ou parcialmente, ou quanto a certas causas). Assim, verificado o perecimento do bem antes da tradição, o comprador não está obrigado a pagar o preço; dando-se, a seu turno, o perecimento parcial, diminui-se, proporcionalmente, o montante do preço devido. Há traspasso do risco ao comprador se tiver havido entrega, se tiver incorrido em mora (accipidendi) ou então se tiver havido cláusula em contrário. Cf. F. C. PONTES DE MIRANDA, Tratado de Direito Privado XXXIX cit. (nt. 411 supra), p. 274 [= $\$ 4322$, 1]; em geral, essa interpretação parece manter-se em relação ao correspondente art. 492 do Código Civil de 2002. Cf. v.g., P. L. NetTo LôBo, in A. JunqueIRA DE AZEVEdo (coord.), Comentários ao Código Civil - Parte Especial - Das Várias Espécies de Contratos - Da Compra e Venda - Da Troca ou Permuta - Do Contrato Estimatório Da Doação - arts. 481 a 564 VI, São Paulo, Saraiva, 2003, p. 65, principalmente.

Tratar-se-ia, como observa E. C. SILVEIRA MARCHI, de uma das mais relevantes diferenças entre o direito romano e algumas das modernas codificações de base romanista, já que o primeiro (ao menos com base no panorama fornecido pela compilação justinianéia) teria acolhido a disciplina oposta, atribuindo ao comprador os riscos pelo perecimento casual da res vendita desde o momento da celebração - ou «perfeição» - do negócio. Cf. Dos riscos cit. (nt. 409 supra), pp. 46-47. Não teria, assim, o legislador brasileiro, como pretende O. GOMES, seguido o direito romano também na regulamentação desse problema. Cf. Contratos, $4^{\mathrm{a}}$ ed., Rio de Janeiro, Forense, 1973, p. 252 [= $\$ 176]$. 
contrapartida, se permanecesse obrigado ao pagamento de todo o preço, mesmo sem receber a coisa (perecida) ou ter de recebê-la deteriorada, o risco caberia, então, ao comprador (periculum emptoris) ${ }^{412}$.

A compilação justinianéia pareceria, como já se adiantou, acolher essa última solução para o problema dos riscos de perecimento (ou deterioração) fortuito na compra e venda: periculum est emptoris ${ }^{413}$.

Ter-se-ia firmado como doutrina tradicional ${ }^{414}$, inicialmente, aquela segundo a qual essa regra ou princípio de atribuição de riscos de perecimento fortuito na compra e venda já remontasse ao direito clássico ${ }^{415}$, concentrando-se os esforços - principalmente no âmbito da Pandectística ${ }^{416}$ - em explicar (diante de sua aparente «iniquidade» ${ }^{417}$ ) a razão da regra acolhida pelo direito romano (periculum emptoris) ${ }^{418}$.

A seu turno, ter-se-iam ocupado os estudiosos, no início do século XX, com outra questão, não consistente na elucidação - pela formulação de «Begründungsmodelle» - do princípio romano, mas precisamente relativa à sua vigência ${ }^{419}$. Surgem, assim, opiniões favoráveis à vigência, no direito romano clássico - como princípio - da solução contrária, a saber, periculum venditoris, atribuindo-se o princípio oposto às interpolações justinianéias, o que estaria em consonância com a nova estrutura assumida pela compra e venda (não mais obrigacional, mas real ou à vista) ${ }^{420}$.

412 Cf. M. KASER - R. KNÜTEL, Römisches cit. (nt. 379 supra), p. 229; P. JÖRS - W. KUNKEL - L. WENGER, Römisches Recht, $4^{\mathrm{a}}$ ed., Berlin, Springer, 1986, p. 309; limitadamente à hipótese de periculum emptoris, cf. E. C. SilveIRA MARCHI, Periculum cit. (nt. 409 supra), pp. 26-27; ID., Dos riscos cit. (nt. 409 supra), p. 47; ID., Acerca cit. (nt. 409 supra), p. 38.

${ }^{413}$ Cf. E. C. SilveIRA MARCHI, Periculum cit. (nt. 409 supra), p. 27; ID., Dos riscos cit. (nt. 409 supra), pp. 46-47; ID., Acerca cit. (nt. 409 supra), pp. 37-38; já nesse sentido, M. KonstANTINOVITCH, "Le periculum» cit. (nt. 410 supra), p. 08, 10, com base em D. 18, 6; C. 48, 4 e Inst. 2, 23, 3, sedes materiae do problema na compilação justinianéia.

${ }^{414}$ Não se poderia, nos limites desse estudo, percorrer, minuciosamente, as numerosas e variadas teorias avançadas nessa matéria concernente ao periculum rei venditae. Reenvia-se ao pormenorizado panorama doutrinário oferecido por M. PENNITZ, Das periculum cit. (nt. 30 supra), pp. 08-47.

${ }^{415}$ Cf. E. C. SilveIRA MARCHI, Periculum cit. (nt. 409 supra), pp. 27-28.

${ }^{416}$ Cf. M. PENNITZ, Das periculum cit. (nt. 30 supra), p. 05.

417 Com efeito, a perplexidade dessa disciplina estaria no fato de sobrecarregar a situação jurídica do comprador, sobre o qual recaía o risco de perecimento fortuito da coisa antes mesmo que o objeto adqurido estivesse em seu poder de fato. Cf. E. C. SILVEIRA MARCHI, Dos riscos cit. (nt. 409 supra), p. 47; ID., Acerca cit. (nt. 409 supra), pp. 37-38.

418 Dentre as várias teses, remontantes até mesmo à Pandectística, ressaltam-se: (a) teoria do «desfazimento» da compra e venda («Entäusserungstheorie»); (b) teoria da culpa («Verschuldentheorie»); (c) teoria da dupla estipulação; (d) teoria da compra e venda à vista ou real; (e) teoria da compra e venda como «parte da traditio». Segue-se, fundamentalmente, o agrupamento das várias doutrinas proposto por E. C. SILVEIRA MARCHI, Dos riscos cit. (nt. 30 supra), pp. 47-53.

${ }_{419}$ Cf. M. PENNITZ, Das periculum cit. (nt. 409 supra), p. 05.

${ }^{420}$ Iniciou-se esse filão interpretativo, que teria um precursor em J. CUJAS (supra), primeiramente, na moderna literatura, com C. ARNÒ, La teorica del periculum rei venditae nel diritto romano classico, Torino, Unione Tipografica, 1897, p. 24, principalmente; ao qual aderem, sucessivamente, F. HAYMANN, Textkritische I cit. (nt. 211 supra), p. 257, principalmente; M. KONSTANTINOVITCH, «Le periculum» cit. (nt. 
A communis opinio sobre essa matéria ${ }^{421}$, atualmente, alinhar-se-ia, por um lado, à proposição tradicional, a saber, periculum emptoris como o princípio de atribuição de riscos pelo perecimento fortuito da coisa vendida no direito clássico, limitado, contudo, (a) aos casos de vis maior, por força do reconhecimento de um custodiam praestare do vendedor, e (b) ao galgar do estágio de emptio perfecta («perfecta emptione periculum ad emptorem respicit») ${ }^{422}$.

À parte o problema da responsabilidade por custodia do vendedor, do qual se ocupará em seguida, a segunda limitação aludida poderia ser compreendida a partir da distinção de dois estágios na compra e venda: o da «conclusão» (ou «celebração») e o da «perfeição» (ou «aperfeiçoamento») ${ }^{423}$. Em regra, esses dois momentos coincidiriam; excepcionalmente, porém, poder-se-ia ter uma compra e venda celebrada mas não perfecta $^{424}$, com a conseqüência de não haver traspasso do risco ao comprador.

Tornar-se-ia perfecta a compra e venda ${ }^{425}$, a seguir o discurso de Paulo - com a consequência da passagem do risco do vendedor ao comprador - pelo atendimento a certos pressupostos, tais como a não sujeição da venda a cláusula condicional, a determinação do objeto do contrato, e a fixação do preço ${ }^{426}$.

410 supra), pp. 10-11; 67-68; 71-72 (v.g.) - sobre essa obra, cf., ademais, P. Huvelin, Compte rendu de M. KONSTANTINOVITCH, Le «periculum rei venditae en droit romain», in RHD 4 (1924), pp. 318-319; E. BETTI, «Periculum»-Problema del rischio contrattuale in dirito romano classico e giustinianeo, in Studi in onore di Pietro De Francisci I, Milano, Giuffrè, 1956, p. 168.

${ }^{421}$ Teria cabido a E. SECKEL - E. LEVY, Gefahrtragung beim Kauf im klassischen römischen Recht, in SZ 47 (1927), pp. 117-263, o pioneirismo dessa corrente. Nesse sentido, cf. E. C. SILVEIRA MARCHI, Dos riscos cit. (nt. 409 supra), pp. 57-58, e ulterior literatura em M. KASER, Das römische Privatrecht I cit. (nt. 05 supra), p. 552, nt. 61 .

${ }^{422}$ Cf. E. C. Silveira Marchi, Periculum cit. (nt. 409 supra), p. 28; ID., Dos riscos cit. (nt. 409 supra), p. 58; ID., Acerca cit. (nt. 409 supra), p. 38.

${ }^{423}$ Cf. E. C. SilveIRA MARCHI, Dos riscos cit. (nt. 409 supra), p. 60.

${ }^{424}$ Cf. M. KASER, Das römische Privatrecht I cit. (nt. 05 supra), p. 552.

${ }^{425}$ A síntese que se segue corresponde à concepção de «perfeição» da doutrina que se poderia admitir como communis opinio na matéria, seguida, v.g., por M. KASER, Das römische Privatrecht I cit. (nt. 05 supra), pp. 552-553. O assunto é, entretanto, controverso, como observa E. C. SILVEIRA MARCHI, Dos riscos cit. (nt. 409 supra), pp. 61-65.

${ }^{426}$ Cf. 33 ad ed., D. 18, 6, 8 pr.: Necessario sciendum est, quando perfecta sit emptio: tunc enim sciemus, cuius periculum sit: nam perfecta emptione periculum ad emptorem respiciet. Et si id quod venierit appareat quid quale quantum sit, sit et pretium, et pure venit, perfecta es emptio: quod si sub condicione res venierit, si quidem defecerit condicio, nulla est emptio, sicuti nec stipulatio: quod si exstiterit, Proculus et Octavenus emptoris esse periculum aiunt: idem Pomponius libro nono probat. Quod si pendente condicione emptor vel venditor decesserit, constat, si exstiterit condicio, heredes quoque obligatos esse quasi iam contracta emptione in praeteritum. Quod si pendente condicione res tradita sit, emptor non poterit eam usucapere pro emptore. Et quod pretii solutum est repetetur et fructus medii temporis venditoris sunt (sicuti stipulationes et legata condicionalia peremuntur), si pendente condicione res exstincta fuerit: sane si exstet res, licet deterior effecta, potest dici esse damnum emptoris. = É necessário saber quando o contrato de compra e venda esteja perfeito. Assim, pois, saberemos de quem seja o risco. Pois, sendo perfeita a compra e venda, o risco cabe ao comprador. E a venda é perfeita se aquilo que tenha sido vendido resulte em sua identidade, qualidade e quantidade, se o preço for determinado, e se a própria venda for pura. Contudo, se a coisa for vendida sob condição, e porventura não se implementar a condição, não há venda, tal como se dá também em 
Logo, não atendidos esses pressupostos (valeria dizer, não sendo a compra e venda perfecta), configurar-se-iam «situações de exceção», nas quais não haveria aplicabilidade de periculum emptoris em caso de perda da coisa, suportando o vendedor o risco do perecimento ou deterioração fortuitos da coisa vendida ${ }^{427}$.

Além dessas soluções que, mesmo em seus contemperamentos, poder-se-iam denominar monistas («periculum emptoris» ou «periculum venditoris» como a regra aplicada em matéria de periculum rei venditae no direito romano clássico), assumiria ainda relevância outra vertente, com antecedentes ainda na primeira metade do século $\mathrm{XX}^{428}$, e que tem granjeado acolhimento - como linha metodológica - em investigações atuais do problema $^{429}$.

relação à stipulatio. Se, porém, a <condição> implementar-se, Próculo e Otaveno dizem que o risco é do comprador; e isso também Pompônio aprova, no livro nono. Todavia, se, pendente a condição, o comprador ou o vendedor morrer, é certo que, se a condição se implementar, os herdeiros estão obrigados, tal como se a venda estivesse sido contratada já no passado. E se, pendente a condição, a coisa tenha sido entregue, o comprador não poderá usucapi-la pro emptore. E <nesse caso>, se a coisa tiver-se extinguido, durante a pendência da condição, o que tiver sido pago do preço seja repetido e os frutos, <produzidos nesse ínterim> cabem ao vendedor (tal como se extinguem as stipulationes e os legados condicionais). Se a coisa ainda existe, ainda que tenha sido deteriorada, é certo que pode ser dito que o dano cabe ao comprador). Considerou-se também a tradução de M. KASER - R. KNÜTEL, Römisches cit. (nt. 379 supra), p. 230.

${ }^{427}$ Essas hipóteses excepcionais, nas quais a perfeição não coincidira com, mas suceder-se-ia à conclusão do negócio, seriam, v.g., (a) compra e venda condicionada ou a termo (Paul. 33 ad ed., D. 18, 6, 8 pr.), (b) casos de não individualização da merx, v.g., compra e venda de uma provisão limitada (vat. 16; Alex., C. 4, 48, 2, 1-2, de 223), compra e venda alternativa, compra e venda com cláusula de degustação, compra e venda com preço dependente da medição da mercadoria (Gai. 10 ad ed. prov., D. 18, 1, 35, 5-7); (c) casos nos quais a mercadoria devesse ser produzida pelo vendedor, hipóteses nas quais apresentasse vícios ou defeitos (Ulp. 74 ad ed., D. 21, 1, 59), ou estivesse em posse alheia (Afr. 8 quaest., D. 19, 2, 33). Cf. M. KASER, Das römische Privatrecht I cit. (nt. 01 supra), pp. 552-553; E. C. SILVEIRA MARCHI, Dos riscos cit. (nt. 409 supra), p. 61.

${ }^{428}$ Com efeito, E. RABEL já teria evidenciado a dificuldade de se individualizar um princípio único (uma «Hauptregel») seguido pela iurisprudentia clássica, sustentando, ao invés, uma interpretação casuística do problema: «Wir müssen aber auch annehmen, dass die Klassiker keine breitere Lehre entwickelt haben, die sachlich die Gefahrtragung beim Kauf zusammenfasste» (= Devemos também admitir que os <juristas> clássicos não desenvolveram qualquer doutrina mais ampla, que efetivamente abrangesse o <problema> do risco de perda fortuita na compra e venda). Cf. Gefahrtragung beim Kauf, in SZ 42 (1921), pp. 554-555; 559.

De certo modo, na Escola Humanista, verificar-se-iam já acenos no sentido de se tratar de uma matéria controvertida entre os juristas romanos. Com efeito, ao passar em revista os princípios gerais de atribuição dos riscos na compra e venda - e especificamente diante das dificuldades oferecidas por Afr. 8 quaest., D. 19, 2, 33 - , C. VAN ECK (1662-1732) declara não ser desrespeitoso à autoridades do jurista romano (parece subentender-se Africano) afimar que, no tratamento desse problema, não eram os veteres rigorosamente concordes. Cf. Principia juris civilis secundum ordinem digestorum - in usum domesticarum scholarum seu collegiorum, quae vocant, vulgata \& in duas partes divisa, Franeker, Gyselaar, 1689, p. 381.

${ }^{429}$ Cf. M. TALAmanCA, Vendita cit. (nt. 21 supra), p. 452 e nt. 1538; ID., Istituzioni cit. (nt. 05 supra), p. 588; ID., Considerazioni sul «periculum rei venditae», in Seminarios Complutenses de Derecho Romano VII, Madrid, Alvarez, 1995, pp. 225 (v.g.); E. C. SIlveIRA MARCHI, Dos riscos cit. (nt. 409 supra), p. 71, e, concretamente, em ID., Periculum cit. (nt. 409 supra), p. 32, nt. 19; 35; 57; ID., Acerca cit. (nt. 409 supra), pp. 39-40; 59-60, no que concerne a demonstrar o papel exercido pela traditio em algumas das soluções em matéria de periculum rei venditae; mais recentemente, também É. JAKAB, Risikomanagement in Weinkauf Periculum und Praxis im Imperium Romanum, München, Beck, 2009, p. 199; 203, limitadamente ao problema dos riscos na compra e venda de vinhos. 
Grosso modo: se, por um lado, seria acertado que periculum emptoris consiste no princípio geral do direito justinianeu, por outro, o direito clássico - também em relação a essa matéria - caracterizar-se-ia por um «modelo elástico», comportante de variedade de soluções (ora periculum venditoris, ora periculum emptoris), baseadas em elementos como as particularidades das fattispecie consideradas (v.g., especificidades da res vendita, efetivação ou da traditio, poder exercido sobre a coisa) e o posicionamento pessoal de cada jurista $^{430}$.

Tendo-se em consideração esse quadro doutrinário esboçado acerca do problema do periculum rei venditae, compreendem-se também, em certa medida, algumas das várias opiniões dos autores acerca da responsabilidade por custodia do vendedor.

\section{O problema da responsabilidade por custodia do vendedor}

\subsection{Dificuldades teóricas de uma custodia venditoris}

Como já referido, o reconhecimento de um custodiam praestare a cargo do vendedor constitui o objeto de uma secular polêmica na doutrina romanística ${ }^{431}$.

De fato, alguns obstáculos à admissão de uma responsabilidade por custodia do vendedor apresentar-se-iam já pelo confronto hipotético dessa com os demais - embora também relativamente discutíveis - casos de aplicação de custodiam praestare ${ }^{432}$.

A obrigação principal do vendedor, consistente em um tradere, diferiria, com efeito, daquela de devedores como, v.g., o tintureiro e o alfaiate (fullo e sarcinator), comodatário e credor pignoratício, obrigados a um reddere da coisa detida (isso é, locada ou comodada $)^{433}$.

Além disso, por força da natureza consensual da compra e venda (supra), o vendedor - da conclusão do negócio até à efetivação da entrega (traditio) - não transfere qualquer direito sobre a coisa ao comprador, permanecendo na posição - tendencialmente - de seu proprietário ${ }^{434}$. Dentre aqueles casos de aplicação de custodiam praestare, seria

\footnotetext{
${ }^{430}$ Cf. E. C. SilveIRA MARChI, Dos riscos cit. (nt. 409 supra), pp. 70-71.

${ }^{431}$ Cf., v.g., C. A. CANNATA, Ricerche cit. (nt. 21 supra), pp. 134-135, com ampla indicação bibliográfica.

${ }^{432}$ Cf. supra (Parte I, Cap. II, 2.3).

${ }^{433}$ Cf. M. SERrano-VICENTE, Custodiam cit. (nt. 26 supra), p. 263.

${ }^{434}$ Cf. M. TAlamanCA, Custodia cit. (nt. 16 supra), p. 563; ID., Vendita cit. (nt. 21 supra), p. 448.
} 
esse, portanto, o único em que o devedor (vendedor) responderia pelo perecimento de coisa própria, ainda que destinada a ser transferida ao comprador ${ }^{435}$.

Outra dificuldade oposta a uma custodia do vendedor no direito seria a impossibilidade de se justificar tal regime de responsabilidade com base na lógica da utilitas contrahentium («Utilitätsgedanken»), uma vez que tanto o vendedor quanto o comprador, na emptio venditio, aufeririam vantagens do negócio ${ }^{436}$.

Entretanto, os maiores empecilhos à possibilidade de se conceber um custodiam praestare do vendedor no direito romano parecem ter provindo das conclusões em matéria de periculum rei venditae, e tanto por parte do filão interpretativo que admite a «normalidade» ${ }^{437}$ do periculum emptoris ${ }^{438}$, quanto da corrente diametralmente oposta.

De um lado, J. BARON considera imcompatível uma responsabilidade do vendedor por custodia técnica, uma vez que os juristas romanos teriam atribuído ao comprador a suportação de todo o Gefahr desde a conclusão do negócio, não constituindo exceção os riscos compreendidos naquela ${ }^{439}$. Ou seja, periculum emptoris, por sua generalidade, excluía a possibilidade de reconhecimento de uma Custodia-Haftung geral do vendedor ${ }^{440}$.

Por outro lado, assertores do periculum venditoris como princípio aplicado ao problema do risco de perecimento fortuito da coisa vendida no direito romano esforçaramse também por demonstrar a estraneidade de um custodiam praestare no direito clássico ${ }^{441}$.

A garantia, representada pela custodia, apenas seria necessária como contrapeso do periculum emptoris, por subtrair ao comprador uma parte da carga representada por esse úlimo, a saber, aquela que confrontaria com os limites da vis maior ${ }^{442}$.

${ }^{435}$ Essa particularidade já fora notada, em relação à hipótese excepcional em que o autor admite uma custodia venditoris (infra), por J. BARON, «Diligentia» cit. (nt. 175 supra), p. 277; e, posteriormente, v.g., por V. ARANGIO-RUIZ, Responsabilità cit. (nt. 04 supra), p. 147; A. METRO, L'obbligazione cit. (nt. 22 supra), p. 94; 187; e mais claramente, p. 192, nt. 249; M. BAUER, Periculum emptoris cit. (nt. 30 supra), 1998, p. 61.

${ }^{436}$ Cf. J. PARIS, La responsabilité cit. (nt. 42 supra), pp. 223-225, principalmente; esse aspecto foi também posto em relevo por M. BAUER, Periculum cit. (nt. 30 supra), pp. 61-62, como uma das causas do debate na doutrina, mas por ele afastado como empecilho.

${ }^{437}$ A expressão é de M. TAlAMANCA, Custodia cit. (nt. 16 supra), p. 563.

438 Nesse caso, como se demonstrará, tratar-se-ia apenas de um posicionamento menos recente, aparentemente não retomado na literatura romanística moderna.

${ }^{439}$ Cf. Die Haftung cit. (nt. 198 supra), pp. 270-271; 275.

440 J. BARON admite-a, entretanto, excepcionalmente, em uma modalidade de compra e venda, a saber, a Specieskauf mit Quantitätenpreis, isso é, no caso de venda por peso, medida ou contagem: até a efetivação dessas operações, responderia o vendedor pela «höchte Diligentia», ou seja, por todo dano, exceto aqueles causados por vis maior ou caso fortuito, o que valeria dizer, segundo o autor, que ele responderia por «custodia im höchsten Sinne». Cf. «Diligentia» cit. (nt. 175 supra), pp. 61-62; 88; 270-271; 307-308; ID., Die Haftung cit. (nt. 198 supra), pp. 271-272.

${ }^{441}$ Cf., v.g., H. HAYMANN, Textkritische I cit. (nt. 211 supra), pp. 256-257; E. BETTI, «Periculum» cit. (nt. 420 supra), pp. 137-138, principalmente.

${ }^{442}$ Em contrapartida, segundo o autor, dado que os juristas clássicos não conheciam esse princípio, mas o oposto - periculum venditoris - não teriam tido motivo para agravar a responsabilidade do vendedor pela 
Em contrapartida, partidários do periculum emptoris como E. SECKEL sustentaram a aplicabilidade - ao que parece, generalizada - de custodiam praestare ao vendedor. No período que medeia entre a conclusão do negócio e a entrega, sua posição seria equiparável à do comodatário, justificando-se a extensão, também àquele, do regime de responsabilidade aplicável ao último ${ }^{443}$.

A seu turno, V. ARANGIO-RuIZ, na investigação do problema, pretendeu demonstrar, afastando-se os impedimentos no exame desse problema específico, a independência dos problemas, de modo que as conclusões em tema de periculum rei venditae não precluíssem aquelas em matéria de custodiam praestare relacionado ao vendedor $^{444}$.

Superados, em grande parte, esses condicionamentos advindos dos resultados obtidos no estudo do tema correlato, e aparentemente, não apenas pelo caráter sempre discutível das soluções monistas, como também pela valoração mais precisa da interrelação entre custodiam praestare e periculum emptoris ${ }^{445}$, deu-se lugar a uma consideração não apriorística dos testemunhos das fontes.

perda da coisa vendida. Cf. Textkritische I cit. (nt. 211 supra), pp. 256-257. A existência de custodiam praestare em fontes relacionadas à compra e venda são explicadas por esses autores como inserções compilatórias destinadas a contrabalançar o - então - princípio geral de atribuição dos riscos (periculum emptoris).

Seria oponível a essa explicação a estranheza do procedimento compilatório: se, em outros setores, procuraram esses eliminar a figura da custódia, como se admite, resultaria obscura a tendência contrária no que concerne ao contrato de compra e venda. Nesse sentido, M. BAUER, Periculum cit. (nt. 30 supra), p. 63.

${ }^{443}$ Cf. Custodia, in H. HeUMANN - E. SECKEL, Custodia, in Handlexicon cit. (nt. 18 supra), pp. 117-118; M. KASER, Das römische Privatrecht I cit. (nt. 05 supra), p. 552. Contra, F. HAYMANN, para quem essa equiparação não levaria em consideração o interesse - não raramente verificável na prática - do comprador na dilação do cumprimento da obrigação, o que não consentiria, sob essa perspectiva da repartição de interesses, equiparar o vendedor ao comodatário, e o comprador ao comodante. Em outros termos, essa tentativa nada mais seria do que a expressão de fundamentar a Custodia-Haftung do vendedor com base na utilitas contrahentium. Cf. Textkritische I cit. (nt. 211 supra), p. 255; ID., Zur Klassizität des periculum emptoris, in SZ 28 (1928), pp. 314-418.

Mais recentemente, prosélitos da «normalidade» do periculum emptoris recorrem, para explicar a razão de ser da custodia venditoris, a uma diversa concepção da compra e venda romana, a saber, não apenas um negócio com efeitos meramente obrigacionais, sendo já suficiente o acordo para gerar a idéia de que a coisa já pertencia ao comprador. Desse modo, encontrariam explicação não apenas a regra periculum emptoris e a responsabilidade por custodia do vendedor, como também a obrigação deste de restituição dos frutos produzidos e o ônus, suportado pelo comprador, dos gastos de conservação da coisa até a efetiva entrega. Cf., nesse sentido. W. ERSNT, Periculum est emptoris, in SZ 99 (1982), pp. 243-244. A seu turno, J. G. WOLF reafirma, como fundamento último desses regras, o resquício da idéia de «Barkauf» («vendita a contanti»). Cf. Per una storia della emptio venditio: l'acquisto in contanti quale sfondo della compravendita romanaUna lezione, in IURA 52 (2001), pp. 42-43, limitadamente à custodia.

${ }^{444}$ Cf. Responsabilità cit. (nt. 04 supra), pp. 149-150.

445 Cf. V. ARANGIO-RUIZ, Responsabilità cit. (nt. 04 supra), pp. 149-150; também M. KASER, Die actio furti cit. (nt. 258 supra), pp. 114-115 e nt. 102. 
Observa C. A. CANNATA que não se poderia negar a existência de um custodiam praestare do vendedor, diante dos vários textos que o mencionam ${ }^{446}$, e cujas alterações, ainda que possíveis, não teriam sido efetuadas com o propósito de inserir uma referência à custodia, termo pouco significativo no ambiente jurídico pós-clássico ${ }^{447}$.

Essa parece ser, com efeito, a tendência dos mais recentes estudos na matéria ${ }^{448}-\mathrm{a}$ admissão de custodiam praestare no regime jurídico da compra e venda, não obstante a complexidade que ainda oferece ${ }^{449}$ - centrando-se a investigação em determinar os limites nos quais se dava essa aplicação de custodiam praestare ao vendedor no direito romano ${ }^{450}$.

Seguindo-se essa orientação, objetiva-se, na segunda parte do presente estudo, analisar as fontes jurídicas romanas que possam fornecer dados para reconstrução do problema, escopo para o qual convergiriam as noções gerais percorridas até então sobre a natureza, o conteúdo e a evolução de custodiam praestare na iurisprudentia romana ${ }^{451}$.

\subsection{Estabelecimento da base textual}

\subsubsection{Critérios gerais para a identificação de custodiam praestare nas fontes romanas}

Para a identificação de custodiam praestare nas fontes, em geral, fixaram-se alguns critérios $^{452}$ além da simples presença, nos textos, do dado terminológico: custodia, custodiam praestare, custodiae nomine teneri.

Principalmente na época de larga difusão do método interpolacionístico, considerou-se necessário, nessa busca, levar em conta também outras expressões com as

\footnotetext{
${ }^{446}$ A «polêmica secular» sobre esse assunto, segundo o autor, ter-se-ia arrefecido já na década de 60, quando o posicionamento radical de C. ARNÒ e F. HAYMANN (supra) foi definitivamente superado pela tese de E. SECKEL, que se afirmou como communis opinio em matéria de periculum rei venditae: nessa se reconhecia uma custodia do vendedor até a tradição da coisa, limitando-se o periculum aos eventos considerados de força maior (ou seja, ao periculum vis maioris) - H. HEUMANN - ID., Custodia, in Handlexicon cit. (nt. 18 supra), pp. 117-118. Cf. Ricerche cit. (nt. 21 supra), pp. 134-135.

${ }^{447}$ Cf. Ricerche cit. (nt. 21 supra), pp. 135-136.

${ }^{448}$ Como noticia, v.g., E. C. SILVEIRA MARCHI, Dos riscos cit. (nt. 409 supra), p. 59.

${ }^{449}$ Cf. M. KASER, Das römische Privatrecht I cit. (nt. 05 supra), p. 508; 551; M. TALAMANCA, Vendita cit. (nt. 21 supra), p. 446; 448; M. SERRANO-VICENTE, Custodiam praestare cit. (nt. 26 supra), p. $263 ; 288$.

${ }^{450}$ Cf. M. Talamanca, Considerazioni cit. (nt. 429 supra), p. 232, nt. 46.

451 Por outros termos, esses aspectos que conformariam o desdobramento conceitual de custodiam praestare, e verificável em sede de discussão de outras relações contratuais (comodato, locação), poderiam ser de auxílio para a valoração, em termos dogmáticos e históricos, dos textos em matéria de compra e venda. Faz-se preceder à análise desses a sua seleção e a explicação dos critérios para a individualização da base textual em princípio útil com vistas aos objetivos dessa investigação.

${ }^{452}$ Cf. V. ARANGIO-RUIZ, Responsabilità cit. (nt. 04 supra), p. 100.
} 
quais os juristas pós-clássicos ou os compiladores justinianeus ${ }^{453}$ substituíram custodiam praestare dos textos clássicos, tais como diligentia, exactissima diligentia ${ }^{454}$.

Além disso, dever-se-iam considerar os textos nos quais os limites da responsabilidade por inadimplemento fossem estabelecidos na vis maior ${ }^{455}$, e também aqueles em se verificasse o emprego do termo «periculum» que, embora designe, algumas vezes, os eventos inseríveis na categoria da vis maior, em outras ocorrências, aludiria ao risco limitado a certos eventos, tecnicamente denominado custodia $^{456}$.

A responsabilidade por custodia seria referida ainda por outra forma que não explicitamente, a saber, pela legitimação - absoluta - do devedor à actio furti ou a outra ação ${ }^{457}$.Com efeito, reconheceu-se nessa legitimação à actio furti de certos devedores uma «sombra» de custodiam praestare ${ }^{458}$.

Outro indício, ainda, de envolvimento de custodiam praestare, seria a presença do termo culpa, conceito ao qual, juntamente com o dolo, os juristas pós-clássicos teriam reconduzido todo o sistema da responsabilidade contratual ${ }^{459}$.

\subsubsection{Critérios para a seleção dos textos úteis à reconstrução do problema no âmbito da «emptio venditio»}

No que concerne, especificamente, aos textos em matéria de compra e venda, verificam-se ${ }^{460}$, por um lado, aqueles nos quais recorreria o termo-indício («custodia», «custodiam praestare») e, por outro, aqueles nos quais se poderiam identificar manipulações destinadas a sobrepor a diligentia à custodia, tal como ocorrido em relação a outras espécies contratuais (v.g., comodato, locação) ${ }^{461}$.

${ }^{453}$ Cf. supra (Parte I, Cap. II, 2.4).

${ }^{454}$ Cf. V. ARANGIO-RUIZ, Responsabilità cit. (nt. 04 supra), p. 100.

${ }^{455}$ Assim, v.g., Gai. 2 aur., D. 44, 7, 1, 4 e Gai. 2 cot. rer., D. 18, 6, 2, 1.

${ }^{456}$ Assim, v.g., em Ulp. 29 ad Sab., D. 47, 2, 14, 16; Gai. 5 ad ed. prov., D. 19, 2, 40. Cf. V. ARANGIORUIZ, Responsabilità cit. (nt. 04 supra), pp. 100-101.

${ }^{457}$ Cf. G. I. LuZzatTo, Caso cit. (nt. 119 supra), p. 180.

${ }^{458}$ Aduz-se como exemplo Ulp. 38 ad ed., D. 47, 5, 1, 4. Cf. V. ARANGIO-RUIZ, Responsabilità cit. (nt. 04 supra), p. 103.

${ }^{459}$ Cf. V. ARANGIO-RuIZ, Responsabilità cit. (nt. 04 supra), p. 102.

${ }^{460}$ Não faltariam, também na sede desse contrato (emptio venditio), testemunhos de um uso atécnico de custodia (custódio, guardião) ou, de todo modo, não relacionado ao problema discutido (responsabilidade), como se poderia vislumbrar em Iavol. 5 ex post. Lab., D. 41, 2, 51. Cf. J. PARIS, La responsabilité cit. (nt. 42 supra), p. 08 e nt. 02; E. VOLKMAR, Custodia, in VIR I cit. (nt. 48 supra), col. 1153 [= II.B] (supra)

${ }^{461}$ Cf. C. A. Cannata, Ricerche cit. (nt. 21 supra), p. 136, nt. 54; M. Talamanca, Vendita cit. (nt. 21 supra), p. 448, nt. 1501. 
Tais critérios, entretanto, não poderiam ser exaurientes para a seleção dos textos úteis à reconstrução do problema, de modo a implicar o recurso a outros, como a individualização dos textos nos quais se discuta acerca da responsabilidade do vendedor pelo furto da res vendita. Por ser esse o evento típico integrante do conteúdo de custodiam praestare, far-se-ia necessário examinar a provável operatividade desse nas soluções dos juristas.

Dada a correlação estabelecida por Gaio entre a legitimação ativa à actio furti e custodiam praestare (Gai. 3, 205-206) ${ }^{462}$, os textos nos quais se discute a legitimação ativa do vendedor à actio furti exigiriam - em princípio - um exame a fim de determinar se a responsabilidade por custódia consistisse, também neste caso, na base do interesse na conservação da coisa, fundamento da legitimação à propositura do meio processual.

Em síntese, prestar-se-iam como principais critérios para a seleção dos textos para a análise: (a) a existência do termo custodia nos textos jurídicos relacionados à emptio venditio, quer componha ou não a locução técnica ou (b) a presença de elementos textuais que denunciariam a admitida sobreposição ao conceito clássico ${ }^{463}$; (c) as fattispecie típicas em que se dá o envolvimento do instituto (furto da coisa devida) ${ }^{464}$; e (d) a discussão do correlato problema da legitimação ativa à actio furti ${ }^{465}$.

A base textual resultante desses critérios reuniria textos historicamente remontáveis - à parte Inst. 3, 23, 3a - à iurisprudentia tardo-republicana e aos séculos II e III d. C.

Dada, em geral, a orientação de recentes estudos sobre a responsabilidade contratual no sentido de apresentar um quadro articulado do problema, segundo as várias épocas e as variadas figuras e escolas de juristas ${ }^{466}$, e, mais especificamente, a historicização de custodiam praestare também no direito clássico, pareceu mais conveniente examinar esses testemunhos sob um critério prevalentemente histórico.

Desse modo, organizam-se os textos de que se dipõe segundo as épocas às quais remontariam $^{467}$ a fim de se poder valorar o problema da responsabilidade por custodia do vendedor no panorama conceitual da iurisprudentia em cada período.

${ }^{462}$ Cf. supra (Parte I, Cap. II, 2.2.1).

${ }^{463}$ Cf. Inst. 3, 23, 3a; Gai. 10 ad ed. prov., D. 18, 1, 35, 4; Gai. 2 cot. rer., D. 18, 6, 2, 1; Paul. 5 ad Sab., D. 18, 6, 3; Ulp. 28 ad Sab., D. 18, 6, 4, 1-2; Alf. 2 dig., D. 18, 6, 12; Ner. 3 membr., D. 19, 1, 31 pr.; Paul. 7 ad Plaut., D. 19, 1, 36; Ulp. 29 ad Sab., D. 47, 2, 14 pr.-1.

${ }^{464}$ Cf. Paul. 3. epit. Alf., D. 18, 6, 15, 1; Paul. 3 Alf. Epit., D. 18, 6, 13-15 pr.

${ }^{465}$ Cf. Papin. 12 quaest., D. 47, 2, 81 pr.

${ }^{466}$ Cf. R. CARDILLI, L'obbligazione cit. (nt. 04 supra), pp. 189-503; resumidamente, ID., L'obligation cit. (nt. 82 supra), pp. 91-130.

${ }^{467} \mathrm{E}$ tal procedimento com base seja na atribuição do texto ao jurista, seja com base nas informações fornecidas pelas respectivas inscriptiones. 
Resulta, portanto, um plano de análise que tem como ponto de partida textos da época tardo-republicana que sugeririam um envolvimento, a partir da solução concreta dos responsa, com um custodiam prarestare do vendedor, e que prossegue com testemunhos mais concludentes, dentre outros motivos, pela presença da locução - da iurisprudentia dos séculos II e III d. C. 
(PARTE II)

AnÁlise dos TeXtos EM MATÉRIA DE COMPRA E VENDA

\section{Capítulo I \\ «VESTÍGIOS» DO «CUSTODIAM PRAESTARE» DO VENDEDOR NA \\ IURISPRUdentia Republicana: Alfeno}

\section{Generalidades}

Pela análise dos textos seguintes objetiva-se investigar a possibilidade de estabelecer um termo a partir do qual os juristas romanos teriam - por qualquer modo (isso é, por força de acordo das partes ou como elemento interno da obrigação) - reconhecido, na compra e venda, um «custodiam praestare» do vendedor.

Para tanto, parte-se dos textos atribuíveis aos juristas mais remotos: nesse caso, precisamente - tendo-se em consideração o exame do problema no âmbito da compra e venda - a Alfeno, jurista situável na época tardo-republicana.

Com efeito, é somente a partir daquele momento ${ }^{468}$ que se apresentam alguns elementos nas fontes passíveis de conexão com o problema da custodia, fazendo-se ausentes indícios de uma implicação do instituto na emptio venditio noticiada já por juristas anteriores a Quinto Múcio Cévola, como pretende visualizar R. CARDILLI, em relação ao comodato ${ }^{469}$.

\section{O furto antes da traditio da madeira comprada}

Paul. 3 epit. Alf., D. 18, 6, 15, 1: Materia empta si furto perisset, postquam tradita esset, emptoris esse periculo respondit, si minus, venditoris: videri autem trabes
Se a madeira de construção comprada perecesse por furto, depois que tivesse sido entregue, respondeu <Alfeno> que o risco cabe ao comprador; se não <tivesse

\footnotetext{
468 Já na Pandectística se identificam esforços no sentido de fazer remontar ao período republicano - e, precisamente, a Alfeno - uma responsabilidade por custodia do vendedor. Cf., v.g., A. PERNICE, Labeo II cit. (nt. 186 supra), p. 357; em contrapartida, contra o reconhecimento generalizado de uma custodia venditoris, J. BARON, Die Haftung cit. (nt. 198 supra), p. 275.

${ }^{469}$ Em outros termos, a seguir a interpretação desse autor, uma referêcia aos «veteres» (Ulp. 28 ad ed., D. 13, 6, 5, 6, 9 e 11), termo que designaria a geração de juristas anterior (ou no máximo contemporânea) a Quinto Múcio. Cf. L'obbligazione cit. (nt. 04 supra), pp. 170-171, principalmente; ID., L'obligation cit. (nt. 82 supra), p. 93.
} 
traditas, quas emptor signasset. sido entregue>, ao vendedor. Consideramse, pois, entregues, as vigas sobre as quais o comprador tivesse colocado uma $\operatorname{marca}^{470}$.

Alfeno teria opinado (ou reportado um parecer de Sérvio Sulpício Rufo «respondit») ${ }^{471}$ que, no caso de furto de madeira de construção ${ }^{472}$ vendida e entregue, o risco representado por esse evento (periculum) caberia ao comprador; em caso contrário ou seja, se não tivesse sido entregue -, o vendedor suportaria o risco. Precisa-se, in fine, que a aposição de uma marca ${ }^{473}$ sobre as vigas («trabes») ${ }^{474}$ caracterizaria a traditio da mercadoria.

O texto provém de uma síntese (epítome) feita por Paulo, jurista do século III d.C. ${ }^{475}$, da obra de Alfeno, que teria vivido no final da época republicana ${ }^{476}$. É, com efeito, pela conexão com esse último - evidenciada pela inscriptio - que o texto assume importância para a reconstrução do problema no século I a. C. ${ }^{477}$.

\footnotetext{
${ }^{470}$ Conferiram-se também as traduções de E. C. SILVEIRA MARCHI, Acerca cit. (nt. 409 supra), p. 37, dos fragmentos 13 (infra) e 15, das quais se diverge apenas por razões estilísticas, tendo em vista a exigência de uniformização, também sob esse aspecto, da presente exposição.

${ }^{471}$ Trata-se, nesse caso, de um ponto controverso.

$472 \mathrm{O}$ significado estrito de «materia» corresponderia a materiais - especialmente madeira - empregados em construção, em contraposição a «lignum»: Ulp. 25 ad Sab., D. 32, 55 pr: «materia est, quae ad aedificandum fulciendum necessaria est, lignum, quidquid comburendi causa paratum est» (= «Materia» <madeira> é aquilo que é necessário para edificar e sustentar, «lignum» <lenha>, qualquer coisa preparada para ser queimada). Cf. H. HEUMANN - E. SECKEL, Materia, in Handlexicon cit. (nt. 18 supra), p. 355.

${ }^{473}$ Cf. H. HEUMANN - E. SECKEL, Signare, in Handlexicon cit. (nt. 18 supra), p. 540.

${ }^{474}$ Cf. H. HeUMANN - E. SECKEL, Trabs, in Handlexicon cit. (nt. 18 supra), p. 588.

${ }^{475}$ Sobre Paulo, infra (Parte II, Cap. III, 3.3); de interesse, por ora, o autor da obra por ele epitomada.

476 Sabe-se que o jurista, proveniente de uma família de artesãos (sapateiros, especificamente) de Cremona (HOR. serm. 1, 3, 130-132: «“...ut Alfenus vafer omni abiecto instrumento artis clausaque taberna sutor erat...') (= como o hábil Alfeno, <mesmo> deixando de lado os instrumentos de trabalho e tendo fechado a oficina, era sapateiro), foi discípulo de Sérvio Sulpício Rufo (GELL. noct. act. 7, 5, 1: «Alfenus iurisconsultus, Servii Sulpicii discipulus rerumque antiquarum non incuriosus, in libro digestorum tricesimo et quarto...») (= Alfeno jurisconsulto, discípulo de Sérvio Sulpício e interessado pelas coisas antigas, no livro trigésimo quarto dos digesta...), e, dentre os cargos públicos exercidos, conta-se aquele de consul suffectus, em 39 a. C. (Pomp. l. sing. enchir., D. 1, 2, 2, 44: «ex his auditoribus plurimum auctoritatis habuit Alfenus Varus et Aulus Ofilius, ex quibus Varus et consul fuit...») (= desses ouvintes <de Sérvio Sulpício>, tiveram grande autoridade Alfeno Varo e Aulo Ofílio, dos quais Varo também foi cônsul...). Cf. P. KRÜGER, Geschichte der Quellen und Literatur des römischen Rechts, $2^{\mathrm{a}}$ ed., München-Leipzig, Duncker \& Humblot, p. 69; W. KUNKEL, Die römischen Juristen - Herkunft und soziale Stellung, Köln-Weimar-Wien, Böhlau, 2001 [reimpr. 2a ed., 1967], p. 29; L. WENGER, Die Quellen des romischen Rechts, Wien, Holzhausens, 1953, p. 484; R. ORESTANO, Alfeno Varo, in NNDI 1 (1957), p. 477; A. GUARINO, L'esegesi I cit. (nt. 314 supra), p. 142.

${ }^{477}$ E em maior medida, ainda, pois - segundo P. KRÜGER - nos fragmentos do epítome de Paulo conservados na compilação justinianéia não se poderiam verificar (de modo claro, ao menos) inserções do epitomador. Cf. Geschichte cit. (nt. 476 supra), p. 71.
} 
Ao jurista tardo-republicano são atribuídos 40 livros de digesta $^{478}$, nos quais foram recolhidos e ordenados tanto pareceres próprios quanto os de seu mestre ${ }^{479}$. Conhece-se essa obra por fragmentos recolhidos no Digesto, provenientes, porém, de dois epítomes: um, anônimo (em sete livros), e outro, de Paulo (que perfaria, ao menos, oito livros) ${ }^{480}$.

No Digesto foram reportados, ao todo, 71 fragmentos atribuídos a Alfeno (com um total de 104 decisões), além de 18 citações por juristas posteriores ${ }^{481}$; externamente, esses textos não apresentariam uma uniformidade, podendo consistir tanto (aproximativamente, a metade) em responsa (divididos em três partes: Sachverhalt - questão - decisão), quanto em outros não subsumíveis inteiramente a esse esquema, como ainda em simples fórmulas e definições ${ }^{482}$.

O livro três do epítome de Paulo da obra (os digesta) de Alfeno ${ }^{483}$, do qual foi extraído o texto em exame, teria sido dedicado às actiones in rem e aos bonae fidei iudicia; da reconstrução de O. LENEL, ter-se-ia, ainda, que, originalmente (isso é, na síntese de Paulo), o texto transcrito (ou melhor, o fragmento a que pertence: 15) conectava-se (como sequência) - dele separado, no Digesto, pelo fragmento 14 - com D. $18,6,13^{484}$.

${ }^{478}$ Cf. Index auctorum (digeston bibl ił tessar aøont a); é-lhe atribuída também outra obra, de nome Coniectanea, em dois livros, no mínimo (referida por GELL. noct. act. 7, 5, 1), e de conteúdo controverso. Cf. P. KRÜGER, Geschichte cit. (nt. 476 supra), pp. 69-70; L. WENGER, Die Quellen cit. (nt. 476 supra), p. 484 e nt. 110; R. ORESTANO, Alfeno Varo cit. (nt. 477 supra), p. 478; A. GUARINO, L'esegesi I cit. (nt. 314 supra), p. 143.

${ }^{479}$ A referência a Sérvio Sulpício Rufo seria claramente verificável em alguns casos nos quais se apresentam locuções como, v.g., «respondit» ou «ait»; entretanto, nem todas as afirmações e posicionamentos do discípulo seriam de se reconduzir ao mestre. Cf., nesse sentido, P. KRÜGER, Geschichte cit. (nt. 476 supra), p. 71; R. ORESTANO, Alfeno Varo cit. (nt. 477 supra), p. 477; mais recentemente, essa parece ser a opinião seguida por, v.g., H.-J. ROTH, Alfeni Digesta - Eine spätrepublikanische Juristenschrift, Berlin, Duncker \& Humblot, 1999, p. 25, ao invés de posições mais radicais sustentadas anteriormente, v.g., por F. P. BREMER, Iurisprudentiae antehadrianae quae supersunt I - Liberae rei publicae iuris consulti, Leipzig, Teubner, 1896, p. 161.

${ }^{480}$ Cf. P. KRÜGER, Geschichte cit. (nt. 476 supra), pp. 69-70; L. WENGER, Die Quellen cit. (nt. 476 supra), p. 484 e nt. 110; R. OReStANO, Alfeno Varo cit. (nt. 476 supra), p. 478; A. GuARINO, L'esegesi I cit. (nt. 314 supra), pp. 142-143; H.-J. RoTH, Alfeni Digesta cit. (nt. 479 supra), pp. 19-20.

${ }^{481}$ Alfeno teria sido, como observa H. HAUSMANINGER, o único jurista pré-classico de cuja obra grandes fragmentos foram reportados na compilação justinianéia. Cf. Casebook zum römischen Vetragsrecht, Wien, Manz, 2002, p. 220, nt. (*).

${ }^{482}$ Cf. H.-J. RoTH, Alfeni Digesta cit. (nt. 479 supra), p. 20; 26 e nt. 01.

${ }^{483}$ Não se faria conhecer, como observa O. LENEL, a ordem de disposição das matérias seguida por Paulo no epítome dos digesta de Alfeno; seguramente, não seria - como no epítome anônimo - aquela do edictum perpetuum, sendo provável, de todo modo, que Paulo tenha respeitado a ordem das matérias originalmente dada pelo autor epitomado. Cf. Palingenesia Iuris Civilis - Iuris consultorum reliquiae quae Iustiniani digestis continentur ceteraque iuris prudentiae civilis fragmenta minora secundum autores et libros I, Leipzig, Tauschnitz 1889, col. 37, nt. 01.

${ }^{484}$ Cf. Palingenesia I cit. (nt. 483 supra), col. 47, nt. 02 - Pal. Alf. 52. 
Esses fragmentos (13 e 15) corresponderiam - aparentemente - a um responsum de Alfeno que não seguiria, entretanto, inteiramente a estrutura tripartida a que se aludiu (Sachverhalt-quaestio - decisão) característica dos responsa desse jurista ${ }^{485}$.

A importância desse parágrafo do fragmento de Paulo-Alfeno para a reconstrução do problema da custodia na compra e venda estaria, como aparece já à primeira vista, no Sachverhalt: precisamente, em uma de suas distinctiones ${ }^{486}$, a saber, o perecimento - por furto - da coisa vendida antes da traditio («...si minus venditoris») ${ }^{487}$.

$\mathrm{Na}$ decisão, atribui-se o periculum (concretamente, o furto da coisa) ao comprador, se já tivesse havido a tradição da madeira, ou, em caso contrário ( «si minus» - isso é, não efetuada a traditio $)^{488}$, ao vendedor. As discussões nas quais se envolvem os intérpretes das fontes romanas parecem concentrar-se nessa última hipótese: o furto da coisa vendida antes da entrega ${ }^{489}$.

De fato, a solução consistente em fazer suportar o periculum de perecimento da coisa pelo vendedor antes da entrega estaria em contraste com o - pretendido - princípio geral periculum est emptoris, o que explicaria os esforços de parte da doutrina romanística para explicar o fundamento dessa divergência verificada no texto do jurista ${ }^{490}$.

${ }^{485}$ Cf. H.-J. Roth, Alfeni Digesta cit. (nt. 479 supra), p. 60; 64 e nt. 158.

${ }^{486}$ As distinctiones, presentes em algumas fattispecie consideradas por Alfeno, e traço característico de alguns de seus responsa (dentre os quais aquele do texto em exame do fragmento 13), consistiriam em uma técnica de, na resposta à quaestio, apresentar variações do Sachverhalt («Sachverhaltsalternativen»), com soluções, respectivamente, divergentes. Cf. H.-J. ROTH, Alfeni Digesta cit. (nt. 479 supra), p. 45 ; 64 e nt. 158.

${ }^{487}$ Essa circunstância, qual seja, de o furto representar o «evento típico» coberto pela «responsabilidade por custodia», nos termos da doutrina majoritária, justificaria a opção de partir, para a análise dos textos de Paulo-Alfeno, desse $(15,1)$ e não do fragmento 13 , continuado em 15 pr., que assume, por outro lado, precedência - sob a perspectiva da seqüência textual - na reconstrução palingenética de O. LENEL (supra).

${ }^{488}$ Cf., já nesse sentido, gl. si minus a D. 18, 6, 15, 1, atribuída a AZO: «id est si non tradita esset» (= isso é, se não tivesse sido entregue); J. PARIS, La responsabilité cit. (nt. 42 supra), p. 234; V. ARANGIO-RUIZ, La responsabilità cit. (nt. 04 supra), p. 158; ID., La compravendita II cit. (nt. 403 supra), p. 250, nt. 01; implicitamente, M. TALAMANCA, Considerazioni cit. (nt. 429 supra), pp. 230-231.

Por sua vez, G. BESELER considerou impróprio (além de supérfluo e errado, dogmaticamente) «si minus» que, a rigor sintático, deveria contrapor-se a «si furto perisset», significando, assim, um «si non perisset» («si materia furto non perisset, postquam tradita esset») e não no sentido de «si materia furto perisset, antequam tradita esset». Cf. Romanistische Studien, in TR 8 (1928), p. 296. Todavia, embora razoável a crítica textual desse autor, reputa V. ARANGIO-RUIZ que tais impropriedades não teriam sido estranhas também aos juristas romanos, principalmente quando o contexto do discurso era tão claro - como nesse caso, entende-se, a favor da segunda hipótese - a ponto de não dar lugar a equívocos. Cf. La compravendita II cit. (nt. 403 supra), p. 250, nt. 01; E. C. SilveIRA MARCHI, Acerca cit. (nt. 409 supra), p. 48, nt. 26.

489 Tratar-se-ia do suporte fático no qual poderia ter aplicação um possível «custodiam praestare» do vendedor. Cf. C. A. CANNATA, Ricerche cit. (nt. 21 supra), p. 120, afirmação válida, no discurso do autor, para as demais fattispecie presentes nos responsa que recolhem, de algum modo, material alfeniano (infra).

${ }^{490}$ A saber, aquela vertente representada por autores (dita «dominante») que, à parte divergências quanto a aspectos particulares (concernentes às exceções ou limitações do princípio, talvez), admitem, como ponto de convergência, a validade geral de periculum emptoris no direito romano do período clássico. 
Em contrapartida, a vertente alinhada à tese do periculum est venditoris como o princípio geral no direito clássico não vê, em geral, problemas em relação à substância da solução contida nesse texto, tomando-o como expressão genuína da doutrina dos juristas clássicos na matéria (periculum rei venditae) ${ }^{491}$.

Dentre as tentativas às quais se fez alusão ${ }^{492}$, remontaria à Glosa ${ }^{493}$ a individualização da ratio decidendi na noção de compra e venda genérica: obrigado à entrega de coisas determinadas pelo gênero (madeira, viga), o vendedor não estaria liberado pela subtração da coisa, objeto da prestação, uma vez que teria aplicação a regra «genus non perit» ${ }^{494}$.

Opor-se-ia a essa explicação, que recorre à idéia da compra e venda genérica (e, portanto, imperfecta), a própria designação do objeto da prestação: «materia empta»: essa sugeriria tratar-se de coisas devidamente individualizadas (integrantes de uma reserva de madeira $)^{495}$, constituindo, assim, objeto de obrigação específica, sem necessidade de individualização ${ }^{496}$.

${ }^{491}$ Cf., v.g., C. ARNÒ, La teorica cit. (nt. 420 supra), pp.19-20; F. HAYMANN, Textkritische Studien zum Obligationrecht II - Periculum emptoris, in SZ 41 (1920), p. 76; M. KonSTANTINOTICH, Le "periculum rei venditae» cit. (nt. 420 supra), pp. 160-161; adere, substancialmente, à tese desses dois últimos autores P. Huvelin, Compte rendu de M. KOnSTANTINOVITCH, Le «periculum rei venditae» cit. (nt. 420 supra) p. 319 e 327; M. SARGENTI, Problemi cit. (nt. 03 supra), pp. 219-220.

${ }^{492}$ Uma síntese das - por ele denominadas - «soluções harmonizadoras» oferece E. C. SILVEIRA MARCHI, Acerca cit. (nt. 409 supra), pp. 52-53.

${ }^{493}$ Como já observou, dentre outros, J. PARIS, La responsabilité cit. (nt. 42 supra), p. 238, nt. 02.

${ }^{494}$ Cf. gl. quod si a D. 18, 6, 15 pr.: «sed nonne post emptionem emptoris debet esse periculum? Resp. dic quod si in specie facta fuit venditio, pacto suscepit venditor periculum: si autem in genere, tunc est planum; quia genus non perit...» (= mas, porventura, após a compra e venda, o risco não deve ser do comprador? Resposta: há de se dizer que se a venda foi feita de uma espécie, <e > o vendedor, mediante um pacto, assumiu o risco; se, porém, <foi feita> de um gênero, então é claro, poque o gênero não perece...). A glosa foi aplicada, de fato, ao principium do fragmento 15, mas pareceria abranger também - como fundamento - o parágrafo seguinte. Seguem essa orientação (compra e venda genérica), v.g., R. JHERING, Beiträge zur Lehre von der Gefahr beim Kaufcontract (1859), in Gesammelte Ausfsätze aus den Jahrbüchern für die Dogmatik des heutigen römischen und deutschen Privatrechts I, Darmstadt, Scientia, 1981 [reimpr. Jena, 1881], p. 471; É. CuQ, Manuel des institutions juridiques des romains II, $2^{\mathrm{a}}$ ed., Paris, Plon, 1928, p. 460, nt. 07; P. F. GIRARD - F. SENN, Manuel élémentaire de droit romain, $8^{\mathrm{a}}$ ed., Paris, Rousseau, 1929, p. 581, nt. 05, in fine; J. PARIS, La responsabilité cit. (nt. 42 supra), pp. 238-239; L. DE SARLO, Alfeno Varo e i suoi digesta, Milano, Giuffrè, 1940, p. 133; R. ROBAYE, L'obligation cit. (nt. 42 supra), pp. 364-365, embora admitam tratar-se, no caso, de venda de um gênero limitado (certa quantidade de madeira a ser individualizada conferindo «perfeição» ao negócio - pela entrega); para M. SERRANO-VICENTE, que mais recentemente se alinha a essa teoria (gênero limitado), uma prova disso estaria na designação genérica «materia» seguida, no final do texto, de «trabes», isso é, uma denominação assumida após a individualização - demarcação - das vigas pelo comprador. Cf. Custodiam praestare cit. (nt. 26 supra), p. 275; 277.

${ }^{495}$ Cf. M. Talamanca, Considerazioni cit. (nt. 429 supra), p. 230.

496 Analogamente à construção que se verifica também no fragmento 13 («lectos emptos») (infra): A. PERNICE, Labeo II cit. (nt. 186 supra), p. 357, nt. 46 (limitadamente à «materia empta»); G. THIELMANN, Traditio und Gefahrübergang, in SZ 106 (1989), p. 303-304; M. TALAMANCA, Vendita cit. (nt. 21 supra), p. 361, nt. 584; E. C. SILVEIRA MARCHI, Acerca cit. (nt. 409 supra), p. 54.

Aduz M. TALAMANCA outro argumento contrário: a tese da compra e venda genérica não explicaria a razão pela qual Alfeno, no final do texto, esforça-se por interpretar a signatio como traditio. Com efeito, a marcação seria já uma admensio, apta a individualizar o objeto da prestação, tornar perfecta a compra e 
A seu turno, pretendeu-se individualizar o fundamento da decisão (contrária ao «princípio») na culpa do vendedor pelo furto da coisa: por outros termos, o devedor suportaria o prejuízo decorrente da subtração do objeto da prestação, nesse caso, pela inobservância - restanto intocado periculum est emptoris - da diligência adequada para evitar tal evento ${ }^{497}$.

O recurso à noção de culpa do vendedor como fundamento da solução encontraria como obstáculo, segundo E. C. SILVEIRA MARCHI, a ausência de apoio textual para poderse afirmar que, para o jurista - fosse ele Alfeno ou Paulo -, tivesse algum relevo essa circunstância (isso é, o «Schuldmoment») ${ }^{498}$.

Entretanto, em vista do evento (furto) considerado por Paulo-Alfeno, granjeou acolhida a explicação do texto com base na «responsabilidade por custodia» do vendedor $^{499}$ : a afirmação de que esse deveria suportar o periculum quando ainda não efetuada a tradição da coisa, importaria no reconhecimento, a seu cargo, de um «custodiam praestare $^{500}$.

Essa proposição remontaria já a J. BARON ${ }^{501}$ e, sem as limitações desse último ${ }^{502}$, parece ter encontrado favor nos estudos sobre o tema embasados nos métodos da Crítica

venda e operar o traspasso do risco, resultando, se tal fosse o caso, desnecessária a equiparação feita pelo jurista republicano. Se, conclui o autor, o não traspasso do risco dependesse, no texto em exame, da ausência de «perfeição» do negócio, por faltar individualização da coisa a partir de um gênero, não se compreenderia o porquê de Alfeno ter apresentado a questão em termos de traditio e não de admensio e equiparado a signatio à tradição, para efeitos de transmissão do periculum. Cf. Considerazioni cit. (nt. 429 supra), p. 230, nt. 42.

Por sua vez, R. CARDILLI notou que, se a natureza genérica do objeto da prestação consistisse no elemento essencial para a solução proposta, qual seja, a atribuição do periculum ao vendedor até a efetivação da entrega (traditio), não teria sido necessária a especificação, feita pelo jurista, do evento que foi a causa do perecimento, o «furto perierit». Cf. L'obbligazione cit. (nt. 04 supra), p. 301.

${ }^{497}$ Trata-se de uma interpretação que, aparentemente, teria seguidores dentre aqueles que consideram a custodia uma responsabilidade «subjetiva», isso é, sempre culpa, como, v.g., P. VocI, 'Diligentia' cit. (nt. 12 supra), p. 133, nt. 04; mas também, aparentemente, J. PARIS, La responsabilité cit. (nt. 42 supra), p. 239.

${ }^{498}$ Cf. Acerca cit. (nt. 409 supra), p. 59.

${ }^{499}$ Compreendida essa nos termos da linha interpretativa desenvolvida a partir de J. BARON (supra) e consolidada como doutrina majoritária (supra): responsabilidade - independentemente de culpa - por certos eventos «típicos» (furto, dano causado injustamente por terceiros, fuga de escravos custodiendi).

${ }^{500}$ A «doutrina dominante» em matéria de periculum rei venditae, tomaria esse fragmento, ao lado de Paul. 3 Alf. epit., D. 18, 6, 13, como os textos probantes do caráter clássico de periculum emptoris, limitado, entretanto pela responsabilidade por custodia do vendedor. Cf. E. C. SILVEIRA MARCHI, Acerca cit. (nt. 409 supra), p. 49.

${ }^{501}$ Para reconhecer um papel exercido pela responsabilidade por custodia nesse texto, em matéria de compra e venda, o autor teve de nele admitir a existência de uma Specieskauf mit Quantitätenpreis (único caso que, para ele, a Custodiahaftung era aplicada à compra e venda). Com efeito, segundo J. BARON, o reconhecimento da existência dessa modalidade negocial encontraria apoio em «materia empta» (e não, em geral, uma «res empta»): a madeira destinada à construção costumava, em Roma, ser comprada ad mensuram («nach Maß»), e a realização dessa medição estaria ligada à transferência da coisa. Cf. «Diligentia» cit. (nt. 175 supra), p. 64; ID., Die Haftung cit. (nt. 196 supra), p. 274. Um precedente dessa interpretação poderia ser visualizado já em gl. materia a D. 18, 6, 15, 1 . 
Interpolacionística que, em geral, pretenderam ver no texto um testemunho do reconhecimento, já desde o final da República (Alfeno), de uma «custodia clássica» do vendedor $^{503}$.

Com efeito, mesmo a utilização de «periculum» e não de «custodia» no texto em exame não seria um empecilho - a seguir, principalmente, E. SECKEL - E. LEVY - à admissão da responsabilidade por custodia como fundamento da decisão ${ }^{504}$. Antes, essa denominação não habitual da custodia - como quer V. ARANGIO-RUIZ - é que teria sido a razão de o texto ter-se subtraído à intervenção dos comissários justinianeus ${ }^{505}$.

«Periculum» poderia ter sido utilizado atecnicamente, mas, por sua referência ao perecimento por furto (evento considerado no texto), deveria ser compreendido como «periculum furti», aludindo, portanto, àquele risco tipicamente compreendido na responsabilidade por custodia $^{506}$.

Em contrapartida, o dado terminológico constitui, para outros autores, o principal obstáculo a essa interpretação ${ }^{507}$.

Em primeiro lugar, notou H. VoGT, resultaria injustificada a admissão, tout court, de que Alfeno tenha empregado «periculum» em duas acepções diversas sem uma elucidação: referido ao comprador, no sentido de dever de executar a contraprestação

${ }^{502}$ De fato, na literatura interpolacionística inclinada ao reconhecimento de uma aplicação da custodia clássica também ao contrato de compra e venda (infra), não se verifica a necessidade de ver na venda da madeira uma modalidade de negócio ad mensuram.

503 Tratar-se-ia, para aqueles que admitem tal interpretação, do indício mais antigo dessa custodia venditoris, como nota R. CARDILLI, L'obbligazione cit. (nt. 04 supra), p. 300. Cf., v.g., e mais expressivamente, V. ARANGIO-RUIZ, La responsabilità cit. (nt. 04 supra), p. 158; ID., La compravendita II cit. (nt. 403 supra), p. 250.

${ }^{504}$ Cf. Gefahrtragung cit. (nt. 421 supra), p. 247; 250, nt. 02; mais recentemente, também G. THIELMANN, Traditio cit. (nt. 496 supra), pp. 304-305; Contra, H. VoGT, Zur Gefahrtragung beim Sklavenkauf, in Festschrift Paul Koschaker II, Weimar, Böhlaus, 1932, pp. 163-164.

${ }^{505}$ E exprimir - sem intervenções bizantinas - a doutrina dos juristas clássicos acerca do tema (custodiam praestare do vendedor, independente de qualquer cláusula contratual). Cf. Responsabilità cit. (nt. 04 supra), p. 158.

${ }^{506}$ Cf. V. ARANGIO RUIZ, Responsabilità cit. (nt. 04 supra), p. 158. O uso de periculum referido à responsabilidade por furto («responsabilità oggettiva por furto», para V. ARANGIO-RUIZ), não seria isolado (não obstante, o autor não menciona quais as outras ocorrências de tal fenômeno, qual seja, de «periculum» referido, precisamente, a custodiam praestare), ainda que não seja o mais difuso, já que em geral, ao se empregar o termo tout court, sem ulteriores complementos, aludiriam os juristar clássicos aos riscos compreendidos nos casos de força maior. Cf. La compravendita II cit. (nt. 403 supra), p. 250.

Não convincente, segundo E. C. SILVEIRA MARCHI, o recurso à atecnicidade do uso de «periculum» em Paul. 3 Alf. epit., D. 18, 6, 13 e 15. Cf. Acerca cit. (nt. 409 supra), p. 50 e nt. 34; aparentemente, já também nesse sentido, M. SARGENTI, Problemi cit. (nt. 03 supra), p. 220.

${ }^{507}$ Cf., v.g., R. CARDILli, L'obbligazione cit. (nt. 04 supra), p. 300; E. C. SILVEIRA MARCHI, Acerca cit. (nt. 409 supra), p. 50 e nt. 34. 
(pagamento do preço) («Zahlungspflicht»), e ao vendedor, no de dever de ressarcimento do dano pelo inadimplemento ( $«$ Schadensersatzpflicht») ${ }^{508}$.

Ademais, far-se-ia ausente uma referência qualquer a um dever de custodia do vendedor, seja expresso por custodiam praestare, seja por outras locuções correlatas como se verifica em outros textos atinentes também à compra e venda ${ }^{509}$.

A tese da responsabilidade por custodia, ainda, não encontraria apoio sob a perspectiva histórica: a seguir a reconstrução do problema de R. CARDILLI ${ }^{510}$, «custodiam praestare», anterior (ou, no máximo, contemporaneamente) a Quinto Múcio Cévola ou, em outros termos, para os «veteres», referia-se apenas à fuga de animais (cavalos) e, em algumas situações, a escravos comodados; o furto não teria, ainda, adentrado o seu conteúdo $^{511}$.

Desse modo, pois, seria de se considerar o emprego de «periculum» pelo jurista não uma utilização em sentido atécnico (como um «periculum custodiae») - na linha de, v.g., E. SECKEL - E. LEVY e V. ARANGIO-RUIZ ${ }^{512}$ - mas o resultado de uma escolha dogmática consciente: a subtração clandestina da madeira comprada, por não integrar um evento pelo qual o vendedor devesse custodiam praestare, significaria um periculum, a ser atribuído a uma das partes ${ }^{513}$.

Resta, assim, considerar o texto como relativo a um problema de suportação, pelo vendedor, do «periculum» decorrente do furto: por outros termos, a impostazione do

${ }^{508}$ Cf. Zur Gefahrtragung cit. (nt. 421 supra), p. 164. Embora não exclua a abstrata possibilidade de um uso genérico e omnicompreensivo do termo, M. TALAMANCA considera de grande relevo, em vista da interpretação do texto, a utilização de periculum também com relação ao comprador. Cf. Vendita cit. (nt. 21 supra), p. 453, nt. 1556; ID., Considerazioni cit. (nt. 429 supra), p. 231, nt. 43.

${ }^{509}$ Como em, v.g., Paul. 2 inst., D. 18, 6, 3; Ner. 3 membr., D. 19, 1, 31 pr., Gai. 10 ad ed. prov., D. 18, 1, 35, 4. Cf., nesse sentido, E. C. SiLVEIRA MARCHI, Acerca cit. (nt. 409 supra), pp. 50-51.

${ }^{510}$ A proposição parece, de qualquer modo, encontrar um «spunto» já em C. A. CANNATA, que insiste, na leitura dos textos de Alfeno, na limitação da concepção republicana da custodia. Cf. Ricerche cit. (nt. 21 supra), p. 121.

${ }^{511}$ Cf. L'obbligazione cit. (nt. 04 supra), p. 300. Independentemente de se aceitar ou não a reconstrução histórica do problema por R. CARDILLI, embasada em sua interpretação dos «veteres» referidos em Ulp. 28 ad ed., D. 13, 6, 5, 6, 9 e 13, e da compreensão do furto como conteúdo de «custodiam praestare» apenas na época de Labeão, parece-nos que a ausência de outros testemunhos de uma utilização, por Sérvio Sulpício Rufo ou seu discípulo, da noção de custodiam praestare (conexa com o furto ou qualquer outro evento), poderia constituir, de todo modo, um ulterior elemento (ex silentio) contra a custodia do vendedor como fundamento da decisão dada por Paulo-Alfeno no texto em exame.

De fato, M. TALAMANCA individualiza como argumento contra a referibilidade do «periculum» à «custodia» nessa fattispecie a não praticabilidade de sua aplicação ao caso tratado imediata e correlacionadamente em D. 18, 6, 13 e 15 pr. (infra). Cf. Considerazioni cit. (nt. 429 supra), p. 231, nt. 43 e p. 230 , nt. 38, principalmente.

${ }^{512}$ Cf. Gefahrtragung cit. (nt. 428 supra), p. 244; 250, nt. 02 e La compravendita II cit. (nt. 403 supra), p. 250, respectivamente.

${ }^{513}$ Cf. R. CARDILLI, L'obbligazione cit. (nt. 04 supra), p. 300. 
problema da subtração da res vendita antes da tradição ter-se-ia dado, por Alfeno, em termos de «periculum»e não de «responsabilidade» 514 .

Além disso, como nota E. C. SILVEIRA MARCHI, a utilização de «periculum» na solução dada por Paulo-Alfeno, poderia não estar relacionada ao risco do furto, especificamente, mas em geral: o vendedor suportaria o periculum antes da tradição da coisa vendida ${ }^{515}$.

Com efeito, partindo-se da linha metodológica em tema de periculum rei venditae inaugurada por E. RABEL e seguida, principalmente, por M. TALAMANCA ${ }^{516}$, não seria necessário explicar a solução de atribuição de risco ao vendedor com base na custodia do vendedor ou recorrer a qualquer outra «solução harmonizadora» 517 .

Considerando-se o direito clássico como informado por um quadro complexo - no qual conviviam soluções diferenciadas (periculum emptoris e periculum venditoris) conforme diversos elementos determinantes (v.g., natureza da coisa, realização da traditio) - ter-se-ia, no texto em exame, um testemunho da solução favorável ao periculum venditoris com fundamento na realização ou não da traditio ( «res perit domino») ${ }^{518}$.

Logo, não obstante a sugestão dos elementos da fattispecie analisada - furto da coisa vendida e periculum venditoris -, (a) a terminologia (falta de referência à custodia), (b) a ausência de dados para se saber se custodiam praestare, para os juristas republicanos, já compreendesse o furto, e (c) a não incontrastada «doutrina dominante» em matéria de periculum rei venditae parecem indicar como preferível essa interpretação.

\footnotetext{
${ }^{514}$ Segundo C. A. CANNATA, a consideração de um problema prático em termos de «responsabilidade» ou «risco» seria arbitrária, com a única reserva de que a impostazione em termos de risco seria rigorosamente correta desde (a) que houvesse um desfalque («ammanco») objetivo, de modo a tornar impossível objetivamente a realização de uma situação final prevista no contrato; e (b) que o critério empregado para a solução do problema não excluisse qualquer margem de álea (como, v.g., o dolus). Cf. Per lo studio cit. (nt. 91 supra), p. 28 e nt. 04. Não parece, assim, que se possa verificar a ausência desses pressupostos na fattispecie de Alfeno para a sua apresentação em termos de risco (periculum).

${ }_{515}$ Cf. Acerca cit. (nt. 409 supra), p. 51.

${ }_{516}^{516}$ Cf. supra (Parte I, Cap. III, 4).

517 A tese da «responsabilidade por custodia» do vendedor, uma das principais vias para explicar o pretendido «desvio» do pretenso princípio em matéria de atribuição de riscos na compra e venda (periculum est emptoris) - E. C. SILVEIRA MARCHI, Acerca cit. (nt. 409 supra), p. 53 -, encontraria, já por si mesma, muitos obstáculos à sua admissão como ratio decidendi do responsum, como demonstrado supra.

${ }^{518}$ Cf. M. TALAMANCA, Considerazioni cit. (nt. 429 supra), pp. 230-231; E. C. SILVEIRA MARCHI, Acerca cit. (nt. 409 supra), pp. 50-51. Trata-se de um resultado que, na prática, equivale àquele sustentado pela corrente do periculum venditoris como «princípio clássico» na matéria (solução monista). Decorre, porém, não - como nesse último caso - da verificação de um princípio de validade geral, mas do resultado de uma análise casuística, a que dá lugar uma linha metodológica diversa, a saber, aquela que admite a existência, na iurisprudentia clássica, de decisões divergentes quanto ao problema de atribuição do risco de perecimento da coisa vendida (Gefahrtragung), fundamentadas em diversos fatores de valoração (linha jurisprudencial, natureza do objeto da prestação, efetivação ou não da entrega).
} 
Limitadamente à hipótese discutida (isso é, de perecimento da coisa por furto antes da tradição), seria de se concluir: o vendedor suporta o «periculum» ${ }^{519}$, se a madeira comprada não tivesse ainda sido entregue (em contraposição à hipótese contrária, na qual o risco seria suportado pelo comprador). Aplicado, no caso, o princípio da traditio (res perit domino), compreender-se-ia a frase final: consideram-se «traditas»-para fins de traspasso do risco - as vigas assinaladas , por aposição do selo ${ }^{520}$, pelo adquirente ${ }^{521}$.

No caso concreto, subjacente ao responsum, a traditio (tomada como momento decisivo para o traspasso do risco) teria sido realizada, como quer M. TALAMANCA ${ }^{522}$, por essa forma: a marcação das «trabes» ${ }^{523}$.

Para o tema estudado, enfim, resultaria que Paul. 3 epit. Alf., D. 18, 6, 15, 1 não seria, sem maiores elementos de apoio, probante da existência de um custodiam praestare do vendedor (referido, concretamente, ao furto da coisa vendida) já na época de Alfeno.

\section{A destruição pelo edil das camas vendidas}

519 Nota R. CARDILli que o responsum de Alfeno nada informa a respeito dos efeitos práticos do reconhecimento do periculum venditoris, ou seja, não se afirma que ele deveria responder nos limites do preço. «Periculum» exprimiria, segundo o autor, a mesma idéia de «damnum domini», «damnum coloni esse» em Ulp. 32 ad ed., D. 19 2, 15, 2, a saber, o reconhecimento ou não, sob o aspecto material, do praestare do locador. Cf. L'obbligazione cit. (nt. 04 supra), pp. 301-302.

${ }^{520}$ Tem-se notícia da difusão, no comércio romano, da marcação das mercadorias pelo seu fabricante ou comerciante: assim, gêneros alimentícios, vasilhames (cerâmica, vidro), recebiam selos seja como marca da propriedade, seja como testemunho da proveniência de uma determinada oficina de produção. Cf. V. СНАРот, Signum, in Dictionnaire des antiquités grecques et romaines IV, Paris, Hachette, s.d., p. 1330; W. HatTo Gross, Signum, in KlP V (1975), col. 184. Seria conjecturável, assim, que também fosse de uso, na venda de certos produtos, a aposição de um selo por parte do adquirente, com a finalidade de assinalar as coisas que passavam ao seu domínio. Cf. E. C. SiLVEIRA MARCHI cit. (nt. 409 supra), p. 48 e nt. 28.

521 Para V. ARANGIO-RUIZ, a solução reportar-se-ia a um uso do comércio de certas mercadorias, conforme o qual, essas, uma vez assinaladas pelo comprador, eram consideradas em depósito junto do vendedor, limitando-se a sua responsabilidade ao dolus, eximindo-se o vendedor da responsabilidade por furto (custodiam praestare). Cf. Responsabilità cit. (nt. 04 supra), p. 158; de acordo, substancialmente, M. SERRANO-VICENTE, Custodiam praestare cit. (nt. 26 supra), p. 276.

${ }^{522}$ Cf. Considerazioni cit. (nt. 429 supra), p. 230.

${ }^{523}$ De todo modo, a signatio pelo comprador não parece ter sido, sempre e em relação ao comércio de todos os produtos, interpretada como tradição, aspecto esse já notado pela gl. «signasset»a D. 18, 6, 15 pr. «Not. signationem vel designationem pro traditione haberi... Sed secus in vino, \& aliis similibus vino...» (= Há de se notar que a assinalação ou a designação é tida como tradição.... Mas diversamente em relação ao vinho e a outras <coisas> semelhantes a ele). A propósito, individualiza-se uma controvérsia entre juristas mais tardios (em relação a Alfeno) quanto ao valor a ser atribuído à signatio dos dolia (barris): Ulp. 28 ad Sab., D. 18, 6, 1, 2: Si dolium signatum sit ab emptore, Trebatius ait traditum id videri: Labeo contra, quod et verum est: magis enim ne summutetur, signare solere, quam ut traditum videatur (= Se um barril tiver sido marcado pelo comprador, Trebácio disse que ele parece ter sido entregue; Labeão <disse> o contrário, o que também é acertado: pois se costuma assinalar <os barris> mais para que não sejam trocados do que para serem considerados entregues). Dessume-se do texto que Labeão (cuja opinião acolheu Ulpiano), no século I d. C. divergisse de seu mestre, Trebácio que, por sua vez, alinha-se, implicitamente, à orientação sustentada pelo jurista republicano, a saber, a equiparação da signatio à traditio. Cf. M. TALAMANCA, Considerazioni cit. (nt. 429 supra), pp. 233-235. 
Paul. 3 Alf. epit., D. 18, 6, 13: Lectos emptos aedilis, cum in via publica positi essent, concidit: si traditi essent emptori aut per eum stetisset quo minus traderentur, emptoris periculum esse placet

Paul. 3 epit. Alf. , D. 18, 6, 15 pr.: Quod si neque traditi essent neque emptor in mora fuisset quo minus traderentur, venditoris periculum erit.
O edil destruiu algumas camas vendidas que tinham sido postas na via pública. Se tivessem sido entregues ao comprador ou dele dependido a não realização da entrega, admite-se que o risco seja do comprador...

O edil ordenou a destruição de camas que tinham sido vendidas e colocadas na via pública ${ }^{524}$. Distingue-se: (a) se tivessem sido entregues ao comprador ou tivesse dependido desse último o fato de não ter sido realizada a entrega, decide-se $(« p l a c e t »)^{525}$ que o risco de sua destruição caiba-lhe (13); (b) se, todavia, não tivessem sido entregues, e nem o comprador estivesse em mora para recebê-los, o risco seria, então, do vendedor (15 pr.).

Não obstante a variação na transcrição das inscriptiones no Digesto, esses textos foram extraídos da mesma obra, a saber, o epítome paulino dos digesta de Alfeno ${ }^{526}$, devendo-se tais divergências, muito provavelmente, a descuidos dos compiladores ou de seus copistas ${ }^{527}$.

\footnotetext{
${ }^{524}$ Dentre as incumbências desse magistrado (aedilis) estava o policiamento das vias públicas: a «cura urbis», referida por CIC. leg. 3, 7 («'sunto aediles curatores urbis annonae ludorumque sollemnium...'») (=e sejam os edis os encarregados da administração da cidade, do abastecimento de trigo e dos jogos festivos...), incumbente aos edis, em geral, compreenderia tanto a supervisão do tráfego nas ruas e nos mercados, dos banhos públicos, bordéis, funerais e do abastecimento de água da cidade. Cf. D. MEdicus, Aediles, in KlP I (1964), cols. 83-84; N. BENKE - F.-S. MEISSEL, Übungsbuch römisches Schuldrecht, Wien, Manz, 2006, p. 140, nt. 38.

Em uma monografia atribuída a Papiniano ( Ast unomico" monobibl o") (já referida supra), da qual se recolheram fragmentos em D. 43, 10, fr. único, ter-se-ia um testemunho das finalidades da supervisão das ruas pelos ast unomoi, a saber, evitar que fossem colocados nas vias públicas, na frente das oficinas, determinados objetos que pudessem impedir o tráfego de veículos (cf. § 4, transcrito supra). À parte as incertezas acerca dessa obra do jurista severiano e da não identificação (tout court) dos așt unomoi e aedilis cf. A. MANNZMANN, Ast unomoi, in KlP I (1964), col. 669 - o fragmento pareceria contribuir para elucidar a situação presente no Sachverhalt do texto em exame. Assim, é possível que o vendedor fosse um artesão (ou comerciante apenas) de mobiliário e tenha, após ultimado a encomenda ou efetuada a venda das camas já prontas, colocado-as do lado de fora da oficina ou loja, obstruindo a passagem. Cf. E. C. SILVEIRA MARCHI, Acerca cit. (nt. 409 supra), p. 41, nt. 09.

${ }^{525}$ Expressões como «placet», «placuit», e semelhantemente «receptum est», «constat» indicariam uma doutrina jurídica dominante, aceita sem necessidade de uma fundamentação ulterior. Cf., nesse sentido, $\mathrm{H}$. HAUSMANINGER, Casebook cit. (nt. 482 supra), p. 117. Já H. HEUMANN - E. SECKEL parecem distinguir entre o uso no presente «placet», indicativo de um posicionamento individual do autor do texto, e «placuit», «placebat», utilizados para exprimir uma opinião já aceita, incontrovertidamente. Cf. Placere, in Handlexicon cit. (nt. 18 supra), p. 432.

${ }^{526} \mathrm{Cf}$. a reconstrução palingenética dos fragmentos propostas por O. LENEL supra.

${ }^{527}$ Encontra-se, ainda, com referência ao epítome de Paulo, a inscriptio: Alfenus libro...digestorum a Paulo epitomatorum. Cf. H.-J. RotH, Alfeni Digesta cit. (nt. 479 supra), p. 20 e nt. 27.
} 
Entre esses textos, os compiladores inseriram outro, de Juliano, no qual se considera a hipótese de uma atuação injusta («non iure») por parte do magistrado (edil):

Iul. 3 ad Urs. Fer., D. 18, 6, 14: eumque cum aedili, si id non iure fecisset, habiturum actionem legis Aquiliae: aut certe cum venditore ex empto agendum esse, ut is actiones suas, quas cum aedile habuisset, ei praestaret e <admite-se que> ${ }^{528}$ ele <comprador> terá contra o edil, se tivesse feito isso <destruição das camas> injustamente, a actio legis Aquiliae ou, em todo caso, <admite-se que> <o comprador> haverá de agir contra o vendedor ex empto, para que esse lhe transferisse as ações que tivesse contra o edil.

O comprador, em caso de uma atuação ilegítima por parte do edil, teria a ação ex lege Aquilia contra esse último pelos danos causados; ou, em todo caso, ser-lhe-ia possível propor a actio empti contra o vendedor para que esse lhe cedesse as ações que tivesse contra o magistrado ${ }^{529}$.

Também a possível conexão dos textos (13 e 15 pr., especificamente) com posicionamentos de um jurista tardo-republicano (Alfeno, especificamente) ${ }^{530}$ assumiria relevância para a reconstrução do problema da custodia na compra e venda nesse período.

\footnotetext{
${ }^{528}$ Coordenando-se o fragmento 14 com o precedente, «eumque...habiturum...Aquiliae» constituiria uma oração de acusativo com infinitivo (futuro, no caso), introduzida por «placet», do fragmento 13, e também, com outras elipses, «aut certe...agendum esse», como se verificaria, mais claramente, na tradução de $\mathrm{O}$. BEHRENDS - R. KNÜTEL - B. KuPISCH - H. HeRMANn SEILER, Corpus Iuris Civlis - Text und Übersetzung III - Digesten 11-20, Müller, Heidelberg, 1999, p. 507.

${ }^{529}$ Segundo M. TALAMANCA, dado o modo de valoração do jurista, nesse caso, corresponder àquele de Alfeno no caso das camas destruídas pelo edil, é possível que o discurso original de Juliano (cf. O. LENEL, Pal. Iul. 910) já dependesse do caso discutido pelo jurista republicano. Tal proposição encontraria sustento na alternativa entre a legitimação direta à actio legis Aquiliae (para o caso da traditio), e a propositura da actio ex empto, para a cessão das ações (no caso de mora do credor). Cf. Vendita cit. (nt. 21 supra), p. 454, nt.
} 1565.

As duas soluções dadas ao problema de uma atuação ilegítima por parte do edil parecem corresponder às duas situações consideradas precedentemente no texto de Paulo-Alfeno: (a) com a entrega das camas por parte do vendedor, o comprador, como proprietário que sofre o dano, é o legitimado à actio legis Aquiliae contra o causador; (b) se, todavia, não houve a entrega (por estar o comprador em mora), a propriedade seria ainda do vendedor quando tivesse havido a destruição; ele, de fato, não responderia à contraparte, já que, pela mora, sua responsabilidade estaria limitada ao dolo; entretanto, seria obrigado a ceder as ações que, como proprietário das coisas injustamente danificadas, tivesse contra o edil, dentre as quais a actio legis Aquiliae. Cf., nesse sentido, aparentemente, P. VocI, 'Diligentia' cit. (nt. 12 supra), p. 130, e já gl. Aquilia a D. 18, 6, 14: «primo casu quando fuerunt traditi» (= no primeiro caso, quando foram entregues); gl. «cum venditore»: «sc. secundo casu» (= a saber, no segundo caso); mais recentemente, diversa interpretação do texto por M. SERRANO-VICENTE, Custodiam praestare cit. (nt. 26 supra), p. 279

${ }^{530}$ Não falta quem atribua a decisão ao epitomador, Paulo, como, v.g., F. P. BREMER, Iurisprudentiae Antehadrianae I cit. (nt. 479 supra), p. 164; contra, não excluindo a possibilidade de a utilização de «placet», e por conseguinte, a solução, proviessem já de Alfeno Varo, P. KRÜGER, Geschichte cit. (nt. 476 supra), p. 71 , nt. 54 . 
Embora o evento causador da impossibilidade do objeto da prestação não seja, neste, aquele «típico» (furto), pretendeu-se individualizar, também aqui - como fundamento da decisão - um «custodiam praestare» do vendedor ${ }^{531}$.

Tal como o anterior, esses textos, por encerrarem uma solução contrária ao periculum est emptoris, atribuindo (no fragmento 15 pr.) o risco da destruição dos leitos ao vendedor antes da tradição (isso é, periculum venditoris), exigiu por parte da doutrina alinhada à tese do periculum emptoris como princípio geral no direito clássico, esforços intepretativos de conciliação desse «testemunho contrário» ${ }^{532}$.

De semelhante modo, a corrente antagônica àquela do periculum emptoris considera também esse caso das camas destruídas um testemunho a favor do princípio contrário (periculum venditoris) como aquele aplicado pelos juristas clássicos no tratamento do problema da suportação do risco contratual na compra e venda ${ }^{533}$.

Uma das vias pelas quais se buscou conciliar essa decisão com a doutrina do periculum rei venditae foi, tal como em relação à venda da madeira, considerar o caso como atinente a uma compra e venda genérica, tese essa remontante a ACCURSIO ${ }^{534}$, dandose por explicado o não traspasso do risco pela ausência de individualização da coisa ${ }^{535}$.

Ainda que em relação ao caso anterior pudessem haver certas hesitações em vista de elementos do Sachverhalt apresentado ${ }^{536}$, neste, reconhece-se que «lectos emptos» indicaria uma coisa determinada (logo, um compra e venda de espécie) como objeto da prestação $^{537}$.

Outra vertente visualiza na conduta reprovável do vendedor (logo, em sua culpa) o elemento determinante da decisão: ter-se-ia, portanto, não o enfrentamento de um problema de risco contratual, mas de responsabilidade por culpa, consistente, no caso

\footnotetext{
${ }^{531}$ Tratar-se-ia, entretanto, de apenas uma de várias outras tentativas de explicação da solução que se apresenta nos fragmentos de Paulo-Alfeno (periculum venditoris).

${ }^{532}$ Com efeito, esses fragmentos do epitome paulino dos digesta de Alfeno Varo (D. 18, 6, 13 e 15) representam, como observou M. SARGENTI, um «arduo problema» para a doutrina do periculum emptoris. Cf. Problemi cit. (nt. 03 supra), p. 247.

${ }^{533}$ Cf., v.g., C. ARNÒ, La teorica cit. (nt. 420 supra), p. 18; F. HAYMANN, Textkritische II cit. (nt. 492 supra), pp. 75-76; M. KonSTANTINOTICH, Le «periculum rei venditae» cit. (nt. 420 supra), p. 160-161; P. HuVElin, Compte rendu de M. KONSTANTINOVITCH, «Le periculum rei venditae» cit. (nt. 420 supra), p. 319 e 327; M. SARGENTI, Rischio (diritto romano), in ED 40 (1989), p. 1127.

${ }^{534}$ Cf. gl. lectos emptos a D. 18, 6, 13: «in genere...» (= <camas> em gênero).

${ }^{535}$ A essa interpretação se refere, refutando-a, C. ARNÒ, La teorica cit. (nt. 420 supra), p. 09.

${ }^{536}$ Com efeito admite M. SARGENTI a possibilidade de uma «leitura» daquele texto capaz de dar lugar à sua consideração como um caso de compra e venda genérica (materia empta). Cf. Problemi cit. (nt. 03 supra), p. 248.

${ }^{537}$ Cf. v.g., M. SARgENTI, Problemi cit. (nt. 03 supra), p. 248; E. BETTI, «Periculum» cit. (nt. 420 supra), pp. 174-175; G. ThIELMAnN, Traditio cit. (nt. 496 supra), p. 303-304; M. TAlAMANCA, Vendita cit. (nt. 21 supra), pp. 452-453 e nt. 1554; R. CARDILli, L'obbligazione cit. (nt. 04 supra), p. 298; E. C. SILVEIRA MARCHI, Acerca cit. (nt. 409 supra), p. 54; M. SERRANO-VICENTE, Custodiam cit. (nt. 26 supra), p. 278.
} 
concreto, na obstrução da via pública, fato que teria desencadeado a providência tomada pelo magistrado $^{538}$.

Essa interpretação encontraria obstáculos como a ausência de referências à culpa e, em especial, a não possibilidade de caracterizá-la, sem mais, o simples fato de deixar as camas vendidas na via pública, uma vez que tal era consentido a alguns artesãos ${ }^{539}$. Além disso, notou R. CARDILLI que o aspecto da conduta do vendedor não teria desempenhado um papel decisivo na solução do jurista, pois que, doutro modo, não teria havido necessidade de condicionar a condenação do vendedor à não realização da traditio das $\operatorname{camas}^{540}$.

Por fim, a doutrina alinhada ao periculum emptoris propõe, como chave interpretativa para o pretendido desvio do «princípio» clássico, também a responsabilidade por custodia do vendedor («custodiam praestare $)^{541}$.

O evento causador da destruição do objeto da prestação, neste caso, seria a ordem emanada do edil: juridicamente, dessa providência do magistrado teria resultado um dano patrimonial para o proprietário das coisas danificadas (destruídas).

Como observa E. C. Silveira MARChi, o caráter da providência edilícia já constiuiria um obstáculo à aceitação da custodia como fundamento da decisão, pois que a ordem dada pelo magistrado seria equiparável à vis maior (como, v.g., o ataque de salteadores), exorbitando do âmbito de um pretendido custodiam praestare do vendedor ${ }^{542}$.

Ainda que não se recorra à equiparação, tout court, do evento à vis maior, a tese da responsabilidade por custodia careceria também de apoio: dois textos informam acerca de uma «controvérsia» na qual se viram envolvidos Juliano e Marcelo acerca da compreensão

${ }^{538}$ Cf., v.g., J. BARON, «Diligentia» cit. (nt. 175 supra), p. 64; J. PARIS, La responsabilité cit. (nt. 42 supra), p. 233; L. De SARLO, Alfeno Varo cit. (nt. 495 supra), p. 91; M. SERRANO-VICENTE, Custodiam cit. (nt. 26 supra), pp. 278-279; R. ROBAYE, L'obligation cit. (nt. 42 supra), p. 364; G. ThIELMANN, Traditio (cit. 496 supra), p. 303; 308-309.

${ }^{539}$ Cf. M. SARGenti, Problemi cit. (nt. 03 supra), p. 248, e o texto de Papiniano reportado supra.

${ }^{540}$ Com efeito, segundo o autor, a ratio decidendi seria bastante explícita na busca de individualizar o proprietário da coisa destruída, pela indagação acerca da efetivação ou não da traditio dos bens, e não se fundaria, portanto, em um culpam praestare do vendedor. Entretanto, não se exclui que a conduta do vendedor de obstruir a via pública, ainda que indiretamente, possa ter condicionado a solução de Alfeno, ao agravar o praestare do vendedor, em derrogação à regra (normal, para R. CARDILLI), do periculum est emptoris. Cf. L'obbligazione cit. (nt. 04 supra), p. 298.

${ }^{541}$ A atuação do funcionário público, por si mesma, seria considerada um evento de força maior; entretanto, deveria ela ser considerada, no caso, com a providência tomada pelo vendedor de colocar as mercadorias na via pública, expondo-as a eventualidades como a intervenção edilícia. Desse modo, portanto, não se deveria toma-la por uma força maior, mas reconhecer a violação da custodia incumbente ao vendedor. Cf. E. SECKEL - E. LEVY, Die Gefahrtragung cit. (nt. 421 supra), p. 246.

${ }^{542}$ A irresistibilidade de que se reveste a providência do magistrado evidenciar-se-ia, como nota o autor, na hipótese de uma conduta arbitrária ou ilegal do edil, hábil a excluir, com maior razão ainda, a responsabilidade do vendedor. Cf. Acerca cit. (nt. 409 supra), pp. 43-44; 59. 
do «damnum iniuria ab alio datum» na custodia devida por certos devedores (comodatário e locatário) $)^{543}$.

Se, por um lado, não é seguro que se considerasse apenas o caso de atuação legítima do edil, não se devendo negar - sem ulteriores provas -, a presença do elemento iniuria no dano causado (o que tornaria possível, em princípio, esse enquadramento da fattispecie - um dano ilicitamente causado por terceiro) ${ }^{544}$, por outro, não se poderia afirmar que, no final da República, a custodia já abrangesse, em seu conteúdo, o damnum iniuria ab alio datum.

Com efeito, a seguir a notícia da aludida «controvérsia», Juliano teria dado por impassível de dúvidas («procul dubio») a inserção do dano causado por terceiros iniuria dentre os eventos contrastáveis pela custodia incumbente a certos devedores. Assim, se esse era o panorama até o século II d. C., com maior razão seria de reputar existente esse limite para a iurisprudentia tardo-republicana ${ }^{545}$.

Resta, portanto, considerar a decisão de Paulo-Alfeno sob a perspectiva do problema da atribuição de risco (Gefahrtragung) ${ }^{546}$ : partindo-se, assim, da «Mittelmeinung» que admite um quadro elástico na regulamentação do problema pelos juristas clássicos, a questão concentrar-se-ia em determinar qual o fator determinante, no responsum, da suportação do periculum pelo vendedor.

O fundamento da solução - periculum venditoris - estaria, portanto, na não efetivação da entrega das camas (traditio) $)^{547}$. Por outros termos, ter-se-ia mais uma

${ }^{543}$ Cf. supra (Parte I, Cap. II, 2.2.3).

${ }^{544}$ Cf. Ulp. 18 ad ed., D. 9, 2, 29, 7, texto no qual também se prevê a actio legis Aquiliae contra o edil.

${ }^{545}$ E mesmo que se considere o texto sob a perspectiva do epitomador, Paulo, seria discutível ainda a evitabilidade abstrata desse dano («custodiri potuit»), de modo a consentir a sua explicação com base na responsabilidade por custodia do vendedor.

${ }^{546}$ Dê-se, ainda, notícia da tentativa, por parte de V. ARANGIO-RUIZ de provar a extraneidade do problema discutido no texto àquela da distribuição do risco contratual (periculum). Não se trataria, segundo o autor, de um caso de força maior (logo, periculum teria sido empregado em sentido indubitavelmente atécnico), mas de uma contravenção às normas sobre o uso das vias públicas, cujas consequências - uma vez inobservadas - deveriam ser suportadas pelo autor - vendedor ou comprador - da contravenção (ou seja, aquele que causou a obstrução da via pública). Cf. La compravendita II cit. (nt. 403 supra), p. 270.

O problema central enfrentado pelo texto seria, dessa forma, a determinação do autor das contravenções, a fim de aplicar as sanções correspondentes. A hipótese de V. ARANGIO-RUIZ poderia ser refutada, segundo E. C. SILVEIRA MARChI, pela verificação de que a discussão nos textos restringe-se a dois sujeitos, a saber, o vendedor e o comprador. Desse modo, pois, assistindo razão ao primeiro autor, o jurista deveria ter considerado outras possibilidades: v.g., a autoria do delito poderia ser de um terceiro sujeito, como o transportador da mercadoria vendida. Por essas razões, sustenta-se que a passagem de Paulo refira-se, propriamente, ao periculum em sentido técnico-jurídico, qual seja, o risco representado pela destruição das camas vendidas. Cf. Acerca cit. (nt. 409 supra), pp. 45-46.

${ }^{547}$ Cf. M. TAlamanCA, Vendita cit. (nt. 21 supra), p. 452; E. C. SilveIRA MARChI, Acerca cit. (nt. 409 supra), p. 40; 43. 
fattispecie na qual o papel decisivo na resolução do problema - suportação do periculum seria desempenhado pela tradição.

Concretamente, o risco (ou dano) decorrente da destruição das camas vendidas caberia ao comprador se lhe tivessem já sido entregues ou dele dependido (por estar em mora) a não realização da entrega; em contrapartida, se o vendedor não tivesse realizado a tradição das coisas, nem o adquirente estivesse em mora para retirá-las, cabe ao primeiro as consequências danosas (periculum) decorrentes da ordem do edil. E tal porque, antes da traditio, seria o proprietário a suporta o risco de perecimento fortuito (res perit domino $)^{548}$.

Em relação, portanto, ao problema da custodia na compra e venda, essa fattispecie também não parece fornecer indícios de sua operatividade, de modo a permitir a admissão de sua existência no regime jurídico da compra e venda já na época de Alfeno Varo.

\section{O incêndio da «insula custodienda»}

Alf. Var. 2 dig., D. 18, 6, 12 (11): Si vendita insula combusta esset, cum incendium sine culpa fieri non possit, quid iuris sit? Respondit: quia sine patris familias culpa fieri potest neque, si servorum neglegentia factum esset, continuo dominus in culpa erit, quam ob rem si venditor eam diligentiam adhibuisset in insula custodienda, quam debent homines frugi et diligentes praestare, si quid accidisset, nihil ad eum pertinebit.
Se um prédio <de andares> vendido tivesse sido incendiado, já que um incêndio não pode dar-se sem culpa, qual a solução jurídica? Respondeu: pois que <um incêndio> pode dar-se sem culpa do paterfamilias, e se tivesse acontecido por negligência dos escravos, o proprietário não estará, sem mais, em culpa; por isso, se o vendedor tivesse aplicado aquela diligência, em relação ao prédio que deve ser custodiado, que devem os homens honestos e diligentes observar, se algo acontecesse, nada sofrerá < da consequência danosa do evento>.

Por fim, outro texto ainda referível a Alfeno e discutido em alguns estudos atinentes ao tema da responsabilidade por custodia, provém do epítome dito «anônimo» dos digesta de autoria do jurista do final da época republicana ${ }^{549}$.

Indaga-se (quaesitum): se uma insula ${ }^{550}$ vendida tivesse sido incendiada - e dado que um incêndio não pode ser causado sem culpa de alguém- qual a solução? ${ }^{551}$.

\footnotetext{
${ }^{548}$ Cf., mais recentemente, E. C. SILVEIRA MARCHI, Acerca cit. (nt. 409 supra), p. 59.

${ }^{549}$ É o que se infere a partir da inscriptio: Alfenus (ou Alfenus Varus) libro...digestorum ou, também encontrável nas fontes, Alfenus libro...epitomarum, variações essas sem maiores impilicações, atribuíveis a falhas dos compiladores ou dos copistas de que se serviam. Cf. H.-J. Roth, Alfeni Digesta cit. (nt. 479 supra), p. 20 e nt. 27.
} 
Respondeu (responsum) ${ }^{552}$ : dado que um incêndio pode ser causado sem culpa do paterfamilias e que o proprietário não é necessariamente culpado se algo ocorreu por culpa dos escravos, o vendedor não suportará qualquer consequência do fato se tivesse observado aquela diligência, na custódia do imóvel vendido, que devem observar as pessoas honestas e diligentes.

O segundo livro desse epítome (que seguiria, aparentemente, a ordem do edictum $)^{553}$ abrange variadas matérias ${ }^{554}$, dentre as quais contratos de compra e venda e

${ }^{550}$ Originariamente, a «insula», no âmbito de um agrupamento urbano, consistia em um único imóvel, com prédios residenciais, acessórios, pátio e jardim, separado dos vizinhos por ruas e por um «ambitus» (isso é, uma distância legalmente prescrita) (FEST. verb. sign.: «ambitus proprie dicitur circuitus aedificorum patens in latitudinem pedes duos et semissem, in longitudinem idem quod aedificum...» (= diz-se, propriamente, «ambitus» a distância existente entre edifícios, <consistente>, em latitude, em dois pés e meio, e, em longitude, a mesma <medida> que o edifício...) - W. M. LindSAY, Sexti Pompei cit. (nt. 39 supra), p. 05, e provavelmente dessa separação é que adviria o nome «insula» (ilha) dado a essas construções (FEST. verb. sign.: «insulae dictae proprie, quae non iunguntur communibus parietibus cum vicinis, circumituque publico aut privato cinguntur...» (= «insulas» propriamente ditas <são> aquelas que não se juntam aos vizinhos por paredes comuns, e são isoladas pelo percurso público ou privado) - W. M. LINDSAY, Sexti Pompei cit. (nt. 39 supra), pp. 98-99.

Entretanto, esse espaçamento entre as moradias - ambitus - não mais se verifica no curso do século II a. C., encostando-se essas edificações uma às outras. E assim, já a partir do final da República, «insula» designaria um prédio de vários pavimentos, em cujas unidades habitavam (geralmente como locatários «insularii») diversas famílias (ou, por outros termos, a «Miethaus») (MART. epigramm. 4, 37: «ex insulis fundisque tricies soldum...» = capital total de três milhões em casas de apartamentos e imóveis...). Contrapunha-se, assim, à «domus», destinada essa à moradia de uma só família (e, de fato, forma de habitação apenas dos mais ricos), ainda que pudesse comportar outro andar («Einzelhaus»). Cf. E. R. FIECHTER, Römisches Haus, in RE I A-1 (1914), cols. 982-983; ID., Insula, in RE IX-2 (1916), cols. 15931594.

Nessas insulae - edifícios construídos verticalmente, dotados de vários andares (contignationes) e compartimentos (cenacula) - alojava-se a maior parte da população de Roma e das grandes cidades do Império, e representaria, ao contrário do que vulgarmente se reputa, a típica moradia romana. Cf. E. C. SilveIra MARCHI, A Propriedade Horizontal no Direito Romano, São Paulo, Quartier Latin, pp. 16-17.

Segundo U. E. PAOLI, essas seriam o protótipo da moderna casa, pelos seguintes fatores: (a) poderiam ter, em geral, três ou quatro pavimentos, alcançando a altitude de aproximadamente 18 metros; (b) as paredes exteriores tinham várias janelas e balcões; (c) as paredes externas constituíam, ademais, uma única fachada; (d) os espaços interiores não foram planejados para um determinado fim, carecendo, portanto, de uma característica própria de certos cômodos (como, v.g., o tablinum ou o oecus das domus); poderia, assim, o locatário utilizá-los e adaptá-los de acordo com as necessidades de sua família. Cf. Das Leben im Alten Rom, trad. al. de G. ОтTO - L. RÜDIGER, Vita Romana, $2^{\text {a }}$ ed., Bern-München, Francke, 1961, p. 78.

É possível que, no curso da época imperial, o termo tenha sofrido um ulterior alargamento conceitual, pois a extensão das cifras de um recenseamento do período (1681 domus para 44300 insulae, no total; 1790 domus para 46602 insulae, no breviarium), sugeriria que «insula» não mais designasse todo o prédio (isso é a Miethaus), mas a unidade, ou seja, os apartamentos (Mietseinzelwohnung). Cf. E. R. FIECHTER, Insula cit. (nt. 552 supra), col. 1594; também G. HUMBERT, Insula, in Dictionnaire des antiquités grecques et romaines III, Paris, Hachette, 1900, pp. 546-547.

551 «Quid iuris sit?» denunciaria, segundo R. CARDILLI, a reproposição - em termos de escola - de um quaesitum ao qual corresponderia, por sua vez, o responsum do texto. Cf. L'obbligazione cit. (nt. 04 supra), p. 292.

552 Segundo H. HEUMANN - E. SECKEL, o «respondit» indicaria, sem dúvidas, a proveniência do responsum de Sérvio Sulpício Rufo. Cf. Custodia, in Handlexicon cit. (nt. 18 supra), p. 118.

${ }_{553}$ À parte o já discorrido acerca do jurista, de sua obra (os digesta) e da transmissão textual dessa para o Digesto de Justiniano por dois epítomes (o paulino e o anônimo), aduza-se, como diferença entre elas a diversa ordem de exposição da matéria. Os fragmentos do epítome atribuído a Paulo não se acomodariam à ordem do edictum perpetuum, sendo provável que o jurista do século III d. C. tenha observado a disposição original dada à obra por Alfeno. A seu turno, o epítome anônimo - provavelmente em função de seu uso 
locação; o fragmento 12 inicia, na reconstrução palingenética de O. LENEL, uma cadeia de três outros dedicados à emptio venditio ${ }^{555}$.

A fraseologia difícil do texto, em geral, sugeriu a identificação de não poucas manipulações por parte dos comissários de Justiniano, constituindo objeto de críticas textuais no que se refere a, praticamente, cada uma de suas sentenças ${ }^{556}$.

Dada a referência a uma «insula custodienda» in fine, alguns intérpretes pretenderam coligar o texto em exame ao problema da «responsabilidade por custodia». Com efeito, F. Schulz sustentou que, originariamente, o texto de Alfeno referia-se à responsabilidade absoluta do proprietário pelos atos de seus subalternos, fato que, para o autor, entraria nos limites da responsabilidade clássica por custodia $^{557}$.

Aos compiladores seria atribuível a atenuação dessa responsabilidade absoluta, pela introdução de outra, embasada na noção de culpa in eligendo, de modo que a decisão do jurista republicano teria sido acolhida no enunciado da questão, e afastada em seguida ${ }^{558}$.

Também E. SECKEL ${ }^{559}$, na reconstrução do teor originário do texto que propõe, esforça-se para recuperar a pretensa responsabilidade por custodia técnica do vendedor: «...respondit (sc. Servius), <etiam>si venditor eam diligentiam adhibuisset in insula custodienda, quam debe<re>nt homines frugi et diligentes praestare, <tamen eum custodiae nomine teneri. sed> si <casu maiore> quid accidisset, nihil ad eum pertine $\left\langle r e>{ }^{560}\right.$.

prático nos foros - já pareceria seguir a ordem do Edito Perpétuo. Cf. O. LENEL, Palingenesia I cit. (nt. 483 supra), col. 37, nt. 01.

${ }_{555}^{55}$ Assim, v.g., actio negatoria, pauperies, actio legis Aquiliae, actio de peculio e de in rem verso.

${ }^{555}$ Cf. Pal. Alf. 12-14. Dessa reconstrução, entretanto, não parecem deduzíveis informações de auxílio para a elucidação do fragmento no contexo da obra originária (epítome), já que os textos confrontantes não parecem concatenar-se diretamente com o discurso desenvolvido em Alf. 2 dig., D. 18, 6, 12.

${ }^{556}$ Cf., v.g., L. LUSIGNANI, La responsabilità per custodia secondo il diritto romano II - L'emptio venditio, Parma, Adorni-Ugolotti, 1903, p. 19; F. HaYmann, Textkritische II cit. (nt. 492 supra), p. 119; M. KONSTANTINOVITCH, Le «periculum rei venditae» cit. (nt. 420 supra), p. 253; J. PARIS, La responsabilité cit. (nt. 42 supra), pp. 240-241; também C. A. CANNATA considera o texto notavelmente alterado (formalmente, ao que parece), Ricerche cit. (nt. 21 supra), p. 120, nt. 04.

${ }^{557}$ Cf. Rezension de L. LuSIGNANI, Studi sulla responsabilità per custodia secondo il diritto romano - IIl receptum nautarum cauponum stabulariorum - Gli altri casi di locate conduction; II - L'emptio venditio, in Krit. Vjschr. 14 (1912), p. 60.

${ }^{558}$ Cf. F. SCHUlz, Rezension de L. LuSIGNANi cit. (nt. 557 supra), p. 60.

${ }^{559}$ A esse autor, especificamente, é atribuída a reconstituição do fragmento (cf. Index Interpolationum, p. 336) em H. HeUMmAN - E. SECKEL, Custodia, in Handlexicon cit. (nt. 18 supra), p. 118.

${ }^{560}$ (= ... respondeu (Sérvio) que, mesmo se o vendedor tivesse observado, no prédio a ser custodiado, aquela diligência que as pessoas honestas e diligentes devessem observar, ele, contudo, responde a título de custódia. Mas se algo tivesse ocorrido por caso maior, <respondeu> que nenhuma consequência cabe-lhe); contra essa reconstrução, v.g., P. KRÜCKMANN, para quem a Zufallhaftung não estaria presente na órbita de idéias de Alfeno; faltaria, ademais, provas para a pretendida atenuação da originária custodia pela inserção da diligentia. Cf. Custodia cit. (nt. 237 supra), p. 23. 
Afora os estudiosos que se opõem a uma custodia do vendedor no direito clássico, limitando-se sua responsabilidade à culpa (e para os quais não haveria, logo, problemas substanciais no texto de Alfeno Varo) ${ }^{561}$, o maior obstáculo a essa interpretação estaria, aparentemente, nos próprios elementos do Sachverhalt.

Oferece já um primeiro problema o caráter da coisa, pretensamente o objeto do custodiam praestare do vendedor - uma «insula»-, por não se adequar aos limites conceituais do instituto traçados por J. BARON, a saber, a sua limitação às coisas móveis ${ }^{562}$.

Além disso, o evento considerado não seria um daqueles «típicos» que integrariam o conteúdo da responsabilidade por custodia (fuga, furto, damnum iniuria datum), mas o incendium da insula custodienda vendida.

Ainda que o primeiro óbice (isso é, a aplicação de «custodiam praestare» às coisas imóveis) seja controverso ${ }^{563}$, deve-se reconhecer que, em nenhum outro texto, seja de Alfeno, seja de outro jurista, encontram-se elementos concludentes para se afirmar que a custodia do devedor fosse suficiente para evitar também o incêndio da coisa devida.

A hipótese de interpolação parece encontrar amparo na concepção, vigente na época, de uma «responsabilidade objetiva» (custodia) como critério geral no direito clássico. Admitindo-se, por outro lado, a coexistência dos vários «critérios» (dolus, culpa, custodia) já desde a época clássica - e de um perfil «típico» de custodiam praestare - não haveria razões para se suspeitar da genuinidade de «si venditor...praestare».

Dar-se-ia, assim, lugar à consideração do provável sentido do responsum: diante da certeza com a qual se teria enunciado a origem culposa do incêndio ${ }^{564}$ («cum incendiumpossit» $)^{565}$, o jurista consultado teria acorrido a esclarecer (a) que o incêndio poderia dar-se sem culpa do paterfamilias ${ }^{566}$, e (b) mesmo que se devesse a um comportamento culposo (negligência) dos escravos, isso não implicaria, tout court, a culpa do proprietário ${ }^{567}$.

${ }^{561}$ Cf. J. PARIS, La responsabilité cit. (nt. 42 supra), pp. 241-242.

${ }^{562} \mathrm{Cf}$., entretanto, a «Nuance» reconhecida pelo autor em relação ao incêndio culposo, em Die Haftung cit. (nt. 198 supra), p. 296.

${ }^{563}$ Cf. infra (Parte II, Cap. III).

${ }^{564}$ Cf. R. CARDILLI, L'obbligazione cit. (nt. 04 supra), p. 292; 295.

565 De fato, acena-se nas fontes ao caráter mais frequentemente culposo dos incêndios causados nas cidades: Paul. 1. sing. de off. praef. vig., D. 1, 15, 3, 1: «et quia plerumque incendia culpa fiunt inhabitantium...» (= e porque, na maioria das vezes, os incêndios dão-se por culpa dos habitantes <das moradias >...). Talvez seja esse o sentido do trecho na apresentação do quaesitum, contra o qual, em seu caráter absoluto, ter-se-ia pronunciado o respondente.

566 Segundo J. BARON, o texto poderia ser compreendido do seguinte modo: o consulente teria apresentado o problema consistente em saber qual a solução jurídica se um imóvel vendido tivesse sido incendiado, aduzindo que um incêndio não poderia ter ocorrido sem culpa de alguém. O jurista teria ponderado: um incêndio poderia muito bem verificar-se sem culpa de uma pessoa (ou seja, por casus), e, ainda que tivesse sido causado por culpa, não do vendedor propriamente, mas de seu escravo, não deveria o primeiro forçosamente responder pela ocorrência. Cf. «Diligentia» cit. (nt. 175 supra), p. 60, nt. 21. Também 
Concretamente, a hipótese examinada pelo jurista seria, conforme R. CARDILLI, aquela - normal - de um incêndio culposo, e os seus esforços estariam concentrados em dar precisão ao modo de valoração da culpa do vendedor em relação ao fato do escravo, justificando-se sua intervenção para estabelecer os limites da imputação do fato do escravo ao dominus ${ }^{568}$.

Assim, ainda que o servus tivesse sido negligente, a culpa do proprietário poderia ser excluída pela prova da adequação da vigilância empregada sobre os escravos utilizados no imóvel: portanto, para Alfeno, a negligência dos escravos, causa do dano na coisa vendida, não implicava - automaticamente (como poderia ser sustentado por outros juristas) - no reconhecimento da culpa do proprietário $^{569}$.

Tendo o vendedor da insula observado a diligentia que lhe é exigida (ou seja, aquela típica dos homens «frugi et diligentes») e, não obstante, ocorrido o incêndio, não deveria sofrer as consequências desse - diz-se, com efeito: «nihil ad eum pertinebit» ${ }^{570}$.

Essa afirmação final assumiria o significado, aproximativamente, de que não lhe caberia qualquer prejuízo («nihil») decorrente da perda da coisa objeto da prestação ${ }^{571}$ : em outros termos, poder-se-ia pensar, como observa M. TALAMANCA, que Alfeno pretendesse excluir seja tanto a responsabilidade por inadimplemento, seja a suportação do risco pelo vendedor $^{572}$.

Nesses termos, seria o periculum suportado pelo comprador, solução que, se possível e mesmo provável para um jurista do século III d. C. (situado em uma época na qual o periculum emptoris já se encontraria consolidado como princípio), não poderia, sem mais, ser tomada como aquela do jurista tardo-republicano ${ }^{573}$.

C. A. CANNATA admite que o texto, originalmente, devesse distinguir entre um caso de incêndio fortuito e um de incêndio culposo. Cf. Ricerche cit. (nt. 21 supra), p. 120, nt. 04.

${ }^{567}$ Cf. J. BARON, Die Haftung cit. (nt. 198 supra), p. 296-297, nt. 159; R. CARDILLI, L'obbligazione cit. (nt. 04 supra), p. 292.

${ }^{568}$ Cf. L'obbligazione cit. (nt. 04 supra), pp. 292-293; 295; parece também ser esse o entendimento de Cf. O. BEREHNDS - R. KNÜTEL - B. KUPISCH - H. HERMANN SEILER, Corpus Iuris Civilis III cit. (nt. 529 supra), p. 507, nt. 01 (à tradução).

${ }^{569}$ Cf. R. CARDILLI, L'obbligazione cit. (nt. 04 supra), pp. 292-293.

${ }^{570}$ Para R. CARDILLI, se o vendedor pudesse provar que custodiou a insula tal como teria feito o modelo comportamental tomado por parâmetro - os «homines frugi et diligentes» - estaria exonerado do dever de stare praes pelo evento (isto é, o incêndio). Cf. L'obbligazione cit. (nt. 04 supra), p. 292.

${ }^{571}$ Como nota C. A. CANNATA, utilizam-se, mais frequentemente, expressões como «periculum pertinet» (ou «spectat», ou ainda «respicit») em relação ao credor (que, nos casos examinados de compra e venda corresponderiam ao comprador); dentre as exceções, entretanto, estaria esse texto, no qual a expressão é referida ao devedor (vendedor): «nihil ad eum pertinebit». Cf. Per lo studio cit. (nt. 91 supra), p. 29 e nt. 05.

${ }^{572}$ Cf. Considerazioni cit. (nt. 429 supra), p. 232.

${ }^{573}$ De fato, Alfeno Varo parece aplicar, em dois outros fragmentos - 3 Alf. epit., D. 18, 6, 13 e 15 -, a solução contrária: periculum est venditoris (supra). Não se exclui que a divergência desse texto, no que respeita à solução que parece acolher, em relação àqueles citados (provenientes do epítome paulino), deva-se, 
Em suma, a «impostazione» do problema por Alfeno Varo teria sido aquela da atribuição do risco contratual, conjugado, nesse caso específico, com a distinção originariamente, ao menos - entre incêndio (ou, em geral, evento) fortuito ou culposo ${ }^{574}$.

Assim, no que concerne ao problema investigado, seja o evento (incendium), seja a natureza do objeto da prestação (um imóvel), presentes na fattispecie, não consentiriam visualizar nesse texto o tratamento de um problema afeito ao custodiam praestare do vendedor $^{575}$. O «custodire», evocado por «insula custodienda» assumiria uma acepção, muito provavelmente, atécnica ${ }^{576}$.

Ainda uma vez, portanto, não se pode extrair do texto de Paulo-Alfeno informações que permitam fazer retroceder à época tardo-republicana a existência de um custodiam praestare a cargo do vendedor.

\section{A ausência de fontes para a reconstrução do problema do século I d. C.}

Ainda que o início do século I d. C. forneça indícios textuais de um custodiam praestare relacionado ao furto e aplicado por Labeão em matéria de locatio conductio $^{577}$, mais especificamente, aos já referidos fullo e sarcinator $^{578}$, e ao horrearius $^{579}$, não se apresentariam fontes, remontáveis a esse período, em matéria de custodiam praestare relacionado ao contrato de compra e venda.

Com efeito, algumas tentativas, já não recentes ${ }^{580}$, de visualização da CustodiaHaftung em textos como, v.g., Lab. 2 pith., D. 19, 1, 54 pr., não parecem ter encontrado favor entre os estudiosos ${ }^{581}$.

nesse caso, a uma intervenção por parte do epitomador anônimo. M. TALAMANCA, Considerazioni cit. (nt. 429 supra), p. 232.

${ }_{574}^{575}$ Cf. C. A. CANnAta, Ricerche cit. (nt. 21 supra), p. 120 e nt. 04.

575 A discussão, como parece sugerir M. TALAMANCA, comprovaria apenas o reconhecimento da culpa como critério de responsabilidade do vendedor reconhecido pela iurisprudentia romana. Cf. Vendita cit. (nt. 21 supra), p. 447 e nt. 1492; já nesse sentido, aparentemente, J. BARON, «Diligentia» cit. (nt. 175 supra), pp. 60-61.

${ }^{576}$ Cf. M. TAlamanca, Vendita cit. (nt. 21 supra), p. 447, nt. 1492; R. CARDILli, L'obbligazione cit. (nt. 04 supra), p. 294.

${ }^{577}$ Segundo R. CARDILLI, mesmo que não explicitamente, far-se-ia presente, nessas formulações, a lógica própria de custodiam praestare: um stare praes pelo furto da coisa, independentemente da análise acerca do comportamento do conductor. Cf. L'obbligazione cit. (nt. 04 supra), pp. 372-375.

${ }_{578}$ Cf. 5 ex post. a Iav. epit., D. 19, 2, 60, 2.

${ }^{579}$ Cf. 5 ex post. a Iav. epit., D. $19,2,60,9$.

${ }^{580}$ Cf. G. BESELER, Romanistiche cit. (nt. 489 supra), p. 300.

${ }^{581}$ Com efeito, v.g., J. PARIS, La responsabilité cit. (nt. 42 supra), p. 257; H. VoGT, Zur Gefahrtragung cit. (nt. 505 supra), p. 163; mais recentemente, também M. TALAMANCA, Vendita cit. (nt. 21 supra), p. 447, nt. 1492. 


\section{Conclusões parciais}

Na tentativa de realizar uma reconstrução do problema de custodiam praestare na compra e venda, pareceu oportuno partir de um primeiro grupo de textos nos quais parecia haver algum indício de envolvimento do instituto, atribuídos - ou de algum modo, reportáveis - a juristas mais remotos.

Em geral, o delineamento de um custodiam praestare na iuriprudentia republicana oferece dificuldades em função, aparentemente, dos testemunhos indiretos que restaram, não sendo de compartilhar, sem mais, a posição de K. VISKY, ao sustentar que, já a partir dessa época, figuraria ele como um grau de responsabilidade tal como o dolus e a culpa ${ }^{582}$.

Se, por um lado, seria acertado que o tratamento orgânico e autônomo da custodia apenas se verificaria no curso da iurisrpudentia adrianéia $^{583}$, não se poderiam negar alguns testemunhos provenientes de juristas republicanos, nos quais, entretanto, a custodia referida ao comodato - relacionava-se à fuga de animais e de certos escravos e não ainda ao furto $^{584}$.

No que concerne à compra e venda, a análise desses «vestígios» com base na literatura mais recente, confirmaria esses resultados: à parte um uso atécnico do termo (em Alf. 2 dig., D. 18, 6, 12), o «periculum», relacionado ao furto da coisa, e atribuído ao vendedor antes da tradição (correspondente ao Sachverhalt de Paul. 3 Alf. epit., D. 18, 6, $15,1)$ não corresponderia a um custodiam praestare do vendedor.

Por outros termos, mesmo determinadas fattispecie (como a do último texto referido) que, mais tarde, poderiam ser consideradas em termos de custodia do vendedor, teriam sido tratadas por Alfeno sob outras perspectivas, dentre as quais - mais expressivamente - a atribuição do risco pelo perecimento da coisa ${ }^{585}$.

Desse modo, restaria concluir, limitadamente à emptio venditio, que o reconhecimento de um custodiam praestare do vendedor não se teria verificado ainda no final do século I a. C.

${ }^{582}$ Cf. La responsabilité cit. (nt. 230 supra), p. 460.

${ }^{583}$ Cf. C. A. CANNATA, Ricerche cit. (nt. 21 supra), p. 119.

${ }^{584}$ Cf. C. A. CANnATA, Ricerche cit. (nt. 21 supra), pp. 119-121; R. CARDILli, L'obbligazione cit. (nt. 04 supra), p. 371.

${ }_{585}$ Poder-se-ia, segundo C. A. CANNATA, identificar na casuística de Alfeno alguns aspectos do regime da custodia, mas soluções em termos de custodiam praestare far-se-iam de todo ausentes. E ainda que em termos de atribuição de risco pudessem ser obtidas soluções coincidentes com aquelas alcançáveis com o critério da custodia, a «impostazione» seria bastante diversa. Cf. Ricerche cit. (nt. 21 supra), pp. 120-121; 136-137. 


\section{Capítulo II}

\section{«CUSTODIAM PRAESTARE» DO VENDEDOR NA IURISPRUDENTIA ADRIANÉIA: Nerácio, Gaio, Celso e Juliano}

\section{Generalidades}

Diante das conclusões obtidas pela análise dos textos precedentes no que respeita ao seu envolvimento com um «custodiam praestare» do vendedor, os textos compreendidos neste grupo - Ner. 3 membr., D. 19, 1, 31 pr., Gai. 10 ad ed. prov., D. 18, 1, 35, 4 (Inst. 3, 23, 3a) e Ulp. 29 ad Sab., D. 47, 2, 14 pr.-1 - seriam aqueles mais remotos para a verificação efetiva do problema.

Tais testemunhos provêm de juristas (Nerácio, Gaio, Celso e Juliano, citados os dois últimos por Ulpiano) que, embora não perfeitamente contemporâneos, viveram e produziram entre o final do século I d. C. e o início do seguinte, tendo, muito provavelmente, convivido sob Adriano ${ }^{586}$.

Como ponto de partida, tem-se - diferentemente dos textos anteriores - dados mais concludentes, ao menos sob o ponto de vista terminológico: «custodia», «custodiam praestare» relacionados, em geral, ao Sachverhalt típico, a saber, o furto da coisa vendida.

A documentação relativa a esse período oferece um quadro complexo, não sendo possível determinar, em alguns casos, qual fosse a exata posição de certo jurista quanto à configuração do «custodiam praestare» na compra e venda. Como problema, assume primazia aquele concernente à posição assumida por «custodiam praestare» no regime jurídico da compra e venda: por outros termos, examina-se a sua configuração, no âmbito desse contrato, como naturalia negotii ${ }^{587}$ (ou seja, elemento integrante da compra e venda,

\footnotetext{
${ }^{586}$ Cf. M. SERRANO-VICENTE, Custodiam praestare cit. (nt. 26 supra), p. 288.

${ }^{587}$ A terminologia, embora corrente nos manuais escolásticos de instituições de direito privado romano cf., v.g., E. VOLTERRA, Istituzioni cit. (nt. 21 supra), p. 152; M. TALAMANCA, Istituzioni cit. (nt. 05 supra), p. 194 - , não provém diretamente das fontes jurídicas romanas, mas sim, ao que parece, dos intérpretes medievais. Cf. M. TAlamAnCA, Istituzioni cit. (nt. 05 supra), p. 194; M. F. CURSI, Alle origini degli accidentalia negotii - Le premesse teoriche dela categoria moderna nelle sistematiche dei giuristi romani, in Index 29 (2001), p. 316; R. FIORI, Il problema dell'oggetto del contrato nella tradizione civilistica, in R. CARDILli et al., Modelli teorici e metodologici nella storia del diritto privato - Obbligazioni e diritti reali, Napoli, Jovene, 2003, pp. 182-183; 186-188.

Emprega-se a forma neutra plural - «naturalia», «accidentalia» e também «essentialia» - por ser ela a mais difusamente utilizada na doutrina. Cf., v.g., M. TALAMANCA, Istituzioni cit. (nt. 05 supra), pp. 194-195. Não se desconhece, todavia, a opção desse último autor pelo neutro singular em outras obras. Cf. M. TALAmANCA, Vendita cit. (nt. 21 supra), p. 448 (v.g.; o uso estende-se ao longo de toda a exposição); ID., Considerazioni cit. (nt. 429 supra), p. 246.
} 
salvo disposição contrária), ou accidentalia negotii (dependente, para isso, de pacto específico $^{588}$.

Examinar-se-ão, a seguir, tais textos, seguindo-se - tendencialmente, ao menos um critério cronológico: dá-se, nesses termos, precedência àquele atribuído a Nerácio ${ }^{589}$.

\section{Roubo (vi ademptio) da coisa vendida}

Ner. 3 membr., D. 19, 1, 31 pr.: Si ea res, quam ex empto praestare debebam, vi mihi adempta fuerit: quamvis eam custodire debuerim, tamen propius est, ut nihil amplius quam actiones persequendae eius praestari a me emptori oporteat, quia custodia adversus vim parum proficit. Actiones autem eas non solum arbitrio, sed etiam periculo tuo tibi praestare debebo, ut omne lucrum ac dispendium te sequatur.
Se aquela coisa que eu devia prestar em razão da compra, tivesse sido de mim arrebatada mediante força, embora eu tivesse devido custodiá-la, é mais apropriado, contudo, que eu tenha de prestar nada mais do que as ações para a persecução dela ao comprador, porque a custódia contra a força pouco adianta. Deverei, porém, prestar-te essas ações não somente ao teu arbítrio, mas também ao teu risco, de modo que te caibam todo lucro e dispêndio.

A coisa vendida, mas não ainda entregue, foi subtraída violentamente do vendedor. Ainda que tivesse devido custodiá-la, afirma-se que é mais apropriado que ele, alienante, esteja obrigado apenas a ceder as ações para a persecução da coisa ao comprador, uma vez que a «custodia» de pouco adianta contra a força.

Uma vez limitada a obrigação do vendedor a tanto, estabelece-se que a cessão dessas ações deva-se dar não só «arbitrio», mas também «periculo» da contraparte (referida, então, como «tu», e não mais como «emptor»), de modo que lhe caibam tanto os lucros quando as despesas.

\footnotetext{
${ }^{588}$ A discussão limitar-se-ia a esses termos - «elemento natural» ou «acidental» - pois que não procederia a configuração de «custodiam praestare» como «essentialia negotii», em razão do caráter disponível restando inelidível, porém, o pactum de dolo non praestando - das regras que disciplinam a individualização dos critérios de responsabilidade. Cf. M. TAlamancA, Vendita cit. (nt. 21 supra), p. 448, nt. 1505; também M. KASER, Das römische Privatrecht I cit. (nt. 05 supra), p. 504, nt. 06. Contudo, M. TALAMANCA, na discussão do texto de Nerácio (infra), afirma que «sembra seguirsi qui l'opinione che fa della responsabilità per custodia, se non un essentiale, almeno un naturale negotii». Cf. Considerazioni cit. (nt. 429 supra), p. 246.

${ }^{589}$ Embora Pomp. l. sing. enchir., D. 1, 2, 2, 53 coloque Nerácio em segundo lugar ao lado de Celso (filius) na direção da escola proculeiana, e não se admitindo uma chefia conjunta por parte dos dois juristas, tal ordem deveria ser invertida, uma vez que Nerácio sem dúvida era mais velho do que Celso e provavelmente faleceu antes deste último. Cf., nesse sentido, W. KunKEL, Die römischen cit. (nt. 476 supra), p. 144 , nt. 197.
} 
Atribui-se o texto a Nerácio Prisco, jurista que teria vivido no final do século I d. C. (período no qual desempenhou alguns cargos administrativos ${ }^{590}$ ) e início do seguinte ${ }^{591}$; segundo o relato de Pompônio, foi ele um dos corifeus da escola proculeiana ${ }^{592}$.

Dentre suas obras estão: libri $X V$ regularum, libri III responsorum, libri VII membranarum, libri ex Plautio, libri IV epistularum e, finalmente, um liber singularis de nuptiis $^{593}$, todas de cunho preponderantemente prático, destinadas ao tratamento de casos concretos $^{594}$

O texto transcrito provém de um fragmento extraído do terceiro livro de sua obra denominada membranae ${ }^{595}$, a mais utilizada pelos compiladores do Digesto (44 fragmentos ao todo $)^{596}$, e que, em termos gerais, consistiria em um compêndio de quaestiones e responsa ${ }^{597}$.

${ }^{590}$ Provavelmente originário da cidade sanita de Saepinum, Nerácio exerceu cargos como o de cônsul, praefectus aerarii Saturni, governador da Panônia (98 d. C.), e também integrou o consilium de Trajano e Adriano (cf. Papin. 11 quaest., D. 37, 12, 5). Tem-se notícia de que, por um momento, o imperador Trajano cogitou em nomeá-lo sucessor. Cf. P. Wenger, Die Quellen cit. (nt. 476 supra), p. 501; F. SCHULZ, Geschichte der römischen Rechtswissenschaft, Wien, Böhlaus, 1961, p. 123; Cf. W. KUNKEL, Die römischen cit. (nt. 476 supra), pp. 144-145 e nt. 198; R. ORESTANO, Nerazio Prisco, in NNDI 11 (1968), p. 233 ; A. GUARINO, L'esegesi I cit. (nt. 314 supra), p. 198; R. GREINER, Opera Neratii - Drei Textgeschichten, Kahrlsruhe, Müller, 1973, pp. 01-03.

${ }^{591}$ Cf. R. ORESTANO, Nerazio cit. (nt. 590 supra), p. 233.

592 Cf. l. sing. enchir., D. 1, 2, 2, 53. Cf. W. KUNKEL, Die römischen cit. (nt. 476 supra), p. 144, nt. 197; G. DULCKEIT - F. SCHWARZ - W. WALDSTEIN, Römische Rechtsgeschichte, 9a ed., München, Beck, 1995, p. 260. Sobre a contemporaneidade de Nerácio e Celso filius na chefia da escola proculeiana, cf. supra.

${ }^{593}$ Cf. A. GuARINO, L'esegesi I cit. (nt. 314 supra), pp. 198-199.

${ }^{594}$ Cf. M. KASER, Römische Rechtgeschichte, Göttingen, Vandenhoeck \& Ruprecht, 1950, p. 170.

${ }^{595}$ É provável que tal (singular) título - «membranae» - deva-se ao fato de que a obra continha respostas a questões jurídicas escritas sobre folhas de pergaminho, utilizadas, nessa época, para a realização de esboços, minutas, anotações, e não porque se tratasse de um codex propriamente. Cf. F. SCHULZ, Geschichte cit. (nt. 590 supra), p. 289; A. GUARINO, L'esegesi I cit. (nt. 314 supra), pp. 198-199; sobre a discussão, mais pormenorizadamente, R. GREINER, Opera Neratii cit. (nt. 590 supra), pp. 09-10.

596 Cf. P. Wenger, Die Quellen cit. (nt. 476 supra), p. 501; R. GREINER, Opera Neratii cit. (nt. 592 supra), p. 09.

597 Os libri membranarum são arrolados por F. SCHULZ na «Literatur der Problemata», categoria compreensiva dos trabalhos que contêm, exclusivamente, problemata, ou seja, questões jurídicas complexas e intrincadas, solucionadas mediante discussões de variada extensão. Cf. F. SCHULZ, Geschichte cit. (nt. 590 supra), p. 282; 289.

Por sua vez, R. GREINER considera que, seja o caráter (isto é, se uma obra doutrinária, comentário, monografia ou compêndio de problemas jurídicos), seja a finalidade desse trabalho de Nerácio, não sejam de fácil determinação, dada a não uniformidade do conteúdo e da forma de exposição das discussões presentes em cada fragamento. As membranae conteriam, segundo esse autor, um material bastante diversificado: v.g., decisões de casos concretos (similares à estrutura dos responsa), manifestações que se apresentam como relatos de disputationes em um consilium, trabalhos doutrinários.

Dessa não uniformidade, conclui o autor que tal obra fosse - como o seu título sugere - um conjunto de apontamentos («Notizien»): nas membranae Nerácio teria reunido aquilo de que se ocupara - como interessantes questões jurídicas - sem conferir-lhe, contudo, uma forma unitária de exposição e uma unidade sistemática da matéria.

Os libri membranarum não teriam, por fim, uma destinação nem prática nem didática, mas sim teriam consistido em um trabalho dirigido aos seus colegas de profissão, contribuindo para as discussões científicas de seu tempo. Cf. Opera Neratii cit. (nt. 590 supra), pp. 11-12; 26-27. 
A organização das matérias nessa obra não parece seguir um sistema conhecido: de fato, as opiniões do jurista concernentes a problemas afeitos a uma mesma «área jurídica» ou relativos a um específico tema ou instituto ( $v \cdot g$., sucessões, dote, servidões) não se encontram reunidas, mas dispersas nos vários livros ${ }^{598}$.

Por sua vez, embora provável que, originalmente, as matérias seguissem uma determinada sequiência em cada livro, pelo que foi conservado das membranae, essa ordem não se permite entrever ${ }^{599}$.

Assim, como os demais libri de que se compõe essa obra, o terceiro não trata de uma matéria específica ${ }^{600}$, reunindo posições do jurista acerca de variados temas: v.g., actio Publiciana, usufruto, direito sucesssório, dote ${ }^{601}$. O fragmento 31 situa-se entre dois textos que, por se referirem a outros problemas (estranhos mesmo à compra e venda) ${ }^{602}$, não parecem oferecer informações de relevo para a sua interpretação.

Não se faz presente, no texto, a locução «custodiam praestare», mas sim um «..custodire debuerim» ${ }^{603}$ e o substantivo «custodia». Entretanto, esses elementos textuais, juntamente com o contexto da discussão (fattispecie) (relativa à - eventual responsabilidade do devedor pela perda da res vendita antes da entrega), parecem assinalar a relevância desse para o tema em estudo ${ }^{604}$.

Como evento causador da impossibilidade de cumprimento da obrigação por parte do vendedor tem-se a subtração violenta («vi mihi adempta») da coisa vendida, indicada essa última genericamente, sem maiores detalhes («ea res») ${ }^{605}$.

Porém, com base na seqüência do texto $(\S 1)^{606}$, suspeitou-se que, genuinamente, Nerácio tivesse em consideração não uma «res» em geral, mas sim um escravo («...sed et id, quod emptor iam tunc sibi tradito servo...») ${ }^{607}$.

${ }^{598}$ Cf. R. GREINER, Opera Neratii cit. (nt. 592 supra), p. 11.

599 Já nesse sentido, a observação de O. LENEL, quanto à dificuldade de identificar uma ordem certa de disposição das matérias («certum rerum ordinem in his libris non invenio») nesses livros. Cf. Palingenesia I cit. (nt. 483 supra), col. 765, nt. I; R. GREINER, Opera Neratii cit. (nt. 590 supra), p. 11.

${ }^{600}$ Com efeito, não há sugestões de epígrafe, para qualquer um de seus livros, por O. LENEL, Pal. Ner. 0357, o que pareceria encontrar explicação na provável «natureza» das membranae.

${ }^{601}$ Cf., respectivamente, (Ner. 3 membr.), D. 6, 2 17; D. 7, 1, 44; D. 10, 2, 54; D. 23, 3, 53.

${ }^{602}$ Cf. O. LENEL, Pal. Ner. 20 e 21, correspondentemente, Ner. 3 membr., D. 10, 2, 54 (herança) e D. 23, 3,53 (dote).

${ }^{603}$ Indício, segundo E. BETTI, da nova concepção da custodia como «dovere di contegno». Cf. «Periculum» cit. (nt. 420 supra), p. 140; de modo semelhante, A. METRO, L' obbligazione cit. (nt. 22 supra), p. 205 , nt. 279.

${ }^{604}$ Por outros termos, a «custodia» (e também o «custodire»), referida no texto de Nerácio, não teria um sentido apenas genérico (guarda, vigilância), mas sim - em princípio - aquele técnico por ele assumido no âmbito do direito das obrigações, independentemente do problema dos possíveis remanejamentos compilatórios.

${ }^{605}$ Entretanto, tendo-se em consideração o evento (subtração violenta), a «res» teria natureza móvel como observa M. TALAMANCA, Considerazioni cit. (nt. 429 supra), p. 248. 
Tratar-se-ia, aparentemente, da hipótese de roubo ${ }^{608}$ ( «rapina»; «bona vi rapta» ${ }^{609}$ ) da res vendita, figura delitual do ius civile que gerava a obrigação, por parte do raptor, de

${ }^{606}$ Et non solum quod ipse per eum adquisii praestare debeo, sed et id, quod emptor iam tunc sibi tradito servo adquisiturus fuisset. (= E não apenas devo prestar aquilo que eu próprio adquiri por meio dele < do escravo>, mas também aquilo que o comprador teria adquirido se, então, o escravo já lhe tivesse sido entregue).

${ }^{607}$ Cf. L. LuSIGNANI, La responsabilità II cit. (nt. 556 supra), p. 34. Por sua vez, considera irrelevante tal circunstância para a interpretação do texto F. SCHULZ, Rezension de L. LUSIGNANI, La responsabilità cit. (nt. 557 supra), p. 68. Sobre essa circunstância, cf. infra.

${ }^{608} \mathrm{O}$ dado textual é «vi mihi adempta». Adimo, adimere (e ademptio) assumem, nas fontes jurídicas, significados como «retirar», «subtrair» «privar de»: v.g., vida, direitos (como cidadania), patrimônio (no sentido de confiscação de bens); em particular, ademptio é o termo técnico para exprimir a retirada ou anulação de um legado (mas também, em geral, de um pecúlio, de uma herança e da manumissão testamentária). Cf. H. HEUMANN - E. SECKEL, Adimere, in Handlexicon cit. (nt. 18 supra), p. 14; A. BERGER, Ademptio (bonorum, legati e libertatis), in Encyclopedic cit. (nt. 57 supra), pp. 348-349.

Desse modo, a ademptio vi da coisa vendida corresponderia ao significado, por assim dizer, basilar de «retirada», «subtração», «arrebatamento», para o qual concorreu o emprego da força, e perfaria os elementos característicos do roubo (rapina).

As fontes, entretanto, nas respectivas sedes materiae da actio vi bonorum raptorum, não parecem empregar esse verbo (adimo, adimere), mas, sobretudo, rapio, rapere: Gai. 3, 209 («qui res alienas rapit..»; «..etsi quis unam rem licet minimam rapuerit»); Inst. 4, 2 pr. («qui res alienas rapit...»; «...etiamsi quis unam rem licet minimam rapuerit»; «...eum qui vi rapit»; «...quisque rapuerit...»; «...eo animo rapuit»; «...hoc animo rapuit»; «..nemini liceat vi rapere..»; «...in mobilibus rebus, quae rapi possunt...»; «...ut intersit eius non rapi...»; «...qui rapinam passus est...»). Paul. 22 ad ed., D. 47, 8, 1 («qui rem rapuit...»); Ulp. 26 ad ed., D. 47, 8, 2, 2 («...is qui rapit»; «...bonave rapiat»); 10 («...eum qui vi rapit...»); 11 («...rapta esse dicuntur»; «...bona rapta..», «...bona rapta sit»); 12 («...et quid aut rapuerit...»; «...vel raptum...»; «... rei raptum...»); 14 («...qui rapuerunt...»); 18 («...suam rem rapuit...»; «... rapuit <fugitivum suum>....»; 21 («si per vim adductum pecus incluerit quis, utique vi bonorum raptorum conveniri poterit»); 22 («... ut intersit mea non rapi...»); 23 («.... si intersit mostra non esse raptam...»); 25 («... eaque <res instruendi sui causa〉 raptae sint...»); Paul. 54 ad ed., D. 47, 8, 3 («si servus rapuerit...»).

Não parece, contudo, haver graves obstáculos - no que concerne, ao menos, à terminologia - para admissão de que se trata, no caso, de roubo: adimo corresponderia a rapio, na acepção de «retirada», em relação ao qual também se aduz, em alguns casos, nas fontes (supra), a circunstância de se tratar de uma atuação violenta («vi»); de semelhante modo, Ulpiano recorre a outro verbo, em um mesmo fragmento (26 ad ed., D. 47, 8, 2) - adduco («per vim») - de modo que não haveria um absoluto rigor terminológico também nesse caso.

Interpretam-na como rapina, ademais - implícita ou explicitamente - autores como J. PARIS, La responsabilité cit. (nt. 42 supra), p. 232; V. ARANGIO RUIZ, Responsabilità cit. (nt. 04 supra), p. 157 (ao considerar que a ação a ser cedida ao comprador seja a actio vi bonorum raptorum); mais explicitamente, ID., La compravendita II cit. (nt. 403 supra), p. 248; E. BETTI, «Periculum» cit. (nt. 420 supra), pp. 140-141; C. A. CANnAta, Ricerche cit. (nt. 21 supra), p. 91; A. METro, L' obbligazione cit. (nt. 22 supra), p. 120; R. GreINER, Opera Neratii cit. (nt. 590 supra), p. 89; M. TAlAMANCA, Vendita cit. (nt. 21 supra), p. 426, nts. 1273 e 1277; por sua vez, em ID., Considerazioni cit. (nt. 429 supra), p. 247, o autor limita-se à leitura do evento como um caso de perecimento por «vis maior»; M. SERRANO-VICENTE, Custodiam praestare cit. (nt. 26 supra), p. 355 e nt. 1129, principalmente.

${ }^{609}$ Esse delito não teria recebido um nome específico nas fontes romanas, sendo designada pela perífrase «bona vi rapta», de que deriva o nome da ação («actio vi bonorum raptorum»). Cf. U. BRASIELLO, Rapina (diritto romano), in NNDI 14 (1957). p. 768. Note-se, contudo, que, se por um lado, a perífrase é utilizada para designar o delito em Gai. 3, 182 («transeamus nunc ad obligationes, quae ex delicto nascuntur, veluti si quis furtum fecerit, bona rapuerit, damnum dederit, iniuriam commiserit»), por outro, o termo «rapina» recorre em Inst. 4, 1 pr. («... in quattuor genera dividuntur: hae vero unius generis sunt, nam omnes ex re nascuntur, id est ex ipso maleficio, veluti ex furto aut rapina aut damno aut iniuria») ; Inst. 3, 2 pr. («...qui rapinam passus est...») e em textos do Digesto e do Codex: v.g., Ulp. 23 ad ed., D. 11, 5, 1, 1 («...si rapinas fecerint inter se collusores...»); Ulp. 29 ad Sab., D. 50, 17, 23 («...rapinae a nullo praestantur»); Maec. 8 fideicomiss., D. 35, 2, 30 pr. («...furta, rapinae, incendia...»); Iust. C. 9, 13, 1 (de 533) («...ancillae vel libertinae rapinam passae...»). Cf., em relação aos últimos (Codex e Digesto), H. HEUMANN - E. SECKEL, Rapina, in Handlexicon cit. (nt. 18 supra), p. 490. 
pagar uma poena correpondente (dentro de um ano) ao quádruplo do valor da coisa e, depois disso («post annum»), ao valor simples ${ }^{610}$.

Considerando a relação contratual existente entre vendedor (o implícito ego) e comprador, declara aquele ser mais acertado que sua obrigação limite-se à cessão das ações à contraparte. E, assim, mesmo se tivesse devido custodiar a coisa vendida («quamvis eam custodire debuerim») ${ }^{611}$.

Seguindo-se a lógica do texto, o fundamento, aparentemente, dessa limitação estaria no fato de que a custodia não poderia contrastar a força («quia custodia adversus vim parum proficit»), ou seja, não pode ela (ou seria pouco eficiente para tanto) evitar a ademptio vi da res vendita ${ }^{612}$.

Com base na exposição precedente, verificou-se que, nas fontes em que se apresenta a discussão de um problema relacionado ao «custodiam praestare» de um devedor, esse está relacionado a eventos como fuga de escravos (em determinados casos), furto (principalmente) e dano causado por terceiros à coisa devida (que deve ser restituída à contraparte $)^{613}$.

Nerácio, entretanto, não se confronta com nenhuma dessas hipóteses de perda do objeto da prestação, mas sim com aquela de subtração violenta da coisa vendida, diante da qual opinaria ser mais adequado - «propius est» ${ }^{614}$ - excluir a responsabilidade do vendedor pela impossibilidade de cumprir a prestação ${ }^{615}$.

\footnotetext{
${ }^{610}$ A previsão da actio vi bonorum raptorum no edito (Ulp. 56 ad ed., D. 47, 8, 2, pr.) ter-se-ia verificado na primeira metade do século I a. C., sobrepondo-se parcialmente às já existentes actio legis Aquiliae e actio furti, e destinava-se à proteção daqueles que tinham sido vítimas da subtação violenta de sua coisa. Por se tratar de uma fattispecie que integrava, de todo modo, a figura do furtum (Gai. 3, 209; Inst. 4, 2 pr.), teria sido possível a sua inserção dentre as obligationes ex delicto do ius civile. Cf. U. BRASIELlO, Rapina cit. (nt. 609 supra), p. 768; M. TALAMANCA, Istituzioni cit. (nt. 05 supra), pp. 628-629.

Em outras palavras, embora a actio e a poena prevista fossem de origem pretoriana, a origem civilística da fattispecie (no caso da rapina, decorrente de seu desprendimento da figura do furtum) tinha prevalência sob o plano classificatório. Em contrapartida, a natureza pretoriana da actio far-se-ia sentir na sua sujeição ao prazo de decadência de um ano após a possibilidade de sua propositura (ao contrário, portanto, da perpetuidade das ações civis). Cf. M. TALAMANCA, Istituzioni cit. (nt. 05 supra), p. 616; 618.

${ }^{611}$ É essa última sentença que assume maior relevância para o problema de que ora se ocupa (a saber, o da posição de «custodiam praestare» na compra e venda), como observa J. PARIS, La responsabilité cit. (nt. 42 supra), p. 231.

${ }^{612}$ Cf. P. VocI, 'Diligentia' cit. (nt. 12 supra), p. 74, nt. 48.

${ }^{613}$ Em relação à época de Nerácio, entretanto, os eventos típicos a que se destinava evitar com a obrigação de «custodiam praestare» seriam, mais seguramente, a fuga de escravos (remontante à discussão entre os veteres em matéria de comodato) e o furto (já considerado por Labeão, no âmbito da locatio horrei). Com efeito, ao que parece, até Juliano parecia fora de dúvidas («procul dubio») que o dano causado injustamente por terceiros («damnum iniuria ab alio datum») não fizesse parte do conteúdo da custodia. Cf. Parte I, Cap. II, 2.2.3)

${ }^{614}$ Com esses termos, Nerácio estaria a indicar, segundo R. GREINER, que a solução por ele dada (isso é, a exclusão, em termos gerais, da responsabilidade por vis) não era incontroversa entre os juristas. Esses, segundo o autor, apenas admitiam tal liberação em caso de «vis magna» ou «maior»: Gai. 2 rer. cott., D.18,
} 
E tal solução - a limitação da obrigação do devedor ao dever de cessão das ações ao comprador $^{616}$ - valeria ainda que ele, vendedor, tivesse devido custodiar a coisa. Em princípio, «quamvis eam custodire debuerim» poderia aludir tanto a uma obrigação existente, em geral, a cargo do vendedor, como a uma especificamente assumida ${ }^{617}$.

Por outros termos, para utilizar os termos empregados no início, o «custodiam praestare» incumbente ao vendedor poderia - abstratamente - figurar nesse texto de Nerácio como um elemento natural (naturalia negotii) ou acidental (accidentalia negotii) do contrato de compra e venda.

Embora essa determinação não modifique a solução dada pelo jurista ${ }^{618}$, a interpretação desse trecho - que parece requerer, para uma mais exata individualização de

6, 2, 1; Afr. 8 quaest., D. 19, 2, 33; Flor. 7 inst., D. 19, 2, 36; Ulp. 28 ad ed., D. 19, 5, 17, 4. Cf. Opera Neratii cit. (nt. 596 supra), p. 89.

Já M. TALAMANCA interpreta o evento considerado por Nerácio como «vis maior», ainda que não o qualifique com maior precisão (isso é, como, v.g., rapina). Cf. Considerazioni cit. (nt. 429 supra), pp. 247248.

${ }^{615}$ Cf. V. ARANGIO-RUIZ, Responsabilità cit. (nt. 04 supra), p. 163; ID., La compravendita II cit. (nt. 403 supra), p. 248; A. METRO, L' obbligazione cit. (nt. 22 supra), p. 120; R. GREINER, Opera Neratii cit. (nt. 590 supra), p. 89; M. Talamanca, Vendita cit. (nt. 21 supra), p. 429 e nt. 1303; M. Pennitz, Das periculum cit. (nt. 30 supra), pp. 388-389.

Já nesse sentido a interpretação de J. CUJAS: Vim ab alio sibi illatam venditor non praestat, puta, si res vendita ei per vim erepta sit, sed praestat, ut dixi, custodiam tantum eam, quae a bono patrefam. praestari, et rem servare potuisset, non custodiam inanem, quae rem servare non potuisset puta adversus vim praedonum, vel adversos alia quaecumque detrimenta fatalia. (= o vendedor não responde pela violência praticada contra ele por um terceiro, como, por exemplo, se a coisa vendita for dele subtraída mediante força, mas está obrigado, como disse, somente àquela custódia, que pudesse ser prestada por um bom paterfamilias, e conservar a coisa, mas não aquela custódia vã, que não pudesse conservar a coisa, como, por exemplo, contra $\mathrm{o}$ ataque de salteadores, ou contra quaisquer outros danos fatais). Cf. Recitationes solemnes, in Opera Jacobi Cujacii VII, Prati, Giachetti, 1839, cols. 1276-1277 (a D. 19, 1, 31).

Também H. DONEAU cita o texto que se estuda como uma hipótese em que o vendedor «non teneatur»: Cui consequens est, ut sive res vendita perierit, aut deterior facta sit, sive quid accedere potuerit, neque acceserit ante traditionem: si quidem contigerit casu, venditor non teneatur, sed periculum sit emptoris. Sin culpa, et vel levissima negligentia venditoris, id omne venditor praestare debeat. L. quod saepe, 35 . §. si res D. de contrah. empt. <D. 18, 1, 35, 4> L. si ea res, 31. <D. 19, 1, 31 pr. $>$ L. venditor, 36. D. de act. empt. <D. 19, 1, 36> L. si vendita, de per. et comm. rei vend. <D. 18, 6, 12>. Cf. Commentarii de jure civili, in Opera Omnia III, cols. 795-796.

${ }^{616}$ Cf. K.-H. Below, Die Haftung für lucrum cessans in römischen Recht, München, Beck, 1964, p. 91; M. TAlamanca, Vendita cit. (nt. 21 supra), p. 429.

${ }^{617}$ Com efeito, abstratamente as duas «leituras» seriam possíveis: (a) é mais apropriado que o vendedor não esteja obrigado a nada mais do que a cessão das ações, ainda que tivesse devido custodiar a coisa (obrigação decorrente do contrato de que é parte); ou (b) é mais apropriado que o vendedor não esteja obrigado a nada mais do que a cessão das ações, ainda que tivesse devido custodiar a coisa (obrigação assumida por ele expressamente na compra e venda celebrada).

${ }^{618}$ De fato, tanto em um caso como em outro, o elemento que parece determinar a solução encontrada por Nerácio é o evento causador da impossibilidade da prestação: assim, a custodia devida pelo vendedor, decorra ela do contrato (ex lege) ou de uma convenção específica, não poderia evitar a subtração da coisa mediante força: ou seja, a rapina excederia os parâmetros de proteção que o «custodiam praestare», mediante uma valoração típica, poderia oferecer. 
seu sentido, outros elementos além dos estritamente textuais - permitiria conhecer a opinião de Nerácio em relação ao «custodiam praestare» do vendedor ${ }^{619}$.

Os antigos comentários não parecem ter considerado a possível alusão do trecho «quamvis eam custodire debuerim» a uma «custodia» convencional, mas sim como designativa de uma obrigação do vendedor de «servare» a coisa alienada ${ }^{620}$.

Autores como, v.g., V. ARANGIO RUIZ ${ }^{621}$, nem mesmo consideram, em relação a esse texto, a possibilidade de uma outra leitura ${ }^{622}$, reputando que o «custodire debuerim» referido por Nerácio constitua um testemunho a favor da existência de um «custodiam praestare» a cargo do devedor, que não teria eficácia, nesta hipótese, em razão dos limites (a força maior) da «responsabilidade por custodia» ${ }^{623}$.

Por outro lado, esforçou-se E. BETTI para demonstrar a referência, originariamente, a uma responsabilidade por custodia convencional (isso é, accidentalia negotii) ${ }^{624}$, obliterada entretanto por interpolações que tiveram por escopo introduzir o «custodiam

${ }^{619} \mathrm{E}$, dentro de certos limites, obter um dado (mais ou menos seguro), para uma possível valoração, ainda que aproximativa, do quadro da iurisprudentia do final do século I e início do século II d. C. em relação a essa matéria.

620 Assim, v.g., J. CUJAS: Ex huius legis initio intelligimus, post venditionem et ante traditionem venditorem in servanda re vendita, non tantum dolum, sed etiam culpam praestare oportere: et talem custodiam sive diligentiam, qualem servandis rebus suis, bonus, id est, frugi et diligens paterfamilias, adhibere solet. Itaque si dolo vel culpa levi venditoris res vedita interierit, tenetur emptori actione ex empto, 1. si ut certo $5 \S$. nunc videndum, com. $\langle$ D. $13,6,5,2>1$. contractus 23 . de reg. jur. $\langle$ D. $50,17,23>1$. 3. de peric. rei vend. $\langle$ D. $18,6,3\rangle$ 1. quod saepe 35. §. si res, de contr. empt. $\langle$ D. $18,1,35,4>1$. eum qui 14 . de furt. $\langle$ D. 47, 2, 14> et 1. 37. inf. h. t. 〈D. 47, 2, 37>. (= Do início desse fragmento compreendemos que o vendedor, após a venda e antes da tradição, deve responder não só pelo dolo, mas também pela culpa na conservação da coisa vendida. E deve <observar> tal custódia ou diligência que um bom, isso é, um probo e diligente paterfamilias costuma aplicar na conservação das suas próprias coisas). Cf. Recitationes solemnes, in Opera VII cit. (nt. 615 supra), cols. 1276-1277 (a D. 19, 1, 31).

${ }^{621} \mathrm{O}$ autor, embora admita as incertezas decorrentes de certos textos, admite ser muito provável a existência da «responsabilità per custodia» do vendedor. A idéia fundamental que permeia a investigação do autor (em geral, dentro de certos limites, mas com algumas particularidades em relação aos textos em matéria de compra e venda), é aquela segundo a qual o vendedor, no direito clássico, era responsável por custodia (entende-se, era essa um naturalia negotii), e as referências a um pacto em alguns textos (que, em contrapartida, torná-la-ia um accidentalia negotii), seriam indícios da intervenção dos compiladores que, nesse expediente, teriam visto mais uma forma de desmantelamento da responsabilidade por custodia clássica. Cf. La compravendita II cit. (nt. 403 supra), p. 247.

${ }^{622}$ A saber, aquela de uma referência, por Nerácio, a uma obrigação assumida convencionalmente pelo comprador. A possibilidade dessa outra leitura é, entretanto, considerada (mas refutada) em relação a Gai. 10 ad ed. prov., D. 18, 1, 35, 4 (sobre o qual, infra). Cf. V. ARANGIO-RUIZ, La compravendita II cit. (nt. 403 supra), p. 248.

${ }^{623}$ A afirmação de Nerácio equivaleria a dizer, segundo o autor, que, se a coisa tivesse sido furtada, o vendedor não teria nem o dever nem a faculdade de ceder a ação penal, mas permaneceria responsável diante do comprador, de modo que a propositura da ação (actio furti, entende-se) corresponderia ao seu próprio interesse. Cf. Responsabilità cit. (nt. 04 supra), p. 157; ID., La compravendita II cit. (nt. 403 supra), pp. 248249. Com efeito, nessa equivalência estabelecida pelo autor - correspondente à sua interpretação global do texto - expressar-se-ia, mais claramente, a sua posição a favor de um «custodiam praestare» como elemento natural da emptio venditio, já que não parece condicionar a responsabilidade do vendedor, no caso de furto da res vendita, à averiguação da intercorrência de uma convenção entre os contratantes.

${ }^{624}$ Já nesse sentido, J. PARIS, La responsabilité cit. (nt. 42 supra), p. 231. 
praestare» (reinterpretado como diligentia in custodiendo) como «responsabilidade legal» na compra e venda ${ }^{625}$.

Favorável à aplicação do periculum venditoris no direito clássico (solução monista), o vendedor só poderia responder por custodia se a tivesse expressamente assumido («custodiam suscipere $)^{626}$. Com efeito, na compra e venda, um «custodiam praestare» a cargo do vendedor como elemento natural só teria sentido como contrapeso de uma regra de atribuição dos riscos desfavorável para o comprador (periculum emptoris $)^{627}$.

Em contrapartida, C. A. CANNATA considera que, se fosse necessário - como sustenta E. BETTI - um pacto («assunzione pattizia») para criar a obrigação de custodiar a coisa, esse deveria - por se tratar de um aspecto de grande relevância para o caso considerado - ser enunciado já no período inicial, isso é, no relato da fattispecie ${ }^{628}$.

Também favorável ao «custodiam praestare» como elemento natural do contrato, P. VocI, que se apóia na correpondência entre o «debebam» inicial, e o «debuerim» subsequiente, indicativo da origem da obrigação com a conclusão da compra e venda ${ }^{629}$.

Contrário também à crítica textual de E. BETTI ${ }^{630}$, retoma M. TALAMANCA a leitura do trecho de Nerácio como alusivo à «responsabilidade por custodia» como naturalia

625 «Si ea res, quam ex empto praestare debebam, vi mihi adempta fuerit: quamvis [eam custodire debuerim] <eius custodiam susceperim>, tamen propius est, ut nihil amplius quam actiones persequendae eius praestari a me emptori oporteat, [quia custodia adversus vim parum proficit]. [Actiones autem eas]

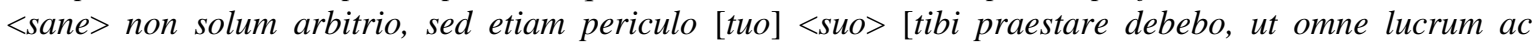
dispendium te sequatur]». (= Se aquela coisa, que eu devia prestar em razão da venda, tivesse sido de mim arrebatada mediante força: embora eu tivesse assumido a custódia dela, é mais apropriado, contudo, que eu tenha de prestar nada mais do que as ações para a persecução dela ao comprador, evidentemente não apenas ao seu arbítrio, mas também ao seu risco). Cf. E. BETTI, «Periculum» cit. (nt. 420 supra), p. 140; Contra a tese de E. BETTI, em geral, C. A. CANNATA, Ricerche cit. (nt. 21 supra), p. 75, nt. 57; 136 e nt. 55.

${ }^{626}$ Cf. E. BETTI, «Periculum» cit. (nt. 420 supra), pp. 140-141.

${ }^{627} \mathrm{E}$, assim, por admitir E. BETTI a vigência de periculum emptoris como regra apenas no direito justinianeu, o propósito de elevar a responsabilidade por custodia a elemento natural do contrato só poderia também ser de proveniência compilatória. Compreende-se, pois, a afirmação do autor de que, no direito clássico, tanto o caso quanto o sentido da decisão teriam sido diversos: seguindo-se a reconstrução do texto por ele proposta (supra), Nerácio, na hipótese de rapina da coisa vendida e não ainda entregue, teria dito que, mesmo tendo o vendedor assumido a custodia, ele não estaria obrigado senão a transferir as ações ao comprador. Por se tratar de roubo da coisa, esse exorbitaria dos limites da custodia (eventualmente assumida), integrando o periculum, que repercutiria também na esfera do vendedor. Explica-se, no entanto, a atribuição das ações «arbitrio» e «periculo» ao comprador como uma solução eqüitativa por parte de Nerácio. Cf. E. BETTI, «Periculum» cit. (nt. 420 supra), pp. 140-141.

${ }^{628}$ Cf. Ricerche cit. (nt. 21 supra), p. 75, nt. 57.

${ }^{629}$ Cf. 'Diligentia' cit. (nt. 12 supra), p. 67 e nt. 32; contra tal argumento, M. TALAMANCA, Vendita cit. (nt. 21 supra), p. 448, nt. 1502.

${ }^{630}$ Tratar-se-ia, segundo M. TALAMANCA, de uma crítica pré-concebida, que inverte o teor literal do texto no sentido de uma assunção convencional da custodia. Cf. Vendita cit. (nt. 21 supra), p. 449, nt. 1512; ID., Considerazioni cit. (nt. 429 supra), p. 246, nt. 103; 248, nt. 109. 
negotii: a atribuição dessa opinião ao jurista estaria mais conforme, segundo o autor, à orientação proculeiana favorável à aplicação de periculum emptoris ${ }^{631}$.

Mais recentemente, M. SERRANO-VICENTE repropõe a leitura de «quamvis eam custodire debuerim» como alusiva a um pacto pelo qual se assume a custodia como atividade técnica, tal como aquela devida pelo comodatário e pelo conductor rei servandae $^{632}$. Tal como Gaio ${ }^{633}$, Nerácio aludiria a um «custodiam praestare» de natureza convencional, introduzido, provavelmente no âmbito da prática negocial a fim de corrigir por agravar a posição jurídica do vendedor - os excessos da então regra periculum emptoris $^{634}$.

Embora não responsável o vendedor pelo incumprimento da prestação, o comprador poderia dele pretender a cessão das ações («actiones... praestari... oporteat») ${ }^{635}$, referidas, genericamente, como «actiones persequendae eius» (a saber, a $\langle r e s »,\langle r e i\rangle)^{636}$.

${ }^{631}$ Cf. M. TALAMANCA, Vendita cit. (nt. 21 supra), p. 449; 455.

${ }_{632}^{63}$ Cf. Custodiam praestare cit. (nt. 26 supra), p. 300.

${ }^{633} \mathrm{Em} 10$ ad ed., D. 18, 1, 35, 4. Cf. infra.

${ }^{634}$ Segundo o autor, seria possível que essa tendência à inserção do pacto coincida - em meados século II d. C. - com os resultados alcançados no âmbito do comodato, com a criação da actio in ius, que implicaria a prestação de custodia nesse contrato como obrigação própria do iudicium bonae fidei. Na base dessa assimilação de um instituto fecundo para o comodato estaria a verificação do caráter excessivo e frequentemente injusto da aplicação de periculum emptoris, para a correção do qual «custodiam praestare» constituiria um instrumento bastante útil. Cf. M. SERRANO-VICENTE, Custodiam praestare cit. (nt. 26 supra), p. 300

635 «Actiones praestare», assim como «actionem mandare» (infra) e «actionem cedere», nas fontes (cf., além do texto estudado, outros fragmentos citados por H. HeumANN - E. SECKEL: Paul. 9 ad ed., D. 3, 5, 20, 3; Ulp. 15 ad ed., D. 5, 3, 20, 17; Ulp. 16 ad ed., D. 6, 1, 17, 1; Paul. 13 ad ed., D. 6, 1, 69; Paul. 29 ad Sab., D. 14, 1, 5 pr., Ulp. 30 ad ed., D. 16, 3, 1, 11; Paul. 31 ad ed., D. 16, 3, 2; Afr., 7 quaest., D. 16, 3, 16; Paul. 5 ad Plaut., D. 17, 1, 45 pr.; 5; Ulp. 32 ad ed., D. 19, 2, 11 pr.; Marcell. 6 dig., D. 19, 2, 47; Paul. 14 ad Plaut., D. 46, 1, 36; Papin. 28 quaest., D. 46, 3, 95, 10), assumem o sentido de cessão, transferência («abtreten», «zedieren») do direito de ação («Klagrecht»). Cf. Praestare, in Handlexicon cit. (nt. 18 supra), p. 453; também ID., Cedere in ibidem, p. 62; ID., Mandare in ibidem, p. 331. Sobre a terminologia, cf., ainda, a lista oferecida por F. SchULZ, Klagen-Cession im Interesse des Cessionars oder des Cedenten im klassischen römischen Recht, in SZ 27 (1906), pp. 148-150.

Tal cessão (cessio actionis) operar-se-ia por meio da representação processual: o credor (cedente) constituía o sujeito a quem queria transferir o crédito (cessionário) cognitor ou procurator in rem suam. Com isso, possibilitava-se (pelo iussum do cedente) a este último perseguir a coisa judicialmente em nome próprio (na intentio da fórmula figurava o representado; na condemnatio, por sua vez, o representante) (Gai. 2, 39; 4, 86), executar o devedor (vat. 317) e fazer imputar o resultado ao seu próprio patrimônio (in rem suam). Cf. M. KASER, Das römische Privatrecht cit. (nt. 05 supra), p. 653 e nts. 07-08; M. TALAMANCA, Istituzioni cit. (nt. 05 supra), p. 653; 342-343; ID., Vendita cit. (nt. 21 supra), p. 427; P. JÖRS - W. KUNKEL - L. WENGER et. al., Römisches Recht cit. (nt. 412 supra), pp. 277-278 e nt. 05. [= § 106].

${ }^{636}$ Cf. M. Talamanca, Vendita cit. (nt. 21 supra), p. 426, nt. 1273; 429, nt. 1303. Também assim, J. CUJAS: «Alioqui si res vendita venditori sit vi erepta, periculum ejus rei ad eum non pertinet: et in hoc tantum tenetur, ut cedat emptori actiones, quas adversus praedonem vel raptorem habet...». (= A propósito, se a coisa vendida for subtraída mediante força do vendedor, o risco desse fato não cabe a ele. E ficará obrigado apenas nisso, isso é, para que ceda ao comprador as ações que tiver contra o salteador ou ladrão...»). Cf. Commentaria, in Opera VII, cols. 1276-1277. 
O fenômeno, designado na doutrina como «stellvertretendes commodum», apresentar-se-ia, no caso, em relação às ações nascentes da rapina ${ }^{637}$ : em princípio, a actio vi bonorum raptorum, de natureza controversa ainda na época de Gaio, a actio furti, a condictio ex causa furtiva e a vindicatio ${ }^{638}$.

A referência genérica ${ }^{639}$, por parte do jurista, oferece problemas aos intérpretes para determinar quais fossem essas actiones («persequendae») ${ }^{640}$ de cuja cessão se tratava: por um lado, há autores que restringem o discurso de Nerácio à ação penal, isso é, à actio vi

${ }^{637}$ Cf. M. TAlamanCA, Vendita cit. (nt. 21 supra), p. 426.

${ }^{638}$ Como recorda Gaio $(4,8)$, alguns juristas consideravam-na uma ação de caráter tão-só penal («poenam tantum consequimur...»), tal como a actio furti e a actio iniuriarum, pois do mesmo fato surgiriam outras ações como a vindicatio e a condictio. Essa orientação, favorável, na prática, ao concurso cumulativo com as ações reipersecutórias, apoiava-se no fato de que o delictum derivava da figura do furto, em razão do que se deveria reconhecer caráter exclusivamente penal também à actio vi bonorum raptorum. Cf. Ulp. 38 ad ed., D. $13,1,10,1$ («ei quoque, qui vi bonorum raptorum tenetur, condici posse Iulianus libro vicensimo secundo digestorum significat...»).

Justiniano, por sua vez, teria seguido opinião diversa - que já remontaria, segundo M. KASER, ao «frühklasssicher Zeit» - segundo a qual a referida actio era de natureza mixta (Inst. 4, 6, 19), destinada à obtenção do simplum, a título de ressarcimento, e do triplum, a título de poena (Inst. 4, 2 pr.). Disso resultava, portanto, a exclusão do concurso cumulativo com a vindicatio ou a condictio ex causa furtiva. Cf. M. KASER, Das römische Privatrecht I cit. (nt. 05 supra), pp. 626-627 e nt. 13; M. TALAMANCA, Istituzioni cit. (nt. 05 supra), pp. 628-629.

${ }^{639}$ Cf. M. TALAMANCA, Vendita cit. (nt. 21 supra), p. 426, nt. 1273.

${ }^{640} \mathrm{O}$ significado dessa expressão - que recorre em outros textos das fontes (v.g., Paul. 7 ad ed., D. 50, 16, 14, 1 e Gai. 7 ad ed. prov., D. 6, 2, 13 pr.) - dado por H. HEUMANN - E. SECKEL é o de «persecução judicial» («gerichtlich verfolgen»), «fazer valer» («geltend machen»). Cf. Persequi, in Handlexicon cit. (nt. 18 supra), p. 424; também nesse sentido J. MENNER - B. SCHMEISSER - J. ZEROBIN, Persequor, in VIR IV-1, Berlin-New York, 1985, col. 692 («iudiciaria persecutio»).

As actiones são diferenciadas por Gaio (4, 6-9) conforme destinem-se à obtenção de uma res, de uma poena ou de ambas (res et poena): correspondentemente, distinguem-se entre ações reipersecutórias $(v \cdot g$., actiones ex contractu), meramente penais (v.g., actio furti) e mistas (v.g., actio legis Aquiliae). Cf., v.g., P. JÖRS - W. KUNKEL - L. WENGER et al., Römisches Recht cit. (nt. 412 supra), p. 225; M. KASER, Das römische Privatrecht I cit. (nt. 05 supra), p. 501 e nt. 21.

Essa classificação é retomada nas Institutas imperiais (4, 6, 16-19): actiones «rei persequendae gratia», «poenae persequendae 〈gratia〉» e «mixtae»: na primeira categoria estariam todas as actiones in rem e a maior parte das actiones in personam (como as ações ex contractu); essas últimas também podem ser «poenae persequendae causa» (como as ações ex delicto, v.g, actio furti), e «mixtae», («tam poenae quam rei persequendae») (como certas ações ex delicto, v.g, actio vi bonorum raptorum).

Nerácio refere-se às «actiones persequendae eius», isso é, «actiones persequendae 〈rei>»: parece tratarse, com efeito, de uma locução que consentiria duas interpretações: no sentido genérico, de actiones destinadas à persecução judicial da coisa (independetemente da natureza da ação) (como parece ser Paul. 7 ad ed., D. 50, 16, 14, 1); por outro lado, em acepção mais técnica, de ações «rei persequendae gratia» (ou seja, «reipersecutórias», como na linguagem das Institutas de Justiniano). De todo modo, parece também que, ao menos sob a perspectiva estritamente terminológica, não haveria como determinar o acerto de uma ou outra leitura. 
bonorum raptorum ${ }^{641}$; outros, apenas às «reipersecutórias», a saber, a condictio e a vindicatio $^{642}$.

A seu turno, M. TALAMANCA considera possível conceber, também nesse aspecto (isso é, a inserção das ações penais na obrigação de cessão do vendedor), a existência de uma questão controvertida entre os juristas, dando lugar a soluções diferenciadas em função de ser o vendedor responsável ou não pela perda da res vendita ${ }^{643}$.

De todo modo, ainda que reconheça o autor a prevalência de elementos de dúvida nas fontes, observa que o trecho final («ut omne lucrum et dispendium...sequatur») poderia consistir em um indício a favor da cessão também das ações penais ${ }^{644}$.

Ainda relacionada à obrigação de transferência das actiones, a parte seguinte do texto («actiones autem...sequatur») $)^{645}$ - na que se poderia identificar uma tentativa de tornar mais precisa a decisão do jurista ${ }^{646}$ - oferece também dificuldades de interpretação: afirma-se que as ações deveriam ser cedidas não só «arbitrio», mas também «periculo tuo» (isso é, do comprador).

${ }^{641}$ Cf. V. ARANGIO-RuIZ, Responsabilità cit. (nt. 04 supra), p. 157 (sem se deter, contudo, no obstáculo representado pelo dado textual, que se refere a «actiones»); ainda menos claro a respeito («... cedendo al compratore l'azione contro il rapinatore»), mas provavelmente no mesmo sentido, ID., La compravendita II cit. (nt. 403 supra), p. 249; também, aparentemente, R. GREINER, para quem, no tempo de Nerácio (e mesmo posteriormente) seria ainda possível considerar a actio vi bonorum raptorum como meramente reipersecutória («sachverfolgend»). Cf. Opera Neratii cit. (nt. 590 supra), p. 89.

${ }^{642}$ Cf. J. PARIS, La responsabilité cit. (nt. 42 supra), p. 232-232 (que sustenta a assimilação compilatória das ações penais - actiofurti e vi bonorum raptorum - às reipersecutórias, do que teria resultado o reconhecimento do dever do vendedor de também cedê-las à contraparte); E. BETTI, «Periculum» cit. (nt. 420 supra), p. 140; M. PENNITZ, Das periculum cit. (nt. 30 supra), p. 390.

Por sua vez, J. CUJAS compreende em «actiones persequendae eius» tanto as ações reipersecutórias de fato quanto as ações penais: «Alioqui si res vendita venditori sit vi erepta, periculum ejus rei ad eum non pertinet: et in hoc tantum tenetur, ut cedat emptori actiones, quas adversus praedonem vel raptorem habet, veluti actionem vi bonorum raptorum aut furti, quae cum ea semper concurrit, et condictionem furtivam, et vindicationem, et ut si quid hisce actionibus ipse venditor consecutus fuerit, id emptori praestet, d. 1 . eum qui $\langle$ D. 47, 2, 14>» (= A propósito, se a coisa vendita for subtraída mediante força do vendedor, o risco desse evento não lhe cabe, e apenas nisso estará obrigado, para que que ceda ao comprador as ações que tiver contra o salteador ou ladrão, como por exemplo, a actio vi bonorum raptorum ou $\langle$ actio $\rangle$ furti, que com ela sempre concorre, e a condictio furtiva, e a vindicatio, e se o próprio vendedor tiver obtido algo <com a propositura> dessas ações, para que preste isso ao comprador). Cf. Recitationes solemnes, in Opera VII cit. (nt. 615 supra), cols. 1276-1277 (a D. 19, 1, 31).

${ }^{643}$ Cf. Vendita cit. (nt. 21 supra), p. 429.

644 Não concludentemente, entretanto, já que admite o remanejamento (mais precisamente, um encurtamento) dessa parte do texto (cf. nota seguinte). Cf. M. TALAMANCA, Vendita cit. (nt. 21 supra), p. 429, nt. 1303.

${ }^{645}$ Reputam-na interpolada G. BESELER, Beiträge zur Kritik der römischen Rechtsquellen III, Tübingen, Mohr, 1913, p. 70; R. GREINER, Opera Neratii cit. (nt. 590 supra), p. 90. Por sua vez, M. TALAMANCA não exclui a possibilidade de uma abreviação do discurso do jurista nessa passagem, pois que a frase conclusiva («ut...sequatur») pareceria expor uma consequência do fato de as ações serem cedidas «non solum arbitrio, sed etiam periculo tuo», o que necessitaria de alguma mediação ou particularização. Cf. Considerazioni cit. (nt. 492 supra), p. 246.

${ }^{646}$ Cf. M. TALAMANCA, Considerazioni cit. (nt. 492 supra), p. 246. 
Por um lado, E. BETTI admite que, no direito clássico, Nerácio tivesse considerado conforme à eqüidade dar ao comprador uma espécie de opção (arbitrium), conforme os seus próprios interesses, quanto à propositura das ações reipersecutórias, contanto que assumisse o risco de perda da lide (por outros termos, uma cessão efetuada pro soluto) ${ }^{647}$.

Em contrapartida, embora admita a possibilidade - gramatical, ao menos - dessa leitura, M. TALAMANCA propõe uma outra, cuja vantagem seria aquela de salvar a «lógica interna» do texto. $\mathrm{O}$ trecho em discussão poderia ser interpretado como uma contraposição pensada por Nerácio entre duas hipóteses, a saber, aquela em que o vendedor incorreria na responsabilidade por custodia e aquela em que, por se tratar de vis maior, estaria essa excluída ${ }^{648}$.

A cessão das ações, no primeiro caso - não tratado, explicitamente, no texto -, darse-ia «arbitrio» do comprador (isso é, necessitaria de seu assentimento ${ }^{649}$ ), mas «periculo» do vendedor, no sentido de que seria pro solvendo e não pro soluto ${ }^{650}$. No segundo, considerado efetivamente pelo jurista, o vendedor cederia as ações - de semelhante modo «arbitrio» do comprador, e também (eis o aspecto diferencial), «periculo tuo» (ou seja, pro soluto $)^{651}$.

${ }^{647}$ Cf. «Periculum» cit. (nt. 420 supra), p. 141. Como observa M. TALAMANCA, o comprador já se beneficiava, segundo E. BETTI, do periculum venditoris no caso de perecimento da coisa antes da traditio. Cf. Considerazioni cit. (nt. 429 supra), p. 247. Assim, ao que parece (dada a ausência de maior circunstanciação do argumento pelo próprio autor), o comprador, caso julgasse ser-lhe de interesse, poderia requerer a cessão das ações cujos riscos de resultado de propositura - por equidade, nesse caso - caberiam a ele mesmo e não ao vendedor, que já suportava o periculum (por se tratar, na hipótese, de rapina).

${ }^{648}$ Cf. M. TAlamancA, Considerazioni cit. (nt. 429 supra), pp. 247-248; já assim em ID., Vendita cit. (nt. 21 supra), p. 427.

${ }^{649} \mathrm{E}$ esse, então, seria o sentido de «arbitrium» empregado nessa frase: «arbítrio», «vontade» («Gutdünken», «Willkür»). Cf. HeUMMANN-E. SECKEL, Arbitrium, in Handlexicon cit. (nt. 18 supra), p. 29. Também interpreta o texto, embora considere-o interpolado, nesse sentido F. HAYMANN, Textkritische I cit. (nt. 211 supra), p. 332.

${ }^{650}$ Essa contraposição, «pro solvendo» e «pro soluto» consistiria, pelo que se entende da interpretação de M. TALAMANCA do Gedankengang de Nerácio, na propositura das ações (sempre «arbitrio» do comprador) pelo emptor, respectivamente, sem arcar com o risco econômico do resultado, na primeira hipótese e, na segunda, assumindo-o o comprador e beneficiário da cessio. Cf. Considerazioni cit. (nt. 429 supra), p. 247 , nt. 108 , mais claramente.

Em síntese: sendo o vendedor responsável pelo fato, estaria ele obrigado ao ressarcimento integral na medida do «id quod interest»; não era liberado pela simples cessão das ações. Nesta hipótese, não existiria um direito específico do credor a obter a cessão, e o vendedor não incorre, pela recusa de efetuar a cessão, em uma responsabilidade diversa daquela - geral - pelo ressarcimento do dano. A seu turno, se o vendedor não fosse responsável, a pretensão do comprador limitar-se-ia à cessão da ações, e a ele, exclusivamente, dizia respeito o resultado do processo. A cessão, neste caso, consistia em um dever do vendedor, cuja recusa implicava na responsabilidade pelo «id quod interest», calculado com base no valor das ações cuja cessão fora requerida, e não no valor da coisa. Cf. M. TALAMANCA, Vendita cit. (nt. 429 supra), p. 427, nt. 1293.

${ }^{651}$ Por outros termos, para Nerácio, a contraposição estaria articulada toda na alternativa «periculo tuo»e «periculo 〈meo〉», e o arbitrium consistiria no elemento de identidade, uma vez que em ambos os casos, o consentimento do comprador para a cessão das ações faz-se necessário. Entretanto, não seria de se desconhecer, como pondera M. TALAMANCA, a diferença (sob o plano econômico, sobretudo), entre as duas hipóteses, no que concerne ao significado do arbitrium. Com efeito, na primeira hipótese (vendedor 
Embora não se contraponha a essa interpretação, M. SERRANO-VICENTE sustenta a possibilidade de explicar a passagem com base na «dinâmica do texto»: a menção ao arbitrium dever-se-ia, segundo o autor, à referência a um oportere a cargo do vendedor, decorrente da propositura da actio empti; com efeito, após a litis contestatio, a cessão já não dependeria da vontade do demandado ${ }^{652}$.

Por fim, resta considerar o fundamento desta decisão: o vendedor não responde pelo evento causador (ademptio vi) da impossibilidade do cumprimento da obrigação, limitando-se à cessão das ações deste decorrentes, «quia custodia adversus vim parum proficit» (porque a custódia é pouco eficaz contra a força).

$\mathrm{Na}$ época da Crítica Interpolacionística, principalmente, suspeitou-se da genuinidade dessa frase conclusiva ${ }^{653}$ : Nerácio não poderia, segundo F. HAYMANN, ter-se limitado a tal indicação genérica («vis»), uma vez que - nos casos em que realmente se respondia por custodia - apenas uma atuação violenta, indicada como «vis cui resisti non potest», é que teria efeito liberátorio de responsabilidade ${ }^{654}$.

Contudo, outros consideraram a afirmação do jurista consentânea com a noção clássica de «custodiam praestare: de fato, F. SCHULZ visualizava na vis, referida por Nerácio, o limite da «responsabilidade por custodia» no direito clássico ${ }^{655}$.

Também favorável à autenticidade do trecho, V. ARANGIO-RUIZ: tanto a «vis» quanto a «custodia» seriam termos objetivamente «incomensuráveis» para o jurista ${ }^{656}$, pois Nerácio, ao concluir que a «custodia» de pouco adianta contra a força, não estaria

responsável «por custodia»), a iniciativa de gozar do benefício da cessão cabe ao comprador (mesmo no sentido de aceitar a proposta que lhe é feita pela contraparte); por outro lado, ocorrendo a perda da coisa vendida por vis maior, não coberta pelo «custodiam praestare» do vendedor, o comprador deve também concordar com a realização cessão que, entretanto, representa a sua única alternativa sob o plano econômico, sobre ele recaindo, ademais, os riscos dessa operação («periculo tuo»). Considerazioni cit. (nt. 492 supra), p. 247 e nt. 108; já nesse sentido, ID., Vendita cit. (nt. 21 supra), p. 427 e nt. 1293; 429 e nt. 1301

${ }^{652} \mathrm{O}$ autor reconhece, entretanto, as dificuldades dessa sua proposta, uma vez que, em princípio, o arbitrium (capacidade de decisão) caberia ao juiz. Cf. Custodiam cit. (nt. 429 supra), p. 302 e nt. 939.

${ }^{653}$ Cf. v.g., F. HAYMANN, Textkritische I cit. (nt. 211 supra), pp. 331-332: «Es ist ebenso undenkbar, daß ein genialer Praktiker gesagt habe, man könne mit keiner custodia, cura oder diligentia eine Sache vor Beschädigung schützen, wie daß Bewachung gegen Gewalt zuwenig ausrichte» (= É, do mesmo modo, impensável que um prático genial tenha dito que não se possa, com nenhuma custódia, cuidado ou diligência, proteger uma coisa do dano, como que a guarda pouco pudesse contra a força). Cf. também L. LUSIGNANI, $L a$ responsabilità II cit. (nt. 556 supra), p. 34.

654 A crítica de F. HAYMANN compreende-se na orientação geral do autor de não reconhecer um «custodiam praestare» a cargo do vendedor. Para o autor, a afirmação «fatalista» de Nerácio não poderia corresponder ao pensamento do jurista clássico, uma vez que a «custodia» pode pouco contra a força, mas não sempre. Caso se tratasse da existência de um «custodiam praestare» na compra e venda, o jurista teria discutido, diante do evento considerado, $v, g$., se o vendedor não teria possibilitado a ocorrência dessa vis, seja mediante comportamento positivo ou omissão de determinadas medidas. Cf. Textkritische I cit. (nt. 211 supra), p. 331; mais recentemente, também R. GREINER, Opera Neratii cit. (nt. 590 supra), p. 89.

${ }^{655}$ Cf. Rezension de L. LuSIGNANI, La responsabilità cit. (nt. 557 supra), p. 68.

${ }^{656}$ Cf. Responsabilità cit. (nt. 04 supra), p. 163. 
limitando a sua afirmação a um caso específico, no qual a atividade de guarda de um contratante não teria conseguido evitar a subtração violenta da coisa vendida, mas sim em geral $^{657}$.

A seu turno, as suspeitas de E. BETTI recaem sobre o termo «custodia» que, nessa passagem, denunciaria a nova concepção da custodia como dever de comportamento («dovere di contegno»), ou seja, o «custodire debere» ${ }^{658}$.

Já C. A. CANNATA visualiza nesse trecho uma afirmação central para a determinação dos limites do conteúdo de «custodiam praestare» nessa época: de Nerácio resultaria que a custodia era uma atividade considerada hábil apenas para evitar a subtração da coisa devida a ações não violentas (em outros termos, praticadas «clam», mas não $\ll v i »)^{659}$.

A linha argumentativa do jurista teria paralelos, assim, com a de Juliano ${ }^{660}$ : até essa época, incontroversamente, «custodiam praestare» representaria uma responsabilidade pelo furto da coisa devida; os esforços dos dois juristas estariam, portanto, no sentido de traçar os limites externos dessa responsabilidade: um, dela excluindo a ademptio vi ${ }^{661}$; outro, o damnum iniuria causado por terceiros ${ }^{662}$.

Substancialmente de acordo com os resultados de C. A. CANNATA, M. SERRANOVICENTE considera a afirmação de Nerácio como indicativa de que, para esse jurista, a

657 Por outro lado, tratando-se do furto, o sujeito obrigado a «custodiam praestare» não poderia demonstrar que, naquele caso, especificamente, a sua atividade de custódia da coisa não teria sido eficiente «parum proficit». Cf. V. ARANGIO-RUIZ, Responsabilità cit. (nt. 04 supra), p. 163.

${ }^{658}$ Cf. «Periculum» cit. (nt. 420 supra), p. 140.

${ }^{659}$ Cf. Ricerche cit. (nt. 21 supra), p. 76, nt. 58.

${ }^{660}$ Aproximação essa já notada pelos Glosadores e Cultos: gl. vim a D. 19, 1, 31, texto ao qual se apõe: «cui resisti non potest, ut s. quod me causa 1. $\ddot{y} \&$ facit j. loca. 1. sed de damno, s. commod. 1. ad eos.», remetendo, portanto, a D. 13, 6, 19 e D. 19, 2, 41. Também J. CUJAS: «Qua enim custodia, aut diligentia id consequi possit ut superet vim praedonum, aut damna fatalia? Custodia, inquit, adversus vim parum proficit. Et ita etiam in 1. sed de damno 41. tit. seq. <D. 19, 2, 41> Qua custodia, inquit consequi potest ne damnum injuria ab alio dari possit? Quod et ita scriptum est in 1 . ad eos 19. com. <D. 13, 6, 19> 1. 2 in fin. de peric. rei vend. $\langle$ D.18, 6, 2 in fine $>1$. cum duobus 52. §. damna, pro soc. $\langle$ D. 17, 2, 52, 3>». (= Qual custódia, pois, ou diligência, poderia conseguir que se superasse a força dos salteradores ou os danos fatais? Custódia, diz, contra a força pouco adianta. E assim também em D. 19, 2, 41: qual custódia, diz, pode conseguir, a fim de que um dano injusto causado por terceiro não se verifique? O que foi também escrito assim em D. 13, 6, 19, D. 18, 6, 2 e D. 17, 2, 52, 3). Cf. Recitationes solemnes, in Opera VII cit. (nt. 615 supra), col. 1276 (a D. 19, $1,31)$.

${ }^{661}$ Pretendeu-se, todavia, que «custodiam praestare» abrangesse também a rapina, com base no fato de alguns contratantes (Ulp. 56 ad ed., D. 47, 8, 2, 22) serem - à semelhança do que se passa com a actio furti legitimados à propositura da actio vi bonorum raptorum. $\mathrm{O}$ interesse a tal legitimação estaria, portanto, no fato de responderem tais devedores pela perda da coisa devida ao roubo. Cf., nesse sentido, F. SCHULZ, Die Aktivlegitimation zur actio furti, in SZ 23 (1912), p. 36.

Contudo, tratar-se-iam de situações nas quais tais contratantes teriam assumido tal periculum que, em nenhum outro texto, estaria relacionado com «custodiam praestare». Cf. P. VocI, 'Diligentia' cit. (nt. 12 supra), pp. 67-68; M. SERRANO VICENTE, Custodiam praestare cit. (nt. 26 supra), p. 355, nt. 1129.

${ }^{662}$ Cf. R. GREINER, Opera Neratii cit. (nt. 590 supra), p. 90; M. SERRANO-VICENTE, Custodiam praestare cit. (nt. 26 supra), p. 355. 
custodia teria conteúdo idêntico àquela devida pelo comodatário e o conductor rei servandae: atuação destinada a evitar o furto da coisa, objeto da prestação ${ }^{663}$.

Com «quia custodia adversus vim parum proficit», o jurista adrianeu teria esclarecido o limite da custodia tal como era observado pela iurisprudentia, uma vez que, diante do seu significado basilar de «guarda», «vigilância», (por outros termos, por se tratar de um «conceito aberto»), estaria ele suscetível de extensão ${ }^{664}$.

Da interpretação do texto atribuído a Nerácio, poder-se-ia, a título conclusivo, condensar alguns resultados:

O jurista ocupa-se de um caso - fosse ele real ou hipotético ${ }^{665}$ - de subtração violenta («vi ademptio»), passível de identificação com a rapina, da coisa vendida («res») que poderia, concretamente, tratar-se de um «servus», como sugere o $\S 1^{666}$, e afirma ser mais adequado («propius») que a obrigação do vendedor limite-se à cessão das ações («actiones persequendae eius praestare») ao comprador ${ }^{667}$.

Precisando-se mais a afirmação, diz-se, na seqüencia, que tal cessão - por procuratio in rem suam - dar-se-ia não só «arbitrio», mas também «periculo» do

${ }^{663}$ Cf. Custodiam cit. (nt. 26 supra), p. 301.

${ }^{664}$ Cf. M. SERRANO-VICENTE, Custodiam cit. (nt. 26 supra), p. 355.

${ }^{665} \mathrm{E}$ tal dúvida em razão da natureza variada do material de que se compõem as membranae de Nerácio. Cf. supra.

${ }^{666}$ A circunstância parece, como já sustentava F. SCHULZ, para a interpretação desse texto e da sua solução, irrelevante. Cf. Rezension de L. LUSIGNANI, La responsabilità cit. (nt. 557 supra), p. 68.

Sabe-se, por outros textos, que os «veteres», em matéria de comodato, discutiam a respeito da existência de um «custodiam praestare» a cargo do comodatário em relação também ao «servus». A solução dada é de que, em alguns casos, seria de se reconhecer tal obrigação: assim, se tivesse sido entregue agrilhoado ou em razão da idade, circunstâncias que denotariam a tendência do escravo à fuga, que é o evento especificamente considerado nessa hipótese (e não o furto).

Seria, talvez, possível imaginar uma provável discussão, com soluções diferenciadas, caso se tratasse da fuga do escravo vendido: fosse ele um servus custodiendus (isso é, que por algumas circunstâncias, requeresse uma atividade de vigilância maior por parte do vendedor), responderia esse; caso contrário, não. No entanto, Nerácio considera um caso de subtração violenta do escravo, evento para prevenção do qual aquelas particularidades não parecem influenciar na solução, fundamentada na inevitabilidade (mesmo para aquele obrigado a «custodiam praestare») da ademptio vi.

Assim, se o vendedor devesse «custodiam praestare» (como elemento natural ou acidental do contrato), em relação ao escravo vendido, e fosse ele subtraído clandestinamente (furto), responderia à contraparte na medida do id quod interest; se fugisse, responderia se a obrigação se estendesse à prevenção da fuga (o que dependeria de algumas circunstâncias concretas da coisa, em analogia com o comodato). Porém, se o escravo fosse roubado - tal como qualquer outra res - o vendedor não deveria responder, pelos limites de «custodiam praestare».

${ }^{667}$ A referência genérica («actiones persequendae eius») também não permite determinar quais fossem as actiones a que se referia o jurista, uma vez que da rapina (ou, de todo modo, da ademptio vi), surgiriam ações penais (actio vi bonorum raptorum e actio furti) e reipersecutórias (vindicatio e condictio furtiva). A natureza «reipersecutória», «penal» ou «mista» das ações influenciaria apenas na possibilidade de cumulação ou não das várias ações, mas não na determinação de quais fossem aquelas a serem cedidas ao beneficiário (comprador). Em outros termos, o vendedor poderia - em princípio - cedê-las todas (aquelas nascentes de um mesmo fato), mas a propositura dessas pelo comprador estaria limitada pela natureza dos meios processuais que escolhesse. 
adquirente: por outros termos, caber-lhe-iam os resultados (fossem benéficos ou não) da propositura das ações («omne lucrum ac dispendium») ${ }^{668}$.

A solução dada pelo jurista seria a mesma ainda que o vendedor devesse custodiar a coisa («quamvis eam custodire debuerim»). A leitura dessa locução não é incontroversa, como se demonstrou, já que, abstratamente, poderia aludir tanto a uma obrigação decorrente do próprio contrato como a uma especialmente convencionada ${ }^{669}$.

Diante da ausência de outros textos de Nerácio para confronto ${ }^{670}$, o impasse parece resolver-se a favor da tese que visualiza, no texto, uma orientação favorável à custodia como um naturalia negotii ${ }^{671}$.

Com efeito, o impasse textual encontraria um elemento de apoio para essa opção interpretativa na orientação proculeiana em matéria de periculum rei venditae (periculum emptoris), de que esse texto constituiria (in fine, principalmente), ademais, prova ${ }^{672}$.

A opinião contrária - sustentada por E. BETTI, e amparada na crítica textual por ele proposta (e, ao que consta, sem acolhida) - não foi retomada com argumentos, ao menos sob uma perspectiva estritamente técnica, probantes, uma vez que amparada, ao que parece, na semelhança com as vicissitudes de outros institutos jurídicos ${ }^{673}$.

668 Embora seja controversa a exata interpretação desse trecho, ele parece, contudo, afirmar a não responsabilidade do vendedor pela impossibilidade da prestação decorrente rapina, e a suportação do periculum pelo comprador.

${ }^{669}$ Cf. supra.

${ }^{670}$ De fato, contrariamente a Gaio, de qual se dispõe de outros testemunhos nessa matéria (cf. infra), parece esse texto tratar-se do único dentre aqueles conservados na compilação justinianéia, no qual Nerácio ocupa-se com um problema afeito à responsabilidade contratual na compra e venda.

${ }^{671}$ Seguida, com efeito, pela maioria dos estudiosos do tema (cf. supra).

672 Cf., substancialmente, M. TALAMANCA, Considerazioni cit. (nt. 429 supra), p. 246: «in accordo con l'accentuazione dell'accollo del rischio contrattuale a carico del compratore, di cui si stava dicendo, sembra seguirsi qui l'opinione che fa della responsabilità per custodia, se non un essentiale, almeno un naturale negotii, il che reentra senza alcuna difficoltà nel quadro che si sta delineando» (= de conformidade com a acentuação da atribuição do risco contratual a cargo do comprador, de que se estava dizendo, parece seguirse, aqui, a opinião que faz da responsabilidade por custodia, se não um elemento essencial, ao menos um elemento natural do negócio, o que se insere, sem nenhuma dificuldade, no quadro que se está delineando). Com efeito, já em estudo anterior o autor sustentava ser possível ainda estender essa orientação aparentemente seguida por Nerácio (a custodia como naturalia negotii do contrato de compra e venda) - e que prevaleceria na iurisprudentia posterior - aos proculeianos em geral. Cf. Vendita cit. (nt. 21 supra), p. $449 ; 455$.

${ }^{673}$ Os argumentos de M. SERRANO-VICENTE, Custodiam praestare cit. (nt. 26 supra), p. 300, para a retomada da tese de «custodiam praestare» como (inicialmente) «accidentalia negotii» do contrato de compra e venda parece ressentir essa influência, uma vez que o autor propõe a introdução dessa prestação, na emptio venditio, pela prática negocial e sua incorporação gradual como elemento natural do negócio (tal como, v.g., a responsabilidade por evicção).

Não se refuta que, também nessa matéria, tal «evolução» possa ter-se verificado: antes, como se verá, é o que parece sugerir o conjunto dos textos concernentes. Entretanto, parece discutível tomá-la como argumento (como parece ser o caso) para decidir acerca da orientação de Nerácio a favor de um «custodiam praestare» accidentalia negotii, pelo fato tão-só de ser, juntamente com os de Gaio, os textos mais remotos a fornecer elementos sobre o tema. 
Por fim, o fundamento dessa solução dada por Nerácio - «quia custodia adversus vim parum proficit» - assumiria também relevância por informar acerca dos limites de «custodiam praestare»: assim, no período compreendido entre o final do século I d. C. e início do seguinte, restariam excluídos de seu conteúdo os eventos violentos causadores da perda do objeto da prestação (como, v.g., a rapina).

Por Juliano, mais tarde, sabe-se que tais eventos eram ainda mais limitados, uma vez que o dano causado por terceiros («damnum iniuria ab alio datum») não integrava o conteúdo de «custodiam praestare». Se, por um lado, esta limitação até então observada pela iurisprudentia foi, em partes, modificada por Marcelo, por outro, não aquela fixada por Nerácio: a rapina continuaria excluída do conteúdo de «custodiam praestare» ${ }^{674}$.

\section{O furto da «res vendita»}

Gai. 10 ad ed. prov., D. 18, 1, 35, 4: Si res vendita per furtum perierit, prius animadvertendum erit, quid inter eos de custodia rei convenerat: si nihil appareat convenisse, talis custodia desideranda est a venditore, qualem bonus pater familias suis rebus adhibet: quam si praestiterit et tamen rem perdidit, securus esse debet, ut tamen scilicet vindicationem rei et condictionem exhibeat emptori. Unde videbimus in personam eius, qui alienam rem vendiderit: cum is nullam vindicationem aut condictionem habere possit, ob id ipsum damnandus est, quia, si suam rem vendidisset, potuisset eas actiones ad emptorem transferre.
Se a coisa vendida tiver-se perdido por furto, averiguar-se-á, primeiramente, aquilo que fora acordado entre < as partes contratantes> sobre a custódia da coisa. Se resultar que nada foi acordado, há de se requerer do vendedor a custódia que um bom pater familias aplica às suas coisas. Se a tivesse prestado e, não obstante, perdeu a coisa, não deve responder, contanto que transfira ao comprador a rei vindicatio e a condictio. $\mathrm{E}$, assim, veremos em relação àquele que tiver vendido coisa alheia: pois que esse não pode ter nem vidicatio, nem condictio, há de ser condenado por isso mesmo, uma vez que, se tivesse vendido coisa sua, teria podido transferir essas ações ao comprador.

Ao se considerar a hipótese de perda da coisa vendida por furto, afirma-se que, em primeiro lugar, há de se verificar - a fim (entende-se) de decidir acerca das conseqüências,

\footnotetext{
Além disso - e também aqui parece apoiar-se o autor (cf. ibidem, pp. 299-300) - visualizar em Gaio, jurista posterior (e favorável, ao que parece, ao «custodiam praestare» como elemento convencional), um parâmetro para interpretação do texto de Nerácio (e estabelecer uma consonância de posicionamentos entre os dois juristas, fundamentado em critério cronológico) seria também questionável. Com efeito, Gaio, contrariamente a Nerácio (corifeu proculeiano), teria sido mais inclinado às orientações sabinianas, o que poderia não ser um aspecto sem repercussão sobre o problema do periculum rei venditae e, consequentemente, sobre a «posição» de «custodiam praestare» no negócio.

${ }^{674}$ Cf. Ulp. 28 ad ed., D. 13, 6, 5, 4 («vi latronum ereptum»); Gai. 9 ad ed. prov., D. 13, 6, 18 pr. («latronum hostiumve incursus») e Ulp. 29 ad Sab., D. 50, 17, 23 («rapinae»).
} 
para as partes, da perda do objeto da prestação - o que fora convencionado entre vendedor e comprador acerca da custódia da coisa («de custodia rei»).

Se nada tiver sido acordado a esse respeito - única hipótese tratada no texto - a custódia que o vendedor deveria observar seria aquela que o bonus pater familias aplica, em geral, às suas próprias coisas. Desse modo, se a coisa vendida (mas não ainda entregue) tiver sido furtada do vendedor, não responderá esse, contanto que tenha observado tal custódia.

Estará ele, porém, obrigado a ceder a vindicatio e a condictio à contraparte: por essa razão, se o vendedor não fosse proprietário da coisa furtada, já que não poderia realizar tal transferência dos meios processuais, seria então - por essa impossibilidade - condenado ${ }^{675}$.

Não se apresenta a locução em sua forma consueta - «custodiam praestare» ${ }^{676}$ mas a conexão desse texto com o respectivo problema, além dos dados «custodia rei», «talis custodia», parece encontrar apoio no evento presente no Sachverhalt: o furto da coisa vendida ${ }^{677}$.

A consideração dessa hipótese provém de Gaio, jurista do século II d. C. ${ }^{678}$, contemporâneo de Africano e Pompônio, que, embora pouco conhecido (ou talvez até desconhecido) de seus contemporâneos, granjeou larga fama em época pós-clássica, particularmente no século $\mathrm{V}$ d. $\mathrm{C}^{679}$.

${ }^{675}$ Em linhas gerais, vislumbrou-se uma aproximação, no que concerne à linha expositiva, desse com o texto de Nerácio: considera-se a obrigação de tradere do vendedor, a sua impossibilidade devido a uma subtração da res vendita, a questão acerca da possível responsabilidade do vendedor, e a solução no sentido de reduzi-la à obrigação de ceder as ações ao comprador. Cf. M. SERRANO-VICENTE, Custodiam praestare cit. (nt. 26 supra), p. 299.

${ }^{676}$ De todo modo, nota-se que, na seqüência do texto, o «praestiterit» tem por objeto «quam», relativo à «custodia», qualificada como aquela própria de um bonus paterfamilias.

${ }^{677}$ Estaria presente, como afirma M. PENNITZ, o «Kernbereich» da «responsabilidade por custodia» clássica. Cf. Das periculum cit. (nt. 409 supra), p. 386; já nesse sentido, C. A. CANNATA, Ricerche cit. (nt. 21 supra), p. 136 e nt. 61; G. MACCORMACK, Custodia cit. (nt. 264 supra), p. 182 e nt. 111.

${ }^{678}$ É provável que Gaio já tivesse nascido na época de Adriano (imperador de 117 a 138 d.C.) e, de todo modo, não teria falecido antes da época de Cômodo (imperador de 180 a 192 d. C.), pois lhe é atribuído um comentário ao senatusconsulto Orfitianum (de 178 d. C.). Cf. P. KRÜGER, Geschichte cit. (nt. 476 supra), p. 201; P. Wenger, Die Quellen cit. (nt. 476 supra), p. 506; R. ORESTANO, Gaio, in NNDI 7 (1968), pp. 732733; A. GUARINO, L'esegesi I cit. (nt. 314 supra), pp. 217-229.

Os dados biográficos do jurista são, porém, bastante escassos: sua proveniência de alguma província oriental helênica remanesce uma hipótese, sem dados concludentes; parece ter-se consagrado ao estudo e ao ensino; não exerceu qualquer carreira política; e, com muita probabilidade, não dispôs do ius respondendi. Cf. P. KRÜGER, Geschichte cit. (nt. 476 supra), pp. 211-212; M. KASER, Römische Rechtsgeschichte cit. (nt. 594 supra), p. 172; A. GUARINO, L'esegesi I cit. (nt. 314 supra), pp. 217-218; R. ORESTANO, Gaio cit. (nt. 678 supra), p. 732; G. DULCKEIT - F. SCHWARZ - W. WALDSTEIN, Römische cit. (nt. 592 supra) p. 265.

${ }^{679}$ Cf., v.g., Theod. et Valentin., C. Th. 1, 4, 3 (de 426) (inclusão na «lei das citações»), que pressupõe, como nota P. KRÜGER, a sua penetração tanto nas escolas quanto na prática jurídicas, e finalmente, sob Justiniano, a sua referência como «Gaius noster» (const. Imperatoriam, § 6; const. Omnem, § 1; Inst. 4, 18, 5 e Pomp. 22 ad Q. Muc., D. 45, 3, 39, sobre o qual, infra). Cf. Geschichte cit. (nt. 476 supra), p. 211 e nt. 66; W. KUNKEL, Die römischen cit. (nt. 476 supra), p. 187; A. GUARINO, L'esegesi I cit. (nt. 314 supra), pp. 216217. 
Dentre as particularidades desse jurista, podem-se contar o fato de se fazer conhecer apenas por seu prenome, o qual aparece vinculado às obras cuja autoria lhe é atribuída, e também ser um dos únicos juristas - ao lado de Florentino e Calistrato ${ }^{680}$ - não citados nos escritos de outros clássicos ${ }^{681}$.

Gaio ocupou-se com o direito privado, e revelou-se um autor bastante fecundo, conquanto não muito original e independente ${ }^{682}$, dotado de vasto conhecimento dos juristas anteriores, de Quinto Múcio a Juliano, do qual acolhe frequentemente as opiniões; em contrapartida, não parece atualizado em relação às normas mais recentes ${ }^{683}$.

Tanto o âmbito de sua obra, quanto o seu caráter «enciclopédico» e as inclinações por aspectos históricos do direito aproximam-no de Pompônio; o estilo de sua exposição seria, ademais, claro e elegante ${ }^{684}$.

Dentre os principais trabalhos atribuídos a Gaio estão aqueles de caráter elementar: as institutiones (ou institutionum commentarii quattuor) (as «Institutas de Gaio»), os libri III regularum e - provavelmente devidos a reformulações pós-clássicas - o liber singularis regularum e o libri VII rerum cottidianarum sive aureorum ${ }^{685}$.

A produção gaiana compreende, além disso: os libri ex Q. Mucio, os libri VI ad legem XII tabularum, os libri ad edictum praetoris urbani ou urbicum, os libri XXX ad edictum provinciale, os libri II ad edictum aedilium curulium, os libri II de fideicomissis, o liber singularis de tacitis fideicomissis, os libri III de manumissionibus, os libri III de verborum obligationibus, os libri singulares (monografias): dotalicion, ad SC. Tertullianum, ad SC. Orfitianum, de formula hipothecaria, de casibus, ad legem Glitiam, e os libri XV ad legem Iuliam et Papiam ${ }^{686}$.

O texto em exame integra um fragmento extraído do décimo livro dos comentários ao edito provincial (ad edictum provinciale), que perfazem um total de $30 \operatorname{livros}^{687}$,

${ }^{680}$ Cf. M. TALAMANCA, Istituzioni cit. (nt. 05 supra), p. 06.

${ }^{681}$ Com efeito, o «Gaius» referido em alguns textos - v.g., Iul. 2 ad Urs. Fer., D. 24, 3, 59, Iav. 2 ex Cass., D. 35, 1, 54 pr., Iav. 11 ex Cass., D. 46, 3, 78 - tratar-se-ia de Cássio Longino; por sua vez, o «Gaius noster», citado no final de um texto de Pompônio (22 ad Q. Muc., D. 45, 3, 39), é admitido comumente como uma interpolação. Cf. W. KUNKEL, Die römischen cit. (nt. 476 supra), p. 187 e nt. 341.

${ }^{682}$ Cf. R. ORESTANO, Gaio cit. (nt. 678 supra), p. 733.

${ }^{683}$ Cf. W. KUnKel, Die römischen cit. (nt. 476 supra), p. 191; A. GUARINO, L'esegesi I cit. (nt. 314 supra), p. 219.

${ }^{684}$ Cf. P. KRÜGER, Geschichte cit. (nt. 476 supra), p. 201; 204; W. KUNKEL, Die römischen cit. (nt. 476 supra), p. 189; A. GUARINO, L'esegesi I cit. (nt. 314 supra), p. 218; 212; R. ORESTANO, Gaio cit. (nt. 678 supra), p. 732.

${ }^{685}$ Cf. A. GUARINO, L'esegesi I cit. (nt. 314 supra), p. 220.

${ }^{686}$ Cf. O. LENEL, Palingenesia I cit. (nt. 483 supra), cols. 182-266; P. KRÜGER, Geschichte cit. (nt. 476 supra), pp. 201-21; A. GUARINO, L'esegesi I cit. (nt. 314 supra), p. 220.

${ }^{687}$ A obra gaiana recebeu, porém, o nome de «ad edictum provinciale bibl ia / b» (ou seja, XXXII) (cf. Index auct. XX, 1). Com efeito, os 30 primeiros livros consistem em comentários ao edictum provinciale, ao 
escritos, muito provavelmente, ainda sob Antonino Pio (138-161 d. C. $)^{688}$. Essa obra assume uma posição particular na iurisprudentia romana, pois teria sido o único comentário ao edito provincial, que - a seguir a opinião majoritária - seria não o edito de uma determinada província, mas sim de caráter geral, proposto para todas elas ${ }^{689}$.

Os fragmentos do comentário gaiano revelariam uma coincidência substancial com aqueles comentários ao edito do pretor urbano subseqüentes a Adriano, seja na estrutura, seja no conteúdo ${ }^{690}$. Portanto, é de se supor que o edictum comentado por Gaio não teria divergido em muitos aspectos do primeiro, concordância que teria permitido aos compiladores fazer largo uso ${ }^{691}$ dessa obra na composição do Digesto.

Em suma, Gaio dedicava-se, nesse trabalho, ao tratamento do ius honorarium ${ }^{692}$, conforme a estrutura dos demais comentários ad edictum (isto é, do pretor urbano). Seguindo-se, assim, a ordem do edito, o livro 10 encerra regras concernentes às actiones fiduciae vel contra, mandati vel contra, pro socio, empti venditi e locati conducti ${ }^{693}$.

O fragmento 35 principia a secção (composta de seis fragmentos, contando-se com aquele referido in fine) dedicada à compra e venda (emptio venditio), sendo intercalado, entre os $\S \S 4$ e 5 - a seguir a reconstrução de O. LENEL - por D. 47, 2, $49^{694}$.

Gaio determina ${ }^{695}$ a relação existente entre a dação de arras e a convenção sobre o preço, da qual depende a existência da compra e venda ${ }^{696}$; esclarece que o negócio é imperfectum se a determinação do preço é deixada ao arbítrio do vendedor ${ }^{697}$; considera

passo que os dois últimos tratam do edito do edil (ad edictum aedilium curulium) que, nessa sede, figuram como livros 31 e 32, o que provavelmente se deve a uma conexão estabelecida entre os dois comentários por um autor pós-clássico. Cf. O. LENEl, Palingenesia I cit. (nt. 483 supra), col. 189, nt. I; P. KRÜGER, Geschichte cit. (nt. 476 supra), p. 202 e nt. 10; F. SCHULZ, Geschichte cit. (nt. 590 supra), p. 236.

De todo modo, muito se discute sobre o significado de «edictum provinciale», acerca do qual Gaio parece ser o único a ter escrito comentários. Cf. um panorama dessas discussões em F. KNIEP, Der Rechtsgelehrte Gaius und die Ediktskommentare, Jena, Fischer, 1910, pp. 124-126; 149-154, principalmente; W. KUNKEL, Die römischen cit. (nt. 476 supra), p. 193; F. SCHULZ, Geschichte cit. (nt. 590 supra), p. 237; A. GUARINO, L'esegesi I cit. (nt. 314 supra), p. 219.

${ }^{688}$ Cf. O. LENEL, Palingenesia I cit. (nt. 483 supra), col. 189, nt. I.

689 Cf. W. KunKEL, Die römischen cit. (nt. 476 supra), pp. 192-193, com remissão, em notas, às principais teses a respeito do edictum provinciale, sob a perspectiva de sua utilização como argumento (um dos principais, aliás) favorável à origem provinciana de Gaio.

${ }^{690}$ Cf. W. KUNKEL, Die römischen cit. (nt. 476 supra), p. 193.

${ }^{691}$ Cf. O. LENEL, Pal. Gai. 53-388 (com efeito, 335 fragmentos).

${ }^{692}$ Cf. P. KRÜGER, Geschichte cit. (nt. 476 supra), p. 202

${ }^{693}$ Cf. O. LENEL, Pal. Gai. 231-246.

${ }^{694}$ Cf. Pal. Gai. 238.

${ }^{695}$ Cf., respectivamente, 10 ad ed. prov., D. 18, 1, 35, pr-3. Cf. uma síntese do teor do fragmento («inhaltliche Zusammenhang») oferece M. PENNITZ, Das periculum cit. (nt. 409 supra), pp. 280-281.

${ }^{696}$ Cf., também, Gai. 3, 139, textos que reafirmariam a noção das arras para os clássicos: confirmação da conclusão do negócio realizada pelo consenso. Cf. M. KASER, Das römische Privatrecht I cit. (nt. 05 supra), pp. 547-548 e nt. 21.

${ }^{697}$ Excluía-se, no direito romano, a determinação do preço por arbitragem de uma das partes, devendo esse ser fixado ou mediante uma precisa soma de dinheiro ou per relationem (entende-se a relatio a um dado 
hipóteses em que a ilicitude do objeto da prestação pode afetar a obrigação ${ }^{698}$; em conexão com esse último problema, afirma a validade da venda do escravo fugitivo (caso encontrado) por um mandatário ${ }^{699}$.

Antes de tratar daquelas coisas que se individualizam a partir do peso, número e medida (tendo-se em vista o momento da «perfeição» da venda) ${ }^{700}$, o jurista ter-se-ia ocupado com a determinação das conseqüências da subtração clandestina da coisa vendida antes da entrega ${ }^{701}$.

De semelhante modo, nesse texto também não se determina o objeto da prestação, considerando-se uma genérica $\left\langle r e s\right.$ vendita ${ }^{702}$; entretanto, o evento, que influi sobre a possibilidade de cumprimento da obrigação do vendedor («perierit»), é o furto («per furtum») que - desde Labeão, ao menos ${ }^{703}$ - integraria o «conteúdo típico» de «custodiam praestare».

Confrontado com essa hipótese, Gaio parece fazer com que a solução dependa («prius animadvertendum erit») do que fora convencionado entre as partes acerca da custódia da coisa («quid inter eos de custodia rei convenerat»): trata-se, em princípio, do elemento decisivo ${ }^{704}$, cujo conteúdo, entretanto, não é incontroverso entre os estudiosos.

J. PARIS nega à locução «custodia» a acepção técnica de «responsabilidade por custodia», que indicaria tão-só, nesse texto, a guarda da res vendita, em relação à qual as partes poderiam aduzir, mediante pactos, quaisquer outras obrigações especiais ${ }^{705}$.

objetivo): nesse caso, a individualização do preço não se verificava no ato mesmo de celebração do negócio, mas nesse se estabeleciam critérios com base nos quais fosse ela determinável (assim, v.g., o preço da venda poderia consistir naquele pago, a seu turno, pelo vendedor, quando adquiriu a coisa, ou na soma de dinheiro existente em certo local) (cf., v.g., Ulp. 28 ad Sab., D. 18, 1, 7, 1-2). Cf. M. TALAMANCA, Istituzioni cit. (nt. 05 supra), p. $517 ; 585$.

${ }^{698}$ Cf. M. TALAMANCA, Istituzioni cit. (nt. 05 supra), p. 519.

${ }^{699}$ O pronunciamento do jurista sobre esse problema encontraria explicação pela invalidade da venda de coisa furtada: com efeito, o servo, ao fugir, cometia furto de si mesmo («sui furtum facit»), e tornava-se «urtivus»; nessa condição, não se poderia - validamente - vendê-lo: «furtivus autem servus non potest vendi», como notou J. CUJAS. Cf. Recitationes solemnes, in Opera VI cit. (nt. 615 supra), col. 1129 (a D. 18, $1,35,4)$.

${ }^{700}$ Cf. 10 ad ed. prov., D. 18, 1, 35, 5 e 7, principalmente.

$701 \mathrm{Ou}$, como prefere M. PENNITZ, o jurista ter-se-ia ocupado, nesse parágrafo, com o chamado «stellvertretendes commodum», após o furto de uma coisa vendida. Cf. Das periculum cit. (nt. 30 supra), p. 280.

${ }^{702}$ No parágrafo precedente $(\S 3)$, trata-se de uma hipótese de venda de um «servus fugitivus», mas não parece - e também não teria pretendido a doutrina consultada - haver uma relação necessária ou sugestiva com o texto ora estudado. De todo modo, uma vez que se considera o evento furto, a possível implicação de um escravo como objeto concreto da prestação parece ser circunstância irrelevante para a solução. De qualquer modo, por força do evento (furtum), a res vendita teria natureza móvel. Nesse sentido, v.g., M. PENNITZ, Das periculum cit. (nt. 30 supra), p. 385.

${ }^{703}$ Cf. R. CARDILLI, L'obligation cit. (nt. 04 supra), p. 372-373.

${ }^{704}$ Cf., nesse sentido, aparentemente, M. PENNITZ, Das periculum cit. (nt. 30 supra), p. 385.

${ }^{705}$ Cf. Responsabilité cit. (nt. 42 supra), p. 223; 336-337. 
Por sua vez, sustenta V. ARANGIO-RuIZ que o pacto aludido por Gaio tivesse por efeito - originalmente - ou a exclusão de «custodiam praestare», elemento natural do contrato, ou a extensão desse, de modo a compreender eventos dele exorbitantes: «si res vendita per furtum perierit, prius animadvertendum est, quid inter eos convenerat: si nihil appareat convenisse, custodia desideranda est a venditore» ${ }^{706}$.

Supera-se o obstáculo que se apresenta a essa interpretação - a saber, o regime resultante da ausência de convenção a respeito («si nihil...emptori»), não correspondente ao da «custodia clássica» ${ }^{707}$ - com a admissão de interpolações. A identificação da custodia, em caso de inexistência de especial acordo, com aquela (diligentia) devida por um bonus pater familias denunciaria, assim, a intervenção compilatória ${ }^{708}$.

Por esse modo, segundo V. ARANGIO-RUIZ, os comissários justinianeus, visaram ao conferir um sentido atécnico ao termo «custodia» ${ }^{709}$ - a transformar o «custodiam praestare», elemento natural do contrato de compra e venda, em elemento acidental ${ }^{710}$, dependente de uma assunção explícita, o que teria consistido em uma das formas pelas quais os bizantinos buscaram suprimir ou atenuar a «responsabilidade objetiva» clássica $^{711}$.

${ }^{706}$ (= Se a coisa vendida tiver-se perdido por furto, há de se averiguar, primeiramente, o que fora convencionado entre as partes: se resultar que nada foi convencionado, há de se requerer do vendedor a custódia). Cf. La compravendita II cit. (nt. 403 supra), p. 248; também admite ter sido esse o teor original do texto (isso é, responsabilidade absoluta pelo furto na ausência de convenção), F. ScHUlz, Rezension de L. LUSIGNANI, La responsanbilità cit. (nt. 557 supra), p. 69. Por outros termos: «custodiam praestare» figuraria como elemento natural da compra e venda, e um eventual pacto teria por efeito ou excluí-la (e diminuir, assim, a extensão da responsabilidade do vendedor, não compreendendo tout court o stare praes pelo furto), ou então derrogá-la pela sobreposição de um regime ainda mais gravoso para o vendedor, tornando-o responsável tambem por eventos (v.g., subtração violenta) não integrantes do seu «conteúdo típico» (v.g., furto, damnum iniuria datum).

${ }^{707}$ Crítica que lhe faz, precisamente, M. SERRANO-VICENTE: o jurista não poderia aludir, nessa passagem, a uma exoneração de responsabilidade, já que do conteúdo do texto se poderia verificar que a «custodia» exigida do vendedor, na ausência de um pacto, não se identificaria com «custodiam praestare». Cf. Custodiam praestare cit. (nt. 26 supra), p. 293, nt. 902.

Como efeito, considera-se que essa «custodia» poderia ter sido observada pelo vendedor e ainda assim ter ocorrido o furto da coisa, com a consequência de liberá-lo da responsabilidade, o que diverge do regime a que estão submetidos aqueles devedores obrigados a «custodiam praestare», para os quais surge o dever de responder tout court pela ocorrência de certos eventos (v.g., furto, dano causado por terceiros).

708 Cf. V. ARANGIO-RuIZ, Responsabilità cit. (nt. 04 supra), p. 160; pp. 74-75 e nt. 01; ID., La compravendita II cit. (nt. 403 supra), p. 218; p. 248; mais recentemente, A. METRO, L'obbligazione cit. (nt. 22 supra), pp. 199-200 e nt. 271.

${ }^{709}$ Cf. Responsabilità cit. (nt. 04 supra), p. 160; p. 74, nt. 01.

${ }^{710}$ Cf. Responsabilità cit. (nt. 04 supra), p. 159, nt. 01.

711 Conforme o autor, ter-se-ia uma prova de que fosse essa a doutrina acolhida pelo direito justinianeu em Inst. 3, 23, 3a, texto no qual a custodia do vendedor está subordinada a uma assunção explícita («custodiam susceperit»); ademais, as Institutas imperiais corresponderiam ao setor da compilação no qual se deu, mais incisivamente, a incidência das concepções do ambiente jurídico bizantino em matéria de ilícito contratual. Cf. Responsabilità cit. (nt. 04 supra), pp. 150-153. 
Em contrapartida, E. BETTI sustenta que o pacto referido por Gaio teria por conteúdo, precisamente, o «custodiam praestare», já que esse, no direito clássico, era apenas um accidentalia negotii na compra e venda ${ }^{712}$. As interpolações ${ }^{713}$ revelariam o propósito de elevar as ocorrências da responsabilidade «pattizia» a responsabilidade ex lege, contrabalanceando a regra - no direito pós-clássico - periculum est emptoris ${ }^{714}$.

À parte os «guasti» decorrentes da subjetivização da custodia $^{715}$, a convenção «de custodia rei» aludida por Gaio, segundo M. TALAMANCA, teria por conteúdo «custodiam praestare $^{716}$.

A ausência de indícios de reinterpretação compilatória da custodia em diligentia in custodiendo em Inst. 3, 23, 3a (infra), por sugerir uma reprodução do original, seria um ulterior indício de que, para Gaio - jurista que, muito provavelmente, serviu de base para esse texto do manual imperial - a custodia consistia em um elemento acidental do contrato de compra e venda ${ }^{717}$.

Aduz R. CARDILli um ulterior argumento a favor da configuração de «custodiam praestare» como elemento acidental nesse texto. Traduziria ela uma maior conformidade com a «lógica» do jurista ao qual é atribuído: com efeito, Gaio não poderia fundamentá-lo - tratando-se do vendedor - como um naturalia negotii nem com base na existência de um prestação acessória de custódia da coisa, nem ainda com recurso à utilitas contrahentium $^{718}$.

${ }^{712}$ Cf. «Periculum» cit. (nt. 429 supra), p. 139.

713 «Si res vendita per furtum perierit, prius animadvertendum erit, quid inter eos de [custodia rei] <re custodienda> convenerat: si nihil appareat convenisse, [talis custodia] <ea diligentia > desideranda est a venditore, qualem bonus pater familias suis rebus adhibet». (= Se a coisa vendida tiver-se perdido por furto, averiguar-se-á, primeiramente, aquilo que fora acordado entre as partes acerca da coisa a ser custodiada. Se resultar que nada fora acordado, há de se requerer do vendedor a diligência que um bom pater familias dispensa às suas coisas). Cf. E. BETTI, «Periculum» cit. (nt. 420 supra), p. 139.

${ }_{714}$ Cf. «Periculum» cit. (nt. 420 supra), p. 139.

${ }^{715}$ Não se indicam, entretanto, com precisão, quais fossem essas corruptelas do texto.

${ }^{716}$ Cf. Vendita cit. (nt. 21 supra), p. 448, nt. 1507.

717 Cf. M. TAlamancA, Vendita cit. (nt. 21 supra), p. 448, nts. 1501 e 1508. Por outros termos, o «custodiam praestare» convencional nas Institutas de Justiniano, conservado em seu teor literal (e não reformulado em termos de diligentia), comprovaria a conexão com o pensamento genuíno de Gaio, cuja obra teria sido utilizada na na composição daquelas.

Já V. ARANGIO-RUIZ suspeita, em relação ao aludido parágrafo das Institutas, da fidelidade dos compiladores à fonte gaiana que tiveram por base: para o autor, tanto Inst. 3, 23, 3a quanto o estado atual de Gai. 10 ad ed. prov., D. 18, 1, 35, 4 denunciariam o propósito compilatório de tornar a custodia um elemento acidental no regime jurídico da compra e venda. Cf. Responsabilità cit. (nt. 04 supra), p. 153.

${ }^{718}$ Tal como se poderia inferir do «Gedankengang» do jurista, respectivamente, em 5 ad ed. prov., D. 19, 2, 40 (neste caso, dir-se-ia que o vendedor «non pro custodia sed pro re pretium accipit») e Gai. 3, 205-206. Cf. L'obbligazione cit. (nt. 04 supra), p. 494. Note-se, entretanto, que a utilitas contrahentium é um fundamento do regime agravado de responsabilidade ao qual recorre Gaio nas Institutas (3, 205-206), mas nem sempre de modo rigorosamente coerente: assim, justifica-se, por um lado, o «custodiam praestare» do comodatário com o «utendi commodum», e por outro, o do fullo e sarcinator, conductore operis, com o «mercedem capiendo». 
Mais recentemente, também M. SERRANO-VICENTE sustenta ser o «custodiam praestare» o objeto do pacto referido por Gaio (ou, em outros termos, sua conformação como accidentalia negotii) ${ }^{719}$. Do texto se poderia deduzir o propósito do jurista, cuja atenção estava voltada a resolver a relação entre custodia e periculum, de aplicar também à compra e venda um regime já vigente no âmbito da locação e do comodato ${ }^{720}$.

De todo modo, a existência de tal obrigação dependeria da intermediação de um pacto entre os contratantes, cujo teor poderia - em princípio - consistir tanto na assunção do periculum furti quanto na submissão a um regime de responsabilidade análogo ao do comodatário $^{721}$.

Gaio, entretanto, não se detém no caso de se ter convencionado algo sobre a custodia da coisa, ou seja - como se tem admitido -, na hipótese de assunção de «custodiam praestare» pelo devedor. Considera o jurista a outra: «si nihil appareat convenisse», isso é, na qual nada se convencionou, exigindo do vendedor aquela «custodia» que um bonus pater familias costuma exercer sobre as suas próprias coisas («talis custodia...adhibet»).

Como já se notou, V. ARANGIO-RUIZ, pretendeu que a identificação da «custodia»a ser observada em caso de inexistência de específica convenção com a diligentia do bonus pater familias denunciaria a intervenção justinianéia que teria, nesse caso, privado o termo de tecnicidade e subordinado o «custodiam praestare» a uma assunção expressa ${ }^{722}$.

Em contrapartida, salva a genuinidade substancial do texto ${ }^{723}$, vislumbrou J. PARIS a coerência de se identificar tal «custodia» com a diligentia boni patrisfamilias na guarda da coisa (valeria dizer, a diligentia in custodiendo). Logo, ausente uma convenção, dever-

\footnotetext{
${ }^{719}$ Cf. Custodiam cit. (nt. 26 supra), p. 293; 295, especialmente.

${ }^{720}$ Por outros termos: diante da perda da coisa devida ao furto, teria o jurista buscado determinar se o periculum emptoris englobaria também esse evento ou se, ao invés disso, caberia ao vendedor uma responsabilidade, o que equivalia, em suma, na verificação da existência de um «custodiam praestare» a seu cargo. Tal perquirição, como nota o autor, faria sentido no âmbito de uma corrente jurisprudencial clássica preocupada em corrigir os desajustes (contrários à boa-fé) resultantes da aplicação de periculum emptoris. Cf. M. SERRANo-Vicente, Custodiam cit. (nt. 26 supra), p. 292; 294-295.

${ }^{721}$ No caso da compra e venda (contrariamente ao comodato), tratar-se-ia de situações distintas: no primeiro caso, ao assumir o periculum, a relação contratual estaria praticamente extinta, podendo o comprador reclamar o preço com a propositura da actio empti; em contrapartida, na segunda hipótese, o comprador poderia não apenas obter a restituição do preço pago, mas também o id quod interest no cumprimento da prestação pelo vendedor. Cf. M. SERRANO-VICENTE, Custodiam cit. (nt. 26 supra), p. 293, nt. 903.

${ }^{722}$ Cf. Responsabilità cit. (nt. 04 supra), p. 160; pp. 74-75; ID., La compravendita II cit. (nt. 403 supra), p. $218,248$.

${ }^{723}$ De fato, suspeita-se da formulação: «talis custodiam... qualem...». Cf., v.g., H. HEUMANN - E. SECKEL, Custodia, in Handlexicon cit. (nt. 18 supra), p. 118; J. PARIS, La responsabilité cit. (nt. 42 supra), p. 223; A. METRo, L'obbligazione cit. (nt. 22 supra), pp. 199-200; C. A. CANNATA, Ricerche cit. (nt. 21 supra), p. 58, para quem essas «precisazioni ulteriori», verificáveis em vários outros textos, seriam atribuíveis a um ambiente diverso daquele da iurisprudentia clássica.
} 
se-ia uma guarda normal (custodia), em relação à qual se deve observar a diligência de um bonus pater familias ${ }^{724}$.

Também E. BETTI sustenta que se haveria de requerer do vendedor, na falta de um pacto «de re custodienda», aquela que teria sido, na iurisrpudentia clássica, o critério adotado para a valoração do comportamento devido na emptio venditio e na locação, a saber, a diligentia do pater familias ${ }^{725}$.

De semelhante modo, M. TALAMANCA: o vendedor estaria obrigado, ausente uma convenção acerca dos critérios de determinação de responsabilidade - mais especificamente, de um «custodiam praestare» - , à diligentia diligentis, isso é, a diligentia normal $^{726}$.

Assim, estando o vendedor, ante traditionem, obrigado nesses limites (isso é, à observância da diligentia do bonus paterfamilias), ele apenas responderia pelo inadimplemento que tenha por causa a violação desse seu dever, isto é, por culpa (e, evidentemente, também por dolus), consistente na inobservância da diligentia normal ${ }^{727}$.

${ }^{724}$ Cf. La responsabilité cit. (nt. 42 supra), pp. 223-224; 337.

${ }^{725}$ Cf. «Periculum» cit. (nt. 420 supra), pp. 136-137.

${ }^{726}$ Cf. Vendita cit. (nt. 21 supra), p. 448, nt. 1507; também nesse sentido, mas sem novos argumentos, M. SERRANO-VICENTE, Custodiam cit. (nt. 26 supra), p. 294.

${ }^{727}$ Cf. J. PARIS, La responsabilité cit. (nt. 42 supra), pp. 223-224; M. TALAMANCA, Vendita cit. (nt. 21 supra), p. 448, nt. 1507. Já nesse sentido, cf. gl. qualem bonus pater familias a D. 18, 1, 35, 4, e a epígrafe ao texto dada por BALDO: «Venditor tenetur praestare custodiam in re vendita: \& si sine culpa sua perdatur, non tenetur nisi ut actionem cedat: quam si cedere non potest, sine culpa tenetur». (= $\mathrm{O}$ vendedor está obrigado a prestar a custódia em relação à coisa vendida: e se ela se perder sem culpa sua, não está obrigado senão a ceder a ação; se não pode cedê-la, deve responder sem culpa). E também. J. CUJAS: «Res vendita subrepta est venditori. Quaeritur cui perierit, emptorine, an venditori? Distinguendum est hoc modo: vel custodiam ejus suscepit venditor usque ad traditionem cujus generis conventio legitima est, 1 . contractus, inf. de reg. jur.; 1. in princ. inf. de peric.et comm. rei vend. Hoc casu ad venditoris (sic!) periculum rei pertinet $\S$ cum autem, Inst. eod. ubi eadem species proponitur. Vel non suscepit custodiam, et hoc casu custodia talis in eo desideratur, qualem diligentissimus paterfamilias suis rebus adhibet, 1. custodia, inf. de per. et comm. rei vend. Objicitur d. §. cum autem, ubi dicitur hoc casu, ubi custodiam non suscepit, eum esse securum. Ex quo apparet eum custodiam praestare non debere. Resp. haec non pugnant inter se, custodiam praestare, et securum esse. Imo vero ipse est securus quod custodiam praestitit, ac dolo omni, ac culpa caret. Sed dicet quis. Ergo nihil interest quando convenit de custodia praestanda, vel quando non convenit, quia utroque casu praestanda est. Resp. multum interesse, quia quo casu convenit de custodia praestanda, periculum pertinet ad venditorem: quo casu non convenit, si eam praestitit, securus est, nec periculum sustinet. D. §. cum autem et h. $\S$ ». (= A coisa vendida foi subtraída do vendedor. Pergunta-se a quem cabe $\langle 0$ risco $\rangle$ de perecimento: ao comprador ou ao vendedor? Há de se distinguir por este modo: ou o vendedor assumiu a

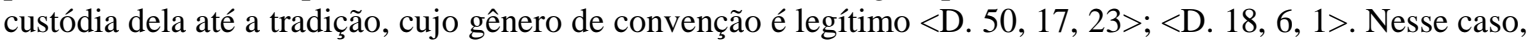
o risco da coisa cabe ao vendedor: <Inst. 3, 23, 3 a>, onde se propõe a mesma espécie. Ou não assumiu a custódia, e nesse caso, há de se requerer dele a custódia tal qual um diligentíssimo paterfamilias aplica às suas coisas <D. 18, 6, 1>. Objeta-se <com base em> < Inst. 3, 23, 3 a >, no qual se diz que, nesse caso, em que não assumiu a custódia, o vendedor não é responsável. Disso, parece que ele (<o vendedor>) não responde pela custódia. Respondo: essas <afirmações> não se contradizem: 'garantir a custódia' e 'não responder'. Com efeito, não responde ele que prestou a custódia, e carece de todo dolo e de culpa. Mas alguém dirá: logo, nada importa que se convencionou acerca da custódia a ser prestada ou não convencionou, porque em ambos os casos ela há de ser prestada. Respondo: importa muito, porque, no caso em que se convencionou sobre a custódia a ser prestada, o risco cabe ao vendedor; no caso em que não se convenciou, 
Por outro lado, tendo observado esse comportamento, o vendedor não deverá responder - «securus esse debet» ${ }^{728}$ - ao comprador pela perda da res vendita devida ao furto $^{729}$. Essa liberação, contudo, é limitada - «ut tamen scilicet ${ }^{730}$ - pelo dever de cessão da vindicatio e da condictio ao comprador (exhibere $)^{731}$.

Uma vez excluída a responsabilidade do vendedor pelo furto, caberia à contraparte a suportação do risco, ou seja, o pagamento do preço mesmo sem receber a coisa. Como contrapeso desse gravame, atribuem-se-lhe algumas ações que o vendedor teria contra aquele que subtraiu a res vendita ${ }^{732}$.

Mais uma vez, portanto, trata-se de um problema relacionado ao stellvertretendes commodum $^{733}$, ou seja, a constituição do comprador como procurator in rem suam a fim de que este propusesse, em seu próprio proveito, as ações que caberiam, em princípio, ao vendedor $^{734}$.

Favorável, por sua vez, ao periculum venditoris como regra no direito clássico, E. BETTI sustenta que também essa passagem foi alterada pelos compiladores: originalmente,

se se a prestou, não responde, nem suporta o risco <Inst. 3, 23, 3 a〉). Cf. Recitationes solemnes, in Opera VII cit. (nt. 615 supra), cols. 1128-1129 (a D. 18, 1, 35, 4).

${ }^{728}$ Como nota E. BETTI, «securus esse debet», «securus erit» (Inst. 3, 23, 3 a, sobre o qual, infra) são locuções técnicas utilizadas por Gaio para exprimir que certo devedor, diante da impossibilidade do objeto da prestação, não incorria em responsabilidade (com efeito, Gai. 2 aur., D. 44, 7, 1, 4-5: «...is vero qui utendum accepit, si maiore casu, cui humana infirmitas resistere non potest, veluti incêndio ruina naufragio, rem quam accepit amiserit, securus est»). Cf. «Periculum» cit (nt. 420 supra), pp. 138-139.

Também nesse sentido a tradução: «hat er diese eingehalten und geht die Sache gleichwohl verloren, so mu $\beta$ er vor einer Inanspruchnahme sicher sein», cf. O. BEREHDS - R. KNÜTEL - B. KUPISCH - H. HERMANN SEILER, Corpus Iuris III cit. (nt. 528 supra), p. 451; «se, dunque, il venditore ha perso la cosa, pur avendo prestato tale custodia, egli deve essere sicuro <rispetto ad ogni pretesa che venga vantata nei suoi confronti>», cf. S. SCHIPANI (cur.), Iustiniani Augusti Digesta seu Pandectae - Digesti o Pandette dell'Imperatore Giustiniano - Testo e traduzione III, Milano, Giuffrè, 2007, p. 340.

${ }^{729}$ Cf. J. PARIS, La responsabilité cit. (nt. 42 supra), p. 224; M. SERRANO-VICENTE, Custodiam praestare cit. (nt. 26 supra), p. 290; 294; M. PENNITZ, Das periculum cit. (nt. 30 supra), p. 386.

${ }^{730}$ Essa locução («ut tamen scilicet») assume, em geral, uma função limitativa. Cf. R. KÜHNER - C. STEGMAnN, Ausführliche Grammatik der lateinischen Sprache II - Satzlehre, 5 ${ }^{\mathrm{a}}$ ed., Darmstadt, Wissenschaftliche Buchgesellschaft, 1976, pp. 249-251.

Encontramo-la, nas fontes jurídicas, também em Gai. 3, 175, em cujo contexto é vertida como «selbstverständlich jedoch so...», cf. H. L. W. NELSON - U. MANTHE, Gai Institutiones III 88-181 - Die Kontraktsobligationen - Text und Kommentar, Duncker \& Humblot, p. 412.

${ }^{731}$ Exhibere, nesse contexto (tal como em Ulp. 33 ad Sab., D. 30, 57), equivaleria a praestare ou cedere actiones, ou seja, transferência, cessão do exercício de certas ações (supra). Cf. H. HEUMANN - E. SECKEL, Exhibere, in Handlexicon cit. (nt. 18 supra), p. 190. Desse modo, admitida essa limitação, parece discutível a tradução italiana - «egli deve essere sicuro 〈rispetto ad ogni pretesa che venga vantata nei suoi confronti〉», ao inserir «ogni» (supra, nt. 728). Com efeito, o vendedor poderia ser demandado, não para indenizar o comprador pelo perecimento da coisa vendida, mas para ceder-lhe os meios processuais (vindicatio e condictio), pretensão veiculável, provavelmente, pela actio empti. Cf. M. SERRANO-VICENTE, Custodiam praestare cit. (nt. 26 supra), p. 290.

${ }^{732}$ Cf. J. PARIS, La responsabilité cit. (nt. 42 supra), pp. 224-225; M. SERRANO-VICENTE, Custodiam cit. (nt. 26 supra), pp. 289-290.

${ }_{733}$ Cf. M. PENNITZ, Das periculum cit. (nt. 30 supra), p. 280.

${ }^{734}$ Cf. E. BETTI, «Periculum» cit. (nt. 420 supra), p. 139. 
a atribuição desse commodum dava-se apenas na hipótese de assunção da custodia pelo vendedor, prestando-se como sucedâneo da responsabilidade pelo furto ${ }^{735}$.

Entretanto, os comissários de Justiniano teriam generalizado tal solução, estendendo-a também ao caso de não assunção de «custodiam praestare», a fim de contrabalançar a regra contrária então introduzida na regulamentação do problema da repartição do risco na compra e venda: periculum emptoris ${ }^{736}$.

Já M. SERRRANO-VICENTE considera o dever de cessão das ações uma decorrência da boa-fé que preside a relação contratual: uma vez que ao comprador caberia o risco, nada podendo obter a título de indenização com a actio empti («securus»), resultaria um enriquecimento injusto caso o vendedor propusesse as ações contra o ladrão e obtivesse êxito disso ${ }^{737}$.

A iurisprudentia, com vistas à correção desse desajuste, teria considerado uma obrigação do vendedor a cessão das ações à contraparte sobre a qual gravava o periculum, fazendo com que ao emptor correspondesse também um commodum ${ }^{738}$.

De qualquer modo, a cessão das ações teria - no caso de não ser o vendedor responsável pelo perecimento - efeito liberatório ${ }^{739}$. Em razão do furto, estaria o vendedor, em princípio, legitimado à actio furti e às ações - de natureza «reipersecutória» vindicatio e condictio ex causa furtiva ${ }^{740}$, que lhe caberiam com fundamento na condição de proprietário (dominus) da coisa ${ }^{741}$.

\footnotetext{
${ }^{735}$ Cf. «Periculum» cit. (nt. 420 supra), p. 139.

${ }^{736}$ «quam si praestiterit et tamen rem perdidit, securus esse debet, [ut tamen scilicet] <quod si custodiam susceperit, in ea causa est ut> vindicationem rei et condictionem exhibeat emptori». (= se a tivesse observado e, ainda assim, perdeu a coisa, não deve responder; contudo, se tiver assumido a custodia, nesse caso, deve transferir ao comprador a rei vindicatio e a condictio). Cf. E. BETTI, «Periculum» cit. (nt. 420 supra), p. 140.

${ }^{737}$ Cf. Custodiam cit. (nt. 26 supra), p. 290; já nesse sentido, J. PARIS, La responsabilité cit. (nt. 42 supra), pp. 224-225.

${ }^{738}$ Cf. M. SERRANO-ViCENTE, Custodiam cit. (nt. 26 supra), p. 290.

739 Também nesse caso, dentro da proposta interpretativa do autor, seria possível inferir que a cessão - em decorrência da não responsabilidade do vendedor - dar-se-ia «arbitrio» e «periculo» do comprador. Outra seria a situação caso o vendedor tivesse assumido o «custodiam praestare»: assim, caso a contraparte preferisse a propositura das ações ao invés do ressarcimento pela actio empti, seria ela realizada ao risco do vendedor. Cf. M. TALAmanCA, Vendita cit. (nt. 21 supra), p. 429.

${ }^{740}$ Cf., nesse sentido, M. SERrANO-VICENTE, Custodiam cit. (nt. 26 supra), p. 290, sem, contudo, assinalar as fontes.

${ }^{741}$ Cf. M. TAlamanCA, Vendita cit. (nt. 21 supra), p. 428. Se, por um lado, não se apresentam problemas em relação à vindicatio e à condictio, ações «reipersecutórias», cuja legitimiação ativa cabe exclusivamente ao proprietário, maiores discussões existem quanto ao fundamento da legitimação do vendedor à actio furti. De qualquer modo, independentemente do fundamento, limitando-nos ao aspecto que ora interessa (a saber, se seria o vendedor o legitimado ativo e se ela integraria a obrigação de cessão), as fontes pareceriam concordes em atribuí-la também ao vendedor.
} 
Entretanto, o texto limita-se a atribuir ao vendedor a obrigação de ceder apenas essas duas últimas, não fazendo menção à actio furti ${ }^{742}$. Também quanto a esse aspecto, não há concordância entre os estudiosos do tema.

Por um lado, J. PARIS pretendeu, com fundamento na inserção da actio furti dentre as ações que deveriam ser cedidas ao comprador em outros fragmentos ${ }^{743}$, que também neste não existiriam razões para retirá-la dos «débris juridiques» da coisa - ou seja, as ações que permitiram ao vendedor a reobtenção da res - que o vendedor está obrigado a transferir ao comprador ${ }^{744}$.

No que concerne ao problema da compreensão das ações penais na obrigação de cessão do vendedor, propõe M. TALAMANCA, como hipótese (geral), a possibilidade de se tratar de questão controversa entre os juristas, cujas soluções poderiam articular-se em função da responsabilidade ou não do vendedor pela perda do objeto da prestação ${ }^{745}$.

Embora não seja relevante para o problema específico da custodia na compra e venda $^{746}$, o restante do texto («unde...transferre») poderia, segundo M. PENNITZ, explicar a omissão da actio furti dentre as ações a cuja transferência estaria obrigado o vendedor ${ }^{747}$.

Gaio conclui o discurso com o exame da situação do vendedor de coisa alheia que, antes da tradição, é dele furtada: nesse caso, pois que o vendedor não poderia - dada a falta de legitimação ativa - ceder as ações, disso decorreria sua responsabilidade, podendo então o comprador valer-se da actio empti como Schadenersatzklage ${ }^{748}$.

${ }^{742}$ Cf. J. PARIS, La responsabilité cit. (nt. 42 supra), p. 225; M. TALAMANCA, Vendita cit. (nt. 21 supra), p. 429, nt. 1303; M. SERRANO-VICENTE, Custodiam cit. (nt. 26 supra), p. 291.

${ }^{743}$ Orientação essa que parece remontar à Glosa (cf. gl. emptori a D. 18, 1, 35, 4: «actionem etiam furti, quae venditori competit. ut infra de fur. l. eum, qui. in princ. \& l. si vendidero \& infra de act. empt. l. si ea res. in princ.» (= também a actio furti, que compete ao vendedor, como em <D. 47, 2, 14 pr.>; <D. 47, 2, $81>$, <D. 19, 1, 31 pr.>).

${ }_{745}^{744}$ Cf. La responsabilité cit. (nt. 42 supra), pp. 224-225.

${ }^{745}$ Não se desenvolve ulteriormente essa hipótese. Como reconhece o autor, nas fontes, há prevalência dos elementos de dúvidas, o que torna essa valoração bastante complexa: no que respeita especificamente a Gai. 10 ad ed. prov., D. 18, 1, 35, 4, essa dificuldade manifesta-se pelo confronto com Inst. 3, 23, 3a, texto a ele relacionado (em ambos os casos não haveria responsabilidade do vendedor), mas contrastantes quanto à questão da cessão das ações penais: no primeiro, faz-se ausente tal menção; no segundo, aduzem-se a actio furti e actio damni iniuriae após uma uma discussão relativa apenas às ações «reipersecutórias». Cf. Vendita cit. (nt. 21 supra), p. 429 e nt. 1303.

${ }^{746} \mathrm{Cf}$., nesse sentido, J. PARIS, La responsabilité cit. (nt. 42 supra), p. 225.

747 Cf. Das periculum cit. (nt. 30 supra), p. 386, nt. 81; mais recentemente, também M. SERRANOVICENTE, Custodiam praestare cit. (nt. 26 supra), p. 291.

${ }^{748}$ Cf., nesse sentido, M. PENNITZ, Das periculum cit. (nt. 30 supra), p. 386. Contestam a autenticidade dessa passagem do texto, v.g., J. PARIS, La responsabilité cit. (nt. 42 supra), p. 225. Cf., também, gl. si res a D. 19, 1, 31 pr.: «sed pone quod res sua non erat, \& vendidit quod non habet: non potest cedere, scilicet vindicationem, \& condictionem. Nunquid eo ipso damnabitur? Responsio huius quaestionis non est in litera: \& secundum omnes respondetur quod damnatur: quia si suam rem vendidisset, potuisset emptori actiones suas cedere» (= considera, porém, que a coisa não era sua e vendeu o que não tem: não pode ceder, a saber, a vindicatio e a condictio. Acaso há de ser condenado por esse fato mesmo? A resposta a essa questão não está escrita: e segundo todos, responda-se que é condenado, porque se tivesse vendido coisa sua, teria podido 
O jurista não poderia, portanto, ter-se referido à actio furti uma vez que essa, contrariamente à condictio e à vindicatio, cuja legitimação dependeria da propriedade da coisa, compete não exclusivamente ao proprietário - mas, em princípio, como quer o autor (com base em Gai. 3, 203) - àquele a quem interesse a conservação da coisa ${ }^{749}$.

À guisa de conclusão, ter-se-ia: a solução, para Gaio, de um problema de responsabilidade pelo furto da res vendita antes da tradição dependia da verificação da existência de uma convenção entre as partes sobre a custódia da coisa ( «de custodia rei»). Vale dizer, portanto, que o vendedor não responderia por tal evento, causador da perda do objeto da prestação, tout court ${ }^{750}$.

O jurista considera apenas a hipótese em que nada se tenha convencionado ( «si nihil appareat convenisse»), e fixa, como obrigação do vendedor uma «custodia» tal como aquela que um bonus pater familias exerce sobre as suas próprias coisas ${ }^{751}$.

Admite-se que essa possa ter sido cumprida e, ainda assim, não ter sido capaz de evitar o furto («quam...tamen...perdidit»), caso em que o vendedor restaria liberado («securus esse debet»). Esse regime parece assinalar, portanto, que essa «talis custodia...adhibet» se tratasse da diligentia normal exigida do vendedor, pela inobservância da qual (isso é, por culpa) deveria responder ${ }^{752}$.

ceder as suas ações ao comprador). Ao menos sob a perspectiva do «resultado», isso é, da solução, tal interpretação corresponde à de J. CuJAS: «Quod si rem alienam quis vendiderit, non videbatur condemnandus, ut has actiones mandaret, cum eas non haberet. Resp. tamen, eo magis esse damnandum, quod culpae ejus hoc adscribatur, qui vendidit rem, quam alienam esse sciebat, et qua subrepta, sciebat sibi non competere jus mandandarum actionum. Tenebitur ergo in idem, quod interfuit emptoris actiones esse mandatas» (Mas se alguém tiver vendido coisa alheia, não parece que <possa> ser condenado para que ceda as ações, pois que não nas tem. Respondo, contudo, que ele há de ser condenado, porque tal <isso é, a impossibilidade da cessão> deve ser atribuído à culpa do que vendeu coisa que sabia ser alheia e, sendo ela subtraída, sabia que não lhe competiria o direito de ceder as ações). Cf. Recitationes solemnes, in Opera VII cit. (nt. 615 supra), col. 1130 (a D. 18, 1, 35, 4).

${ }^{749}$ Cf. M. PenNitz, Das periculum cit. (nt. 30 supra), p. 386, nt. 81. Por outros termos - assim entendemos - Gaio estaria atento à seqüência do discurso, na qual trata especificamente da hipótese de furto da coisa alienada a non domino: o vendedor, com efeito, não poderia ceder o de que não disporia (e por essa razão seria condenado, isso é, responderia), mas em princípio, a actio furti poderia caber-lhe. É o que parece sugerir também M. SERRANO-VICENTE, Custodiam praestare cit. (nt. 26 supra), p. 291.

${ }^{750}$ Isso se verificaria, por outro lado, caso estivesse ele obrigado a «custodiam praestare», de que decorria uma responsabilidade pelo resultado, segundo a intepretação que se poderia considerar hoje majoritária (supra).

751 «Custodia» teria sido empregado, nessa passagem, por sugestão da utilização do termo na frase anterior. Cf. J. PARIS, La responsabilité cit. (nt. 42 supra), p. 224. O significado, contudo, seria aquele - não técnico - de diligência aplicada à guarda (custodia) da coisa, tal como propõe E. BETTI, «Periculum» cit. (nt. 420 supra), p. 139.

${ }^{752}$ Superados, em grande parte, os postulados da Crítica Interpolacionística na análise dessa matéria, não se tem mais reputado como intervenção compilatória para introduzir a «diligentia» formulações como aquelas presentes nesse texto. Com efeito, vislumbra-se na coerência dos testemunhos gaianos sobre a diligentia um conceito conhecido e empregado pelos juristas no âmbito do comodato, a possibilidade de que Gaio tenha pretendido, pela primeira vez, construir um sistema de responsabilidade contratual fundamentado nesse conceito. Cf. SERRANO-VICENTE, Custodiam cit. (nt. 26 supra), p. 298. 
Assim, adimplida a obrigação dele exigível (diligentia in custodiendo), não haveria culpa na perda da coisa por furto, e o vendedor deveria tão-só ceder ao comprador as ações - nomeadamente vindicatio e condictio - como contrapeso do periculum que sobre este último gravava ${ }^{753}$.

Em contrapartida, se algo fosse convencionado (hipótese não tratada) - dir-se-ia «si quid appareat convenisse» - tal pacto teria por teor a assunção, pelo vendedor, de «custodiam praestare», com a consequiência de que, nesse caso, responderia ele - sem mais - pela perda da coisa devida ao furto ${ }^{754}$.

Resultaria, portanto que, segundo Gaio, «custodiam praestare» seria um accidentalia negotii no regime jurídico da compra e venda, isso é, dependeria, para nela figurar de uma convenção específica. Seu conteúdo, além disso, parece ser - tal como nos demais textos atribuídos ao jurista ${ }^{755}$ - um «praestare» do vendedor pelo furto da coisa ${ }^{756}$.

Ao contrário, porém, de Nerácio, em relação ao qual se está limitado a um único texto sobre a matéria, a individualização da orientação seguida por Gaio poderia contar com informações presentes em outros textos da compilação justinianéia.

Limitadamente à compra e venda, assume importância Inst. 3, 23, 3 a:

Quod si fugerit homo qui veniit aut subreptus fuerit, ita ut neque dolus neque culpa venditoris interveniat, animadvertendum erit, an custodiam eius usque ad traditionem venditor susceperit. Sane enim, si susceperit, ad ipsius
Se fugir ou for furtado o escravo vendido, sem que haja dolo ou culpa do vendedor, averiguar-se-á se o vendedor assumira a custódia dele até à entrega. É certo, pois, que se $<\mathrm{a}>$ tivesse assumido, esse evento corre a seu risco; se não a

${ }^{753}$ E assim, sob esse último aspecto, se entendermos que já Gaio aplicava generalizadamente, o periculum emptoris. Caso contrário, isso é, se fosse ele alinhado ao filão jurisprudencial favorável ao periculum venditoris, a cessão dar-se-ia aqui periculo do vendedor.

${ }_{754}$ Cf. SERRANO-VICENTE, Custodiam cit. (nt. 26 supra), p. 293.

755 Assume especial relevância, para tanto, um dos textos fundamentais nos estudos sobre o tema: Gai. 3, 205-206.

${ }^{756}$ Pretende M. SERRANO-VICENTE que Gaio, contrariamente a Nerácio (para o qual a prestação teria conteúdo idêntico àquela devida pelo comodatário e conductor rei servandae), tenha operado uma «relativização» do conteúdo da «prestação de custodia» na compra e venda, uma vez que a convenção a que alude o jurista poderia tanto estender-se a todo tipo de risco quanto limitar-se ao dolo. Em outras palavras, parece admitir-se, nesse caso, a possibilidade de conferir a ela um alcance distinto segundo as determinações das partes contratantes. Cf. Custodiam cit. (nt. 26 supra), p. 289, nt. 888; 290; também 301.

Trata-se de uma proposição que não recebe ulterior aprofundamento por parte do autor. Aparentemente e assim entendemos - apóia-se ela na - de fato possível - leitura de «quid inter eos de custodia convenerat», termos em que a obrigação assumida pelo vendedor poderia ser tanto superior àquela representada por «custodiam praestare» (isso é, superando-se o seu «conteúdo típico»), quanto reduzir-se ainda mais do que aquela que resulta como «normal» (aplicada na ausência de pactuação diversa), isso é, a diligentia diligentis, restringindo-se ao dolum praestare.

Contudo, tal «leitura» não parece encontrar elementos de apoio em outros textos de Gaio que a consintam, sendo preferível identificar o conteúdo do pacto aludido por Gaio com o «custodiam praestare», tese para a qual concorre o evento típico considerado nessa fattispecie: o furto da coisa devida. 
periculum is casus pertinet: si non susceperit, securus erit. Idem et in ceteris animalibus ceterisque rebus intellegimus. Utique tamen vindicationem rei et condictionem exhibere debebit emptori, quia sane, qui rem nondum emptori tradidit, adhuc ipse dominus est. Idem est etiam de furti et de damni iniuriae actione. tiver assumido, não será responsável. A mesma coisa entendemos também em relação aos outros seres animados ${ }^{757}$ e às demais coisas. Em todo caso, porém, deverá <o vendedor> ceder ao comprador a rei vindicatio e a condictio, pois, como é certo, aquele que ainda não entregou a coisa ao comprador, é, até então o proprietário <dela>. Isso também vale para a actio furti e a actio damni iniuriae $^{758}$.

Constitui esse texto a seqüência do parágrafo terceiro do título 23 (no qual se trata especificamente da compra e venda) do livro terceiro (dedicado à matéria de sucessões e obrigações) das Institutas imperiais. Depois de se ocupar, no principium e $\S \S 1$ e 2 dos aspectos gerais da emptio venditio ${ }^{759}$, inicia-se o tratamento do problema do periculum rei venditae.

A disciplina justinianéia da repartição dos riscos na compra e venda seria, segundo o § 3: uma vez contraída a compra e venda, o comprador suporta o risco (periculum) de perecimento ou deterioração da coisa, mesmo antes de sua tradição; por outros termos, deveria ele pagar o preço convencionado, ainda que não pudesse mais receber a coisa (ou, ao menos, em sua integridade), devido a um evento cuja ocorrência não dependa de culpa (ou dolus) do vendedor ${ }^{760}$.

${ }^{757}$ Preferiu-se a tradução de animales como seres animados, tendo em consideração a referência ao «servus» no início do texto, versão essa, ademais, que não parece encontrar obstáculos sob o ponto de vista do latim. Cf. v.g., E. NARDI, Istituzioni di diritto romano - Testi II, Milano, Giuffrè, 1986, p. 143 («esseri animati»).

${ }^{758}$ Além das traduções já referidas, considerou-se também aquela de E. C. SILVEIRA MARCHI, Dos riscos cit. (nt. 409 supra), p. 60, nt. 38.

${ }^{759}$ Sinteticamente, momento em que se considera contraído o negócio (convenção sobre o preço, para as vendas «sine scriptura»; e confecção formal dos «instrumenta emptionis», no caso das vendas por escritura), requisitos do preço - fixação, certeza, consistência em dinheiro - e, relacionado a esse último aspecto, a diferenciação com outros contratos, como a permuta. Cf., v.g., E. NARDI, Schema delle Istituzioni di Giustiniano nel loro quadro generale, Milano, Giuffrè, 1978, p. 54.

${ }^{760}$ Cf. leitura sumária do título 23 e de seu $§ 3$ em E. NARDI, Istituzioni di diritto romano - C - Guida ai testi, Milano, Giuffrè, 1975, pp. 148-150.

Transcreve-se: Cum autem emptio et venditio contracta sit (quod effici diximus simulatque de pretio convenerit, cum sine scriptura res agitur), periculum rei venditae statim ad emptorem pertinet, tametsi adhuc ea res emptori tradita non sit. Itaque si homo mortuus sit vel aliqua parte corporis laesus fuerit, aut aedes totae aut aliqua ex parte incendio consumptae fuerint, aut fundus vi fluminis totus vel aliqua ex parte ablatus sit, sive etiam inundatione aquae aut arboribus turbine deiectis longe minora ut deterior esse coeperit: emptoris damnum est, cui necesse est, licet rem non fuerit nactus, pretium solvere. Quidquid enim sine dolo et culpa venditoris accidit, in eo venditor securus est. Sed et si post emptionem fundo aliquid per alluvionem accessit, ad emptoris commodum pertinet: nam et commodum eius esse debet cuius periculum est. (= Quando uma compra e venda tiver sido contraída (o que dissemos ter ocorrido quando convencionado sobre o preço <Inst. 3, 23 pr.>, quando <o negócio> faz-se sem escritura), o risco da coisa vendida cabe imediatamente ao comprador, ainda que até então a coisa não tenha sido entregue ao comprador. Assim, se o escravo tiver morrido ou tiver sido lesado em alguma parte do corpo, ou o edifício tiver sido consumido inteiramente ou 
Após considerar alguns eventos - morte ou lesão do escravo, incêndio (total ou parcial) do prédio, carregamento do imóvel por força das águas, sua diminuição por inundação ou ainda seu deterioramento resultante da derrubada das árvores por ventos que recairiam na esfera de riscos do emptor, introduzem-se as hipóteses de fuga e de furto do escravo vendido ( $\$ 3$ a).

Contanto que, para a ocorrência desses, não tenha havido dolo ou culpa do vendedor, remete-se - a fim, subentende-se, de solucionar a questão (de responsabilidade ou de risco) - à verificação da existência de uma convenção entre as partes pela qual se tenha assumido a custódia. Se positivamente, o «periculum» seria do vendedor; doutro modo, não assumida essa, ele não deveria responder ( «securus erit»).

Tal solução seria de se observar em relação às demais coisas (animadas e inanimadas). De todo modo, o vendedor deveria ceder à contraparte não apenas a vindicatio e a condictio (das quais seria o legitimado por ser ainda proprietário da res vendita), mas também a actio furti e a actio legis Aquiliae.

No que concerne ao Sachverhalt, em linhas gerais, já J. CUJAS havia notado a relação com o texto anteriormente tratado, de Gaio: «ubi eadem species proponitur» ${ }^{761}$; essa interrelação se manteve na doutrina sucessiva ${ }^{762}$, em decorrência - também - dos elementos textuais que sugeririam a proveniência do texto de material gaiano ${ }^{763}$.

em parte por um incêndio, ou um imóvel tiver sido levado total ou em alguma parte pela força de um rio, ou também tiver-se tornado consideravelmente menor ou pior por uma inundação da água ou pela derrubada das árvores devida a um ciclone, o dano é do comprador, que terá de pagar o preço, embora não tenha obtido a coisa. Tudo aquilo, pois, que ocorre sem dolo e culpa do vendedor, por isso não responde. Porém, também se, após a venda, algo tiver acedido ao imóvel por aluvião, essa vantagem cabe ao comprador: pois a vantagem também deve ser daquele de quem é o risco).

${ }^{761}$ Cf. Recitationes solemnes, in Opera VII cit. (nt. 615 supra), col. 1129 (D. 18, 1, 35, 4).

${ }^{762}$ Cf. v.g., J. PARIS, La responsabilité cit. (nt. 42 supra), p. 340; V. ARANGIO-RUIZ, Responsabilità cit. (nt. 04 supra), pp. 151-152; E. BETTI, «Periculum» cit. (nt. 420 supra), p. 139; M. KASER, Die actio cit. (nt. 258 supra), p. 108, nt. 73; M. TAlamancA, Vendita cit. (nt. 21 supra), p. 448, nt. 1508; ID., Considerazioni cit. (nt. 429 supra), p. 260 e nt. 157; M. BAUER, Periculum emptoris cit. (nt. 30 supra), p. 89; M. PENNITZ, Das periculum cit. (nt. 30 supra), pp. 386-387 e nt. 80; M. SERRANO-VICENTE, Custodiam praestare cit. (nt. 26 supra), p. 295. Já também, mas a partir de «quidquid...», R. GNEIST, Institutionum et regularum iuris romani syntagma - exhibens Gai et Iustiniani institutionum synopsin, Ulpiani librum singularem regularum, Pauli sententiarum delectum, tabulas systema institutionum iuris romiani illustrantes praemissis duodecim tabularum fragmentis, Leipzig, Teubner, 1858, p. 203.

763 Assim, v.g.: «animadvertendum erit», «securus erit», «utique tamen»; ainda, outros termos correntes nos escritos atribuídos a Gaio: «idem...intellegemus», «quia sane» (empregado 28 vezes apenas nas Institutas). Cf. C. FERRINI, Sulle fonti delle 'Istituzioni' di Giustiniano, in BIDR 13 (1901), p. 179 [= E. Albertario (cur.), Opere di Contardo Ferrini II - Studi sulle fonti del diritto romano, Milano, Ulrico Hoepli, 1929, p. 393]; em geral, L. Labruna - E. De Simone - S. Di SAlvo, Lessico di Gaio I, Napoli, Jovene, 1985, p. 221. 
Embora não seja possível determinar com precisão a fonte clássica que teria servido de base aos compiladores para a confecção desse texto ${ }^{764}$, os elementos supra-aludidos parecem sugestivos, e assumiram relevância não só para determinar a orientação do «direito justinianeu», mas também - como ulterior supedâneo - de Gaio quanto ao «custodiam praestare» do vendedor ${ }^{765}$.

No entanto, ao contrário de uma genérica «res vendita», o texto das Institutas imperiais abre-se com a hipótese de fuga («si fugerit») do escravo («homo») ${ }^{766}$ vendido, à qual se aduz a de subtração clandestina, isso é, furto («aut subreptus fuerit») ${ }^{767}$.

Tem-se notícia de que os «veteres» discutiam acerca da existência de um «custodiam praestare» do devedor no caso de fuga do escravo comodado e a solução reportada por Ulpiano é a de que, em alguns casos («interdum»), «et hominis custodia praestanda est»: assim, se foi entregue ao comodatário agrilhoado, ou, se por razão de sua

764 As Institutiones ou Elementa consistiam em um manual elementar de direito, dedicado aos principiantes («cupida legum iuventus»), aprontado em 533 d. C., por uma comissão formada por três membros (Triboniano, Teófilo e Doroteu) (cf. const. Imperatoriam, § 3). Tal como as Institutas de Gaio, utilizadas no ensino como manual preparatório até à reforma de dezembro de 533 d. C. (cf. const. Omnem, $\S$ 1), o manual imperial divida-se em quatro livros, subdividos em vários títulos, e esses em parágrafos.

Não obstante formarem um discurso único, os textos recolhidos nesses vários títulos resultam de uma conjunção de fragmentos extraídos das Institutas de Gaio, das res cottidianae (atribuídas ao mesmo jurista), de outras obras de cunho didático («institutiones») de autoria de outros juristas (v.g., Florentino, Marciano, Ulpiano e Paulo), bem como de fragmentos recolhidos no Digesto e trechos de constituições imperiais (cf. const. Imperatoriam, § 6). Cf. A. GUARINO, L'esegesi I cit. (nt. 314 supra), pp. 514-515.

Como notado por alguns autores, não há nas Institutas de Gaio um texto correspondente ao $\S 3$ do título 23 do manual de Justiniano. Cf. v.g., V. ARANGIO-RuIZ, La compravendita II cit. (nt. 403 supra), p. 263.

Nas reconstruções palingenéticas das Institutas de Justiniano, limitando-nos ora ao $\S 3 \mathrm{a}$, reputa-se que provenha - mas reconhecendo-se o caráter muito conjectural da hipótese - das res cottidianae. Cf. A. ZocCo-RosA, Imp. Iustiniani Institutionum Palingenesia II, Catania, Istituto di storia del diritto romano, 1911, p. 435.

As res cottidianae ou libri aureorum (a primeira denominação é referida pela const. Imperatoriam, § 6; a outra, no Index auctorum do Digesto, 20, 4; nesse, contudo, apresentam-se tanto um como o outro título) contêm uma exposição elementar do direito privado, que parece consistir em uma reelaboração das Institutas, menos rica de informações históricas, porém mais completa no que respeita à exposição do direito vigente e de sua aplicação prática (característica da qual teria provindo o seu nome). De cunho preponderantemente didático e isagógico, a obra compunha-se de sete livros, dos quais apenas os três primeiros foram aproveitados para o Digesto (concernentes, respectivamente, às pessoas, às coisas, modos de aquisição da propriedade e contratos e, finalmente, aos delitos e às «variae causarum figurae»).

Devido às vantagens, dentre elas, a superioridade sistemática, dessa obra em relação às Institutas, os compiladores justinianeus tê-la-iam preferido, em maior medida, a essas últimas, seja para a composição do Digesto seja para a das Institutas imperiais. Cf. P. KRÜGER, Geschichte cit. (nt. 476 supra), p. 203, nt. 20.

Entretanto, muito se discute sobre a genuinidade das res cottidianae, a qual para alguns estudiosos teria consistido em uma (prolixa) paráfrase, de proveniência pós-clássica, das institutiones. Cf. V. ARANGIO-RUIZ, Ancora sulle res cottidianae - Studio di giurisprudenza postclassica, in Studi in onore di Pietro Bonfante I, Milano, Fratelli Treves, 1930, p. 495; E. AlberTARIO, Studi di diritto romano III - Obbligazioni, Milano, Giuffrè, 1936, p. 97, nt. *; A. GUARINO, L'esegesi I cit. (nt. 314 supra), p. 220.

${ }^{765}$ É o que se depreende, v.g., de M. TALAMANCA, Vendita cit. (nt. 21 supra), p. 448 e nt. 1501; 461 e nt. 1627.

${ }^{766}$ Embora não único, esse (o de escravo, servus) parece ser o único significado possível para o termo. Cf.

H. HeUMANN - E. SECKEL, Homo, in Handlexicon cit. (nt. 18 supra), p. 237.

${ }^{767}$ Cf. H. HEUMANN - E. SECKEL, Subripere, in Handlexicon cit. (nt. 18 supra), p. 561. 
idade, requereria uma vigilância ${ }^{768}$, e também se foi acordado («actum est») que o devedor «custodiam praestet ${ }^{769}$.

Por sua vez, o furto é o evento típico que integra o conteúdo de «custodiam praestare» também nas demais relações contratuais (v.g., comodato, locação), e a particularidade, nesse caso, seria apenas a de se considerar o furto - concretamente - de um escravo vendido.

Se a fuga ou o furto do escravo não tiverem ocorrido por dolo ou culpa do vendedor («ita ut neque dolus neque culpa venditoris») ${ }^{770}$, há de se verificar, ainda - a fim de solucionar o problema - se ele assumiu a custódia do «homo» («an custodia eius ...susceperit»).

Segundo J. PARIS, a «custodia» empregada nesse texto assumiria não o sentido técnico de «responsabilité absolue du cas fortuit», mas simplemente a guarda: essa custodiae susceptio seria uma promessa particular do vendedor pela qual assumiria a obrigação de guardar o escravo ${ }^{771}$.

Por outro lado, V. ARANGIO-RUIZ parece identificar essa «custodia» com «custodiam praestare», mas contesta a genuinidade da solução presente no texto ${ }^{772}$, cujo teor original poderia ser reconstruído pela eliminação do caráter convencional com o qual a custódia nele se apresenta ${ }^{773}$.

Em sentido oposto, E. BETTI visualiza nas alterações sofridas por esse texto a tendência compilatória de elevar as ocorrências da responsabilidade convencional a responsabilidade ex lege, a fim de servir de contrapeso à - então - regra periculum est emptoris $^{774}$.

\footnotetext{
${ }^{768}$ Tais casos seriam considerados como de assunção tácita - «stillschweigende custodia-Übernahme» de «custodiam praestare». Cf. M. PENNITZ, Das periculum cit. (nt. 30 supra), p. 387.

${ }^{769}$ Cf. Ulp. 28 ad Sab., D. 13, 6, 5, 6 (supra).

770 Assim, v.g., se o vendedor tivesse facilitado dolosamente, ou por negligência, a fuga ou a subtração do escravo que deveria entregar ao comprador, caso em que responderia - «de plein droit» - à contraparte por dolus ou culpa pela perda do objeto da prestação. Cf., nesse sentido, J. PARIS, La responsabilité cit. (nt. 42 supra), p. 221.

${ }^{771}$ Por outros termos, tratar-se-ia de uma promesssa de garantia especial, pela qual o vendedor teria agravado a sua responsabilidade - normal - por dolo e culpa. Cf. La responsabilité cit. (nt. 42 supra), p. 221; 339-340.

772 As Institutas imperiais, para V. ARANGIO-RUIZ, consistem no setor da compilação no qual se teria verificado a incidência, mais evidentemente, das idéias do ambiente jurídico justinianeu em matéria de ilícito contratual, o que parece ser relevante para compreender a valoração do autor sobre a «doutrina» nelas exposta. Cf. Responsabilità cit. (nt. 04 supra), p. 150; cf., também, ID., La compravendita II cit. (nt. 403 supra), p. 264.

${ }_{773}$ Cf. Responsabilità cit. (nt. 04 supra), pp. 151-153; 153-154 e nt. 01; ID., La compravendita II cit. (nt. 403 supra), pp. 263-264.

${ }^{774}$ Dentre elas, destacar-se-iam o esforço de converter a questão gaiana de responsabilidade em problema concernente ao risco contratual («ipsius periculum»), pela inserção do texto na respectiva sedes materiae do manual justinianeu, e o alcance geral conferido à atribuição do commodum repraesentationis ao comprador,
} 
Também M. BAUER considera que, ao contrário da mera reformulação textual verificável em outros textos para a introdução do «Verschuldensprinzip ${ }^{775}$, a «custodia», no texto das Institutas, teria sido eliminada substancialmente, por meio de um artifício, a saber, a sua configuração como elemento acidental do contrato, dependente de convenção entre as partes ${ }^{776}$.

A configuração de «custodiam praestare» como cláusula contratual específica não teria resultado, entretanto, de um trabalho novo do autor do texto das Institutas, mas encontrava apoio no texto clássico que, muito provavelmente, serviu de base ao primeiro: Gai. 10 ad ed. prov., D. 18, 1, 35, 4. Nesse, com efeito, a custodia configurava-se como elemento acidental pelo fato de tratar - originalmente - de um caso de compra e venda de $\operatorname{escravos}^{777}$.

Dado que o vendedor só estaria obrigado a «custodiam praestare» em relação a um servus custodiendus ${ }^{778}$, integrando a fuga de um servus non custodiendus o âmbito da vis maior $^{779}$, Gaio teria, naquele texto, considerado a hipótese de um escravo ${ }^{780}$ e determinado que para que sobre o vendedor gravasse o risco de furto também de um escravo non custodiendus seria necessária uma cláusula expressa de assunção da custodia $^{781}$.

Os compiladores, por sua vez, teriam tomado esse «Sonderfall» - a saber, um Sachverhalt no qual a fuga do escravo estava na base da ratio decidendi - isolando-o de seu contexto original (isso é, da concreta relação com a compra e venda de escravos) e generalizado, por esse modo, a exigência da assunção convencional da custodia $^{782}$.

Já M. TALAMANCA afasta as suspeitas de invervenção compilatória com base na ausência de indícios de reinterpretação - automática, para os comissários de Justiniano da custodia em sentido subjetivo (diligentia in custodiendo) ${ }^{783}$. Essa circunstância indicaria, segundo o autor, uma reprodução, sem modificações, do texto original de gaiano,

isso é, também no caso de não ter o vendedor assumido «custodiam praestare». Cf. «Periculum» cit. (nt. 420 supra), p. 139.

${ }^{775}$ Assim, v.g., Gai. 2 cot. rer.., D. 18, 6, 2, 1; Paul. 5 ad Sab., D. 18, 6, 3; Gai. 9 ad ed. prov., D. 13, 6, $18 \mathrm{pr}$.

${ }^{776}$ Cf. Periculum emptoris cit. (nt. 30 supra), p. 88.

${ }^{777}$ Cf. M. BAUER, Periculum emptoris cit. (nt. 30 supra), p. 89; 169; 173.

${ }^{778}$ Cf. supra.

${ }^{779}$ Cf. Gai. 9 ad ed. prov., D. 13, 6, 18 pr.; Ulp. 29 ad Sab., D. 50, 17, 23.

${ }^{780}$ Cf. M. BAUER, Periculum emptoris cit. (nt. 30 supra), pp. 89-90; 169.

${ }^{781}$ Cf. M. BAUER, Periculum emptoris cit. (nt. 30 supra), p. 89.

${ }^{782}$ Cf. M. BAUER, Periculum emptoris cit. (nt. 30 supra), p. 90; já nesse sentido, E. SECKEL - E. LEVY, Zur Gefahrtragung cit. (nt. 421 supra), p. 148.

${ }^{783}$ Cf. Vendita cit. (nt. 21 supra), p. 448. 
corroborando assim, que, para esse jurista (Gaio), «custodiam praestare» era um elemento acidental na emptio venditio ${ }^{784}$.

Seguindo-se, ainda, o teor do texto, a solução dependeria da verificação da assunção, pelo vendedor, da «custodia» da coisa: (a) se a tivesse assumido, esse evento pertence ao «periculum» do vendedor; (b) em contrapartida, se não na tivesse assumido, «securus erit».

Nesse último caso, como já sugere a formulação textual («securus erit») ${ }^{785}$, o vendedor não responderia ${ }^{786}$, o que pressupõe a observância, de sua parte, do comportamento que dele seria exigível pela contraparte (a saber, a ausência de dolo e culpa $)^{787}$.

A seu turno, as consequências da assunção da «custodia» já oferecem maiores dificuldades de interpretação: o vendedor, «si susceperit», suporta o «periculum».

Por um lado, interpretou-se o «periculum», tendo-se em consideração a fattispecie apresentada no início («si fugerit homo qui veniit aut subreptus fuerit...»), como «periculum custodiae», isso é, a assunção pelo vendedor de apenas alguns riscos, constitutivos de hipóteses de casus minor, e não de uma completa «Gefahrübernahme» ${ }^{788}$.

Por outro, identifica-se no texto uma incongruência de caráter dogmático, indício do afastamento do compilador do texto original que lhe teria servido de base para a redação do $§ 3 \mathrm{a}$ : assim, enquanto Gaio pareceria tratar de um caso de responsabilidade («securus esse debet»), a solução, no manual justinianeu, seria dada em termos de «periculum», vale dizer, a susceptio custodiae implicaria o periculum venditori ${ }^{789}$.

${ }^{784}$ Cf. Vendita cit. (nt. 21 supra), p. 448 e nt. 1501.

${ }^{785} \mathrm{O}$ emprego do termo em sentido diverso das Institutas daria apoio à tese da origem pós-clássica das res cottidianae, redigidas com base nas primeiras. Cf. V. ARANGIO-RUIZ, Responsabilità cit. (nt. 04 supra), p. 152, nt. 01; ID., La compravendita II cit. (nt. 403 supra), p. 264.

${ }^{786}$ Cf. J. PARIS, La responsabilité cit. (nt. 42 supra), p. 221; M. BAUER, Periculum emptoris cit. (nt. 30 supra), p. 88; M. PENNITZ, Das periculum cit. (nt. 30 supra), p. 388.

${ }^{787} \mathrm{Com}$ efeito, inexistindo qualquer regulamentação particular quanto à responsabilidade do vendedor, esse estaria sujeito ao regime «normal» na compra e venda, devendo responder à contraparte pela perda da coisa devida ao seu dolo ou culpa («neque dolus neque culpa venditoris»). Cf. M. BAUER, Periculum emptoris cit. (nt. 30 supra), p. 88. O comportamento do vendedor, nesse caso, poderia corresponder, como admite M. PENNITZ, àquele do modelo de bonus pater familias adotado em Gai. 10 ad ed. prov., D. 18, 1, 35, 4. Cf. Das periculum cit. (nt. 30 supra), p. 387, nt. 83.

V. ARANGIO-RUIZ indica como um acréscimo pós-clássico «ut....interveniat», de clara inspiração justinianéia, segundo o autor. Cf. Responsabilità cit. (nt. 04 supra), pp. 152-153. Não na exclui também M. PENNITZ, Das periculum cit. (nt. 30 supra), p. 387, nt. 83.

${ }^{788}$ Cf., v.g., E. SECKEL - E. LEVY, Gefahrtragung cit. (nt. 421 supra), p. 147; M. BAUER, Periculum emptoris cit. (nt. 30 supra), p. 88; M. PENNITZ, Das periculum cit. (nt. 30 supra), p. 388 (que interpreta a passagem como a afirmação da responsabilidade do vendedor, que seria obrigado, pela actio empti da contraparte, ao ressarcimento).

${ }^{789}$ Cf. M. SERRANO-VICENTE, Custodiam praestare cit. (nt. 26 supra), p. 296-297; já nesse sentido, E. BETTI, «Periculum» cit. (nt. 420 supra), p. 139. 
Essa solução, formulada tendo-se em vista o Sachverhalt apresentado no início (fuga e furto do escravo vendido), é estendida às demais coisas, animadas ou inanimadas («idem...intellegimus») $)^{790}$. Também nas Institutas imperiais, parece repetir-se a limitação à liberação do vendedor no caso de não ter assumido «custodiam praestare» («utique tamen...emptori») ${ }^{791}$ : a obrigação de ceder ao emptor os meios processuais de que dispusesse $\mathrm{e}^{792}$.

Nomeadamente, impõe-se ao vendedor ceder - «exhibere» - a vindicatio e a condictio furtiva, às quais está legitimado por sua condição ante traditionem de proprietário da coisa, e também - em uma ulterior extensão («idem...actione») $)^{793}$ - a actio furti e a actio legis Aquiliae.

Favorável a uma responsabilidade por custodia do vendedor de escravos, F. SCHULZ reputa não clássica a inclusão do caso de furto (que não necessitaria de qualquer pacto), assim como a obrigação de cessão da actio furti, condictio e da actio ex lege Aquilia (cuja exata denominação seria - ao contrário do que se verifica - «damni iniuria actio») ${ }^{794}$.

Para V. ARANGIO-Ruiz, o fato de se considerar, em primeiro lugar, a questão relativa às ações «reipersecutórias» seria o principal argumento contra a genuinidade do texto. Com efeito, Gaio (principalmente), diante de um problema atinente à custodia, deveria dedicar sua atenção imediatamente ao problema da legitimação ativa à actio furti $^{795}$.

Ao tratar desse ponto fundamental, o jurista ou teria inferido a legitimação do vendedor a partir da custodia ou, se excluída essa, a actio furti caberia ao comprador, resultando «aberrante» (e, portanto, pós-clássica) a cessão dessa prevista no texto ${ }^{796}$.

Por sua vez, E. BETTI considera que a atribuição do commodum repraesentationis ao comprador no caso de não assunção da custodia pelo vendedor constitua uma das modificações sofridas pelo texto em época pós-clássica. No direito clássico, entretanto,

\footnotetext{
${ }^{790}$ Formulação essa que pareceu suspeita já a E. SECKEL - E. LEVY, Gefahrtragung cit. (nt. 421 supra), p. 145, nt. 06; V. ARANGIO-RUIZ, Responsabilità cit. (nt. 04 supra), pp. 152-153; E. BeTTI, «Periculum» cit. (nt. 420 supra), p. 139; M. KASER, Die actio cit. (nt. 258 supra), p. 109, nt. 79; P. VocI, 'Diligentia' cit. (nt. 12 supra), p. 70, nt. 39; M. BAUER, Periculum emptoris cit. (nt. 30 supra), p. 90. 799.

${ }^{791}$ Cf., sob o ponto de vista sintático, R. KüHNER - C. STEGMANN, Grammatik II-2 cit. (nt. 730 supra), p.

${ }_{792}$ Cf. M. PENNITZ, Das periculum cit. (nt. 30 supra), p. 388.

${ }^{793}$ Considerada também suspeita por E. BETTI, «Periculum» cit. (nt. 420 supra), p. 139.

${ }^{794}$ Cf. Rezension de a L. LUSIGNANI, La responsabilità cit. (nt. 557 upra), p. 70.

795 Cf. Responsabilità cit. (nt. 04 supra), p. 152.

${ }^{796}$ Cf. V. ARANGIO-RUIZ, Responsabilità cit. (nt. 04 supra), p. 152.
} 
esse commodum figuraria como um sucedâneo do ressarcimento devido ao comprador no caso de assunção de «custodiam praestare ${ }^{797}$.

O comprador, assim, originalmente, uma vez constituído procurator in rem suam proporia - em seu próprio nome, mas sob risco do vendedor - as ações que caberiam, em princípio, a esse último, a saber, a vindicatio e a condictio $^{798}$.

Como já notado por J. PARIS, esse texto assumiria também um valor - e para esse autor, absoluto $^{799}$ - para a individualização da posição do direito justinianeu nessa matéria. De fato, se compreendida a «custodia» referida nas Institutas como «custodiam praestare», a doutrina acolhida pelos compiladores teria sido a de sua configuração como accidentalia negotii na compra e venda ${ }^{800}$.

Pretendeu-se, por um lado, explicar essa «opção» dos justinianeus como um dentre vários expedientes utilizados por esses para a supressão da «responsabilidade por custodia» clássica: assim, sua subordinação a um pacto específico teria consistido em uma forma de afastá-la - como naturalia negotii - do regime jurídico da compra e venda ${ }^{801}$.

Já M. TALAMANCA sustenta que tal configuração poderia ser explicada com base na concepção da compra e venda como negócio translativo que, no âmbito das Institutas imperiais, conviviria com a emptio venditio obrigatória do direito clássico ${ }^{802}$.

Além disso, em Inst. 3, 23, 3, seria identificável o intento do compilador de dar unidade à matéria tratada mediante o princípio da emptio contracta (e não da emptio perfecta), no que se poderia vislumbrar uma influência daquela estrutura do negócio. Resultaria, portanto, natural a atribuição ao comprador - proprietário com base no contrato - tanto do commodum e do incommodum quanto do periculum, contanto que não fosse o vendedor responsável (por dolus, culpa, ou - por assunção específica - custodia) $^{803}$.

${ }^{797}$ Cf. «Periculum» cit. (nt. 420 supra), p. 139.

798 «ane enim, si susceperit, ad ipsum is casus pertinet, ita ut vindicationem rei et condictionem <suo periculo> exhibeat emptori: si non susceperit, securus erit» (= É certo, pois, que se tivesse assumido <a custódia>, esse evento cabe-lhe, de modo que ceda, ao seu risco, ao comprador, a vindicatio e a condictio da coisa: se não <na> tiver assumido, não será responsável). Cf. E. BETTI, «Periculum» cit. (nt. 420 supra), pp. 138-139.

${ }^{799}$ Cf. La responsabilité cit. (nt. 42 supra), pp. 220-221.

${ }^{800}$ A possibilidade de se visualizar esse texto como a «doutrina compilatória» quanto ao problema de que se ocupa pareceria encontrar apoio não apenas na sua situação nas Institutas imperiais, síntese dos rudimentos do direito dedicada aos «Iustiniani novi» (cf. const. Omnen, § 2), e, nesse sentido, a apresentação dos aspectos essenciais de cada matéria tratada, mas também de uma consideração do próprio teor do texto, em que se empregam expressões generalizantes (v.g., «idem et....intellegimus»). Cf. V. ARANGIO-RUIZ, Responsabilità cit. (nt. 04 supra), p. 150.

${ }^{801}$ Cf., nesse sentido, V. ARANGIO-RuIZ, Responsabilità cit. (nt. 04 supra), pp. 153-154 e nt. 01; M. BAUER, Periculum emptoris cit. (nt. 30 supra), p. 88.

${ }^{802}$ Cf. Vendita cit. (nt. 21 supra), p. 461 e nt. 1627.

${ }^{803}$ Cf. M. TAlamanCA, Vendita cit. (nt. 21 supra), p. 461 e nt. 1628. 
Com efeito, uma vez que se considera o emptor proprietário da res vendita pelo negócio estabelecido, deveria ele mesmo zelar pela sua conservação, pois, se verificado o seu perecimento, casum sentit dominus ${ }^{804}$.

Em suma, sob a perspectiva da individualização do pensamento de Gaio - dada a semelhança notada entre os dois textos, o que faria supor ter sido Gai. 10 ad ed. prov., D. 18, 1, 35, 4 o modelo para o texto das Institutas - atestaria esse último a orientação do jurista pelo «custodiam praestare» como accidentalia negotii na compra e venda.

No entanto, se admitida a generalização pelos compiladores de uma solução («Sonderfall») restrita, naquele, à compra e venda de escravo, a afirmação não valeria mais para Gaio (em geral), mas corresponderia, ainda, à «posição» assumida pelo direito justinianeu na matéria ${ }^{805}$.

\section{O furto da «res vendita» $\mathrm{e}$ a legitimação ativa à actio furti}

Ulp. 29 ad Sab., D. 47, 2, 14 pr.: Eum qui emit, si non tradita est ei res, furti actionem non habere, sed adhuc venditoris esse hanc actionem Celsus scripsit. Mandare eum plane oportebit emptori furti actionem et condictionem et vindicationem, et si quid ex his actionibus fuerit consecutus, id praestare eum emptori oportebit: quae sententia vera est, et ita et Iulianus. Et sane periculum rei ad emptorem pertinet, dummodo custodiam venditor ante traditionem praestet.

1. Adeo autem emptor ante traditionem furti non habet actionem, ut sit quaesitum, an ipse subripiendo rem
Celso escreveu: aquele que comprou, se não lhe foi entregue a coisa, não tem a actio furti, pois que, até então, essa ação é do vendedor. Evidentemente, será necessário que ele (<vendedor>) ceda ao comprador a actio furti, a condictio e a vindicatio, e, se tiver sido obtido algo $<$ da propositura dessas ações, será necessário que ele <vendedor> preste isso ao comprador. Esse parecer é acertado, e assim também <opina> Juliano. E, certamente, o risco da coisa cabe ao comprador, contanto que o vendedor responda pela custódia até a entrega.

1. Precisamente porque o comprador, antes da entrega, não tem a actio furti, questiona-se se o próprio comprador

${ }^{804}$ Cf. M. TAlamancA, Vendita cit. (nt. 21 supra), p. 461 e nt. 1627. Em outros termos - assim entendemos - o autor pretende que a concepção da compra e venda como negócio de alienação possa explicar a atribuição ao comprador do risco de perecimento que se deva a todos os eventos «fortuitos» (é de se entender), até mesmo daqueles que comporiam o âmbito de ocorrências «coberto» pelo «custodiam praestare» do vendedor (v.g., furto), e isso por aplicação do princípio casum sentit dominus.

O contrabalanceamento dessa situação de distribuição dos «riscos» contratuais poderia dar-se pela aposição de um pacto sobre a custodia que teria por efeito agravar a situação do vendedor por alargar a sua esfera de responsabilidade pela impossibilidade do objeto da prestação devida a certos eventos.

${ }^{805}$ A manutenção do termo no manual justinianeu, e não a sua reformulação (como verificado em outros textos) constituiria um indício relevante da reprodução fidedigna da solução presente no «Vorlage» (isso é, Gai. 10 ad ed. prov., D. 18, 1, 35, 4), tal como sustentou M. TALAMANCA (supra) e pareceria mais probante em relação à proposta de explicação da posição assumida por Gaio como decorrente da particularidade da fattispecie considerada pelo jurista (isso é, a compra e venda de escravo). 
emptor furti teneatur. Et Iulianus libro vicensimo tertio digestorum scribit: si emptor rem, cuius custodiam venditorem praestare oportebat, soluto pretio subripuerit, furti actione non tenetur. Plane si, antequam pecuniam solveret, rem subtraxerit, furti actione teneri, perinde ac si pignus subtraxisset. subrair a coisa será ele responsável com base na actio furti. E Juliano, no vigésimo livro dos digestos, escreve: se o comprador, tendo pago o preço, tiver subtraído a coisa, por cuja custódia devia responder o vendedor, não será responsável pela actio furti. É certo que, se antes de pagar o preço, tivesse subtraído a coisa, será responsável com base na actio furti, tal como se tivesse subtraído uma coisa dada em penhor.

Celso teria opinado acerca da legitimação à actio furti: tendo o vendedor alienado uma coisa e sendo essa dele furtada antes da entrega ao comprador, a ação contra o ladrão caber-lhe-ia, e não ao comprador. Contudo, estaria o vendedor obrigado a ceder à contraparte a actio furti, a condictio e a vindicatio ou, se já tivesse proposto ele mesmo tais ações, aquilo que tivesse obtido do êxito da demanda.

Com esse parecer alinha-se Ulpiano («...quae sententia vera est...»), e aduz também a concordância de Juliano («...et ita et Iulianus»). E conclui o principium: o periculum rei cabe ao comprador contanto que o vendedor, antes da traditio, «custodiam...praestet».

No $\S 1^{806}$, considera-se a hipótese de subtração da coisa vendida pelo próprio comprador, e - reportando-se novamente Juliano - decide-se que, se esse tivesse furtado a coisa (cuja custodia - «custodiam...praestare oportebat» - devia o vendedor) depois de pagar o preço, não estaria sujeito à actio furti desse último.

Domício Ulpiano viveu sob os imperadores Severos (193-235 d. C.), sendo contemporâneo de Paulo e do célebre jurista romano Papiniano, de quem foi discípulo ${ }^{807}$. Sua produção, realizada principalmente antes de ocupar os vários cargos administrativos

\footnotetext{
${ }^{806}$ Quanto à interrelação dos dois textos, esse último parece consistir em uma corroboração da opinião de Celso e Juliano, seguida por Ulpiano, tentada por esse último: com efeito, tanto seria acertado que o comprador antes da tradição da res vendita não tem a actio furti caso seja ela furtada, que se apresenta a questão («ut sit quaesitum») de sua legitimidade passiva a essa actio caso subtraia ele mesmo a coisa.

${ }^{807}$ Oriundo de Tiro (Ulp. 1 de cens., D. 50, 15, 1), na Fenícia, Ulpiano teria integrado o consilium de um pretor (Ulp. 11 ad ed., D. 4, 2, 9, 3) e, mais tarde, tornou-se adsessor - juntamente com Paulo, do já mencionado Papiniano, então praefectus. Após o exílio a que foi condenado por Heliogábalo (no início de 222 d. C.), Ulpiano retorna a Roma por ordem de Alessandro Severo, de cuja absoluta confiança e proteção desfrutou. O imperador fez dele magister libellorum, admitiu-o em seu consilium, nomeou-o praefectus annonae (março de 222 d. C.) e, finalmente, no término do mesmo ano, elevou-o a praefectus pretorio. Cf. $\mathrm{P}$. KRÜGER, Geschichte cit. (nt. 476 supra), p. 239; L. WENGER, Die Quellen cit. (nt. 476 supra), p. 519; F. SCHULZ, Geschichte cit. (nt. 590 supra), p. 127; M. KASER, Römische Rechtsgeschichte cit. (nt. 594 supra), p. 175; W. KUNKEL, Die römsichen cit. (nt. 447 supra), pp. 245-246 e nt. 509; R. ORESTANO, Ulpiano (Domitius Ulpianus), in NNDI 19 (1957), p. 1106; A. GUARINO, L'esegesi I cit. (nt. 314 supra), pp. 225-226; 234; G. DULCKEIT - F. SCHWARZ - W. WALDSTEIN, Römische Rechtsgeschichte cit. (nt. 592 supra), p. 267.
} 
no governo de Alessandro Severo ${ }^{808}$ (222-235 d. C.), é bastante vasta e destinou-se, sobretudo, a finalidades práticas ${ }^{809}$.

Dentre as principais obras de Ulpiano estão ${ }^{810}$ : os libri LXXXI ad edictum praetoris, os libri II ad edictum aedilium curulium, os libri LI ad Masurium Sabinum, os libri VI fideicomissorum, os libri IV de appellationibus, os libri IV ad legem Aeliam Sentiam, os libri XX ad legem Iuliam et Papiam, os libri IV ad legem Iuliam de adulteriis, os libri X de officio proconsulis, os libri III de officio consulis, os libri singulares «de officio consularium», «de officio praefecti urbi», «de officio praefecti vigilum», «de officio curatoris reipublicae», os libri $X$ de omnibus tribunalibus; além disso, os libri II responsorum, os libri X disputationum e, finalmente, os libri II institutionum e os libri VII regularum ${ }^{811}$.

Em geral, ressentem-se elas de maior superficialidade em comparação às de seus contemporâneos (Papiniano e Paulo ${ }^{812}$ ), e caracterizam-se pela presença de cópias literais de cláusulas editais, textos de leis e de senatusconsultos e citações textuais de obras de outros juristas $^{813}$.

O texto transcrito provém dos comentários de Ulpiano ad Sabinum ${ }^{814}$, que se estendem por 51 livros: embora aparentemente incompleta ${ }^{815}$, trata-se da exposição do ius civile mais ampla após a - não conhecida diretamente - obra de Sabino ${ }^{816}$. No $29^{\circ}$ livro

\footnotetext{
${ }^{808}$ Cf. L. Wenger, Die Quellen cit. (nt. 476 supra), p. 519. 235.

${ }^{809}$ Cf. P. KRÜGER, Geschichte cit. (nt. 476 supra), p. 240; A. GUARINO, L'esegesi I cit. (nt. 314 supra), p.

${ }^{810}$ Excluem-se aquelas obras cuja atribuição a Ulpiano muito seguramente não procede: libri VI opinionum e o liber singularis regularum. Cf. A. GUARINO, L'esegesi I cit. (nt. 314 supra), p. 237.

${ }^{811}$ Cf. A. GUARINO, L'esegesi I cit. (nt. 314 supra), pp. 235-237.

${ }^{812}$ Há, entretanto, muitos paralelismos entre Ulpiano e Paulo: v.g., o domínio da literatura jurídica clássica, clareza na exposição, o caráter «enciclopédico», a necessidade de compendiar. Cf. M. KASER, Römische Rechtsgeschichte cit. (nt. 594 supra), p. 175; L. WENGER, Die Quellen cit. (nt. 476 supra), p. 520; R. ORESTANO, Ulpiano cit. (nt. 809 supra), p. 1106. Mais pormenores em Cf. P. KRÜGER, Geschichte cit. (nt. 476 supra), p. 250.

${ }^{813}$ Trata-se do jurista cujas obras foram empregadas em maior quantidade pelos compiladores justinianeus, representando cerca de um terço do total do Digesto. Cf. L. WENGER, Die Quellen cit. (nt. 476 supra), pp. 591-520; R. ORESTANO, Ulpiano cit. (nt. 809 supra), p. 1107; A. GUARINO, L'esegesi I cit. (nt. 314 supra), pp. 235-236; 506.

Com efeito, além de Modestino, que se considera seu discípulo, arrolando-o dentre os corifeus da iurisprudentia (Mod. 4 excusat., D. 27, 1, 13, 2), outros elementos nas fontes assinalariam para a sua estima pelos pósteros: «prudentissimus vir» (Diocl. et Maxim., C. 9, 41, 11, de 290), «summi ingenii vir» (C. 6, 51, 1, 9), «vir disertissimus» (Iust., C. 6, 25, 10, de 534). «sof utat os» (Nov. 97, 6, 1, de 539). Cf. P. KRÜGER, Geschichte cit. (nt. 476 supra), p. 249, nt. 211.

${ }^{814}$ Por sua vez, «ad Massurium Sabinum» aparece, excepcionalmente, em dois textos: Ulp. 8 ad Mass. Sab., D. 50, 7, 1, na inscriptio e Iust., C. 6, 24, 14 pr., de 531, referido no texto. Cf. P. KRÜGER, Geschichte cit. (nt. 476 supra), p. 243, nt. 168.

${ }^{815}$ Cf. P. KRÜGER, Geschichte cit. (nt. 476 supra), p. 244; M. KASER, Römische Rechtsgeschichte cit. (nt. 594 supra), p. 175; G. DULCKEIT - F. SCHWARZ - W. WALDSTEIN, Römische Rechtsgeschichte cit. (nt. 592 supra), p. 267.

${ }^{816}$ Cf. P. KRÜGER, Geschichte cit. (nt. 476 supra), p. 243.
} 
desses, tratou o jurista - tal como, parcialmente, no livro precedente e também no seguinte $^{817}$ - da compra e venda ${ }^{818}$.

Para a composição dessa, o jurista valeu-se de variados trabalhos: em primeiro lugar, dos digesta de Juliano e dos libri ex Sabino de Pompônio; além disso, teria haurido de Sabino (ius civile), de Labeão (posteriores), de Cássio (ius civile), e também de Nerácio, Celso, Marcelo, Cévola e Papiniano ${ }^{819}$.

Ulpiano refere-se, no principium, a Juvêncio Celso (chamado, por outros juristas, de Celso filius, adulescens ou, mais freqüentemente, tão-só Celso) ${ }^{820}$, sucessor de seu pai (de quem foi, talvez, discípulo) - juntamente com Nerácio Prisco (supra) - na direção da escola proculeiana $^{821}$.

Escreveu Celso: os libri digestorum (39 no total) ${ }^{822}$, dos quais uma parte é dedicada ao ius honorarium (livros 1 a 27) e a restante ao ius civile, os libri epistularum (11 ao menos), os libri quaestionum (12 ao menos) e os comentarii (ao menos em 7 livros) ${ }^{823}$.

Caracteriza-se o jurista pela pureza e clareza de sua linguagem, pela independência de suas construções jurídicas bem como pela agudeza de sua crítica; suas obras foram utilizadas ainda por outros jurisconsultos como Pompônio, Paulo e Modestino ${ }^{824}$.

Em seguida, aduz-se à opinião de $\operatorname{Celso}^{825}$ a concordância de Juliano, contemporâneo do primeiro e corifeu da escola oposta (sabiniana) ${ }^{826}$. Célebre em seu

${ }^{817}$ Cf. O. LENEL, Pal. Ulp. 2707-2720; 2736-2737.

${ }^{818}$ E especificamente no que concerne ao texto em estudo, situa-se esse em uma subsecção denominada por O. LENEL de «de custodia a venditore praestanda». Cf. Pal. Ulp. 2731-273.

819 Cf. P. KRÜGER, Geschichte cit. (nt. 476 supra), pp. 243-244; R. ORESTANO, Ulpiano cit. (nt. 809 supra), p. 1107.

${ }^{820}$ Cf. P. KRÜGER, Geschichte cit. (nt. 476 supra), p. 180, nt. 02.

${ }^{821}$ Dentre os cargos ocupados pelo jurista contam-se: pretor em 106 ou 107 d. C. (PLIN. epist. 6, 5, 4), legato na Trácia (entre 107 e 117 d. C.), e por duas vezes, cônsul (Pomp. l. sing. enchir., D. 1, 2, 2, 53), a última das quais em 129 d. C. (Ulp. 15 ad ed., D. 5, 3, 20, 6; Diocl. et Maxim., C. 7, 9, 3, de 290 ou 293). Integrou, ainda, o consilium do imperador Adriano, falecendo, muito provavelmente, antes do término do governo deste, já que Juliano parece referir-se a ele como defunctus em uma passagem de sua obra (29 dig., D. 28, 2, 13 pr.). Cf. P. KRÜGER, Geschichte cit. (nt. 476 supra), pp. 180-181; W. KUNKEL, Die römischen cit. (nt. 476 supra), p. 146; M. KASER, Römische Rechtsgeschichte cit. (nt. 594 supra), p. 170; L. WENGER, Die Quellen cit. (nt. 476 supra), p. 501; F. SCHUlZ, Geschichte cit. (nt. 590 supra), p. 123; R. ORESTANO, Celso Giuvenzio (figlio) (P. Juventius Celsus Titus Aufidius Hoenius Severianus), in NNDI 3 (1957), p. 91; A. GuARINO, L'esegesi I cit. (nt. 314 supra), p. 197; G. DULCKEIT - F. SCHWARZ - W. WALDSTEIN, Römische Rechtsgeschichte cit. (nt. 592 supra), p. 260.

${ }^{822}$ Trata-se de sua principal obra, na qual o jurista refundiu grande parte dos seus escritos e decisões anteriores. De acordo com aquilo que restou (os fragmentos recolhidos no Digesto), parece verossímil que Celso procurou conferir ao seu trabalho um caráter mais prático do que dogmático. Cf. R. ORESTANO, Celso Giuvenzio cit (nt. 821 supra), p. 91.

${ }^{823}$ Cf. A. GUARINO, L'esegesi I cit. (nt. 314 supra), p. 198.

824 À parte a citação de juristas mais antigos (v.g., Quinto Múcio Cévola, Rutílio Rufo, Túbero, Trebácio), seviu-se Celso das obras de juristas como Labeão, Nerva, Próculo, Sabino, Cássio. Cf. P. KRÜGER, Geschichte cit. (nt. 476 supra), pp. 181-182; M. KASER, Römische Rechtsgeschichte cit. (nt. 594 supra), p. 170; L. Wenger, Die Quellen cit. (nt. 476 supra), p. 501; R. ORESTANo, Celso Giuvenzio cit (nt. 821 supra), p. 91; G. DULCKEIT - F. SCHWARZ - W. WALDSTEIN, Römische Rechtsgeschichte cit. (nt. 592 supra), p. 260. 
tempo e também posteriormente, Sálvio Juliano representa o encerramento da época das controvérsias de escola e a abertura de nova via na iurisprudentia, a saber, a tendência sistemática que consiste na principal característica dos juristas do período adrianeu ${ }^{827}$.

Se, por um lado, revela menos originalidade de expressão comparativamente a Celso, Juliano é-lhe superior no que concerne à riqueza de pensamento e arte de exposição, superando também todos os juristas em intuição jurídica e virtuosidade de tratamento do caso concreto, inclusive Papiniano ${ }^{828}$.

Atribuem-se-lhe antologias anotadas como os libri IV ad Urseium Ferocem (em 10 livros, provavelmente), e os libri VI ex Minicio, e um - provavelmente compilado em época pós-clássica - liber singularis de ambiguitatibus; porém, os libri XC digestorum, dedicados tanto à matéria do edito pretório quanto ao ius civile, constituem sua principal obra $^{829}$, à qual foram, em edições sucessivas, apostas notae de juristas como Marcelo, Cévola e Paulo; tiveram-na por base também os comentários ad edictum de Paulo e Ulpiano $^{830}$.

${ }^{825}$ Proveniente, embora Ulpiano não refira expressamente, do livro 12 digestorum, dedicado a duas matérias: de furtis e de operis libertorum. Cf. O. LENEL, Pal. Cels. 101.

${ }^{826}$ Os dados biográficos - concernentes ao local de proveniência, parentesco e cargos assumidos - de Sálvio Juliano são bastante controvertidos: ao que parece, exerceu funções como decemvir litibus iudicandis, quaestor (sob Adriano), tribunus plebis, praetor, praefectus aerarii Saturni e praefectus aerarii militaris, cônsul por duas vezes (o segundo, muito provavelmente em 148 d. C.), curator aedium sacrarum (150 d. C.), pontifex, sodalis (Hadrianalis e Antoninianus), governador da Germania inferior (sob Antonino Pio), e da Hispania inferior (sob Marco Aurélio e Lúcio Vero) (de 161 a 166 d. C.) e, finalmente, da África. Integrou, ainda, o consilium de todos esses imperadores em cujos governos viveu (Adriano, Antonino Pio e os divi fratres). Teria sido bisavô materno (proavus) do imperador Dídio Juliano. No que respeita à sua carreira de jurista, Juliano apresenta-se como discípulo de Javoleno (Iul. 42 dig., D. 40, 2, 5), e tornou-se célebre por ter sido responsável pela organização do Edictum Perpetuum sob Adriano. Cf. P. KRÜGER, Geschichte cit. (nt. 476 supra), p. 182; W. KUNKEL, Die römischen cit. (nt. 476 supra), pp. 157-166; M. KASER, Römische Rechtsgeschichte cit. (nt. 594 supra), p. 170; também 129-130; L. WENGER, Die Quellen cit. (nt. 476 supra), p. 503; F. SCHUlZ, Geschichte cit. (nt. 590 supra), p. 124; R. ORESTANO, Giuliano Salvio (Lucius [o anche Publius?] Octavius Cornelius P. filius Salvius Iulianus Aemilianus), in NNDI 7 (1957), p. 913; A. GUARINO, L'esegesi I cit. (nt. 314 supra), pp. 206-207; G. DUlCKEIT - F. SCHWARZ - W. WALDSTEIN, Römische Rechtsgeschichte cit. (nt. 592 supra), pp. 260-261.

${ }^{827}$ Com efeito, depois de Labeão, Juliano teria sido um grande fomentador do desenvolvimento dogmático do direito clássico; tal como aquele, representa um inovador revolucionário, dando, porém à dogmática clássica a sua configuração, em geral, sólida e permanente. Cf. A. GUARINO, L'esegesi I cit. (nt. 314 supra), p. 209; G. DULCKEIT - F. SCHWARZ - W. WALDSTEIN, Römische Rechtsgeschichte cit. (nt. 592 supra), p. 260.

${ }^{828}$ Cf. M. KASER, Römische Rechtsgeschichte cit. (nt. 594 supra), p. 170; L. WENGER, Die Quellen cit. (nt. 476 supra), p. 503; G. DULCKEIT - F. SCHWARZ - W. WALDSTEIN, Römische Rechtsgeschichte cit. (nt. 592 supra), pp. 260-261.

${ }^{829}$ E dela provêm as referências às citações do jurista por Ulpiano: no principium («...et ita et Iulianus»), a seguir a reconstrução de O. LENEL, a opinião encontrar-se-ia no livro 22 digestorum, dedicado ao furto (de furtis) e a temas correlacionados (v.g., condictio furtiva, actio furti noxalis), bem como uma subsecção de operis libertorum. Cf. Pal. Iul. 339. Por sua vez, conforme o mesmo autor, a citação do $§ 1$ («vincensio tertio digestorum») estaria incorreta, devendo-se substitui-la por livro 22 digestorum. Cf. Palingenesia I cit. (nt. 484 supra), col. 376, nt. 01.

${ }^{830}$ Cf. P. KRÜGER, Geschichte cit. (nt. 476 supra), p. 183; M. KASER, Römische Rechtsgeschichte cit. (nt. 594 supra), p. 170; R. ORESTANO, Giuliano Salvio cit (nt. 826 supra), p. 914; A. GUARINO, L'esegesi I cit. 
Em seu principal trabalho (os digesta), Juliano cita, dentre outros, Quinto Múcio Cévola, Aquílio Galo, Sérvio, Labeão, Mela, Sabino, Cássio, Próculo, Pégaso, Nerva, Atilicino, Valério Severo, Javoleno, Aristão e Pompônio ${ }^{831}$.

O texto atribuído a Ulpiano assume relevância nessa sede por citar juristas precedentes - Celso e, por duas vezes, Juliano - atribuindo-lhes opiniões com relação, em geral, à legitimação ativa à actio furti no caso de ser a coisa vendida furtada antes de sua entrega ao comprador. E, nesse contexto, menciona-se ainda, por duas vezes, uma custodia a cargo do vendedor (como objeto de praestare).

Celso teria escrito que a actio furti, antes da tradição da coisa ao comprador, cabe exclusivamente ao vendedor, e disso se infere que, no contexto original (12 dig.), o jurista considerasse o caso de furto da coisa vendida ${ }^{832}$. A «sententia» iria além, a seguir o dado textual: o vendedor deveria ceder («mandare») ${ }^{833}$ ao comprador não só aquela actio, mas também a condictio e a vindicatio.

E - aparentemente como «motivação» ${ }^{834}$ - aduz-se «et sane periculum rei ad emptorem pertinet, dummodo custodiam venditor ante traditionem praestet $\gg:$ o risco da coisa cabe ao comprador, contanto que o vendedor responda pela custódia antes da entrega.

A conclusão do principium oferece dificuldades: «dummodo»(«contanto que»), partícula que condicionaria o traspasso do periculum à responsabilidade por custodia do vendedor, construção que não teria paralelo em outras fontes ${ }^{835}$. Na literatura mais recente, entretanto, parece encontrar acolhida uma leitura da conjunção em sentido adversativo: o

(nt. 314 supra), pp. 209-210. E também consiste no jurista que, após Ulpiano e Paulo, foi o mais aproveitado pelos compiladores justinianeus do Digesto. Cf. L. WENGER, Die Quellen cit. (nt. 476 supra), p. 503.

${ }^{831}$ Por sua vez, Celso não é citado nem uma vez por Juliano, assim como esse não é referido pelo primeiro em suas obras, o que parece sugerir a existência de uma provável rivalidade pessoal entre as duas figuras de juristas, já situados, em seu tempo, na chefia de escolas antagônicas. Alguns textos, que sugerem o contrário (ou seja, o «diálogo» entre os dois juristas podem ser interpretados por outro modo: assim, v.g., Ulp. 29 ad ed., D. 14, 6, 7 pr. (a observação de Juliano referir-se-ia a Nerácio) e Iul. 29 dig., D. 28, 2, 13 pr. (a frase final não seria de se atribuir ao autor do Edito Perpétuo). Cf. P. KRÜGER, Geschichte cit. (nt. 476 supra), p. 184 e nt. 40; L. WENGER, Die Quellen cit. (nt. 476 supra), p. 503; A. GUARINO, L'esegesi I cit. (nt. 314 supra), p. 210.

${ }^{832}$ Pode ser, pelo caráter predominantemente prático dos digesta de Celso (supra), que fosse um caso concreto submetido à apreciação do jurisconsulto; de todo modo, a determinação dessa circunstância não parece ser relevante para o tema estudado.

833 «Mandare actionem» equivale à «cedere», isso é, a cessão do exercício de uma ação a alguém. Cf. H. HeUMMAN - E. SECKEL, Mandare, in Handlexicon cit. (nt. 18 supra), p. 331.

${ }^{834}$ Cf., nesse sentido, E. BETTI, «Periculum» cit. (nt. 420 supra), p. 141.

835 Cf. F. SChulz, Rezension de L. LusignAni, La responsabilità cit. (nt. 557 supra), p. 66; 94; F. HAYMAnN, Textkritische I cit. (nt. 211 supra), p. 320; ID., Textkritische II cit. (nt. 492 supra), p. 123. Por outro lado, consideram-no genuíno, E. SECKEL - E. LEVY, Gefahrtragung cit. (nt. 421 supra), p. 251; R. RoBAYE, L'obligation cit. (nt. 42 supra), p. 377; P. VocI, 'Diligentia' cit. (nt. 12 supra), p. 74, nt. 50. 
risco da coisa vendida cabe ao comprador, ao passo que o vendedor, antes da tradição, tem de responder pela custodia $^{836}$.

No que concerne à solução, V. ARANGIO RUIZ atribui aos compiladores seja o estabelecimento do dever de cessão da actio furti dessa à contraparte, seja a - com esse contraditória - hipótese de propositura das ações pelo próprio devedor ${ }^{837}$. Apesar da má acomodação do último período («et sane..»), no fechamento da discussão, o texto teria conservado um resquício clássico, consistente na apresentação de «custodiam praestare» como «critério normal» (um naturalia negotii) de responsabilidade ${ }^{838}$.

E. BETTI, apoiado em hipóteses de interpolação, pretendeu reconstituir o teor originário do texto que pudesse restituir-lhe uma coerência entre decisão e fundamento: o absurdo, no seu estado atual, residiria na justificativa da legitimação do vendedor à actio furti com base na atribuição do risco ao comprador ${ }^{839}$.

Dar-se-ia tal restituição do teor original pela eliminação, fundamentalmente, de «mandare...oportebit», e a substituição de «emptorem» por «venditorem» na sentença final $^{840}$. Resultaria, assim, que o vendedor é o legitimado ativo à actio furti porque suporta o periculum: esse último, com efeito, seria o fundamento do interesse legitimante àquela, e

836 Assim, mais recentemente, M. KASER, que conjectura a substituição do originário «dum» por «dummodo», provalmente devida a um erro de transcrição de abreviatura pelo copista. Cf. Die actio cit. (nt. 258 supra), p. 121; nt. 131. A interpretação do texto nesse sentido já remonta, em partes, a autores precedentes: v.g., J. C. HASSE, Die Culpa cit. (nt. 196 supra), p. 313.

837 Originalmente, a obrigação de cessão teria por objeto, segundo o autor, apenas as ações reipersecutórias: a vindicatio e a condcitio ex causa furtiva. Cf. Responsabilità cit. (nt. 04 supra), p. 154.

${ }^{838}$ Considerando-se, em geral, a leitura de V. ARANGIO-RUIZ do principium, a demarcação visualizada pelo autor entre «solução clássica» e «justinianéia» dar-se-ia nos seguintes termos: o vendedor, responsável por custodia (como declarado in fine), seria, por essa razão, o legitimado ativo à actio furti; por sua vez, o compilador teria estabelecido, no início, o dever de cessão dessa ao comprador, a quem cabia, na solução originária apenas a suportação do periculum em sentido estrito. Cf. Responsabilità cit. (nt. 04 supra), pp. $154-155 ; 157$.

${ }^{839}$ Cf. E. BETTI, «Periculum» cit. (nt. 420 supra), pp. 141-142.

840 «Eum qui emit, si non tradita est ei res, furti actionem non habere, sed adhuc venditoris esse hanc actionem Celsus scripsit. Quae sententia vera est, et ita et Iulianus. Et sane periculum rei ad 〈venditorem> pertinet. <Quod si> custodiam venditor ante traditionem praestare <receperit>, mandare eum oportebit emptori condictionem et vindicationem, et si quid ex his actionibus fuerit consecutus, id praestare». (= Celso escreveu: aquele que comprou, se não lhe foi entregue a coisa, não tem a actio furti, pois que, até então, essa ação é do vendedor. Esse parecer é acertado, e assim também <opina> Juliano. E, certamente, o risco da coisa cabe ao vendedor. Porém, se o vendedor tiver assumido a garantia pela custódia antes da entrega, será necessário que ele ceda ao comprador a condictio e a vindicatio, e se algo tiver sido obtido <da propositura> dessas ações, será necessário que ele <vendedor> preste <isso> ao comprador). Cf. E. BETTI, «Periculum» cit. (nt. 420 supra), p. 142.

Ainda uma vez, a «restituição» da lógica do texto pretendida pelo autor ampara-se na hipótese por ele admitida e sistematicamente aplicada à análise de todos os textos concernentes à matéria: «custodiam praestare» era um elemento dependente de pacto para integrar o regime jurídico da compra e venda. A cessão das ações, também presente nos fragmentos anteriores, seria um sucedâneo do ressarcimento devido por força da responsabilidade por custodia do vendedor: por outros termos, ao invés de indenizar o comprador, poderia o vendedor transferir-lhe os meios para a persecução da coisa junto ao terceiro que a furtou. 
não a propriedade ou o «custodiam praestare», mero elemento acidental, para o autor, da compra e venda ${ }^{841}$.

Por outro lado, M. TALAMANCA considera que o principium não forneça elementos suficientes para se afirmar que nele haja um aceno à responsabilidade por custodia convencional. Além disso, não exclui o autor a possibilidade de que o acostamento da actio furti às ações reipersecutórias (vindicatio e condictio furtiva) derive de uma reescritura do texto, dada a similitude com o Gedankengang de Inst. $3,23,3 \mathrm{a}^{842}$.

Entretanto, no que concerne ao $\S 1$, esse aludiria, segundo o autor, à assunção convencional da responsabilidade por custodia $^{843}$. Ainda que abstratamente possível, seria menos provável, segundo o autor, que, para Juliano, o quanto dito no texto - um vendedor que pode ou não («oportebat») dever a custodia - estivesse relacionado com a exclusão pactual dessa responsabilidade ${ }^{844}$.

Assim interpretado, essse parágrafo assumiria relevância por demonstrar o alinhamento (ainda) de Juliano com o filão que considera a custodia um elemento acidental - tal como, provavelmente, Gaio - na compra e venda ${ }^{845}$.

Em contrapartida, R. CARDILLI pretende que o texto (tanto o principium como o $\S$ 1) preste-se a infirmar tendências generalizantes da perspectiva gaiana (qual seja, a da custodia como elemento acidental), uma vez que o «custodiam praestare» do vendedor, neste, não dependeria da existência de um pacto entre os contratantes ${ }^{846}$.

Por sua vez, M. SERRANO-VICENTE sustenta que Ulpiano - com apoio na opinião de Juliano unida àquela de Celso - fundamenta a legitimação ativa do vendedor à actio furti em seu «custodiam praestare», que teria, para Juliano, natureza pactual no âmbito da compra e venda ${ }^{847}$.

Substancialmente de acordo com M. TALAMANCA sobre a interpretação do $\S 1^{848}$, concentra-se esse autor na tentativa de esclarecimento do principium.

${ }^{841}$ Cf. E. BETTI, «Periculum» cit. (nt. 420 supra), pp. 142-143.

${ }^{842}$ Cf. Vendita cit. (nt. 21 supra), p. 429, nt. 1303; 449, nt. 1511 e 1515.

${ }^{843}$ Cf. Vendita cit. (nt. 21 supra), pp. 448-449.

${ }^{844}$ Cf. M. TalamancA, Vendita cit. (nt. 21 supra), p. 449, nt. 1510. Por outros termos a hipótese abstratamente possível - mas menos provável, segundo o autor, seria aquela segundo a qual Juliano considerasse «custodiam praestare» um «naturale negotii», e a convenção teria por finalidade não estabelecer, mas sim excluir a custodia como critério para a determinação da responsabilidade do vendedor.

${ }^{845}$ Cf. M. TAlamancA, Vendita cit. (nt. 21 supra), p. 449, nt. 1511; também M. SERRANO-VICENTE considera que, nessa passagem, «custodiam praestare» é tratado como uma possibilidade e não como uma exigência geral, corroborando-se, assim, a posição de Juliano nesse ponto específico da matéria. Cf. Custodiam praestare cit. (nt. 26 supra), pp. 303-305, especialmente p. 305.

${ }^{846}$ Cf. L'obbligazione cit. (nt. 04 supra), p. 494.

${ }^{847}$ Custodiam praestare cit. (nt. 26 supra), p. 302.

${ }^{848}$ Cf. M. SERRANO-VICENTE, Custodiam praestare cit. (nt. 26 supra), p. 305. 
A causa da disfunção presente no texto dever-se-ia ao fato de que Ulpiano pertence a uma época na qual a valoração das obrigações do vendedor encontrar-se-ia modificada, e de acordo com essa perspectiva, enuncia-se como princípio geral in fine: «et sane periculum rei ad emptorem pertinet, dummodo custodiam venditor ante traditionem praestet» $^{849}$.

Entretanto, a aplicação deste princípio seria contraditória, pois se afirma que o vendedor deve ceder ao comprador as ações (ou o quanto tiver obtido da propositura delas), por ser ele o contratante que suporta o «periculum» ${ }^{850}$.

Essa contradição, segundo M. SERRANO-VICENTE, ter-se-ia originado da tentativa de coordenar a opinião de Juliano e Celso - «et ita (Celsus) et Iulianus» - para os quais, salvo a hipótese de pacto, o vendedor não deveria custodiam praestare, com a orientação dos juristas severianos (Ulpiano, no caso), para os quais a custodia já figura como elemento natural da compra e venda (infra $)^{851}$.

\section{Conclusões parciais}

Em uma leitura de conjunto, a explicação dessa «divergência» entre os textos poderia, como parece propor M. TALAMANCA, encontrar explicão em orientações diversas das escolas de direito em Roma (a saber, proculeianos e sabinianos).

Assim, o filão sabiniano - representado, no caso, por textos de Gaio (aquele extraído do comentário ad edictum provinciale e, indiretamente, aquele inserido nas Institutas imperiais), e pela opinião de Juliano reportada no texto de Ulpiano - teria considerado «custodiam praestare» um elemento acidental do contrato de compra e venda $^{852}$.

Em contrapartida - a seguir a leitura que faz o autor do texto atribuído a Nerácio os proculeianos teriam assumido a configuração da custodia como elemento natural, opinião essa que prevaleceria na iurisprudentia tardo-clássica (tal como se verificaria nos textos de Ulpiano e, provavelmente também de Paulo, nessa matéria) ${ }^{853}$.

\footnotetext{
${ }^{849}$ Em outros termos, para o autor, o «periculum emptoris» é limitado pela prestação de custodia que incumbe ao vendedor (ou seja, responsabilidade em caso de perda da prestação devida a furto ou dano). Cf. M. SERRANO-VICENTE, Custodiam praestare cit. (nt. 26 supra), p. 304.

${ }^{850}$ Cf. M. SERRANO-VICENTE, Custodiam praestare cit. (nt. 26 supra), p. 304.

${ }^{851}$ Cf. Custodiam praestare cit. (nt. 26 supra), p. 304.

${ }^{852}$ Cf. M. TALAMANCA, Vendita cit. (nt. 21 supra), p. 449.

${ }^{853}$ Cf. M. TALAMANCA, Vendita cit. (nt. 21 supra), p. 449 e nt. 1516.
} 
Embora divergente de M. TALAMANCA quanto à interpretação desses textos examinados em particular, também R. CARDILLI prefere admitir - contrariamente a interpretações menos recentes e embasadas no método interpolacionístico (v.g., V. ArAngio-Ruiz e E. BetTi) -, a possibilidade de discordância de orientações entre os juristas, sem recorrer ao expediente da não genuinidade de uma das soluções representadas nas fontes.

Recorre o autor à hipótese de um provável controversum que teria divido os juristas a partir de Sabino: de um lado, aqueles que, ao acentuar a analogia entre a obrigação de rem restituere do comodatário e do locatário (conductor) e a de possessionem tradere do vendedor, consideraram-no também responsável pelo furto da coisa vendida ante traditionem $^{854}$. De outro lado, uma outra corrente de juristas - dentre os quais Gaio - teria admitido um agravamento do normal «culpam praestare» do vendedor apenas por convenção ${ }^{855}$.

Portanto, no que se refere ao complexo quadro da iurisprudentia adrianéia, seria preferível admitir, no que respeita à posição de custodiam praestare no contrato de compra e venda, a existência de posicionamentos diversos dos juristas: accidentalia negotii (Gaio e Juliano) e naturalia negotii (Nerácio).

\footnotetext{
${ }^{854}$ Seria, aparentemente, o caso de Celso e Juliano. Cf. L'obbligazione cit. (nt. 04 supra), p. 395.

855 Cf. L'obbligazione cit. (nt. 04 supra), p. 395; e representaria, como já propunha M. KASER, uma «Sondermeinung» na matéria. Cf. Das römische Privatrecht I cit. (nt. 05 supra), p. 508, nt. 39.
} 


\section{Capítulo III}

\section{«CUSTOdiam Praestare» do Vendedor na IURISPRUdentia SEVERIANA: Papiniano, Ulpiano e Paulo}

\section{Generalidades}

Nessa secção se reúnem os textos atribuídos aos juristas da época severiana Papiniano, Ulpiano e Paulo - com exceção de um, cuja autoria seria de Gaio. O texto de Papiniano versa sobre o problema da legitimação ativa à actio furti do vendedor, retomando-se, em parte, a discussão já apresentada no capítulo anterior ${ }^{856}$.

A maior parte dos textos, entretanto, situa-se em D. 18, 6 do Digesto, sedes materiae do periculum rei venditae, e têm como elemento comum, em regra, o fato de referir-se à compra e venda de vinhos. Por esse atrelamento, refletido na disposição que a ele deram os compiladores no Digesto, justifica-se o tratamento do texto atribuído a Gaio nesta e não na secção anterior ${ }^{857}$.

Analisa-se, por fim, um discutido texto de Paulo, no qual se estabeleceria uma correlação do problema da responsabilidade por custodia com danos que costumam acometer coisas imóveis, consistindo no aspecto diferencial dos textos até o momento analisados - em sua maior parte - relacionados à típica hipótese do furto da res vendita ${ }^{858}$.

\section{O furto do escravo vendido}

Papin. 12 quaest., D. 47, 2, 81 pr.: Si vendidero neque tradidero servum et is sine culpa mea subripiatur, magis est, ut mihi furti competat actio: et mea videtur interesse, quia dominium apud me fuit vel quoniam ad praestandas actiones teneor.
Se eu tiver vendido, mas não entregado um escravo e esse for furtado sem minha culpa, deve competir-me a ação de furto. Pois parece que sou eu quem tem interesse, já que tinha a propriedade dele ou porque estou obrigado a ceder as ações.

\footnotetext{
${ }^{856}$ Em relação ao texto de Ulpiano (29 ad Sab., D. 47, 2, 14 pr.).

857 Com efeito, o texto de Gaio relaciona-se a uma modalidade de venda de vinho (ad mensuram) e correlaciona-se diretamente com o fragmento anterior, na cadeia de textos dispostas pelos compiladores, de modo que sua análise em conjunto com esses pareceu mais conveniente.

858 Outro traço comum, ao menos no que se relaciona a esses dois últimos grupos de textos mencionados (isso é, atinentes à compra e venda de vinhos e imóveis), seria a ausência de indícios de uma custodia convencional. Cf. M. KASER, Die actio cit. (nt. 258 supra), p. 106.
} 
Um escravo («servum») vendido foi furtado («subripuerit»), sem culpa do vendedor, antes de sua entrega ao comprador. Decide o jurista ${ }^{859}$ que a actio furti contra o ladrão caberia ao vendedor porque dele seria o interesse, aduzindo-se duas razões para tanto: (a) porque dele era a propriedade («quia dominium apud me fuit») e (b) porque estaria obrigado a ceder as ações («quoniam ad praestandas actiones teneor»).

Emílio Papiniano, cuja produção jurídica data do final do século II d. C. ${ }^{860}$ e início do seguinte, tornou-se muito célebre entre os pósteros, que o consideraram o maior dos juristas romanos ${ }^{861}$.

São-lhe atribuídos: os libri XXXVII quaestionum (escritos, provavelmente, entre 193 e 198 d. C.), os libri XIX responsorum, os libri II definitionum, os libri II de adulteriis (resumidos, em época pós-classica, em um liber singularis de adulteriis) e também - mas de genuidade discutida - uma já referida obra monográfica denominada Ast unomico," monobibl $0^{\prime 862}$.

Caracteriza-se Papiniano - cujas obras pertencem aos gêneros literários práticocasuísticos, semelhantemente àquelas dos grandes juristas clássicos - por um estilo sintético, limitado ao essencial, revelando mestria em sumariar, de forma não complexa, a apresentação do caso, a sua decisão e o fundamento dessa ${ }^{863}$.

As quaestiones, ao lado dos responsa, consistem em uma de suas principais obras: segue-se a estrutura dos digesta, designação essa que corresponderia melhor ao conteúdo do trabalho, e compõe-se tanto de discussões dogmáticas quanto de exames casuísticos ${ }^{864}$.

Nelas se aduzem opiniões de juristas precedentes (v.g., Quinto Múcio, Sérvio, Alfeno Varro, Labeão, Sabino, Cássio, Pégaso, Nerva, Célio Sabino, Nerácio, Aristão e, mais frequentemente, Juliano), sem nomeá-los em alguns casos, e também se referem

\footnotetext{
${ }^{859}$ Provavelmente se confrontava Papiniano com um caso concreto, dado o caráter também práticocasuístico de suas quaestiones. Cf. infra.

${ }^{860}$ Também os dados biográficos de Papiniano são bastante controvertidos. Sabe-se que foi muito próximo de Setímio Severo (193-211 d. C.), por quem foi nomeado magister libellorum e, mais tarde, praefectus praetorio (provavelmente em 203 d. C.), cargo do qual foi destituído por Caracala talvez já mesmo em 211 d. C., ano da ascenção desse ao trono. São também incertos a origem síria do jurista, a sua adfinitas com o imperador Septímio Severo, o fato de ter sido professor na escola de Beirute e, finalmente, as razões que motivaram o seu assassinato. Cf. P. KRÜGER, Geschichte cit. (nt. 476 supra), pp. 220-221; L. WENGER, Die Quellen cit. (nt. 476 supra), p. 512; F. SCHUlZ, Geschichte cit. (nt. 590 supra), p. 126; M. KASER, Römische Rechtsgeschichte cit. (nt. 594 supra), p. 174; W. KUNKEL, Die römsichen cit. (nt. 447 supra), pp. 224-229; A. GUARINO, L'esegesi I cit. (nt. 314 supra), pp. 226-229; G. DULCKEIT - F. SCHWARZ W. WALDSTEIN, Römische Rechtsgeschichte cit. (nt. 592 supra), p. 266.

${ }^{861}$ Cf. P. KRÜGER, Geschichte cit. (nt. 476 supra), p. 224, nt. 83; M. KASER, Römische Rechtsgeschichte cit. (nt. 594 supra), p. 175; L. WENGER, Die Quellen cit. (nt. 476 supra), pp. 514-515.

${ }^{862}$ Cf. A. GUARINO, L'esegesi I cit. (nt. 314 supra), pp. 230-231.

${ }^{863}$ Cf. M. KASER, Römische Rechtsgeschichte cit. (nt. 594 supra), pp. 174-175.

${ }^{864}$ Cf. P. KRÜGER, Geschichte cit. (nt. 476 supra), p. 221; A. GUARINO, L'esegesi I cit. (nt. 314 supra), p. 230.
} 
algumas constituições imperiais, sobre as quais se dá ou não um aprofundamento ulterior $^{865}$.

A importância desse texto consiste na possibilidade de extrair dele informações acerca da responsabilidade do vendedor por custodia em razão do tratamento, pelo jurista, de problemas correlatos, como o furto e a legitimação à actio furti ${ }^{866}$.

Em relação a esse último, sabe-se que o legitimado ativo à aludida actio era o sujeito que tinha o prevalente interesse na conservação da coisa subtraída, ainda que não fosse o seu proprietário ${ }^{867}$. Nesses termos, aproximativamente, o discurso de Gaio, no desenvolvimento do qual tratou o jurista dos sujeitos responsáveis pela custodia (fullo, sarcinator e comodatário) ${ }^{868}$.

Em relação a esses, a idéia fundamental consistiria: aquele que perdeu, por furto uma coisa a cuja restituição estava obrigado, deve - se for responsável pelo furto mesmo sem culpa - ter a actio furti, por se tratar do sujeito que suportaria o prejuízo ${ }^{869}$.

Pretendeu-se ${ }^{870}$ que o único fundamento do interesse, base da legitimação à actio furti, consistisse na responsabilidade por custodia. Entretanto, como observa M. KASER, se tivesse sido essa a única solução admitida pelos juristas romanos, poderiam ter eles feito referência diretamente a um custodiam praestare e não, como se verifica nas fontes, a um genérico «interesse» ${ }^{871}$.

Com efeito, esse interesse aludido poderia depender, além da responsabilidade do devedor furtado por custodia (que corresponderia a um «Haftungsinteresse»), de uma «legitimação própria» («Eigenberechtigung»), que se deduziria de certas «dinglichen oder quasidinglichen Berechtigungen» (e conformantes, a seu turno, de um «Eingeninteresse»), independentes da primeira ${ }^{872}$.

${ }^{865}$ Cf. P. KRÜGER, Geschichte cit. (nt. 476 supra), p. 222.

${ }^{866}$ Já entrevia essa correlação, em geral, V. ARANGIO-RUIZ, Responsabilità cit. (nt. 21 supra), p. 153.

${ }^{867}$ Cf. Gai. 3, 203.

${ }^{868}$ Cf. Gai. 3, 205-206.

${ }^{869}$ A pretensão punitiva conferiria ao devedor furtado, primeiramente a reparação pelo ilícito sofrido, e, ao mesmo tempo, representaria - como contrapeso do risco - uma espécie de regresso contra o ladrão (entende-se, por ter ele, devedor, de responder à contraparte contratual), sem que esse montante fosse determinado pela extensão de sua responsabilidade perante o credor. Cf. M. KASER, Die actio cit. (nt. 258 supra), p. 101.

${ }^{870}$ Cf., mais recentemente, R. RoBAYE, L'obligation cit. (nt. 42 supra), p. 385.

${ }^{871}$ Cf. M. KASER, Die actio cit. (nt. 258 supra), p. 102; M. TALAMANCA, Vendita cit. (nt. 21 supra), p. 428, nt. 1299; M. SERRANO-VICENTE, Custodiam cit. (nt. 26 supra), p. 347, nt. 1115.

${ }^{872}$ Cf. M. KASER, Die actio cit. (nt. 258 supra), pp. 102-104, com exemplos. 
Diante desse quadro, a partir do qual restariam mais bem elucidados os parágrafos de Gaio concernentes ao assunto ${ }^{873}$, restaria indagar acerca do interesse que fundamenta a legitimação ativa do vendedor à actio furti.

Considera Papiniano o caso de um escravo que, antes da entrega ao comprador, fora subtraído e afirma ser o vendedor («magis est») o legitimado à actio furti. A concreta res vendita (servus) assumiria relevância, seguramente, em relação à fuga, pois só se responderia por essa, nos termos da custodia, se se tratasse de um servus custodiendus. $\mathrm{O}$ jurista, entretanto, alude não à fuga, mas à subreptio, isso é, ao furto do escravo vendido.

Na fattispecie, diz-se apenas que o vendedor é o legitimado ativo à propositura da actio furti contra o ladrão do escravo vendido. Disso se procurou, por algum modo, inferir que tal legitimação decorresse da responsabilidade por custodia do vendedor, prestando-se o texto em análise a concluir pela sua operatividade na compra e venda.

Assim, v.g., V. ARANGIO-RuIZ, ainda que admita a existência de remanejamentos textuais, sustenta que se teria conservado a substância da decisão clássica: precisamente, a responsabilidade por custodia do vendedor é que daria fundamento à legitimação ativa afirmada por Papiniano ${ }^{874}$.

Entretanto, observa M. KASER que a particularidade da posição jurídica do vendedor em relação aos demais devedores responsáveis por custodia (v.g., conductores operis, comodatário), imporia considerar diversamente a base de seu interesse à actio furti $^{875}$.

Com efeito, o vendedor é - tendencialmente, ao menos - proprietário da coisa furtada, de modo que poderiam concorrer para a sua legitimação à aludida ação dois fundamentos de um «interesse rem salvam esse», a saber: (a) a propriedade e (b) uma (eventual) responsabilidade por custodia. Gaio, assim, teria feito entrar o vendedor na hipótese do $§ 203$ : o seu interesse decorreria da sua condição de proprietário ${ }^{876}$.

Nesse caso, portanto, não parece que se possa partir da legitimação ativa do vendedor a actio furti contra o ladrão do escravo subtraído - «sine culpa» - para concluir que o fundamento do interesse para aquela consistisse em um custodiam praestare a seu $\operatorname{cargo}^{877}$.

${ }^{873}$ Cf. M. KASER, Die actio cit. (nt. 258 supra), p. 104.

${ }^{874}$ Cf. Responsabilità cit. (nt. 04 supra), p. 155.

${ }^{875}$ Cf. M. KASER, Die actio cit. (nt. 258 supra), pp. 118-119.

${ }^{876}$ Cf. M. KASER, Die actio cit. (nt. 258 supra), p. 119; M. TAlamanCA, Vendita cit. (nt. 21 supra), p. 428.

${ }^{877}$ Com efeito, essa observação já proviria de J. BARON, ao advertir que não se deveria inferir do fato de alguns devedores terem a actio furti que fossem eles responsáveis por «custodia técnica». Em contrapartida, 
Logo, não parece ser possível extrair do texto de Papiniano ilações que permitam conhecer qual o posicionamento do jurista quanto a existência de um custodiam praestare a cargo do vendedor. Além disso, como observa M. TALAMANCA, o andamento do texto não seria muito coerente, e, no geral, parece que dele se possa concluir apenas que o vendedor não fosse responsável pelo furto do servus, devendo, não obstante, «praestare actiones», muito provavelmente, as reipersecutórias ${ }^{878}$.

\section{Custodiam praestare na compra e venda de vinhos}

\subsection{Compra e venda de vinho ad mensuram}

\subsubsection{Custodiam praestare na compra e venda de vinho ad mensuram}

Ulp. 28 ad Sab., D. 18, 6, 1, 1: Sed et custodiam ad diem mensurae venditor praestare debet: priusquam enim admetiatur vinum, prope quasi nondum venit. Post mensuram factam venditoris desinit esse periculum: et ante mensuram periculo liberatur, si non ad mensuram vendidit, sed forte amphoras vel etiam singula dolia.
$\mathrm{O}$ vendedor deve responder também pela custódia até o momento da medição <do vinho>. Antes, pois, que o vinho seja medido, é como se ainda não fosse ainda vendido. Após a realização da medida, o risco deixa de ser do vendedor. E, antes da medição, <o vendedor> libera-se do risco, se não vendeu <o vinho> por medida, mas, por exemplo, ânforas ou também tonéis um a um.

Deveria o vendedor de vinho ad mensuram também «custodiam praestare» até o dia da medição da mercadoria. Pois antes dessa operação, o vinho não se teria ainda como vendido. Após essa, deixaria o risco («periculum») de gravar sobre o vendedor, e, mesmo antes da medição, o vendedor não suportaria o risco se não tivesse vendido o vinho $a d$ mensuram, mas sim ânforas ou tonéis individuais.

O texto assume importância para esse estudo em vista da presença da locução, apresentada, nesse contexto de compra e venda de vinho, em sua forma técnica e, por assim dizer, habitual: «custodiam praestare (debet)».

seria possível afirmar que, pelo fato de certos devedores responderem por «custodia técnica», era-lhes concedida a actio furti como ressarcimento: em outros termos, a investigação deveria partir da Haftung für technische Custodia e não da legitimação ativa à actio furti. Cf. Die Haftung cit. (nt. 175 supra), p. 284; mais recentemente, também M. SERRANO-VICENTE, Custodiam praestare cit. (nt. 26 supra), p. 347, nt. 1151.

${ }^{878}$ Cf. Vendita cit. (nt. 21 supra), p. 492, nt. 1303. 
Provém o texto de Ulpiano ${ }^{879}$, e integraria o fragmento de abertura de uma secção dedicada especificamente à compra e venda de vinhos ${ }^{880}$ - do $28^{\circ}$ livro de seus comentários ad Sabinum, concernente, em sua maior parte, à emptio venditio em geral ${ }^{881}$. Inicialmente, o jurista $(p r .)^{882}$ teria tratado da distribuição de certos riscos na compra e venda perfecta e naquela com cláusula de degustação, passando, no $\S 1$, a considerar a compra e venda com cláusula de medição (ad mensuram $)^{883}$.

A passagem do principium ao $\S 1$ não parece, de fato, clara, circunstância essa que deu fundamento à suspeita, por parte de certos autores, de que o texto ulpianeu apresentase, no estado atual, abreviado ${ }^{884}$. Também a conformação do texto, em geral, denunciaria intervenções por parte dos compiladores, em vista de uma pretendida confusão em sua estrutura: «deve-se a custodia porque, até o dia da medição, não se tem ainda a compra e venda; efetuada a medida, ou não sendo ela necessária, o risco cabe ao comprador» ${ }^{885}$.

${ }^{879}$ Reevia-se, para os dados biográficos e estilísticos desse jurista do período severiano, ao capítulo precedente (Parte II, Cap. II, 4). Convém, nessa sede, aduzir que, se, por um lado, Paulo é o jurista mais frequentemente citado no que concerne ao problema do periculum rei venditae em geral (D. 18, 1-D. 19, 1), por outro, os textos de Ulpiano assumiriam prevalência no que respeita ao problema do Gefahrtragung no específico contexto da compra e venda de vinhos. Cf. É. JAKAB, Risikomangement cit. (nt. 429 supra), pp. 193-194.

${ }^{880}$ Compor-se-ia essa dos dois longos fragmentos ulpianeus recolhidos em D. 18, 6: D. 18, 6, 1 e D. 18 , 6, 4. Cf. O. LenEL, Palingenesia II cit. (nt. 483 supra), cols. 1121-1122 - Pal. Ulp. 2717-2718.

${ }^{881}$ Cf. O. Lenel, Palingenesia II cit. (nt. 483 supra), cols. 1115-1122 - Pal. Ulp. 2701-2720. Desses, com efeito, 13 fragmentos dizem respeito à compra e venda (Pal. Ulp. 2707-2720).

${ }^{882}$ Ulp. 28 ad ed., D. 18, 6, 1 pr.: Si vinum venditum acuerit vel quid aliud vitii sustinuerit, emptoris erit damnum, quemadmodum si vinum esset effusum vel vasis contusis vel qua alia ex causa. Sed si venditor se periculo subiecit, in id tempus periculum sustinebit, quoad se subiecit: quod si non designavit tempus, eatenus periculum sustinere debet, quoad degustetur vinum, videlicet quasi tunc plenissime veneat, cum fuerit degustatum. Aut igitur convenit quoad periculum vini sustineat, et eatenus sustinebit, aut non convenit et usque ad degustationem sustinebit. Sed si nondum sunt degustata, signata tamen ab emptore vasa vel dolia, consequenter dicemus adhuc periculum esse venditoris, nisi si aliud convenit (= Se o vinho vendido tiver azedado ou for afetado por algum outro vício, o dano será do comprador, tal como se o vinho se tivesse derramando ou devido à ruptura dos recipientes ou por qualquer outra causa. Mas se o vendedor tiver assumido o risco, suportá-lo-á naquele período de tempo no qual o assumiu. Porém, se <o vendedor> não designou o período, deve ele suportar o risco até que o vinho seja degustado, como se a venda tivesse sido definitivamente concluída quando o vinho tiver sido degustado. Logo, ou se convencionou até que ponto se suporte o risco do vinho, e suportá-lo-á até esse momento, ou não se convencionou e suportá-lo-á até a degustação. Mas se não foram ainda degustados, mas marcadas as jarras ou os tonéis pelo comprador, diremos, coerentemente, que o risco ainda é do vendedor, a não ser que se tenha convencionado outra coisa).

Esse fragmento, a partir da disposição que a ele deram os compiladores na sedes materiae do periculum rei venditae, figuraria como um «Leitfaden», ou seja, um compêndio que forneceria as diretrizes e principais definições úteis para todo o título (D. 18, 6). Cf. É. JAKAB, Risikomanagement cit. (nt. 429 supra), p. 205; cf., também, a contextualização de M. PENNITZ, Das periculum cit. (nt. 30 supra), p. 399.

${ }^{883}$ Cf. J. BARON, «Diligentia» cit. (nt. 175 supra), pp. 272-273.

${ }^{884}$ Cf. G. MACCORMACK, Custodia cit. (nt. 264 supra), p. 184.

${ }^{885}$ Cf. V. ArANGIO-RUIZ, Responsabilità cit. (nt. 04 supra), p. 160, nt. 01. 
A previsão da admensio, como observa M. TALAMANCA, poderia dar-se não só no âmbito da venda de um gênero limitado, mas também na venda, sob medida, de um conjunto já individualizado de coisas fungíveis ${ }^{886}$.

Está-se informado, pelo texto de Ulpiano, que há uma venda de vinho ad mensuram, mas não seria possível determinar se a medição devesse ser realizada a partir de uma reserva especificamente determinada ou de um estoque mais amplo (caracterizandose, então, uma venda de gênero limitado $)^{887}$.

Até à realização da admensio, a compra e venda seria considerada uma fattispecie contratual incompleta («prope quase nondum venit»), razão pela qual se atribuiria ao vendedor o risco - aparentemente total - da coisa («periculum») ${ }^{888}$. Além da suportação do risco contratual, o vendedor estaria também («et») obrigado a «custodiam praestare» até a o dies mensurae ${ }^{889}$.

E. BeTti contesta, também nessa sede, a genuinidade de custodia em sua acepção técnica (isso é, de custodiam praestare), ainda que admita a possibilidade da presença do termo, originalmente, porém em sua acepção atécnica de dever de observar certo comportamento (ou seja, «dovere di contegno») ${ }^{890}$.

Mesmo entre prosélitos do periculum emptoris como princípio geralmente aplicável, propõe-se, mais recentemente, a eliminação da custodia como elemento espúrio desse texto, e sua substituição por «periculum». A interpolação de «custodia» teria tido por fim a harmonização desse texto com a sua sequência, a saber, Ulp. 28 ad ed., D. 18, 6, 4, 1, mediante a supressão da menção ao periculum venditoris, não mais ajustado à necessidade de «equilíbrio conceitual» pretendida pelos comissários justinianeus ${ }^{891}$.

Em recente estudo, É. JAKAB pretendeu distinguir (com base no fragmento ulpianeu supratranscrito), no âmbito da compra e venda de vinhos, os riscos contratuais específicos

\footnotetext{
${ }^{886}$ Cf. Vendita cit. (nt. 21 supra), pp. 362-363, nt. 600.

${ }^{887}$ Cf. M. TALAMANCA, Vendita cit. (nt. 21 supra), p. 363, nt. 608; aparentemente a favor dessa última alternativa, M. M. BENITEZ LOPEZ, La venta de vino y otras mercancias em la jurisprudencia romana, Dykinson, Madrid, 1994, p. 106.

${ }^{888}$ Cf. M. TALAMANCA, Vendita cit. (nt. 21 supra), p. 33; 424.

${ }^{889}$ Cf. M. PENNITZ, Das periculum cit. (nt. 30 supra), p. 399.

${ }^{890}$ Os compiladores teriam substituído o originário «custodiam debere» por «custodiam praestare», reinterpretando o dever de observância de um determinado comportamento como medida de responsabilidade. Essa, com efeito, teria sido introduzida no lugar da originária questão da suportação de risco, valendo, então, como contrapeso da atribuição do periculum ao comprador: Sed et custodiam ad diem mensurae venditor [praestare] debet: priusquam enim admetiatur vinum, [prope quasi nondum venit] $<$ periculo eius est>. Post mensuram factam venditoris desinit esse periculum: et ante mensuram periculo liberatur, si non ad mensuram vendidit, sed forte amphoras vel etiam singula dolia (= Mas também o vendedor deve também observar a custódia até o momento da medição <do vinho>. Pois antes que seja o vinho medido, ele está sob seu risco). Cf. «Periculum» cit. (nt. 420 supra), p. 158.

${ }^{891}$ Cf. M. SERRANO-VICENTE, Custodiam praestare cit. (nt. 26 supra), p. 310.
} 
dessa mercadoria, classificando-os em «riscos de qualidade» (v.g., acidez e bolor - acor e mисоr) e «riscos de quantidade» (v.g., vazamento e furto). O jurista severiano também teria feito menção a duas cláusulas típicas destinadas a cobrir essas duas principais modalidades de riscos: a «degustatio»e a «mensura» ${ }^{892}$.

No que concerne ao texto em análise, Ulpiano teria pretendido pôr em relevo que a mensura, ou seja, a cláusula de medição, consistia em uma complexa imputação do risco ao vendedor, que compreendia também aqueles riscos abrangidos pela custodia (periculum custodiae), de modo que qualquer perda, que afetasse a quantidade da mercadoria, deveria ser suportada pelo vendedor ${ }^{893}$.

A seu turno, não se realizando a venda ad mensuram (isso é, com cláusula de medição), mas se pagando por determinados barris ou ânforas ${ }^{894}$, o jurista teria acorrido a elucidar que o periculum, desde a celebração do contrato, não gravava sobre o vendedor ${ }^{895}$.

\subsection{2. «Custodia plena» do vendedor antes da medição do vinho}

Gai. 2 cott. rer., D. $18,6,2,1$ :

Vejamos, pois, por qual custódia esteja

${ }^{892}$ Cf. É. JAKAB, Risikomanagement cit. (nt. 429 supra), pp. 206-207.

${ }^{893}$ Cf. É. JAKAB, Risikomanagement cit. (nt. 429 supra), p. 241.

894 «Amphora», nas fontes latinas, poderia significar tanto um recipiente quanto uma unidade de medida (Maßbegriff). No primeiro caso, trata-se de cântaro ou jarro, na maior parte feito de argila, arrolhado e vedado seja com gesso (cf. PETR. sat. 34; ColvM. de agr. 12, 39), seja com breu (Hor. carm., 3, 8, 10). Podiam assumir formatos variados, e eram utilizados para o armazenamento (e também o transporte) de gêneros alimentícios (como, v.g., vinho, azeite), e de outras substâncias (como, v.g., urina, de largo uso nas tinturarias).

Como medida de capacidade (Hohlmaß), «amphora» representa - já desde o século I d. C. - a unidade de medida habitual dos romanos para líquidos (equivalente a, em um referencial contemporâneo, aproximadamente, 26,26 litros). Cf. W. H. GROß - H. Chantraine, Amphora, in KlP I (1964), p. 318 ; H. HEUMANN - E. SECKEL, Amphora, in Handlexicon cit. (nt. 18 supra), p. 31.

Aparentemente, o termo, nesse texto, teria sido empregado na primeira acepção, isso é, como a venda do vinho já envasado em ânforas, figurando essas, então, como as unidades objetos da negociação. Nesse sentido, É. JAKAB, Risikomanagement cit. (nt. 429 supra), p. 240.

Por sua vez, consistiam os «dolia» nos recipientes romanos de maiores dimensões, e de variadas formas (um elemento comum seria a ausência de gargalo), geralmente de argila, e destinados ao armazenamento de alimentos (v.g., azeite, vinagre, cereais). Cf., a propósito, CAT. agr. 10, 4; 11, 1; 13, 2; Iul. 6 ex Min., D. 50, $16,206$.

Os dolia também eram utilizados na produção de vinho, dentro dos quais esse passava pelo processo de fermentação nas caves (cellae vinariae); nesse emprego, procedia-se à betumação do interior das jarras com breu. Após a fermentação, dava-se o transvasamento do vinho dos dolia para as ânforas. Há, por outro lado, raros testemunhos de dolia feitos de outros materiais, como madeira (cf. Plin. nat. 8, 16) e chumbo (cf. Scaev. 6 dig., D. 33, 7, 26). O emprego de barris de madeira (tal como se verifica em tempos menos remotos) corresponde - como já atestariam fontes latinas do século I d. C. (cf. PLIN. nat. 14, 132) - a usos nórdicos. Cf. W. H. Groß, Dolium, in KlP II (1979), p. 118; A. MAU, Dolium, in RE IX (1903), pp. 1284-1286.

Com efeito, também na literatura arqueológica dedicada ao estudo da produção vinícola no Império Romano, verifica-se a oposição entre a vinificação do tipo itálico (feita em dolia) e aquela - difundida, v.g., na Lusitânia - na qual se empregavam já os tonéis (de madeira), influenciada por técnicas celtas. Cf. J. P. BRUN, Archéologie du vin et de l'huile dans l'Empire romain, Paris, Errance, 2004, p. 289, principalmente.

${ }^{895}$ Cf. É. JAKAB, Risikomanagement cit. (nt. 429 supra), p. 240. 
Custodiam autem ante admetiendi diem qualem praestare venditorem oporteat, utrum plenam, ut et diligentiam praestet, an vero dolum dumtaxat, videamus. Et puto eam diligentiam venditorem exhibere debere, ut fatale damnum vel vis magna sit excusatum. obrigado a responder o vendedor antes do momento para se efetuar a medição: se plena, de modo que responda também pela $\langle$ falta $>$ de diligência, ou apenas por dolo. E considero que o vendedor deve observar tal diligência, de maneira que $<$ lhe> sejam excusáveis o dano fatal ou a força maior.

Indaga-se Gaio ${ }^{896}$ qual a custodia devida pelo vendedor de vinho antes do prazo acordado para a realização da medição («ante admetiendi diem»): (a) se plena, de modo a exigir também a observância da diligência, ou (b) se apenas a abstenção de um comportamento doloso. Considera o jurista que se exige do vendedor a observância daquela diligência de modo que se lhe excuse apenas a perda do vinho vendido por um dano fatal ou por uma força maior.

O fragmento em que se insere, extraído do segundo livro das Res cottidianae ${ }^{897}$, figura, na disposição estabelecida pelos compiladores, como sequência de um discurso relativo ao momento oportuno, em caso de ausência de convenção, para a retirada do vinum doliare comprado. Seria esse, a seguir o relato de Ulpiano, o período anterior à nova vindima, para a qual os barris seriam necessários ${ }^{898}$.

O texto de Gaio viria a precisar ( $p r$.) que tal seria de se entender no caso de se tratar de um vendedor comum, para o qual os recipientes seriam necessários apenas para uma nova vindima, ao passo que, se fosse o vendedor um comerciante da mercadoria («mercator»), o prazo para a retirada do vinho seria determinado tendo em vista a sua conveniência.

Assume relevância, entretanto, em vista do objeto do presente estudo, o $§ 1$, no qual se faz referência, a um «custodiam praestare» do vendedor antes do prazo para a medição do vinho. Observa-se que, se no texto anterior, o jurista preocupa-se em afirmar que, na venda ad mensuram, o vendedor, antes da realização da operação, deveria também («et custodiam») responder pela custodia, neste, colher-se-ia o intento, por parte de Gaio, de elucidar - aparentemente em vista dessa modalidade de venda - o conteúdo desse «custodiam praestare».

\footnotetext{
${ }^{896}$ Reenvia-se ao quanto já discorrido sobre a vida e o caráter da obra de Gaio (Parte II, Cap. II, 3).

${ }^{897}$ Mais precisamente, em uma secção dessa obra dedicada às obrigações oriundas dos contratos («de obligationibus quae ex contractu nascuntur»). Cf. O. LENEL, Palingenesia cit. (nt. 483 supra), col. 258 - Pal. Gai. 499.

${ }^{898}$ Cf. V. ARANGIO-RUIZ, La compravendita cit. (nt. 403 supra), pp. 73-74.
} 
Gaio teria apresentado dois possíveis significados da locução - uma, mais ampla, abrangente também da diligência («custodia plena»), e outra, mais restrita, limitada à responsabilidade por dolo -, optando pela primeira ${ }^{899}$. Essa implicaria, ademais, a excusabilidade do vendedor, em caso de impossibilidade do objeto da prestação, apenas quando fosse essa devida a eventos caracterizáveis como damnum fatale ou vis magna ${ }^{900}$.

A maneira como o jurista delineia os limites da custodia devida pelo vendedor expôs o texto sob comento a suspeitas de remanejamentos por parte dos compiladores, em razão, principalmente, da conexão que nele se estabelece entre o custodiam praestare e os critérios ditos «subjetivos» de responsabilidade (culpa, diligentia) $)^{901}$.

De fato, Gaio, autor das Institutas, obra que abriga os parágrafos que teriam servido de base para a reconstrução do regime da custodia clássica, não poderia ter tergiversado ao confrontar-se com a questão de estabelecer os limites dessa responsabilidade, uma vez que custodiam praestare afigurava-se-lhe como uma noção bastante clara e precisa ${ }^{902}$.

Entretanto, se sob o ponto de vista teórico, a confusão de idéias seria extrema, considera V. ARANGIO-RUIZ que, em termos práticos, o regime resultante não se diversifica muito do praestare custodiam de Gaio ${ }^{903}$.

Por sua vez, R. CARDILli visualiza no texto mais um testemunho, em matéria de compra e venda, da tendência seguida por Gaio no que concerne à dogmática do inadimplemento, a saber, a valoração da custodia como diligentia in custodiendo. Com efeito, a releitura teria sido apenas teórica, perseguindo-se finalidades «acadêmicas», sem repercussões no plano prático ${ }^{904}$.

De qualquer modo, os limites estabelecidos pela afirmação de Gaio sugeririam uma extensão do conteúdo de custodiam praestare. Como observa M. PENNITZ, a ausência de uma menção concreta ao furto nesse texto, levaria a supor que ao vendedor de vinhos coubesse uma esfera de riscos muito mais ampla do que o simples periculum furti ${ }^{905}$.

Essa extensão do conteúdo da custodia poderia encontrar explicação, para o autor, na natureza do vinho que, antes da medição, estaria, em regra, depositado nos barris do

\footnotetext{
${ }^{899}$ Segundo J. BARON, Gaio distingue três graus de Haftung: custodia plena que compreende, em si, a diligentia; custodia não plena, que corresponderia àquela de Gai. 10 ad ed. prov., D. 18, 1, 35, 4, ou seja, a custodia boni patrisfamilias; e, por fim, uma custodia limitada ao dolus. Cf. «Diligentia» cit. (nt. 175 supra), p. 64; de semelhante modo, ID., Die Haftung cit. (nt. 198 supra), p. 237.

${ }^{900}$ Cf. M. PENNITZ, Das periculum cit. (nt. 30 supra), p. 401.

${ }^{901}$ Cf. v.g., M. TAlAMANCA, Vendita cit. (nt. 21 supra), p. 424, nt. 1255; contra, v.g., G. MACCORMACK, Custodia cit. (nt. 264 supra), p. 176.

902 Cf. V. ARANGIO-RUIZ, Responsabilità cit. (nt. 04 supra), p. 74.

${ }^{903}$ Cf. Responsabilità cit. (nt. 04 supra), p. 74.

${ }^{904}$ Cf. L'obbligazione cit. (nt. 04 supra), p. 495, nt. 20.

905 Cf. Das periculum cit. (nt. 30 supra), p. 402.
} 
vendedor, e exigiriam, por parte desse, uma vigilância mais efetiva, tendo-se em vista o caráter delicado e o valor da mercadoria ${ }^{906}$.

Por outro lado, É. JAKAB parece limitar - também em relação a esse texto - a operatividade de custodiam praestare aos «riscos de quantidade», ainda que não esclareça, qual o risco concreto que viria considerado (provavelmente, o furto) ${ }^{907}$.

Dentre outros elementos de dúvida, um de interesse para o problema de que nos ocupamos seria a ausência de um suporte textual para afirmar que o vendedor de vinhos, para Gaio, devesse custodiam praestare por assunção explícita $^{908}$.

\subsection{Limites do «custodiam praestare» do vendedor}

Paul. 5 ad Sab., D. 18, 6, 3: Custodiam autem venditor talem praestare debet, quam praestant hi quibus res commodata est, ut diligentiam praestet exactiorem, quam in suis rebus adhiberet.
O vendedor deve, pois, responder pela custódia pela qual respondem aqueles aos quais uma coisa foi comodada, de modo que aplique uma diligência maior do que aquela que aplicaria aos seus próprios negócios.

O texto de Paulo, inserido pelos compiladores na imediata sequência do texto de Gaio transcrito supra, ocupar-se-ia também da custodia à qual estaria o vendedor obrigado a «praestare»: essa seria a custodia pela qual respondem aqueles que recebem algo em empréstimo para usar (isso é, os comodatários), a saber, uma diligentia maior do que aquela observada na consecução dos negócios próprios.

Ainda que não haja elementos textuais que permitam afirmar a pertinência do texto à compra e venda de vinhos, essa é inferida por M. PENNITZ, aparentemente, com base na disposição dada pelos compiladores ${ }^{909}$.

Júlio Paulo viveu entre o final do século II d. C. e início do século III d. C., foi discípulo de Cervídio Cévola ${ }^{910}$, e contemporâneo de Ulpiano, junto com o qual ocupou vários cargos sob os imperadores Severos ${ }^{911}$.

${ }^{906}$ Cf. M. PENNITZ, Das periculum cit. (nt. 30 supra), p. 402.

${ }^{907}$ Cf. É. JAKAB, Risikomanagement cit. (nt. 429 supra), p. 241.

${ }^{908}$ Com efeito, aparentemente, tratar-se-ia de um naturalia negotii, e - segundo a doutrina majoritária Gaio parece ter sido favorável a uma configuração de custodiam praestare como elemento acidental do contrato de compra e venda.

${ }^{909}$ Cf. Das periculum cit. (nt. 30 supra), p. 401; já nesse sentido, J. BARON, Die Haftung cit. (nt. 198 supra), pp. 273-274.

${ }^{910}$ Cf. P. KRÜGER, Geschichte cit. (nt. 476 supra), p. 216, nt. 28; W. KUNKEL, Die römsichen cit. (nt. 447 supra), p. 244, nt. 500. 
Paulo foi um jurista profícuo ${ }^{912}$, que se serviu de todas as formas de expressão da iurisprudentia clássica (comentários a leis, senatusconsultos, edito, obras de juristas precedentes, monografias, decisões de casos práticos e também literatura didática), revelando qualidades como independência, elegância, agudeza e lógica no pensamento, método de trabalho, precisão de exposição e rigor na comprovação ${ }^{913}$.

Em comparação - aliás, recorrente, dada a semelhança entre a orientação do trabalho e capacidade ${ }^{914}$ - com Ulpiano, Paulo apresenta-se dotado de maior originalidade no que concerne à mais sólida tendência que nele se verifica de consolidação teórica dos conceitos jurídicos ${ }^{915}$.

Dentre suas principais obras ${ }^{916}$ enumeram-se: as notae aos digesta de Juliano, às quaestiones e aos responsa de Papiniano, os libri IV ad Neratium, as notae ao compêndio de piqana; de Labeão, os libri III manualium, os libri III institutionum, os libri VI regularum (com base no qual a escola pós-clássica elaborou um liber singularis regularum), os libri V sententiarum ${ }^{917}$, os libri XVIII ad Plautium e - as mais importantes no âmbito do direito privado ${ }^{918}$ - os libri LXXVIII ad edictum e os libri XVI ad Sabinum ${ }^{919}$.

Nos livros ad Sabinum, Paulo - tal como Pompônio - não teve por base o texto de Sabino, mas apenas expõe o ius civile de acordo com a sistemática de sua obra, utilizando

${ }^{911}$ Há poucas informações sobre a vida de Paulo: suspeita-se que tivesse sido ou romano propriamente ou, ao menos, italiano. Foi adsessor de Papiniano, quando este desempenhou o cargo de praefectus praetorio (Paul. 3 quaest., D. 12, 1, 40), assumiu, mais tarde, a chefia da secção da chancelaria imperial «a memoria» (magister memoriae), e integrou o consilium imperial de Septímio Severo e Caracala (Paul. 1 decret., D. 4, 4, 38 pr; Paul. 3 decret., D. 29, 2, 97; Paul. 3 decret., D. 49, 14, 50). Por fim, tornou-se praefectus praetorio, tal como Ulpiano, sob governo de Alessandro Severo (223-235 d. C.). Cf. P. KRÜGER, Geschichte cit. (nt. 476 supra), pp. 227-228; L. WENGER, Die Quellen cit. (nt. 476 supra), p. 516; F. ScHUlZ, Geschichte cit. (nt. 590 supra), p. 126 (com dúvidas, porém, quanto ao exercício pelo jurista do último cargo referido); W. KUNKEL, Die römischen cit. (nt. 476 supra), pp. 244-245; R. ORESTANO, Paolo (Julius Paulus), in NNDI 12 (1957), p. 362; A. GUARINO, L'esegesi I cit. (nt. 314 supra), p. 231; G. DULCKEIT - F. SCHWARZ - W. WALDSTEIN, Römische Rechtsgeschichte cit. (nt. 592 supra), pp. 266-267.

912 Com efeito, teria sido ele autor de aproximativamente 319 livros. Cf. P. KRÜGER, Geschichte cit. (nt. 476 supra), p. 228; L. Wenger, Die Quellen cit. (nt. 476 supra), p. 516; R. Orestano, Paolo cit. (nt. 911 supra), p. 362.

${ }_{913}$ Cf. L. Wenger, Die Quellen cit. (nt. 476 supra), p. 517.

914 Ambos pertenceriam à categoria de grandes recolhedores e compiladores da tradição jurídica. Cf. R. ORESTANO, Paolo cit. (nt. 911 supra), p. 362.

${ }_{915}$ Cf. M. KASER, Römische Rechtsgeschichte cit. (nt. 594 supra), p. 175.

${ }^{916}$ Um elenco completo das obras de Paulo é dado por O. LENEL, Palingenesia I cit. (nt. 483 supra), cols. 951-1308 - Paul. Pal. 01-2094. Um sumário recenseamento delas se encontra em P. KRÜGER, Geschichte cit. (nt. 476 supra), pp. 229-238.

${ }^{917}$ Cf. A. GUARINO, L'esegesi I cit. (nt. 314 supra), pp. 232-233.

${ }^{918}$ Cf. P. KRÜGER, Geschichte cit. (nt. 476 supra), pp. 230-231.

919 De fato, a obra paulina supreende não apenas pela extensão, mas também pelos vários setores do direito sobre os quais versou o jurista: direito privado, público, processual e penal. Cf. L. WENGER, Die Quellen cit. (nt. 476 supra), p. 517. 
tanto o próprio Sabino como outros juristas. Sua principal fonte consiste na «Bearbeitung» de Pompônio; vale-se também da literatura de Juliano, Africano, Marcelo e Cévola ${ }^{920}$.

Assim, diferentemente das outras obras da iurisprudentia em que há referência a um jurista, o título do tratado sobre o ius civile de Paulo (ad Sabinum) explica-se não por consistir em um comentário ou reelaboração da obra de Sabino, mas por seguir a estrutura e o sistema desse ${ }^{921}$.

A seguir a reconstrução de O. LENEL, o fragmento de Paulo situava-se, originariamente, em uma secção do livro $5^{\circ}$ de seus comentários ad Sabinum ${ }^{922}$, dedicada, propriamente, à responsabilidade por custodia do vendedor («de custodia a venditore praestanda») ${ }^{923}$.

Também nesse caso, a importância do texto para o estudo em desenvolvimento decorreria do fato de constituir um testemunho de um jurista da época severiana acerca do custodiam praestare do vendedor.

V. ARANGIO-RUIZ contesta o teor atual do texto, que, originalmente, reduzia-se à afirmação: «custodiam autem venditor praestare debet», sobre a qual interviera, primeiramente, um autor pós-clássico a fim de esclarecer a idéia, e mais tarde, os comissários justinianeus, com o estabelecimento da equação «custodia = exacta diligentia» ${ }^{924}$.

Propõe, desse modo, tanto a eliminação de «ut diligentiam-adhiberet» como da remissão ao comodato «quam commodata est», já que Paulo não teria tido razões para se reportar a um contrato tão distinto da compra e venda, sendo-lhe ademais bem clara a noção de custodia $^{925}$.

Também contrário à genuinidade do texto, E. BETTI sustenta que o alargamento do âmbito de responsabilidade do vendedor até os limites da vis maior corresponderia à

${ }^{920}$ Cf. P. KRÜGER, Geschichte cit. (nt. 446 supra), p. 231.

921 Cf. R. ORESTANO, Paolo cit. (nt. 911 supra), p. 362.

922 Reunia esse variadas matérias, a contar com os testemunhos que foram reportados na compilação: $d e$ statuliberis (1695-1698); de mancipationibus (1699-1700); e de emptione et venditione (1701-1726). Cf. Palingenesia I cit. (nt. 484 supra), cols. 1263-1267 - Pal. Paul. 1695-1726.

${ }_{923}$ Cf. O. LENEL, Palingenesia I cit. (nt. 483 supra), col. 1267 - Pal. Paul. 1722-1726.

${ }_{924}$ Cf. La compravendita II cit. (nt. 403 supra), p. 249; Responsabilità cit. (nt. 196 supra), p. 159.

${ }^{925}$ Cf. La compravendita II cit. (nt. 403 supra), p. 249; Responsabilità cit. (nt. 196 supra), p. 159 e nt. 01.

Para P. KRÜCKMANN, o estabelecimento dessa conexão com o comodatário decorreria do contexto, isso é, por se tratar o caso de uma compra e venda ad mensuram, na qual se daria o adiamento do cumprimento da prestação pelo vendedor, não passível de generalização. Cf. Custodia cit. (nt. 236 supra), pp. 37-38. 
disciplina justinianéia, a fim de contrabalançar a atribuição do risco contratual - periculum emptoris (alçado a princípio nessa época) - ao comprador ${ }^{926}$.

Para M. TALAMANCA, o texto encerraria uma contradição intrínseca, por impor ao vendedor a diligentia típica do comodato - correspondente, no sistema de conversão da custodia, em diligentia (exacta ou exactissima) in custodiendo - , e findar por dele exigir não mais do que um grau de «diligentia» superior àquela «quam in suis» ${ }^{927}$.

Já M. SERRANO-VICENTE vislumbra na afirmação do jurista e no contexto do fragmento - mais propriamente, na equiparação do «custodiam praestare» do vendedor ao do comodatário - o primeiro testemunho da consolidação, na iuriprudentia severiana, da custodia como um elemento natural do contrato de compra e venda ${ }^{928}$.

De todo modo, a criticada equiparação com o comodato (que constituiria em uma das hipóteses bastante seguras de aplicação da responsabilidade por custodia) e os elementos sugestivos de uma mentalidade estranha àquela da iurisprudentia clássica ${ }^{929}$, não infirmariam a existência, para Paulo, de um custodiam praestare a cargo do vendedor de vinhos (ad mensuram, no caso) como elemento natural do contrato.

\subsection{Custodiam praestare na compra e venda de vinho per aversionem}

Ulp. 28 ad Sab., D. 18, 6 ,4, 1: $S i$ aversione vinum venit, custodia tantum praestanda est. Ex hoc apparet, si non ita vinum venit, ut degustaretur, neque acorem neque mucorem venditorem praestare debere, sed omne periculum ad emptorem pertinere: difficile autem est, ut quisquam sic emat, ut ne degustet. Quare si dies degustationi adiectus non erit, quandoque degustare emptor poterit et quoad degustaverit, periculum acoris et mucoris ad venditorem pertinebit: dies enim degustationi praestitutus meliorem
Se o vinho é vendido por aversão, há de se responder apenas pela custódia. Disso resulta que, se o vinho não foi vendido assim, para que seja degustado, o vendedor não deve responder nem pela acidez, nem pelo surgimento de fungos, mas todo o risco cabe ao comprador. É difícil, contudo, que alguém compre desse modo, isso é, sem que deguste. Por isso, se não tiver sido designado um termo para a degustação, o comprador poderá degustar a qualquer momento, e até que tenha degustado, o risco de acidez e de

\footnotetext{
${ }^{926}$ Originalmente, portanto: [Custodiam] <diligentiam> autem venditor [talem] praestare debet, quam praestant [hi quibus res commodata est] 〈homines frugi et diligentes〉, [ut diligentiam praeste] 〈et ideo〉 exactiorem $\langle e a\rangle$, quam in suis rebus adhiberet (= $\mathrm{O}$ vendedor, pois, deve observar a diligência que observam os homens diligentes, e mesmo maior do que aquela que aplicaria às suas próprias coisas). Cf. E. BETTI, «Periculum» cit. (nt. 420 supra), p. 155.

${ }^{927}$ Cf. Vendita cit. (nt. 21 supra), p. 449, nt. 1513.

${ }^{928}$ Cf. Custodiam praestare cit. (nt. 26 supra), p. 303.

${ }^{929}$ Cf. C. A. CANNATA, Ricerche cit. (nt. 21 supra), p. 58.
} 
condicionem emptoris facit ${ }^{930}$.

2: Vino autem per aversionem vendito finis custodiae est avehendi tempus. Quod ita erit accipiendum, si adiectum tempus est: ceterum si non sit adiectum, videndum, ne infinitam custodiam non debeat venditor. Et est verius secundum ea quae supra ostendimus, aut interesse, quid de tempore actum sit, aut denuntiare ei, ut tollat vinum: certe antequam ad vindemiam fuerint dolia necessaria, debet avehi vinum. emboloramento caberá ao vendedor. Com efeito, um termo fixado para a degustação torna melhor a situação do comprador.

Sendo, pois, o vinho vendido por aversão, o término da custódia consiste no momento de ser retirado. O que assim há de ser aceito, se um termo foi fixado. Em contrapartida, se não tiver sido estabelecido <um termo>, há de se ver, a fim de que o vendedor não deva uma custódia indeterminadamente. E é mais acertado, conforme o que sustentamos acima, que, ou importa aquilo que foi acordado acerca do tempo, ou interpelá-lo (<o comprador>) para que retire o vinho. Certamente, o vinho deve ser retirado antes que os tonéis sejam necessários para a vindima.

Mais uma vez, Ulpiano ${ }^{931}$ ocupa-se com a compra e venda de vinhos: sendo essa mercadoria vendida aversione, caberia ao vendedor apenas uma custodia praestanda. Assim, não responderia o vendedor pelo periculum do acor e mucor, incumbindo ao comprador a suportação de «omne periculum». Contudo, havendo - como parece ser difuso na prática de comercialização dessa mercadoria («difficile-degustet») - a previsão de uma cláusula de degustação, caberia ao vendedor, até a realização dessa, também o periculum do acor e mucor («periculum-pertinebit»).

Retoma o jurista, aparentemente, o ponto de partida, a saber, a custodia devida pelo vendedor, preocupando-se em estabelecer os seus limites temporais: estaria esse obrigado a uma custodia até o momento da retirada da mercadoria adquirida. Esse, por sua vez, resultaria ou da avença entre as partes («quid-actum sit»), ou da interpelação, por parte do vendedor («denuntiare-vinum»), para que a contraparte procedesse à retirada ${ }^{932}$.

\footnotetext{
${ }^{930}$ A correção já proposta por T. MOMMSEN - P. KRÜGER, Corpus Iuris Civilis I - Institutiones - Digesta, Hildesheim, Weidmann, 1963, p. 274, nt. 20: [emptoris] <eius> é hoje corroborada por M. TALAMANCA, Vendita cit. (nt. 21 supra), p. 424, nt. 1249.

${ }^{931}$ Sobre o jurista, cf. supra (Parte II, Cap. II, 4).

932 O inciso final parece relacionar-se - como observa o próprio jurista («secundum ea quae supra ostendimus») ao discurso de Ulpiano acerca do momento conveniente para se retirar a mercadoria da adega do vendedor, estabelecendo-se que tal seria o período anterior à próxima colheita (vindima), em vista da qual o venedor-produtor necessitaria dos barris vazios para o início de uma nova etapa produtiva - Ulp. 28 ad ed., D. $18,6,4$.
} 
Os $\S \S 1$ e 2 do fragmento 4 encerrariam a secção do $28^{\circ}$ livro de comentários $a d$ Sabinum de Ulpiano dedicada à compra e venda de vinho: com efeito, na reconstrução palingenética de O. LENEL, precedem-nos o fragmento D. 18, 6, 1 (transcrito supra) e o principium do fragmento $4^{933}$.

Assim, a considerar o estado atual do fragmento ulpianeu, o jurista, após discutir sobre a extensão temporal da suportação do risco - concretamente, do risco de acor e mисоr - em uma venda de vinho com cláusula de degustação («intra diem certum») no caso de essa operação ter sido obstada pelo vendedor (pr. $)^{934}$, passaria a tratar da compra e venda «per aversionem» ${ }^{935}$.

Parece tratar-se da venda de um conjunto individualizado de coisas fungíveis (concretamente, um estoque de vinho) por um preço determinado, não dependendo esse de operações como a medição ${ }^{936}$.

Para M. TALAMANCA, a intenção do jurista pode ter sido a de salientar que na venda per aversionem, qualquer periculum - compreendendo-se esse em sentido muito lato, ou seja, relativo seja à deterioração seja ao perecimento - devendo o vendedor responder apenas por custodia $^{937}$.

Essa particularidade - isso é de só ter de responder pela custodia - demonstraria que Ulpiano tinha em consideração um tipo contratual no qual o vinho vendido não era retirado imediatamente, mas permanecia, ainda, por um certo tempo, com o vendedor, período durante o qual o jurista teria pretendido limitar o risco incumbente a esse último ${ }^{938}$.

933 Cf. O. LENEL, Palingenesia II cit. (nt. 483 supra), cols. 1121-1122 - Pal. Ulp. 2717-2718.

934 Por outros termos, discute-se, nessa hipótese, se o vendedor, a quem se deveria a não realização da degustatio do vinho, deveria suportar o periculum acoris et mucoris (isso é, o risco do azedume e do emboloramento da mercadoria) apenas antes ou também após o momento (dies) em que aquela operação deveria ter ocorrido. E Ulpiano teria indicado as vias para a solução: (a) a observância daquilo que fora convencionado entre as partes («quid actum sit»); (b) nada resultando dessa verificação, o periculum deveria ser suportado («periculum respicere») pelo vendedor também no período posterior ao termo fixado para a degustação («ultra diem degustando praefinitum»), uma vez que dele teria, de fato, dependido a não realização daquela.

935 Em H. HeumanN-E. SECKEL, Aversione, in Handlexicon cit. (nt. 18 supra), p. 46, encontra-se «in Bausch und Bogen» que, na compra e venda, verificar-se-ia na hipótese de fixação do preço em geral, sem correlação com número, medida ou peso. Nos dicionários, dão-se significados como «em grosso», «por junto» (cf. F. R. SANTOS SARAIVA, Aversio, in Novissimo diccionario latino-portuguez, Rio de Janeiro, Garnier, s.d., p. 134). Outras possibilidades de versão em português encontram-se em M. DE ALMEIDA E SOUSA DE LOBÃO, Fascículo de dissertações jurídico-práticas I cit. (nt. 411 supra), p. 326: venda de vinho «por grosso», «a olho», «em montão» ou - como na linguagem dos juristas (romanos) - «por aversão».

$\mathrm{O}$ significado jurídico de aversione venire (tradicionalmente interpretado como venda «in Bausch und Bogen» tem sido objeto de muitas discussões na doutrina romanística especializada, como nota É. JAKAB, Risikomangement cit. (nt. 429 supra), pp. 243-248.

${ }^{936}$ É o que parece sugerir M. TALAMANCA, Vendita cit. (nt. 21 supra), p. 362, nt. 600.

${ }^{937}$ Cf. Considerazioni cit. (nt. 429 supra), p. 285, nt. 237.

${ }^{938}$ Cf. É. JAKAB, Risikomanagement cit. (nt. 429 supra), p. 255. 
A sequência do texto poderia ser interpretada, segundo É. JAKAB, nos seguintes termos: se tivesse havido a venda do vinho aversione, mas sem a previsão da cláusula de degustatio, o vendedor não suportaria o periculum do acor e mucor ( «riscos de qualidade»), que caberiam, então, ao comprador. Por outro termos, seriam a aversione e a degustatio cláusulas independentes ${ }^{939}$.

Além disso, todo o texto poderia ser compreendido a partir de uma interação de riscos contratuais específicos da compra e venda de vinho: assim, se o vinho é vendido aversione, o «risco de quantidade» seria imputado ao comprador ${ }^{940}$ a partir da celebração da compra e venda; se tiver sido, ademais, inserida uma cláusula de degustação, o «risco de qualidade» seria suportado pelo vendedor até a realização da prova; se, contudo, a venda deu-se aversione, sem degustatio, «omne periculum» - isso é, tanto o «risco de qualidade» quanto o «risco de quantidade» - seriam suportados pelo comprador ${ }^{941}$.

Para o presente estudo assume relevância a previsão da custodia nessa modalidade negocial (venda per aversionem do vinho) compreendida, pela doutrina mais recente ${ }^{942} \mathrm{e}$ especializada, em seu significado técnico, a saber, «custodiam praestare» ${ }^{943}$.

\section{Custodiam praestare na compra e venda de imóveis}

Paul. 7 ad Plaut., D. 19, 1, 36: Venditor domus antequam eam tradat, damni infecti stipulationem interponere debet, quia, antequam vacuam possessionem tradat, custodiam et diligentiam praestare debet et pars est custodiae diligentiaeque hanc interponere stipulationem: et ideo si id neglexerit, tenebitur emptori.
O vendedor de uma casa, antes de efetuar a sua entrega, deve interpor a stipulatio damni infecti, porque, antes de entregar a posse plena, deve responder pela custódia e a diligência, e é parte da custódia e da diligência interpor essa stipulatio. E assim, se tiver omitido essa providência, responderá ao comprador.

Afirma Paulo ${ }^{944}$ que o vendedor de uma casa está obrigado, antes de proceder à sua entrega ao comprador, a interpor a stipulatio para fazer-se prestar a caução de dano infecto

\footnotetext{
${ }^{939}$ Cf. Risikomanagement cit. (nt. 429 supra), p. 255.

940 Nesse caso, a cláusula (aversione) comportaria uma atribuição imanente do risco ao comprador («imanente Risikozuweisung»). Cf. É. JAKAB, Risikomanagement cit. (nt. 429 supra), p. 258.

${ }_{941}$ Cf. É. JAKAB, Risikomanagement cit. (nt. 429 supra), pp. 256-257.

942 Além dos autores já citados, M. SERRANO-VICENTE, Custodiam praestare cit. (nt. 26 supra), p. 311; M. PENNITZ, Das periculum cit. (nt. 30 supra), p. 403.

${ }^{943}$ Não se compreende, assim, a alusão de M. M. BENITEZ LOPEZ a uma orientação diversa da communis opinio no sentido de interpretar o dado textual como alusivo a uma simples atividade de cuidado da mercadoria antes da traditio, sem implicações com o regime de responsabilidade por determinados eventos. Cf. La venta cit. (nt. 8897supra), p. 117; também assim, P. KRÜCKMANN, Custodia cit. (nt. 237 supra), p. 02 , nt. 01.

${ }^{944}$ Sobre o jurista, cf. supra (Parte II, Cap. III, 3.2).
} 
(stipulatio damni infecti). Essa providência - «interponere stipulationem» - decorreria («pars custodiae diligentiaeque») de um «custodiam et diligentiam praestare» a que estaria obrigado o vendedor antes da tradição do imóvel. Conseqüentemente, responderia ao comprador caso a tivesse omitido («et ideo-emptori»).

Originariamente, o texto ${ }^{945}$ figurava em uma secção do livro $7^{\circ}$ ad Plautium $^{946}$, na qual Paulo tratava acerca do furto ${ }^{947}$.

Reveste-se de importância, para o presente estudo, em razão da locução, apresentada em sua forma técnica («custodiam praestare»), relacionada, entretanto, a uma compra e venda cujo objeto da prestação consiste - diferentemente das demais hipóteses tratadas até o momento - em um imóvel («domus»).

J. BARON teria limitado a sua Custodia-Haftung às coisas móveis, uma vez que os imóveis - grandes ou pequenos que fossem - não poderiam ser custodiados por uma só pessoa $^{948}$.

De fato, seja em relação aos demais contratos, seja em relação à própria compra e venda, as discussões, em torno dos textos fundamentais, sobre a eventual responsabilidade pelo furto relacionavam-se aos bens móveis inanimados: assim, em relação ao fullo e sarcinator (principalmente) e ao comodatário ${ }^{949}$.

Precedentemente, examinou-se um texto atribuído a Alfeno (2 dig., D. 18, 6, 12), no qual o jurista se referia a uma «insula custodienda», e o seu exame resultou por afastar qualquer pertinência com um problema afeito à responsabilidade por custodia. Paulo, entretanto, relaciona um «custodiam praestare» (locução técnica) a uma domus nesse texto.

A situação que Paulo parece considerar seria, aproximadamente a seguinte: o vendedor de uma casa ao lado da qual se encontre um edifício vizinho em risco de ruína deveria, antes da entrega do imóvel ao comprador, requerer - por stipulatio - uma caução (cautio damni infecti) do proprietário do prédio periclitante. Essa providência seria, como

${ }^{945}$ Cf. O. Lenel, Palingenesia I cit. (nt. 484 supra), cols. 1158 - Pal. Paul. 1139.

${ }^{946}$ Os libri XVIII ad Plautium teriam o direito privado por matéria: tratar-se-ia de uma atualização do texto de Plauto (jurista do século I d. C., que teria escrito uma obra dedicada, preponderamente, ao ius honorarium), com as contribuições nele feitas já por Javoleno e Pompônio, pela inserção, por parte de Paulo, tanto da literatura jurídica posterior quanto de observações e explicações próprias. Cf. P. KRÜGER, Geschichte cit. (nt. 446 supra), p. 229; L. WENGER, Die Quellen cit. (nt. 476 supra), p. 504.

${ }^{947}$ Cf. O. Lenel, Palingenesia I cit. (nt. 483 supra), cols. 1158-1160 - Pal. Paul. 1139-1142.

${ }^{948}$ Cf. Die Haftung cit. (nt. 198 supra), p. 201.

${ }^{949}$ Cf. C. A. CANNATA, Ricerche cit. (nt. 21 supra), pp. 137-138. 
quer o jurista, parte da custodia e da diligentia que o vendedor deve praestare ao comprador $^{950}$.

A consideração desse problema seria compreensível em vista do panorama urbanístico romano. Com efeito, afirma G. MACCORMACK que a cautio damni infecti, na época clássica, consistia em uma importante precaução à qual recorreria todo sensível pater familias habitante de um distrito urbano ${ }^{951}$.

Os quarteirões residenciais em Roma compunham-se de ruas estreitas, repletas de blocos de apartamentos (as denominadas insulae) ${ }^{952}$. Dada as condições concretas em que tais construções se erigiam, a possibilidade de desmoronamento desses prédios não se afigurava remota ${ }^{953}$.

Assim, o proprietário de uma insula, ao mesmo tempo em que seu imóvel representava uma ameaça às demais edificações dos arredores, era também ameçado pelas condições das habitações adjacentes ${ }^{954}$. Além do risco de ruína dos prédios vizinhos, outros fatores ${ }^{955}$ concorreriam para que o proprietário de um imóvel buscasse precaver-se dos danos que pudessem ser causados - v.g., durante atividades de demolição, construção e reforma - ao seu edifício ${ }^{956}$.

Diante dessas circunstâncias, supõe-se que o adquirente de um imóvel residencial iria requerer de seus vizinhos a prestação de cautiones, bem como deveria, a seu turno, prestar-lhas ${ }^{957}$. Com frequiência, o proprietário que decidisse vender o imóvel já havia tomado a providência de requerer as cautiones; doutro modo, infere-se que, tão logo tivesse celebrado a venda, estaria obrigado, perante o comprador, a assegurar que as cautiones foram tomadas ${ }^{958}$.

${ }^{950}$ Cf., aproximativamente, C. A. CANNATA, Sul problema (1996) cit. (nt. 01 supra), p. 79.

${ }^{951}$ Cf. The Cautio Damni Infecti - Buyer and Seller, in SZ 88 (1971), p. 300.

952 Cf. supra (Parte II, Cap. I, 4).

${ }^{953}$ Cf. G. MACCORMACK, The Cautio cit. (nt. 951 supra), p. 300.

${ }^{954}$ Cf. G. MACCORMACK, The Cautio cit. (nt. 951 supra), p. 300.

955 Com efeito, ansiosos pela obtenção de um largo e rápido proveito, especuladores do ramo da construção valiam-se de materiais de baixo custo, resultando em edificações mais leves do que o normal. As condições destes prédios requeriam um grande número de reparações, sendo, em alguns casos, quando se deterioravam, demolidos e erigidos novos blocos. Outros eventos ainda - tais como incêndios freqüentes devastavam grandes áreas da cidade e requeriam vastas operações de reedificação. Cf. G. MACCORMACK, The Cautio cit. (nt. 951 supra), p. 300.

${ }_{956}$ Cf. G. MACCORMACK, The Cautio cit. (nt. 951 supra), p. 301.

$957 \mathrm{O}$ requerimento destas cautiones não competia exclusivamente ao proprietário do prédio, mas também aos ocupantes - v.g., locatário, sua esposa, seus hóspedes (Ulp. 53 ad ed., D. 39, 2, 13, 5) - de cada unidade (apartamentos). Cf. G. MACCORMACK, The Cautio cit. (nt. 951 supra), p. 301 e nt. 03; mais detalhadamente, A. MASI, Denuncia di nuova opera e di danno temuto, in ED 12 (1957), pp. 162-168.

${ }^{958}$ Cf. G. MACCORMACK, The Cautio cit. (nt. 951 supra), p. 301. 
Em vista, pois, desse quadro, conclui G. MACCORMACK que a proteção do comprador apenas seria suficiente se o vendedor estivesse obrigado a tomar a caução do proprietário (v.g.) do prédio em ruína ${ }^{959}$.

Já V. ARANGIO-RuIZ individualizou um traço diferencial da compra e venda em relação às demais aplicações da responsabilidade por custodia nas quais o devedor detém coisa alheia no fato de estender-se essa também aos imóveis. Tratar-se-ia de uma particular aplicação da custodia que imporia ao vendedor, nas relações de vizinhança, a defesa da liberdade e da integridade dos imóveis, mediante a exigência ao vizinho, quando necessária, da cautio damni infecti ${ }^{960}$.

Também C. A. CANNATA pretendeu vislumbrar nessa aplicação o que denominou de «flexibilidade»e «adaptabilidade» de custodiam praestare, por adapatar-se o seu conteúdo tanto às particularidades da relação em que passava a viger (compra e venda) quanto às singularidades do objeto da prestação ${ }^{961}$.

De fato, o único modo de proteger o imóvel vendido seria, nessas situações, requerer a prestação da caução. Se, por um lado, não haveria problemas em reconhecer na preservação do edifício vendido um ato de custodia, por outro, a aplicação a essa situação dos esquemas da responsabilidade por custodia não seria uma solução simples ${ }^{962}$.

Com efeito, uma tal aplicação implicaria afirmar a responsabilidade do vendedor no caso de ruína do edifício vizinho e danificação da casa vendida. Não haveria, portanto, coerência nessa solução, uma vez que o vendedor não poderia evitar esse dano pela custodia do imóvel ${ }^{963}$.

O modo, segundo C. A. CANNATA, pelo qual o vendedor poderia defender (custodiar) o imóvel alienado seria diverso: proceder à obtenção da cautio damni infecti, de tal forma que, se viesse a ruir o edifício vizinho e afetasse a domus vendida, não seria ele responsável perante o comprador ${ }^{964}$.

Já para P. KRÜCKMANN, nessa fattispecie não se trataria de um objeto corpóreo sobre o qual se pudesse exercer a custodia, sendo impossível se imaginar a incidência de

${ }^{959}$ Cf. The Cautio cit. (nt. 951 supra), p. 301.

${ }^{960}$ Cf. Responsabilità cit. (nt. 04 supra), p. 160.

${ }^{961}$ Cf. Ricerche cit. (nt. 21 supra), p. 136; M. KASER, Die actio cit. (nt. 258 supra), pp. 106-107.

${ }^{962}$ Cf. C. A. CANNATA, Sul problema (1996) cit. (nt. 01 supra), p. 79.

${ }^{963}$ Cf. C. A. CANnATA, Sul problema (1996) cit. (nt. 01 supra), pp. 79-80.

964 Cf. Sul problema (1996) cit. (nt. 01 supra), p. 80; M. SERRANO-VICENTE, Custodiam praestare cit. (nt. 26 supra), p. 303. 
uma Zufallhaftung. Em contrapartida, poder-se-ia explicar o teor do texto, sem dificuldades, com base na a culpa ${ }^{965}$.

Paulo teria, com efeito, tratado por três vezes a custodia em conexão com a cautio damni infecti: Paul. 48 ad ed., D. 39, 2, 18, 8-9 ${ }^{966}$; Paul. 10 ad Sab., D. 39, 2, 38 pr $^{967}$. Nos primeiros textos, custodia deveria ser entendida simplesmente como culpa; no segundo, o

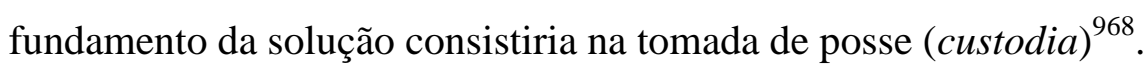

A vinculação desse texto com o problema da responsabilidade encontra oposição em M. TALAMANCA, para quem custodiam praestare consistia, essencialmente, na assunção de garantia contra o furto, não podendo ter, portanto, qualquer relação com a compra e venda de coisas imóveis. Os elementos textuais poderiam ser explicados, segundo o autor, como empregos atécnicos, ou então - em relação ao texto em exame uma inserção de custodia no sintagma custodia diligentiaque ${ }^{969}$.

Porém, como esse autor mesmo reconhece, tratar-se-ia de um fenômeno oposto àquele verificado na modificação de outros textos ${ }^{970}$, aos quais teria sido inserida a diligentia e não a custodia. Se, por um lado, em Paul. 10 ad Sab., D. 39, 2, 38 pr. «custodia» parece, de fato, assumir um significado atécnico, não se poderia afirmar com a mesma segurança em relação ao texto supra, no qual se faz acompanhar de «praestare».

Assim, parece preferível a interpretação de C. A. CANNATA que, apoiado não apenas no dado textual, reconhece as diferenças necessárias de operatividade prática do custodiam praestare no caso do vendedor de imóveis

\footnotetext{
${ }^{965}$ Cf. Custodia cit. (nt. 237 supra), p. 09.

966 Venditorem autem aedium prius, quam possessionem tradat, stipulari oportet, quia huius quoque rei culpam praestat (= Pois é necessário que o vendedor de um prédio, antes que entregue a posse desse, estipule, porque também responde pela culpa <deste fato>). 9: Sed quid fiet, si venditor sine culpa stipulari non potuerit et ob hoc emptor stipulatus fuerit? Nonne damnum patitur? An hoc damnum in aliena re acciderit, revolvitur autem ad emptorem, quia actionem ex empto non habet? Sed nihil in hac causa proficit stipulatio, nisi in id, quod post traditionem accidit, quia, dum venditoris custodia est, is stipulari debet omnemque diligentiam emptori praestare: et quod alia actione quaeri potest, id in stipulationem damni infecti omnino non deducitur (= Mas o que ocorre se o vendedor não tiver podido, sem culpa sua, estipular e, por essa razão, o comprador tiver estipulado? Porventura não sofre o dano? Se esse dano se der em coisa alheia, recairá também sobre o comprador, pois que não tem a actio ex empto? Porém a stipulatio, nesse caso, de nada adianta, a não ser no que concerne àquilo que ocorre após a entrega, pois enquanto a custódia cabe ao vendedor, este deve estipular e garantir a observância de toda diligência ao comprador. E o que pode ser pedido com outra ação não será deduzido pela stipulatio damni infecti).

967 Emptor aedium ante traditam sibi possessionem ideo inutiliter stipulatur, quia venditor omnem diligentiam ei praestare debet. Tunc certe utiliter stipulatur, cum omnis culpa a venditore aberit, veluti si precario emptori in his aedibus esse permisit custodiamque ei afuturus tradidit (= O comprador de um prédio, antes que lhe seja entregue a posse, estipula inutilmente <a cautio damni infecti >, porque o vendedor deve prestar-lhe toda a diligência. E, sem dúvida, estipula utilmente, quando o vendedor não incorrer em culpa, como por exemplo, se concedeu ao comprador a posse precária do prédio e, porque se ausentaria, transferiu-lhe a custódia $<$ da coisa $>$ ).

${ }^{968}$ Cf. Custodia cit. (nt. 237 supra), pp. 10-11.

${ }^{969}$ Cf. Vendita cit. (nt. 21 supra), p. 448, nt. 1501.

${ }^{970}$ Cf. Vendita cit. (nt. 21 supra), p. 448, nt. 1501.
} 


\section{Conclusões parciais}

Os textos examinados nessa secção, atribuídos, salvo Gai. 2 cott. rer., D. 18, 6, 2, 1, a juristas da época severiana oferecem um quadro, de certo modo, não menos complexo do que o verificado na secção anterior.

Se, por um lado, não se apresenta, nesses, a questão de se determinar a posição na emptio venditio como naturalia ou accidentalia negotii, as fattispecie nas quais se apresenta a locução-guia - à parte Papin. 12 quaest., D. 47, 2, 81 pr. (relacionado ao furto e ao problema da legitimação à actio furti) - não parecem consentir a individualização do exato conteúdo de custodiam praestare.

Essa assertiva vale, em especial, para as modalidades de comercialização de vinhos (ad mensuram, per aversionem): especialmente Gai. 2 cot. rer., D. 18, 6, 2, 1 sugeriria a possibilidade de a «custodia plena» do vendedor abranger outros riscos que não aqueles típicos, dada a generalidade da afirmação nele contida.

Por fim, o reconhecimento de um custodiam praestare ao vendedor de uma domus parece implicar uma diferenciação ou adaptação do conteúdo «típico» da responsabilidade por custodia (furto, damnum iniuria datum causado por terceiros). A custodia a ser observada pelo vendedor, nesse caso, implicaria a tomada de providências diversas (como a de requerer a cautio damni infecti do proprietário do imóvel vizinho que ameace o edifício vendido) daquelas aptas à proteção de um coisa móvel a fim de que não seja subtraída ou danificada. 


\section{CONCLUSÕES}

Retomam-se, em síntese, a linha expositiva seguida e os resultados que puderam ser individualizados no curso dessa exposição.

O objeto de nossa análise consistiu em um dos clássicos temas da ciência romanística - a responsabilidade por «custodia»-, tema constantemente revisitado e ao qual já se dedicou uma vasta literatura científica.

Como noção primeira, consistiria em um regime de responsabilidade por certos eventos típicos ao qual estariam sujeitos determinados devedores independentemente de culpa, isso é, tão-só pela verificação de certas modalidades de impossibilidade do objeto da prestação (coisa a restituir ou a entregar).

Discute-se, a respeito desse instituto, não só a sua natureza jurídica (v.g., «critério de responsabilidade» ou «prestação»), mas também o seu conteúdo (isso é, os eventos típicos pelos quais se respondia), e as figuras de devedores às quais se aplicava.

Dentre essas, tem-se como uma das mais discutidas, a sua aplicação à compra e venda (emptio venditio), mais precisamente, ao vendedor. Sobre esse problema é que procurou concentrar-se a investigação que se conduziu.

Partiu-se do espólio das fontes, a fim de se verificar os empregos do termo na linguagem dos juristas, e desse procedimento, individualizou-se o uso, no âmbito do direito das obrigações, de custodia correlacionada - em regra - ao verbo praestare. Dado que em todos os demais empregos subjaz a custodia o significado basilar de «guarda», «vigilância», o tecnicismo da locução pareceu dever-se a «praestare».

Procedeu-se, então, ao estudo desse vocábulo nas fontes jurídicas, passando-se pelas vivas discussões acerca da individualização de seu significado técnico-jurídico específico que se manifestaria em locuções como «dolum, culpam, custodiam praestare».

Seguiu-se ao estudo terminológico da locução «custodiam praestare» a exposição das principais interpretações doutrinárias sobre o assunto, da Pandectística às mais recentes contribuições. Dada certa convergência de um filão interpretativo que se poderia denominar majoritário, fixaram-se, no final dessa apresentação, os principais delineamentos do instituto em torno de textos fundamentais para sua reconstrução.

«Custodiam praestare» - prestação ou critério de responsabilidade - indicaria um regime de responsabilidade, independente da verificação da culpa, por certos eventos 
(furto, dano causado por terceiros, fuga de escravos em certas situações), aplicável a determinados devedores (v.g., comodatário, fullo, sarcinator, horrearius) e que teria sofrido alterações no curso do direito romano, sendo transformada em diligentia in custodiendo.

A partir desse «quadro» de «problemas gerais» do instituto, iniciou-se a análise do questão no âmbito da compra e venda. Expuseram-se os principais contornos do contrato (emptio venditio) e as dificuldades de admissão de um custodiam praestare do vendedor.

Em parte superados esses empecilhos teóricos, o problema concentrar-se-ia na verificação direta dos textos nos quais se apresentava a locução. Além desses, outros critérios poderiam coadjuvar na seleção da base textual para a reconstrução da custodia venditoris no curso da iurisprudentia romana.

Da conjugação desses critérios, selecionaram-se textos remontantes ao período tardo-republicano e aos séculos II e III d. C., à parte um texto das Institutas. Seguiu-se o critério cronológico para o exame desses, ordenando-os, pela atribuição ao jurista ou por elementos das inscriptiones, segundo o período da iurisprudentia a que se ligavam.

Consistiram os textos em: Paul. 3 Alf. epit, D. 18, 6, 15, 1; Paul. 3 Alf. epit., D. 18, 6, 13-15 pr.; Alf. 2 dig., D. 18, 6, 12; Ner. 3 membr., D. 19, 1, 31 pr.; Gai. 10 ad ed. prov., D. 18, 1, 35, 4 (Inst. 3, 23, 3a); Ulp. 29 ad Sab., D. 47, 2, 14 pr.-1; Papin. 12 quaest., D. 47, 2, 81 pr.; Ulp. 28 ad Sab., D. 18, 6, 1, 1; Gai. 2 cot. rer., D. 18, 6, 2, 1; Paul. 5 ad Sab., D. 18, 6, 3; Ulp. 28 ad Sab., D. 18, 6, 4, 1-2 e Paul. 7 ad Plaut., D. 19, 1, 36.

Com o objetivo de realizar uma reconstrução do problema de custodiam praestare na compra e venda, pareceu oportuno partir de um primeiro grupo de textos nos quais parecia haver algum indício de envolvimento do instituto, atribuídos - ou de algum modo, reportáveis - a juristas mais remotos (Alfeno).

Se, por um lado, seria acertado que o tratamento orgânico e autônomo da custodia apenas se verificaria no curso da iurisrpudentia adrianéia, não se poderiam negar alguns testemunhos provenientes de juristas republicanos, para os quais, entretanto, a custodia referida ao comodato - relacionava-se à fuga de animais e de escravos, mas não ainda ao furto.

No que concerne à compra e venda, a análise desses «vestígios», com base na literatura mais recente, confirmaria que, à parte um uso atécnico do termo (em Alf. 2 dig., D. 18, 6, 12), o «periculum», relacionado ao furto da coisa, e atribuído ao vendedor antes da tradição (como em Paul. 3 Alf. epit., D. 18, 6, 15, 1) não corresponderia a um custodiam praestare do vendedor. 
Por outros termos, mesmo determinadas fattispecie (como a do último texto referido) que, mais tarde, poderiam ser consideradas em termos de custodia do vendedor, teriam sido tratadas por Alfeno sob outras perspectivas, dentre as quais - mais expressivamente - a atribuição do risco (periculum) pelo perecimento da coisa.

Conclui-se, assim, limitadamente à emptio venditio, que o reconhecimento de um custodiam praestare do vendedor não se teria verificado ainda no final do século I a. C., ao qual remontariam esses testemunhos de Alfeno.

Para o início do século I d. C., conquanto haja fontes concernentes à matéria relativas a outros contratos (locatio conductio, principalmente), fazem-se ausentes textos para a cognição do problema na compra e venda.

Retoma-se a análise a partir dos textos provenientes da iurisprudentia adrianéia (Nerácio, Gaio e Juliano), que exprimiriam uma divergência quanto à configuração de custodiam praestare na compra e venda como elemento natural ou acidental do contrato. A orientação que parece receber acolhida hoje, no que respeita a uma visão de conjunto desses textos, seria a de explicar essas dissonâncias com base em orientações diversas ou das escolas de direito em Roma (a saber, proculeianos e sabinianos) ou apenas de juristas.

Parecem portanto, superadas, as tentativas de, nessa matéria, considerar uma ou outra opinião como expressão da iurisprudentia clássica, e a outra, atribuível aos compiladores.

Por sua vez, os textos atribuídos aos juristas da época severiana (Papiniano, Ulpiano e Paulo) ofereceriam um quadro, de certo modo, não menos complexo do que o verificado na secção anterior.

Se, por um lado, não se apresenta, nesses, a questão de se determinar a posição de custodiam praestare na emptio venditio como naturalia ou accidentalia negotii, as fattispecie nas quais se apresenta a locução-guia - à parte Papin. 12 quaest., D. 47, 2, 81 pr. (relacionado ao furto e ao problema da legitimação à actio furti) - não parecem consentir a individualização do exato conteúdo de custodiam praestare.

Essa assertiva valeria, em especial, para as modalidades de comercialização de vinhos (ad mensuram, per aversionem): especialmente Gai. 2 cot. rer., D. 18, 6, 2, 1 sugeriria a possibilidade de a «custodia plena» do vendedor abranger outros riscos que não aqueles típicos, dada a generalidade da afirmação nele contida.

Por fim, o reconhecimento de um custodiam praestare ao vendedor de uma domus parece implicar uma diferenciação ou adaptação do conteúdo «típico» da responsabilidade por custodia (furto, damnum iniuria datum causado por terceiros). A custodia a ser 
observada pelo vendedor, nesse caso, implicaria a tomada de providências diversas (como a de requerer a cautio damni infecti do proprietário do imóvel vizinho que ameace o edifício vendido) daquelas aptas à proteção de um coisa móvel a fim de que não seja subtraída ou danificada.

Esses, resumidamente, os resultados que se puderam recolher a partir do exame dos textos e da literatura crítica. Ainda que muitos aspectos requeiram ainda elucidação, no que respeita à análise exegética dos textos, no conjunto restaria confirmado que o problema de uma custodia venditoris centrar-se-ia não mais na determinação de sua existência ou não no direito clássico, mas na determinação dos seus limites. 


\section{I - FonTES JURídicAs ANTIGAS*}

\section{A) Fontes Pré-Justinianéias}

$\begin{array}{lll}\text { Codex Theodosianus } & & \\ 1,5,3 & : & 15, \text { nt. } 63 \\ 4,10,3 & : & 15, \text { nt. } 63 \\ 4,12,1 & : & 15, \text { nt. } 63 \\ 6,22,7 & : & 15, \text { nt. } 63 \\ 7,13,7 & : & 15, \text { nt. } 63 \\ 8,11,5 & : & 15, \text { nt. } 63 \\ 7,16,1 & : & 10, \text { nt. } 49 \\ 9,24,1,1 & : & 10, \text { nt. } 49 \\ 9,27,3 & : & 10, \text { nt. } 49 \\ 9,40,13 & : & 14, \text { nt. } 59 \\ 10,4,1 & : & 15, \text { nt. } 63 \\ 10,10,34 & : & 15, \text { nt. } 63 \\ 11,31,9 & : & 15, \text { nt. } 63 \\ 12,1,166 & : & 15, \text { nt. } 63 \\ 16,5,54 & : & 15, \text { nt. } 63\end{array}$

\section{Collatio}

$\begin{array}{lll}9,2,2 & : & 12, \text { nt. } 56 ; 14, \text { nt. } 61 \\ 10,2,1 & : & 3, \text { nt. } 11 ; 33, \text { nt. } 152 \\ 10,2,2 & : & 15, \text { nt. } 63 \\ 10,7,3 & : & 12, \text { nt. } 54 \\ 10,7,4 & : & 10, \text { nt. } 49 \\ 10,9 & : & 66, \text { nt. } 316\end{array}$

Fragmenta Vaticana

$\begin{array}{lll}226 & : & 19, \text { nt. } 85 \\ 249,7 & : & 19, \text { nt. } 85\end{array}$

*Assinalam-se com asterisco (*) as páginas ou notas nas quais as fontes foram transcritas e traduzidas.

\section{Gai Institutiones}

$\begin{array}{lll}1,13 & : & 12, \text { nt. } 56 ; 14, \text { nt. } 61 \\ 2,67 & : & 12, \text { nt. } 55 \\ 2,155 & : & 19, \text { nt. } 85 \\ 3,50 & : & 19, \text { nt. } 85 \\ 3,51 & : & 19, \text { nt. } 85 \\ 3,141 & : & 79, \text { nt. } 387 \\ 3,175 & : & 145, \text { nt. } 730 \\ 3,182 & : & 123, \text { nt. } 608 \\ 3,203 & : & 57^{*} ; 170, \text { nt. } 867 \\ 3,205 & : & 46, \text { nt. } 226 ; 57^{*} ; \\ & & 170, \text { nt. } 868 \\ 3,206 & : & 57 * ; 17, \text { nt. } 70 ; 170, \\ & & \text { nt. } 868 \\ 3,207 & : & 17, \text { nt. } 74 \\ 3,209 & : & 123, \text { nt. } 608 \\ 4,2 & : & 20, \text { nt. } 90^{*} ; 25, \text { nt. } \\ & & 106\end{array}$

Pauli Sententiae

$\begin{array}{lll}2,4,2 & : & 67, \text { nt. } 325 \\ 2,4,3 & : & 16, \text { nt. } 66 ; 17, \text { nt. } \\ & & 73 ; 67, \text { nt. } 325 \\ 2,43 & : & 64, \text { nt. } 311 \\ 3,6,39 & : & 12, \text { nt. } 54 \\ 3,6,44 & : & 12, \text { nt. } 54 \\ 3,8,4 & : & 21, \text { nt. } 95 \\ 4,3,4 & : & 19, \text { nt. } 85 \\ 5,31,1 & : & 13, \text { nt. } 58 \\ 5,31,2 & : & 13, \text { nt. } 58\end{array}$

\section{Ulpiani Epitome}

$\begin{array}{lll}1,11 & : & 14, \text { nt. } 61 \\ 29,1 & : & 19, \text { nt. } 85\end{array}$




\section{B) Corpus Iuris Civilis}

\section{Institutiones}

$$
\begin{aligned}
& \text { 1, 12, } 6 \\
& 2,19,1 \\
& 2,20,35 \\
& 2,25 \text { pr. } \\
& 3,2 \text { pr. } \\
& 3,13 \text { pr. } \\
& 3,14,2 \\
& 3,14,4 \\
& 3,23,2 \\
& 3,23,3
\end{aligned}
$$$$
3,23,3 \mathrm{a}
$$$$
3,24,5
$$$$
3,25,9
$$$$
\text { 4, } 1 \text { pr. }
$$$$
4,1,8
$$$$
4,1,16
$$$$
\text { 4, } 2 \text { pr. }
$$$$
4,6,19
$$$$
4,18,5
$$

\section{Digesta}

$1,2,1$
$1,2,2,30$
$1,2,2,35$
$1,2,2,44$
$1,2,2,49$
$1,2,2,53$

19, nt. 85

19 , nt. 85

19, nt. 85

21, nt. 95

123, nt. 608

26, nt. 115

64, nt. 311

66, nt. 321

79, nt. 387

82 , nt. 406; 150, nt. $760 *$

58, nt. 281; 82, nt. 406; 95, nt. 463;

119; 145, nt. 728;

\begin{tabular}{|c|c|c|}
\hline $1,5,7$ & : & 13, nt. 57 \\
\hline $1,15,3,1$ & : & 115 , nt. 565 \\
\hline $1,15,3,2$ & : & 66, nt. 316 \\
\hline $1,16,6 \mathrm{pr}$ & $:$ & 13, nt. 58 \\
\hline $2,4,19$ & : & 19, nt. 85 \\
\hline $2,11,2,9$ & : & 19, nt. 85 \\
\hline $2,11,4,1$ & $:$ & 12, nt. 56 \\
\hline $2,12,9$ & : & 13, nt. 58 \\
\hline $2,14,52,1$ & : & 19, nt. 85 \\
\hline $2,14,52,3$ & : & 20, nt. 87 \\
\hline $3,3,42,2$ & : & 19, nt. 85 \\
\hline $3,5,18,4$ & : & 21, nt. 96 \\
\hline $4,2,9,3$ & : & 159, nt. 807 \\
\hline $4,2,21,6$ & : & 19, nt. 85 \\
\hline $4,4,25,1$ & $:$ & 19, nt. 85 \\
\hline $4,4,38 \mathrm{pr}$ & $:$ & 179, nt. 911 \\
\hline $4,6,9$ & : & 12, nt. 56 \\
\hline $4,6,28,1$ & : & 12, nt. $56 ; 14$, nt. 61 \\
\hline $4,6,41$ & : & 21, nt. 95 \\
\hline $4,9,1,1$ & : & 17, nt. 70 \\
\hline $4,9,1,3$ & : & 10, nt. 49 \\
\hline $4,9,1,8$ & : & 17 , nt. 70 \\
\hline $4,9,3,1$ & : & 66, nt. 318 \\
\hline $4,9,3,2$ & : & 66, nt. 318 \\
\hline $4,9,5$ pr. & : & $\begin{array}{l}10, \text { nt. } 49 ; 17 \text {, nt. } \\
70 ; 65 \text {, nt. } 314 ; 66 \text {, } \\
\text { nt. } 318\end{array}$ \\
\hline $5,1,27$ & : & 12, nt. 54 \\
\hline $5,1,41$ & : & 21, nt. 96 \\
\hline $5,2,27 \mathrm{pr}$ & : & 19, nt. 85 \\
\hline $5,3,20,6$ & : & 161, nt. 821 \\
\hline $5,3,33,1$ & : & 21, nt. 96 \\
\hline $5,3,36,1$ & : & 19, nt. 85 \\
\hline $6,1,17,1$ & : & 20, nt. $89 ; 21$, nt. 97 \\
\hline $6,2,13 \mathrm{pr}$ & : & 129, nt. 640 \\
\hline $6,2,17$ & : & 122, nt. 601 \\
\hline $7,1,36,2$ & : & 21, nt. 96 \\
\hline
\end{tabular}
$149^{*}$

58 , nt. 281

58 , nt. 281

123, nt. 08

19 , nt. 85

64, nt. 311

123, nt. 608; 129, nt. 638

$$
\begin{array}{ll}
: & 129, \text { nt. } 638 \\
: & 137, \text { nt. } 679
\end{array}
$$




\begin{tabular}{|c|c|c|c|c|c|}
\hline $7,1,44$ & : & 122, nt. 601 & & & 104, nt. 511 \\
\hline $7,1,46$ & $:$ & 21, nt. 96 & $13,6,5,13$ & $:$ & 16, nt. $66 ; 62$, nt. \\
\hline $7,1,73$ & $:$ & 10, nt. 49 & & & 299; 104, nt. 511 \\
\hline $7,4,24,1$ & $:$ & 15 , nt. 63 & $13,6,11$ & $:$ & 97, nt. 469 \\
\hline \multirow[t]{2}{*}{$7,9,2$} & $:$ & 17 , nt. $76 ; 67$, nt. & $13,6,5,14$ & $:$ & 17, nt. 73 \\
\hline & & 322 & $13,6,5,15$ & : & 17, nt. $73 ; 17$, nt. 78 \\
\hline $8,1,11,1$ & $:$ & 15 , nt. 63 & $13,6,10,1$ & $:$ & 16 , nt. $65 ; 17$, nt. \\
\hline $8,1,15,1$ & $:$ & 19, nt. 85 & & & $73 ; 17$, nt. $78 ; 67$ \\
\hline $8,3,20 \mathrm{pr}$ & $:$ & 21, nt. 96 & & & nt. 323 \\
\hline $8,4,6,3$ & $:$ & 21, nt. 96 & $13,6,18$ pr. & $:$ & 58 , nt. $281 ; 61$, nt. \\
\hline $8,6,7$ & $:$ & 15 , nt. 63 & & & $297 ; 68 * ; 68$, nt. \\
\hline $9,2,29,7$ & $:$ & 111, nt. 544 & & & $323 ; 136$, nt. 674 \\
\hline $9,3,6,2$ & $:$ & 29, nt. 139 & & & 154,$775 ; 154$, nt. \\
\hline $9,4,26,6$ & $:$ & 19, nt. 85 & & & 779 \\
\hline $10,2,54$ & $:$ & 122, nt. 601 & $13,6,19$ & $:$ & $62 *$ \\
\hline $10,3,7,8$ & $:$ & 12, nt. 54 & $13,7,6,1$ & $:$ & 20, nt. 89 \\
\hline $10,4,9,5$ & $:$ & 19, nt. 85 & $13,7,13,1$ & $:$ & 16 , nt. $65 ; 17$, nt. \\
\hline $11,4,1,7$ & $:$ & 12, nt. 56 & & & $75 ; 17$, nt. $78 ; 66$ \\
\hline $11,4,4$ & $:$ & 12, nt. $56 ; 14$, nt. 61 & & & nt. 321 \\
\hline $11,5,1,1$ & $:$ & 123, nt. 608 & $14,6,7$ pr. & $:$ & 163, nt. 831 \\
\hline $12,1,40$ & $:$ & 179, nt. 911 & $15,1,40,1$ & $:$ & 20, nt. 88 \\
\hline $12,2,26 \mathrm{pr}$ & $:$ & 15, nt. 63 & $15,3,20$ & $:$ & 20, nt. 87 \\
\hline $12,4,16$ & $:$ & 80, nt. 394 & $16,3,1 \mathrm{pr}$. & $:$ & 10, nt. $49 ; 17$, nt. 74 \\
\hline $13,1,10,1$ & : & 129, nt. 638 & $16,3,1,9$ & $:$ & 10, nt. 49 \\
\hline \multirow[t]{2}{*}{$13,6,5,2$} & $:$ & 3 , nt. $11 ; 23$, nt. & $16,3,1,12$ & $:$ & 10, nt. 49 \\
\hline & & $\begin{array}{l}105 ; 32 \text {, nt. } 105 ; 33 \text {, } \\
\text { nt. } 152\end{array}$ & $16,3,1,35$ & $:$ & $\begin{array}{l}\text { 16, nt. } 65 ; 17, \text { nt. } \\
74 ; 17, \text { nt. } 78 ; 64\end{array}$ \\
\hline $13,6,5,3$ & $:$ & 3 , nt. $11 ; 33$, nt. 152 & & & nt. 312 \\
\hline \multirow[t]{2}{*}{$13,6,5,4$} & $:$ & 3 , nt. $11 ; 33$, nt. & $17,1,5,1$ & $:$ & 15 , nt. 63 \\
\hline & & $152 ; 136$, nt. 674 & $17,1,22,5$ & $:$ & 19, nt. 85 \\
\hline \multirow[t]{2}{*}{$13,6,5,5$} & $:$ & 16 , nt. $65 ; 17$, nt. & $17,2,52,2$ & $:$ & 66, nt. 320 \\
\hline & & 73; 64, nt. 311 & $17,2,52,3$ & $:$ & 17, nt. 71 \\
\hline \multirow[t]{2}{*}{$13,6,5,6$} & $:$ & $\begin{array}{l}60 * 64, \text { nt. } 311 \\
104, \text { nt. } 511 ; 97, \text { nt. }\end{array}$ & $18,1,1 \mathrm{pr}$ & $:$ & $\begin{array}{l}78, \text { nt. } 378 ; 79 \text {, nt. } \\
387\end{array}$ \\
\hline & & $469 ; 153$, nt. 769 & $18,1,1,1$ & $:$ & 79, nt. 387 \\
\hline \multirow[t]{2}{*}{$13,6,5,9$} & $:$ & 17 , nt. $73 ; 60$, nt. & $18,1,25,1$ & $:$ & 80, nt. 392 \\
\hline & & $290^{*} ; 64$, nt. 311 & $18,1,35,4$ & $:$ & 16 , nt. $65 ; 16-17$, nt. \\
\hline
\end{tabular}


69; 95, nt. 463; 119;

126, nt. 622; 128,

nt. $633 ; 137^{*} ; 155$,

nt. $787 ; 158$, nt. 805

$18,1,43,2$

$18,1,68$ pr.

$18,1,68,2$

$18,1,80,3$

$18,2,14,1$

$18,2,19$ pr.

$18,4,2,5$

$18,4,2,7$

$18,4,3$

$18,4,21$

$18,6,1 \mathrm{pr}$.

$18,6,1,1$

$18,6,1,2$

$18,6,2,1$

$18,6,3$

$18,6,4,1$

$18,6,4,2$

$18,6,5$ pr.

$18,6,8 \mathrm{pr}$.

$18,6,12$

$18,6,13$
29, nt. 139; 81, nt.

401

: $\quad 82$, nt. 406; 82, nt. 406

: $\quad 81$, nt. 401

: $\quad$ 80, nt. 396

: $\quad 82$, nt. 406

: $\quad 81$, nt. 405

: $\quad 82$, nt. 405

: $\quad 82$, nt. 405

: $\quad 82$, nt. 406

: $\quad$ 82, nt. 406

: $\quad 173$, nt. $882 *$

: $\quad 16-17$, nt. $69 ; 172 *$

: $\quad 106$, nt. 523

: $\quad 16$, nt. $65 ; 16-17$, nt.

69; 17, nt. 78; 94,

nt. $455 ; 95$, nt. 463 ;

124, nt. 614; 154,

nt. $775 ; 176^{*} ; 189$

: 17 , nt. 73 ; 95 , nt.

463; 154, nt. 775;

$178 *$

: $\quad 16-17$, nt. $69 ; 95$, nt. $463 ; 181 *$

: $\quad 16-17$, nt. $69 ; 95$, nt. $463 ; 182 *$

: $\quad 81$, nt. 405

: $\quad$ 88, nt. $426^{*}$

: $\quad 82$, nt. 406; 94, nt.

463; 112*; 114, nt.

$555 ; 118 ; 186$

$19,1,36$

$18,7,1$

$19,1,2,1$

$19,1,3,1$

$19,1,6,8$

$19,1,9$

$19,1,11,2$

$19,1,11,8$

$19,1,13,16$

$19,1,13,17$

$19,1,13,20$

$19,1,24,2$

$19,1,30,1$

19, 1, $31 \mathrm{pr}$.

$19,1,38,1$

$19,1,40$

19, 1, 54 pr.

$19,1,55$

$19,2,9,5$

$19,2,15,2$

$19,2,25,3$

$19,2,25,4$

$19,2,25,5$
104, nt. 512; 117, nt. 573

: $108^{*}$

: 106, nt. 523; 117, nt. 573

61, nt. 296; 97*; 118

15, nt. 63

81, nt. 397

81, nt. 397

81, nt. 405

80, nt. 389

79, nt. 389; 80, nt. 392

80, nt. 392

30, nt. $141^{*}$

82, nt. 405

80, nt. 389

20, nt. 89

29, nt. 139; 80, nt. 392; 81, nt. 401

16-17, nt. $69 ; 21$, nt. 96; 95, nt. 463; 119; $120 *$

16 , nt. $66 ; 16-17$, nt. $69 ; 95$, nt. 463; 186*

80, nt. 389

: $\quad 10$, nt. 49

: $\quad 82$, nt. $406 ; 118$

: $\quad 21$, nt. 97

: $\quad 46$, nt. 226

: $\quad 21$, nt. $96 ; 106$, nt. 519

: $\quad 58$, nt. 281

: $\quad 58$, nt. 281

: $\quad 58$, nt. 281 


\begin{tabular}{|c|c|c|c|c|c|}
\hline $19,2,25,6$ & $:$ & 58, nt. 281 & $24,3,64,5$ & $:$ & 21, nt. 95 \\
\hline $19,2,25,7$ & $:$ & 58, nt. 281 & $25,3,1,11$ & $:$ & 13, nt. 57 \\
\hline $19,2,25,8$ & : & 58, nt. 281 & $25,4,1,10$ & $:$ & 13, nt. 57 \\
\hline \multirow[t]{2}{*}{$19,2,33$} & $:$ & 80, nt. $392 ; 124$, nt. & $25,4,2,1$ & $:$ & 13, nt. 57 \\
\hline & & 614 & $26,7,48$ & : & 10, nt. 49 \\
\hline $19,2,36$ & $:$ & 124, nt. 614 & $27,1,13,2$ & $:$ & 160, nt. 813 \\
\hline \multirow[t]{2}{*}{$19,2,40$} & $:$ & 10, nt. $49 ; 66$, nt. & $27,1,41,1$ & $:$ & 15 , nt. 63 \\
\hline & & 318; 94, nt. 456 & $27,10,7,1$ & $:$ & 19, nt. 85 \\
\hline \multirow[t]{2}{*}{$19,2,41$} & $:$ & 16 , nt. $65 ; 17$, nt. & $28,1,9$ & : & 12, nt. $56 ; 14$, nt. 61 \\
\hline & & $70 ; 63 *$ & $28,2,13$ pr. & $:$ & 161, nt. 821; 163, \\
\hline \multirow[t]{2}{*}{$19,2,55 \mathrm{pr}$} & : & 17, nt. $70 ; 66$, nt. & & & nt. 831 \\
\hline & & 316 & $28,3,6,7$ & $:$ & 12, nt. 56 \\
\hline $19,2,60,2$ & $:$ & 117, nt. 578 & $28,6,37$ & $:$ & 15 , nt. 63 \\
\hline $19,2,60,6$ & : & 66, nt. 316 & $29,2,20$ pr. & $:$ & 10, nt. 49 \\
\hline \multirow[t]{2}{*}{$19,2,60,9$} & $:$ & 17, nt. $70 ; 66$, nt. & $29,2,97$ & : & 179, nt. 911 \\
\hline & & 316; 117, nt. 579 & $29,5,1$ pr. & $:$ & 10, nt. 49 \\
\hline \multirow[t]{2}{*}{$19,4,1 \mathrm{pr}}$. & $:$ & 79 , nt. $389 ; 80$, nt. & $30,16,224$ & : & 13, nt. 56 \\
\hline & & $391^{*}, 80$, nt. 392 & 30,57 & $:$ & 145, nt. 731 \\
\hline $19,5,5,4$ & $:$ & 17, nt. 72 & $30,70,3$ & $:$ & 20, nt. 87 \\
\hline \multirow[t]{2}{*}{$19,5,17,4$} & $:$ & 67 , nt. $323 ; 124$, nt. & $31,33,1$ & $:$ & 21, nt. 95 \\
\hline & & 614 & $31,77,21$ & $:$ & 10, nt. 49 \\
\hline $19,5,20,1$ & $:$ & 21 , nt. 96 & 32,55 & $:$ & 98, nt. $473^{*}$ \\
\hline $21,1,17,15$ & : & 10, nt. 49 & 32,84 & : & 12, nt. 54 \\
\hline $21,1,29$ pr. & $:$ & 20, nt. 87 & $33,1,2,4$ & $:$ & 19, nt. 85 \\
\hline $21,1,31,14$ & : & 29, nt. 139 & $33,1,10,123$ & $:$ & 20, nt. 88 \\
\hline $21,1,55$ & : & 19, nt. 85 & $33,1,19,1$ & $:$ & 20, nt. 88 \\
\hline $22,1,3, \mathrm{pr}$ & : & 19, nt. 85 & $33,1,19,2$ & $:$ & 20, nt. 88 \\
\hline $22,1,4$ pr. & : & 81, nt. 397 & $33,2,33 \mathrm{pr}$ & $:$ & 20, nt. 88 \\
\hline $22,1,18,1$ & $:$ & 80, nt. 389 & $33,2,33,1$ & $:$ & 20, nt. 88 \\
\hline $22,5,3,5$ & : & 12, nt. $56 ; 14$, nt. 61 & $33,7,12,29$ & $:$ & 12, nt. 54 \\
\hline $23,3,9,3$ & $:$ & 10, nt. 49 & $33,7,12,35$ & $:$ & 10, nt. 49 \\
\hline $23,3,53$ & : & 122, nt. 601 & $33,7,15,2$ & : & 10, nt. 49 \\
\hline $24,3,59$ & : & 138, nt. 681 & $33,7,26$ & $:$ & 175, nt. 894 \\
\hline $23,4,18$ & $:$ & 15 , nt. 63 & $34,1,9,1$ & $:$ & 20, nt. 88 \\
\hline $24,1,50 \mathrm{pr}$ & $:$ & 21, nt. 96 & $34,1,15,1$ & : & 20, nt. 88 \\
\hline $24,2,6$ & : & 19, nt. 85 & $34,1,15,2$ & $:$ & 20, nt. 88 \\
\hline $24,3,12$ & $:$ & 19, nt. 85 & $34,1,17$ & $:$ & 10, nt. 49 \\
\hline
\end{tabular}




\begin{tabular}{|c|c|c|c|c|c|}
\hline $34,1,20,1$ & : & 21 , nt. 96 & $41,2,3,15$ & : & 12 , nt. 55 \\
\hline $34,2,35$ pr. & $:$ & 21, nt. 96 & $41,2,3,23$ & $:$ & 12, nt. 54 \\
\hline $34,2,35,1$ & $:$ & 21, nt. 96 & $41,2,10,1$ & $:$ & 12, nt. 54 \\
\hline $34,2,39,1$ & $:$ & 12, nt. 54 & $41,2,39$ & $:$ & 12, nt. 54 \\
\hline $35,1,54$ pr. & $:$ & 138, nt. 681 & $41,2,44$ pr. & $:$ & 12, nt. 54 \\
\hline $35,1,70$ & $:$ & 15 , nt. 63 & $41,2,51$ & $:$ & 12 , nt. $55 ; 14$, nt. \\
\hline $35,2,30 \mathrm{pr}$. & $:$ & 123, nt. 608 & & & 59; 94, nt. 460 \\
\hline $35,2,32,4$ & $:$ & 21, nt. 95 & $41,5,2$ pr. & $:$ & 12, nt. 54 \\
\hline $36,2,26,2$ & $:$ & 20, nt. 87 & $42,1,4,5$ & $:$ & 19, nt. 85 \\
\hline $36,3,5,1$ & : & 12, nt. 54 & $42,4,9,1$ & $:$ & 12, nt. 54 \\
\hline $36,4,5$ pr. & $:$ & 12, nt. 54 & $42,4,12$ & $:$ & 12, nt. 54 \\
\hline $37,9,1,17$ & $:$ & 12, nt. 55 & $42,6,1,6$ & $:$ & 19, nt. 85 \\
\hline $37,9,1,25$ & $:$ & 10, nt. 49 & $43,5,3,3$ & $:$ & 10, nt. 49 \\
\hline $37,12,5$ & $:$ & 121, nt. 590 & 43,10, fr. un. & $:$ & 107, nt. 524 \\
\hline $38,1,49$ & $:$ & 10, nt. 49 & $43,16,1,33$ & $:$ & 12 , nt. 55 \\
\hline $38,2,14,9$ & $:$ & 19, nt. 85 & $43,17,3,8$ & $:$ & 12, nt. 54 \\
\hline $38,15,2,2$ & $:$ & 13, nt. 58 & $43,20,1,13$ & $:$ & 19, nt. 85 \\
\hline $39,1,1,20$ & $:$ & 19, nt. 85 & $44,7,1,4$ & $:$ & 58, nt. $281 ; 64$, nt. \\
\hline $39,1,22 \mathrm{pr}$ & $:$ & 20, nt. 87 & & & $311 ; 94$, nt. 455 \\
\hline $39,2,9$ pr. & $:$ & 15 , nt. 63 & & & 145, nt. 730 \\
\hline $39,2,13,5$ & $:$ & 186, nt. 957 & $44,7,3$ & $:$ & 20, nt. $90^{*} ; 23$, nt. \\
\hline \multirow[t]{2}{*}{$39,2,18,8$} & $:$ & 82, nt. $406 ; 188$, nt. & & & $102 ; 23$, nt. $105 ; 26$, \\
\hline & & $966^{*}$ & & & nt. 115 \\
\hline $39,2,18,9$ & $:$ & 16-17, nt. 69 & $45,1,2,5$ & $:$ & 21, nt. 93 \\
\hline \multirow[t]{2}{*}{$39,2,38 \mathrm{pr}$} & $:$ & 12, nt. $55 ; 82$, nt. & $45,1,91,3$ & $:$ & 2, nt. 7 \\
\hline & & 406; 188, nt. $967^{*}$ & $45,1,114$ & $:$ & 21, nt. 96 \\
\hline $39,2,41$ & $:$ & 19, nt. 85 & $45,3,39$ & $:$ & 137, nt. $679 ; 138$, \\
\hline $39,5,33,3$ & $:$ & 15 , nt. 63 & & & nt. 681 \\
\hline $39,6,33$ & $:$ & 19, nt. 85 & $46,3,78$ & $:$ & 138, nt. 681 \\
\hline $40,2,5$ & $:$ & 162, nt. 826 & $46,6,11$ & $:$ & 21, nt. 97 \\
\hline $40,5,20$ & $:$ & 15 , nt. 63 & $47,2,12 \mathrm{pr}$. & $:$ & 17, nt. 70 \\
\hline 40,10 fr. un. & $:$ & 65, nt. 314 & $47,2,14 \mathrm{pr}$ & $:$ & 95 , nt. $463 ; 119 ;$ \\
\hline $40,12,35$ & $:$ & 10, nt. 49 & & & $158^{*} ; 168$, nt. 858 \\
\hline $41,1,3,2$ & $:$ & 12, nt. 55 & $47,2,14,1$ & $:$ & 16-17, nt. 69 \\
\hline $41,1,31,1$ & $:$ & 12, nt. 54 & $47,2,14,10$ & $:$ & 17, nt. 73 \\
\hline $41,2,3,3$ & $:$ & 12, nt. 55 & $47,2,14,10,15$ & : & 64, nt. 311 \\
\hline $41,2,3,13$ & $:$ & 12, nt. 55 & $47,2,14,15$ & : & 17, nt. 73 \\
\hline
\end{tabular}




\begin{tabular}{|c|c|c|c|c|c|}
\hline $47,2,14,16$ & $:$ & 94, nt. 456 & $48,19,28,14$ & $:$ & 13, nt. 58 \\
\hline $47,2,14,17$ & $:$ & 17, nt. 70 & $48,20,6$ & : & 13 , nt. $56 ; 14$, nt. 61 \\
\hline $47,2,49$ & : & 139 & $49,14,3$ pr. & : & 19, nt. 85 \\
\hline $47,2,52,12$ & $:$ & 12, nt. $56 ; 14$, nt. 61 & $49,14,45,1$ & : & 13 , nt. $56 ; 14$, nt. 61 \\
\hline $47,2,62(61), 6$ & $:$ & 64 , nt. 311 & $49,14,50$ & : & 179, nt. 911 \\
\hline $47,2,62(61), 7$ & $:$ & 10, nt. 49 & $49,16,13,5$ & : & 13, nt. $56 ; 14$, nt. 61 \\
\hline $47,2,81 \mathrm{pr}$. & $:$ & 95, nt. $465 ; 189$ & $50,6,1,2$ & : & 15 , nt. 63 \\
\hline $47,2,81(80), 2$ & $:$ & 17 , nt. 76 & $50,7,1$ & : & 160, nt. 814 \\
\hline $47,2,91,1$ & $:$ & 19, nt. 85 & $50,15,1$ & : & 159, nt. 807 \\
\hline \multirow[t]{2}{*}{$47,5,1,4$} & $:$ & 17, nt. $70 ; 94$, nt. & $50,16,14,1$ & : & 129 , nt. 640 \\
\hline & & 458 & $50,16,66$ & : & 79, nt. 387 \\
\hline $47,8,1$ & $:$ & 123, nt. 608 & $50,16,180$ pr. & : & 10, nt. $49 ; 14$, nt. 61 \\
\hline $47,8,2,2$ & $:$ & 123, nt. 608 & $50,16,206$ & : & 175, nt. 894 \\
\hline $47,8,2,10$ & $:$ & 123, nt. 608 & $50,16,207$ & : & 79, nt. 387 \\
\hline $47,8,2,14$ & $:$ & 123, nt. 608 & $50,16,218$ & : & 21, nt. 93 \\
\hline $47,8,2,18$ & $:$ & 123, nt. 608 & $50,16,224$ & : & 14, nt. 61 \\
\hline $47,8,2,21$ & $:$ & 123, nt. 608 & $50,17,23$ & : & 3 , nt. $11 ; 23$, nt. \\
\hline $47,8,2,22$ & $:$ & $\begin{array}{l}\text { 123, nt. 608; 133, } \\
\text { nt. } 661\end{array}$ & & & $\begin{array}{l}\text { 105; 29, nt. } 139 ; 33 \\
\text { nt. } 152 * ; 34, \text { nt. }\end{array}$ \\
\hline $47,8,2,23$ & $:$ & 123, nt. 608 & & & 154; 61, nt. 297; 82, \\
\hline $47,8,2,25$ & $:$ & 123, nt. 608 & & & nt. $406 ; 123$, nt. \\
\hline $47,18,1 \mathrm{pr}$. & $:$ & 12, nt. 56 & & & $608 ; 136$, nt. 674 \\
\hline $48,1,12,1$ & $:$ & 13, nt. 58 & & & 154, nt. 779 \\
\hline $48,3,1$ & $:$ & 12, nt. 56 & & & \\
\hline $48,3,8$ & $:$ & 12, nt. $56 ; 14$, nt. 61 & & & \\
\hline $48,3,10$ & $:$ & 13, nt. 58 & Codex & & \\
\hline $48,3,11$ pr. & $:$ & 12, nt. 56; 14, nt. 61 & $1,17,2$ pr. & : & 19, nt. 85 \\
\hline $48,3,12$ pr. & : & 13, nt. 58 & $1,19,4$ & : & 19, nt. 85 \\
\hline $48,3,12,1$ & $:$ & 13, nt. 58 & $1,27,2,3$ & : & 10, nt. 49 \\
\hline $48,3,14,3$ & $:$ & 13, nt. 58 & $2,3,9$ & : & 19, nt. 85 \\
\hline $48,3,14,5$ & : & 13, nt. 58 & $2,3,17$ & : & 15 , nt. 63 \\
\hline $48,3,14,6$ & : & 13, nt. 58 & $2,4,6,1$ & : & 19, nt. 85 \\
\hline $48,5,12(11), 5$ & : & 12, nt. $56 ; 14$, nt. 61 & $3,1,14,4$ & : & 19, nt. 85 \\
\hline $48,5,12,13$ & $:$ & 19, nt. 85 & $4,5,10,1$ & : & 19, nt. 85 \\
\hline $48,18,22$ & $:$ & 13, nt. 56; 14, nt. 61 & $4,24,6$ & : & 33 , nt. $152 ; 34$, nt. \\
\hline $48,18,189$ & : & 13, nt. 58 & & & 154 \\
\hline $48,19,28,7$ & $:$ & 13, nt. $56 ; 14$, nt. 61 & $4,65,4$ pr. & : & 66, nt. 316 \\
\hline
\end{tabular}




$\begin{array}{lll}4,65,4,2 & : & 66, \text { nt. } 316 \\ 5,3,20,7 & : & 15, \text { nt. } 63 \\ 5,13,1,16 a & : & 15, \text { nt. } 63 \\ 5,37,16 & : & 19, \text { nt. } 85 \\ 6,24,14 \text { pr. } & : & 160,814 \\ 6,43,1,1 & : & 19, \text { nt. } 85 \\ 7,32,7 & : & 19, \text { nt. } 85 \\ 7,33,5 & : & 19, \text { nt. } 85 \\ 7,54,3,3 & : & 19, \text { nt. } 85 \\ 8,10,5 & : & 15, \text { nt. } 63 \\ 8,13,19 & : & 66, \text { nt. } 321 \\ 8,44,3 & : & 80, \text { nt. } 392 \\ 8,50,7 & : & 19, \text { nt. } 85 \\ 8,52,1 & : & 15, \text { nt. } 63 \\ 8,58,2 & : & 19, \text { nt. } 85 \\ 9,41,11 & : & 160, \text { nt. } 813 \\ 9,4,1,2 & : & 10, \text { nt. } 49 \\ 9,13,1 & : & 123, \text { nt. } 608 \\ 9,36,2,2 & : & 10, \text { nt. } 49 \\ 9,49,8,2 & : & 15, \text { nt. } 63 \\ 12,52,2 & : & 10, \text { nt. } 49 \\ 12,59,3,2 & : & 15, \text { nt. } 63\end{array}$

\section{C) FonTes Bizantinas}

\section{Basilicas}

$\begin{array}{lll}2,3,23 & : & 74, \text { nt. } 362 \\ 3,1,5 & : & 72, \text { nt. } 353 \\ 13,1,10 & : & 72, \text { nt. } 353 \\ 15,1,21 & : & 74, \text { nt. } 362 \\ 53,7,7 & : & 72, \text { nt. } 353 \\ 53,7,10 & : & 72, \text { nt. } 353 \\ 60,12,14 & : & 72, \text { nt. } 353\end{array}$

Scholia Basilicorum

Steph. Tosauthn a
D. $7,9,1$ - B. 16,9 ,

1

Steph. Prqw² a D. $\quad: \quad 76$, nt. 367

7, 9,1 - B. $16,9,1$

Steph. Shmei wsai a : 73 , nt. 354; 122, nt.

D. $13,6,5,2$ - B. $105 ; 75$, nt. $366^{*}$

$13,1,5$

Kyr. Ent a a D. 13, : $\quad 76$, nt. 367; 122, nt.

6, $5,2-$ B. $13,1,5 \quad 105$

Kyr. Ful achn a D. $\quad$ : $\quad 73$, nt. 354

$13,6,5,2$ - B. 13, 1 ,

5

Steph. Shmei wsai a $\quad: \quad 73$, nt. 356; 74, nt.

D. $13,6,5,5-$ D. $\quad 362$

$13,1,5$

Kyr. Ful achn a D. : : 74, nt. 362*

13, 6, 5, 6 - D. 13 ,

1,5

Steph. Fpeidh a D. : $\quad$ 73, nt. 356; 74, nt. 13, $6,5,13$ - B. $13, \quad 362$

1,5

Kyr. Eij pragma a $\quad$ : $\quad 72$, nt. 350

D. $13,6,10,1-\mathrm{B}$.

$13,1,10$

Kyr. (1) crhsameno" : $\quad 74$, nt. $362 ; 76$, nt. a D. $13,6,18$ pr. - $\quad 367$

B. $13,1,18$

Anon. Toi $\theta i$ a D. 13, : $\quad$ 73, nt. 354

6, 18 pr. - B. 13,1 ,

18

Steph. Anagnwqi a : $\quad 74$, nt. 363*

D. $13,6,19$ - B. 13 ,

1,19

Kyr. H a[ ogo" a D. : $\quad 74$, nt. 363

$13,6,19$ - B. 13,1 ,

19

Steph. Eijhøamen a $\quad: \quad 72$, nt. 350 
D. $16,3,1,35$ - B.

$13,2,1$

Steph. Shmei wsai a $\quad$ : $\quad 72$, nt. 350; 73, nt.

D. $17,2,52,3-B$. $361^{*}$

$12,1,50$

Steph. Ouc apait ei : $\quad 76$, nt. 367

a D. 17, 2, 52, 3 - B.

$12,1,50$

Steph. Ht oi a D. 19, : $\quad 74$, nt. 363

1, 40 - B. 20, 1, 39

Steph. Edwca a D.

19, 2, 13, 6 - B. 20 ,

1,13

Steph. Ht oi soi ;a D. : $\quad$ 73, nt. 355

$19,2,40$ - B. 20,1 ,

39

Dor. Dia;a D. 47, 2, ： $\quad$ 73, nt. 357

12 pr. - B. 60,12 ,

12

Dor. Ean a D. 47, 2, : $\quad 72$, nt. 350

14 pr. - B. 60,12 ,

14

Dor. Fzht høh a D. $\quad$ : $\quad 72$, nt. 350

$: 47,2,14,10-B$.

$60,12,14$

Thal. Epeidh;a C. 6, : $\quad$ 73, nt. 357; 73, nt.

2,22 - B. $60,6,39$

Theophili Parafrasis

$3,23,3$ a

$4,1,16-17$

: $\quad 73$, nt. 360

: $\quad 73$, nt. 358 met. 2,22

met. 2, 23

met. 7, 2

met. 7,13

met. 9,1

met. 9,17

met. 10,14

mund. 26

Socr. 16

CAesar

Alex. 13, 1

Alex. 17, 6

Afr. 7, 2

Afr. 46, 4

civ. 1, 17, 3

civ. 1, 59, 2

civ. 1, 75, 2

civ. 2, 19, 3

civ. 2, 36, 3

civ. 3, 25, 2

civ. $3,25,4$

civ. $3,39,1$

civ. $3,40,1$

civ. 3, 101, 2

civ. 3, 104, 3

gall. 2, 29, 4

gall. 7, 27, 1

gall. 7, 55, 4

hisp. 26, 2

Catullus

carm. 2, 33
8 , nt. 41

11, nt. 51

14-15, nt. 61

8 , nt. 41

8 , nt. 41

8, nt. 41

8, nt. 41

11, nt. 52

13, nt. 58

14, nt. 59

11, nt. 52

14, nt. 59

11, nt. 52

11, nt. 52

14, nt. 59

11, nt. 52

14, nt. 59

11, nt. 52

11, nt. 52

14, nt. 59

11 , nt. 52

11, nt. 52

14, nt. 59

14-15, nt. 61

14, nt. 59

14, nt. 59

14, nt. 59

14-15, nt. 61

\section{Cicero}

ad $Q .1,2,14$

14, nt. 61

Att. 14, 5, 2
14, nt. 59

\section{APUleIUS}

flor. 18, 29
18, nt. 83 


\begin{tabular}{|c|c|c|c|c|}
\hline catil. 1,8 & 14, nt. 59 & $8,13,18$ & : & 11, nt. 52 \\
\hline catil. 2, 26 & 14, nt. 59 & & & \\
\hline catil. 4,8 & 14, nt. 59 & FRONTINUS & & \\
\hline ce orat. 2,272 & 11, nt. 52 & strat. $2,2,14$ & $:$ & 11, nt. 52 \\
\hline div. 1,52 & 14, nt. 61 & strat. $3,10,8$ & $:$ & 11, nt. 52 \\
\hline epist. $15,2,6$ & 11, nt. 51 & strat. $3,11,1$ & $:$ & 11, nt. 52 \\
\hline fin. 2,113 & 12, nt. 54 & strat. $5,13,2$ & $:$ & 11, nt. 52 \\
\hline fin. 4,27 & 12, nt. 54 & & & \\
\hline fin. 5,53 & 14, nt. 61 & HORATIUS & & \\
\hline Lael. 14 & 14-15, nt. 61 & epist. $1,11,14$ & $:$ & 18, nt. 83 \\
\hline leg. 2, 29 & 12, nt. 54 & serm. $1,3,130-132$ & $:$ & 98, nt. 477 \\
\hline leg. 3,7 & 107, nt. 524 & & & \\
\hline Marcell. 32 & 14, nt. 59 & Livius & & \\
\hline de or. 2,124 & 12, nt. 54 & $1,15,8$ & $:$ & 11, nt. 52 \\
\hline de or. 2,145 & 12, nt. 54 & $1,43,2$ & $:$ & 11, nt. 52 \\
\hline de or. 2,158 & 11, nt. 51 & $2,11,2$ & $:$ & 11, nt. 52 \\
\hline off. 2,78 & 12, nt. 54 & $5,13,1$ & $:$ & 11, nt. 52 \\
\hline phil. 7, 19 & 11, nt. 52 & $5,40,8$ & $:$ & 12, nt. 54 \\
\hline phil. 9,12 & 18, nt. 83 & $5,46,8$ & $:$ & 14, nt. 59 \\
\hline phil. 12, 24 & 11, nt. 52 & $5,46,9$ & $:$ & 11, nt. 52 \\
\hline phil. 14,34 & 18, nt. 83 & $6,1,2$ & $:$ & 12, nt. 54 \\
\hline top. 66 & 18, nt. 83 & $7,37,13$ & $:$ & 11, nt. 52 \\
\hline tusc. 1,71 & 14-15, nt. 61 & $21,11,3$ & $:$ & 11, nt. 52 \\
\hline tusc. 1,118 & 14-15, nt. 61 & $21,49,7$ & $:$ & 11, nt. 52 \\
\hline tusc. 2,55 & 12, nt. 54 & $23,7,3$ & $:$ & 11, nt. 51 \\
\hline \multirow[t]{2}{*}{ tusc. 5,58} & 11, nt. 52 & $24,37,8$ & $:$ & 11, nt. 52 \\
\hline & & $25,15,13$ & $:$ & 11, nt. 52 \\
\hline COLumela & & $26,16,6$ & $:$ & $14-15$, nt. 61 \\
\hline $1,6,9$ & 12, nt. 54 & $26,46,2$ & $:$ & 14, nt. 59 \\
\hline $1,8,16$ & 14-15, nt. 61 & $28,1,8$ & $:$ & 11, nt. 52 \\
\hline \multirow[t]{2}{*}{$7,8,1$} & 12, nt. 54 & $28,11,6$ & $:$ & 11, nt. 51 \\
\hline & & $28,42,22$ & $:$ & 11, nt. 52 \\
\hline Curtius & & $30,43,5$ & $:$ & $14-15$, nt. 61 \\
\hline $5,2,16$ & 11, nt. 52 & $31,26,17$ & $:$ & 11, nt. 52 \\
\hline $5,4,14$ & 11, nt. 52 & $33,4,2$ & $:$ & 11, nt. 52 \\
\hline $6,5,10$ & 14-15, nt. 61 & $38,1,7$ & $:$ & 12, nt. 54 \\
\hline $8,3,17$ & 14-15, nt. 61 & $39,51,5$ & $:$ & 11, nt. 51 \\
\hline
\end{tabular}




$\begin{array}{lll}43,10,1 & : & 11, \text { nt. } 52 \\ 43,22,1 & : & 11, \text { nt. } 52 \\ 44,31,14 & : & 11, \text { nt. } 52 \\ \text { LUCANUS } & & \\ \text { civ. } 4,30 & : & 18, \text { nt. } 83 \\ & & \\ \text { MACROBIUS } & & \\ \text { sat. } 1,23,6 & : & 18, \text { nt. } 83 \\ & & \\ \text { OVIDIUS } & & \\ \text { fast. } 1,119 & : & 11, \text { nt. } 56 \\ \text { met. } 6,572 & : & 14, \text { nt. } 39 \\ \text { met. } 8,684 & : & 14, \text { nt, } 39 \\ \text { met. } 12,148 & : & 14, \text { nt. } 59 \\ \text { trist. } 3,14,41 & : & 14, \text { nt. } 59\end{array}$

nat. 7, 108

Bacch. 387

Capt. 254

Capt. 457

Merc. 233

Most. 406

Poen. 1365

Rud. 379

Rud. 380

Rud. 625

Rud. 696

Rud. 858

Petronius

34

102

112

Plinius

nat. 5,2
18, nt. 83

14, nt. 59

8 , nt. 40

8 , nt. 40

8 , nt. 40

14, nt. 61

8 , nt. 40

8 , nt. $40 ; 11$, nt. 51

8 , nt. 40

8 , nt. 40

8 , nt. 40

175, nt. 894

12 , nt. 54

: $\quad 11$, nt. 51 nat. 8,16

nat. 14, 132

nat. 21, 9 (12)

nat. $33,5,15$

epist. 6, 5, 4

epist. 10, 19, 1

epist. 10, 52

\section{Propertius}

2, 18,35

QUINTILIANUS

inst. 2, 17, 20

inst. 6, 1, 20

inst. 11, 1, 57

\section{Sallustius}

12, nt. 54

175, nt. 894

175, nt. 894

14, nt. 59

: 11, nt. 51

: $\quad 161$, nt. 821

: $\quad 13$, nt. 58

18-19, nt. 83

catil. 50, 3

14-15, nt. 61

catil. 50, 4

14-15, nt. 61

epist. Mithr. 8

iug. 65,2

11, nt. 51

11, nt. 52

\section{SENECA}

$\begin{array}{lll}\text { benef. } 6,22,1 & : & 12, \text { nt. } 54 \\ \text { benef. } 6,43,3 & : & 12, \text { nt. } 54 \\ \text { contr. } 2,5,4 & : & 14, \text { nt. } 59 \\ \text { contr. } 2,7,3 & : & 14, \text { nt. } 59 \\ \text { dial. } 9,10,3 & : & 14-15, \text { nt. } 61 \\ \text { dial. } 9,11,12 & : & 13, \text { nt. } 58 \\ \text { dial. } 9,16,3 & : & 14-15, \text { nt. } 61 \\ \text { epist. } 5,7 & : & 13, \text { nt. } 58 \\ \text { epist. } 26,10 & : & 14-15, \text { nt. } 61 \\ \text { epist. } 65,16 & : & 14-15, \text { nt. } 61 \\ \text { epist. } 70,23 & : & 14, \text { nt. } 59\end{array}$

SUETONIUS 


$\begin{array}{lll}\text { Aug. } 49 & : & 11, \text { nt. } 52 \\ \text { Aug. } 65 & : & 14, \text { nt. } 59 \\ \text { Cal. } 29 & : & 14-15, \text { nt. } 61 \\ \text { Galba } 12 & : & 11, \text { nt. } 52 \\ \text { Iul. } 68 & : & 11, \text { nt. } 52 \\ \text { Iul. } 86 & : & 14, \text { nt. } 59 \\ \text { Nero } 21 & : & 11, \text { nt. } 52 \\ \text { Tib. } 61 & : & 13, \text { nt. } 58 \\ \text { Vit. } 2 & : & 14-15, \text { nt. } 61 \\ & & \\ \text { TACITUS } & & \\ \text { ann. } 1,28 & : & 14, \text { nt. } 59 \\ \text { ann. } 3,36 & : & 14-15, \text { nt. } 61 \\ \text { ann. } 12,68 & : & 14, \text { nt. } 59 \\ \text { ann. } 13,44 & : & 11, \text { nt. } 51 \\ \text { ann. } 14,25 & : & 14, \text { nt. } 59 \\ \text { hist. 3, 59 } & : & 14, \text { nt. } 59 \\ \text { hist. 3, } 69,4 & : & 11, \text { nt. } 52\end{array}$

Tertulianus

adv. Val. 4, 3

Tibullus

$1,2,5$

$2,4,33$

VELLEIUS

$1,4,2$

$2,42,3$

$2,72,4$

$2,88,2$

\section{VERGILIUS}

Aen. 7, 486

Aen. 6, 574

georg. 4,165

georg. 4,327

\section{III - FONTES JURÍDICAS INTERMÉDIAS}

\section{Glosa}

Aquilia a D. 18, 6, $4 \quad$ : $\quad$ 108, nt. 529

alio fortuito a C. $4, \quad$ : $\quad 36$, nt. 161

34,1

contractus a D. $50, \quad$ : $\quad 23$, nt. 105

17,23

debet a Inst. 3, 14, $3 \quad$ : $\quad 36$, nt. 161

emptori a D. $18,1, \quad$ : $\quad 147$, nt. 743

35,4

etiam si sine culpa a : $\quad 35$, nt. 156

D. $4,9,3,1$

lectos emptos a D. $\quad$ : $\quad 109$, nt. 534

$18,6,13$

materia a D. $18,1, \quad$ : $\quad$ 102, nt. 501

15,1

praestare a D. $50, \quad$ : $\quad 23$, nt. 105

$16,71,1$

qualem bonus pater : $\quad$ 144, nt. 727

familias a D. 18, 1,

35,4

quod si a D. 18, 6, : $\quad$ 101, nt. 494 15

si minus a D. $18,6, \quad$ : $\quad 100$, nt. 489

15,1

si res a D. 19, 1, $31 \quad$ : $\quad 147$, nt. 748

pr.

vel alio fortuito a C. : $\quad 36$, nt. 156

$4,34,1$

vim a D. 19, 1, 31 pr. $\quad$ : $\quad 133$, nt. 660

\section{Ordenações Afonsinas}

IV, $46 \quad$ : $\quad 85$, nt. 410

\section{Ordenações Filipinas}

IV, 53,8 pr. $\quad$ : $\quad 85$, nt. 410 


\begin{tabular}{|c|c|c|}
\hline IV $, 53, \S 2$ & & 34 , nt. $154 *$ \\
\hline $\mathrm{IV}, 53, \S 3$ & & 34 , nt. $154 *$ \\
\hline \multicolumn{3}{|c|}{ Ordenações Manuelinas } \\
\hline $\mathrm{IV}, 31$ & & 85, nt. 410 \\
\hline \multicolumn{3}{|l|}{ Siete Partidas } \\
\hline V, t. II, Ley III & & 34, nt. $154 *$ \\
\hline V, t. 5, Ley XXIII & & 85, nt. 410 \\
\hline
\end{tabular}

IV - FonTES JURídicas MOdERnAS

Alemanha

ALR (Allgemeines Landrecht für die Preußischen Staaten)

$\S 95 \quad: \quad 84$, nt. 410

BGB (Bürgerliches Gesetzbuch)

$\S 275$

$\S 276$

$\S 446, \mathrm{I}, 1$

: $\quad 1$, nt. $2 ; 33$, nt. 154

: $\quad 1$, nt. 2

: $\quad 84$, nt. 410

Argentina

Código Civil (1871)

Art. 511

: $\quad 34$, nt. 154

Art. 514

: $\quad 34$, nt. 154

Áustria

ABGB (Allgemeines Bürgerliches Gesetzbuch)

$\S 1048$

: $\quad 84$, nt. 410

$\S 1049$

: $\quad 84$, nt. 410

$\S 1064$

: $\quad 84$, nt. 410
Código Civil (1916)

Art. 1056

: $\quad 1-2$, nt. 2

Art. 1057

: 1-2, nt. 2; 34, nt. 154

1058

Art. 1127

: $1-2$, nt. $2 ; 34$, nt. 154

: $\quad 86$, nt. 411

Código Civil (2002)

Art. 389

: $\quad 1-2$, nt. 2

Art. 392

: 1-2, nt. 2; 34, nt. 154

Art. 393

: 1-2, nt. 2, 34, nt. 154

Código Comercial (1850)

Art. 206

86, nt. 411

Esboço (A. TEIXEIRA DE FREITAS - 1860 -1865)

Art. 881

34 , nt. 154

Art. 884

: $\quad 34$, nt. $154^{*}$

Art. 903, § 1

: $\quad 85$, nt. 411

Art. 2024

: $\quad 86$, nt. 411

Consolidação das Leis Civis (1858)

Art. 501

34, nt. 154

Art. 502

: $\quad 34$, nt. 154

Art. 538

: $\quad 85$, nt. 411

Art. 539

: $\quad 85$, nt. 411

\section{Chile}

Código Civil (1855)

Art. 1547

: $\quad 34$, nt. 154

\section{França}

Code civil (1804)

Art. 711

: $\quad 85$, nt. 410

Brasil 
Art. 1138, al. 2

: $\quad 84$, nt. 410

Art. 1146

: $\quad 1$, nt. 2

Art. 1147

: $\quad$ 1, nt. 2; 33, nt. 154

Art. 1583

: $\quad 85$, nt. 410

Art. 1624

: $\quad 84$, nt. 410

Itália

Codice civile (1865)

Art. 1125 : $\quad 33$, nt. $154 ; 85$, nt. 410

Codice civile (1942)

Art. 1176

: $\quad 1$, nt. 2

Art. 1218

: $\quad 1$, nt. 2

Art. 1465

: $\quad 85$, nt. 410

\section{Suíça}

OR (Obligationenrecht)

Art. 185, I

85 , nt. 410 


\section{BIBLIOGRAFIA}

Albanese, Bernardo, D.13,6,19 e D. 19,2,41 no quadro dos problemas da "custodia", in Studi in onore di Giuseppe Grosso I, Torino, Giappichelli, 1968, pp. 79-96.

Albertario, Emilio, Corso di diritto romano - Le obbligazioni - Parte Generale I, Milano, Giuffrè, 19, pp. 01-476.

ARNò, Carlo, La teorica del periculum rei venditae nel diritto romano classico, Torino, Unione Tipografica-Editore, 1897, pp. 03-46.

ARANGIO-RuIZ, Vincenzo, La compravendita in diritto romano II, Napoli, Jovene, 1980. , Responsabilità contrattuale in diritto romano, Napoli, Jovene, 1958, pp. 01-281. [reimpr. da $2^{\mathrm{a}}$ ed., 1938]

ARnDTS, L., Lehrbuch der Pandekten, 14ª ed., Stuttgart, Cottaschen, 1889, pp. XXII-1082. SoHM, Rudolph, Institutionen - Geschichte und System des römischen Privatrechts, 16 ${ }^{\mathrm{a}}$ ed., München-Leipzig, Puncker \& Humblot, pp. X-778.

BARON, Julius, Die Haftung bis zur höherem Gewalt, in Archiv für Civilistische Praxis 78 (1892), pp. 203-310. , «Diligentia exactissima, diligentisssimus paterfamilias» oder die Haftung für Custodia, in Archiv für Civilistische Praxis 52 (1869), pp. 44-95.

BAUER, Martin, Periculum emptoris - Eine dogmengeschichtliche Untersuchungen zur Gefahrtragung beim Kauf, Berlin, Duncker \& Humblot, 1998, pp. 17-267.

BESELER, Gehard, Romanistische Studien, in TR 8 (1928), pp. 279-335. 
BetTI, Emilio, «Periculum»-Problema del rischio contrattuale in diritto classico $e$ giustinianeo, in Studi in onore di Pietro De Francisci I, Milano, Giuffrè, 1956, pp. 133197.

, Istituzioni di diritto romano II-1, Padova, Cedam, 1960, pp. IX-528.

, Teoria generale delle obbligazioni II - Struttura dei rapporti d'obbligazione, Milano, Giuffrè, 1953, pp. 07-157.

Bevilaqua, Clóvis, Código Civil dos Estados Unidos do Brasil IV, 6ª ed., Rio de Janeiro, Francisco Alves, 1943, pp. 05-455.

Bonini, Roberto, L'età giustinianea e bizantina, in M. TALAMANCA (dir.), Lineamenti di storia del diritto romano, 2a ed., Milano, Giuffrè, 1989, p. 696.

Bonfante, Pietro, Corso di diritto romano IV - Le obbligazioni, Milano, Giuffrè, 1979. Istituzioni di diritto romano, 10ª ed., Torino, Giappichelli, 1946, pp. XXXI-670. [1 $1^{\mathrm{a}}$ ed., 1896]

BRINZ, Alois, Lehrbuch der Pandekten II, $2^{\mathrm{a}}$ ed., Erlangen, Deichert, 1879, pp. III-882.

BURDESE, Alberto, Vendita (diritto romano), in NNDI 20 (1957), pp. 594-600.

CAnnata, Carlo Augusto, Per lo studio della responsabilità per colpa nel diritto romano classico, Milano, La Goliardica, 1967-1968, pp. II-322.

Responsabilità contrattuale nel diritto romano medievale e moderno, in Digesto IV-Discipline privatistiche - sezione civile 17 (1998), pp. 66-82.

, Richerche sulla responsabilità contrattuale nel diritto romano I, Milano, Giuffrè, 1966, pp. XI-145. 
, Sul problema della responsabilità nel diritto privato romano, in IURA 43 (1992), pp. 1-83.

Sul problema della responsabilità nel diritto privato romano, in IURA 44 (1993), pp. $1-83$.

, Sul problema della responsabilità nel diritto privato romano - Materiali per um corso di Diritto Romano, Catania, Torre, 1996, pp. XXV - 232.

CARDILLI, Riccardo, L'obbligazione di "praestare" e la responsabilità contrattuale in diritto romano (II sec. a.C - II sec. d.C.), Milano, Giuffrè, 1995, pp. XIV-514.

, L'obligation de praestare et la responsabilité contractuelle en droit romain, in RIDA 43 (1996), pp. 81-132.

, Un diritto comune in materia di responsabilità contrattuale nel sistema giuridico romanistico, in Rivista di Diritto Civile (1998), pp. 315-354.

Chamoun, Ebert, Instituições de Direito Romano, $3^{\text {a }}$ ed., Rio de Janeiro, Forense, 1957, pp. 09-524.

CuJAs, Jacques, Commentarius ad titulos digestorum, in Opera Omnia VI, Prati, Giachetti, 1838 .

, Commentarii in lib. IX Quaestionum Papiniani, in Opera Omnia IV, Lutetiae Parisiorum, s. e., 1658.

, Tractatus ad Africanum VIII, in Opera Omnia I, Lutetiae Parisiorum, s. e., 1658.

CUQ, Édouard, Manuel des institutions juridiques des romains, Paris, Plon, 1917, pp. VIII909.

Corradini, Francesco (cur.), Totius latinitatis lexicon I, Padova, Seminario, 1864, pp. XLIX-LXXVII. 
CRIFÒ, Giuliano, Illecito (diritto romano), in NNDI 8 (1957), pp. 153-164.

Cunha Gonçalves, Luís da, Tratado de Direito Civil - Em comentário ao Código Civil português IV-2, 2ª ed., São Paulo, Max Limonad, , pp. 543-1049.

DE MEDIo, Antonio, Caso fortuito e forza maggiore in diritto romano, in BIDR 20 (1908), pp. 157-209.

Demogue, René, Traité des obligations em general I - Sources des obligations V, Paris, Rousseau, 1925, pp. 01-649.

De SARLO, Luigi, Alfeno Varo e i suoi digesta, Milano, Giuffrè, 1940, pp. IX-219.

DE RoBertis, Francesco Maria, I problemi della responsabilità contrattuale nelle Istituzioni di Gaio e le lacune del manoscritto veronese, in Studi in onore di Biondo Biondi I, Milano, Giuffrè, 1965, pp. 375-394.

Responsabilità contrattuale, in ED 29 (1988), pp. 1054-1058.

De ZuluetA, Francis, The Institutes of Gaius II - Commentary, Oxford, Clarendon, 1953, pp. XV-302.

Di MAJO, Adolfo, Responsabilità contrattuale, in Digesto IV - Discipline privatistiche sezione civile 17 (1998), pp. 25-66.

Doneau, Hugues, Commentarii in Codicem Justiniani II, in Opera Omnia IV, Lucae, Riccomini, 1765, cols. 01-1364.

Commentarii de iure civile, in Opera Omnia IV cum notis Osualdi Hilligeri, Lucae, Riccomini, 1764, cols. 01-1406.

ERMINI, Giuseppe, Diritto comune, in NNDI 5 (1957), pp. 827-829.

ERnout, Alfred; MeIllet, Antoine, Dictionnaire étymologique de la langue latine Histoire des mots, $4^{\mathrm{a}}$ ed., Paris, Klinksieck, 2001, pp. 
ERNST, Wolfgang, Periculum est emptoris, in SZ 99 (1982), pp. 216-248.

Ferrini, Contardo, e Grosso, Giuseppe, Manuale di Pandette, $4^{\mathrm{a}}$ ed., Milano, Societa Editrice Libraria, pp. 01-578.

FERRINI, Contardo, Storia e teoria del contratto di commodato nel diritto romano, in E. Albertario (cur.) Opere di Contardo Ferrini III - Studii vari di dirito romano e moderno sulle obbligazioni, sul negozio giuridico, sulle presunzioni, Milano, Hoepli, 1929, pp. 81203.

FERrINI, Contardo, Sulle fonti delle 'Istituzioni' di Giustiniano, in BIDR 13 (1901), pp. 101-207 [= Albertario, Emilio (cur.), Opere di Contardo Ferrini II - Studi sulle fonti del diritto romano, Milano, Ulrico Hoepli, 1929, pp. 307-419].

GIUFFRÈ, Vincenzo, «Scolii», in NNDI 16 (1969), pp. 765-774.

Gomes, Orlando, Contratos, $4^{\mathrm{a}}$ ed., Rio de Janeiro, Forense, 1973, pp. 15-518.

GreINER, Reinhold, Opera Neratii - Drei Textgeschichten, Karlsruhe, Müller, 1973, pp. 01-176.

GROOT, Huig de, De iure belli ac pacis libri III, Paris, Nicolau Buon, 1625, pp. 01-786.

-_-_--, De iure belli ac pacis libri III, trad. fr. PRADIER-FodÉRÉ, Paul, Le droit de la guerre et de la paix, Paris, Presses universitaires de France, 2005, pp. 03-838.

Grosso, Giuseppe, Obbligazioni - Concetto e requisiti della prestazioni, obbligazioni alternative e generiche, $3^{\mathrm{a}}$ ed., Torino, Giappichelli, 1966.

HÄGERSTRÖM, Axel, Der römische Obligationsbegriff II - Über die Verbalobligation, Uppsala-Leipzig, 1941, pp. XI-407.

HARDER, Martin, Commodum eius esse debet, cuius periculum est - Über die actio furti als stellvertretendes commodum beim Kauf, in Festschr. Kaser, München, 1976, pp. 351-372. 
HASSE, Johann Christian, Die Culpa des römischen Rechts, $2^{\mathrm{a}}$ ed., Bonn, Adolph Marcus, 1838, pp. XX-453.

Hatto Gross, Walter, Signum, in KlP (1975), cols. 184-186.

Haymann, Franz, Textkritische Studien zum römischen Obligationsrech, I - Über Haftung für custodia, in SZ 40 (1919), pp. 167-350.

, Textkritische Studien zum römischen Obligationsrecht, II - Periculum est emptoris, in SZ 41 (1920), pp. 44-185.

_ _ Zur Klassizität des periculum emptoris, in SZ 28 (1928), pp. 314-418.

Heumann, Hans; SecKel, Emil, Handlexicon zu den Quellen des römischen Rechts, 10ª ed., Graz, Akademische, 1958.

Huvelin, Paul, Compte rendu de M. Konstantinovitch, Le «periculum rei venditae» em droit romain, in RHD 4 (1924), pp. 318-319.

HuschKE, Philipp Eduard, Iurisprudentiae anteiustinianae quae supersunt - in usum maxime accademicum, $5^{\text {a }}$ ed., Leipzig, Teubner, 1886, pp. XVII-880.

Humbert, G. Insula, in Dictionnaire des antiquités grecques et romaines III, Paris, Hachette, 1900, pp. 546-548.

IMPALlOMENI, Giambattista, Pandettistica, in NNDI 12 (1957), pp. 350-353.

JAKAB, Éva, Risikomanagement in Weinkauf - Periculum und Praxis im Imperium Romanum, München, Beck, 2009, pp. IX-266.

JHERING, Rudolph Von, Das Schuldmoment im römischen Privatrecht, Gießen, Roth, 1867, pp. 01-68. 
KASER, Max, Das romische Privatrecht I - Das altromische, das vorklassische und klassische Recht I, $2^{\mathrm{a}}$ ed., Munchen, Beck, 1971.

; e KNÜTEL, Rolf, Romisches Privatrecht, $19^{\text {a }}$ ed., Munchen, Beck, 2008, pp. VIII433 , Die actio furti des Verkäufers, in SZ 96 (1979), pp. 89-128.

KELLER, Friedrich Ludwig von, Pandekten I, $2^{\mathrm{a}}$ ed., Leipzig, Tauchnitz, 1866, pp. XXVII622.

KRÜCKMANN, Paul, Custodia, in SZ 64 (1944), pp. 01-56.

KRÜCKMANN, Paul, Versicherungshaftung im römischen Recht, in SZ 63 (1943), pp. 01-53.

KRÜGER, Paul, Geschichte der Quellen und Literatur des römischen Rechts, Leipzig, Duncker \& Humblot, 1888, pp. X-389.

_. Geschichte der Quellen und Literatur des römischen Rechts, $2^{\mathrm{a}}$ ed., MünchenLeipzig, Duncker \& Humblot, 1912, pp. X-439.

KunKeL, Wolfgang, Diligentia, in SZ 45 (1925), pp. 266-351.

KNIEP, Ferdinand, Der Rechtsgelehrte Gaius und die Ediktskommentare, Jena, Fischer, 1910, pp.VIII-328.

Labruna, Luigi; De Simone, Enrico, Di Salvo, Settimio, Lessico di Gaio I, Napoli, Jovene, 1985, pp. XXVIII-295.

LÖHR, Egid Von, Beyträge zu der Theorie der Culpa, Gießen-Darmstadt, Heyer, 1808, pp. 02-223.

, Theorie der Culpa - Eine civilistische Abhandlung, Gießen, Heyer, 1806, pp. 01200. 
LUSIGNANI, Luigi, La responsabilità per custodia secondo il diritto romano I - Il receptum nautarum cauponum stabulariorum gli altri casi di locatio conductio, Modena, Soliani (tipografia), 1900, pp. 01-73.

, La responsabilità per custodia secondo il diritto romano II - L'emptio venditio, Parma, Adorni-Ugolotti, 1903, pp. 01-120.

LuZZATTO, Giuseppe Ignazio, Caso fortuito e forza maggiore come limite alla responsabilità contrattuale I - La responsabilità per custodia, Milano, Giffrè, 1938, pp. 01-265.

, Custodia (diritto romano), in NNDI 5 (1957), pp. 93-94.

, Spunti critici in tema di responsabilità contrattuale, in BIDR 63 (1960), pp. 47127.

MACCORMACK, Geoffrey, Custodia and culpa, in SZ 89 (1972), pp. 149-219.

_ The cautio damni infecti - Buyer and Seller, in ZSS 88 (1971), pp. 300-321.

MAREZOLL, Gustav Ludwig Theodor, Lehrbuch der Institutionen des römisches Rechtes, $8^{\mathrm{a}}$ ed., Leipzig, Barth, 1866 [1 ${ }^{\text {a }}$ ed. 1839], pp. XVIII-578.

MARTON, Gèza, Rinascita della dottrina classica della responsabilità per custodia, in IURA 7 (1956), pp. 124-131.

, Un essai de reconstruction du développement probable du système classique romain de responsabilité civile, in RIDA 3 (1949), pp. 177-191.

MAYR, Robert, Praestare, in SZ 42 (1921), pp. 198-227.

Mazeuaud, Henri; Mazeuaud, Léon, e Tunc, André, Traité théorique et pratique de la responsabilité civile délictuelle et contractuelle I, $5^{\mathrm{a}}$ ed., Paris, Montchrestien, 1957, pp. XIII-1050. 
METRO, Antonino, «Custodiam praestare», in LABEO 13 (1967) 1, pp. 60-67.

,L'obbligazione di custodire nel diritto romano, Milano, Giuffrè, 1966, pp. 01-212

NARDI, Enzo, Schema delle istituzioni di Giustiniano nel loro quadro finale, Milano, Giuffrè, 1978, pp. VIII-81.

Netto LôBo, Paulo Luiz, in A. JunQueIRA De AzEVedo (coord.), Comentários ao Código Civil - Parte Especial - Das Várias Espécies de Contratos - Da Compra e Venda - Da Troca ou Permuta - Do Contrato Estimatório - Da Doação (arts. 481 a 564) VI, São Paulo, Saraiva, 2003, pp. XII-385.

NoodT, Gerard, Opera Omnia II - Comentarium in Digesta Justiniani, Sacratissimi Principis - Libros XXVII Digestorum sive Pandectarum, Köln, Johannes Wilhelm Huisch, 1732, pp. 01-449.

ORESTANO, Ricardo, Alfeno Varo, in NNDI 1 (1957), pp. 477-478.

_, Paolo (Iulius Paulus), in NNDI 12 (1957), pp. 362-363. , Ulpiano (Domitius Ulpianus), in NNDI 19 (1957), pp. 1106-1107.

, Celso Giuvenzio (figlio) (P. Juventius Celsus Titus Aufidius Hoenius Severianus), in NNDI 3 (1957), p. 91.

_ Giuliano Salvio (Lucius [o anche Publus?] Octavius Cornelius P. filius Salvius Iulianus Aemilianus), in NNDI 7 (1957), pp. 913-914.

PARIS, Jean, La responsabilité de la custodia en droit romain, Paris, 1926, pp. I-344..

PASTORI, Franco, Gaio e la responsabilità contrattuale, in Labeo 2 (1956) 1, pp. 291-326. , Profilo dogmatico e storico dell'obbligazione romana, Varese-Milano, Cisalpino, pp. 05-307. 
PENNITZ, Martin, Das periculum rei venditae - Ein beitrag zum "aktionenrechtlichen Denken im römischen Privatrecht, Wien, Böhlau, 2000, pp. VI-496.

PEROzZI, Silvio, Istituzioni di diritto romano II - Obbligazioni ed azioni -diritto ereditario-donazioni, Roma, Athaenaeum, 1928, pp. IX-738.

Pontes de Miranda, Francisco Cavalcante, Tratado de Direito Privado XXII - Parte Especial - Direito das Obrigações - Obrigações e suas espécies - Fontes e espécies de obrigações, $3^{\text {a }}$ ed., Rio de Janeiro, Borsoi, 1971, pp. XIV-403.

, Tratado de Direito Privado - Parte Especial XXXIX - Direito das Obrigações Compra-e-venda - Troca - Contrato Estimatório, $3^{\text {a }}$ ed., Rio de Janeiro, Borsoi, 1972, pp. 05-432.

PuCHTA, Georg Friedrich, Cursus der Institutionen I, 10ª ed., Leipzig, Breitkopf u. Härtel, 1892. pp. XVI-676. [1 ${ }^{\text {a }}$ ed. 1841$]$

, Lehrbuch der Pandekten, Leipzig, Barth, 1838, pp. X-614.

, Vorlesungen über das heutige römische Recht II, $6^{\mathrm{a}}$ ed., Leipzig, Tauchnitz, 1874, pp. XX-528.

PUFENDORF, Samuel, De iure naturae et gentium libri VIII, $2^{\mathrm{a}}$ ed., Frankfurt am Main, Johanes Philipp Andrea, 1684, pp. 01-1344.

, De iure naturae et gentium libri VIII, trad. fr. de BARBEYRAC, Jean, Le droit de la nature et des gens ou système général des principes les plus importants de la morale, de la jurisprudence et de la politique II, $6^{\mathrm{a}}$ ed., Basle, Thourneisen, 1750, pp. 01-613.

RABEL, Ernst, Custodia (diritto romano), in NDI 4 (1938), pp. 511-512.

RABEL, Ernst, Gefahrtragung beim Kauf, in SZ 42 (1921), pp. 543-564.

RoBAYE, Robert L'obligation de garde - Essai sur la responsabilité contractuelle en droit romain, Bruxelles, Saint-Louis, 1987, pp. 13-431. 
, Responsabilité objective ou subjective en droit romain - Questions de terminologie et de méthode, in TR 58 (1990), pp. 345-359.

SARGENTI, Manlio, Problemi della responsabilità contrattuale, in SDHI 20 (1954), pp. $127-258$.

Rischio contrattuale (diritto romano), in ED 41 (1989), pp. 1126-1133.

SAVIGnY, Friedrich Carl Von, Obligationen I, trad. it. de PACChIOnI, Giovanni, Le obbligazione I, Torino, UTET, 1912, pp. VIII-486.

, System des heutigen römischen Rechts V, Berlin, Veit u. Comp., 1841, pp. 01-646.

ScheltemA, H. Jan, L'enseignement de droit des antécesseurs, Leiden, Brill, 1970, pp. 0164.

SchiPAnI, Sandro (cur.), Iustiniani Augusti Digesta seu Pandectae - Digesti o Pandette dell'Imperatore Giustiniano I - Texto e traduzione - 1-4, Milano, Giuffrè, 2005.

SchÖMAN, Franz, Lehre vom Schadenerstaze I - Culpa, Gießen-Wetzler, 1806, pp. VI203.

Prüfung der Theorie der Culpa des Herrn Egid Von Löhr als Bestatigung seiner Abhandlung uber Culpa, Gießen-Wetzler, Tasche und Muller, 1806, pp. 03-64.

SCHUlZ, Fritz, Die Aktivlegitimation zur «actio furti», in SZ 23 (1912), pp. 23 -99.

SECKEL, Emil; LEVY, Ernst, Die Gefahrtragung beim Kauf im kass. röm. Recht, in SZ 47 (1927), pp. 117-263.

Serrano-Vicente, Martin, Custodiam Praestare - La prestación de custodia en el derecho romano, Madrid, Tébar, 2006, pp. 23-377. 
Silveira Marchi, Eduardo César, Acerca da «Traditio» no Âmbito do Problema dos Riscos na Compra-e-Venda - Os Casos das «Camas Vendidas» (Paul., 3 Alf. Epit., D. 18,6,13 E15PR.) e Da “Madeira Comprada"(Paul., 3 Alf. Epit., D. 18,6,15,1), in Revista da Faculdade de Direito da USP 99 (2004), pp. 37-60.

A Propriedade Horizontal no Direito Romano, 2a ed., São Paulo, Quartier Latin, 2006, pp. 11-114.

, Dos Riscos pela Perda Fortuita da Coisa Vendida no Direito Romano, in Revista da Faculdade de Direito da USP 96 (2001), pp. 45-73.

, Guia de Metodologia Jurídica - Teses, Monografias, Artigos, $2^{\mathrm{a}}$ ed., São Paulo, Saraiva, 2009, pp. 09-320.

, Periculum Rei Venditae e Periculum Dotis Aestimatae, in Revista da Faculdade de Direito da USP 93 (1998), pp. 25-57.

SCHILLING, Friedrich Adolph, Lehrbuch für Institutionen und Geschichte des römischen Privatrechts III, Leipzig, 1846, p. XVI-977.

StURm, Fritz, Stipulatio Aquiliana - Textgestalt und Tragweite der Aquilianischen Ausgleichsquittung im klassischen römischen Recht, München, Beck, 1972, p. XI-382.

TAFARO, Sebastiano, Regula e ius antiquuum in D. 50,17,23 - Ricerche sulla responsabilità contrattuale I, Bari, Cacucci, 1984, pp. 09-323.

Talamanca, Mario, Colpa civile (diritto romano e intermedio), in ED 7 (1960), pp. 517534.

, Considerazioni sul «periculum rei venditae», in Seminarios Complutenses de Derecho romano VII (1995), Madrid, Ursicino Alvarez, pp. 217-296.

, Custodia (diritto romano), in ED 11 (1962), pp. 561-563. 
Istituzioni di diritto romano, Milano, Giuffre, 1990, pp. VIII-778..

, Vendita (diritto romano), in ED 46 (1993), pp. 303-475.

ThIELMAnN, Georg, Traditio und Gefahrübergang, in SZ 106 (1989), pp. 292-326.

VAn Den Bergh, Govaert C. J. J., 'Custodiam praestare': 'custodia'-liability or liability for failing 'custodia'?, in TR 43 (1975), pp. 59-72.

VAN ECK, Cornelis, Principia juris civilis secundum ordinem digestorum - in usum domesticarum scholarum seu collegiorum, quae vocant, vulgata \& in duas partes divisa, Franeker, Johannes Gyselaar, 1689, pp. XXXI-396.

VAN DER WAL, Nicolaas, e LOKIN, Jan H. A., Historiae iuris graeco-romani delineatio Les sources du droit byzantin de 300 à 1453, Groningen, Forsten, 1985, pp. 07-119.

VINNEN, Arnold, In quattuor libros Institutionum Imperialium Commentarius II, Venetiis, Graziosi, 1768.

VISKY, Károly, La responsabilité dans le droit romain à la fin de la République, in RIDA 3 (1949), pp. 438-484.

VocI, Pasquale, 'Diligentia', 'custodia', 'culpa' - i dati fondamentali, in SDHI 56 (1990), pp. 29-143.

VoGT, Heinrich, Zur Gefahrtragung beim Sklavenkauf, in Festschrift Paul Koschaker II, Weimar, Böhlaus, 1932, pp. 162-168.

ZimMERMAnN, Reinhard, The Law of Obligations - Roman Foundations of the Civilian Tradition, London, Oxford University, 1996, pp. LXIV-1142.

WÄCHTER, Carl Georg von, Pandekten I - Allgemeiner Teil, Leipzig, Breit und Härtel, 1880, pp. XVIII-594. 
Wenger, Leopold, Die Quellen des romischen Rechts, Wien, Holzhausens, 1953, pp. XVIII-911.

Wesel, Uwe, Die Hausarbeit in der Digestenexegese - Eine Einführung für Studenten und Doktoranden, München, Kleist, 1966, pp. 07-83.

Wetter, Paul Van, Pandectes contenant l'histoire du droit romain et la legislation de Justinien III - Les obligations - 1e. Partie, Paris, Librairie Générale de Droit et de Jurisprudence, 1910, pp. 02-519.

Wolf, Joseph Georg, Per una storia della emptio venditio: l'acquisto in contanti quale sfondo della compravendita romana - Una lezione, in IURA 52 (2001), pp. 29-56. 


\section{RESUMO}

A chamada «responsabilidade por custódia» no direito romano é, desde há muito, um tema muito controverso no âmbito das pesquisas romanísticas.

As fontes apresentam um «custodiam praestare» relacionado com algumas figuras de devedores que parece ter relação com o problema da responsabilidade pelo inadimplemento contratual.

Mais precisamente, esse «custodiam praestare», conforme a perspectiva tradicional, consistia em uma «responsabilidade objetiva» por algumas eventos como, v.g., o furto e a fuga de escravos, isso é, uma responsabilidade independente de culpa.

Além das discussões sobre a natureza dessa «custodia» no âmbito do direito privado romano - isso é, se ela consistia em um critério objetivo ou subjetivo de responsabilidade controverte-se ainda acerca dos eventos pelos quais o devedor estaria obrigado a responder, e também as hipóteses nas quais se daria a aplicação dessa figura.

Nos textos em matéria de compra e venda, apresenta-se «custodiam praestare» e também outras locuções que poderiam estar relacionadas com o respectivo âmbito de problemas.

Tem-se como propósito dessa investigação esclarecer: (a) a natureza dessa eventual responsabilidade por custodia, ou seja, se ela consiste em um elemento acidental («accidentalia negotii») ou natural («naturalia negotii») do contrato de compra e venda; (b) o fundamento da legitimação ativa do vendedor à actio furti; (c) o «custodiam praestare» relacionado a modalidades específicas de compra e venda de vinho (com pacto de degustação, medição ou per aversionem); (d) os textos que estabelem uma relação entre essa custodia e a compra e venda de imóveis; (e) as modificações dessa responsabilidade por custodia no direito pós-clássico e justinianeu; (f) a interrelação com um outro problema, a saber, o do risco de perecimento fortuito da coisa vendida (o chamado «periculum rei venditae»)

E, por fim, pretende-se verificar os parelelos entre as modificações gerais do instituto, isso é, aquelas verificadas nos demais contratos, e aquelas específicas do contrato de compra e venda. 


\section{RIASSUNTO}

La cosidetta «responsabilità per custodia» nel diritto romano è, già da molto tempo, uno problema assai discussso nell'ambito delle ricerche romanistiche.

Le fonti ci ofrono un «custodiam praestare» in rapporto con alcuni debbitori che sembra riguardare il problema della responsabilità per l'inadempimento dell'obbligazione.

Più precisamente, questo «custodiam praestare», secondo la dottrina oramai comune, era una responsabilità oggettiva per qualche evento (per esempio, il furto oppure la fuga dello schiavo), ossia, una responsabilità indipendente di colpa.

Oltre le discussioni sulla natura di questa custodia nel del diritto privato romano cioè, si fossi un criterio oggettivo oppure soggettivo di responsabilità - ci sono ancora molte incertezze tra gli studiosi circa gli eventi per cui doveva il debbitore rispondere, e anche le ipotesi nelle quali i romani riconobbero questa figura.

Nei testi giuridici in materia di compravendita si presenta un «custodiam praestare» ed ache altre locuzioni che possono venir ricondotte alla problematica riguardante.

Il proposito di questa indagine consiste nel chiarire: (a) la natura di questa eventuale risponsabilità del venditore, cioè, si si presenta come un elemento accidentale («accidentalia negotii») oppure naturale («naturalia negotii») nella compravendita; (b) il fondamento della legitimazione attiva all'actio furti del venditore; (c) il «custodiam praestare» in rapporto con alcune modalità specifiche di vendita di vino (con patto di degustazione, mensurazione oppure per aversionem); (d) i testi che stabiliscono un rapporto tra la custodia e la compravendita di imobili; (e) i mutamenti della responsabilità per custodia nella compravendita nel diritto postclassico e giustinianeo; (f) i rapporti tra questo e un altro problema, cioè, quello del rischio nella compravendita (il cosidetto «periculum rei venditae»).

$\mathrm{E}$, infine, è nostro proposito verificare i paralelli tra i mutamenti generali del custodiam praestare (cioè, quei avenuti anche per le altri contratti) e questo mutamento specifico nel ambito della compravendita. 


\section{ZUSAMMENFASSUNG}

Die sogennante «Custodiahaftung» im römischen Recht ist, seit Langem, ein sehr umstrittenes Thema im Bereich der romanistischen Forschungen.

Die Quellen belegen uns ein «custodiam praestare» mit der Beziehung auf einige Schuldner ex contractu, dass mit der Haftungsregelung der Nichterfüllung der Verpflichtung zu tun haben zu scheint.

Genauer gesagt, dieser «custodiam praestare», traditionellen Ansicht nach, eine «objektive Haftung» für die jeweiligen Zufälle (z. B., Diebstahl, Skavenflucht) war, d. h., eine Haftung unabhangig von Schuld.

Außer der Dikussionen über die Herkunft dieser «custodia» innerhalb des römischen Privatrechts - wenn sie ein «objetives» oder «sujektives» Haftungskriterium sei - es gibt viele Unsicherheiten unter den Autoren über die Geschehen wofür der Schuldner zu entstehen müsste, und auch die Hipothesen in den die Römer diese Figur erkannten.

Demnach, belegen die juristischen Quellen beim Kauf ein «custodiam praestare» oder andere Ausdrücke die zur der betreffenden Problematik zurückgeführt (sei es auf Grund der terminologischen Spuren,oder auf Grund des Sachverhaltes ) werden können.

So, wir streben nach dieser Forschung erklären: (a) die Natur dieser eventuellen «custodia-Haftung» des Verkäufers, ob sie eine Nebenabrede («accidentale negotii») oder ein «naturale negotii» ist; (b) die Grundung der Aktivlegitimation des Verkäufers zu der actio furti; (c) das «custodiam praestare» in Beziehung auf die spezifischen Arten bei Weinkäufen (mit Degustationsabrede, mit Zumessung, auf Bauch und Bogen); (d) die Texte zu einer «custodia» im Bereich der Grundstückskäufe; (e) Die Umwandlungen der «custodia-Haftung» beim Kauf im spätklassichen und justinianischen Recht; (f) die Wechselbeziehung mit einem anderen Problem verbunden, nametlich erwähnt, dem der Gefahrtragung beim Kauf (das sogennante «periculum rei venditae»).

Und endlich wünschen wir ein Paralell zwischen die gemeinen Wandlungen der «custodiam praestare» (d. h., diese eingetrete auch bei anderen Vetragstypen) und diesen spezifischen des Verkaufs- und Kaufsvertrag aufzeichnen. 